\title{
MARCELLO RIBEIRO
}

\section{VERSÃO CORRIGIDA}

"Tudo o que existe, desde maravilhas a catástrofes, é resultado de algum trabalho, uma vez que ele não se limita apenas ao homem, mas, sim, a todo o universo": o papel da correlação inovadora, um exercício cognitivo?

\author{
UNIVERSIDADE DE SÃO PAULO \\ PROGRAMA DE PÓS-GRADUAÇÃO EM \\ FILOLOGIA E LÍNGUA PORTUGUESA \\ SÃO PAULO \\ 2014
}




\section{MARCELLO RIBEIRO}

\section{VERSÃO CORRIGIDA}

De acordo:

$$
\overline{\text { Prof }{ }^{a} \text {. Dr }{ }^{\mathrm{a}} \text {. Maria Célia Lima-Hernandes }}
$$

"Tudo o que existe, desde maravilhas a catástrofes, é resultado de algum trabalho, uma vez que ele não se limita apenas ao homem, mas, sim, a todo o universo": o papel da correlação inovadora, um exercício cognitivo?

Tese apresentada ao Programa de Pós-Graduação em Filologia e Língua Portuguesa da Universidade de São Paulo, para a obtenção do título de Doutor em Letras, sob a orientação da Profa ${ }^{\text {. }}$ Drâ. Maria Célia Lima-Hernandes.

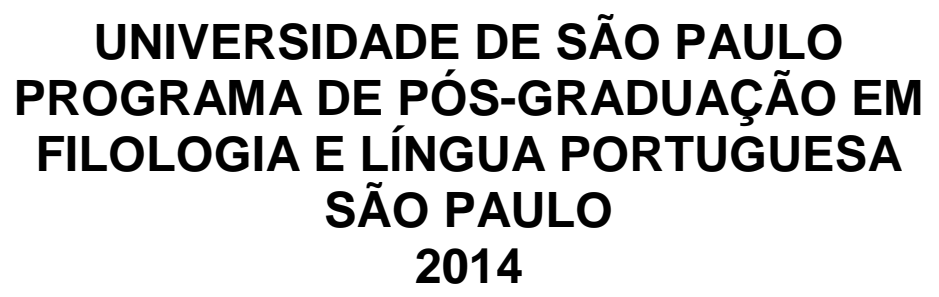


Autorizo a reprodução e divulgação total ou parcial deste trabalho, por qualquer meio convencional ou eletrônico, para fins de estudo e pesquisa, desde que citada a fonte.

\section{RIBEIRO, Marcello}

"Tudo o que existe, desde maravilhas a catástrofes, é resultado de algum trabalho, uma vez que ele não se limita apenas ao homem, mas, sim, a todo o universo": o papel da correlação inovadora, um exercício cognitivo?

/ Marcello Ribeiro; orientadora Maria Célia Lima-Hernandes - São Paulo, 2014. 293 f. : il.

Tese (Doutorado) - Universidade de São Paulo, 2014.

1. Palavra-Chave: Gramaticalização; Pares Correlativos; Padrões Funcionais;

Cognição; Redação 


\section{FOLHA DE APROVAÇÃO}

RIBEIRO, Marcello. "Tudo o que existe, desde maravilhas a catástrofes, é resultado de algum trabalho, uma vez que ele não se limita apenas ao homem, mas, sim, a todo o universo": o papel da correlação inovadora, um exercício cognitivo? Tese apresentada à Faculdade de Filosofia, Letras e Ciências Humanas da Universidade de São Paulo para obtenção do título de Doutor em Letras.

Aprovado em:

\section{Banca Examinadora}

Prof. Dr. Instituição:

Julgamento:

Assinatura:

Prof. Dr. Instituição:

Julgamento:

Assinatura:

Prof. Dr.

Instituição:

Julgamento:

Assinatura:

Prof. Dr.

Instituição:

Julgamento:

Assinatura:

Prof. Dr.

Instituição:

Julgamento:

Assinatura: 


\section{DEDICATÓRIA}

À minha mãe (in memoriam) e minha irmã, ao meu pai, amigos e mestres pelos estudos que me ampliaram a vida, iluminaram a mente e alma ao mostrar um caminho de correlações e interações, $o$ do conhecimento. 


\section{AGRADECIMMENTOS}

A Deus, em Quem me apoiava quando os momentos mais turbulentos pareciam estancar minhas ideias, meus ideais e minha determinação.

À minha orientadora, Profa. Dra. Maria Célia Lima-Hernandes, pelos incomensuráveis estímulo e contribuição no plano intelectual e emocional, pela compreensão frente a tantas condições pouco favoráveis no período em que a pesquisa ocorreu, pela sempre presente amizade e por acreditar em mim e me auxiliar.

Aos Professores do Programa de Pós-Graduação em Filologia e Língua Portuguesa e FFLCH e IP-USP, pelas constantes demonstrações de competência e respeito ao acadêmico; por me auxiliarem no meu desenvolvimento como pesquisador, fato que revitalizou minha prática docente e meu perfil científico de investigador.

Aos Profa. Dra. Maria Maura da Conceição Cezário (UFRJ); Prof. Dr. Ivo da Costa do Rosário (UFF); Profa. Dra. Renata Barbosa Vicente (UFRPE), Profa. Dra. Fraulein de Paula (USP) Profa. Dra. Maria Célia Lima-Hernandes (orientadora-USP), Profa. Dra. Vânia Casseb-Galvão (UFG); Profa. Dra. Briseida Dogo Resende (IP/USP); Profa. Dra. Cristina Lopomo Defendi (IF/SP); Prof. Dr. Marcelo Módolo (FFLCH-USP); Profa. Dra Patrícia Carvalhinhos (FFLCH-USP) 


\section{RESUMO}

Esta tese dedica-se ao estudo do processo de correlação e, como consequência, descreve o comportamento linguístico-discursivo, por padrão, dos pares correlativos que integram o conjunto das porções correlatas empregadas em redações vestibulares, momento em que a pressão pela normatividade é bem grande, mas escreventes habilidosos se utilizam dos pares que fogem ao que se espera e surpreendem o leitor com escolhas criativas, porém não rompem com o processamento cognitivo esperado. Como questões relativas à escolarização, as etapas de desenvolvimento cognitivo e o processo de mudança gramatical estão nesta tese altamente imbricados, e por conta disso considerou-se constitutiva uma amostra com textos produzidos em situações de alta pressão pela normatividade. São redações do banco de dados elaboradas por candidatos da FUVEST (Fundação para o Vestibular de São Paulo), de sete vestibulares distintos, no período de 2004 a 2010 (as 100 melhores e as 100 piores redações de cada exame). No total, analisaram-se 700 textos considerados piores e 700 melhores. Fundamentamos teoricamente esta tese nos estudos sobre cognição, a partir de Tomasello (2003), Givón (2011), sobre gramaticalização Bybee (2003), Traugott e Dasher (2005), Meillet (1965), Heine, Claudi e Hünnemeyer (1991), sobre correlações Oiticica (1952), Chediak (1960); sobre construções, Goldberg (1955), Croft (2001) e sobre a evolução dos estágios da mente humana, com Damásio (2009).O material analisado teve tratamento quantitativo e qualitativo em que se chegou à determinação de que pares correlativos assumem papéis e funções em decorrência das intenções discursivo-pragmáticas dos autores, que buscam em estágios da mente os recursos linguísticos e imagéticos para fundamentarem sua argumentação. $O$ estudo do comportamento de cada par foi realizado levando-se em conta etimologia, estatuto categorial nos dicionários e uma análise sincrônico para estabelecer padrões funcionais e valores semânticos. Foi possível, assim, constatar que os pares correlativos encontram-se em vários níveis de gramaticalização, a depender da categoria analisada, e que estão diretamente ligados a um jogo estratégico funcional-cognitivo.

\section{Palavra-Chave: Gramaticalização; Pares Correlativos; Padrões Funcionais;} Cognição; Redação. 


\begin{abstract}
This thesis is devoted to the study of the correlation process and, consequently, describes the linguistic-discursive behavior, by pattern, of the correlative pairs that constitute the set of related portions employed in the vestibular essays, at this moment, the pressure for normative rules is huge but skilled writers used the pairs escaping from that is expected and also to surprise the reader with creative choices, otherwise they do not break with the expected cognitive processing. As issues relating to schooling, the steps of cognitive development and the process of grammatical change are highly intertwined in this thesis. We considered a sample with constitutive texts produced through normative rules in high pressure situations for the writers. The corpus is composed by essays from the database produced by the FUVEST (Foundation for Vestibular of São Paulo) writers or candidates from seven distinct vestibular, in the period 2004-2010 (the 100 best and 100 worst essays of each exam). In total we analyzed 700 texts considered worst and 700 considered the best ones. We base this argument theoretically in studies of cognition, from Tomasello (2003), Givón (2011); on grammaticalization Bybee (2003), Traugott and Dasher (2005), Meillet (1965), Heine, Claudi and Hünnemeyer (1991); about correlations Oiticica (1952), Chediak (1960) on constructions; Goldberg (1955), Croft (2001) and the human mind stages of evolution, with Damasio (2009). The analyzed material had the quantitative and qualitative treatment through with there came the determination that correlative pairs assume roles and functions as a result of discourse-pragmatic intentions of the authors (writers/candidates), who seek In the mind stages the linguistic and pictorial resources to substantiate the argument. The study of each pair behavior was performed taking into account etymology, categorical status in dictionaries and a synchronic analysis to establish functional standards and semantic values. It was thus possible to observe that the correlated pairs are lying at different levels of grammaticalization; it depends on the category analyzed and which are directly connected to a strategic functional-cognitive roles of a game.
\end{abstract}

Keywords: Grammaticalization; Correlative Pairs; Functional Patterns; Cognition; Essays. 


\section{LISTA DE QUADROS}

Quadro 1 - Quantificações por Estrutura Textual (melhores) .................................... 160

Quadro 2 - Quantificações por Estrutura Textual (piores) ........................................ 162

Quadro 3 - Quantificações das Melhores e Piores ..................................................... 164

Quadro 4 - Pares correlativos adversativos 2004-2007 .......................................... 171

Quadro 5 - Pares correlativos adversativos - 2008-2010 ..................................... 172

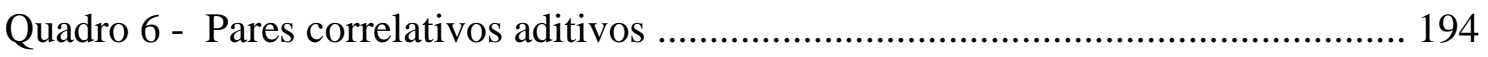

Quadro 7 - Combinações consecutivas ...................................................................... 219

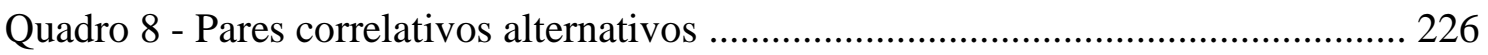

Quadro 9 - Pares correlativos comparativos ............................................................... 235

Quadro 10 - Pares correlativos concessivos ............................................................. 247

Quadro 11 - Pares correlativos condicionais ........................................................ 254

Quadro 12 - Pares correlativos proporcionais ......................................................... 264

Quadro 13 - Pares correlativos e suas funções pragmáticas - Piores 2004 Aditivas.... 288

Quadro 14 - Pares correlativos e suas funções pragmáticas -Piores 2004 Adversativas.. 288

Quadro 15 - Pares correlativos e suas funções pragmáticas - Piores 2004 Comparativas.. 288

Quadro 16 - Pares correlativos e suas funções pragmáticas - Piores 2004 Alternativas.. 288

Quadro 17 - Pares correlativos e suas funções pragmáticas - Piores 2005 Aditivas.... 289

Quadro 18 - Pares correlativos e suas funções pragmáticas - Piores 2005 Adversativas.. 289

Quadro 19 - Pares correlativos e suas funções pragmáticas - Piores 2005 Proporcional. 289

Quadro 20 - Pares correlativos e suas funções pragmáticas - Piores 2005 Alternativas. 290

Quadro 21 - Pares correlativos e suas funções pragmáticas - Piores 2005 Comparativas.290

Quadro 22 - Pares correlativos e suas funções pragmáticas - Piores 2006 Aditivas.... 290

Quadro 23 - Pares correlativos e suas funções pragmáticas - Piores 2006 Adversativas.290

Quadro 24 - Pares correlativos e suas funções pragmáticas - Piores 2006 Proporcional.291

Quadro 25 - Pares correlativos e suas funções pragmáticas - Piores 2006 Comparativa.291

Quadro 26 - Pares correlativos e suas funções pragmáticas - Piores 2006 Alternativa.291

Quadro 27 - Pares correlativos e suas funções pragmáticas - Piores 2007 Adversativas.291

Quadro 28 - Pares correlativos e suas funções pragmáticas - Piores 2007 Comparativas.291

Quadro 29 - Pares correlativos e suas funções pragmáticas - Piores 2007 Consecutivas.292

Quadro 30 - Pares correlativos e suas funções pragmáticas - Piores 2007 Aditivas.....292 
Quadro 31 - Pares correlativos e suas funções pragmáticas - Piores 2007 Alternativas.292

Quadro 32 - Pares correlativos e suas funções pragmáticas - Piores 2008 Aditivas.....292

Quadro 33 - Pares correlativos e suas funções pragmáticas - Piores 2008 Adversativas.293

Quadro 34 - Pares correlativos e suas funções pragmáticas - Piores 2008 Alternativas.293

Quadro 35 - Pares correlativos e suas funções pragmáticas - Piores 2008 Comparativas.293

Quadro 36 - Pares correlativos e suas funções pragmáticas - Piores 2009 Aditivas.....293

Quadro 37 - Pares correlativos e suas funções pragmáticas - Piores 2009 Alternativas.294

Quadro 38 - Pares correlativos e suas funções pragmáticas - Piores 2009 Comparativas.294

Quadro 39 - Pares correlativos e suas funções pragmáticas - Piores 2009 Adversativas.294

Quadro 40 - Pares correlativos e suas funções pragmáticas - Piores 2009 Consecutivas.294

Quadro 41 - Pares correlativos e suas funções pragmáticas - Piores 2009 Proporcional.294

Quadro 42 - Pares correlativos e suas funções pragmáticas - Piores 2010 Aditiva.......295

Quadro 43 - Pares correlativos e suas funções pragmáticas - Piores 2010 Alternativa.295

Quadro 44 - Pares correlativos e suas funções pragmáticas - Piores 2010 Adversativas.295

Quadro 45 - Pares correlativos e suas funções pragmáticas - Piores 2010 Consecutiva.295 


\section{LISTA DE ESQUEMAS}

Esquema 1. Constituintes extrafrasais - modelo de Dik (1989).................................. 31

Esquema 2. Dinamismo da língua (Neves, 2006, adaptado)...................................... 33

Esquema 3. Representação da construção na visão de Croft........................................ 37

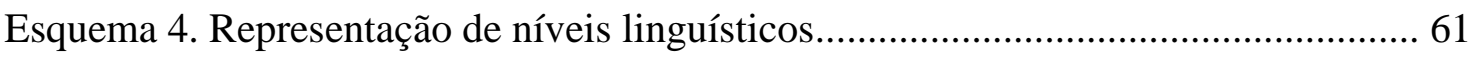

Esquema 5. Curso da aquisição da linguagem da criança......................................... 87

Esquema 6. Modelo de correlação adotado por Oiticica: sujeito composto.................. 108

Esquema 7. Modelo de correlação adotado por Oiticica: aditivas............................. 109

Esquema 8. Modelo de correlação adotado por Oiticica: aditivas adverbiais............... 109

Esquema 9. Modelo de correlação adotado por Oiticica: comparação........................ 110

Esquema 10. Complexidade da dupla negação........................................................ 135

Esquema 11. Correlação: do self central ao self autobiográfico................................ 140

Esquema 12. Esquema interpretativo "é claro que... mas"........................................ 180

Esquema 13. Articulação tema-rema correlação nulitiva........................................... 182

Esquema 14. Articulação tema-rema correlação nulitiva........................................... 183

Esquema 15. Articulação tema-rema correlação nulitiva............................................ 184

Esquema 16. Articulação tema-rema correlação nulitiva............................................ 186

Esquema 17. Representação da distribuição sintático-semântico-pragmática: correlação

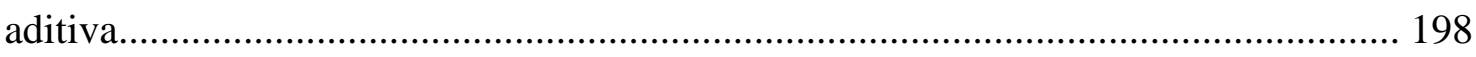

Esquema 18. Aproximação entre adição, comparação e proporcionalidade................. 211

Esquema 19. Processamento comparativo de proporções .......................................... 213

Esquema 20.Correlação e o estabelecimento de recortes específicos.......................... 214

Esquema 21. Proporcionalidade e circunstanciação.................................................. 215

Esquema 22. Processamento comparativo na correlação.......................................... 216

Esquema 23. Elisão de elementos dos pares correlativos.......................................... 217

Esquema 24. Efeito cascata das correlações consecutivas.......................................... 221

Esquema 25. Padrão da correlação consecutiva............................................................ 222

Esquema 26. Construção da correlação alternativa.................................................. 232

Esquema 27. Avaliação na correlação comparativa................................................... 239

Esquema 28. Avaliação na correlação comparativa.................................................. 239

Esquema 29. Convergências de itens específicos na comparação-proporcional.......... 243

Esquema 30. Convergência de itens específicos na comparação-proporcional............ 244 


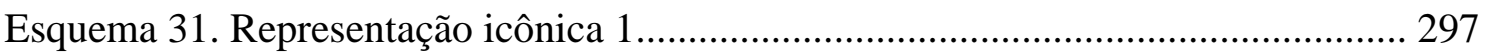

Esquema 32. Representação icônica 2 ...................................................................... 297

Esquema 33 Representação do subprincípio da ordenação linear................................ 301 


\section{LISTA DE FIGURAS}

Figura 1. Contraste de planos discursivos............................................................ 70

Figura 2. Contraste entre inércia e mudança....................................................... 71

Figura 3. Contraste superfundo x superfigura.................................................... 71

Figura 4. Representação do impacto da consciência sobre o self (Damasio, 2009,

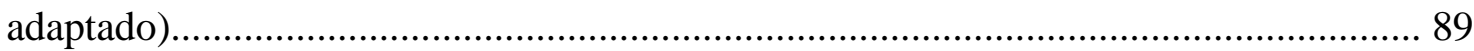

Figura 5. Representação da atuação da polaridade negativa........................................ 133

Figura 6. Proposta temática da Fuvest 2004............................................................ 149

Figura 7. Proposta temática da Fuvest 2005........................................................... 150

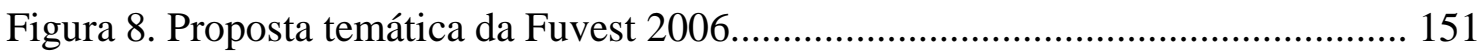

Figura 9. Proposta temática da Fuvest 2007 ....................................................... 152

Figura 10. Proposta temática da Fuvest 2008 ........................................................ 153

Figura 11. Proposta temática da Fuvest 2009..................................................... 155

Figura 12. Proposta temática da Fuvest 2010........................................................ 156

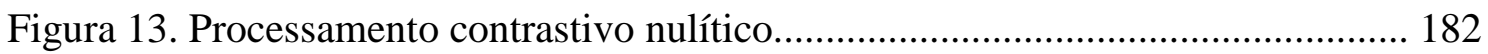

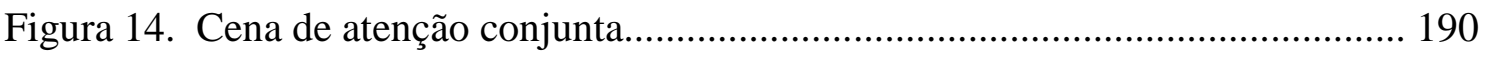




\section{LISTA DE GRÁFICOS}

Gráfico 1. Distribuição metonímica na correlação não nulitiva: o foco no restritor.... 190 


\section{SUMÁRIO}

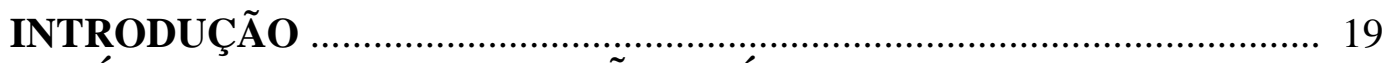

CAPÍTULO 1 FUNDAMENTAÇÃO TEÓRICA ……………………....... 25

1.1 As bases funcionalistas .......................................................................... 25

1.1.1 Língua em uso e gradação linguística …………………………………..... 27

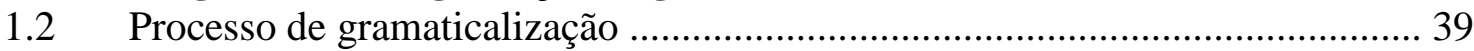

1.2.1 Construções gramaticais como processo cognitivo ............................................ 45

1.3 Correlação entre gramática e cognição................................................................4

$1.4 \quad$ Fundamentos cognitivos ............................................................................ 49

1.4.1 Informatividade e compartilhamento da atenção …………………………....5 50

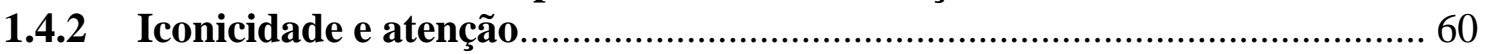

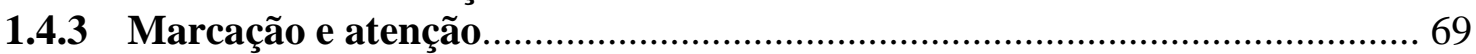

1.4.4 Planos discursivos e atenção .................................................................... 70

1.4.5 Consciência, atenção conjunta e maturação sociocultural.............................. 72

1.4.6 Desenvolvimento humano e aquisição da linguagem.................................... 77

1.4.6.1 O papel cognitivo da interação humana e manifestação de uma gramática

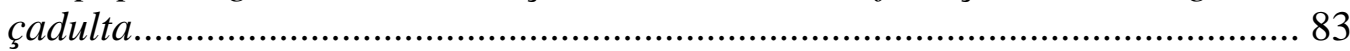

1.4.6.2 Linguagem e mente: o papel da consciência selfiana ....................................... 88

1.4.6.3 A mudança ontogênica e a contribuição dos selves........................................ 92

CAPÍTULO 2 - O PROCESSO DE CORRELAÇÃO: DELINEANDO O OBJETO DE INVESTIGAÇÃO ………………………….... 97

2.1 A correlação e sua gênese nos diversos campos do conhecimento humano.......... 97

2.2 Dependência ou subfunção entre as orações principais e subordinadas: o lugar

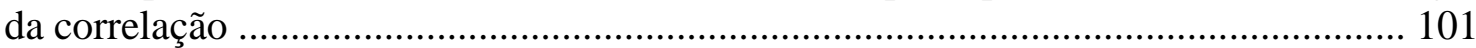

2.3 Definições de correlação: Gramáticas …………………................................... 102

2.3.1 Abordagem tradicional …………………………................................. 102

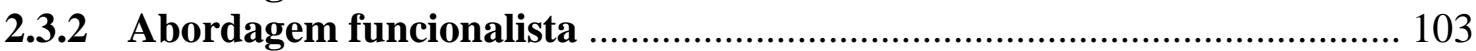

2.3.3 Correlação e entoação: junção possível ………………………………….... 107

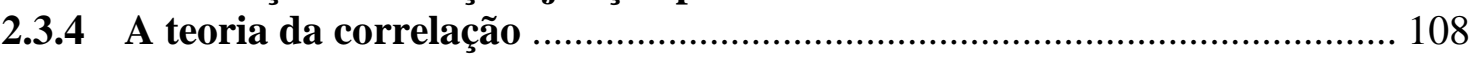

2.4 A posição normativa dos livros didáticos: regresso à Abordagem Tradicional... 116

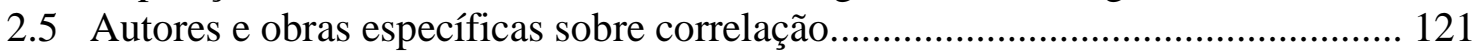

2.6 Da negação à polaridade: um objeto investigativo................................................ 131

2.7 Correlação como processo cognitivo ............................................................... 136

CAPÍTULO 3 - ASPECTOS METODOLÓGICOS .................................... 142

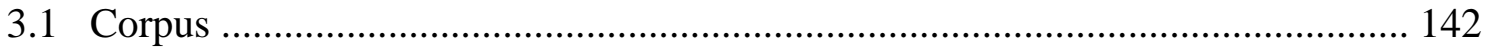

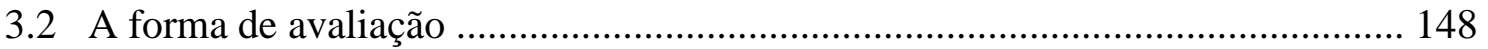

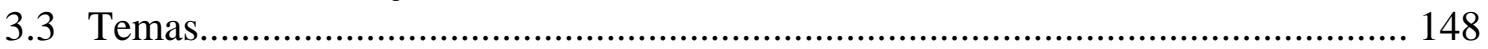

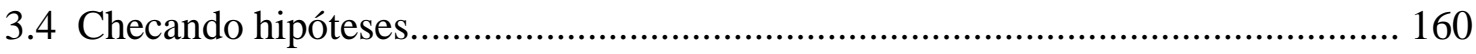

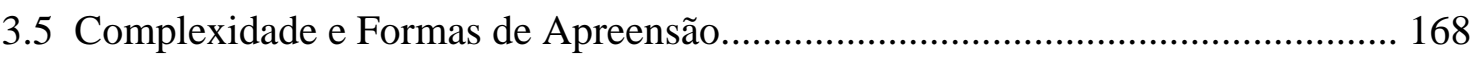

CAPÍTULO 4 - EM BUSCA DE UMA ANÁLISE DISCURSIVOPRAGMÁTICA ENTRE PARES CORRELATIVOS: UM PROCESSAMENTO

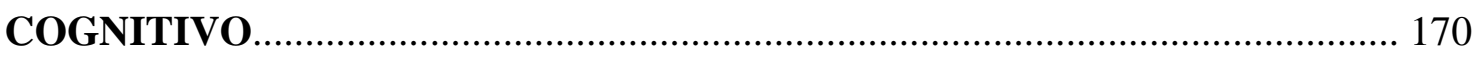

4.1 Pares correlativos adversativos e suas funções pragmáticas.................................. 171

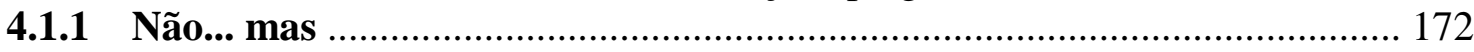

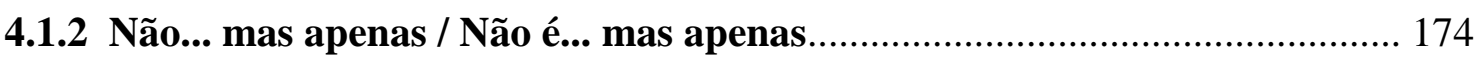

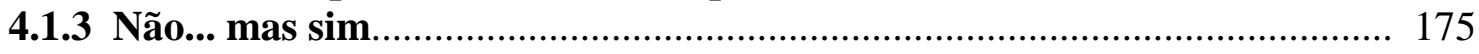


4.1.4 Não que... porém / Não que... mas / Não é que... mas que ......................... 177

4.1.5 É claro que... mas ............................................................................ 179

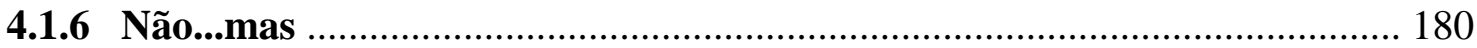

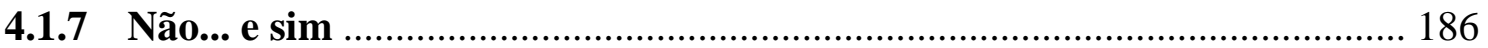

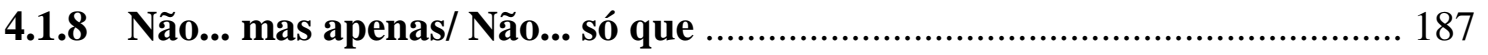

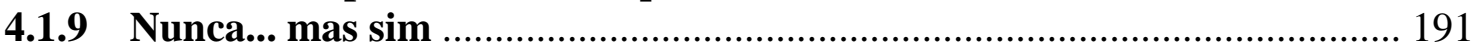

4.1.10 Nnão (V) somente... mas ........................................................................ 192

4.2 Pares correlativos aditivos e suas funções pragmáticas ........................................ 193

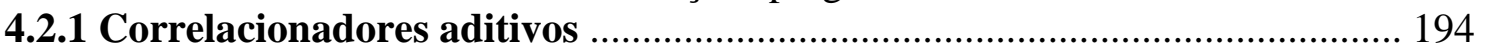

4.2.1.1 "Não só... como também"/ "Não só... mas também"/"Não somente... mas também"/"Não somente... como também"/ "Não apenas... mas também" / "Não apenas... como também" ................................................................................... 195

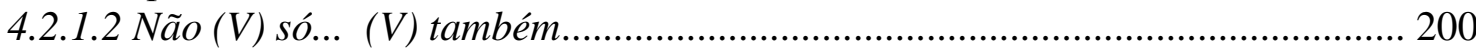

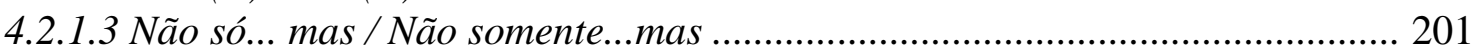

4.2.1.4 Não só... mas principalmente / Não só... mas sim ........................................... 203

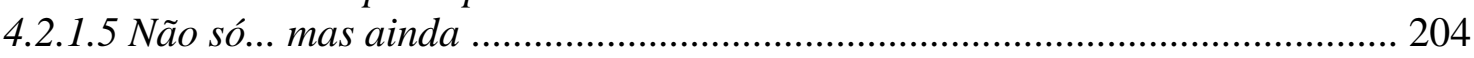

4.2.1.6 Não (V) apenas... mas (V) também / Não (V) apenas... como (V) também...... 205

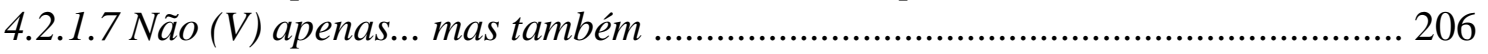

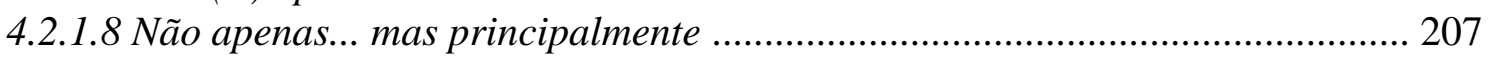

4.2.1.9 Além de... também / Além de... ainda / Além de não... nem ............................. 208

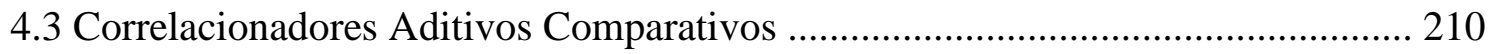

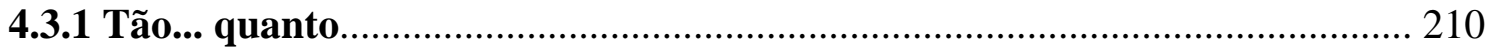

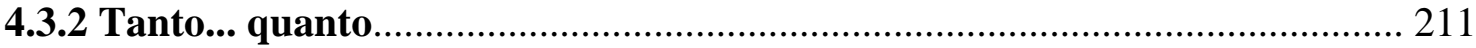

4.3.3 Tanto... como também / Tanto... como / Tanto como... quanto como/ Não só...

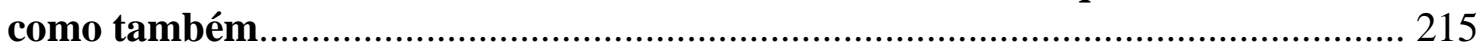

4.3.4 Não apenas... como/ Não apenas... como também / Não só... como / Não somente... como também/ Não só... bem como...................................................... 216

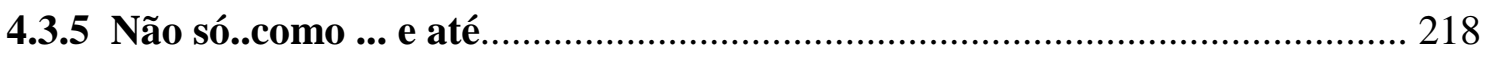

4.4 Pares correlativos consecutivos e suas funções pragmáticas .............................. 219

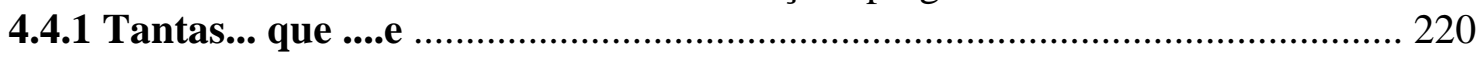

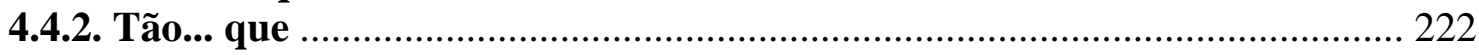

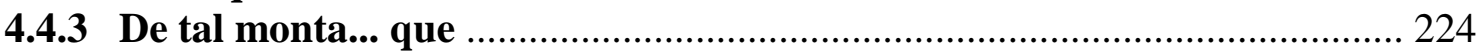

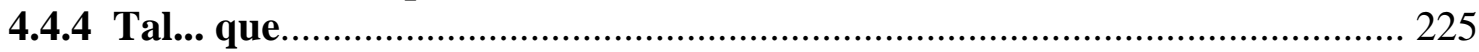

4.5 Pares correlativos alternativos e suas funções pragmáticas ............................... 226

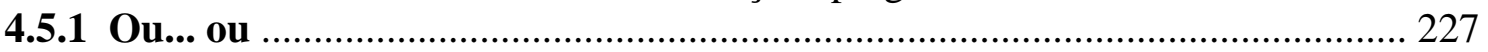

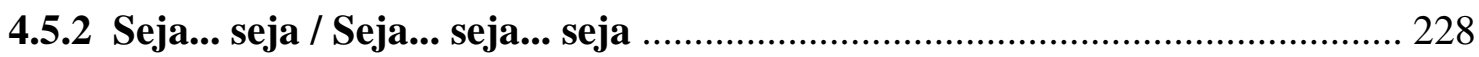

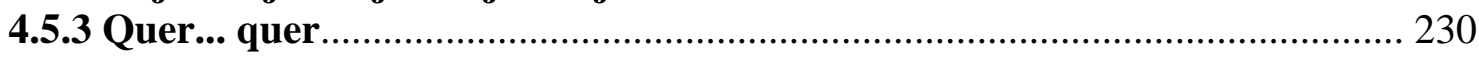

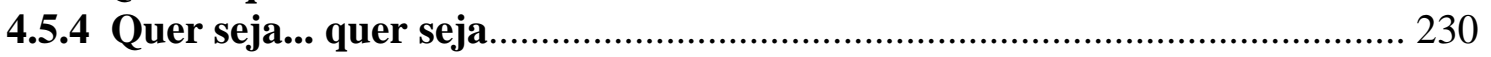

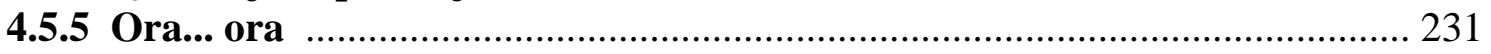

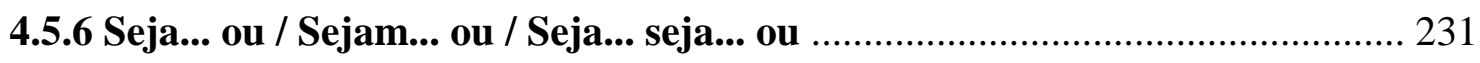

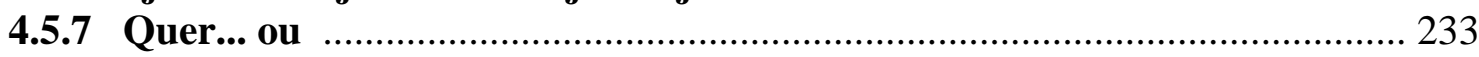

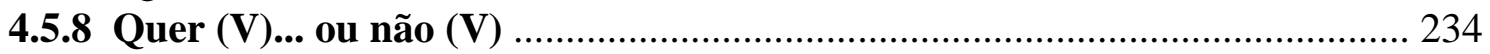

4.6 Pares correlativos comparativos e suas funções pragmáticas ............................. 235

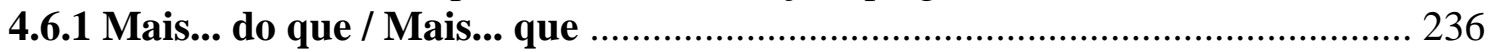

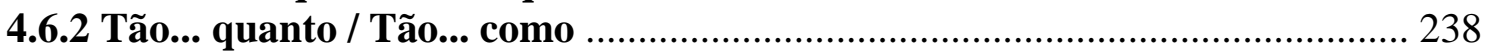

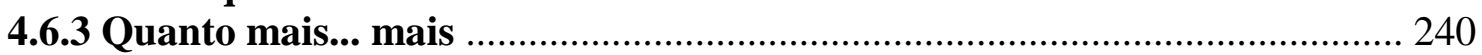

4.7 Par Correlativo Comparativo Proporcional ..................................................... 241

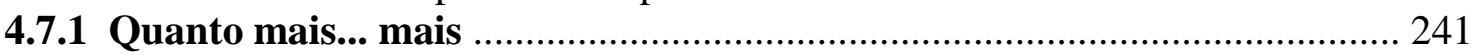

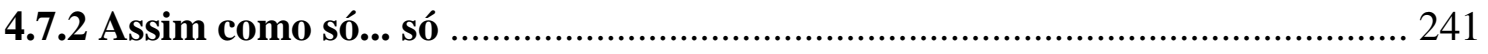

4.7.3 Não só... como também / Não só... como ..................................................... 242 
4.7.4 Tanto mais... quanto menor / Tão mais... quanto mais ............................... 244

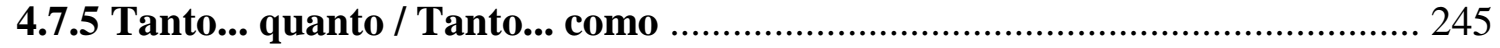

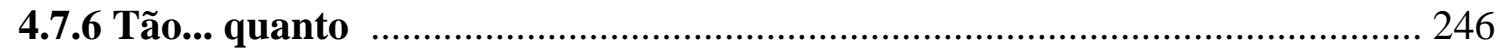

4.8 Pares correlativos concessivos e suas funções pragmáticas ............................... 247

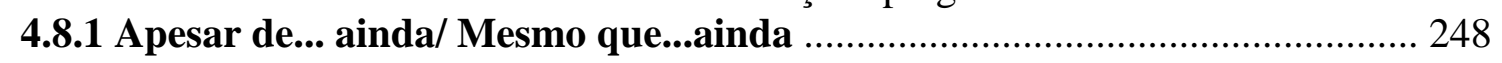

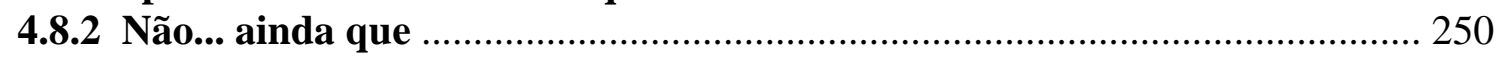

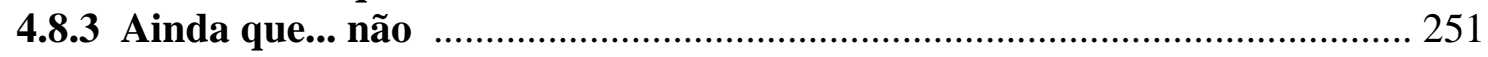

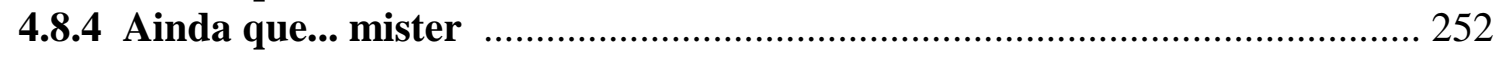

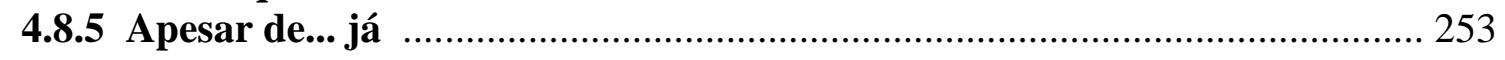

4.9 Pares correlativos condicionais e suas funções pragmáticas.................................. 254

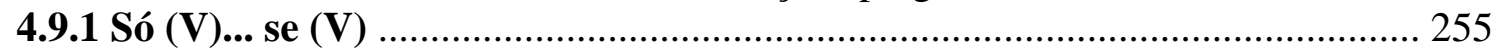

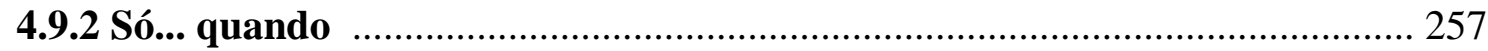

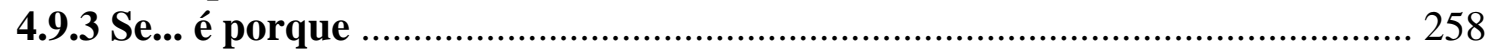

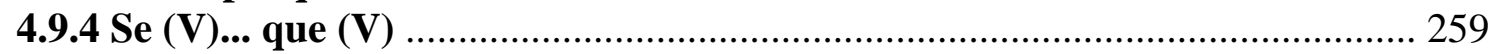

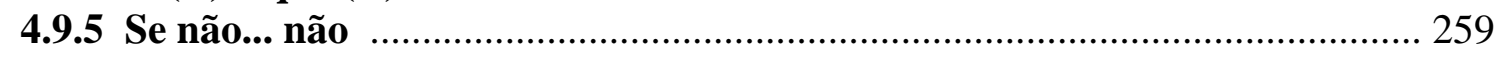

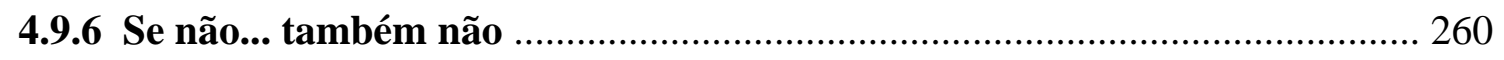

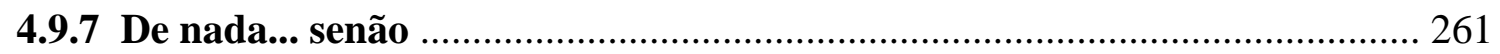

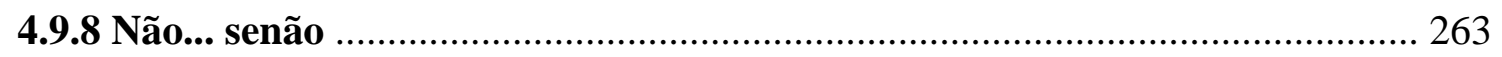

4.10 Pares correlativos proporcionais e suas funções pragmáticas ............................ 264

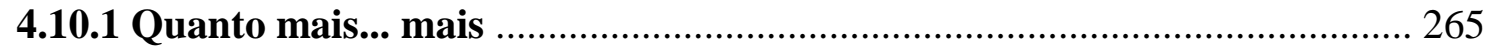

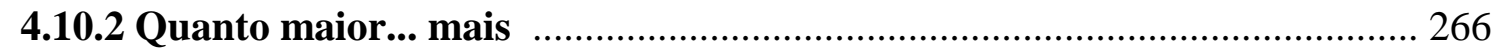

4.10.3 Quanto maior... maior / Quanto maior... maiores...................................... 267

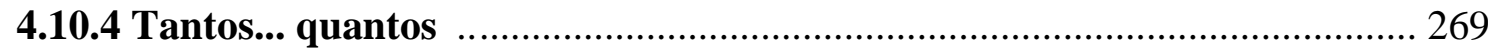

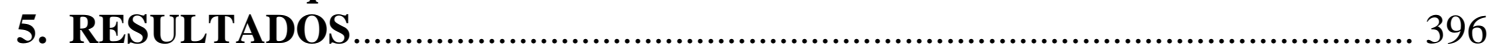

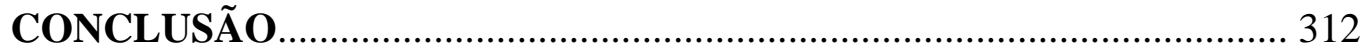

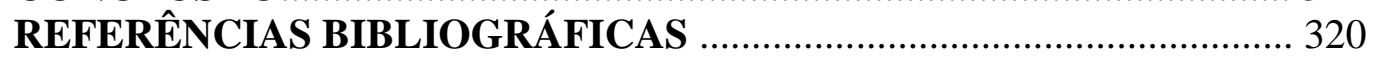


"A maneira como nós dizemos aos outros as coisas é decorrência da nossa atuação inter-subjetiva sobre o mundo e da inserção sócio-cognitiva no mundo em que vivemos" (Marcuschi, 2005,p. 52). 


\section{INTRODUÇÃO}

Esta tese tem como objetivo discutir um processo altamente complexo do ponto de vista cognitivo: pares correlativos são mobilizados para construir uma argumentação sofisticada com a intenção de convencer o outro que lê o texto. Ocorre que o caminho para isso é bem diferente daquele prescrito nas gramáticas normativas.

Por si só, o reconhecimento desse fato torna o trabalho necessário e interessante, pois seu tema pressupõe lidar com a bagagem cognitiva do interlocutor, antecipando uma informação sabidamente conhecida pelo outro. Ao mesmo tempo, cria um espaço de interlocução disparado somente num momento em que esse outro concorda com a primeira informação.

Nas redações da Fuvest, entre os anos de 2004 a 2010, corpus prioritário desta tese, encontrei pares correlatos tanto considerados normatizados como aqueles considerados diferentes porque a estratégia que o deflagra está presente na bagagem cognitiva, herdada historicamente na sociedade.

Só isso não esgotaria o que é, de fato, a correlação, pois, além dos itens que se ligam numa espécie de paralelismo sintático, há um processo sócio-cognitivo instalado nas conceitualizações que tornam símbolos linguísticos orquestrados por processos ou modos de pensar a informação. Uma dessas formas de se pensar e organizar a informação é aquela que todo ser humano tem como mais básica, a analógica. Por processos analógicos, vamos correlacionando informações, porque elas, na verdade, já estão correlacionadas na experiência humana.

Como consequência, descrevo o comportamento linguístico-pragmático que integra o conjunto das porções informativas correlatas empregadas nessas redações vestibulares, momento em que a pressão pela normatividade é bem grande. No entanto, escreventes habilidosos se utilizam dos pares que fogem ao que se espera e surpreendem o leitor com escolhas criativas que, porém, não rompem com o processamento cognitivo esperado.

Partimos do pressuposto que, quando o indivíduo adquire a língua de sua comunidade, carregada de suas experienciações sociais e culturais, conforme vai 
crescendo, outros modelos de língua compõem-se, de modo a torná-lo um sujeito, evolutivamente, adaptável, compartilhador e competente.

Com isso, os seres humanos somente dominam plenamente o uso dos símbolos linguísticos a que estão expostos depois de alguns anos de interação, praticamente contínua, com os outros usuários que se utilizam desses mesmos símbolos e, para isso, acreditamos que o ambiente, ligado aos aspectos culturais que o subjacem, interfere na condição da aquisição da língua.

Linguagem e mente compõem um complexo integrado presente no cérebro humano, que mapeia imagens advindas de regiões que, provavelmente, operam em conjunto para produzir selves ${ }^{l}$ que impulsam o processo de evolução humana.

Aquilo que recebemos como informações que se emulam, como num efeito catraca $^{2}$, alavancam-se para outras informações. Nesse processo, entendemos que estados mentais contínuos, num fluxo da mente, são atinados pela consciência.

No capítulo 1, apresento a fundamentação teórica, sob as bases funcionalistas e cognitivas. Na primeira, aponto o papel da língua em uso de sua gradação, cujos itens lexicais modificam-se e sinalizam para um processo de gramaticalização entre as porções informativas, que se organizam de acordo com as intenções comunicativas do falante/ autor. Na segunda, demonstro como a cognição faz parte da aquisição da linguagem humana, por meio da ontogenia e da filogenia, responsáveis pela maturação sociocultural e adaptativa.

Discuto também de que forma a cognição se manifesta dentro de um sistema comunicativo, a partir das experiências físicas e socioculturais, capazes de dar conta dos ambientes a que o falante está exposto. Demonstro como isso se dá por meio dos estágios selvianos da mente humana ${ }^{3}$, responsáveis pela busca e mobilização de material

\footnotetext{
1 Selves são os estágios pelos quais a mente atravessa no decorrer da evolução humana. Este conceito será aprofundado no capítulo1.

${ }^{2}$ Segundo Tomasello, Kruger e Ranner (1993), um indivíduo ou grupo de indivíduos primeiro inventou uma versão primitiva do artefato ou prática, e depois um usuário ou usuários posteriores fizeram uma modificação, um "aperfeiçoamento" que outros então talvez adotaram sem nenhuma alteração por muitas gerações, até que algum outro indivíduo ou grupo de indivíduos fez outra modificação, que então foi apreendida e usada por outros, e assim por diante ao longo do tempo histórico de acordo com o que às vezes é denominado "efeito catraca".

3 Damasio (2005) defende a ideia de que há uma relação entre cérebro, corpo - propriamente dito (organismo) e meio ambiente. Segue-se daí que a consciência não é "algo dado", mas um processo que resulta da nossa história evolutiva. Para a construção de uma mente consciente, há um desenvolvimento de processos evolutivos do self (en-consciente)
} 
linguístico e pragmático, presentes na consciência, que se concretizam num discurso calcado numa gramática emergente funcional.

É nosso alvo discutir a influência dos princípios da iconicidade, marcação e plano discursivo os quais têm uma relação direta com a funcionalidade da língua e da mente presentes na consciência.

Pelo princípio da iconicidade, mostrarei, por meio dos trechos produzidos pelos candidatos, como a estrutura da dinamicidade, na língua, se reflete na busca pela experiência social e cultural subjacente à consciência. Por esse princípio, demonstrarei de que forma o comportamento do par correlato está diretamente ligado às ideias que o autor quer estabelecer entre as porções informativas. A relação entre forma e significado, por conta da motivação discursivo-pragmática, torna-se aparentemente arbitrária. Isso está diretamente ligado às intenções do autor: pelo subprincípio da quantidade, distribui conteúdo de itens lexicais entre as porções, de acordo com suas necessidades: mais informação, mais forma, pois há maior complexidade, no caso dos textos analisados, para convencer o leitor, argumentando; pelo subprincípio da integração: conteúdos mais próximos cognitivamente, também estão mais integrados, isto é, mente e sintaxe se correlacionam; pelo subprincípio da ordenação linear, os eventos descritos estão linearmente dispostos de modo a espelhar os propósitos comunicacionais do candidato.

Pelo princípio da marcação, apontarei de que forma um item mais marcado se faz presente por conta do contexto a que está inserido e também pela força argumentativa e expressiva que confere ao trecho uma identidade entre o autor e o leitor. Percebe-se que, a partir do momento em que o candidato lança mão de um par correlativo diferente do instituído pela norma culta, é porque busca, na e pela língua,

por meio de etapas a saber: a primeira específica que o cérebro constrói a consciência gerando um processo de self em uma mente em estado de vigília. A essência do self é o enfoque da mente sobre o organismo material que ele habita. A segunda parte da hipótese supõe que o self é construído em estágios. O estágio mais simples tem origem na parte do cérebro que representa o organismo (protosself) e consiste em uma reunião de imagens que descreve aspectos relativamente estáveis do corpo e gera sentimentos espontâneos do corpo vivo (os sentimentos primordiais). $\mathrm{O}$ segundo estágio resulta do estabelecimento de uma relação entre o organismo (como ele é representado pelo protosself) e qualquer parte do cérebro que represente um objeto a ser conhecido. O resultado é o self central. $\mathrm{O}$ terceiro estágio permite que múltiplos objetos, previamente registrados como experiência vivida ou futuro antevisto, interajam com o protosself e produzam pulsos de self central em profusão. O resultado é o self autobiográfico. Os três estágios são construídos em espaços de trabalho separados, mas coordenados. São os espaços de imagem, a arena onde se dá a influência da percepção corrente e das disposições contidas em regiões de convergência-divergência. 
um recurso pragmático, a fim de relacionar dados, ideias, muito próximos da realidade que o cerca.

Pelo plano discursivo, observar trechos argumentativos, divididos entre fundo (porções periféricas, baixa produtividade) e figura (porções centrais, maior complexidade) é entender as causas e as finalidades presentes nesse processo: lançar informações já conhecidas, a $1^{\mathrm{a}}$ porção, e informações novas, na $2^{\mathrm{a}}$ porção, é um jogo estratégico do candidato, para enfatizar, realçar, pela figura, fatos que o remeterão a convencer a banca examinadora sobre seus apontamentos.

No capítulo 2, discorro sobre a correlação, objeto da tese, nos diversos campos do conhecimento e suas diferentes abordagens, em especial, duas delas: a gramatical, que a concebe como aquela adotada pelo indivíduo para relacionar orações por meio de elementos fixos e cristalizados à luz do processo coordenativo ou subordinativo, desfocados das intenções pragmático-discursivas do falante; e a linguística, que vê na correlação um processo instaurado por um elemento morfossintático atrelado a outro, que serve como gatilho psicológico.

Também fará parte da apresentação desse capítulo mostrar as contribuições de cada teórico, de como entende a correlação e de que forma elas se instalam dentro de um continuum relacionado entre os termos.

Discutirei por que a negação é mais marcada com respeito à complexidade das pressuposições pragmáticas que caracterizam o contexto discursivo no qual elas podem ser apropriadamente usadas. Os dados mostram que a negativa está na porção menos complexa, mas é o gatilho para criar porções informativas altamente complexas, que é a correlação.

Ao final desse capítulo, trarei alguns apontamentos a respeito da correlação presente num processo cognitivo, cujo fluxo informativo se dá por um esforço mental e interacional, que visam a atender as expectativas tanto do autor como do leitor. No caso das análises, verifica-se um processo usual presente nos expedientes retóricos a fim de realçar partes de informação para mobilizar o interlocutor.

No capítulo 3, explico, respectivamente, de que forma os dados foram coletados e analisados. Apresentarei, ainda, algumas considerações a respeito do ensino de língua atrelado à produção textual, dicas de instituições e de materiais didáticos que 
apontam como os candidatos devem escrever seus textos de forma a atender a expectativa da banca examinadora.

Também é importante salientar que descreverei e analisarei cada tema da Fuvest, entre os anos de 2004 a 2010, a fim de se entender a complexidade temática que, a cada ano, tem exigido do candidato uma habilidade não somente referente aos aspectos linguístico-estruturais, mas também à organização das informações que satisfaçam a proposta exigida.

As ocorrências de cada par correlativo foram divididas por funções assumidas e funções de comportamentos linguístico-discursivos analisados sob o enfoque funcionalista, calcado nos princípios da iconicidade, marcação e plano discursivo.

É importante salientar que farão parte de nossa análise somente os textos considerados melhores pela banca, entre os anos de 2004 e 2010. Não será foco de nossa análise os textos considerados piores por conta da baixa quantidade de presença de pares correlativos apresentados pelos candidatos, que na maior parte utilizam-se das aditivas e adversativas, para somente aproximar ou não itens lexicais, conforme apontamentos no capítulo de análises.

Para o capítulo 4, há a análise dos dados de acordo com o comportamento funcional e a natureza do padrão percebida. Apresentarei uma tabela distribuída pelos papéis semântico-discursivos, apontados nas estruturas da tese, desenvolvimento e conclusão.

Buscarei entender os mecanismos utilizados por meio das escolhas feitas pelo autor, a forma como influenciam a distribuição das informações entre as porções, os valores semânticos que assumiram por conta das intenções discursivo-pragmáticas do autor, como o autor busca, em suas experiências sociais e culturais, itens que refletirão em que fase do estágio da mente e consciência busca material linguístico adequado.

Faz parte da metodologia desta tese apresentar hipóteses sobre alguns motivos que levam a uma prática pedagógica de aquisição de língua, muitas vezes, calcada numa relação assimétrica, em que se busca o conhecimento considerado como mecânico e pronto, nunca passível de mudança, de ressignificações. 
Para a conclusão, esta tese encaminha alguns apontamentos sobre as hipóteses e se elas se confirmam a partir do comportamento dos pares correlativos, dos papéis e valores semânticos assumidos diante das opções do autor.

Também faz parte de nossas considerações finais, apontar de que forma entendo a língua dentro do processo de gramaticalização, as atitudes linguísticas frente à adequabilidade e ao contexto que viabiliza a ocorrência dos pares correlativos, dentro do uso discursivo-pragmático, a influência dos princípios funcionais da iconicidade, marcação e plano discursivo e a interferência no uso mediado pelos estágios da consciência selfiana.

E por fim, apontarei alguns direcionamentos que se encaminham para a função que a escola deve assumir frente ao ensino aprendizagem, no tocante à aquisição da língua materna. 


\section{CAPÍTULO 1 - FUNDAMENTAÇÃO TEÓRICA}

\subsection{As bases funcionalistas}

São bases para o desenvolvimento desta tese os pressupostos teóricos da linguística funcionalista. Nesse modelo, concebe-se a língua como um fenômeno maleável que pode ser moldado de acordo com a situação real a que o falante está submetido em suas interações sociais.

Sendo o funcionalismo uma corrente linguística cujo foco de interesse é o estudo da estrutura gramatical das línguas ${ }^{4}$, baseia-se na ideia de que a língua é um instrumento de interação social atrelado à competência linguística do falante, às funções cognitivas e sociais. Esses seriam os fatores fundamentais na organização e reorganização da codificação linguística, o que permite afirmar que os contextos de uso remetem a aspectos culturais, sociais, temporais, regionais, históricos, ligados às intenções e pressionam, assim, as escolhas do falante.

Para isso, um conjunto de assunções funcionalistas servirá de aporte para nossas investigações (Halliday, 1973, 1985), o qual defende a ideia de que as formas da língua são meios para um fim, não um fim em si mesmas, em que o falante faz suas escolhas e as seleciona simultaneamente de acordo com suas necessidades. Com o auxílio da gramática, faz suas opções a partir de componentes sintático, semântico e pragmático (Dik, 1997; Givón, 1984; Hengeveld, 1997; Neves, 2006) e que, susceptível às pressões de uso (Dubois, 1993), faz do discurso um evento comunicativo (Beangrande, 1993) calcado na sua competência (Martinet, 1994).

Entende-se que a língua deve ser concebida como um instrumento de interação social (Dik, 1978, 1989) que preze as intenções, a própria informação e a interpretação do interlocutor, a partir de uma gramática, cujos embasamentos cognitivos (Martelotta,

\footnotetext{
${ }^{4}$ Os funcionalistas são motivacionistas por essência, já que acreditam que a forma das línguas não é arbitrária, mas motivada ou icônica, refletindo processos mentais, referentes ao trato com as informações nas diferentes situações de comunicação. Assim,o funcionalismo defende a ideia de que, sendo a linguagem uma habilidade inerente ao homem, a estrutura linguística revela as propriedades da conceitualização de que o homem faz do mundo, através das restrições de funcionamento da sua mente. (Martelotta, 2006, p. 246-247)
} 
2011) estejam lincados com unidades linguísticas, inerentes à organização dos eventos que se adaptam a contextos advindos da criação de novos significados.

Um processo que tem encontrado abrigo nessa concepção funcionalista é a gramaticalização, uma mudança linguística por meio da qual alguns elementos de conteúdo lexical se desenvolvem, no decorrer do tempo, e tornando-se elementos gramaticais e, uma vez gramaticalizados, continuam a desenvolver novas funções gramaticais (Hopper \& Traugott, 1993); é um processo unidirecional, maleável, emergente, que se inicia por meio de fatores que se encontram fora do sistema de estrutura linguística (Heine, 1991), que, acoplados a fatores internos, compõem o fluxo informativo (Chafe, 1987), controlado por um fluxo de atenção e um ponto de vista (De Lancey, 1981), o qual determina a sequência de combinações lexicais discursivopragmáticas a fim de, intencionalmente, atender a propósitos comunicacionais: “estrutura da língua reflete a estrutura da experiência" (Croft, 1991), em que existe uma proximidade icônica entre a combinação de formas linguísticas extensas ou complexas com as de natureza conceptual, numa construção gramatical (Goldberg, 1995).

O fluxo das informações determina a ordenação linear dos sintagmas nominais na frase, a qual se organiza, altera-se a fim de puxar o fluxo de atenção. Prince (1980) aponta que existem princípios e restrições para a inserção de informações dentro das cláusulas, no discurso.

Uma das principais características da linguagem humana diz respeito à singularidade da capacidade de integrar e mobilizar grupos sociais que, historicamente, evoluíram por conta de suas atividades sociocomunicacionais. Desde criança, habilidades como entender seu co-específico da espécie e suas intenções, compreender os diferentes papéis sociais atribuídos a nós enquanto falamos ou ouvimos, dentro do fluxo informativo, perceber nosso papel social no mundo que nos cerca, compartilhando símbolos linguísticos permitem, intersubjetivamente, transformar nossa percepção de ver o outro e correlacionar, interagir com o outro, no jogo da subsistência humana. 


\subsubsection{Língua em uso e gradação linguística}

Entendo a linguagem como um instrumento processual adaptativo e sociocognitivo, em que homens, por meio de convenções sociais, conseguem criar e recriar símbolos e construções linguísticas, a partir da criação de outras, já existentes. É um indício de que língua, transformação e uso são elementos-chave para compreensão do seu funcionamento; e, para isso, esta tese tem Tomasello (2003) como teórico que subsidiará seus apontamentos e análises.

Assumirei a postura teórica cognitivista, que entende a linguagem atrelada à cognição (Langacker, 1987) como um conjunto de sistemas conectados, que envolve a linguagem e nossas percepções experienciais de ver o mundo, por meio dos sentimentos e informações socioculturais que carregamos durante a vida. Nesse sentido, a gramática não pode ser vista como um conjunto de regras fixas, independentes do conteúdo que veiculam aquilo que desejamos expressar, mas sim um conjunto de itens lexicais que se combinam e recombinam a partir das estratégias interativas ligadas a um redimensionamento de sentido, forma e função, a fim de atender ao que o falante pensa, suas crenças, atitudes, valores, persuasão e negociação (Traugott e Dasher, 2005).

Para Bybee (2003), não há uma existência autônoma, não adaptável, não experienciada quando tratamos de gramática, ela é constantemente reconfigurada, dinâmica, que sofre mudanças em relação à estocagem local e ao processamento em tempo real à medida que é organizada e reprojetada na mente humana.

Entendo que a língua é multifuncional; um sistema não autônomo (Givón, 1985), sujeita a pressões oriundas de diferentes situações de comunicação que auxiliam a determinar sua estrutura gramatical (Martellota, 2011). Por conseguinte, o sujeito processa estruturas à utilização de diversos mecanismos linguísticos ligados ao contexto de uso, a fim de satisfazer sua performance linguística.

É um dos focos de análise para os funcionalistas entender de que forma os usos gramaticais se reconfiguram para atender a novos objetivos pragmáticos. Sabe-se que a adaptação das estruturas sintáticas é fato recorrente e que muitas mudanças ocorrem por 
conta da situação de interação ${ }^{5}$, pois as intenções do falante podem impactar eventos específicos de uso e, também, a organização textual. Sendo assim, considero o texto "um evento comunicativo em que convergem ações linguísticas, sociais e cognitivas" (Beaugrande, 1993, p. 10), que, numa perspectiva sociointerativa (Marcuschi, 2008), o interlocutor produz discursos, conjunto de informações coesas e coerentes, de acordo com o gênero discursivo, que o remete à forma de linguagem, às sequências discursivas, às informações, aos argumentos, em que a interação se conforma textualmente sob pressão.

Essas questões movem-se à observação de como diferentes estruturas linguísticas carreiam funções ${ }^{6}$ semelhantes, via processo de correlação. É propósito desta tese entender de que forma o indivíduo busca, ao escrever um texto dissertativoargumentativo, numa situação formal como a de um vestibular, elementos funcionais ligados à sua experiência autobiográfica de mundo, diferentemente daqueles esperados para tal situação, isto é, os mais normativizados, advindos de aulas, material didático, de exposição docente, da própria exigência da escola. Mais especificamente, nas correlativas, o sujeito-autor une porções informativas a fim de argumentar em favor daquilo que pensa e defende, busca na e pela vivência social e cultural atinada à sua língua, fatos que se concretizam e se dividem entre os períodos e atendam às suas necessidades comunicacionais e funcionais. Para isso, integra componentes sintáticos, semânticos e pragmáticos (Givón, 1984) interativos, que lincados à pragmática, confere texto ao autor-falante como a seu interlocutor uma convergência conectiva e discursiva:

Ao falarmos de discurso articulamos o enunciado sobre uma situação de enunciação singular; aquilo que lhe confere uma unidade, que o torna uma totalidade e não um simples conjunto de frases. (Adam, 1999, p. 40).

\footnotetext{
5 “A interação verbal é uma atividade estruturada (com regras, normas e convenções), mas também é uma atividade cooperativa e, desse modo, ativam-se, na linguagem (que é sempre uma interação), dois sistemas de regras: as que regem a constituição das expressões linguísticas (regras sintáticas, semânticas, morfológicas e pragmáticas) e as que regem o modelo de interação verbal no qual as expressões são usadas (regras pragmáticas)." (Neves, 2006, p. 13).

6 Assumimos a concepção de função calcada em Dillinger (1991), que vê o termo usado na linguística para designar relações entre uma forma e outra, uma forma e seu significado e entre o sistema de formas e seu contexto. Também Anscombre \& Zaccaria (1990) e Halliday (1973) que entendem função como uma entidade linguística constituída pelo papel que desempenha no processo comunicativo.
} 
Para Martelotta (2011), os usuários de uma língua são sensíveis à sua mudança, haja vista quando se observa o comportamento de algumas pessoas que se mostram "descontentes" em relação a novos usos. O autor aponta como exemplo para tal situação o uso frequente do gerúndio "em funções não previstas em seu valor tradicional: vamos estar mandando a mercadoria amanhã ou eu gostaria de estar falando com o senhor, por favor" (Martelotta, 2011, p. 38). Isso mostra que os usuários percebem a mudança linguística e são suscetíveis a ela. Chamamos atenção para o fato de que a mudança dos itens de uma língua sinaliza a necessidade que o falante tem de acionar outros mecanismos linguísticos para dentro das estruturas a fim de obter interação, novas negociações de sentido para promover a comunicação.

Para Croft (2008), o conhecimento gramatical não está somente atrelado à estrutura representacional localizada na mente do falante, também tem relação ao campo da Psicologia, nesse sentido, o analista deve se voltar às questões relativas ao papel social que o usuário assume frente ao mundo em que vive, o que representa, os diversos enunciados associados a contextos, associação entre o que o mundo representa e é representado.

Sendo assim, o autor aponta que o uso dos enunciados determina a representação das unidades gramaticais na mente do falante, em que, cada vez que uma palavra ou construção é usada, ativa um modo ou um padrão de modos, em que a frequência condiciona o armazenamento da informação como "uma unidade gramatical convencional" (Croft, 2008, p. 377).

Para Dik, o usuário de uma língua é muito mais que um "animal linguístico" (1989, p. 3), pois, em seu uso, outras funções estão envolvidas nessa capacidade: epistêmica, em que o falante arquiva um item linguístico e o recupera em outras expressões; lógica, em que é capaz de extrair por meio de lógica do raciocínio outras parcelas de conhecimento linguístico para readequá-las; a perceptual, em que o falante percebe o ambiente, busca um item linguístico de sua percepção e assim produz outros itens ou os interpreta; a social, em que o usuário sabe o que e como dizer numa situação comunicativa, a fim de atingir objetivos comunicativos particulares.

Partimos do mesmo princípio institucionalizado por Dik (1989) a respeito do sistema de regras que regem a língua, do ponto de vista funcional: de um lado, as que constituem as expressões linguísticas por meio da sintaxe, morfologia, fonologia e da 
semântica; do outro lado, padrões de interação verbal instados para sua realização, que atendam a propósitos pragmáticos.

Em outras palavras, entender o papel de cada mecanismo linguístico, à luz do funcionalismo, é aceitar o fato de que para cada regra existe uma funcionalidade subjacente ao modo de uso de cada expressão e, com isso, é fundamental apontar que "não cabe uma análise generalista" (Dik, 1989, p. 3), pois cada item assume uma forma/função a partir das intenções de cada falante, isto é, existe uma interação pragmática instalada dentro de cada realização, outro fator relevante à análise de um evento linguístico.

O autor defende que uma análise mais apurada de fatos linguísticos se dá "por meio da sistematicidade da linguagem" (Dik, 1978) sob o prisma do "usuário da língua natural" (Dik, 1978). Isso quer dizer que as expressões linguísticas devem ser pensadas não como objetos isolados, mas como instrumentos que são usados pelo falante para evocar no ouvinte a interpretação que deseja.

Para o autor, ainda, a gramática tem de ser vista como uma construção tripartida: "um gerador computacional, um interpretador e estocador de informações" (Dik, 1989, p. 17), em que, por exemplo, numa estrutura subjacente a uma cláusula, cujos elementos operam em diferentes níveis de complexidade, existe uma mediação entre as escolhas elencadas para formar essa rede de itens linguísticos, relacionados uns aos outros, e as intenções reais de cada uma de suas realizações, em que o sujeito busca de suas experiências determinado elementos àquela situação.

Dik (1978) conceitua que a função pragmática que a língua carrega está ligada ao estatuto informacional dos constituintes em relação à situação comunicativa em que são usadas, distintos por ele em: "topicidade" (1978, p. 2), voltado à caracterização das coisas de que falamos; e o de "focalidade" (1978, p. 2), partes daquilo que consideramos mais relevantes, isto é, focalizarmos para o interlocutor o que nos chama atenção dentro do fluxo informativo. Junto deles, o autor ainda aponta existirem os “constituintes extrafrasais" (1978, p. 2), responsáveis pelas funções pragmáticas: monitoramento do que se fala, como, com quem se fala, contexto, ligados aos aspectos do mundo, traços sociais e culturais, representados pelo esquema a seguir: 


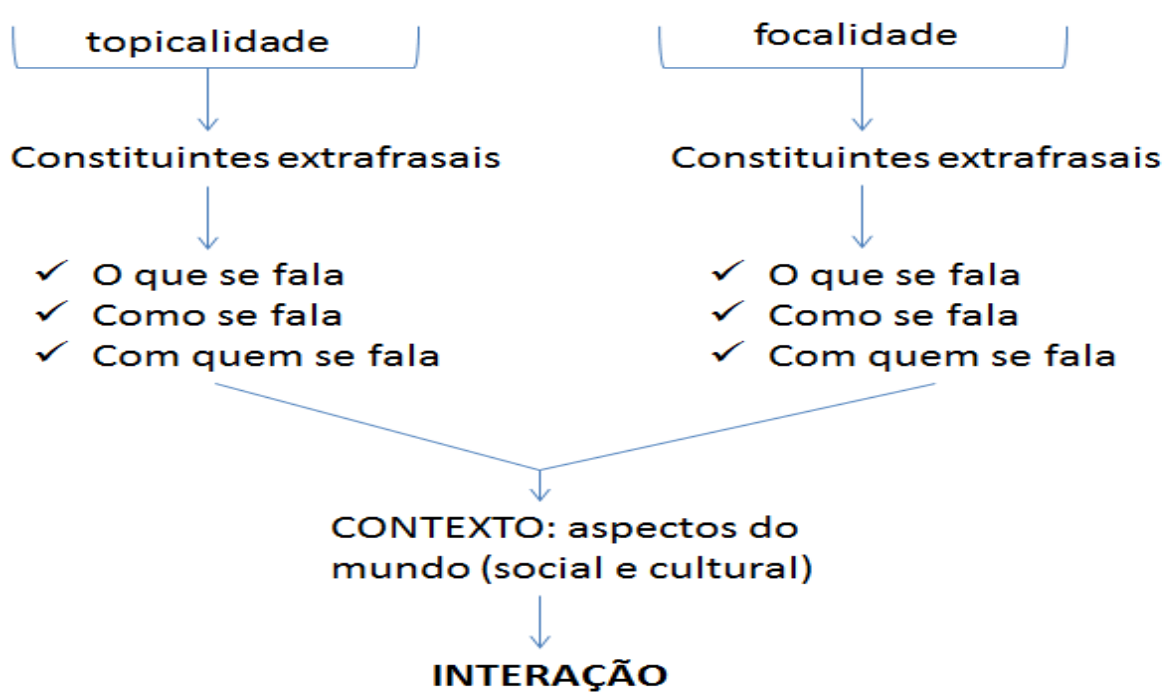

Esquema 1. Constituintes extrafrasais - modelo de Dik (1989)

Ao esquematizar os apontamentos de Dik (1989), chamamos atenção ao contexto que direciona as marcas linguísticas intencionais do falante; assim como o topicalização e a focalização.

Neves (2004, p. 110) aponta para a flexibilidade da gramática, por constituir uma estrutura cognitiva, sensível e ajustável, adapta-se e se acomoda devido às pressões de ordem comunicativa ${ }^{7}$ em que o falante substitui material linguístico antigo por novos, busca pela memória um repertório de estratégias de construção de discursos e agrupando-os de modo improvisado.

Anteriormente, Coseriu (1979) apontava que se tem um sistema de interrelações ressistematizados por meio de feixe de relações imbricadas, que constitui a língua. Isso permite compreender que os elementos linguísticos rotinizados pela regularização, ao serem falados ou escritos de acordo com o gênero a que pertencem, reaparecem de outra forma e até função; saem de sua habitualidade e reaparecem, discursivamente.

\footnotetext{
${ }^{7}$ Essa ideia é referendada também por Bybee e Hopper (200, p.7): “[...] e a gramática é [...] o agregado maleável e internalizado das formações vindas da língua em uso" - do discurso, das experiências com a intenção lingüística que acumulamos durante a vida."
} 
Utilizamos de formas gramaticais com as quais nos familiarizamos, isto é, daquelas com que temos maior contato, vêm de nossas experiências; mas, quando existe uma rotinização excessiva, o item linguístico "que possui uma função, avizinha-se com a qual lhe deu origem, e assim, adquire novos traços semânticos e estruturais em comuns ou próximos" (Tavares, 2012, p. 36). Assim, pode-se apontar que a gramática é composta por esquemas e padrões rotinizados, que são generalizados das estruturas que mais frequentemente são mobilizadas para preencher os objetivos comunicativos do falante. (Englebreston, 2007, p. 89).

Quaisquer porções linguísticas como expressões idiomáticas, clichês, provérbios entre outros, tendem à fixação e rotinização na língua e também são sujeitas a pressões contextuais, como qualquer outra expressão (Hopper, 1987). Não há como negar que elementos recorrentes, na língua, fazem parte da sua gramática, pois preenchem um espaço sintático e, assim, acabam inerentes à utilização e à representação cognitiva do falante, que os lança ao discurso todas as vezes que achar necessário.

Mediante a esses apontamentos, pode-se, então, conceber a língua como um sistema de produção do falante-escritor, carregada de informação, que se codifica por meio da necessidade de criar, expressar pensamentos, reenquadrá-los, recodificá-los, por conta da interação de cada sujeito, historicamente marcado por meio de seus discursos, que os situa e os coloca como primata interativo.

Se a escola teve como papel a transmissão dos elementos que perfazem a norma culta, sistematizada na língua, com princípios e valores formais embutidos nesse fenômeno e, principalmente, de como e por que utilizar-se deles nas situações como a de um vestibular. A utilização de um elemento diferente daquele prescrito na cultura tradicional exigido, por exemplo, nas aulas de língua, sinalizaria que o uso ligado a pressões dos fatores externos e internos sobrepõe-se de tal forma que há de se considerar a gramática como um instrumento revestido com uma "maleabilidade" (Bolinger, 1977 e Hopper, 1987), dinâmico, provisório, o que configura a existência de “categorias não discretas" (Neves, 2010).

Mediante a isso, o esquema explicativo a seguir, tem como objetivo mostrar o dinamismo da língua e as influências dos fatores (interno e externo) subjacentes a ela: 


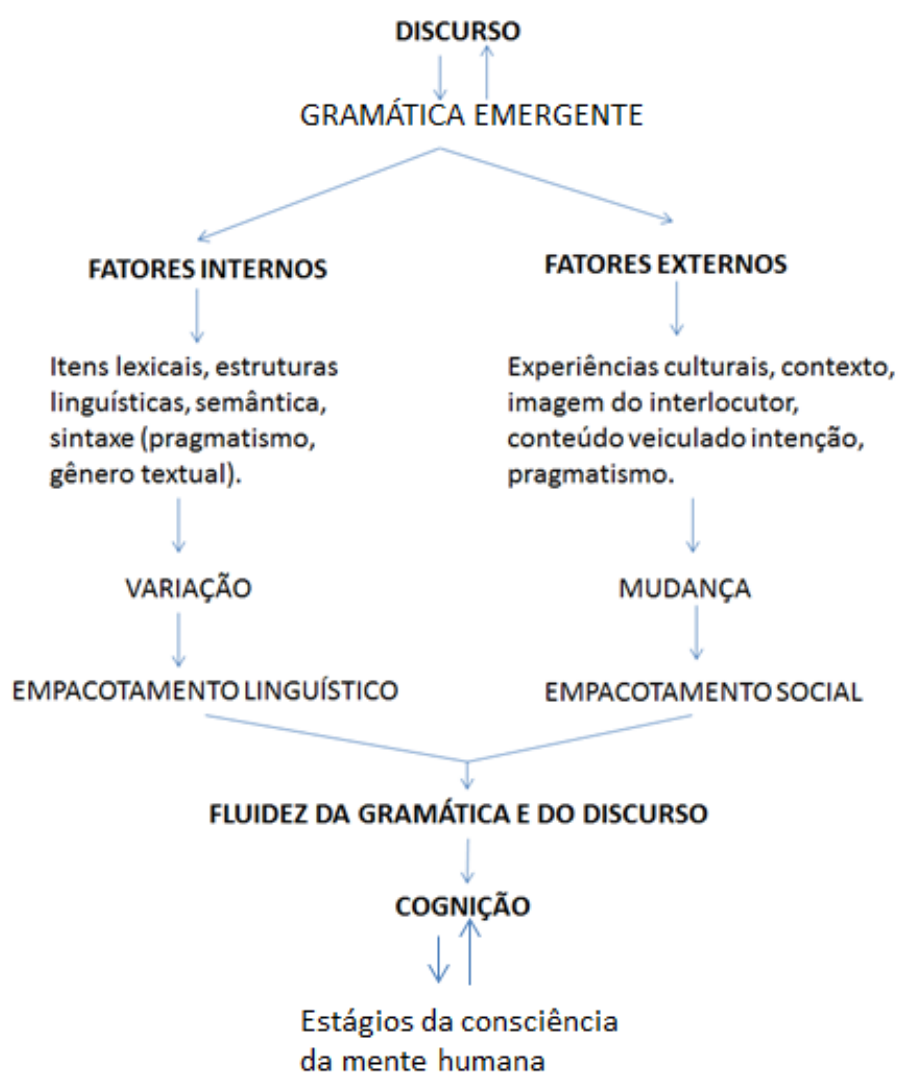

Esquema 2. Dinamismo da língua.(Neves, 2006, adaptado).

Quanto à aba do discurso e gramática, a sistematização convencional seguida pelo usuário que, dentro de uma regularidade, obedece aos padrões da língua, para que haja uma codificação com seu interlocutor, recebe o nome de gramática (Furtado da Cunha, 2003), de tal forma imbricada no discurso que faz o candidato, ao escrever seu trecho argumentativo, se ater a esses dois domínios: o gramatical, atrelado à organização cognitiva de experiências com a língua, pois sabe que, quanto mais se aproximam de um padrão sistemático, normativo, mais aceitabilidade terá seu texto quanto às exigências de um vestibular; e o do discurso, voltado à organização das expressões linguísticas a fim de que os usuários usem o conteúdo das informações para ajustarem-se aos seus interlocutores, sujeita à menor previsibilidade e sistematização, haja vista que o objetivo é o de acoplar itens lexicais, dentro das porções informativas, para tornar mais clara a mensagem e atender às suas necessidades reais.

Quanto aos fatores internos, ligados à mudança estrutural e combinação de oração, a fim de atender a usos específicos, contribuem para que uma forma possa assumir configurações distintas que transmitam um mesmo conteúdo informativo, isto 
é, a língua apresenta uma mudança estrutural para eventos sociais a que o falante estiver exposto, e isso vai se processando num empacotamento linguístico, e é por isso que a gramática é fluída e imbricada no discurso e vice-versa. Quanto aos fatores externos, têm-se as experiências sociais que, ligadas à cultura social, fazem com que o falante combine e recombine imagens que têm do interlocutor, o conteúdo explicitado, o contexto, as intenções, em um empacotamento social que se mobiliza e se modifica conforme esses aspectos.

Entendemos que a mudança ocorre por meio da evolução do homem, da historicidade de sua linguagem, por meio do contato social, da necessidade de pensar, comunicar conteúdos que, ao longo da própria experiência humana, ressignificam e, dentro de um processo, recaem na variação que se adapta e se reconfigura.

Entende-se, assim, que gramática e discurso, imbricados dentro de um processo cíclico, acionam tanto mecanismos subjacentes aos fatores internos, quanto aos fatores externos da língua. O que nos leva a defender essa acepção é que partimos da premissa da língua como instrumento cujos mecanismos são acionados para atender às necessidades comunicativas: estruturas gramaticais estão a serviço do uso para fins comunicacionais; isto quer dizer que a forma em que a língua se apresenta reflete, hipoteticamente, a função atrelada às situações sociocomunicativas:

Não há uma gramática no sentido de uma área da linguagem que é colocada à parte como repositório de uma estrutura abstrata. Ao contrário, há somente tipos de repetição, algumas das quais concernem ao que se têm chamado mais convencionalmente lexicais, algumas idiomáticas, e algumas morfológicas ou gramaticais (...). A gramática de uma língua, então, consiste de um único sistema delimitado, mas de uma coleção de formas ilimitadas que estão constantemente sendo reestruturadas e ressemantizadas durante o efetivo uso. (Hopper, 1998, p. 158-159). ${ }^{8}$

\footnotetext{
8 "What would more conventionally be called lexical, some idiomatic, and some morphological or grammatical (...). The grammar of a language, the, consists not a single delimited system, but rather, of an open ended collection of forms that are constantly being, restructured and resemanticized during actual use. (Hopper, 1998, p. 158/159).
} 
Para isso, existem motivações que levam à competição de forças atreladas a esses fatores as quais fazem da "língua um sistema adaptável” (Dubois, 1985) De um lado, formas cristalizadas tentam fixar-se nas estruturas da língua defendidas pela gramática, como se fosse a única forma de comunicação; e, de outro lado, uma forma fluida que opera de acordo com a função de que o uso requer um mecanismo, cuja capacidade está direcionada a uma estruturação que se organiza e se reorganiza.

Essas motivações levam o falante a determinar sua escolha e adaptá-la a depender daquilo que enxerga, interpreta do mundo que o cerca: "A maneira como nós dizemos aos outros as coisas é decorrência da nossa atuação inter-subjetiva sobre o mundo e da inserção sócio-cognitiva no mundo em que vivemos" (Marcuschi, 2005, p. 52). Dessa forma, constroem-se novos conceitos a partir da linguagem do mundo que nos cerca, mas que é retratada de acordo com as experiências de cada falante atrelada a seu interlocutor, em que sobre esse prisma muda de acordo com o comportamento, atitudes e valores diante de suas diversas realidades.

Para Langacker (1987), o desenvolvimento de uma língua depende da capacidade inata e de certos sistemas simbólicos que a constituem como um instrumento atrelado a não só condições mentais, mas também a condições comunicativas que exercem papel preponderante para sua evolução. Para o autor, ainda existe uma "convergência substancial nos mundos mentais construídos" (Langacker, 1987, p. 233), isto quer dizer que a representação da linguagem muda com o tempo, espaço, de nós com os outros homens; não é uma fotografia mental fixa, imutável, mas que opera também com a interação de outras mentes que nos cercam: "As representações mentais não são fixas, pois elas emergem na interação, são negociadas e móveis" (Marcuschi, 2005, p. 64).

Entender a língua, nessa perspectiva, é perceber que existem diferentes possibilidades de representações que se descrevem no processo de mediação entre os eventos e mobilizam o modo de enxergar e entender o mundo narrado, descrito, opinado pelo contexto de uso situado, isto é, são as ações sociais com "autores sociais" (cf. Mondada, 1995, p. 132). Com isso, cada contexto assume uma descrição própria de quem o enxerga; e a língua é como um guia estabelecendo sentidos àquilo que, intersubjetivamente, queremos construir junto com o interlocutor, uma cultura, num tempo histórico, pautada numa "ação discursiva" (Marcuschi, 2005, p. 74). 
Assim, a dicotomia entre o pensar em algum fato e imediatamente vir à mente, sempre da mesma forma, muda completamente, pois isso é um processo instado entre o momento em que se pensa o fato e contexto, num jogo cognitivo. Esse mesmo processo vislumbra-se ao se sequenciar informações utilizando-se do conhecimento compartilhado, como demonstraremos adiante.

A linguagem é motivada, pois é isso que leva o falante a diversas possibilidades, é uma estratégia cuja mente humana trabalha hipoteticamente de acordo com o que é exposto a ela. Sendo assim, existe um deslocamento do enunciado para a cognição, a linguagem é representada pelas coisas que vemos e sentimos, mas ela "reside primariamente nas mentes individuais, sem as quais a interação linguística não pode ocorrer." (Langacker, 1987, p. 248). O sujeito falante diz para seu interlocutor aquilo que ele quer fazer com que o outro perceba o modo como ele enxerga o mundo e as coisas que o rodeiam, isto é, a linguagem "é uma ação que se dá conjuntamente" (Clark, 1992), em que o falante/escritor migra para seu leitor/interlocutor, conteúdos de domínios conceituais que, num processo interpretativo por meio do material da língua, concretiza e veicula suas ideias nas palavras de Langacker (1987):

a língua é formada e limitada pelas funções que serve. Isto inclui a função semiológica de permitir que conceitualizações sejam simbolizadas por meio de sons e gestos, bem como uma função interativa multifacetada, envolvendo comunicação, manipulação, expressividade e comunhão social.(Langacker, 1987, p. 2). ${ }^{9}$

Partimos da ideia de que a cognição e linguagem são interdependentes, pois, para realizar a concatenação entre as ideias por meio da correlação, por exemplo, verifica-se um exercício cognitivo, uma motivação, ao buscar conceitos que se adicionam ou contrapõem-se por conta da experienciação. Necessita também de uma operação mental suficientemente condizente para dar sentido àquilo que construirá por meio das estruturas linguísticas e do exercício de natureza da língua.

\footnotetext{
9 "Language is shaped and constrained by the functions it serves. This include the semiological function of allowing conceptualizations to be symbolized by means of sounds and gestures as ell as a multifaceted interactive function involving communication, manipulation, expressiveness, and social communion.” (Langacker, 2000, p. 2).
} 
Para isso, o falante/escritor atribui sentidos durante o exercício linguístico, ao escolher determinado item lexical para compor a estrutura, mas que também dependerá tanto de seu conhecimento de mundo como também do enciclopédico estruturado pela cognição. Isso nos leva a apontar que existe uma motivação que impulsiona o leitor a recuperar de sua memória aquilo que parece esquecido, por exemplo, ou informar a ele uma informação desconhecida, ou ainda para produzir algum efeito.

Entendemos que, para isso, faz-se necessário um planejamento mental para que o falante/escritor atinja suas intenções pragmáticas. Nesse aspecto, tanto fatores de ordem cognitiva como linguística adentram interdependentemente, pois escolhe um registro e, linearmente à estrutura sintática, faz a inserção dos itens lexicais que, a partir da busca dos conhecimentos adquiridos ao longo da vida, auxiliam a sua escolha, mas que segue uma ordem sintática que, para Tomasello (2003, p. 18), são constituídos por universos linguísticos que preconizam a comunicação, cognição e a fisiologia humana, disponíveis para todos os seres humanos para cumprirem a tarefa básica de comunicar.

Mas o uso desses universos linguísticos não é tão rígido, pois é possível pensá-lo separadamente. Entende-se que cada um coopera conjuntamente dentro da construção, com o sentido, com o contorno pragmático e informacional.

Dessa forma, a gramática da língua está associada a uma construção, parcialmente arbitrária, como Croft, propõe:

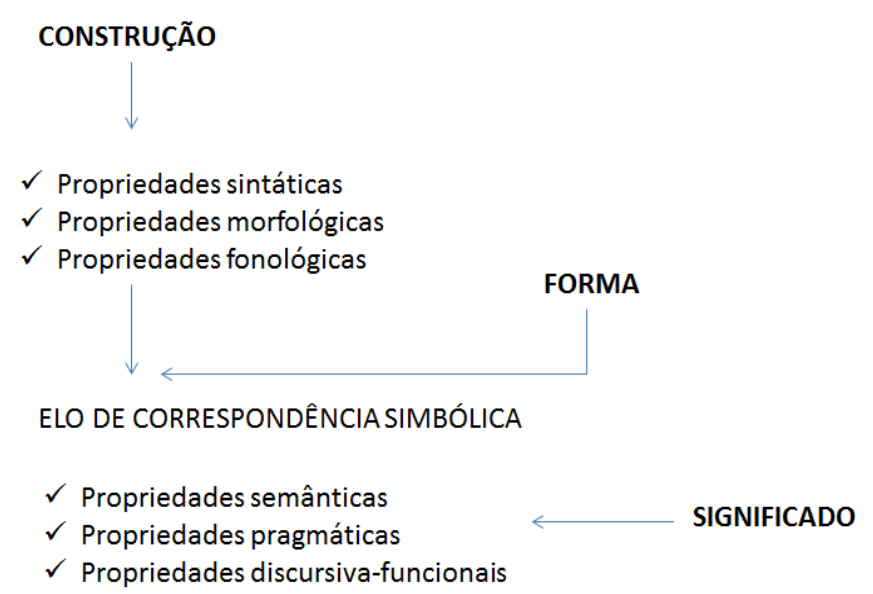

Croft, 2004, p.354

Esquema 3. Representação da construção na visão de Croft. 
Formas e sentido, cognitivamente, são construídos e constituídos a partir de um viés pragmático que move os humanos a utilizarem desses aspectos que, funcionalmente, estão a serviço de uma construção que preserva universalmente alguns elementos conceptuais, mas que possui especificidades para cada língua.

Entendemos que existe um processo que contribui à mudança das estruturas gramaticais ligadas a contextos morfossintáticos e pragmáticos (cf. Martelotta, 2010, p.58), que Traugott (2003, p. 645) caracterizou como gramaticalização. Com isso, poderíamos, então, apontar que uma estrutura pode chegar a se gramaticalizar por conta de um item que também se gramaticalizou. Observemos alguns exemplos:
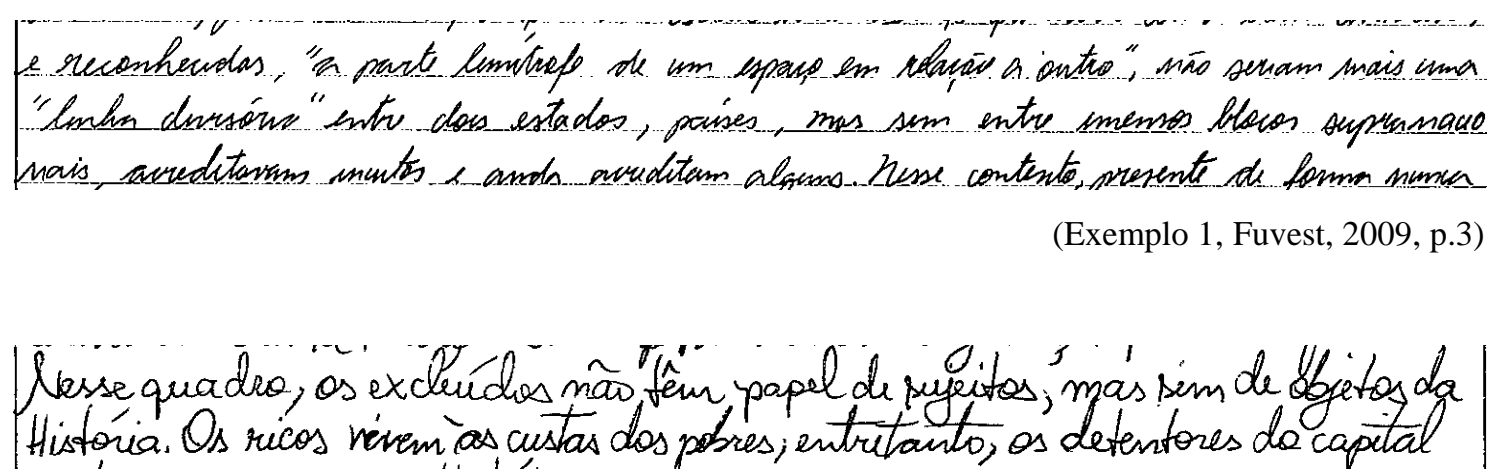

(Exemplo 2, Fuvest, 2004, p.45)

Poderíamos afirmar que a mente codifica um significado, atrela-o a um significado pragmático (Traugott e Dasher, 2005), isto é, a partir do instante que o falante encabeça na primeira oração o item "não" para correlativamente realizar uma polaridade, instala-se aí um mecanismo cognitivo, que funciona como gatilho, para que, na segunda oração, ele lance mão de outro item que caracterize a contrariedade que deseja fazer e, com isso, mobiliza itens lexicais periféricos aos pares correlacionados, que, pragmaticamente, conduz a uma polaridade.

À medida que o sujeito adquire e codifica a linguagem pela influência do mundo cultural onde vive, novos significados ressurgem de acordo com outros contatos a que o sujeito foi exposto. Isso não só se dá pelos processos analógicos conectados com modalidades de pensamento icônico e de indexação, os quais são anteriores e subjacentes à modalidade do pensamento sintático (Deacon, 1998), como também pela “interação falante-ouvinte e estratégias comunicativas” (Hopper\&Traugott, 2003, p. 73). Penso em analogia "como uma ponte entre o idiossincrasia e os vários graus de 
regularidade" (Coates, 1983, p. 320), como um deslize funcional, a fim de conservar a língua como flexível e não como um sistema rígido.

Percebe-se, assim, que a forma e função (significado) são dois aspectos intrínsecos ao processo analógico, ligados de acordo com a necessidade do falante que dá àquela forma significados direcionados ao interlocutor e direcionados no sistema, pois, se novas funções emergem, velhas formas assumem novas funções e, assim, a gramática vai se moldando, estruturando-se. Podemos assumir que não existe uma gramática, mas uma gramaticalização, o processo em direção à gramática (Hopper, 1987); novas estruturas emergem e se rotinizam, entram para a gramática.

\subsection{Processos de gramaticalização}

A gramaticalização ${ }^{10}$ se dá pela influência cognitiva da mente do falante e interlocutor, em que, por exemplo, por meio de um modelo de um léxico mental (Bybee, 2003), as palavras são organizadas de forma ordenada e agrupadas de acordo com a identidade ou similaridade fonológica ou semântica, e assim, formam esquemas de interconexões a partir de traços cultural e socialmente compartilhados no esquema de acordo com a frequência de ocorrência.

Partimos da premissa de que a linguagem constitui-se por meio de um dispositivo cognitivo para se construir um conhecimento, em que tanto os conhecimentos armazenados na memória, quanto aqueles presentes na interação daquele momento de vida do falante são acionados. Assim, entendemos que, a cada situação real de comunicação, mecanismos linguísticos e cognitivos são acionados aos usos reais da língua e que se modificam a cada nova necessidade comunicacional: a chamada teoria da gramaticalização não é uma teoria da linguagem nem da mudança linguística, mas uma teoria do desenvolvimento das formas gramaticais (Heine, 2003) calcadas numa abordagem cognitiva-funcional, que analisa a mudança como um fenômeno gradual e variável.

\footnotetext{
10 Alguns autores utilizam o termo gramatização (Hopper, 1991; Givón, 1995; Matisoff, 1991), sem muitas diferenças significativas, como substitutivo para gramaticalização. O primeiro termo é normalmente empregado para se referir a um processo sincrônico, enquanto o segundo se refere a um processo diacrônico.
} 
Assim, poderíamos apontar que a gramaticalização ocorre também por interferência do fenômeno social e que, ao ser observada a partir da estrutura e da regularidade da gramática de uma língua, entende-se que é um processo contínuo e pelo discurso, como aponta Martelotta (2006): o falante, ao processar seu discurso, aciona e atualiza uma gama de mecanismos cognitivos, como o da simbolização, transferência entre domínios, armazenamento, processo de informações que contribuem à regularidade dos processos das mudanças, dentro da trajetória e da direcionalidade do item linguístico.

Traugott e Dasher (2005) apontam alguns fatores que mostram que a gramaticalização, numa unidirecionalidade, se caracteriza por mecanismos universais de mudança linguística cujas influências cognitivas e comunicacionais são indícios de que a estrutura linguística se repaginaria pelo uso, de acordo com a necessidade do falante:

A) Tendência dos falantes utilizarem-se de expressões novas e dos seus ouvintes captarem e relacionarem aquilo que interessa e instiga;

B) Negociação de sentidos no ato da comunicação como se fosse um fio em que escolhas, adequação, intenção se concretizam na estrutura linguística do discurso;

C) A iconicidade entre a relevância da informação e a quantidade de forma ali presente entre as informações, por exemplo, para o falante conceptualizar aquilo que deseja expressar;

D) Os efeitos de frequência que se instalam por fatores linguísticos e sóciocognitivos;

E) Necessidade de expressar domínios abstratos da cognição em termos de domínios concretos e que, simbolicamente, são representados na estruturação linguística e que são ressignificados de acordo com outras necessidades, a partir de novas experiências;

F) Competição entre a motivação de economia e clareza que tem por objetivo trazer o que é de cunho mais de atenção, diretivo, por exemplo, entre os pares correlativos.

Antoine Meillet (1912) foi o primeiro autor a empregar o termo gramaticalização numa acepção próxima do funcionalismo. Entendia como um continuum em que haveria 
uma transição de itens lexicais para auxiliares e outros morfemas com função gramatical. Também apontava que o aumento de frequência de uso está em correlação inversa à perda do valor expressivo das palavras, isto é, podemos apontar que, dentro desse continuum, existe um percurso em que um morfema se desloca do léxico para a gramática ou de um item menos gramatical para um mais gramatical (cf. Kurylowicz, $1965,1975)$.

Traugott e König (apud Heine et al. 1991, p. 4), entendem a gramaticalização como um processo unidirecional que adquire novas formas gramaticais ou morfossintáticas que aparecem, modificam-se e assumem outros papéis, de ordem natural e não de ordem degenerativa:

A gramaticalização refere-se principalmente a um processo histórico unidirecional e dinâmico por meio do qual itens lexicais, com o passar do tempo, adquirem um novo status como formas gramaticais ou morfossintáticas ${ }^{11}$, e no processo começam a codificar relações que ou não foram codificadas antes ou foram codificadas diferentemente. (Traugott e König, apud Heine et al. 1991, p. 4)

A unidirecionalidade prevê que as mudanças linguísticas no escopo da gramaticalização ocorram em um continuum, do "menos gramatical" para o "mais gramatical" e não vice-versa.

Assim sendo, o princípio da unidirecionalidade aponta para linhas demarcadas, identificadoras e verificadoras do processo de gramaticalização, sem que, com isso, repito, esteja-se dizendo que o item gramaticalizado ou em gramaticalização não poderia, porventura, continuar ocorrendo em formas lexicais ou menos gramaticais.

Segundo Aristóteles:

As palavras faladas são símbolos da experiência mental e as palavras escritas são os símbolos das palavras faladas. Assim como todos os homens não têm a mesma escrita, todos os homens também não têm os mesmos sons da fala, mas as experiências mentais, as quais esses

11 "Grammaticalization refers primarily to the dynamic, unidirectional historical process whereby lexical items in the course of time acquire a new status as grammatical, morphosyntactic forms, and in the process come to code relations that either were not coded before or were coded differently." 
simbolizam diretamente, são as mesmas para todos, como também são as coisas de que nossas experiências são as imagens. (Aristóteles, 1952, p. 25).

Então, itens linguísticos são portadores mais concretos e outros, de significados menos concretos na língua, subjacentes ao conhecimento de mundo trazido pelo falante e pelo ouvinte, que, atrelado às suas experenciações, pragmaticamente, trazem à tona, primeiramente, conceitos que estão próximos da experiência humana que vão se abstratizando, metaforicamente, e satisfazem o seu papel social. Quando se diz que a gramática funcional considera a competência comunicativa, diz-se exatamente que o que ela considera é a capacidade que os indivíduos têm não apenas de codificar e decodificar expressões, mas também de usar e interpretar essas expressões de uma maneira inteiramente satisfatória. (Neves, 2001, p. 15).

Hymes (1974) propunha que, para uma descrição das regras funcionais de linguagem, é necessário acrescentar ao processo tradicional gramatical o uso social e, com isso, por meio do contato interacional entre cultura, língua, sociedade, pensar num processo de gramaticalização em que, metaforicamente, os itens linguísticos se abstratizam, é entender que existe uma extensão gradual do uso que, originalmente, caminha para o abstrato, como afirma Martelotta et alii (1996: 49)

[...] o pensamento trabalha com conceitos adquiridos pelo contato com o mundo concreto. O sistema conceptual que emerge dessa experiência serve de base para a compreensão de uma realidade mais abstrata que constitui o mundo das ideias. É a metáfora que permite que o homem compreenda o mundo das ideias em função do mundo concreto.

Para o processo de abstratização, o falante, ao interpretar aquilo que fala, lê, escreve, utiliza-se de toda bagagem que inclui as experiências psicológicas, culturais, contextuais. Para Martelotta (1996,p. 51), esse é um "fato que se manifesta de modo universal nas línguas humanas de que, por exemplo, partes do corpo se gramaticalizam em objetos e noções especiais, em noções temporais[...]". 
Para Lima-Hernandes (2008, p.26), "analisar o comportamento linguístico de indivíduos permitirá recolher fragmentos de evolução linguística da espécie e, consequentemente, projetar rotas de evolução lingüística”. Assim, o indivíduo inclui na gramática aquilo que, para ele, apresenta uma identidade, interatividade, compartilhamento de informações, em que sugere uma cadeia unidirecional, cujas categorias adquiridas pelo falante em seu desenvolvimento ontogênico são reorganizadas: "parte do corpo > pessoa > objeto > instrumento > espaço > tempo > evento > qualidade".

A autora aponta, ainda, que "as categorias mais à esquerda são incorporadas pelas categorias mais à direita, o que equivaleria a dizer que, pelas categorias mais à direita, pode-se inferir as mais à esquerda" (Lima-Hernandes, 2008, p. 91). Isso equivale a dizer que, para o falante, o que é mais próximo daquilo que, junto com o interlocutor, experiencia, é elidido "da sequência sintática" (Lima-Hernandes, 2008, p. 94), há uma estreita relação entre as ações humanas e de seu amadurecimento mental e físico.

Quando traços linguísticos deslizam para outras formas e funções, ou ainda, desaparecem ou aparecem com outros traços, formando novos itens, é papel "do analista reconhecer que as ações humanas se abstratizam ou tornam-se mais complexas" (cf. Lima-Hernandes, 2008, p. 95); e isso nos remete a apontar que é um processo, exercício cognitivo ligado às experiências do indivíduo, gravadas na memória do falante e, por isso, elididas do sequenciamento sintático, pois já fazem parte da bagagem do interlocutor, há uma identificação.

Um exemplo de pares correlativos, encontrados no corpus, sinaliza a necessidade do escritor de elidir itens linguísticos para opor ideias; isto é, economiza para que a informação se processe mais rapidamente para o leitor:

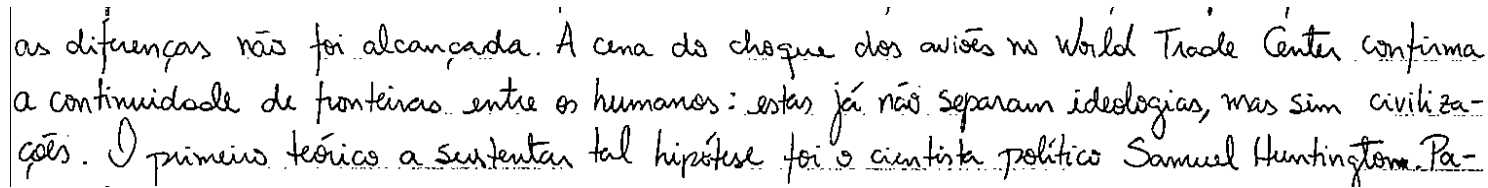
(Exemplo 3, Fuvest, 2009, p.14) 
No exemplo anterior, o verbo apresentado na primeira porção informativa (não separam ideologias) é elidido na segunda porção (mas sim civilizações). A elisão só foi possível graças à explicitação prévia.

Um fator que contribui para a gramaticalização é a frequência. Para Company (2003, p. 28), a frequência de uso é um fator primordial na geração de uma mudança, pois "fixa o uso, o rotiniza, outorga apoio paradigmático e cria estabilidade no sistema".

Bybee (2003) observa que a frequência de uso leva ao enfraquecimento da força semântica de uma forma pelo hábito: formas tornam-se mais gerais e mais abstratas no significado. Essa perda de transparência semântica leva o emprego de construções a novas construções, novos contextos, a outras associações.

A frequência preconiza que a alta recursividade de uma estrutura nas suas manifestações discursivas faz com que aumente a probabilidade dessa estrutura se regularizar linguisticamente. Há estreita relação entre frequência de uso e a presença de itens linguísticos em determinados ambientes textuais, porém há uma tendência de determinados conteúdos serem mais sensíveis ao processo de regularização do que outros. Sweetser (1990) aponta o percurso universal histórico-social > experiência fundante > ato de fala; Traugott e Heine (1991) sugerem a progressão espaço > (tempo) $>$ texto.

A frequência de uso vem sendo utilizada como um forte argumento empírico para conformar processos de gramaticalização. Thompson e Mulac (1991) analisaram a gramaticalização de expressões epistêmicas em epistêmicas parentéticas: construções sujeito + verbo ocorrendo sem complementizador (I think, I guess) são reanalisadas pelos falantes como expressões epistêmicas, que têm liberdade sintática, funcionando semelhantemente a outras expressões epistêmicas, como maybe.

Para os estudos de gramaticalização, é importante salientar que o aumento da frequência do item ao longo do tempo (token frequency) evolue o contexto e todos os itens que também o acompanham. 


\subsubsection{Construções gramaticais como processo cognitivo}

Bybee (2003) aponta que a frequência de uso tem um papel significativo à mudança linguística e é um dos fatores que contribui para a criação de construções na língua. Importante salientar que, apesar da mobilidade, elas não são constituídas por uma lista desestruturada, mas por um inventário estruturado do conhecimento do falante acerca das convenções de sua própria língua (Langacker, 1987); isso porque existe uma "rede taxonômica de construções" (Croft, 2004, p. 340), esquemática.

Para Croft (2004), ainda, as construções, podem representar-se por meio de hierarquias taxonômicas, em que certo número de diferentes construções esquemáticas surgem a partir de outras para compor um enunciado.

Segundo Fillmore (1977), uma palavra se integra a uma construção porque possui uma atomicidade que, ao se juntar com outra, forma um todo, isto é, uma construção informacional. Isso nos remeteria a apontar que "uma construção com seus itens lexicais particulares que se torna gramaticalizada" (Bybee, 2003, p. 602) é entendida "como um processo, por meio do qual ao material lexical, em contextos pragmáticos e morfossintáticos altamente restritos, é atribuída uma função gramatical, e, se já gramatical, é atribuída uma função mais gramatical ainda[...]” (Traugott, 2003, p. $645)$.

Para Fillmore (1977), cada item contém informação sintática e semântica que se combinam para formar unidades complexas, cujas formas não se remetem ao seu próprio significado, por conta da estrutura, que interfere no sentido do vocábulo. Para ele, a gramática se organiza em unidades simbólicas e não leva em consideração um item que sofre interferência, tanto sintática, semântica, morfológica quanto até fonológica, por conta do item que o acompanha.

Tanto para Lakoff quanto para Goldberg $(1987,1995)$, existem vínculos entre as construções que são subpartes de outros vínculos de construções, que podem ser consideradas como instância de outra construção.

Goldberg (1995) defende a ideia de que as construções gramaticais são unidades básicas da língua, as quais constituem um conjunto estruturado de informações que se 
inter-relacionam e se entrelaçam, formam uma rede motivada hierárquica e polissêmica (Lakoff, 1987).

A autora salienta ainda que a linguagem é um sistema (mental) cognitivo, cujas construções são compostas por par forma/sentido com significados não arbitrários, isto é, não são isolados, cada elemento da forma ou do sentido se integram. Além desse fato, a autora sustenta a ideia de que as línguas são aprendidas e demanda de um tempo longo para que haja sua aquisição. Em Goldberg (2006), existem dados de pesquisa que demonstram a habilidade de crianças para extrair regularidades dos estímulos linguísticos a que são expostos, principalmente pela influência da fala das mães.

A autora indica que o nível de frequência de ocorrência de um verbo, por exemplo, refletirá no nível de frequência desse uso em construções que se aproximam da fase concreta da criança, como por exemplo, give (dar), go (algo se movendo), porque envolvem ações que se experenciam no uso diário a que a criança é exposta pelo modelo do adulto; isso quer dizer que existe um entrelaçamento entre a realização da linguagem e as formas de vida de que os humanos participam.

Ao relacionarmos a noção de construção com a linguística cognitiva, alguns princípios estão calcados em Croft (1999) ao apontar que construções são entidades gramaticais independentes que existem na mente como conjunto integrado de categorias, cujas relações constitutivas simbólicas e complexas são organizadas gradualmente em uma rede de conhecimentos. Para o autor, as categorias lexicais sintáticas são definidas a partir das construções.

Entende-se, assim, que por uma concepção a respeito das construções, os componentes inerentes à linguagem são dinâmicos e processuais, em que cabem a variação, arbitrariedade e dinamismo, como elementos que contribuem para que, ontogenicamente, novas construções emerjam, diante de estímulo sociais, linguísticos e até fisiológicos, que, desde a infância, edifica, constrói a linguagem.

Para Croft (2001), ainda, as construções são específicas de cada língua, e para capturá-las é preciso sensibilidade a essa especificidade e às práticas metalinguísticas da comunidade em exame, isto quer dizer que o falante, à medida que for reconhecendo e listando as construções, estará também reconhecendo e listando a maneira como seus elementos e componentes internos se relacionam e como as construções se relacionam entre si. Um indício entre gramática de construção e a gramaticalização para Croft, ainda se dá: no processo de gramaticalização, a construção, como um todo, muda de 
significado; a construção emergente se torna polissêmica em relação ao sentido original e a extensão da construção para novos usos é o reflexo da mudança de sua distribuição.

O que resulta dessa exposição é que a gramática das construções parece funcionar como um "guarda-chuva" que abriga uma gama de variações de forma e sentido sob duas perspectivas: a primeira, orientada por uma abordagem que atende à noção de construção como primitivo da análise linguística; a segunda, calcada na perspectiva biplanar da linguagem que perpetua a proposição do pareamento forma/sentido, cuja atomicidade-núcleo de cada item representa o fenômeno linguístico.

De acordo com estudos recentes (Heine, Claudi e Hünnemeyer, 1991), a gramaticalização é vista como um fenômeno universal de mudança linguística, atrelado a qualquer tipo de função gramatical. Segundo esses autores, há um desenvolvimento que, metaforicamente, se dá desde a infância até a vida adulta. Esse desenvolvimento tem sido representado pelas categorias cognitivas seguintes:

PESSOA $\longrightarrow$ OBJETO $\longrightarrow$ ATIVIDADE $\longrightarrow$ ESPAÇO $\longrightarrow$ TEMPO $\longrightarrow$ QUALIDADE

O surgimento de uma nova função a partir de formas já existentes evidencia uma gramática cujo foco se dá a partir da necessidade discursiva. Segundo Lima-Hernandes (2007), a gramaticalização pode ser considerada paradigma, quando houver uma preocupação voltada a evidenciar a maneira como formas e as suas construções surgem e como são usadas; ou ainda considerada processo, cujo objetivo é o de identificar e analisar itens que se tornam mais gramaticais.

\subsection{Correlação entre gramática e cognição}

Alguns teóricos como Meillet (1982) e Bolinger (1977), entre outros), apontam que a alta frequência de uso está associada à tendência da economia, isto é, quanto maior a regularidade e familiaridade de um elemento linguístico à sua estrutura, com o tempo, ele se desgasta e reduz sua forma. Para Dubois (1985), "as gramáticas codificam melhor o que os falantes fazem mais", além disso, quanto maior a forma linguística de um item, maior é a sua complexidade, pois, se a gramática representa o que o falante 
diz, pensa, experiencia com uma alta rotatividade de uso, o elemento tende à economia, à redução e, assim, haverá uma menor atividade física e mental de esforço para o falante; entretanto, haverá um enfraquecimento da iconicidade, pois o tamanho da forma pode afetar progressivamente a complexidade e o aprofundamento das informações.

A questão é que existem, então, duas forças que disputam: de um lado, a da economia, que contribui para o processamento veloz da língua, facilita a comunicação e interação entre os falantes; do outro, a da iconicidade ${ }^{12}$, que atrela língua à experiência social composta por um conjunto de itens lexicais.

A atenção e a consciência são base para que o indivíduo aprenda uma língua; para isso, então, a iconicidade, por exemplo, revela que a estrutura da linguagem, pela mente humana, está coligada pela experiência da cultura atrelada àquilo que nos é exposto e vivido. Outro princípio ligado a essa questão é o da marcação, introduzido pela Escola de Praga, cuja ideia central está focada na oposição de dois elementos, em que um deles apresente uma característica atípica em relação ao primeiro, sendo ela fonológica, morfológica ou sintática.

As formas marcadas são aquelas de menor frequência de ocorrência nas línguas em geral e em uma língua particular, enquanto a não marcada apresenta-se de forma mais frequente, isto quer dizer que, para ser mais expressivo, os falantes recorrem à forma marcada.

Quanto ao plano discursivo, quando o falante organiza seu discurso, estabelece objetivos por meio de sua percepção, distingue informações daquilo que considera principal e periférico.

Todos esses fenômenos estão lincados no momento em que se atenta para um item linguístico ou uma construção, o indivíduo puxa atenção àquilo com que se identifica, com que possa estabelecer uma interação.

\footnotetext{
12 A iconicidade é um princípio pelo qual se considera que existe uma relação não-arbitrária entre forma e função, ou entre código e mensagem na linguagem humana. Trata-se de uma relação natural ente o código linguístico e o seu designatum.(Neves, 2004, p. 103)
} 


\subsection{Fundamentos cognitivos}

Para Clark (1996), a linguagem é uma ação conjunta que opera simultaneamente em quatro níveis, a saber:

1 - Produção e atenção;

2 - Formulação e identificação;

3 - Sinalização e reconhecimento;

4 - Ação conjunta.

Segundo Clark (1996), cada nível segue uma escala, em que, se alguma estiver prejudicada, haverá problema no ato de comunicar. Cada nível permite o nível (1) acima dele e acontece somente se o nível (1) abaixo foi alcançado com sucesso, por exemplo: alguém não pode reconhecer a intenção comunicativa se não prestar atenção na elocução produzida (Clark, 1996).

Existe uma regularidade linguística, um campo comum da comunidade, que funciona como um dispositivo, em parte, arbitrário, para que se alcance o interlocutor. Isso não somente ocorre na língua, como também no comportamento, atitude das pessoas que, convencionalmente, agem de acordo com o outro e para o outro, para satisfazerem suas necessidades comunicacionais.

Para o autor, ainda, a convenção funciona como modelo coordenativo tanto de língua como de comportamentos que, ao serem transmitidos repetidamente, porque, provavelmente, foram bem sucedidos, passam a fazer parte dos eventos. Somente passam a ser convencionalizados, se houver entendimento e aceitação das pessoas de que se utilizam; inicialmente, são usados por alguns falantes, mas não há uma regularidade; só no momento em que se instalam como mecanismo de uso, inserem-se nesse modelo (Lewis, 1969).

Percebe-se que um elemento linguístico, por exemplo, só se convencionaliza no sistema a partir do momento em que passa a fazer parte da realização conjunta dos participantes do evento, isto é, haverá prioridade de sua utilização, passa a ser característico, peça daquela situação comunicativa. 
Entender o mecanismo e processamento do usuário em relação à sua competência de produzir e interpretar corretamente expressões linguísticas complexas em diferentes situações comunicativas, nos leva a compreender que o indivíduo possui uma capacidade social (Dik, 1989) que o direciona a dizer, como dizer, para quem dizer, a um "parceiro comunicativo particular" (Neves, 2009, p. 74), dando à língua uma forma e sentido que atenda e satisfaça sua participação e dentro do processo interacional. Para Dik (1980), então, entender o mecanismo do processamento da linguagem se faz pela descrição calcada no pragmatismo instalado no jogo discursivo em que cada nível especifica o papel desempenhado pelo falante: no nível semântico, qual a função de cada termo envolvido no processo; no nível sintático, de que forma os itens lexicais se inserem na expressão linguística; e no pragmático, a situação informacional dos constituintes. Para o autor, ainda, a gramática não deve se limitar a escrever as regras, mas sim em termos de sua funcionalidade para atingir o propósito do seu uso. Para esse jogo se efetiva, concorrem forças cognitivas ligadas à atenção humana na língua sobre as quais tratarei nesta seção.

\subsubsection{Informatividade e compartilhamento de atenção}

O princípio da informatividade possibilita focalizar o conhecimento que os interlocutores compartilham (ou que pensam compartilhar) na interação verbal. Esse princípio está voltado ao status informacional, em que o sujeito informa seus interlocutores sobre um fato do seu mundo interior, ou fatos que perfazem a condição do homem, com objetivos intencionais: convencer o seu leitor, ouvinte, sobre uma possível mudança de concepção a respeito do foco, assunto; manipulá-lo a fim de que tome atitudes, ou até mesmo verifique outras possibilidades de enxergar o fato. Esse princípio dá condições ao falante/escritor de julgar informações que considere mais relevantes e distribuí-las entre os constituintes numa sentença, assim poder socializar o que pretende apontar e discutir.

A distribuição dos elementos entre as informações condiz com o dinamismo da língua e isso contribui para que a informatividade seja motivada e, dessa forma, os 
aspectos pragmáticos sejam compreendidos pelo interlocutor a partir do que se comunica.

Quando o falante/escritor lança uma informação nova no discurso, ela passará a ficar armazenada na mente do seu interlocutor. Ao lançá-la na cadeia comunicativa, o falante planeja deixá-la disponível para que uma rede de referências surja com novas topicalizações, denominada por Mondada e Dubois (1995) como referenciação, que diz respeito a uma relação entre o trecho e a parte não linguística da prática em que ele é produzido e interpretado (Mondada; Dubois, 1995, p. 20). Para as autoras, essas práticas não são imputáveis a um sujeito cognitivo abstrato, racional, intencional e ideal, solitário face ao mundo, mas a uma construção de objetos cognitivos e discursivos na intersubjetividade das negociações, das modificações, das ratificações de concepções individuais e públicas do mundo.

Isso quer dizer que, para interagirem, os sujeitos constituem-se por meio da construção de referentes instituídos nos "objetos gerados na produção discursiva" (cf. Marcuschi, 2005, p. 95), presentes na dinamicidade da língua e sujeitos a mudanças, como no caso do dado apresentado em que o candidato projeta, em sua mente, dados que assumem novas significações, de sintáticas a semânticas.

A informação à luz do funcionalismo, como sabemos, não é transmitida em um único plano e, dessa forma, pode-se falar de uma assimetria informacional, em que algumas unidades parecem transmitir informações mais velhas de que outras (Prince, 1981). Para a autora, a partir do conceito que "familiaridade presumida", quando falante e ouvinte jogam interativamente a partir do momento em que novos tópicos se reestruturam no discurso, mudam funcionalmente para que haja um polo comum: foco comunicacional.

O termo 'conhecimento compartilhado', para Prince, é confuso, pois não atende ao leitor específico para aquele gênero de texto ou discurso, pois, se um discurso é compartilhado, presume-se que os dois indivíduos possuem sempre a mesma crença, valores, conhecimentos sobre o tópico, e nem sempre isso pode acontecer.

Para Prince (1981), existe "conjunto de instruções de um falante para um ouvinte", um modelo de discurso, e é por isso que a familiaridade presumida está dentro dessa concepção, pois se pode escrever o mesmo gênero de diferentes formas, com 
estruturas, itens lexicais, de termo, escolha de argumentos de maneira diferente, para atender o leitor específico, isto quer dizer que existe um interlocutor presumido, que espera do seu emissor um ajuste entre os fatores interno e externo da língua a partir de que é o leitor/ouvinte.

Para a autora, o caráter social da linguagem está imbricado num ritual, em que tanto falante como ouvinte se esforçam para que haja um exercício discursivo e interacional e, para isso, elementos como "pacote de informações, hipóteses sobre as suposições do receptor e vice-versa, crenças e estratégias" (Prince, 1981, p. 3), deverão compor as necessidades presumidas para que, assim, se possa estabelecer a comunicação.

Aponta ainda que há uma característica presumivelmente universal a respeito da linguagem: as informações não são transmitidas num plano único, há uma "assimetria informacional" (Prince, 1981, p. 2), em que uma mesma informação muda de acordo com as necessidades de cada um dos envolvidos no processo. Há uma previsibilidade não somente àquilo que dizer, mas como dizer e de que forma distribuir as informações entre as porções informativas.

A autora apresenta três diferentes níveis de se processar as informações dadas, num jogo discursivo cujo cenário é carregado de marcas particularmente intencionais e pragmáticas: a "dadidade" é o senso de previsibilidade/ recuperabilidade (Prince, 1981, p. 5), em que o falante presume que o ouvinte pode ou poderia prever que um item linguístico particular ocorrerá ou ocorreria numa posição dentro de uma sentença. Ao reportar-se sobre a informação nova, distribuída entre os elementos dentro da informação, chamamos atenção para o que Halliday (1967) denomina de informação nova e dada: a primeira, refere-se quando o falante apresenta, lança mão de um item ou conjunto de itens lexicais inovador, isto é, não estava presente em discursos precedentes àqueles ditos pelo falante; a segunda, a dada é aquela que o falante se utiliza, mas que é recuperável de alguma fonte advinda de um meio ambiente.

O outro aspecto da dadidade pode ser aquele denominado "saliência" (Prince, 1981, p. 9), que se caracteriza por aquilo que o falante presume que o ouvinte tem, ou poderia, apropriadamente, ter alguma coisa/entidade particular, na consciência dele/dela, no tempo de ouvir a elocução. Em relação àquilo que Halliday denomina de novo e dado, Chafe (1976) chama atenção para o que se chama de novo: "itens 
conhecidos que são introduzidos, no discurso, pela primeira vez, são tão novos, quanto desconhecidos" (Chafe, 1976, p. 41/42).

O último tipo de dadidade, caracterizado por Prince (1981), é o do conhecimento partilhado, em que o falante presume que o ouvinte sabe ou pode inferir uma coisa particular, mas que não necessariamente esteja pensando a respeito.

Um aspecto interessante nesse quesito é que, se o falante considera aquilo que é mais apropriado focar, é porque tem uma previsão, hipótese comum entre a sua consciência e a do seu interlocutor, e sabe que poderá atingir, mobilizar, o ouvinte por meio disso.

Para Prince (1981, p. 17), ainda, o texto é um modelo de discurso, em que há um conjunto de instruções de um falante para o ouvinte, representado por entidades discursivas que podem representar o indivíduo, uma classe de indivíduos, uma substância, um conceito. Existe um engajamento entre os interlocutores para que se engajem numa interação verbal que, ligados num contexto ${ }^{13}$, motiva formas de enunciados.

Chafe (1984) destaca a dificuldade de se estabelecer uma terminologia satisfatória na área dos estudos de processos cognitivos ao tratar dos termos como informação velha ou dada, informação nova, tópico, comentário, entre outros. Diante disso, o autor prefere substituir as expressões "dado" e "novo" pelos termos correspondentes aos níveis ativado ou não ativado, concebendo-as de modo especialmente cognitivo.

Para o autor, há uma grande quantidade de informação e conhecimento na mente do falante, sendo que apenas uma pequena parte dessa informação é ativada de uma única vez. O importante a ser destacado pelo autor é o fato de que a memória de curto prazo não acumula muita informação. Desse ponto de vista, o termo ativado parece apropriado. O que está em jogo é o fluxo da consciência, aquilo que o falante supõe estar introduzindo na mente dos interlocutores.

Aponta, ainda, que o conceito ativo seria um tipo facilmente acessado, localizado na consciência periférica do indivíduo, mas que não está sendo diretamente

\footnotetext{
${ }^{13}$ Para Connolly, consiste em qualquer parte circundante a um discurso, relevante para sua produção e interpretação.
} 
focalizado. Por fim, um conceito não ativado é aquele situado na memória de longo prazo, que não é nem focalizado, nem ativado perifericamente.

O ativado seria aquele que o falante aciona, por meio do conhecimento social (língua e cultura) presente naquele momento de sua vida, com o qual convive, presente na memória da sua experiência de vida. O periférico é aquele que reativa o conhecimento prévio, anterior ao que ele possui, isto é, fica na memória, mas não é ativado por conta da necessidade do falante, pois outros conhecimentos adentram a mente e vão sendo ressignificados.

Para Connolly (2007), o contexto possui uma dinamicidade acompanhada do discurso orientado e restrito para propósitos comunicacionais particulares. Na sua visão, existem quatro dicotomias básicas para estruturar o conceito de contexto: "discursivo $\mathrm{x}$ situacional; físico x sociocultural; estrito x amplo; mental x extramental" (Connolly, 2007, p. 14).

O contexto situacional está ligado ao universo físico e social, ao cenário imagético correspondente àquilo que o sujeito é exposto, vive, sente no tempo e no espaço e ao contexto sociocultural que interfere na condição do discurso do falante, pois está atrelado à cena, “à ocasião numa dada instância de verbal.” (Hymes, 1972, p. 60). Em relação ao contexto físico, o espaço influencia na condução de enxergar e experienciar o mundo que, atrelado ao sociocultural, faz com que o sujeito se comporte, pense, aja, de acordo com as normas estabelecidas pelo grupo social a que pertence naquele espaço.

Quanto ao contexto estrito, Connolly (2007) vê que o "cotexto" (2007, p. 105), deve ser analisado mediante ao fragmento específico, isto é, o trecho, o recorte daquilo escrito ou falado deve ser visto como material para entender as escolhas comunicacionais; e, quanto ao contexto, tem-se o intertexto, que é a relação do contexto com outros textos e referências, isto é, ao proferir, o falante leva em conta outros discursos atinados a experiências e situações que o levem a costurar, inferir de outras vivências e que o alavancam para outros contextos.

Percebe-se que o contexto é provisório, pois, do ponto de vista dos interlocutores, é ele o responsável para sinalizar escolhas lexicais, a partir da interpretação que os sujeitos envolvidos no processo entendem o universo e estabelece 
uma rede de informações que se inter-relacionam por meio de uma "sequência de pistas" (Cornish, 2009, p. 97). É incompleto e indeterminado.

Aspectos, tais como gênero atrelado à fala e à escrita, ligados a expectativas do usuário particular com o tipo de evento de língua envolvido, conhecimento de mundo, que faz o falante adequar suas escolhas à sua necessidade discursiva, influenciam as convenções sociais que regulam suas opções.

Poderíamos apontar, então, que o contexto, numa visão funcionalista, coopera para uma convergência discursivo-cognitiva em que falantes podem referir-se, fazer inferências, retomar, interpretar e reinterpretar estruturas, que se expandem por meio de fios ligados ao evento comunicativo.

Para Traugott e Dasher (2005), o contexto tem seu sentido redimensionado, mais pela esfera pragmática e menos referenciais, no âmbito das crenças, atitudes, valores, persuasão, que auxiliam na negociação das escolhas e distribuição entre os elementos informacionais e entre as porções informativas que compõem o discurso. Para Oliveira (2006, p. 138), isso pode "deflagrar polissemia, variação e mudança", por conta do alto teor abstrato que os itens assumem para atender o discurso correspondente às intenções e mudanças. Essas ideias têm consonância com as de Bloomfield, a despeito das abordagens distintas:

Todo falante está constantemente adaptando seus hábitos de fala aos de seu interlocutor; ele abre mão de formas que tem usado, adota novas e, talvez mais frequentemente que tudo, muda a frequência das formas faladas sem abandonar inteiramente as velhas ou aceitar qualquer uma que seja realmente nova para ele. (Bloomfield, 1933, p. 327).

Assim, assumir a ideia de que a língua flui, organiza-se funcionalmente, é admitir que a gramática (Neves, 2002, p. 176) “apresenta um caráter - não discreto das categorias; indeterminação semântica, com valorização do papel do contexto; gradualidade das mudanças e coexistência de etapas; com uma regularização, idiomatização e convencionalização contínuas". 
Ainda sobre os apontamentos de Neves (2002, p. 56), é relevante apontar que, quando nos atemos a uma organização gramatical advinda de fluxos que se transformam e se adaptam, é porque há conexão sob a luz do cognitivismo e do socioculturalismo, em que há "um componente conceptual com força condutiva por trás do componente gramatical" (Neves, 2012, p. 53), confluindo as forças tanto internas como externas do sistema, que se conectam e atrelam o discurso à estrutura, a fim de que se atenda à flexibilização e à multiplicidade, necessárias à realização de qualquer língua, em uso.

Para Dik (1989), o usuário é capaz de produzir e interpretar expressões linguísticas de várias estruturas em diferentes situações comunicativas, por conta de sua capacidade epistêmica, lógica, perceptual e social, como expus na seção anterior.

Pelo princípio da informatividade, entende-se a linguagem como uma instituição social cujo sistema se constrói: a partir dos conhecimentos entre os interlocutores.

Na medida em que a ordenação das palavras é considerada uma questão de sintaxe, podemos dizer que, pelo menos em algumas línguas, a estrutura sintática dos enunciados (ou das sentenças) é determinada pela situação de comunicação em que é pronunciada e, em particular, pelo que já é aceito ou dado como informação de fundo, pelo que é apresentado, diante de tal informação, como novo para o ouvinte e, portanto, genuinamente informativo. Considerações dessa natureza estão envolvidas na definição daquilo que os linguistas da Escola de Praga denominavam perspectiva funcional da sentença (Lyons, 1970, p. 210).

O interlocutor compartilha com outros interlocutores ou supõe que isso ocorra na e para a interação, em que pode até manipular e exercer poder sobre o outro a partir do que pretende informar. Com isso, a ordem sintática das construções na situação interativa é fundamental. Tradicionalmente, a cláusula que apresenta a informação velha é denominada tema, enquanto a que apresenta a informação nova é denominada rema (Ilari e Geraldi, 1985). Num texto real, o que se verifica com frequência é a informação velha estar contida no sujeito (tema) e a nova, no predicado ou parte do predicado (rema).

Essas escolhas, como já explanei com Chafe (1977), baseiam-se numa ideia geral acerca do evento presente apenas na mente do falante. À medida que produz o discurso, ele organiza e detalha o conteúdo, focaliza os seres dentro do evento e 
categoria cada um deles dentro de um papel. Quando o informante seleciona informações para supostamente lançar a nova, é porque tem a intenção de prender atenção do leitor/ouvinte e de aumentar o grau de complexidade da discussão, tornando a relação entre as cláusulas mais complexa.

Para Chafe (1987), ainda, a informação se organiza por meio de porções que se remetem a representações mentais, de acordo com o estado da consciência/real do falante, ligado à realidade social que o circunda. Para o autor, as unidades de informações funcionam como fatos que vão se distribuindo entre as cláusulas de acordo com os interesses do falante, e é o estado de consciência que redistribui o que é informação velha ou nova. A considerada velha é aquela que o ouvinte toma como consciente (Chafe, 1976), no momento em que o falante explicita o conteúdo; a nova é aquele que o falante leva em conta conteúdos que estejam na consciência do ouvinte, porém está na memória de longo prazo (Chafe, 1976). Para o autor, o fluxo de informações determina a ordenação linear dos sintagmas nominais (Chafe, 1987) que podem ser alterados na ordem da estrutura entre as cláusulas para atrair o ouvinte, servem para controlar o "fluxo da atenção" (Chafe, 1988).

Fluxo de informação e fluxo de atenção são responsáveis para que se tenham modos diferentes de emissão e codificação de acordo com os interesses de falante e ouvinte. No caso do nosso corpus, utilizado nesta tese, as estruturas discursivas, cujo par correlativo distribui o fluxo da informação, é uma estratégia usada pelo escritor: o que considera como velho já é consciente para o interlocutor, insere na primeira parte da estrutura; aquilo que quer trazer à tona para a consciência, focar a informação por meio do fluxo de atenção, lança para a segunda cláusula.

O foco das análises de Chafe está relacionado não ao conteúdo propriamente, mas como ele é realizado, qual a avaliação que o ouvinte faz dele, como pano de fundo a situações, o contexto atrelado à realidade, que os circula.

Aquilo que o interlocutor possa ter em mente direciona as escolhas linguísticas do falante, por meio foco do conteúdo, de sua extensão, da mudança desse foco.O indivíduo, ao escrever, por exemplo, sobre um tema que precisa discutir, vai se utilizar de referentes, isto é, nomes atribuídos por meio de ideias, por meio de conhecimento de mundo, vai se preocupar como enviar a mensagem, de que forma chegará a ser interpretada pelo ouvinte, com o próprio conteúdo da mensagem. 
Para Chafe (1987), ainda, um falante, com base no contexto extralinguístico, acredita que ele e seu ouvinte compartilham de referentes por meio do ambiente cultural em que estão inseridos. E, a partir disso, é que se pode chegar a entender o porquê das escolhas lexicais, das estruturas discursivas, das ideias escolhidas pelo falante, da utilização de uma língua mais próxima da normatividade, aqui, especificamente, das redações analisadas para esta tese, pois o escrevente sabe que será avaliado por alguém que exigirá tal uso.

O falante, dessa forma, pressupõe o que, como, de que forma falar, para que haja uma aceitabilidade por parte de seu interlocutor; com isso, usa alguns mecanismos tais como imagem do ouvinte/leitor, o ambiente em que está inserido, posição social, gênero, idade, condições de interpretação, informação e sua distribuição entre as cláusulas que, impulsionados por um pragmatismo, faz do ato de comunicar uma ação ordenada por intenções específicas.

Há uma relação entre elementos que compõem a cláusula e a frequência de uso de cada item dentro da estrutura, isto é, há uma categorização estruturada pelo falante que, à medida que produz o discurso, organiza e detalha o conteúdo, atrelado àquele sujeito para um evento específico, assinala o papel, transpõe-no e codifica para determinada situação, e assim, parece testar a fim de obter se houve ou não interação.

Isso nos remete a Labov (1973) que explicita duas premissas centrais:uma, é que a heterogeneidade que se observa nas línguas é ordenada; a outra, é que a produção das formas de uma língua pelos falantes pode ser variável, mas que tem como consequência, a coocorrência de formas intercambiáveis sem que o significado que se intenta veicular seja prejudicado.

Outro ponto que se faz relevante afirmar é a questão de relação entre a informatividade e a codificação do referente ${ }^{14}$, pois muda de acordo como o sujeito vê, entende e aceita as experiências do mundo que o cerceia. É por isso que, ao longo dos anos, o sujeito adquire habilidades de não somente denominar diferentes objetos, que

14 Segundo Lyons (1981), referência é a relação estabelecida entre expressões linguísticas e o que representam no mundo ou no universo discursivo. 
assumem outras formas e papéis, mas também de como inseri-los num contexto informacional e estruturá-los de acordo com suas escolhas.

Para Bolinger (1968, p.17), a língua é adaptativa "se encaixa num estilo, nomeia um novo objeto, ou expressa uma ideia, sucintamente.”, isto quer dizer que expressões se tornam partes dela, cujo equilíbrio é retomado e a nova expressão torna-se um habitante novo à estrutura, pois o vasto caráter aberto da língua, que resulta em "reinvestimentos múltiplos" (Bolinger, 1968, p. 17) é o que faz com que a mudança seja receptiva ao surgimento de uma nova informação.

Em partes são intrinsecamente entrelaçadas e recombináveis de uma variação gradual que advém também de um código genético que carregamos de geração a geração:

Para perceber o valor de tal sistema, podemos comparar o código linguístico com o código genético. Os dois são similares, de muitas formas - tanto mais no que os geneticistas se referente à "sintaxe da cadeia do DNA". A organização hierárquica de unidades de significado, em língua, vindas de palavras, através de frases e sentenças e até no discurso - está em paralelo com as classes de sequências genéticas com suas mensagens herdadas, que controlam o crescimento e o desenvolvimento(Bolinger, 1968, p. 23).

Entendemos, assim, que a língua é conduzida pelos pensamentos através do tempo e dão a ela direção, por meio "dos tópicos" (cf. Chafe, 1984, p. 5), uma coleção de ideias, introduzidas por falantes, que as canalizam por meio de conteúdos informacionais a fim de atrair a atenção do interlocutor; direcionam o que desejam expressar, obedecendo a uma hierarquia para focalizar as mensagens por meio de referentes que, cognitivamente, se instalam na memória por meio de suas experiências advindas tanto sociais, culturais, como também de traços que carrega geneticamente influenciados por esses aspectos.

Para Bolinger (1968), quando vemos um discurso pela escrita, por exemplo, existe uma dimensão horizontal para direita ou esquerda, sinalizando, assim, que a língua muda durante seu percurso, como por exemplo, duas formas que mudaram, mas cujo significado é o mesmo: "não... mas sim", "não... mas” ou até "não... sim", 
correlativas presentes em nossa tese. Para o autor, ainda, as pessoas fazem ajuntamento entre as elocuções, chegam a abandoná-las, por conta de uma armazenagem de estoque linguístico vertical de língua, composto de itens, categorias e conexões, que nos tornam sujeitos competentes para relacionar com um item armazenado e inseri-lo numa estrutura ou também o contrário. Isso se daria a apontar que construções correlatas inovadoras são utilizadas de forma coerente pelo autor que, provavelmente, busca no sistema da língua elementos que se combinam e recombinam e se configuram no uso.

Para Givón (2011), o sujeito ordena as regras gramaticais pelo grau de importância comunicativa, definida como: "Uma regra comunicativa está mais alta na escala de importância comunicativa se dispensar o seu uso (quebrar a regra)" (Givón, 2011, p. 54). Para o autor, quanto mais tempo demorar a transmissão de uma mesma mensagem com mais material linguístico de repetição e redundância, menor será a eficiência comunicativa. O falante/escritor usa as regras da gramática para obter um efeito comunicativo que pode, por exemplo, quebrar uma dessas regras para fazer-se mais compreendido, adequar à intenção contextual, mostrar-se mais habilidoso quanto à sua competência e performance linguísticas, ajudar o seu leitor/ouvinte a entender uma parte solta da mensagem, enfim, um conflito, que poderá levar o falante/escritor “ a penalidade razoável" (cf. Givón, 2010, p. 55), isto é, desobedecer à norma a fím de tornar o que diz ou escreve claro pode ser também fatal àqueles que esperam um uso ligado à normatividade, mas também sugere que a eficiência do processamento e identidade com o interlocutor em detrimento de um uso calcado em regras que, muitas vezes, dificultam a transparência do que se quer dizer, auxilia na comunicação.

\subsubsection{Iconicidade e atenção}

O segundo princípio apontado pelos funcionalistas, que têm como foco entender a organização interna da linguagem entre os usuários de uma língua, é o da iconicidade, tratado anteriormente como "motivação icônica para a forma linguística", entre forma e função, isto é, o código linguístico (expressão) e seu significado (conteúdo) (Neves, 2006, p. 23). 
A motivação pela combinação entre as palavras remonta desde a Antiguidade clássica, em que, de um lado, tem-se os convencionalistas, que defendiam que a língua é fruto de convenção social, o que nos remete a apontar a ideia saussuriana: "o signo linguístico é arbitrário" (Saussure, 1989); do outro lado, têm-se os naturalistas cuja ideia está calcada na relação natural da língua por meio da "expressão e aquilo que ela designa" (Neves, 2004; Cunha, Costa, Cezário, 2003), isto é, para eles, há uma estreita relação entre a realização da língua e a estrutura da experiência do falante subjacente a ela.

Assim, a comunicação, nessa perspectiva, se dá a partir da integralidade de elementos inerentes à sua realização, tais como representada no esquema a seguir:

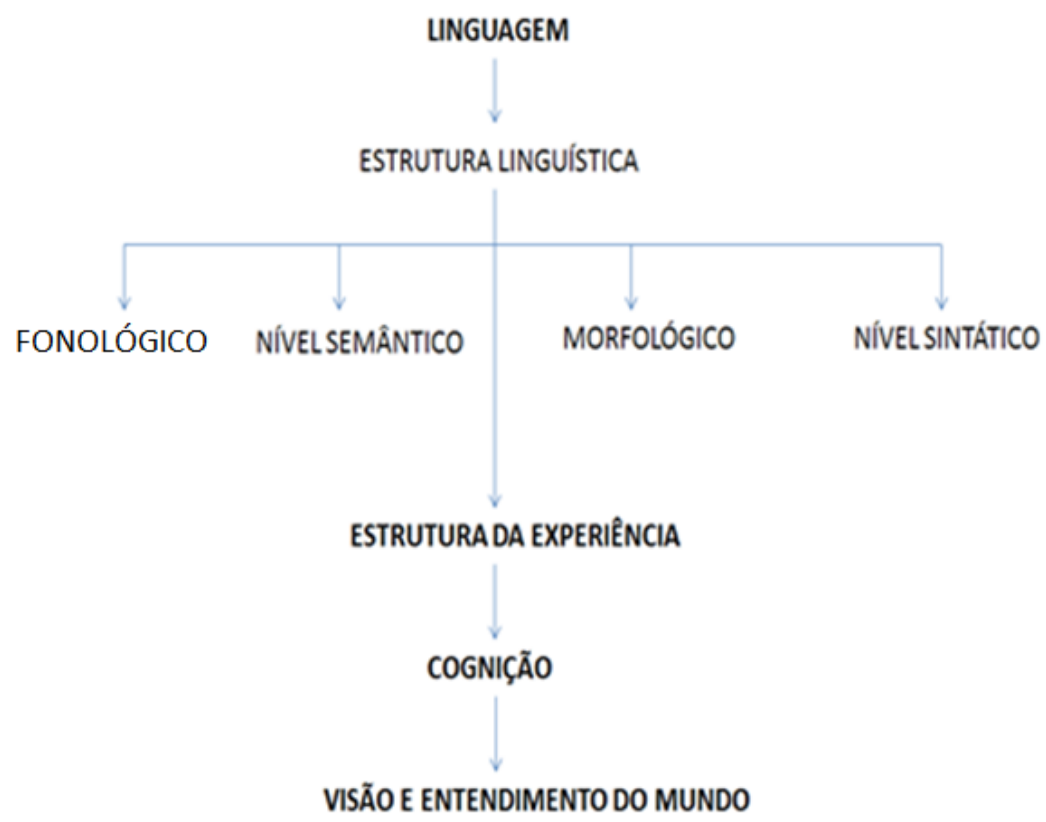

Esquema 4. Representação de níveis linguísticos. (Neves, 2006, adaptado)

Entende-se que a língua não pode ser vista como um conjunto arbitrário de ideias soltas, realizado por meio de palavra que se combinam aleatoriamente, sem finalidade específica; mas, ao contrário, sua realização acontece multipropositalmente, por meio de organizações linguístico-funcionais, que refletem a estrutura das experiências e fazem com que o falante/escritor relacione o gênero escolhido por ele àquela situação/contexto, como por exemplo: conversação, palestra, reunião, carta, bilhete, e-mail, entre outros, que resulta numa combinação entre a estrutura da língua e seus níveis, cuja realização não pode ser totalmente compreendida sem situá-la com "a 
ação conjunta, cognição social, conceituação de experiência, memória e aprendizado, transmissão cultural e evolução, conhecimento partilhado.” (Croft, 2001).

Para o autor, a linguagem ajusta-se ao contexto, em que cada indivíduo esforçase para entender o que um diz ao outro, as intenções envolvidas no processo, e, assim, formam uma ação conjunta para um processo cooperativo, interativo, isto é, para que haja a comunicação, uma atividade ligada por atitudes individuais de cada um dos participantes deve ser assegurada que falante e ouvinte engajem-se.

Ao falar ou escrever, o usuário tem em mente que necessita de um "entrosamento" (Croft, 2001) com as ações do outro participante para alcançar a ação conjunta em que, dentro de um terreno comum, cada qual desempenha seu papel, ligados a uma esfera temática e de seus subtemas a fim de executar plenamente a linguagem. A coordenação é essencial para obter o sucesso nas ações conjuntas, pois, tanto o interlocutor que emite quanto o que recebe, precisam manipular suas atitudes linguísticas a fim de passar, desempenhar e garantir uma habilidade plena para tal fim: o de comunicar.

Quando apontamos a necessidade de uma ação conjunta de cada participante, é porque nos atemos também ao esforço de cada um deles, dentro desse processo, isto é, ambos devem assumir seu papel, para o falante/escritor, a escolha dos itens lexicais, de sua distribuição entre as cláusulas, do tema abordado, dos subtemas que partem dele, e do ouvinte/leitor, também do esforço de garantir uma codificação, atribuir sentidos à mensagem recebida, entre outros.

Percebe-se que, no caso do corpus, sob análise nesta tese, existe um esforço maior do escritor para fazer-se compreendido dentro das ações conjuntas compartilhadas, pois, se houver algum problema, por exemplo, da escolha de um item lexical que provoque dúvida de sentido, falta de clareza do tema exposto, desconexidade entre as ideias apresentadas, por exemplo, o candidato será penalizado perante seus leitores:"Falante e ouvinte devem convergir para um reconhecimento da intenção do falante pelo ouvinte." (cf. Croft, 2001, p. 3).

Para o autor, o problema para a ação conjunta de comunicação é que os participantes não podem ler a mente do outro; para isso, existe a linguagem, que é um dispositivo utilizado pelos primatas humanos, a fim de que haja a resolução do 
problema de coordenação à ação conjunta. Dessa forma, deve existir uma regularidade comportamental comum entre as comunidades linguísticas para que exista uma identidade que, convencionalmente, exige de seus participantes uma regularidade no comportamento das atitudes sociais quanto linguísticas.

Quando pares correlativos se instalam entre as cláusulas, por exemplo, têm-se uma cadeia de combinações de sons, palavras, que, semanticamente, aglutinam significados, de estruturas gramaticais, que, convencionalmente, denominadas de complexas, coexistem por duas razões (Croft, 2001, p. 4):uma, “o número de intenções diferentes do falante a ser comunicado cresce para um número indefinidamente grande"; a outra, seria que "uma mensagem intencional a ser quebrada por partes conceituais recorrentes pode ser recombinada para produzir uma variedade indefinida de mensagens." Isto é, intenções são ingredientes que se combinam ou recombinam com outras intenções experienciais que mudam de acordo com a necessidade de comunicar pragmaticamente diferentes usos para diferentes contextos.

Segundo Tomasello (2003), os humanos têm a capacidade social conjuntiva para a intenção conjunta ao seu meio ambiente, "o que pode mudar de acordo com o tempo e com as pessoas" (cf. Croft, 2001, p, 6). Por isso, a arbitrariedade dos signos, convencional tem sido rediscutida por aqueles que veem a língua dentro de um sistema que, a saber, é “a convenção é parcialmente arbitrária” (Croft, 2001) e que assume diferentes significados conforme as escolhas do falante/escritor que troca as palavras, dentro da construção paradigmática, de acordo com suas intenções, experiências sociais e culturais que o motivam também à mudança das construções sintagmáticas nas estruturas, utilizadas em seu enunciado.

Para Chafe (1977), a experiência do falante é transformada por partes de enunciados linguísticos que são reutilizáveis em partes menores para outras experiências, cuja consciência muda de um bloco para outro, mas que preserva prototipicamente algumas unidades referenciais que servirão de base para outras estruturas linguísticas. Entende-se, assim, uma categoria que relaciona partes da experiência atual do falante/escritor com partes semelhantes de experiências anteriores.

Com isso, ao projetar a atenção para a funcionalidade da língua e ao tratar de seu sistema autônomo, considero a existência de peças que se compõem uma a uma, dentro 
do sistema, que não sendo preenchidas, ao longo do tempo, ou de acordo com a intenção denota o caráter instável que ele possui tanto em série como na função.

Dependendo da tradição cultural, a verbalização de experiências entre as comunidades modifica-se conforme a tradição cultural do grupo, dentro de sua fala, palavras, estruturas, recursos gramaticais, os quais auxiliam na expressividade daquilo que se quer declarar. Isso remete à defesa de que "os usos estabelecem padrões" (cf. Neves, 2003, p. 34). Com isso, compartilho a ideia de Givón (1995), que defende as línguas como em partes, icônicas, em que há uma correspondência entre os arranjos estruturais e suas estruturas semânticas, cujos falantes arquivam suas experiências em repositório mental, mediante as experiências prévias vividas e advindas de tradições culturais, que das relações sociointerativas se concretizam por meio de molduras.

O princípio da iconicidade nos termos de Bolinger (1977) prevê uma conexão não arbitrária e a existência de uma correlação entre forma e função na gramática da língua. Porém, Givón (1991) admite a existência de arbitrariedade na codificação linguística, alegando que a iconicidade do código linguístico está sujeita a pressões diacrônicas corrosivas tanto na forma (código/estrutura) quanto na função (mensagem): por conta do atrito psicológico, o código sofre erosão e a mensagem costuma ser alterada em virtude da elaboração e reelaboração de códigos que assumem formas e funções diferentes, mediante o estágio da evolução humana por meio das experiências do homem, o que Givón (1991) aponta que é por conta de uma elaboração criativa.

Para o autor, os subprincípios associados ao princípio da iconicidade são:
I. Subprincípio da quantidade;
II. Subprincípio da adjacência;
III. Subprincípio da ordenação linear.

Para ele, a gramática é construída a partir desses três princípios icônicos, que se combinam com convenções estruturais aparentemente mais arbitrários. O subprincípio da quantidade em que uma porção maior de informações receberá outra porção maior de codificação; uma informação menor previsível receberá mais material de 
codificação; uma informação mais importante receberá mais material de codificação. Isto quer dizer que aquilo que é mais complexo para o pensamento se refletirá em mais formas dentro da construção linguística. O que é mais simples e esperado tem sua forma mais reduzida. Parece que o falante ativa conhecimentos que não dependem de tantas analogias ou de relações mais complexas. A base cognitiva do princípio da iconicidade está ligada especialmente a áreas de atenção e esforço mental. A complexidade do pensamento tende a refletir-se na complexidade da expressão (Slobin, 1980).

Para esse princípio, quanto maior é o texto, mais informações ele codifica, ou seja: + informação $=$ + estrutura; isto quer dizer, quanto maior a quantidade de informação, maior a quantidade de forma, de tal modo que a estrutura de uma construção gramatical indica a estrutura do conceito que ela expressa. Aquilo que é mais simples e esperado se expressa com o mecanismo morfológico e gramatical menos complexo. Assim, a quantidade, a imprevisibilidade e a importância da informação serão proporcionais ao material de codificação.

A atuação desse subprincípio pode ser vista no comprimento das palavras derivadas em comparação às primitivas de que se originam, refletindo, na forma, a ampliação do seu campo conceitual: belo > beleza > embelezar > embelezamento. Ou ainda, também presente em certas formas verbais em que o falante deseja expressar intensidade da ação descrita, como: “... correram... correram... correram... enquanto isso... O homem correndo... correndo atrás deles...” (Furtado da Cunha, 1998, p. 411).

Givón (1991) apresenta, ainda, outro subprincípio: o da adjacência, que tem como postulado a ideia de que conceitos mais integrados no plano cognitivo se manifestam no nível da codificação linguística com maior integração morfossintática, isto é, a ativação de um conceito desencadeia a ativação de outros conceitos estreitamente a ele relacionados. O que está mais próximo mentalmente, coloca-se mais próximo, sintaticamente. A língua, a partir desse princípio, "não é mapa, diagrama fixo, cujas ideias representam enunciados sempre ordenados por formas e estruturas iguais, pois, se as experiências humanas e a complexidade da língua para representá-las se refletem na estrutura sintática, na organização semântica e cognitiva e se integram para tornar mais claro aquilo que o falante quer expressar para o ouvinte, formas linguísticas se atraem para que possam contribuir com a ordenação de uma sequência de ideias e de argumentos apresentados. 
De acordo com esse subprincípio, a contiguidade linguística tende a refletir na proximidade, por exemplo, entre o verbo e o objeto; há estreita relação entre entidades que estão mais próximas funcionalmente, conceptualmente ou cognitivamente, colocadas uma próxima da outra no nível de codificação, isto é, temporal e espacialmente.

Martelotta (2004), por exemplo, propõe que os advérbios qualitativos, por estarem semanticamente relacionados ao verbo, sendo, inclusive, caracterizados por Castillo (1988-1999) como quase-argumentais, tendem a ocorrer próximos ao verbo. Isso não ocorre com os advérbios de tempo e de lugar, que apenas indicam circunstância que envolve a ação, não interferindo em seu modo de ocorrência.

Hopper associa a transitividade a uma função discursiva-comunicativa: o maior ou menor grau de transitividade parece residir no fato de que o modo como o falante organiza seu texto é determinado, em parte, pela sua percepção, da necessidade de seu interlocutor.

Observem-se: "Ana prometeu sair $>$ Ana prometeu que sairia $>$ Ana prometeu que ele sairia > Ana disse para ele sair > Ana disse que ele saísse > Ana disse: "saia!". (Furtado da Cunha, Tavares, M. A., 2007, p. 158). Esse subprincípio, segundo os autores, correlaciona a "distância linear entre expressões à distância conceptual entre as ideias que elas representam.” (Furtado da Cunha, Tavares, M. A., 2007, p. 159).

Portanto,
A) a distância linguística entre expressões corresponde à distância conceptual entre elas;
B) a separação linguística de uma expressão correspondente à independência conceptual do objeto ou evento o qual representa;
C) a distância social entre o interlocutor corresponde à extensão da mensagem, com conteúdo referencial igual.

O próximo subprincípio ligado à iconicidade é o da ordenação linear, que trata da ordem dos elementos no enunciado, de acordo com o grau de importância que o falante estipula dentro da cadeia sintática. Nesse caso, temos uma conexão entre o tipo de informação veiculada por um elemento da cláusula e a ordenação que ele assume. 
Esse subprincípio tem como foco: a informação mais importante ou urgente tende a ser colocada em primeiro lugar na cadeia linguística, pois é menos acessível e até menos previsível.

Portanto, a iconicidade é um princípio funcional que caminha juntamente com as experiências, com o uso da língua, cujo mecanismo se ajusta no tempo, espaço:

\footnotetext{
Num estágio mais concreto, mais evidente e, portanto, mais acessível à compreensão, está a iconicidade temporal que prevê, na representação linguística de determinados eventos, o gerenciamento da ordem linguística pela ordem dos acontecimentos do mundo real. (cf. Lima-Hernandes, 2006 p 85)
}

Parece que compreender o princípio da iconicidade é também atentar-se para o fato de que a língua é um sistema convencional e isso também nos remete a afirmar que existe uma regularidade comportamental, em parte arbitrária, comum nas comunidades linguísticas como um dispositivo coordenado (Lewis, 1969; Clark, 1996).

Para os autores, as convenções podem emergir quando membros da comunidade compartilham conhecimento por meio de um comportamento repetitivo e, dentro de uma regularidade, passa a ser considerado modelo.

Outro fator que direciona e controla o que se insere, dentro da sentença do material linguístico, é o discursivo-pragmático (Givón, 2001), por duas razões: ser mais familiar para o ouvinte e se desejar chamar atenção especial por considerar aquilo que disse altamente relevante e poder remeter atenção do seu ouvinte ou leitor; mas isso envolve certo julgamento probabilístico do falante, que, por alguns critérios, estabelece o que quer dizer:

A) a familiaridade do ouvinte com o argumento a ser avaliado;

B) julgamento da familiaridade geral do ouvinte como o assunto, bem como sua habilidade em fazer outras inferências relevantes;

C) necessidade de chamar atenção do ouvinte para um argumento que dependerá da avaliação do falante sobre onde a atenção do ouvinte provavelmente estará em, um dado momento. (cf. Givón, 2011, p. 62) 
A estrutura da língua e o modo como codifica as mensagens reflete na estrutura da mensagem no nível da sentença, ao ser equacionada na oração (Chafe, 1979), que especifica o evento, estado ou ação, agente, objeto e o fato atrelado a ele. Parece haver um outro nível de língua que equaciona uma lógica, ordem que direciona os conteúdos proposicionais sequencialmente.

Não podemos deixar de considerar que as propriedades e a estrutura específica dos canais que processam a fala dentro e fora do cérebro neurológico, acústico, articulatório, etc (Givón, 2011), exercem influência nas estruturas da língua, a cognitiva e a perceptual, coligadas, auxiliam para que o processamento das informações se construa e se concretize dentro da sentença comunicacional.

A visão construída de universo humano sob a perspectiva subjetiva do falante para o ouvinte revela como a gramática é moldada por ela que, ontologicamente, contribui para um desenvolvimento da linguagem.

O princípio da ordenação linear está ligado a uma conexão de unidades linguísticas influenciadas pelos aspectos situacional-socioculturais do falante a respeito dos eventos e de seus participantes (Beaugrande, 1993) e que determina suas escolhas para a realização desse princípio.

Segundo o autor, o falante combina os fatos, eventos, por meio dos itens lexicais, para dentro das cláusulas, obedecendo àquilo que, para ele, tem uma sequência de "relações conceptivas ou temporais" (Dik, 1997, p. 134), ou seja, há uma relação direta entre evento/fato $\rightarrow$ conceito $\rightarrow$ tempo. Se a língua é mutável, funcional, então há também uma mobilização daquilo que pensamos, entendemos, codificamos, nominalizamos de acordo com aquilo que vivemos. Isso nos remete a entender a iconicidade como um fenômeno motivado pelas forças externas e internas da língua, que, pelo pragmatismo, faz do sujeito um falante competente e habilidoso para estruturar e organizar itens linguísticos por meio de uma logicidade que, para ele, faça sentido.

Isto quer dizer que a ordenação linear entre os itens lexicais representa que a língua é um mapeamento processual cuja complexidade das estruturas acontece por influências semânticas, cognitivas, sociais, culturais, subjacentes à experienciação 
humana, que direcionam suas escolhas para a ordenação tanto linear dos itens como também espacial e temporal. Esse subprincípio nos imprime algumas premissas funcionalistas expostas por Givón (1979): a estrutura serve a uma função comunicativa cujo significado é contextual e dependente, motivada, iconicamente, por escolhas em que inserem dentro de uma maleabilidade cuja gramática é emergente, porque atende a um propósito comunicativo, calcado numa linguagem sociocultural. Muitos dos pares correlatos encontrados em nosso corpus são advindos de combinações que se concretizam entre as porções informativas, e que parecem representar escolhas simbolicamente marcada pelas experiências culturais do indivíduo.

\subsubsection{Marcação e atenção}

O outro princípio que guia o uso linguístico é o do elemento "marcado" 15 e "não marcado", herdado da linguística estrutural da Escola de Praga. A partir do contraste de dois elementos de uma categoria, seja pelo prisma fonológico, sintático ou morfológico, considera-se um elemento, por exemplo, não marcado, quando contém uma propriedade ausente no outro membro, como a forma "alunos" e "aluno", cuja categoria de número plural x singular, temos uma forma marcada em oposição à forma não marcada. Para Givón (1995), a marcação é um fenômeno ligado ao contexto, em que se insere, porque tem sua base calcada em fatores comunicacionais, socioculturais, cognitivos, porque o falante, para Givón (2011), parece fazer suas escolhas comunicativas a partir de um superuso de um recurso gramatical, pois julga relevante para deixar claro aquilo que aponta, intenciona, ou, também, acredita que, para o ouvinte, será mais difícil de identificar o tópico. Para Givón (1995), ainda, o conceito de discurso formal ou não formal constitui uma diferença entre mais marcado, o primeiro, e menos marcado, o segundo, por considerar que a estrutura marcada tende a ser menos frequente, mais complexa, há um esforço mental maior, demanda mais atenção e processamento, e também por considerar a estrutura marcada maior do que a correspondente.

\footnotetext{
15 Dado o caráter fluido e criativo da língua, busca-se a adoção de parâmetros graduais na análise da marcação: num polo encontram-se as formas de estruturas fortemente marcadas e, no outro, as fracamente marcadas.
} 
Quando o falante quer ser mais expressivo, como afirmado anteriormente, usa formas marcadas, porém é relativo, pois uma forma linguística pode ser mais marcada num contexto de que em outro, como por exemplo, formais marcados na língua oral e considerados não marcados na língua culta.

Nesse ponto, o questionamento investigativo sobre como um par correlativo "não...mas" não institucionalizado nem prescrito pela gramática do português, isto é, marcado, passa a ser uma forma não marcada, num contexto de uso da língua.

Para que a comunicação se processe satisfatoriamente, ou seja, para que interlocutores atinjam seus objetivos comunicacionais, há de se expressar sintaticamente codificando intenções e guiar seu interlocutor na centralização e perifericidade dos enunciados que constituem seu discurso.

\subsubsection{Planos discursivos e atenção}

O falante organiza seu discurso a partir daquilo que considera relevante para o seu interlocutor e, assim, orienta e focaliza aquilo que é considerado central do que é periférico.

Podemos, então, apontar, no plano discursivo, o que Cunha, Costa e Cezário (2003) denominam: foco na informação (figura) e suporte da informação (fundo), o que Givón representa, na figura a seguir:

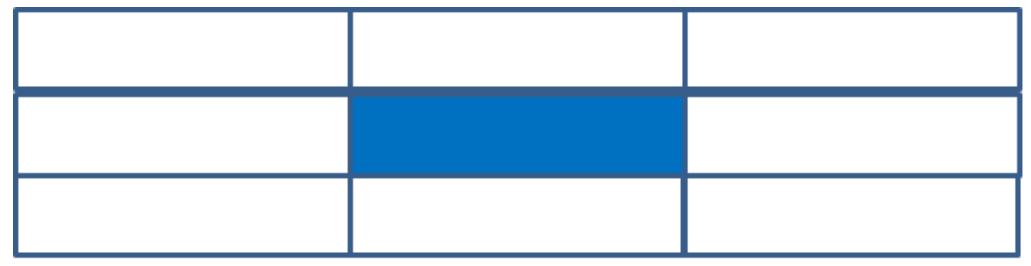

cf. Givón, 2011, p.197

Figura 1. Contraste de planos discursivos.

O que essa figura mostra é que uma parte do discurso, dentro da sentença, se sobressai a outra, isto é, simboliza "uma quebra no padrão, tem valor de surpresa, pode ser isolado." (cf. Givón, 2011). Um texto, dentro da perspectiva discursiva, apresenta 
dados recontados e focalizados, com alto grau de transitividade (figura) periférico, com baixa transitividade (fundo).

Givón diferencia figura e fundo partindo daquilo que está em inércia e de que está em mudança. A inércia corresponde ao fundo, pois não há mudanças, ou figura, corresponde à quebra da inércia, há uma mudança, como mostra a figura a seguir:

INÉRCIA

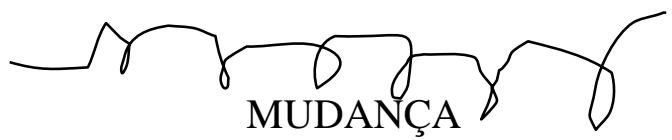

Figura 2. Contraste entre inércia e mudança. (Givón, 2011, adaptado)

Focos de informação surgem à medida que a transitividade se processa como elemento central na sentença que aparece como uma cadeia de eventos pontualmente instados no cerne da comunicação, cujo fundo está ali para que o interlocutor entenda, dentro dessa mesma informação, que, juntamente com a figura, mas com enfoque mais descritivo, avaliativo, é visto e percebido como contraste.

Ambos têm sua representatividade num continuum, em que a saliência, relevância da parte central da sentença, funciona como superfigura e do lado mais neutro, o superfundo:

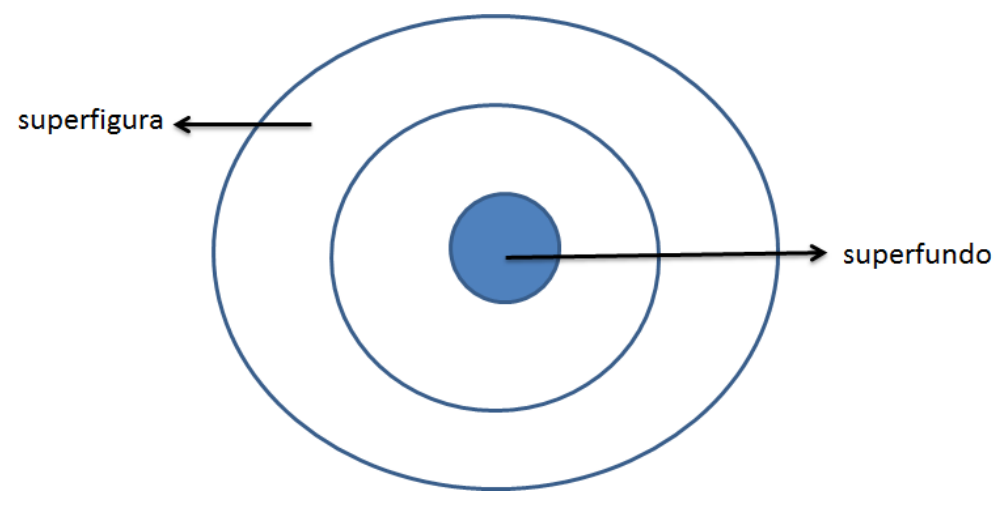

Figura 3. Contraste superfundo x superfigura. (Givón, 2011, adaptado)

Mais do que um princípio funcionalista da língua, os planos discursivos correspondem como queria Givón (2011), a noções derivadas de percepção e cognição humana na qual o sistema de comunicação em processamento e informação é fundado. Por isso é uma ferramenta produtiva para avaliar intenções comunicativas. É o que 
demonstra a seção de análise de dados. Dentre os pares correlatos, por meio das porções informativas, parece existir um processamento, cuja complexidade está calcada nas escolhas intencionais: na $1^{\mathrm{a}}$ porção lança informação já conhecida pelo autor e, na $2^{\mathrm{a}}$, quebra com uma informação surpresa.

\subsubsection{Consciência atenção conjunta e maturação sociocultural}

Tomasello (2003) considera que é possível o fato de que os humanos têm a capacidade social cognitiva para entender que determinados elementos (linguísticos e comportamentais) estão selecionados no seu meio ambiente, em que cada participante pode assumir, numa dada situação particular, certas características notáveis e pertencentes ao seu universo (Lewis, 1969) que os remeterá a um terreno comum, apesar dos fenômenos de indexicalidade e ambiguidade (Clark, 1996). O autor aponta, como exemplo, dois elementos linguísticos como o substantivo "chapéu" e o verbo “encontrar", numa situação em que o falante, ao dizer, "eu encontrei o chapéu” para seu interlocutor, somente haverá conexão se este souber a quem o objeto pertence e se o conhece.

Para isso, os interlocutores devem entender o contexto envolvido nesse cenário, pois ele contribui para coordenar as ações conjuntas, auxilia na manutenção de um exercício entre o falante, interlocutor, cenário, o próprio evento, os elementos constituintes desse processo coordenado não convencional.

Diferentes palavras podem ser usadas para descrever uma situação correta, em que cada uma representa um constructo adequado diante das diversas possibilidades, isto é, são várias alternativas de uso, das quais o sujeito poderá se utilizar; ele escolherá aquela que construirá mais proximamente uma referência entre ele e aquilo que deseja expressar intencionalmente. Mas isso dependerá do conhecimento compartilhado que ambos (falante e interlocutor) comungam, pois uma falha, por exemplo, em um significado, pode acarretar problemas de entendimento e até de aceitabilidade.

Croft (2003) apontou que os significados das palavras mudam com o tempo e com as pessoas, pois a complexidade da linguagem, como ação conjunta, deixa abertos muitos possíveis sentidos de abuso de linguagem, como por exemplo, o uso linguístico da palavra "feto" ou "bebê não nascido". Para o autor, ainda, o uso de determinado item 
linguístico, na estrutura do sistema, está invariavelmente relacionado à onipresença de sua variação, que constituído por meio das experiências e de sua realização fonética, incorporam novos modelos de representação do conhecimento linguístico na mente e fazem com que a linguagem adquira, assim, uma peculiaridade especial, que nos diferencia como primatas.

Existe evidência de que a representação mental de categorias fonológicas inclui a representação dos sinais individuais de sons e as palavras que os contêm. Para Bybee (2001), falantes retêm o conhecimento detalhado de cada som nas palavras que os distingue pela frequência (Bybee, 2001). A autora alega que as formas de alta frequência tendem a ter realizações fonéticas mais reduzidas de que as formas de menor frequência.

O que nos chama atenção para esse aspecto é o fato de que os seres humanos desenvolvem habilidades, desde criança, de detectar sons, até os mais sutis, a que são expostas. Para Vihman e Kunnari (2006), isso se dá por meio de um tipo de aprendizagem implícita, associado ao neocórtex, de entrada sensorial. Bybee e Thompson (1997) apontam que existem evidências substanciais de frequência ligadas a padrões sintáticos que funcionam como relíquias, presentes em estágios anteriores a língua, que têm sobrevivido por conta da frequência e da coerência semântica.

Hopper e Traugott (2003) afirmam que a frequência desenvolve um papel central no processo histórico de gramaticalização, que, por meio de certas estruturas gramaticais, aumenta a regularidade do uso e assim, se submete a alterações gramaticais e fonológicas, mas que, com o tempo , se fixa, perde sua flexibilidade e se reduz foneticamente (Bybee, 2003). Um exemplo citado pela autora é o da construção infinitivo (ir + infinitivo) no tempo futuro, "Ela está indo a Sears para comprar um processador de alimentos", que se modifica sem a possibilidade de inserir uma frase entre ir e o infinitivo, em: ela vai comprar um processador de alimentos.

Para Tomasello (2003), a aquisição sintática sob a luz de uma aprendizagem implícita leva a criança a detectar as regularidades frequenciais, pois são sensíveis ao uso e às suas variantes. Para o autor, ainda, formas mais frequentes são mais propensas a serem produzidas corretamente e as menos, são mais susceptíveis a serem objeto de regularização. 
Croft (2001) aponta que as construções são organizadas em um espaço multidimensional e que se acoplam pela semelhança cultural, que, por conta de um processo de verbalização, assumem outras funções, cujos significados se recaracterizam em um espaço conceitual, por meio da relação de experiências anteriores e atuais, isto é, por conta da linguagem, partes de experiências se recombinam por meio da junção da imagem de objetos, eventos; e, assim, surge um conjunto original daquilo que o falante pretende verbalizar.

Para Croft (2007), ainda, existem particularidades nesse processo: dentre o conjunto disponível de símbolos, o falante seleciona um deles por conta da identificação que estabelece entre o item linguístico e a imagem que o codifica, dentro do espaço e tempo; é um exercício particular de cada falante, que escolhe o tipo de acordo com a necessidade do que comunicar.

Para a seleção de objetos, por exemplo, Croft (2007) aponta que pode ser realizada por meio da categoria flexional de números e quantidades: três livros, por exemplo. $\mathrm{O}$ autor alega também que o evento está atrelado à mente do falante, isto é, está nas atitudes, ações, naquilo que, imageticamente, o autor mobiliza, acredita ser importante para explicitar:

Para conceitos de ação, a seleção é feita através de aspecto gramatical, o que auxilia a individualizar eventos no tempo (comi $\mathrm{x}$ estava comendo), e através de assunto/objeto, uma vez que os eventos também são individualizados pelos participantes (eu li o papel ou ela leu a revista). (Croft, 2007, p. 11). ${ }^{16}$

Existe uma coerência entre as porções no discurso provocada por partículas que funcionam como dispositivo que relaciona um evento a outro por meio de um participante compartilhado, como em "Harry preencheu o formulário e enviou à estância aduaneira" (Croft, 2007, p. 13).

\footnotetext{
16 "For action concepts, selecting is done via grammatical aspect, which helps to individuate, events in time (ate vs. was eating), and via agreement with subject and / or object, since events are also individuated by the participants in them. (I read the paper and she read the magazine)." (Croft, 2007, p. 11).
} 
O que se percebe é um elo entre o que se pensa e sua verbalização, pois existe uma gama de processos de "conceptualização ou de operações de interpretação" (Croft, 2007) que foram identificados na linguagem. Cada verbalização apresenta uma conceituação complexa da experiência original que o falante tem a intenção de comunicar; as que são chamadas de "conceituações convencionalizadas" (Croft, 2007), incorporadas nos recursos disponíveis da gramática de uma língua, funcionam como modelo de verbalização de fala atrelado a uma comunidade que, ao manter suas tradições culturais, exige do falante uma rigidez normativizada de uso.

Para Croft (2007), apesar dessa rigidez de um uso calcada na esfera gramatical, a replicação representa um indício de evolução da língua (Hull, 1988; Croft, 2000), compostos por símbolos de estruturas linguísticas em enunciados, que atrelados à cultura do indivíduo, sinalizam a uma mudança de linguagem.

Para que se entenda a variação, fenômeno de instabilidade linguística, como "parte do processo de verbalização" (Croft, 2007, p. 19), é relevante entender os mecanismos processuais da evolução humana: a primeira, seria a de que trata da mudança do som percebida pela sincronia da língua; a segunda, seria a seleção das variantes de acordo com o ambiente a que pertence (Hull, 1988) e isso leva à escolha mais apropriada com base na identificação entre o falante e o espaço social que o circunda de acordo com o evento. É uma variação condicionada ao valor social, ligada ao uso, condicionada a uma comunidade. Essa variação, como é propagada pela influência do ambiente, pode levar à variação por convenções linguísticas pelos dialetos diante da diversidade linguística que os compõe: "resulta na mudança de linguagem" (Croft, 2007, p. 21).

Assim, percebe-se que o modelo evolucionista entende a linguagem como um mecanismo linguístico composto de enunciados que atendem às diversas comunidades de fala; isso nos remete a apontar que as convenções linguísticas que ativam o conhecimento de mundo, de cultura, que ligados ao papel social a partir do contexto inserido, fazem, do uso, uma sistematização, porque atende às necessidades do falante.

Com isso, é fato, "o conhecimento sistemático de cada falante é diferente, por conta dos diferentes usos a que está exposto" (Croft, 2007, p. 21). Sendo assim, é um dos papéis da sociolinguística correlacionar as variações existentes na expressão verbal às diferenças de natureza social, entendendo cada domínio, o linguístico e o social, 
como fenômenos estruturados e regulares, isto é, dentro de um sistema linguístico existe a possibilidade de realizações de um mesmo item linguístico, um indício de que a variação não é um evento aleatório e inconsequente, mas calcado no uso, coerente:

A existência de variação e de estruturas heterogêneas nas comunidades de fala investigadas está de fato provada. É da existência de qualquer outro tipo de comunidade que se pode duvidar... a heterogeneidade não é apenas comum, é também o resultado natural de fatores lingüísticos básicos. ${ }^{17}$

Entende-se que a linguagem humana é formada por fenômenos que co-ocorrem e se ajustam, adaptam-se às diversas realizações para o processamento discursivo, que ligado a novos comportamentos adquiridos por meio do contato entre os seres que cercam a comunidade, contribuem para uma mudança evolucionária. Nesse sentido a seleção das variantes também são relevantes não só para a sociolinguística como para os estudos sociocognitivos.

Retomando Meillet (1906), a língua, além de ser uma instituição com autonomia própria, também é uma instituição social; e, para explicar os fenômenos das variações, é necessário entender a mudança social embutida nesse processo. Isso quer dizer que uma mudança linguística está atrelada a certas características que a especificam, conforme defendem Weinreich, Labov e Herzog (1968, p.125 e 126):

A) a mudança linguística inicia-se a partir do momento em que passa a ser encontrada num dado subgrupo da comunidade de fala, em que assume um caráter diferenciador e ordenado;

B) a estrutura linguística inclui a diferenciação ordenada dos falantes e dos estilos através de regras que governam a variação na comunidade de fala;

C) toda mudança implica variabilidade e heterogeneidade;

17 "The existence of variation and heterogeneous structures in the speech communities investigated is certainly wellestablished in fact. It is the existence of any type of speech community that may be placed in doubet (...) We come to the realization in recent years that this is the normal situation - that heterogeneity is not only common, it is the natural result of basic linguistic factors." (Labov, W. - 1973., p. 203). 
D) a generalização da mudança linguística não é uniforme nem instantânea, envolve a covariação de mudanças associadas a períodos de tempo;

E) as gramáticas em que ocorrem a mudança linguística são de comunidade de fala, diretamente ligadas à função social que as identifica;

F) quando ocorre, a mudança linguística se dá de maneira ímpar, não está confinada a etapas discretas dentro do sistema linguístico;

G) fatores linguísticos e sociais estão intimamente relacionados no desenvolvimento da mudança linguística.

Mediante ao que os teóricos apontam a respeito da mudança linguística, sugerese que ela se dá como um traço característico de um determinado subgrupo específico da comunidade de fala, em que também caracteriza um valor social significativo para o grupo em que se insere. Foi o que percebi na análise das redações vestibulares.

Entender os mecanismos icônicos e variáveis que se ajustam à mudança linguística, a fim de levar o falante a um gerenciamento de escolhas, mobilidades, que atenda as expectativas do seu interlocutor é, de fato, um compromisso que funcionalistas precisam ter como ordem do dia em sua agenda investigativa e, assim, poderão contribuir para encontrar explicações a respeito desse fenômeno que, às vezes, parece fazer-nos espaçar de nossas certezas.

\subsubsection{Desenvolvimento humano e aquisição da linguagem}

O homem, ao longo de sua jornada, desde criança, cria um conjunto de habilidades que fazem dele um sujeito, de fato, competente, a fim de lidar com escolhas linguísticas, intenções comunicativas, combinações e recombinações vocabulares, a fim de expressar aquilo que pensa, sente e entende o mundo. Mas isso não se dá de uma maneira simples: além de carregar traços genéticos transmitidos pelas gerações, o ambiente cultural a que pertence é um fator significativo que faz o indivíduo observar e entender o outro como um participante ativo da sociedade linguística que o cerceia, e assim, provavelmente, coopera para que o sistema da língua em uso seja flexível, 
adaptável. Então, é fato: escreventes aprendem a correlacionar tanto pares como informações subjacentes a eles, pelo fato de saberem manusear a língua.

A teoria da aquisição baseada no uso ou "linguística cognitiva-funcional" (Tomasello, 2003) tem como hipótese que a aquisição e o desenvolvimento de competências linguísticas humanas são processos sócio-biológicos que envolvem capacidades sócio-cognitivas de compreender e compartilhamento de intenções em atividades sócio-comunicativas. Uma das principais características dessa teoria é a de pautar-se numa análise calcada na evolução da cognição humana (Tomasello, 1999; 2003), produto co-evolutivo de adaptações biológicas específicas à cognição primata e de atividades de colaboração relacionadas à cognição cultural, como por exemplo, criação e uso de símbolos linguísticos, isto é, humanos carregam traços de língua que são biologicamente herdados e culturalmente aprendidos, contrariando a perspectiva estruturalista que considera as competências linguísticas sejam produtos diretos da evolução biológica (Pinker, 1994).

Para Tomasello (2003), habilidades sócio-cognitivas humanas são advindas de uma evolução cultural, a qual permite, por meio de uma transmissão cultural de conhecimentos, já existentes de outra cultura (humana ou não humana), que convenções linguísticas fossem atravessando outras culturas por meio da aprendizagem com seus co-específicos (Tomasello, 2003, p. 5):

Uma hipótese razoável seria, portanto, que o incrível conjunto de habilidades cognitivas e de produtos manifestado pelos homens modernos é o resultado de algum tipo de modo ou modos de transmissão cultural únicos da espécie.

Para Tomasello, ferramentas e comunicação simbólica foram inventadas e, ao longo do tempo, modificadas por outras gerações de espécie, isto é, de geração a geração há uma "evolução cultural cumulativa" (cf. Tomasello, 2003, p. 5), que redefine e aperfeiçoa, podendo ocorrer também de geração a geração nenhuma mudança, até que alguém reinventa, num processo "efeito catraca" (Tomasello, Krunger e Ranner, 1993). O que nos desperta atenção é o fato de que, por meio do efeito catraca, gerações evoluem por meio de invenções criativas que avançam como se fossem catracas que 
impedem que haja um "retorno para trás" (cf. Tomasello, 2003, p. 6), o que equivale a dizer que, por meio desse efeito, as modificações e reelaborações representam uma melhoria, mas que também demandam tempo e adaptação de uma geração para que ocorra uma estabilização.

Tomasello aponta ainda que filogeneticamente "os seres humanos modernos desenvolveram a capacidade de "identificar-se" com seus co-específicos, o que levou a uma compreensão destes com seres mentais e intencionais a eles mesmos." (cf. Tomasello, 2003, p. 13).

O que nos diferencia dos animais é o fato de sermos capazes de combinar recursos cognitivos de maneira diferente de outras espécies animais, pois compartilhamos intenções. É uma motivação exclusivamente humana e, por conta disso, desenvolvemos, ao longo dos tempos, “complexas formas de colaboração caracteristicamente humana que resultaram nas organizações culturais humanas modernas" (cf. Tomasello, 2003 p. 675), em que a linguagem faz parte das cenas de "atenção conjunta" (Tomasello, 2003), em que a compreensão da ação intencional do outro envolve a compreensão dos objetivos da ação do outro em relação a seus estados intencionais dentro de um contexto que tanto como falante e ouvinte devem partilhar para que se direcionem tanto a ação quanto a linguagem atrelada a ele.

Para Tomasello, desde a infância, os símbolos linguísticos arbitrários são compartilhados intersubjetivamente pela criança e pelo adulto, na medida em que ambos compreendem a que função esses símbolos se prestam e qual o seu papel no quadro de atenção cognitiva.

Um falante, ao fazer julgamento daquilo que considera mais relevante, ao ordenar as palavras dentro da estrutura da língua, determinando "uma regra gramatical" (Givón, 2011), estaria atraindo a atenção conjunta do seu co-específico por meio de uma linguagem simbólica composta entre as porções informativas, levando em conta fatores de interação como: avaliação do contexto linguístico, familiaridade do ouvinte à resposta do assunto, inferência, isto é, existe certa liberdade de escolha comunicativa que, calcada nas ações do outro, reflete nossa capacidade de adequar aquilo que falamos a uma representação mental, que interfere basicamente em nossas intenções: 
[...] primatas não-humanos compreendem co-específicos, como seres animados capazes de se moverem por si sós espontaneamente, mas não entendem os outros como agentes intencionais tentando atingir objetivos ou agentes mentais pensando sobre o mundo.(cf. Tomasello, 2003, p. 28).

Falantes fazem escolhas comunicativas de acordo com aquilo que consideram mais adequado para projetar a mensagem, isto é, ao trocar um elemento sintático de posição, por exemplo, acreditam ser mais fácil de identificar e ser inteligível ao seu interlocutor para que possa haver a interação. Para Tomasello (2003), ainda, processos sociais e culturais transformam habilidades cognitivas básicas em habilidades cognitivas extremamente complexas e sofisticadas, em que falante/ouvinte, já durante os primeiros anos de vida, ao serem expostos a situações com indivíduos simbolicamente competentes, consequentemente, com o passar dos anos, criam novas formas de interação cultural "que por sua vez retroagem sobre essas habilidades, modificando-as." (Tomasello, 2003, p. 264). Além disso, o autor considera como hipótese básica que as crianças têm a capacidade de começar a participar de conversas com os outros, um pouco depois de os entenderem como agentes intencionais (com um ano de idade). E só passariam a entender as outras pessoas como agentes mentais alguns anos mais tarde:

[...]para entender que as outras pessoas têm crenças sobre o mundo que diferem das suas próprias, as crianças têm de entabular com elas conversas, nas quais essas diferentes perspectivas ficam claras - seja por um desacordo, um mal-entendido, um pedido de esclarecimento ou uma conversa reflexiva. Isso não exclui outras formas de interação com outros e de observação de seu comportamento como elementos importantes para a construção por parte da criança de uma "teoria da mente"; a questão é que a troca linguística proporciona uma fonte particularmente rica de informação sobre outras mentes.(Tomasello, 2003, p. 254).

Assim como um objeto como "martelo", ao longo da história humana, foi sendo adaptado pelos seres humanos, cujas tradições culturais foram se acumulando e se reorganizando dentro da "evolução cultural cumulativa" (Tomasello, 2003, p. 51), há registros de artefatos parecidos com os de um martelo que foram ampliando sua esfera funcional para dar conta de novas exigências, como por exemplo, de pedras a 
ferramentas complexas compostas por uma pedra amarrada a um pau, até os vários tipos de martelos modernos de metal ou mesmo martelos mecânicos.

Tomasello (2003) afirmou que a evolução cultural cumulativa depende da aprendizagem por imitação e, talvez, de uma instrução ativa por parte dos adultos, em que há um tipo de transmissão fiel necessária para manter o novo modelo dentro do grupo, e, a partir do efeito catraca, haverá possibilidade para inovações variando em função da necessidade do indivíduo na sociedade. No caso específico desta tese, na linguagem, embora cada língua tenha características comuns, existem especificidades dentro do inventário de símbolos linguísticos que o diferenciam e singularizam a partir, por exemplo, das escolhas que o aluno que a manipula faz. Tomasello (2003) aponta que todos os símbolos e construções de uma dada língua evoluem, mudam, de acordo com o tempo histórico.

Um exemplo disso são as palavras independentes que, durante a evolução, tornaram-se marcadores e estruturas discursivas que se congelam em construções sintáticas fixas e organizadas (Traugott e Heine, 1991; Hopper e Traugott, 1993), termos como o passado perfeito do inglês have, em que I have a broken finger "tenho um dedo quebrado" transformou-se em I have broken a finger "quebrei um dedo", em que se apagou o significado de posse.

A linguagem é um elemento universal entre os povos que fizeram o uso torná-la dispersa em diferentes populações, e, a partir disso, outros usos ocorreram e novas dispersões e alterações aconteceram ao longo da história da humanidade. A ontogênese humana, nesse cenário, está nas interações sociais, como por exemplo, na solução de problemas, em que buscam na filogenia do tempo, recursos para desenvolver, praticizar aptidões:

Seres humanos têm capacidade cognitiva que resultam da herança biológica em ações no tempo filogenético; eles usam essas aptidões para explorar recursos culturais que evoluíram no tempo histórico; e fazem isso durante o tempo ontogenético.(Tomasello, 2003, p. 66).

Ao nos remetermos aos nossos pares correlativos, "não..." mais o par constituinte, como por exemplo, "não...mas", ou ainda, "não...sim", entre outros 
expostos nesta tese, verifica-se que tanto o primeiro item, quanto o material de informação inerente a ele, são modelares, artefatos linguísticos já conhecidos para identificar-se com seu co-específico, em que a compreensão é beneficiada porque há uma captação de sentidos. O leitor reconhece no autor sua intenção e, por isso, puxa o fluxo de atenção por meio daquilo que ambos conhecem. É uma estratégia do autor cuja habilidade cognitiva evidencia-se pela sua capacidade de "cooperar com co-específicos na resolução de problemas e na formação de coligações e alianças sociais" (Tomasello, 2003, p. 22). Assim, argumentar a respeito de um tema e escolher formas linguísticas e conteúdo informacional já conhecidos pelo leitor, por exemplo, é reconhecer-se no outro de seu grupo social, a fim de estabelecer interações por meio de representações cognitivas afins.

Ao inserir o outro item constituinte, há um índice de autoria do autor, pois, além de mostrar-se habilidoso no uso de material linguístico cuja forma se faz inovadora, porque foge do que é institucionalizado pela norma da língua, há também a inserção de um conteúdo informacional rico de exemplos, discussões, que funcionam como elementos-surpresa, com o objetivo de mostrar para o leitor o quanto sabe e domina sobre o assunto em relação ao tema tratado. É como se a informação e também o item linguístico estivessem armazenados e fossem redescritos em diferentes formatos, como aponta Smitch (1992):

Minha hipótese é que um modo especificamente humano de obter conhecimento é a mente explorar internamente a informação já armazenada (tanto inata como adquirida), redescrevendo suas representações ou, mais precisamente, reapresentando reiteradamente em diferentes formatos representacionais o que suas representações internas representam.(Smitch, 1992).

Quando o indivíduo atinge um domínio prático de compreensão, de tal modo que consegue adequar e realizar tarefas com destreza, é porque chegou a um corpo avançado de conhecimento advindo de sua observação e reflexão ligadas a um sistema de pensamento capaz de habilitá-lo a perceber, compreender e categorizar sua própria cognição pelo fato de que "ela é expressa externamente pela linguagem" (Tomasello, 2003, p. 273). Para Karmiloff-Smitch (1992), as influências externas podem 
desencadear redescrições representacionais por meio de um impulso interno advindo daquilo a que o indivíduo é exposto, e assim, age como se estivesse observando o comportamento de outra pessoa. A partir do momento em que o sujeito reelabora uma construção linguística mais complexa, por exemplo, é porque ontogenicamente avança de uma forma que o habilita para que construções mais abstratas sejam recombinadas e testadas a partir do outro sujeito, isto é, age, reflete, sobre seu próprio comportamento a partir do seu par, se aceito, passa a adotar aquele comportamento como modelo, passível de mudança pelo efeito catraca que contribui para que redescrevam outras formas. Age aqui um componente de consciência de alta complexidade e de evolução gradativa, sobre o qual trataremos adiante.

\subsubsection{O papel cognitivo da interação humana e a manifestação de uma "gramática adulta"}

Para a formação da cognição humana, processos filogenéticos, ontogenéticos e históricos estão imbricados para que haja o desenvolvimento das habilidades cognitivas e sociocognitivas, pois, desde bebê, ao sermos expostos a indivíduos sociais, simbolicamente interagimos e adquirimos habilidades que possibilitam outras formas de interação sociais e culturais, isto é, habilidades cognitivas básicas são transformadas em habilidades mais complexas, influenciadas pelo ambiente em que o sujeito convive, com as pessoas que cercam seu cotidiano, com o material visual, linguístico, auditivo, perceptivo, sensorial que fazem parte de seu dia a dia.

Fauconnier e Turner (2003) apontam que a evolução humana é continuísta e gradual, isto é, ao contrário de Darwin, que vê para cada evolução uma adaptação singular, os autores preveem uma continuidade de aquisição das habilidades cognitivas humanas em que cada evento singular é provocado por um processo que não se interrompe, isto quer dizer que o surgimento de um elemento da linguagem não estaria ligado a um evento neural adaptativo isolado, mas num processo normal da natureza humana cuja evolução biológica do órgão pode acarretar que novas funções sejam adquiridas ou somente perdidas ou até as duas acontecerem ao mesmo tempo.

Para Damasio (2009), a mente está ligada ao corpo, que contribui para que haja a manutenção da vida e o funcionamento dela. Sendo assim, para evoluirmos, 
compreendermos o mundo ao nosso redor, os aparatos biológico, cultural e social contribuirão, fundamentalmente, para que concebamos o modo como lidarmos com o mundo ao nosso redor.

Enquanto Chomsky (1967) defendia ser razoável considerar a faculdade da linguagem como um órgão composto por um subsistema de estrutura complexa, responsável por uma determinação cognitiva, a corrente cognitivista concebe a linguagem como capacidade que integra modos ou sistemas que trabalham interdependentemente ligados às experiências sensório-motoras esocioculturais humanas.

Para Tomasello (2003), as habilidades cognitivas de linguagem complexa são como xadrez: originalmente, era um jogo simples, mas, à medida que os jogadores foram interagindo com as regras, modificando-as ou acrescentando-as, tornou-se um jogo mais complexo, interativo, de modo a forçar o jogador a criar habilidades cognitivas novas e mais especializadas.

Para o processamento da fala, tanto a emergência de ordenações e construções sintáticas, como as forças pragmáticas que regem a comunicação, os indivíduos, assim como no jogo de xadrez, precisam de um tempo de maturação e não podem ser distintas da realidade do lugar, tempo e comunidade a que pertence o falante, isto é, conforme o indivíduo se adapta, processos de sociogênese evoluem numa escala bem mais rápida de tempo do que o da evolução, em que humanos interagem e transformam por meio do seu co-específico, com formas de cooperação e aprendizagem social, outras possibilidades de criação de artefatos.

No estágio pré-verbal, por exemplo, a comunicação da criança é monoproposicional (Givón, 2011), ao longo da infância, na fase do desenvolvimento do estágio de evolução, a unidade de uma única oração é modificada de tal modo que uma palavra repetidamente torna-se um traço proeminente do discurso multioracional (Keena, 1974). Parece que a criança desenvolveu sua performance comunicativa dentro da estrutura da língua e que percebe que a palavra pode se encaixar dentro de outras estruturas a fim de que haja combinação, que, para ela, logo desenvolva discurso multiproposicional, em que uma série de comentários - asserções são feitas em sucessões sobre o mesmo tópico (Bloom, 1973). 
Para Keenan, a criança pequena ainda tende a assumir que a informação internamente disponível para ela é compartilhada por outros e o discurso infantil inicial é caracterizado pelo lento aprendizado de estratégias para formar o tópico óbvio para os outros - gerando, gradualmente, a criança percebe que aqueles outros não estão a par do que está em sua mente (Keenan, 1974, p. 101).

Compreender que a criança adquire a linguagem durante seu primeiro ano fundamentalmente entre seus familiares mais próximos e que, a partir do contato com outros ambientes, físico e humano, não somente a sua linguagem muda, como também o desenvolvimento cognitivo e linguístico, é fundamental para entender que a "linguagem tem algo especial devido à sua íntima relação com a adaptação sociocognitiva exclusivamente humana [...] e que algumas convenções sociais de que uma língua natural é composta, só podem ser criadas em certos tipos de interação social[...]" (Tomasello, 2003, p. 295).

Assim a ontogênese é o palco das diferenças cognitivas existentes entre a cultura humana em que novas formas de interação social propiciam novas formas de cognição social, entre os indivíduos do grupo aos quais pertencem.

O ambiente físico e social, diversificado, interfere na aquisição e no aprendizado inicial da criança, que, num primeiro momento, desenvolve a capacidade de estocar informações novas para, posteriormente, com a evolução de recursos comunicativos a que ela foi exposta - a saber, o discurso (Givón, 2011) - cria um "background proposicional compartilhado" (Givón,2011) que contribui para que haja um nivelamento daquilo que ela conhece para aquilo que é apresentado por meio de um “continuum observável” (Givón, 2011), cujo desenvolvimento é gradual e composto por uma sobreposição de estágios.

A criança passa por uma transformação em cada estágio e, assim, novos tipos de sistemas de comunicação tornam-se disponíveis e redefinidos. Com base nisso, defendo que existe um modo pragmático pré-sintático do discurso, cujas palavras se combinam de acordo com as escolhas e necessidades do falante, que vai ordenando-as de forma que, primeiramente, apareça o "tópico primeiro, comentário depois” (Givón, 2011). Com isso, não há qualquer subordinação rígida; a coordenação é frouxa, de modo que a criança cria períodos curtos em que praticamente o que aparece são palavras que, aos poucos, se inserem em contextos maiores. Parece que, para a aquisição da língua, o 
cenário que, inicialmente, se desponta é compartilhado a partir do modelo de fala do adulto.

A coordenação parece ser o modo primário da linguagem, que, pela evolução ontogenética, vai se especializando. Decorre que construções mais elaboradas, complexas, correlacionadas ao aumento da capacidade cognitiva e sociocultural, se legitimam na cadeia sintática, surgindo como consequência o processo de subordinação. Isso se dá pela mudança associada à sintatização ligada "à ordenação, modo de complexidade, razão baixa de nome por verbo, morfologia gramatical, modo de processamento, velocidade de transmissão, contexto social e conhecimento de fundo compartilhado" (Givón, 2011, 430).

No desenvolvimento, tanto do contexto sociocultural quanto do sistema comunicativo da criança humana, pode-se observar um aumento na variedade, complexidade e imprevisibilidade da experiência física e sociocultural, correlacionado ao surgimento de um modo comunicativo capaz de dar conta da interação no universo social de estranhos (Givón, 1977, p. 431).

Como é possível depreender desta exposição, a evolução da língua pela criança revela uma complexidade gradual e contínua. Por isso é que não se pode perder de vista que o primeiro estágio de desenvolvimento de aquisição, a criança percebe e entende um jogo existente entre a linguagem e o mundo que a rodeia. Nesse estágio, gestos e vocais são fatores-chave para um sucesso daquilo que ela pede, atos de fala são manipulativos, cuja comunicação, como já explicitei, é monoproposicional, e a estrutura discursiva menor do que a unidade de uma única oração. Esse traço é modificado durante o estágio de aquisição de uma palavra que se torne traço comum e se incorpora em outras orações: discurso multioracional. Logo, o compartilhamento com o adulto faz com que um mero tópico passe a fazer parte de outras orações no discurso da criança e a comunicação passa a ser multiproposicional.

Aplicando essa complexidade gradual à aquisição da gramática da língua, a estruturação da composição do período, no primeiro estágio da codificação verbal se dará pelo objeto e o locativo, concretizados por ela, nessa fase. Somente com a aquisição do desenvolvimento dos estágios da língua, ela vai aumentando seu repertório dentro da estrutura, de modo que, para cada comentário, tem-se maior presença de palavras e verbos, sendo que este último quanto mais complexo, representa um indício 
de que maiores estruturas se desencadeiam cognitivamente e juntamente delas surge a morfologia flexional, marcada, por exemplo, pela pluralização e uso de pronomes.

O modo de processamento das informações e a velocidade de transmissão tornam-se mais rápidas e ligadas ao contexto, fazem com que a criança, em cada ambiente social, mude a comunicação entre seus pares mais próximos ou distintos, ou ainda para tópicos mais elaborados, que, influenciados pelo conhecimento de mundo compartilhado, direcionam e redirecionam aquilo que falam para o interlocutor:

As condições socioculturais associadas ao uso de modo sintático como um registro sincrônico, assim como a mudança sociocultural associada ai surgimento ontogenético de modo sintático, extrapolam, na mesma curva de mudança gradual, da sociedade de íntimos para a sociedade de estranhos.(Givón, 2011, p. 431).

O desenvolvimento cognitivo neurológico e comunicativo apresenta uma contraparte de capacidade em cada estágio evolutivo. Assim, a complexidade pode ser verificada no discurso da criança, cujas construções se efetivam numa gradação; segundo o curso da aquisição da linguagem:

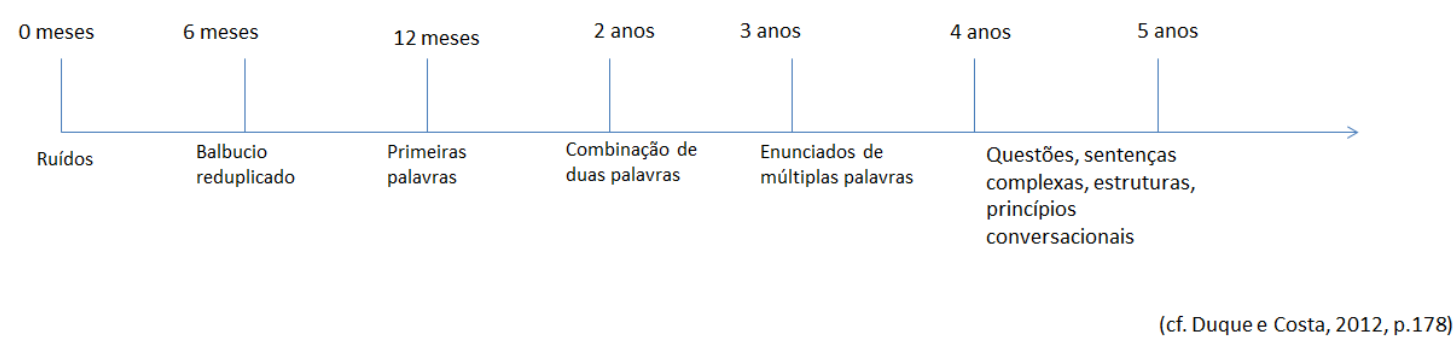

Esquema 5. Curso da aquisição da linguagem da criança

Diante desse quadro que apresenta a aquisição da linguagem da criança, durante seus primeiros anos de vida, algumas considerações se fazem relevantes apontar: para Goldberg (1995), Langacker (1987), Croft (2001), os conhecimentos linguísticos estão ligados ao nível de abstração do falante, em que cada momento, fase, adquire, incorpora novos sentidos às formas que aprende. Fundamentadas em cenas básicas da experiência humana, a criança é sujeita a padrões de gramaticização interlinguística (Slobin, 1980; Choi, Bowerman. 1991). 
Segundo, ainda, Bates (1976) e Clark (1993, 2003), as diferenças nos pares forma-função servem como evidências da evolução do sistema gramatical da criança, que são sensíveis ao contexto a que são expostas. Segundo Tomasello (2003), as primeiras construções parecem ser motivadas lexicalmente por exemplares específicos, e não em parâmetros rígidos, pois existe dentro do processo de aquisição aspectos como “compreensão e produção" (Clark, 2003).

Porque a aquisição de linguagem não se encerra na fase infantil da espécie humana, torna-se relevante discutir o papel da consciência.

Se a gramática da criança, ao longo da sua jornada, muda, é flexível, incorpora novos sentidos e faz o indivíduo, já adulto, compreender e adaptar-se ao contexto que o cerca, e assim, processar e reprocessar informações conforme suas necessidades. Isso é também um exercício presente na escrita, que sofre inferência por conta da fala.

\subsubsection{Linguagem e mente: $o$ papel da consciência selfiana}

Da soma de tudo que o homem chama de seu, como seu corpo físico e psíquico, como também fatos que o rodeiam, seus pertences, experiência, família, antepassados, a linguagem é o mote que o movimenta, faz percebê-lo como ser, que, diferentemente dos outros primatas, alavanca a mudança, suas atitudes interativas, cuja mente se encarrega de trazer à tona a consciência ${ }^{18}$ humana, conteúdos, que, ao longo da vida, fluem por conta de um exercício denominado, por Damasio (2009), de self:

De fato, existe um self, mas ele é um processo, não uma coisa, e o processo está presente em todos os momentos em que presumivelmente estamos conscientes. Podemos considerar o processo do self de uma das perspectivas. Uma é a do observador que aprecia um objeto dinâmico. A outra é a do self como um conhecedor, o

"Consciência é um estado mental - se não há mente, não há consciência; consciência é um estado mental específico, enriquecido por uma sensação do organismo específico na qual a mente atua; e o estado mental inclui o conhecimento que situa essa consciência: o conhecimento de que existem objetos e eventos ao redor. Consciência é um estado mental ao qual foi adicionado o processo da self.” (Damasio, 2009, p. 197). 
processo que dá um foco ao que vivenciamos e por fim nos permite refletir sobre essa vivência.(Damasio, 2009, p. 21).

Os dois selves unidos contribuem para o desenvolvimento evolutivo ${ }^{19}$ da mente humana, em que cada um deles representa um estágio do desenvolvimento evolutivo: para o self como observador, aquilo que nos é exposto repousa, por algum tempo, em nossa mente, que acopla características de comportamentos e de nossa própria história, ao longo da vida. É um processo dinâmico, pois, ao vivenciarmos novas experiências e contextos, um novo registro é destacado e é incluído na personalidade e identidade humana. Para o self como conhecedor, existe um foco naquilo que vivenciamos e juntamente existe uma reflexão sobre isso. Tem-se, assim, sequências de selves que correspondem ao funcionamento da mente humana:

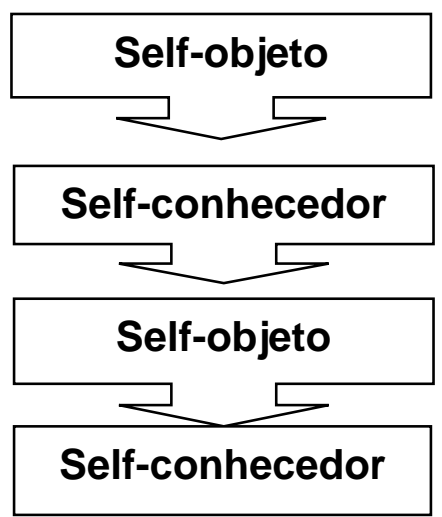

Figura 4. Representação do impacto da consciência sobre o self. (Damasio, 2009, adaptado)

Não há dicotomia entre os dois selves, o que existe é uma continuidade progressiva no fluxo da mente, em que, a partir do self-objeto, outros self-conhecedores desencadeiam camadas de processamentos mentais: "uma coleção dinâmica de processos neurais integrados, centrada na representação do corpo vivo, que encontra expressão em uma coleção dinâmica de processos mentais integrados.” (Damasio, 2009, 22).

\footnotetext{
19 Torna-se relevante frisar que o termo "evolução" não incorpora nenhum julgamento de valor, mas de desenvolvimento natural da espécie humana.
} 
A consciência nesse contexto tem o papel central de organizar os conteúdos mentais, capaz de produzi-los e motivá-los por meio de imagens a que somos expostos, isto é, a partir do momento em que elas são introjetadas mediante àquilo que enxergamos, experenciamos, sentimos, a mente, primeiramente, "permanece inconsciente" (Damasio, 2009), e, a partir de um self, conhecedor, leva o indivíduo a reconhecê-las, por meio de um processo de "subjetividade" (2009), capaz de criar o conhecimento e a cultura, expandidos na memória e corroborados também pelo raciocínio.

Nossa mente, segundo Mithen (2002) acopla não só uma lista de fatos sobre o mundo, mas também aquela que absorve processo de pensamento, cujo registro se acumula ao longo da vida, e, logo depois, ao comprovarmos, combinarmos pedaços de informações que se inserem em outras, ressignificamos outros sentidos gradativamente que se adaptam e se ajustam a outras maneiras específicas de pensar, compreender e agir para soluções.

Ao relacionarmos o conceito de mente (fluida) de Mithen com a aquisição e aprendizagem da língua, entende-se que o ambiente cultural, desde cedo, interfere na aquisição e adaptação da língua a que a criança é exposta. Ela começa a absorver o uso pela capacidade imitativa, que, ao aprender, é rotativo e dinâmico:

Em geral consideramos que nossa mente roda um único e poderoso programa geral, multiuso, normalmente o chamamos de "aprendizagem" e apenas isso. Sendo assim, uma criança começa a absorver conhecimento também irá rodar o programa geral de aprendizado. Num certo dia ela começa a captar dados sobre os sons que ouve saindo da boca das pessoas e sabe as ações que os sucedem o programa roda e a criança aprenderá o significado da palavra... o programa simplesmente continuará rodando, até na fase adulta. (Mithen, 2002, p. 57).

Mas essas analogias são somente um princípio inicial de como entender o processamento da mente, pois ela não simplesmente absorve palavras, resolve problemas, transforma. Há obstáculos que encontra também para que isso possa ocorrer, como discute Chafe (1994, p.21 e 22): 
[... ]para entender a linguagem e a mente mais plenamente, é essencial reconhecer que todos os aspectos da língua e todos os aspectos da mente pertencem a um complexo sistema integrado, cingindo tudo que nos faz humanos. Num foco especial está na consciência, mas anda que discuto excluirá a memória, o imagético, as emoções, a interação social ou qualquer coisa que contribua para a totalidade da experiência humana.

Inicialmente, cientistas e psicólogos acreditavam que a mente da criança funcionava como uma esponja, que vazia, ao ser submetida a informações, ia sugando e encharcando espaços de conteúdos. Num segundo momento, passou-se a entender a mente como se fosse um canivete suíço, em que habilidades e conhecimentos adquiridos preenchiam, satisfatoriamente, cada uma das facas do canivete, mas logo se percebeu que não havia uma dialogicidade, uma relação entre as facas do canivete: "havia uma mentalidade de domínios específicos não-interactantes” (cf. Lima-Hernandes, 2010, p. 94).

Logo após, passou-se a conceber a ideia de que a mente é modular, que, apesar de composta por módulos autônomos, entendeu-se que ela é fluida, em que bases de habilidades e conhecimentos se desenvolvem e assim outros são processualmente adquiridos e ressignificados, imprevisivelmente.

Para Damasio (2009), o cérebro mapeia imagens que não só se referem àquilo que enxergamos, mas sim ao que sentimos, tateamos, ouvimos. É importante apontar que todos esses conhecimentos são decorrentes da evolução humana ${ }^{20}$, pois todos os seres, desde que nascem, começam a desenvolvê-los de forma interativa e adaptativa; um é decorrente do outro. Mesmo que cheguemos a um estágio avançado de consciência, continuamos evoluindo, mas, diferentemente, devido às oportunidades culturais com as quais convivemos. Isso nos remete a apresentar que, conforme experienciamos situações vividas, elas nos tornam conscientes, e isso faz com que

${ }^{20}$ Damásio refere-se ao desenvolvimento cumulativo da espécie, demonstrável nos processamentos cognitivos. 
possamos manipular, transformar, inserir, readequar, de acordo com a sociedade, cultura do indivíduo.

Se a oralidade é um traço de self mais básico dentro da fase do desenvolvimentoaprendizagem da evolução humana, a escrita estaria, então, num outro nível, mais avançado de aquisição. Isso nos remete a apontar que a correlação, objeto de nossa tese, não pode ser usada adequadamente por todos por conta de cada um encontrar-se num estágio selfiano devido às condições sociais a que o escrevente, durante o percurso de sua vida, foi exposto.

Há também o papel da biologia, nesse processo, que influencia na evolução das estruturas cerebrais, presente em quase todos os processos da operação. Uma mente passa a ser consciente a partir do instante da evolução do próprio homem. A consciência revelou o valor biológico, o qual desempenha um extraordinário papel, que liga um longo cordão umbilical à mente, auxiliando nas diversas funções que possibilitaram a linguagem, memória, raciocínio, criatividade do ser humano.

Ao atermos à mente humana, tem-se uma convergência entre a história da biologia e da cultura que nos auxilia a conciliar caminhos do humanismo tradicional com a ciência moderna, pois entender a sociedade por meio das atitudes do homem, principalmente, é resgatar esforços coletivos de cérebros humanos, cuja plasticidade se faz num exercício de idas e voltas (Mithen, 2002, p. 86). O cérebro, nesse contexto, tem papel relevante que, juntamente com o corpo, compõe o organismo que, ao reagir com objetos, há uma interação, uma atuação; registra as várias consequências do organismo com a entidade, em que a memória é protagonista por conta daquilo que é ou foi observado durante a trajetória da vida humana.

Para tratarmos do self e dos estágios de consciência humana, selecionamos Damasio cuja teoria perante uma perspectiva funcionalista do aprimoramento da linguagem.

\subsubsection{A mudança ontogênica e a contribuição dos selves}

O organismo (o corpo e o cérebro) interage com a cultura em que está inserido, e isso nos mobiliza para ações que remetem à mudança coletiva que, de geração em 
geração, que flexivelmente adapta-se e readapta para outros avanços. No tocante à linguagem, parte do pressuposto que um indivíduo lança um item linguístico diferente daquele usual da comunidade a que pertence, isto é, a partir da combinação integrada de parte de itens linguísticos, nasce o self-objeto, que é capaz de gerar conhecimento à mente humana, e que se torna consciente, quando há uma identidade com a situação, ambiente, tempo, intenções daquilo que se quer dizer. Parece que a experiência atrelada à língua faz dessa combinação o aparecimento do elemento novo que, lançado à comunidade, passa a fazer sentido não só ao falante, mas ao seu interlocutor. Há um estado mental consciente, dentro do fluxo, que desperta no outro uma nova possibilidade de um uso de outro item linguístico, funcional, o qual, ao atender a alguns princípios básicos para o ato de comunicar, como facilidade, economia linguística, informação, identidade com os pares da comunidade a que pertence, desencadeará forte possibilidade de se instalar na língua.

Com isso, a hipótese de Damasio (2009) é a de que a consciência é construída por meio de um cérebro que vai se apropriando conscientemente de sua própria evolução. Sendo assim, ele é responsável por gerar um processo de self, cuja essência está no material habitado, propulsor a alavancar estágios que impulsionam e, a nosso ver, dão vida à mente do homem: um estado de vigília.

Ao nos referirmos aos estágios que compõem os selves, baseamo-nos ao esquema apresentado por Damasio (2009, p. 225): o estágio denominado de protosself, que é aquele responsável por reunir imagens que descrevem e nos remetem a uma ligação mais próxima entre cérebro, mente e corpo, e assim, nos alavanca a sensações e sentimentos primordiais lincadas ao nosso organismo. O próximo estágio é o chamado self-central, é responsável pelo estabelecimento de uma relação advinda da mudança do protosself por conta de uma interação entre organismo e objeto, isto é, aquilo que é experenciado pelos seres humanos é resultante daquilo que perceptivamente sentimos, ouvimos, tocamos, escutamos, e que, ao sermos expostos a novas experiências, um novo estímulo de self- central ativa o protosself, e que nos remete a outras imagens e sentimentos. Parece que a linguagem é também descrita a partir de cada pulso, pois, no momento em que há um elo entre língua e sentimento, atrelados à experiência ontogênica e filogênica as quais se imbricam e transformam, imagens se manifestam durante a evolução da mente consciente. 
O terceiro estágio, o self autobiográfico, refere-se aos pulsos do self-central gerados a partir da biografia experienciada do indivíduo, aquilo que é registrado como experiência vivida ou futuro antevisto, cuja arena impulsiona para que o objeto possa ser lincado a outros objetos e assim acumular conhecimentos sobre o organismo individual, social-coletivo, ambiente, entre outros; inclusive, linguístico. Acredita-se que os níveis de self continuam em evolução:

Não deve deixar a impressão de que guarda-mentes adquiriram níveis de self, paravam de evoluir como mentes ou que esses níveis de self finalmente chegaram ao fim de sua evolução. Ao contrário, o processo evolucionário continuou (e continua), possivelmente enriquecido e acelerado pelas pressões criadas pelo autoconhecimento, e não há um fim à vista.(Damasio, 2008, p. 227).

Quando o indivíduo adquire a língua de sua comunidade, a que é exposta a ele, conforme vai crescendo, outros modelos de língua fazem parte de suas experiências, que, por meio de pulsos de self-central, modificam-se de acordo com os grupos sociais para atender não só as suas necessidades comunicativas, mas também seus anseios, sentimentos, que lincados com o seu estado atual biográfico, gerem selves autobiográficos que o levam a sentir um ser social, interativo.

Apontamos, então, que a consciência humana é orquestrada pelos níveis de estágios de selves, cuja a mente, como um rio corrente, é composta por objetos em suas águas, de diversos tamanhos e cores, sendo que alguns são compostos por sentimentos e experiências que foram incorporados, os quais podem ser resgatados a qualquer momento da vida. Alguns desses objetos são carregados de experiências boas e ruins, que, ligados ao corpo e à mente, interferem naquilo que o homem pensa, faz, observa. Segundo, ainda, Damasio (2009), quando se mergulha nas profundezas da mente consciente, descobre-se um conjunto de imagens variadas as quais descrevem os objetos na consciência.

Para o autor, a mente é constituída por meio de um mapa imagético, cuja informação inicial não nos traz nenhum deslumbramento, é estável, é como se fosse um aparato de imagens, que se sequenciam num sentimento primordial e nos vem à mente a fim de mostrar o que temos de conhecimento a respeito do mundo de hoje. Quando 
tratamos de rupturas, mudanças: "o protosself é uma coleção de mapas que permanecem conectadas com sua fonte, uma raiz profunda que não pode ser extirpada." (cf. Damasio, 2009, p. 248).

Assim, pelo par constituinte, percebe-se que o autor, a partir do segundo item, incluirá outras imagens apresentadas no primeiro, a fim de fazer um link com o primeiro par, só que mais expansivo, informacional. Parece que a partir do segundo item, iniciase uma introdução de conteúdos que, ligados à mente, acoplarão para o conhecimento do leitor, informações adicionais que auxiliarão o autor a argumentar. No primeiro item, os objetos listados pelo autor pertencem a um sentimento conhecido entre autor e leitor; a partir do segundo item, o desperta-se um sentimento de conhecer e um destaque à atenção: "O self central é criado pela ligação do protosself modificado com o objeto que causou a modificação, um objeto que agora está marcado pelo sentimento e destacado pela atenção.” (Damasio, 2009, p. 251).

E o último dos selves é o intitulado o self autobiográfico, que se refere ao somatório do que vivenciamos, inclusive experiências daquilo cuja consciência reconhece fazer parte da vida. Trata-se de uma instância de grande abrangência responsável pela pessoalidade e identidade baseadas em conteúdos reais e imaginários. Segundo Damasio é uma "autobiografia que se tornou consciente" (2008, p.259), por isso baseia-se na história memorizada recente e remota e em planos futuros. A diferença para os outros estágios é que envolve reflexão, reavaliação e rearranjo, capazes de modificar tanto a composição factual, quanto emocional. Nesse exercício de reavaliação, uma complexa operação de convergência e divergência alavancam o conhecimento e a própria história autobiográfica.

Ver a língua funcional numa perspectiva cognitiva selfiana é entender como itens ligeiramente neutros, por exemplo, assumem funções que mobilizam o pensamento, sentimento, fluidez humanos. Atenção, complexidade e consciência são aparatos que se desenvolvem, com o tempo, por meio da linguagem adquirida, que não é só output, mas que também impacta o indivíduo, conforme vivencia, torna o uso um exercício selfiano, e, assim, acaba tornando-se um sujeito habilidoso para determinadas situações com as quais concretiza. Esse exercício torna sua mente mais fluida e adaptável, capaz de resolver problemas de adequabilidade, aceitabilidade, por exemplo, em relação ao uso da linguagem em seu cotidiano. 
Hipotetizamos que a correlação sintática seja altamente complexa e demande um self mais abstratizado em pensamento linguístico. Sendo assim, propomos a aplicação de três selves damasianos à análise das construções correlativas no português. $\mathrm{O}$ resultado disso será verificado no capítulo 4, em que desenvolveremos as análises das redações dissertativo-argumentativas, textos altamente complexos que - espera-se tragam exemplares de uma construção altamente complexa também. 


\section{CAPÍTULO 2 - O PROCESSO DE CORRELAÇÃO: DELINEANDO O OBJETO DE INVESTIGAÇÃO}

\subsection{A correlação e sua gênese nos diversos campos do conhecimento humano}

Correlação é um processo tão relevante para a espécie humana que é empregado em diversas áreas de estudos, dentre as quais cito as seguintes: Filosofia, Geociências, Astronomia e Astronáutica, Psicopedagogia, Semiótica, Linguística, Gramática, Fonética, Sociologia, Literatura, Geometria e Informática.

Além do emprego com o significado de "correspondência, relação mútua" (cf. Aulete (1970), Houaiss e Villar (2009), Ferreira (1999) e Borba (1997), verifica-se um emprego muito usual do termo correlação implicado na Teoria da Probabilidade Estatística. Para esse emprego, observa-se o conceito de indicação da força e da direção do relacionamento linear entre duas variáveis x e y, medindo-se essa relação por meio de uma fórmula matemática (cf. Houaiss, entre outros). Correlação (ou co-relação), termo que parte do princípio de que dois termos se ligam linearmente, remete a um elo significativo entre duas partes.

Para a Astronomia, correlação é a interdependência entre as observações quantitativas ou qualitativas, colocada em evidência por uma análise estatística (Mourão, 1995). Para a Contabilidade, o termo está ligado a procedimentos de auditoria, relacionamento entre duas variáveis, mas que são altamente associáveis uma com a outra (Iudícibus, Marion e Pereira, 2003). Na Economia, correlação é uma variação recíproca advinda de variáveis. Pode ser positiva ou negativa. Positiva, quando, por exemplo, o aumento da demanda de certa mercadoria provoca o aumento de seu preço (Sandroni, 1989); negativa, ao se referir à queda na oferta de certa mercadoria, seguida pelo aumento do seu preço. Para a Filosofia, a correlação é uma das quatro formas de oposição enumeradas por Aristóteles, mais precisamente a que ocorre entre termos associados, como a metade e o dobro. Os opostos correlativos não se excluem mutuamente porque um evoca o outro. São termos correlativos, também, o sabível e a ciência, quer dizer, um em relação ao outro. Na lógica escolástica, essa relação foi expressa, dizendo-se que, nela, o sujeito e o termo podem permutar-se. É o que se 
ilustra com o exemplo: "Davi é o sujeito da relação de paternidade enquanto é o objeto da relação de filiação, cujo sujeito é Salomão". Na relação inversa estabelecida, Salomão é o objeto da paternidade de Davi. (cf. Abbagnano, 1999).

Também na Sociologia entende-se que somente a relação entre duas variáveis pode caracterizar o sentido da correlação. Daí a possibilidade de se examinar, simultaneamente, a avaliação de variáveis. Pode ser usada, também, para examinar-se simultaneamente a relação entre uma variável dependente e duas ou mais variáveis independentes. Na Geociência, correlação é a ação de determinar a equivalência de idades geológicas e/ou posições estratigráficas de duas ou mais unidades estratigráficas situadas em áreas reparadas ou, em termos mais amplos, definições da contemporaneidade de eventos nas histórias geológicas de duas áreas. (SUGUIO, 1998). Na Física, a correlação é articulada pela representação de duas variáveis x e y, cuja quantidade se dá pelo quociente da covariância pelo produto dos desvios padrão das variáveis (Houaiss e Villar, 2009 e, na Geometria, em que se representa uma relação mútua entre dois termos, esse conceito entra como método de observação de transformação linear que, no plano, associa pontos a retas, e retas a pontos e, no espaço, associa pontos a planos e planos a pontos (Ferreira, 1986).

O mesmo modo de olhar para as coisas em correlação - para apreender um processo - também vai ser adotado na Biologia, na Psicologia, na Estatística e na Literatura. É na Linguística, contudo, que ela assume um sentido produtivo para se depreender a forma como o indivíduo lida com esse conceito, a forma como ele converte em ferramenta do pensamento lógico o que é matéria-prima para todas as demais áreas.

Segundo Azeredo (2002), correlação "é um processo usual na linguagem da argumentação, utilizado para dar realce às unidades conectadas". A maior parte das palavras gramaticais que a realizam é emprestada de outras classes, como os advérbios “tanto" e "quanto", "mais" e "também”. Essas palavras são mobilizadas, via codificação sintática, para um expediente retórico. 
Recuando à Linguística Funcionalista em suas raízes, chegamos ao Círculo de Praga, porém aplicado ao objeto típico de investigação à época: a fonologia ${ }^{21}$. Naquele momento, correlação é um conjunto de pares de fonemas chamados 'pares correlativos', cujos termos se opõem à ausência ou presença de uma mesma particularidade fônica chamada marca de correlação (o traço) que pode ser: sonoridade em pares, nasalidade em pares. O sistema consonântico de muitas línguas se ordena em função dessas duas correlações.

Na semântica, a correlação parece aproximar-se do paralelismo semântico, em construções coordenadas. Othon Garcia (1997) apresenta um exemplo clássico, que inspira este exemplo: "Fiz duas cirurgias: uma no nariz e outra em Salvador." Um conector coordenativo aditivo exige que duas informações de mesmo campo semântico possam conviver harmonicamente numa sentença. No exemplo, não é isso que se percebe. Fazer duas cirurgias pode implicar dois lugares geográficos ou dois lugares físicos do corpo humano, mas não o sequenciamento de dois campos semânticos misturados ${ }^{22}$. Hjelmslev (2006) reserva o nome de correlação para a relação que existe entre os membros de um paradigma, por oposição à relação reservada para cadeia sintagmática, sendo função o termo genérico que as subsume.

Como já afirmei anteriormente, não é somente nesses campos que a correlação se manifesta. Também na sintaxe, porque é ela que ordena linguisticamente as informações conciliadas. Nesse sentido, encontramos as palavras de Mattoso Câmara (1986), para quem a correlação é uma construção sintática de duas partes relacionadas entre si, de tal sorte que a enunciação de uma, dita prótase, prepara para a enunciação de outra, dita apódose. A correlação se estabelece: a) por coordenação ou b) por subordinação, conforme o conectivo utilizado e a noção de sequência ou sintagma, respectivamente, que daí decorrem exemplos como: "ele não é só bravo, mas também

\footnotetext{
21 Na Fonologia, a correlação é utilizada para indicar uma relação sistemática entre duas séries de sons. Pro exemplo, as séries de fricativas surdas e sonoras do português estão associadas por uma correlação de sonoridades, sendo esta uma marca de correlação (Crystal, 1997).

22 Em Houaiss e Villar (2001), vê-se correlação como correspondência, similitude, analogia entre pessoas, coisas, ideias, etc. relacionadas entre si. Qualidade, atributo do que é correlativo. Interdependência de duas ou mais variáveis. Relação entre duas variáveis que têm como resultado o fato de se tornar como linear a regressão de uma sobre a outra.
} 
agressivo ou ele é tão bravo que chega a ser temerário" (Mattoso, 1986). Na estruturação das formas linguísticas considera-se como correlação a associação dos termos por semelhança ao lado da oposição por seus contrastes.

Se para áreas diversas, dentre as quais situamos a Informática, a correlação é a grandeza que mede a relação de similaridade entre dois fatores, envolvendo um exercício de identificação de desvios e grau de dependência de um fator com a referência ao outro (Fragomeni, 1986), na Gramática esse conceito apresenta-se também como a dinâmica instaurada entre similaridade - desvio - grau de dependência de um fator com a referência ao outro (Fragomeni,1986). Enquanto a tradição polariza em coordenação e subordinação, relegando-se a segundo plano a correlação, os estudos funcionalistas atribuem diferenças em termos de graus de dependência (sincrônica) e desvios de similaridades (diacrônica). Analisei um pouco dessa dissonância a partir dos apontamentos a seguir.

Para Bechara (2009), a coordenação se dá por meio de orações sintaticamente independentes e que podem combinar-se para formar grupos oracionais em períodos compostos; para Luft (2004), as coordenadas são orações de igual função, ligadas por meio de conjunções coordenativas ou por justaposição; para autores mais antigos como Said ali (1966) e Melo (1978), a coordenação é formada por orações que, para o primeiro gramático, são sequentes e se caracterizam por alguma das partículas "e, mas, ou, portanto, logo, porquanto, etc.”; e, para o segundo gramático, caracterizadas por funções ou valores sintáticos paralelos, uma ao lado da outra.

Assim, as orações coordenadas, para esses autores, são definidas como independentes, pois possuem sentido completo. Existe um estabelecimento comunicativo.

No que se refere às subordinadas, Bechara (2009) aponta que uma oração pode funcionar como pertença, membro sintático de outra unidade como em: "O caçador percebeu que a noite chegou", fenômeno denominado pelo gramático de hipotaxe ou subordinação. Já Luft (2004) aponta que a subordinada é aquela que depende de uma oração principal, uma oração regida por outra ou termo desta. Para o gramático são termos correlativos, pois uma está ligada a outra e não existem se houver a anuência de alguma. 


\subsection{Dependência ou subfunção entre as orações principais e subordinadas: o lugar da correlação}

Said Ali (1966) afirma que existe uma oração principal e outra, ou outras, atreladas a ela, consideradas secundárias ou subordinadas, ou seja, "desdobramentos do sujeito, do complemento ou dos determinantes atributivos ou adverbiais em novas orações" (cf. Said Ali, 1966, p. 130). Para Melo (1970), a subordinação se dá pela relação de dependência entre as funções sintáticas, uma oração é parte da outra, exerce uma subfunção. Uma não tem autonomia sem a outra, é parte de outra oração, chamada de principal.

Para esses autores, existe uma relação de dependência sintática de uma oração à outra, cuja função semântica é entendida como parte necessária de uma cláusula à outra. Concebem a sintaxe a partir de um pressuposto teórico de Mattosso Câmara Jr (1986), que parte de uma perspectiva estruturalista que se preocupa com a segmentação do texto em unidades gramaticais, dispostas numa hierarquia, compreendida com estruturas mínimas, ou morfemas, e estruturas máximas, denominadas orações. As intermediárias, segundo Borba (1997), compreendem sintagmas.

Um aspecto que chama atenção é que a abordagem desses conceitos se dá por meio de exemplos trazidos para comprovar a existência de sintaxe à luz da coordenação e subordinação, são advindos de trechos literários ou de períodos artificiais em detrimento da oralidade que se caracteriza por uma situação real de comunicação.

Todos os conceitos apresentados por esses gramáticos estão colocados em princípios sintáticos que não levam em consideração as intenções comunicativas, pois tanto a coordenada, que se caracteriza pela independência entre os períodos, como a subordinada, em que uma existe somente pela outra, estão sob o objeto de uma análise combinatória, formal e estruturada. 


\subsection{Definições de correlação: Gramáticas}

\subsubsection{Abordagem tradicional}

A gramática de João de Barros, de 1496, apresenta a língua pela "construção das partes" (Barros, 1496, p. 30) em que cada oração constrói uma ordem, e que não são uniformes, denominadas de acidentais. Defende, por exemplo, que existe uma concordância entre número e pessoa no que se refere aos substantivos, que também concordam com os adjetivos. Quanto às conjunções, expõe que funcionam como cápsulas que juntam as partes por semelhança como em: "Alexandre e César e Hambel e Porpero e Pierro, foram grandes capitães" (Barros, 1496, p. 33), em que a conjunção "e” tem a função de adicionar partes. Também, as disjuntivas: “... filósofos Sócrates ou Platão, ou Aristóteles...”. Alguns apontamentos de João de Barros (1496), permitem enxergar a sintaxe da língua como um conjunto de partes semelhantes que se encaixam e se combinam. Parece que via, já naquela época, a língua numa perspectiva social, cujo uso se daria numa imitação com base na língua dos latinos, como costume.

Cunha \& Cintra (2001), Kury (2002) e Rocha Lima (2010), utilizam os dois critérios sintáticos e semânticos para distinguir estruturas coordenadas e subordinadas, mas também não se lançam a situações comunicativas. Para esses autores, cada período possui seu papel sintático e semântico.

Para Cunha \& Cintra (2001), as orações coordenadas são da mesma natureza, consideradas autônomas e independentes, cada uma tem sentido próprio; não funcionam como termos de outra oração; mas podem uma enriquecer a outra pelo sentido, ao se totalizarem. Para Kury (2002), a coordenação é composta por orações independentes, isto é, têm sentido próprio, ou seja, poderiam até constituir cada uma seu próprio período. Rocha Lima (2010) afirma que o período composto por coordenação é aquele advindo pela integração de um pensamento comunicativo, pela sucessão de orações gramaticalmente independentes.

A escolha desses gramáticos se deu a partir da análise de livros didáticos mais adotados pelas escolas, nas quais a presença como parte do referencial bibliográfico é maciça. Os autores, ao defenderem a independência entre as orações que compõem o período coordenado, mas que, ao mesmo tempo, veem ali uma integração entre ambas 
em sua totalidade por meio de um pensamento que tem como pano de fundo o ato de comunicar, contradizem-se, pois entendem que, apesar da reparação entre orações que compõem o período, elas são coligadas, a partir do momento de sua realização, cujo sentido se faz presente, por meio de um processo semântico instado na sintaxe.

Parece haver um paradoxo entre o conceito de período composto por coordenação e os comentários de cada gramático: todos apontam que as orações que compõem esse período são independentes, mas, ao mesmo tempo, explicam que existe uma integração de sentidos instituída nesse processo. Com isso, entendemos que a sintaxe e semântica são dois critérios instados na análise desses autores, como se um não tivesse relação com o outro, há uma visão compartimentada a respeito do que é língua e uso.

Quanto ao processo de subordinação, os autores apresentam os seguintes conceitos: Cunha \& Cintra (2001) veem o período composto por subordinação como aquele cujas orações funcionam como termos essenciais, integrantes ou acessórios de outra oração, isto é, uma tem sua existência, se a que está atrelada a ela, também existir. Para Kury (2002), para que haja subordinação, é necessário que o período composto tenha uma oração principal e uma ou mais dependentes dela. Rocha Lima (2010) aponta que a oração principal, no período composto por subordinação, está presa, dependente de outras, em que cada uma tem seu papel como um dos termos da oração principal.

Entende-se que, para esses gramáticos, o processo de subordinação é visto como aquele composto por duas orações que, sem autonomia gramatical, isto é, uma é termo da outra, uma integra a outra, uma não desempenha nenhuma função sintática em outra.

\subsubsection{Abordagem funcionalista}

Estudos mais funcionalistas ligados a descrições gramaticais, como Abreu (1994), Azeredo (2000, 2005, 2011), Perini (2000), Neves (2000) e Mateus et alii (2003), veem alternativas para a descrição nos processos de estruturação sintática.

Para Abreu (1997), os termos subordinação e estruturação devem ser denominados "articulação sintática", para que, assim, pudessem ser evitadas classificações inadequadas para casos em que houver dúvidas quanto à classificação. $\mathrm{O}$ 
termo "articulação sintática" abarca termos como conjunções, preposições, locuções prepositivas, conjuntivas, pronomes etc., que marcam a ligação entre orações.

Azeredo (2011) aponta que palavras, sintagmas e orações se conectam, no discurso, em virtude de variadas relações semânticas. Para ele, existem conexões implícitas e explícitas, quando se estabelecem, no interior do período, tem-se a conexão sintática; no interior do texto, a conexão textual. Para o autor, as conexões sintáticas podem ser tipificadas em: justaposição, quando não há qualquer marca formal (concordância, conectivos) entre os elementos unidos; subordinação, quando há marca formal, se realizado por meio de conectivos de subordinação (preposições, conjunções, subordinativos e pronomes relativos) que se prestam a criar estruturas distintas das unidades ou construções que introduzem; e a coordenação, quando há marcas formais, se realizando por meio dos conectivos de coordenação (conjunção coordenativa ou coordenantes) que se prestam a ligar duas ou mais unidades que tenham a mesma natureza gramatical ou a mesma função sintática (Azeredo, 2002,p.155).

Em relação ao período composto, o que chama a atenção é que o autor denomina justaposto um processo de construção cujas orações vêm combinadas sem qualquer palavra que as ligue (Azeredo, 2000:210). Tanto na fala como na escrita, é comum que as orações ocorram, postas, lado a lado, no período, e unidas por uma relação de sentido que pode parecer natural, por motivos variados, dependendo do conhecimento da realidade entre leitor e ouvinte.

Outro aspecto explicitado por Azeredo (2002,p.211) a respeito das conexões é o da transposição: "processo gramatical pelo qual se formam sintagmas derivados de outras unidades, as quais podem ser sintagmas básicos ou orações constituídas por transpositores”. Para o autor, a subordinada está atrelada ao processo de transposição, pois permite expandir infinitamente os enunciados, mediante um número limitado de meios, que, ligados aos transpositores, estabelece um número limitado de relações semânticas fundamentais.

Azeredo entende o processo subordinado como aquele que depende do conhecimento e das experiências sociais do falante/leitor, a fim de que haja comunicação. De fato, é possível verificar isso em períodos como: "Talvez a greve tenha terminado, os ônibus voltaram a circular" ou "Eu estava muito cansado; dormi imediatamente". Apesar de orações justapostas, o falante/leitor ativa seu mecanismo de 
conhecimentos prévios de mundo para entender a mensagem e a conexão é feita mentalmente.

A gramática funcionalista de Neves (2000) apresenta uma abordagem baseada na língua em uso, princípio básico de todas as vertentes funcionalistas. A autora, em relação à subordinação, parte da análise dos itens lexicais e gramaticais para classificálos de acordo com as diversas construções que os instanciam, sejam elas coordenadas ou subordinadas. A subordinada, para a autora, ocorre na complementação e na adjunção, que seriam as subordinadas substantivas e adjetivas, respectivamente, na gramática tradicional.

[...]a complementação e a adjunção podem fazer-se com orações introduzidas por conjunções integrantes e por pronomes relativos, respectivamente, elementos que as transformam em termos ou em partes do termo da predicação matriz, comparando enunciados complexos. (Neves, 2000,p.24)

Um bloco de construções complexas não permite entender uma parte como constituinte de outra, sem se levar em consideração a informação como inerente a esse processo.

É necessário lembrar que Givón (1979) já mostrara o papel determinante que têm as orações do tipo adverbial de marcar o fundo na organização discursiva. Chafe (1984) também argumentou nessa direção afirmando que as adverbiais poderiam entrar no discurso para servir de pista para o fluxo de informação.

De acordo com Perini (2000,p.129), a dicotomia instaurada entre os conceitos de coordenação e subordinação representa uma "significação e está longe de dar conta de todos os fatos". A subordinação, segundo o autor, é um fenômeno estrutural externo expresso por Jespersen: "um membro de uma sentença que tem forma semelhante à de uma sentença" (Jespersen, 1937,p.166), ou ainda expressa por Martinet (1979, p.17): “[...] entre os elementos determinantes de uma frase, encontram-se com frequência partes do enunciado que apresentam a mesma forma que uma frase completa [...]". Ainda Perini (2000) defende que as orações subordinadas são marcadas pela presença 
de certos elementos sintáticos ou morfológicos, que as caracterizam como subordinada. Esses elementos têm função semântica.

Mateus et alii (2003), apesar de sua gramática de cunho formalista, trazem inovações significativas para os estudos descritivos da língua portuguesa. As autoras propõem três processos de estruturação sintática: coordenação, subordinação e oposição. A subordinação opera no nível das unidades oracionais frásicas e apresenta maior mobilidade de constituintes. Adicionalmente, esse tipo oracional desempenha uma função sintática e uma função temática em relação à outra. A coordenação, por sua vez, funciona como um mecanismo gerador recursivo, em que se combinam constituintes ou partes de constituintes.

De todos os apontamentos explicitados, a ideia que paira, inicialmente, para os apontamentos e análises posteriores é que a sintaxe é constituída por feixes simples, composto por palavras e feixes compostos que, dentro das construções e de sua posição no aparato discursivo, assumem significados diferentes, que se abarcam e se alargam diante das necessidades e experiências dos falantes.

Na sua proposta de uma gramática funcional, Halliday (1985) põe em cheque a dicotomia entre coordenação x subordinação, defendendo que, na organização dos blocos enunciativos complexos, conjugam-se dois eixos: a da interdependência entre os elementos na parataxe e da hipotaxe, por meio de elementos com diferente estatuto, e também um sistema lógico-semântico, em um processo desvinculado da organização e da estruturação do enunciado.

No sistema tático, há uma relação de elementos que vêm um em seguida do outro (parataxe) e outro de um sistema que se apresenta por meio de uma relação de dominação de um em relação ao outro, isto é, haverá o elemento que modifica e o outro modificado (hipotaxe). Esse eixo não admite relações de encaixamento e que uma oração "não compõe diretamente o enunciado do ato da fala" (Neves, 2006,p.228). As relações de encaixamento, as mais complexas, ficam fora desse eixo tático, aquelas em que uma oração não compõe diretamente o enunciado do ato de fala, pois ele funciona como constituinte da frase, numa visão tradicional. A frase complexa, nesse caso, funcionaria como mecanismo constituinte, que entra no eixo tático para compô-la, e não como mecanismo de relação. 
Considerando que a fala utiliza a prosódia para conectar informações, seria lícito afirmar que nem sempre existiria hipotaxe nem encaixamento, porque não existe relação formalizada com elementos gramaticais. No entanto, seria lícito também afirmar que a parataxe é, indubitavelmente, o processo de combinação de orações típico de frases mais tenras de aquisição de linguagem. Dessa forma, mesmo com uma gramática abstratizada, ainda assim, os falantes se serviriam de processos mais básicos para se comunicarem.

Uma proposta que pode ser considerada de caráter inaugural no desenvolvimento da compreensão de como as orações se organizam em uma frase complexa é a que está em Matthiessen e Thompson (1988), em que se considera que a relação da interdependência das orações em um enunciado complexo tem de se completar, considerando sua função discursiva, pois quem fala ou escreve constrói. Na análise do período "não vou à festa, não gosto de sair de casa", não se pode deixar de levar em conta a intuição do falante, suas escolhas, pois se apresenta dentro de um continuum um partilhamento como, por exemplo, do sujeito atrelado ao tempo ou modo verbal, constituindo um entrelaçamento.

Para Givón (1990), há um continuum na hierarquia da integração de orações, negando uma fronteira rígida entre coordenação e subordinação. Segundo ele, existe entre as orações, uma relação icônica entre sintaxe e os eventos, ligadas a um contexto de tempo, causa, condição, lugar, concessão, entre outros.

\subsubsection{Correlação e entoação: junção possível}

Há outro aspecto que deve ser explicitado aqui. A entoação funciona, muitas vezes, como um marcador formal da presença de pares correlativos, num continuum. Segundo Neves (2006,p.263), a origem desses marcadores é conhecida, sendo possível traçar-se o percurso de seu desenvolvimento histórico, que, em geral, representa um processo de gramaticalização. É interessante frisar que, ao analisar os pares correlativos, percebe-se uma mistura entre esses elementos com valores prosódicos com outros mais formais. 
Sabemos que os advérbios invariavelmente dão origem a conjunções nas línguas. Mithun (1988), a esse respeito, mostra uma falta de distinção clara entre essas classes apontando que muitos desses elementos estão em fase de transição, uns mais distantes, outros mais próximos do processo de gramaticalização. Poderíamos evidenciar que existe, entre os itens que compõem o par, uma fluidez entre o papel semânticodiscursivo e o papel relacional de tais partículas. Isso coloca em xeque o relacionamento entre as orações sob o prisma de estatutos, pois fluida poderia ser a própria classificação atribuída aos elementos dentro do contexto pragmático.

\subsubsection{A teoria da correlação}

Em 1952 (p.13), Oiticica afirma, na obra Teoria da Correlação, "que esse processo de composição de período (...) sempre andava confundindo com o da subordinação em todas as gramáticas brasileiras ou estrangeiras”. Esse autor entendia a correlação como um processo que, se mencionado o primeiro termo, somos obrigados a mencionar o segundo, daí tê-lo rotulado como termos independentes. No exemplo "Não somente Marilda socorreu a pobre família, mas também adotou as duas órfãs", ele analisa que o primeiro item é 'denotativo negativo de restrição' e o segundo é “denotativo de inclusão" (cf. Oiticica, 1952,p.22). Já, no exemplo "Não somente Amélia, mas também Lúcia gostam muito de literatura", ele afirma que seria absurdo, como fazem muitos, supor período composto, analisando duas orações. Ele defende que existem dois sujeitos do período simples:

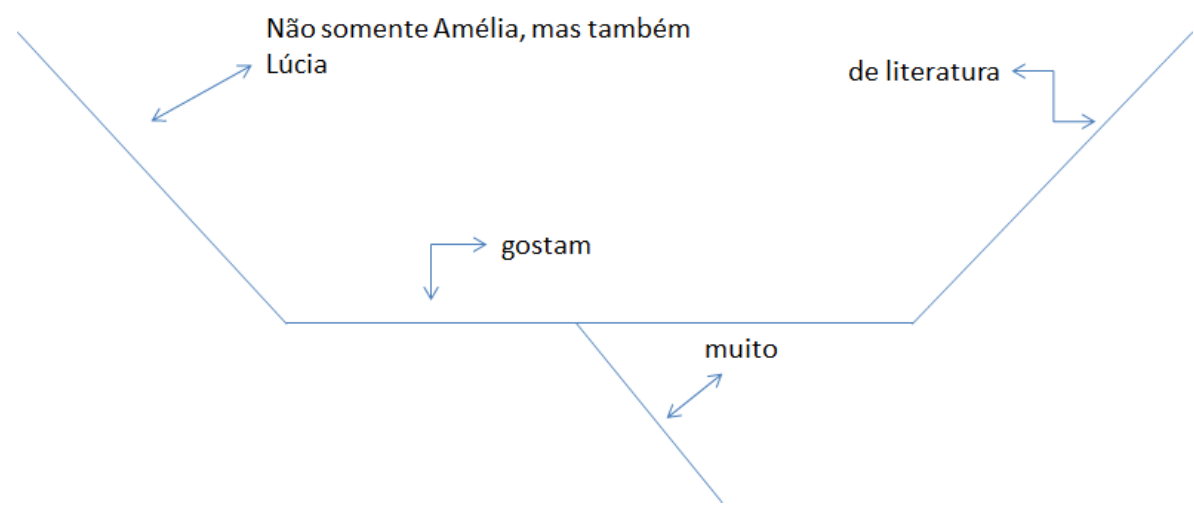

Esquema 6. Modelo de correlação adotado por Oiticica: sujeito composto 
Nesse esquema, o autor coloca os dois itens juntos, apontando que existem dois sujeitos para um mesmo período, logo, é perceptível que há a substituição de uma estrutura coordenada (como apontavam os tradicionalistas) por uma correlação (visão funcional).

No esquema a seguir, o autor demonstra que, ao empregar dois objetos correlacionados aditivamente, há uma preocupação não em classificar, mas, sim, em explicitar o fluxo da informação. Nele, os dois itens se correlacionam aditivamente: "Ele empregou bem não só o irmão, como ainda as cunhadas":

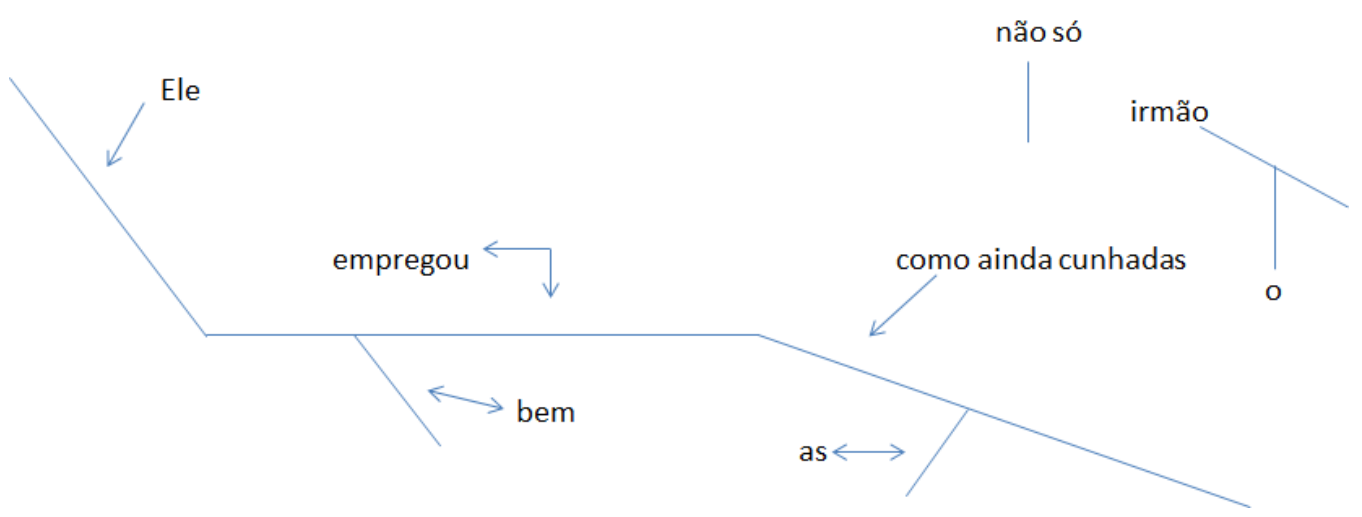

Esquema 7. Modelo de correlação adotado por Oiticica: aditivas

Apesar do esquema de árvores para compor a análise da estrutura, o que o diferencia dos estruturalistas é o modo como concebe os termos da oração: indispensáveis ao discurso como se fosse um elo.

Em outro esquema, Oiticica (1952) representa o exemplo: "Ele tem casa não só aqui, como em Minas", a seguir:

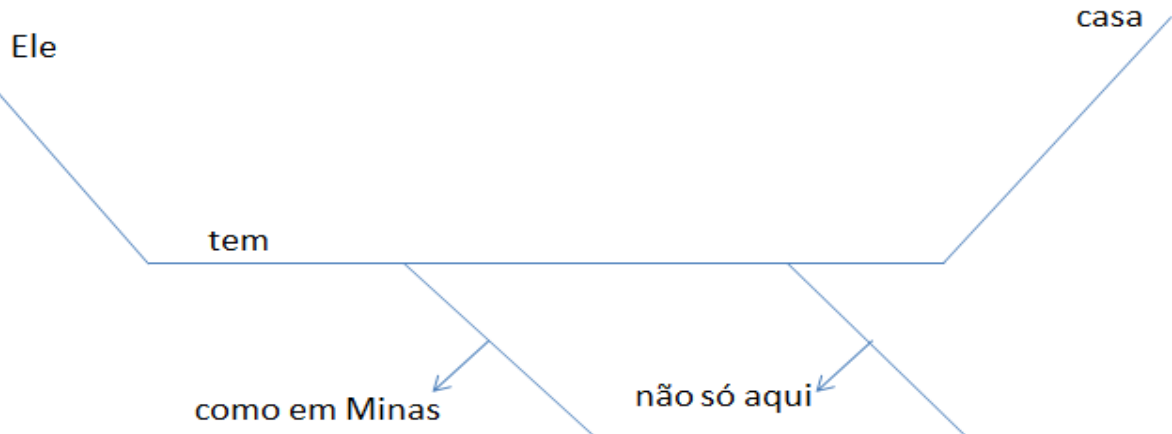

Esquema 8. Modelo de correlação adotado por Oiticica: aditivas adverbiais 
O autor classifica esse período de adjunto adverbial correlacionado aditivamente; não aceita o período separadamente, pois uma oração necessita da outra. Isso permite explanar a não autonomia do pensamento manifestada por uma construção sintática também não autônoma, em que a declaratividade parcial de um período depende da declaração total ou parcial de outra, presa por conectivos.

Outro exemplo de Oiticica (1952) apresenta o caso de uma oração comparativa: "Houve, nessa ocasião, descomedimento do povo, como da polícia", equivalente semanticamente a: não só do povo, como da polícia (correlação dos complementos), segundo o autor (cf. Oiticica, 1952,p.24):

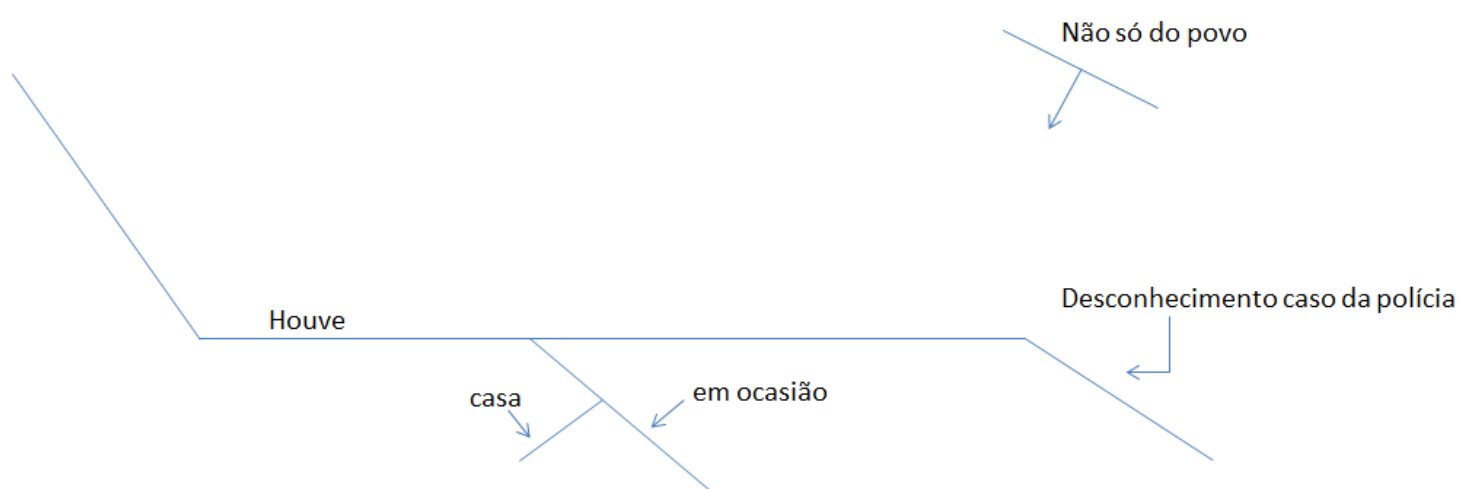

Esquema 9. Modelo de correlação adotado por Oiticica: comparação

Para se entender a correlação, é necessário perceber que as orações se entrelaçam funcionalmente, a partir do uso, experiências linguísticas do falante, resultando, depois, numa disposição sintática, em que os termos se encadeiam um em relação ao outro.

Essa descrição de Oiticica aborda a sintaxe numa perspectiva baseada nas funções em que a intensificação de um membro da oração pede um termo em correlação ao outro.

Em consonância a essa ideia, Chediak (1960) lamentou que a correlação não seja excluída dos processos de subordinação e coordenação, contrariando a tradição, enxergava e defendia que a análise do período sintático deveria corresponder à realidade linguística. 
Para o autor, já naquela época, fazia-se necessário uma reclassificação do período sintático, principalmente àqueles moldes usados em que não se enquadram todas as possibilidades de estruturação do período.

Seus questionamentos davam indícios de que o pensamento, atrelado à língua e seu uso, deve ser peça-chave para a realização do período, e assim, não há como destituí-lo de sua própria realização: "não só ela mentiu, como ainda prejudicou a irmã" (cf. Chediak, 1960, p. 225). Esse exemplo, comenta o autor, não pode ser considerado coordenado se há uma interdependência entre os períodos.

Pauliukonis (2001) afirma que, nesse tipo de construção, há o equilíbrio entre dois termos. Apesar dos ensinamentos de Oiticica (1952), o termo correlação é normalmente associado à subordinação. Rodrigues (2007) explica que, embora tal associação ocorra, não é frequente a menção explícita à categoria "orações correlatas". A autora esclarece que, em geral, se fala da existência de orações que se ligam às outras por meio de conjunções que vêm aos pares. Nesse sentido, a correlação também não deixa de ser associada à coordenação.

Referenda essa análise a de Rocha Lima (2010 p.261), que, ao apresentar as orações aditivas, chama a atenção para o fato de que fórmulas correlativas como "não só... mas também”, "não só... mas ainda", "não só... senão também”, "não só... senão", podem dar mais vigor à coordenação.

Ao realizar levantamentos sobre o tratamento dado pelos gramáticos tradicionais sobre a correlação, percebi que Cunha (1990), Cunha \& Cintra (2001) e Rocha Lima (2010) não fazem referência à nomenclatura de orações correlatas. No entanto, Cunha e Cintra (2001) referem-se, no capítulo das orações subordinadas, que orações comparativas, consecutivas e, às vezes, proporcionais podem estar em correlação com um membro da oração principal. Apesar de Rocha Lima (2010) não fazer menção sobre a nomenclatura de orações correlatas, indiretamente menciona os termos fórmulas correlativas e expressões correlativas para tratar de orações subordinadas comparativas, proporcionais e coordenadas aditivas.

Alguns outros gramáticos preocupam-se em distinguir as orações correlatas. São eles Luft, Kury, Melo e Azeredo. Luft (2002) explicita a nomenclatura de orações correlatas aditivas, comparativas e consecutivas, afirmando, também, que outros 
gramáticos as consideram proporcionais correlativas. Kury(2002), por sua vez, explicita orações consecutivas correlativas e orações proporcionais correlatas. Menciona as aditivas com correlação, palavra ou locução correlativa nas orações comparativas e comparativa quantitativa, que se relacionam por meio de uma palavra intensiva da oração principal.

Ao que parece, os gramáticos tradicionais não veem a correlação como um processo de articulação. Azeredo (1979, p.1) analisa que a maioria dos gramáticos brasileiros entende que a correlação serve apenas para fundamentar algumas classificações coordenadas e subordinadas. Segundo Rosário (2007), isso se dá por influência da Nomenclatura Gramatical Brasileira.

Para Melo (1978), haveria um terceiro processo sintático, o da correlação, em que se observa a interdependência das funções. Um fato que chama a atenção é que a maioria dos gramáticos considera correlativa apenas as subordinadas adverbiais, talvez porque se apresentam em grande número de conectivos que se subordinam em relação à oração principal. Ele não leva em consideração, por exemplo, o caráter enfático do período: "Tanto o animei, que ele publicou o trabalho".

Tradicionalmente, o que se teria aqui, seria um período de causa e consequência estabelecido pela consecutiva (tanto... que). Para Oiticica(1952), porém, a segunda oração “que ele publicou o trabalho”, exprime a consequência de outro fato, pois haveria uma ênfase referida ao fato causador. Essa ênfase, para o autor, é provocada pela palavra intensiva (tão, tanto, tal). Esse tipo de construção seria correlativa (cf. Oiticica (1952, p. 41).

Mediante isso, o autor faz algumas considerações relevantes: a oração correlata consecutiva exprime uma consequência; resultado de um fato enfático, isto é, "com vigor acima do comum" (Oiticica, 1952,p.41). Para o autor, não há característica de oração subordinada, e muito menos adverbial, pois o termo se prende à ênfase e não ao verbo.

Outro estudioso que não poderíamos deixar de apresentar é Câmara Jr., figura tradicional e representativa, que via a correlação como "uma construção sintática de duas partes relacionadas entre si, de tal sorte que a enunciação de uma "prótase", 
prepara a "apódase", constituídas por meio da coordenação e subordinação" (Câmara Jr., 1981, p.87).

Carone (2003, p.62) prefere, também, considerar as correlativas, bem como as justapostas, como variantes dos processos de subordinação e coordenação, pois, para a autora, são procedimentos sintáticos distintos.

Já Othon M. Garcia (1988), que se preocupa com a comunicação, as frases "não fui à festa do seu aniversário: não me convidaram" ou "não fui à festa do seu aniversário: não posso saber quem estava lá” são casos de coordenação, posto que as “orações são ligadas por conectivos, separadas na fala por uma ligeira pausa com entoação variável, marcada, na escrita, por vírgula, ponto e vírgula ou, mais comumente, por dois pontos" (cf. Garcia, 1988, p.23).

Nesta tese assumo que o processo correlativo e a justaposição são mecanismos de articulação de intenções discursivo-pragmáticas que se servem dos processos tradicionais de combinação de orações. Nesse sentido, a correlação, foco desta tese é um processo cuja ferramenta está ligada à codificação linguística de intenções comunicativas.

Para Garcia, ainda, a correlação pode ser denominada de "subordinação psicológica" (Garcia, 1988, p.23), pois aponta que o segundo elemento de cada par não goza de autonomia de sentido. A relação entre as duas porções é de dependência, nitidamente insinuada pela entonação de voz. No exemplo "O dia estava muito quente e eu fiquei logo exausto" (Garcia, 1988,p.24) existe uma falsa coordenação, pois são independentes quanto à forma, mas não quanto ao sentido, pois o "e" está aproximando dois fatos independentes, entre "estar muito quente" e "ficar logo exausto". Existiria, assim, uma coesão de causa e efeito. A independência seria sintática, não semântica nem psicológica.

Essa dependência psicológica parece responder melhor ao que funcionalistas contemporâneos, como Lima-Hernandes e Barrozo (2010), apontam a respeito do conceito de correlação: relação entre dois pares em que o primeiro item serve de gatilho para o segundo, que seria psicológico. 
Em relação à coordenação, Garcia ${ }^{23}$ aponta que é um 'processo de encadeamento de valores sintáticos idênticos' (cf. Garcia, 1988, p.28), isto é, existe um paralelismo ou simetria de construção em que a ideia similar deve corresponder à forma verbal similar. Seria, então, possível questionar o seguinte: essa configuração remeteria ao princípio de iconicidade, o que produziria uma proximidade e combinação de palavras feitas para que os fluxos de informação paralelamente desenhassem as intenções do leitor?

Parece que o paralelismo, simetria de construções, analogamente vai se construindo como bloco que se gramaticaliza e se torna como diretriz eficaz à sua época: "o paralelismo não constitui uma norma rígida, nem sempre é, pode ou deve ser levado à risca, pois a índole e as tradições da língua impõem ou justificam outros padrões" (cf. Garcia, 1988, p.28).

O autor observa que, como aplicamos, por exemplo, o paralelismo no processo correlativo aditivo (“não só... mas também”), teremos um saneamento da frase, evitando construções 'incorretas'. Observemos os exemplos a que ele se reporta como ilustrativos do saneamento operado: "não saí de casa não só porque estava chovendo, mas, também, porque era ponto facultativo" (Garcia, 1988,p.29), "não saí de casa não só por estar chovendo, mas também por ser ponto facultativo" (Garcia, 1988,p.29). No primeiro caso, as orações causais são desenvolvidas e, no segundo, são reduzidas, tanto uma como outra seriam aceitas, porque respeitam o paralelismo gramatical estrito.

Os casos que soam incorretos e precisam de saneamento são aqueles que ele classifica como derivados de cruzamento ou contaminação sintáticos. São eles: "Sentime deprimido pela angústia, não tanto por causa do perigo que corria meu velho amigo, mas também devido à relação que meu espírito artificialmente estabelecia entre a sua saúde e meu amor"(cf. Garcia, 1988, p.29).

O par se consolida pela presença de "não tanto", que existe "quanto". Nesse sentido, a construção "mas também” seria um erro grave de correlação, uma mistura

\footnotetext{
23 Escolheu-se esse autor para discutirmos nosso objeto, haja vista que nosso corpus advém de textos dissertativoargumentativos, produzidos por alunos. Temos como referência a clássica obra de Garcia, Comunicação em Prosa Moderna, cuja finalidade é a de que aproveitem as observações e regras sugeridas pelo autor, a fim de que possam escrever melhor e mais adequadamente. Entretanto, o que se percebe nos casos apontados pelo autor que, apesar de mostrar ocorrências de uso, no caso específico das correlativas, logo aponta que são "condenáveis e defeituosas" (Garcia 1988,p.30), como no exemplo anterior.
} 
sintática que se deve evitar pelos princípios da gramática normativa. Essa correlação está presente na língua em uso, segundo o autor, apesar de ser um "defeito de construção" (cf. Garcia, 1988, p.30).

Percebe-se que períodos que, estruturalmente, fujam daquilo que os gramáticos apontam devem ser evitados em nome da clareza e da objetividade, mesmo acertando a codificação em conformidade com a intenção, como no exemplo anterior, em que não houve prejuízo à comunicação.

Parece que a correlação entendida como "processo de intensificação de um dos membros da frase que pede outro termo" (Melo, 1978,p.152), ainda é vista pelos gramáticos longe de aceitar a língua inerente a necessidades discursivas.

Ney (1955, p.61), ao analisar o período "Quintília mostrou-se-lhe tão graciosa, que ele cuidou estar aceito", argumenta que o termo correlativo tão (denotativo gradativo) exige o segundo termo de correlação; assim, uma oração depende da outra. Ao fazer uso do primeiro termo, o segundo se impõe para que se complete a declaração.

O que difere a acepção aqui adotada para correlação da dos estudiosos do termo é que, nesta tese, considero que o falante, ao acionar um item correlativo, entre as cláusulas, cognitivamente, instala o outro para fazer o elo e consolidar o fluxo informativo.

De todos os apontamentos a respeito do conceito de correlação, há um ponto comum entre todos os anteriores: ao relacionar termos, existe um feixe comum e é nele que a correlação se instaura, dentro de um continuum (Lehmann, 1988) de fala ou escrita.

Termos, como conexão, interdependência, arranjo, parte constituinte, encadeamento, combinação, entre outros, têm, todos, um conceito em comum: elo estabelecido entre as partes de um todo que se configura para um sentido comum a fim de que haja comunicação a partir de um contexto ${ }^{24}$, uso. 24 Assumo o conceito de Houaiss e Villar (2001,p.86): contexto: “1. Interrelação de circunstâncias que acompanham
um fato ou uma situação. 2. Encadeamento de discurso". Estenderíamos o conceito de Houaiss, incluindo a
experiência do falante atrelada ao ambiente em que convive. Para nós, isso se reflete, instaciamente, para o uso da
língua. Ao nos atermos àquilo que Houaiss e Villar nos definiu a respeito de contexto, isto nos leva a refletir sobre a 
A cada discurso atrelado a uma experiência, a uma visão do mundo, dos atos e ideologias, carregadas dentro de nossa própria visão de língua, cultura e sociedade, existe o contexto, o qual coopera para que, cada vez mais, os falantes se recolham para nossas próprias práticas e as ressignificam a partir da apreensão daquilo que compreendem e entendem da realidade que os cerca.

\subsection{A posição normativa dos livros didáticos: regresso à Abordagem Tradicional}

No tocante aos livros didáticos, fizemos uma busca naqueles que mais se têm adotado como material obrigatório às aulas de língua, com objetivo de verificar como tratam a questão da coordenação e subordinação. O que se constatou é que todos, ainda, continuam apontando os dois processos à luz do tradicionalismo, como se o discurso atrelado à língua em uso não fizesse parte da estrutura linguística: a coordenação, de forma geral, é vista como um período composto cujas orações têm estrutura sintática completa, isto é, são autônomas, uma não depende da outra, díspares, e que a segunda oração do período não precisa nem deve funcionar como termo da primeira. Quanto à subordinação, todos apontam que fazem parte de um período composto ao precedido por duas orações em que a segunda depende sintaticamente da primeira, denominada oração principal. Vejamos nominalmente cada uma das obras e exemplos que subjazem o conceito de cada tipo de oração:

Para a obra Português. Linguagens, de Cereja e Cocha Magalhães (2012), a oração subordinada é aquela que depende sintaticamente da oração principal. Exemplo: "Ouvi que eles gritavam palavras de ordem”. A oração coordenada é aquela independente sintaticamente, dentro de um período composto, em que nenhuma funciona como termo da outra, como no exemplo: "muda de atitude e ajude muita gente a ganhar a vida", ou ainda, "separe o lixo e acerte na lata". Para os autores, períodos como esses visam à comunicação direta com o público, chamam atenção para alguns

língua e seu uso, ligado a seu tempo, pois se "o tempo passa, as pessoas mudam, e nem tudo o que foi dito permanecerá em seu sentido se lido em outro contexto” (cf. Lima-Hernandes, 2012,p.6). 
aspectos e atitudes em relação ao comportamento da sociedade. As únicas correlativas apresentadas pelos autores são aquelas que fazem parte do período coordenado aditivo, tais quais: "não só... mas também”, "tanto... como".

Outra obra adotada pelas escolas brasileiras é denominada Novas Palavras, (Amaral et alli), 2010. Para eles, a subordinação advém de uma estrutura formal, cujo período é denominado composto por subordinação, em que se tem: OP $\rightarrow$ O. Subordinada, isto é, duas orações que possuem uma relação sintática, há uma articulação, a compreensão de uma interfere na da outra do ponto de vista do sentido, como no exemplo: "todos desejavam que você voltasse". A coordenação é aquela que possui um período composto cujas orações têm estrutura sintática completa, em que a segunda não precisa funcionar como termo da primeira, como no exemplo: "Zacarias era atacante do time, porém raramente fazia um gol". Também é importante salientar que a única correlativa apontada pela obra faz parte das coordenadas aditivas: "não só... mas também".

A próxima obra cotada para adoção tem sido a Gramática/Texto. Análise e Construção de Sentidos (2012), de Marcela Pontara, Maria Bernadete M. Abaurre, Maria Luiza M. Abaurre.

Para as autoras, o período composto por subordinação é aquele constituído por uma oração principal à qual se subordinam as demais orações, que atuam, sintaticamente, como termos da oração principal, como no exemplo: "meu pai contou que o professor batia nos alunos". A coordenação é aquele período constituído por orações sintaticamente independentes, que se organizam em uma sequência. Apontam também que há uma restrição semântico-pragmática, em algumas delas, como no exemplo: "Vim, vi e venci", que exige uma ordenação quanto ao critério cronológico, cujo contexto da enunciação determina a disposição às orações. Em relação ao significado, alegam que cada uma das orações coordenadas "vale por si só", cujo sentido é constituído pela soma de todas elas. Quanto às correlativas, as únicas encontradas na obra, foram aquelas classificadas como coordenadas aditivas: "não só... mas também" e "não apenas... como".

A próxima obra, denominada Português (Ser Protagonista), de Barreto, (2010), tem sido também adotada nas escolas brasileiras e, segundo as livrarias pesquisadas, é 
uma obra que os professores consideram como um material didático diferenciado, porque é inovador, apresenta textos variados e exercícios ligados à realidade do aluno.

Para o autor, a oração coordenada é aquela com uma independência sintática cujo sentido se constrói pela combinação. Exemplo: "Perdi a corrida. Estou pagando a aposta". Existe uma relação entre os eventos, uma complementariedade sequencial entre as orações expressas, como em: "um mágico puxou a cartola; uma tartaruga saiu dentro dela". Apresenta como correlativa aditiva o par: "não só... mas também”. Já a subordinada exerce no interior de uma oração principal diversas funções sintáticas por meio dos sintagmas nominais no período simples, como no exemplo: "O pai decidiu que ela não ia”.

A Gramática em prática: textos e exercícios, de D’Avila, (2011), apresenta o período composto por subordinação como processo pelo qual juntamos unidades, criando para elas diferentes funções, e estabelecendo entre elas relações de dependência, como em: "Juca esperou que a irmã chegasse", em que se tem a oração principal como primeiro termo e a subordinada no segundo termo, atrelado a ela. Para a autora, a coordenação é um processo de encadeamento das unidades em que não acontece dependência entre elas, como em: "Pedro lava a louça e Cecília varre a casa". Os pares correlativos, considerados parte da oração coordenada aditiva, apresentados na unidade, são: “não só... mas também" e "não só... como também”.

Mesquita e Rivas escreveram a Gramática Pedagógica (2009), outra obra adotada pelas escolas brasileiras, a qual prevê a oração subordinada como aquela que completa o sentido da outra - chamada de Oração Principal - da qual é dependente; exerce uma função sintática, como no exemplo: "Espero que você se recupere rapidamente", em que a oração "que você se recupere" está atrelada à oração principal "espero", a fim de que haja estabelecimento de sentido entre ambas. Para os autores, a oração coordenada é aquela que exerce função independente em relação à outra atrelada a ela, como em: "Não demorou muito e o monstro deu sua primeira investida". O único exemplo de correlativa apresentado por eles é o da coordenada aditiva "não só... como também".

Outra gramática adotada pelas escolas como livro-base para aulas de língua é a Gramática em Textos, Sarmento (2012), que também aponta que orações coordenadas são aquelas cujos períodos são independentes como em: "De repente se zanga e quebra 
trezentos ônibus nas ruas de Salvador", tendo o "e" como síndeto aditivo que encabeça a oração do segundo período. Apresenta também correlativos classificados como aditivos como: "não só... como também", "não só... mas ainda" e "não só... mas também". Para a autora, o período subordinado é aquele formado por duas ou mais orações de sentido dependente, sendo uma das orações a principal: "Detesto que contem piadas sujas em minha frente".

O título Gramática, de Faraco, Moura e Maruxo (2012), bastante adotada pelas escolas, prevê o período composto por coordenação aquele cujas orações são sintaticamente independentes, pois nenhuma exerce função sintática em relação à outra, como em: "O robô dança rap e corre", sendo o "e" também um aditivo. Os outros apontam que cada oração vale por si, embora a expressão complete o pensamento do autor se levarmos em conta as duas orações. O único exemplo de correlativa encontrado foi o de adição, pela oração coordenada: "não só... mas também".

Também tem sido adotada pelas escolas a Gramática de hoje, Terra e Nicola (1995), que também apontam o período coordenado como aquele composto por unidades autônomas, do ponto de vista sintático, não há uma independência entre as orações. O exemplo apresentado por eles foi: "aos oito anos de idade, Bruce Wayne assume a luta contra o crime e adota o nome de Batman". Também consideram o "e" como aditivo, mas atrelado a períodos sintaticamente independentes. O período composto por subordinação é apresentado por aquele cujas orações exercem função sintática em relação à outra. Apresentam como correlativa, somente a aditiva, não só... mas também, que classificam como parte da oração que encabeça uma coordenada sindética aditiva.

Dentre todas essas apontadas, a gramática mais adotada pelas escolas brasileiras, segundo o site da Editora Scipione, como uma das mais vendidas, e também segundo depoimentos de vendedores de alguns dos principais estabelecimentos que comercializam livros didáticos, é a nova edição de Gramática da Língua Portuguesa, de 2001, de Pasquale Cipro Neto e Ulisses Infante. Para esses autores, o período composto por subordinação é aquele em que um termo atua como determinante de outro termo, relação que pode ser verificada entre um verbo e seus complementos por exemplo. No período composto, considera-se subordinada a oração que desempenha função de termo de outra oração atrelada à principal, como em: "Percebeu que os homens se 
aproximavam", em "que os homens se aproximavam" está subordinada à principal "percebeu". Para o período composto por coordenação, termos de mesma função sintática são relacionados entre si, não há uma hierarquia entre eles, pois são sintaticamente equivalentes, como em: "comprei o livro, li os poemas e fiz o trabalho". Cada oração é independente uma da outra, sintaticamente. Nenhuma oração desempenha papel de termo de outra oração.

De todas as obras expostas, percebe-se que a situação comunicativa a que o falante/aluno é exposto, não é levada em consideração, pois todas as gramáticas veem o período composto por subordinação como aquele em que uma oração depende da outra, uma não existe sem a outra, não tem valor por si só. Outro dado que despertou a atenção foram os tipos de oração utilizadas para exemplificar esse período: parecem soltas e com conteúdo pouco relacionado ao contexto. A sintaxe é separada dos vieses semântico e pragmático, como se as orações que se integram fossem totalmente imparciais uma a outra, isto é, são vistas como se uma não dissesse nada sobre a outra, houvesse uma ruptura. $\mathrm{O}$ que se percebe, ao analisar um texto, é que o usuário da língua parece utilizar a estruturação do período para lincar informações, com um interesse discursivo, enfatizando uma ou outra ideia, relacionando tópicos, muito além daquilo que é exposto pelas gramáticas pedagógicas apresentadas.

Quanto à coordenação, todos os livros apontam que as orações se constituem como independentes, isto é, cada qual tem sentido completo e, por isso, há um paralelismo de funções ou valores sintáticos, ligados entre si por meio de conjunções coordenativas ou por justaposição. A ênfase dos conceitos, comentários e dos exercícios apresentados está na classificação, como se não houvesse um encadeamento discursivo.

É certo que os autores dos livros didáticos, seguindo a linha dos gramáticos tradicionais, apresentam e entendem como processo de articulação de orações somente o período composto por coordenação e subordinação, deixando para segundo plano o processo da correlação, entendido como um subtipo de subordinação. 


\subsection{Autores e obras específicas sobre correlação}

Ao relacionar o contexto em que os candidatos cujos textos foram analisados e classificados pela banca da Fundação FUVEST à situação de uso exigida, um uso representante do padrão culto de língua, ao escreverem sobre determinado tema, por mais que estejam pressionados à utilização de uma norma conservadora, "novas formas" (Tarallo, 1999, p.19) surgem e analisá-las a partir do contexto "é estudar a incorporação de elementos dos dados sob análise" (Lima-Hernandes, 2012, p.7).

Entender o contexto no uso e estabelecer lógica é acertar o ruído cultural aí instalado, pois a cultura está entrelaçada na "transmissão de contextos socioculturais através, não somente de pessoas de grupo culturalmente distintos, mas ainda de gerações distintas de um mesmo grupo" (Lima-Hernandes, 2012, p.9). Contexto e cognição caminham juntos. Não se pode tratar de língua como processo de realização prática que, metonimicamente, faz do falante um sujeito que estabelece relações e ligações, sem considerar que esse falante cria e recria e que tudo isso se dá por conta do contexto produtivo que, linearmente, na estrutura linguística contribui para que a comunicação se efetive, pragmaticamente.

Na busca pelo aprofundamento e revisão dos teóricos que se debruçaram sobre os estudos a respeito das correlações linguísticas, destaco o pesquisador Marcelo Módolo, que apresentou em sua tese de doutoramento, em 2004, o tema Gramaticalização das conjunções correlativas no português, cujo objetivo foi mostrar que as correlações conjuncionais do português - aditiva, alternativa, consecutiva e comparativa, para o autor as mais recorrentes e produtivas no português brasileiro, devem ser tratadas como um processo distinto de ligação sintática, pois não se encaixam nas classificações tradicionais coordenativas e subordinativas.

Para o pesquisador, a correlação possui traços tanto de coordenação quanto de subordinação, diferentemente instituído pelos gramáticos do português brasileiro, que definem a coordenação como a relação sintática entre duas sentenças independentes uma da outra, autônomas; enquanto na subordinação se estabelece por meio de uma relação sintática em que uma sentença subordinada completa o sentido de outra, chamada de principal ou matriz, isto é, são interdependentes para poderem existir. 
Módolo aponta que, para os estudos sintáticos, tanto a coordenação quanto a subordinação são operadas geralmente por conjunções; que ligam, geralmente, constituintes de um sintagma, um sintagma a outro e uma sentença a outra. Entretanto, o pesquisador defende um terceiro tipo de ligação sintática, o da correlação, que caracteriza e especifica como "correlação conjuncional, um tipo de conexão sintática de uso relativamente frequente, particularmente útil para emprestar vigor a um raciocínio, estabelecendo uma coesão forte entre sentenças ou sintagmas, e aparecendo, principalmente, nos textos apologéticos e enfáticos" (cf. Módolo, 2004, p. 37), isto é, destaca o uso da correlação como um recurso muito maior do que informar, objetivamente, os acontecimentos, mas funcionam para defender e posicionar-se.

O pesquisador apresenta alguns aspectos funcionalistas ligados à ocorrência de correlatas, como a aditiva subjacente à construção "não só... mas também", mais prototípica, cujos operadores só (advérbio) e mas (conjunção). Há entre os dois pares: "não só" como denotativa negativa de restrição e "mas também" denotativa de inclusão, assim "no par correlativo aditivo, certas conjunções, que encabeçam a segunda sentença, estão correlacionados com expressões adverbiais de focalização da primeira sentença." (cf. Módolo, 2004, p. 67).

Para as alternativas, o autor aponta que esse tipo de conexão exprime a “incompatibilidade dos conceitos envolvidos" (2004). Nas comparativas, há uma correlação que se manifesta entre os pares para estabelecer uma igualdade, superioridade ou inferioridade entre duas realidades ou conceitos.

Para os consecutivos, o autor apresenta a mais prototípica: "é tanto... que", sendo a consequência resultante de uma ênfase referida ao fato causador, representada por meio do intensificador tanto. As proporcionais, que, para o autor, fincadas nas concepções de Barreto (2010), têm a noção conformativa, sobreposta a ela, implicam uma ideia de um acordo entre as duas asserções das duas sentenças correlacionadas.

Ainda apresenta a correlata equiparativa, quando o segundo termo é posto com o mesmo grau de importância em relação ao primeiro que defende tratar de uma comparativa de igualdade. Outra apresentada é a correlata hipotética: "se... então", que defende como primeiro elemento do par uma construção condicional realçada por um elemento conclusivo, resumitivo (então). 
Sequencialmente, o autor apresenta duas maneiras de correlativas: espelhadas e não espelhadas. Baseia-se na classificação apontada por Maciel (1931), que conceitua as correlativas espelhadas como aquelas formadas pelos pares: tal... tal, qual... qual, quanto... quanto, ora... ora, ou... ou, que são estruturas similares umas às outras. Observa que as estruturas dissimilares são denominadas não espelhadas como: tal... qual, assim... como, tal... que, tanto... quanto.

Módolo defende a ideia de que as correlações espelhadas sofrem um processo de reativação (repetição), como na língua falada, proposta por Castilho $(1997,1998)$. Essa forma para o texto escrito se apresenta naturalmente "por conta do espelhamento que a escrita tem em relação à fala" (Módolo, 2004, p. 75). Para o autor ainda, as correlatas não espelhadas são formadas por conjunções, que se expressam por meio de advérbios focalizadores. Aponta sobre a necessidade discursiva de lincar estruturas correlativas, por meio de cláusulas interdependentes, em que o segundo par da estrutura constituinte dá à sentença um sentido que só se torna completo, a partir da relação com o primeiro.

Módolo busca no latim correlativas espelhadas "já... já", "nem... nem” e “ou... ou", para mostrar o processo de gramaticalização que se instalou nesses pares em que, por exemplo, aponta que a correlação alternativa "já... já", desde o século XCII, era utilizada como um recurso discursivo para enfatizar ideias. Segundo os dados apresentados pelo autor, apesar de o valor semântico do advérbio ser conservado, o significado inicial sofreu mudanças ao longo do tempo, ficando mais abstrato. Quanto às correlativas não espelhadas, o pesquisador mostra que elas resultam de um processo de gramaticalização que representa foco, quantidade e inclusão. Para isso, utiliza-se das correlativas de desigualdade, acompanhadas da preposição "de", em estruturas do século XIX. Segundo o autor, a gramaticalização da preposição "de", como introdutora do segundo elemento do par correlativo comparativo, no início assumiu as funções do ablativo latino de reprovação, logo, por analogia, contrai-se como pronome demonstrativo neutro "o", e passa a reger as sentenças, para tornar marcados traços de gênero e número, perdendo sua função pronominal.

Ao final, conclui que a correlação é um processo intermediário entre a coordenação e subordinação, que funciona como elemento estruturador de cláusulas que tem como escopo a argumentatividade provocada pelo elo entre termos indissociáveis e co-relacionados, que são alienares, pois assumem diversos papéis. 
Outro teórico que também contribuiu para podermos compreender o mecanismo das correlações, seu papel, função, é Rosário, que apresentou sua tese de doutoramento em 2012, com o tema Construções correlatas aditivas em perspectiva funcional. Considerou, à luz da vertente funcionalista, a correlação como um processo distinto da coordenação e subordinação, que se inserem em um continuum, compartilhando muitas propriedades em comum. Rosário conceitua a correlação na inspiração de Câmara Jr (1981), que a vê como uma construção sintática prototípica, composta por duas partes que se relacionam interdependentemente, encabeçados por correlatores, numa enunciação de uma prótase que se relaciona a outra, a apódose. Também se apoia nos apontamentos de Oiticica (1952), Ney (1955), Módolo (1999), Perini (2000), Rodrigues (2007), Castilho (2002), que defendem a correlação como um processo de ligação intersentencional de duas orações que estabelecem uma ligação interdependente, produtiva, enfática. Rosário propõe, em sua pesquisa, que a correlação aditiva seja analisada em uma perspectiva que a esquematize em micro, meso e macro construções; e, para isso, utilizou-se de um corpus de textos políticos, extraídos da Assembleia Legislativa do Estado do Rio de Janeiro, do ano de 2009. Sua hipótese foi a de que a correlação serve a outras funções pragmáticas e discursivas dos demais processos.

Rosário teve como objetivos responder às seguintes questões: quais seriam as motivações para o uso de construções correlativas no português brasileiro? Quais seriam as principais propriedades morfossintáticas das construções correlatas aditivas que as distinguem da coordenação e da subordinação? E por fim qual tratamento dado à correlação aditiva, que as esquematize em micro, meso e macro construções?

Para Rosário, o uso das construções correlatas se dá pela necessidade comunicativa, que faz com que o falante busque pelo uso, outras formas linguísticas, às quais se gramaticalizam, bem como na existência de conteúdos cognitivos para os quais não se encontram designações linguísticas adequadas. Ainda para o autor, a correlação aditiva seria uma estratégia de cunho mais discursivo do que sintático. Aponta também que as construções correlatas são marcadas em relação às coordenadas, pois tendem a ser mais complexas (maiores) em relação à sua estrutura, são interdependentes; são bem menos frequentes e mais complexas, haja vista que exigem maior esforço mental ao serem processadas, com maior demanda de tempo. 
O autor aponta, ainda, que, para os gramáticos e outros teóricos consultados, tanto a coordenação como a correlação aditivas possuem traços em comum: uma relação cognitiva maximizada e de camadas, que tem como foco a adição, que ligam elementos frásicos e não frásicos, cujos elementos se unem por ordem de natureza sintática.

Outro ponto levantado pelo autor é a capacidade verifuncional e argumentativa que as correlatas possuem e exercem como função; diferentemente das coordenadas, voltadas somente a aproximar ou copular elementos, sem a preocupação frequente com ênfase ou intensificação.

Rosário alega que, pela tradição, é muito provável o fato de que as correlatas não sejam consideradas um terceiro processo de estruturação sintática, por conta da tradição estruturalista binária e dicotômica subordinada e coordenada. Para o autor, as sentenças complexas aditivas, ao descreverem e adicionarem eventos, cuja descrição, o conteúdo e a situação se reúnem, se combinam, a adição expressaria a união, não só de elementos aditivos, mas de outras relações, também.

Interessante apontar que o autor explicita a tendência de pesquisadores com foco no funcionalismo linguístico norte-americano associarem a análise dos fenômenos linguísticos aos conhecimentos advindos da teoria dos gêneros; isto porque o discurso é o objetivo privilegiado das análises funcionais (Oliveira e Votre, 2009).

Rosário, para tratar mais especificamente dessa questão, embasa-se nos apontamentos teóricos de Marcuschi (2005), Machado e Mello (2004), que têm como foco a associação entre linguagem x experiências culturais e sociais x gênero textual carregados de uma dinamicidade, plasticidade tanto linguística quanto cognitiva, integrados ao sistema de língua, que oferecem a possibilidade de experimentação e elaboração de gêneros e estilos coligados à situação, à necessidade do autor mediante às suas expectativas, o que confere um caráter fronteiriço e fluido à língua.

Rosário, calcado nas concepções hibridistas da oralidade $\mathrm{x}$ a escrita, de Marcuschi (2005), dentro do continuum da língua, exibe possibilidades de uso de gêneros textuais que se mesclam tanto nas duas modalidades, cujo meio de produção e concepção discursiva devem ser analisados na perspectiva do uso do código, e não do sistema, pois há um hibridismo presente nas diversas mídias, cujos contextos 
inviabilizam a dicotomia de um uso relativizado somente para uma ou outra modalidade. Compartilho dessa posição de Rosário.

O pesquisador selecionou 1.275 discursos de diferentes extensões, textos de base sincrônica, que espelham o uso real da língua contemporânea. Ao analisar, primeiramente, os padrões micro-construcionais correlativos aditivos, encontrou várias ocorrências de padrões que compartilham importantes propriedades, mas que se diferem umas das outras pelo seu grau de produtividade e flutuação, que segundo princípio laboviano do uniformitarismo, constituem uma espécie de estoque para as possíveis mudanças diacrônicas no futuro.

Após estabelecer 28 padrões micro-construcionais correlativos aditivos, o autor aponta que muitos deles apresentam semelhanças entre si e outros já são mais idiossincráticos. Outra observação é que a partícula negativa "não" aparece em todos os padrões correlativos. Sendo assim, parece que se estabelecem uma ação aditiva.

O pesquisador também revela que elementos existentes na língua, tais como não, só, somente, apenas, ligados a outros como "mas, como, e, também, sim", assumem outras funções e significados, que permite que outros correlatos aditivos apareçam no sistema da língua. Para ele ainda, inspirado nas concepções de Traugott (2003), não há formas totalmente novas, mas uma recombinação com a reutilização de formas já existentes.

Com isso, pode-se concluir ainda nos pressupostos de Goldberg e Jackendolf (2004), as construções demonstram variações sintáticas e semânticas, que diferem pelo grau de produtividade, pois quanto mais há utilização, mais novas formas são formadas e a variação tende a ser um fenômeno presente, indiscutivelmente.

Quanto aos padrões meso-construcionais, segundo Rosário, são menos composicionais em termos de significado do que as micro-construções ; que são mais produtivos, quando encabeçados pelo item "mas", como: "não apenas... mas, não só... mas, não só... mas também, não apenas... mas também, mas... também, não somente... mas também, não somente... mas, não... mas também", entre outros. Após dividir em cinco padrões meso-construcionais, o autor chegou a algumas conclusões: a maior ocorrência verificada nesse tipo de padrão se recruta pelos itens "mas" e "também", típicos do português correlativo brasileiro, revelando-se, assim, como uso preferencial, a 
fim de tornar o discurso mais expressivo. Outro item encabeçado, comprovado pelo pesquisador, como preferência dos usuários da língua é o "não só" na constituição dos pares correlativos, também seguido de "mas".

Das considerações a respeito dos meso-construcionais, vale ressaltar que, segundo o autor, em termos semânticos, os padrões formados por "não... só", "não... apenas", "não... somente" e não simplesmente, instanciado pelo item "não", funcionam como restritores ou focalizadores negativos.

Rosário, ainda, calcado nos aportes teóricos de Bybee (2010), esclarece que um membro mais frequente serve como o central da categoria, e assim, outras formas aparecem pela adição de membros semelhantes, que analogicamente, contribuem para formação de novos itens construcionais. Um dado revelado é que nos discursos políticos, gênero textual de análise, as correlações dão força à argumentação. De um lado a prótase, que contém a informação dada em contraste com a apódose, que veicula uma informação nova, surpreendente para o leitor. Isso leva Rosário a entender que a correlação propicia uma força à argumentação, persuasão.

Por fim, após a investigação dos dados, duas importantes constatações foram asseveradas: os padrões correlativos aditivos não poderiam estar a serviço somente de reunir, ligar termos ou orações, como apontam os gramáticos; outra é que seria possível estabelecer um padrão macro-construcional para a correlação aditiva, isso porque advêm de padrões meso e micro-construcionais, uma prova cabal de que a reunião, recombinação de elementos, cujos itens correlatos aditivos se reúnem, servem para que outros padrões surjam funcionalmente.

Rosário, ao final, prova que a correlação apresenta um estatuto, cujas características diferem dos princípios tradicionais em relação aos processos de estruturação sintáticos, e está a serviço de uma gramática que enxerga o discurso como elemento subjacente ao processo sintático e que tem como foco o ato de comunicar.

Existem vários aportes no que diz respeito ao tratamento das correlações, dentre eles, apontamos Vaz Leão (1961), que concebe a correlação como um aparato composto de dois termos correlatos lógicos que servem para satisfazer a necessidade do falante, o qual pretende evidenciar dois fatos entre uma estrutura; como exemplo, cita a correlação hipotética. Uma explicação dada pela autora que tipifica a hipótese como exemplo 
correlativo, seria a necessidade do autor adentrar-se, na mente do leitor, e trazer este à tona o que supostamente teria esquecido no primeiro item, é intencional.

Como expus anteriormente, Carone (2003) entende a correlação como espécie de variante da coordenação e subordinação; já Azevedo (2002), ao concordar com os apontamentos de Luft (1978), defendia que é um processo composto ora da subordinação, ora da coordenação, um mecanismo de recurso enfático. Bechara (2009) defende como um processo de ligação, cujo valor sintático está caracterizado por subordinação, coordenação, correlação e justaposição. Finalmente, Módolo e Rosário aproximam-se da perspectiva de Carone, mas somente quanto a forma de classificar a correlação: trata-se de um terceiro processo para combinação de orações.

Melo (1978) considera a correlação como um terceiro elemento inerente à estruturação sintática, mais complexo, em que existe, de certo modo, uma interdependência, ligado à subordinação, uma complementação da primeira oração ligada à segunda: um elemento de ênfase, que existe um outro.

Para Rodrigues (2007), a correlação é um processo em que duas orações são formalmente interdependentes, que se materializam por meio de expressões correlatas. Ney (1955) inclui o fenômeno como um processo também independente, advindo de dois conectivos claros ou subentendidos, em que se fazem a correlação.

Percebe-se que a maioria dos autores veem o processo correlativo distinto da coordenação e subordinação, pois entendem que, quando há interdependência entre as orações, é porque a expressão de um deles desemboca no outro, obrigatoriamente, há um vínculo.

Para Lima-Hernandes, a correlação acontece devido “à aproximação de segmentos que compõem uma nova combinação que as atrai e as repele ao mesmo tempo pelo contraste" (Lima-Hernandes, 2010, s.p.), que nem sempre se apresenta à luz de pares legalmente constituídos pela normatividade da língua, o que torna o fenômeno ainda mais curioso: por mais que instituamos a norma padrão como recurso empregado, principalmente nas situações contextuais mais formais, de um par correlativo, diferentemente daquele esperado numa modalidade escrita, como entender um uso como "não... mas", objeto de nossa tese, nesse tipo de modalidade? Assim, não há como 
dissociar o uso real de língua, aquele pré-programado na mente humana, de situações que exigem do falante-escritor uma experienciação advinda de sua natureza.

Para Dias e Lima-Hernandes (2010), a correlação deve ser vista sob o ponto de vista pragmático e discursivo. Segundo as autoras, a melhor definição para a correlação deve ser a seguinte:

[...] processo de ligação entre duas porções informativas conectadas intrinsecamente por dois elementos: um elemento morfossintático (cognição subordinativa) e um elemento psicológico que funciona como gatilho de uma segunda porção informativa num molde previamente projetado (Dias \& Lima-Hernandes, 2010, s.p.)

Para as autoras, a sintaxe é o lócus ideal para que pistas discursivas apareçam por meio da bagagem pragmática trazida pelo interlocutor. Apesar da ligadura sintática entre os períodos, quando o falante utiliza-se de um par correlativo, tem aí um objetivo comunicacional bastante claro: focaliza suas escolhas informacionais, distribuindo-as dentro do período, dando relevo àquela parte que considera mais proeminente para seus objetivos.

Em artigo intitulado Não que eu não saiba o que é normativo, mas as pessoas estão usando assim: correlações inovadoras no Português brasileiro, LimaHernandes busca fazer uma releitura dos processos de combinação de orações num modelo dinâmico advinda da produção de estruturas sintáticas reais, produzidas por fatores e situações comunicativas.

Exemplos tais como: “... a hora que eles chega... aí ele rola " ou " e eu chego... tá tudo em ordem" levaram a evidenciar que a noção de tempo pode ser codificada, por meio de vários processos de combinação de oração. Isso nos conduz a entender que pelo continuum correlativo há uma relação interdependente, em que pontos do período sinalizam as intenções do falante durante seu ato por meio do aparato sintático dos itens linguísticos que se combinam. Também o cuidado com a atenção de seu interlocutor demanda que se dê relevo a determinada porção informativa.

$\mathrm{O}$ enfoque do trabalho deu-se a partir do questionamento a respeito do embate em relação à bipartição entre a classificação dos processos de combinações de orações 
que se dá por meio da coordenação e subordinação; isto porque, para a autora, existem estruturas que não se encaixam nessas condições, e com isso, ficam à deriva daquilo que se pode entender nesse processo.

O item linguístico evidenciado nesse artigo, foi a cognição conjunção adversativa 'mas', que, apesar de ser classificada como coordenativa, a autora evidencia casos que apontam para uma subordinação por meio de um processo correlativo.

A autora verifica que nesse processo complexo e econômico, selecionado pelo falante, não há total liberdade, pois, ao lançar o primeiro par, espera-se que o outro seja exibido na sequência, além de, muitas vezes, não poder ser alterado. Fazendo um paralelo com que a autora expõe e com o par correlativo de análise: "não... mas sim", por exemplo, encontrados nas redações da Fuvest, um grau alto de gramaticalização se evidenciaria, e por isso mesmo ainda poderia ser alvo de preconceitos por parte de alguns professores de língua.

Lima-Hernandes (2010), ao retirar um dado de um texto da redação vestibular da Fuvest, verifica a polaridade como gatilho de mudança na fronteira sintática: "a honra praticamente não existe mais, somente o interesse por riqueza, beleza e vaidade" (Fuvest). Para a autora, o item "mas" pode ter sofrido uma mudança de fronteira sintática. Sendo assim, reanalisado como parte do membro da segunda oração, e não mais da primeira.

Para sua pesquisa foram utilizados pares: "não que... mas", "não que... não", "não... mas", "não... mas sim", "nada contra... mas", "tudo bem que não... mas", e chegou a algumas conclusões: a correlação não normativa parece ser percebida como um uso positivo, por conta da alta avaliação dada aos textos que contêm esses pares. Outra questão à que se chegou é que o processo correlativo é utilizado como recurso para se combinar informações por meio de operadores em sintonia. Existem para esse processo elementos cognitivos que estão a serviço da argumentação e a polaridade é um recurso utilizado a fim de estabelecer não um contraste, mas uma focalização, tal como: "não que todos brasileiros sejam desonestos, mas devem estar atentos" (Fuvest); no jogo em que uma não desconsidera a outra: “... o livro é uma fonte de conhecimento, "não é a única, mas é uma das mais usadas em toda a esfera do ensino" (Fuvest); nos itens "não... mas sim", o item tipicamente adversativo enfatiza a informação de polaridade por meio de dois advérbios; para os itens correlativos "nada contra... mas", o 
item "mas" sinaliza o principal argumento para ser contra: "a ciência se multiplica em níveis surpreendentes graças à capacidade de armazenar o conhecimento. Nada contra o velho, mas sou um internauta plugado na net" (Fuvest). E com o último par correlativo: "tudo bem que não... mas", a estratégia discursiva adotada pelo falante parece ser utilizada pela oposição.

A autora deixa clara a ideia de que a língua deve ser analisada sob o enfoque funcional e que deveria ser também esse o papel da escola que parece enxergá-la às avessas: "a dinâmica da língua não pode ser detida pela normatividade escolar" (cf. Lima-Hernandes, 2010, s.p.).

Verifica-se, dessa forma, que os itens lexicais dentro das orações, num processamento sintático complexo, interagem e, com isso, mudam, gramaticalizam-se, assumindo funções e papéis, demandados pela situação comunicativa a que estão sujeitos, sofrendo pressão de aspectos sociais, históricos e cognitivos, ao mesmo tempo.

\subsection{Da negação à polaridade: um objeto investigativo}

A negação, para os estudos de gramaticalização, apresenta-se como um elemento investigativo a fim de se provar a integração entre itens e as estruturas, pois parece que a negativa é um elemento influenciador das mudanças de alguns itens nas línguas em geral. Se fizermos uma interface com a cognição, perceberemos que a negação tem um papel funcional considerável no português brasileiro.

Ao remetermos à análise das estruturas compostas pelos constituintes correlativos, de nossa tese, encabeçados pelo "não" + par constituinte correlativo há um

processo de gramaticalização engatilhado como uma mola propulsora que alavanca o deslizamento dos sentidos: mais concreto para o mais abstrato.

Para Lima-Hernandes, "o desenvolvimento de itens e estruturas no português, como em diversas línguas, evidencia que a presença de uma partícula negativa pode desencadear um jogo de prevalência da polaridade negativa sobre a positiva" (LimaHernandes, 2008). A autora defende que esse jogo de prevalência tem início por meio de inovações linguísticas ocasionadas pela perda de transparência conceitual, por meio 
de implicaturas convencionais e analogias (metáfora). Adicionam-se como motivação a reinterpretação induzida pelo contexto (a chamada metonímia), gerada por implicaturas conversacionais.

Entende-se, assim, "polaridade como um campo de tensão gradual que se move entre dois pontos extremos de configuração da informação sentencional: polaridade negativa e polaridade afirmativa" (cf. Lima-Hernandes e Barroso, 2007, p. 01). Para Givón (2011), a negação vai além do tratamento tradicional, dado entre as cláusulas numa lógica proposicional, a partir do momento em que a pragmática age sobre a sintaxe da língua. Isso pode ser observado com a análise do escopo da negação, no exemplo que segue:

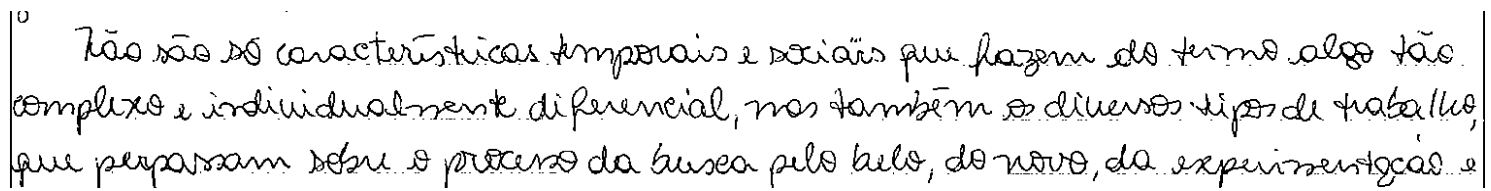
(Exemplo 4, Fuvest, 2006, p.92)

As informações "características temporais e sociais (...)" e "diversos tipos de trabalho (...)" são distribuídas nos dois pontos da correlação e ambas são escopadas pela negação, que se encontra numa posição sintática mais alta hierarquicamente.

No par correlativo, encabeçado pela negativa, também em posição mais alta, os argumentos referenciais citados são aqueles de conhecimento do leitor, isto é, "um argumento referencial já foi mencionado no discurso precedente" (Givón, 2011, p. 54), e por isso, é mais definido e o efeito é a adição:

$$
\text { Ná publccidadé é comum recorrer a cuna celebridede pana }
$$
se vender um produto populan. Nesse caso, é preferivel insorir a ima. gem de unón una pessoa que tenha alguma admiracais por pante do público-aluo. Nesse sentido, um famoso jogador de fukbol da selecás brasileira de futebol da Capa de 1970, Gerson, fei contratado pana protagonizan um "propaganda de cigono. Na ocasias, " "slogan" sugeriu as público que o importante é "levan vantagem emtuds". Alcuntado de "Lei de Gerson", a propaganda nás só deu origemauma frase que passou a canacterizan o pors brasileiro, como também produziv efeito na inagem-que - perorativa gue o jogador adquiriu diante de seus admiradores.

(Exemplo 5, Fuvest, 2010, p.24) 
Percebe-se que o elemento "não" do primeiro par correlativo, que encabeça a oração, recupera a ideia já tratada no trecho, e por isso não apresenta informação nova. É como se tivesse objetivo somente de recuperar o dito, atentar para o leitor, puxar seu fluxo de atenção, para que depois, no outro par, lançasse uma nova informação: "quando um falante enuncia uma sentença negativa no discurso, ele assume mais sobre o que o ouvinte conhece do que quando ele enuncia uma afirmativa.” (cf. Givón, 2011, p. 155)

Algumas vezes, nas correlações, a negativa é encabeçada como um recurso para especificar o objeto, fato. Nesses usos, é comum que as informações estejam em correlação e escopada pela negação hierarquicamente mais baixa. No exemplo seguinte, a negação atinge dois objetos diretos:

Adinamizacióo do traballo e a pressāo do capital repnimem nāo apenos os desqualificados como também os que nāo se a fustam a napidez de producấo, como os artistus. Eles näo sequem a semana capitalista, o "David" de

(Exemplo 6, Fuvest, 2006, p.60)

Percebe-se, no referido par, os artistas que não se adaptam à realidade da rapidez de produção, também são encaixados no conceito do que é desqualificado, para o mercado de trabalho. Então, temos:

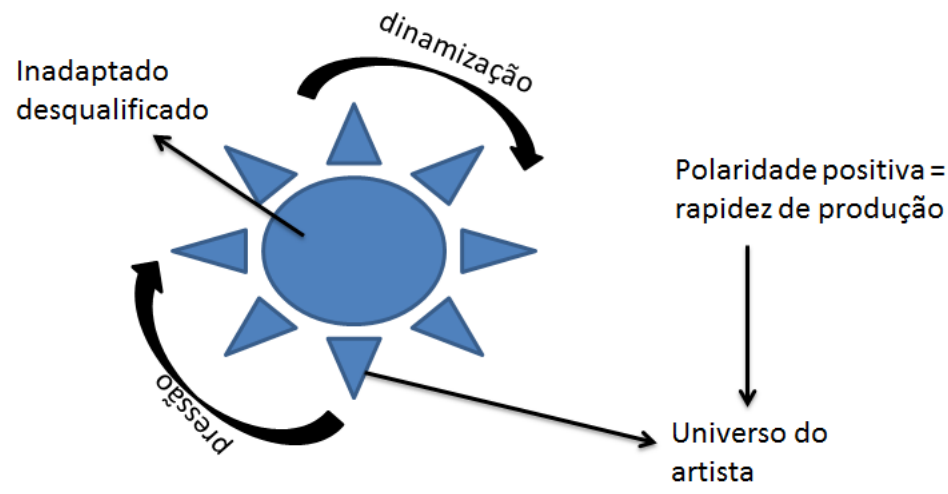

Figura 5. Representação da atuação da polaridade negativa

Quando se lança uma negativa, o contexto discursivo está atrelado a uma intenção prévia de adicionar ou avaliar lançando sua convicção sobre o dito, o escrevente confere mais persuasão à sua argumentação. 
Para Givón (2011), ainda, “as orações negativas são mais marcadas com respeito à complexidade das pressuposições pragmáticas que caracterizam o contexto discursivo no qual elas podem ser apropriadamente usadas" (cf. Givón, 2011, p. 173), o que reflete a contribuição do uso e suas motivações, que levam o falante à busca de conteúdo informativo para distribuir entre as partes da cláusula. Mas um outro ponto também fazse necessário revelar: a polaridade negativa conjuga-se a uma informação que é tornada alvo de baixa atenção. Essa estratégia garante que o foco sobre a segunda informação seja evidenciado:

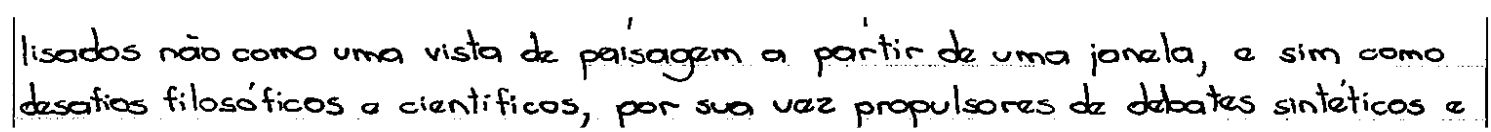

(Exemplo 7, Fuvest, 2010, p.72)

O falante desloca sua forma entonacional para o elemento negativo do primeiro item do par com o fim de buscar entre ele e seu interlocutor um fio condutor, para que juntos, possa estabelecer um espaço conjunto de atenção. Isso também é uma estratégia discursiva.

Ainda para Givón (2011), as orações negativas carregam menos informações novas no discurso, e com isso mostram-se mais conservadoras, em comprovação com a afirmativa ou com aquela que faz o jogo da polaridade, tal como evidenciado no exemplo anterior.

Clark (1974) alude ao fato de que um falante faz suposições sobre as crenças do seu ouvinte, quando produz uma negação, e dessa forma pressupõe que as negativas são mais complexas em relação ao processamento como um ato de fala psicológica, pois há uma quebra de uniformidade ligada ao aspecto pragmático no tocante ao uso da língua. Por isso é que a entonação ascendente se faz presente; esta se liga à menor quantidade de itens para facilitar o processamento da informação, junto ao primeiro par correlativo negativo.

A aquisição da sintaxe da negação, comparada à sentença da afirmação, se faz mais tardia por apresentar-se, psicologicamente, de uma forma que exige maior raciocínio de ideias, concatenação, logicidade. Ela é influenciada pelos domínios pragmático e cognitivo, demandando que a quebra de uniformidade codificada seja exigida do interlocutor em termos de maior processamento mental para que haja a 
interação, pois "reflete fatos pragmáticos e ontológicos profundos sobre o modo como o organismo humano percebe e interpreta o universo.” (cf. Givón, 2011, p. 196).

Entende-se que a negação é usada para quebrar as convicções do ouvinte-autor, recurso usado, estrategicamente, não somente para negar, mas quebrar a expectativa daquilo que o interlocutor acreditava ser verdadeiro ou ainda esperava escutar ou ler: é um jogo excessivamente persuasivo, cujas escolhas não são feitas aleatoriamente:

que a autoridade, pura e simples. Nã é dizer que o estudo académico nã tem valor, mas
que a producáo deve ser julgada pelo que ela é, não por quem a fez, possibilitando a
red separąão de joio e trigo, em vez do joio banito e do trigo feio. (Exemplo 8, Fuvest, 2008, p.41)

Nesse exemplo, o autor, ao tratar da questão do papel da academia parte de um conceito já conhecido e estabelecido socialmente entre ele e o seu interlocutor: "valor da academia" e lança, por meio da adversidade, a novidade: "que a produção deve ser julgada pelo que ela é".

Diríamos que, na negativa, tem-se a parte tenra, morna, provavelmente para que, num jogo, primeiramente a fim de chamar o leitor lance mão de uma informação considerada pertinente entre ambos. A parte mais incisiva é guardada para depois.

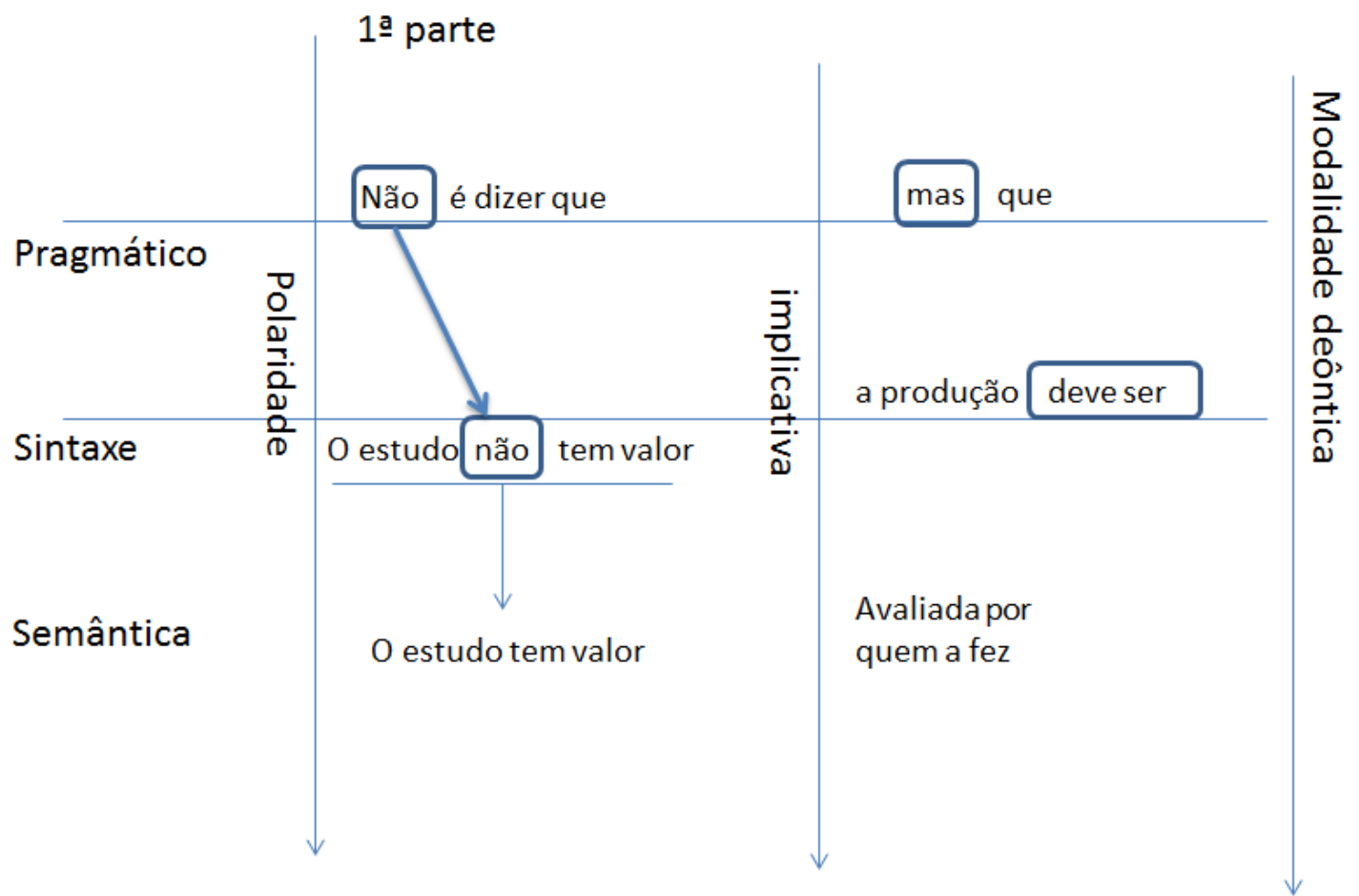


O item polar não apresentado sintaticamente no nível mais alto toma como escopo o item polar não do nível da sintático gerando como efeito a anulação da negação: "O estudo tem valor". O item polar mas sinaliza o contraste decorrente da implicatura ou pressuposição de compartilhamento informacional. No nível do discurso e não no nível da conversação on line, tal como ocorre com a primeira porção. Estratégias discursivo-pragmáticas cortam os vários momentos da codificação para deixar pistas sobre intenção do escrevente (polaridade, pressuposição e modalidade deôntica a serviço da preservação da face).

Percebe-se que o primeiro item do par serve de estratégia eficiente para produzir relevância às informações no segundo item do par, o que realmente pensa sobre o assunto, o que defende. Entendo que o fundo, aqui, não se anula, mas cria um esteio para a construção do argumento decisivo (figura).

A negação, portanto, está num cenário de normalidade e anormalidade, inércia e mudança, numa quebra imediata de linearidade, a fim de checar tanto a habilidade de quem ouve, lê, quanto trazer à tona uma necessidade inerente à capacidade humana: a da construção de um espaço conjunto e de interação.

\subsection{Correlação como processo cognitivo}

Entendo que a correlação é um processo cognitivo instalado entre duas porções constituintes dentro de uma mesma cláusula, em que o primeiro elemento linguístico alavanca o segundo para que realize a comunicação por meio de uma intenção, hipoteticamente, selfiana. Essa dinamicidade do fluxo da consciência humana, inicia-se por meio de um estágio, o protosself, responsável por instaurar imagens lincadas ao sentimento num determinado tempo, associado ao ato de dizer sobre um objeto, logo após alavancando outros dois estágios: o self central o que protagoniza uma informação a fim de puxar a atenção do leitor, no primeiro par correlativo, que ao engatilhar o segundo, aciona novas experiências e informações para surpreender o leitor, por meio do self autobiográfico. Intuo que a correlação seja um exercício que serve para focar a intenção daquilo que se quer dizer; é manipulativo no tocante ao caráter enfático quanto 
às escolhas dos itens lexicais que se redistribuem entre as cláusulas, intencionalmente. Também intuo que fazem parte desse gatilho estágios que caracterizam a consciência na mente humana, auxiliando na coordenação e materialização que trazem à tona o conteúdo experiencial distributivo entre as porções informativas.

Outra hipótese que dá um enfoque contributivo às pesquisas sobre o tema referese à questão dos itens lexicais que compõem as cláusulas correlativas: são pares funcionais que parecem advirem das experiências culturais, imitativas de cada indivíduo, que lança mão de utilizar-se dos itens linguísticos diferentes daqueles ditados e cristalizados pelo uso da gramática normativa, prescritiva. Isso é um recurso utilizado pelo autor/falante que vai buscar na memória ${ }^{25}$ aquilo que despertou interação entre o organismo (corpo e cérebro) e os objetos, reagindo a isso. $\mathrm{O}$ uso do item acopla-se com as várias sequências imagéticas ligadas ao evento aludido.

Um dos elementos analisados na correlação é o que se fez pelo recorte daquelas que apresentaram a polaridade como recurso linguístico num jogo discursivo: primeiro nega para logo incluir, afirmar, opor-se, enfatizar, como um recurso usado pelo falante/escritor inerente, principalmente, a textos cujos gêneros discursivos estão calcados na argumentação, opinião, mas que num jogo formalista, foge do protocolo “em relação ao registro e do tipo de discurso" (Guimarães, 1987, p. 123).

Diante disso, assumo que assim como as escolhas experienciais, que se concretizam na língua são advindas do exercício selfiano na transposição entre os estágios, o uso de um item linguístico, que constitui os pares, acompanha também esse processo mental, e, é por isso, que parece destoar do que se esperaria para o gênero discursivo sob análise, cujo texto se daria numa formalidade calcada na norma, um item diferente do que se espera.

As "vicissitudes do discurso é que determinam em grande parte o uso de uma construção ou outra" (cf. Rosário \& Rodrigues, 2010, p. 44), e esta tese mostra que, ao escrever, o autor busca na e pela memória, aquilo que é consciente, vigília de suas experiências, com objetivo de não só informar, mas inserir material linguístico, aqui, no

\footnotetext{
${ }^{25}$ De acordo com Damasio (2009), memória é objeto composto das atividades sensitivas e motoras relacionadas à interação entre o organismo e o objeto durante dado tempo.
} 
caso, entre as cláusulas correlativas, para despertar, no leitor, o fluxo de atenção e inovar o que traz à tona.

Para Givón (1979), a maior integração semântica ou pragmática acarreta também maior integridade sintática para que haja uma organização retórica do discurso. Por isso, hipotetizo que, quanto aos estágios que compõem a mente humana, ações coordenadas, expostas durante a vida humana, contribuem para que venham cenas e eventos imagéticos e linguísticos que servirão de base para que se busque motivar e desenvolver estruturas, que num processo de combinação, ampliam formas e funções cujos sentidos se reenquadram.

O indivíduo, ao proferir, escrever, porções informativas cujos períodos são formados pelas cláusulas que os constituem, por meio de pares correlativos, parece fazer e - isto investigarei - um esforço mental maior na segunda parte da cláusula, pois é aí que busca pelo self autobiográfico uma infinidade de componentes, tanto linguístico como imagético, guardados na memória, que, em vigília, ativam e são processados àquilo que para ele faz sentido coligar.

Outro fator que justifica esta investigação é a possibilidade de que a funcionalidade da língua faz parte de um processamento mental, em que o falante, organiza seu discurso, buscando, em virtude de suas necessidades comunicacionais, itens e material de conteúdo linguístico que o remeta a responder pelo self do meio em que vive, de modo a satisfazer o elo: consciência - mente - língua - estágios selfianos.

Outro aspecto que leva a entender a correlação como um mecanismo em que duas porções informativas se acoplam, de diferentes formas, com diversos elementos, interdependentes, continuamente, muito mais complexo do que a subordinação e a coordenação, é que se constitui por meio de itens lexicais num arranjo sintático que se estabelece entre as cláusulas, fazendo com que o falante pareça ter necessidade de marcar por meio de um elemento correlativo seu objetivo. A meu ver, vai além de suprir a necessidade comunicacional, quer realçar, persuadir, garantir de fato, que o interlocutor concorde com seu ponto de vista.

Para isso, a correlação é um recurso lógico que, muitas vezes, se faz pelo jogo intencional: pouca informação para a primeira porção, e muita para a segunda; isto é, são duas porções que se ligam por meio de um processo sintático-discursivo, em que a 
noção de justaposição, atrelada numa visão tradicional, perde a força, quando entendida somente pelo prisma estrutural, sem levar em conta o discurso que ambas porções carregam.

Entendo também que existe uma relação esquemática que caracteriza a correlação: encabeça o item 'não', que a depender do domínio de atuação pode produzir a restrição do foco de atenção adicionando, contrastando ou negando a informação supostamente compartilhada entre os interlocutores.

Não há como negar nessa estratégia usada pelo autor que mecanismos imagéticos são acionados para que se construa o self autobiográfico correlativo: o material informativo de cada item é subsidiado por um conjunto biográfico de memórias incitado por um conjunto de self central coerente, que apesar de inicialmente parecer confuso, ao se materializar na escrita, principalmente, torna-se mais coeso. Para cada porção existe um volume de material selfiano, que se distribui, intencionalmente.

A questão da valoração dos conteúdos processados pelas imagens também se faz relevante nesse processo. Parece que só se materializam aqueles que, para o autor, são coesos e coerentes, não somente para constituírem, de fato, parte de sua argumentação, como também, aqueles, que para ele denunciarem escolhas relevantes.

Parece existir uma microssequência de imagens que pulsa a todo instante, mas que são escolhidas aquelas mais confiáveis, ocorridas em momento de vigília. Mas e a questão funcionalista da língua, nesse cenário? A propósito, há uma intersecção entre os pulsos de imagens produzidas em maior ou menor escala na vigília e o conteúdo da linguagem para esse processo. E aí é que princípios funcionalistas, tais como a iconicidade permitirão reconhecer esse paralelo.

As ideias de Croft (2008) a respeito da cooperação entre falante e ouvinte, permitem avaliar as correlativas, como um esforço maior do autor para que haja o processamento interacional. Por isso, é importante salientar a questão da crença, intenções e ações do falante, de suas escolhas, presentes nesse processo complexo e que demanda atenção.

Ao verificar pares correlativos mais funcionais, forjados daqueles instituídos pela normatividade constata-se um uso mais ligado à realidade experiencial do autor. Isso nos leva a apontar que pensar na correlação é entender que o processo sintático é 
um mecanismo linguístico fragmentado, como se o cérebro, em seu estado de vigília, também refratasse a língua em microitens linguísticos sem pulso. A dinâmica, no entanto, molda-se pelas necessidades pragmáticas, imbuídas de toda criação humana: o ato de comunicar.

A correlação vai além de uma visão bipartida entre coordenada e subordinada; ela participa de um processo instado na mente humana, que na profusão de ideias, concatenam-se de forma a lincar pensamentos, que atrelados à imagem dos eventos, cria jogos discursivo-pragmáticos para persuadir o ouvinte. Isto quer dizer que, quando o falante-autor se utiliza da correlação, tem algo a mais do que dizer somente, vai além de simplesmente comunicar.

Quando Givón (1979) apontou que existe uma integração sintática calcada na semântica ou pragmática, alertou para verificar que integrar orações não é por si só combinar palavras, mas propor uma combinação motivada pelas necessidades cognitivas do falante ou escritor. No que diz respeito à construção de uma mente consciente à luz de uma contribuição cognitiva, a correlação é uma distribuição de elementos entre partes das cláusulas, interdependentes, mas que se subdividem em estágios ligados àquilo que a mente capta dentro da experiência consciente.

Consolidando a hipótese que aqui se construiu é possível que, na trajetória correlata entre a parataxe $\rightarrow$ hipotaxe, estágios selfianos se concretizam e contribuem para que haja esse continuum defendido por Lehmann. Se a mente produz, capta, nos traz à tona imagens que se dialogam entre àquilo que o ser humano carrega biologicamente e aquilo que traz a partir da cultura a que é submetido, então, entende-se que há uma mudança entre os estágios de selfies de um par a outro:

\section{Correlação}

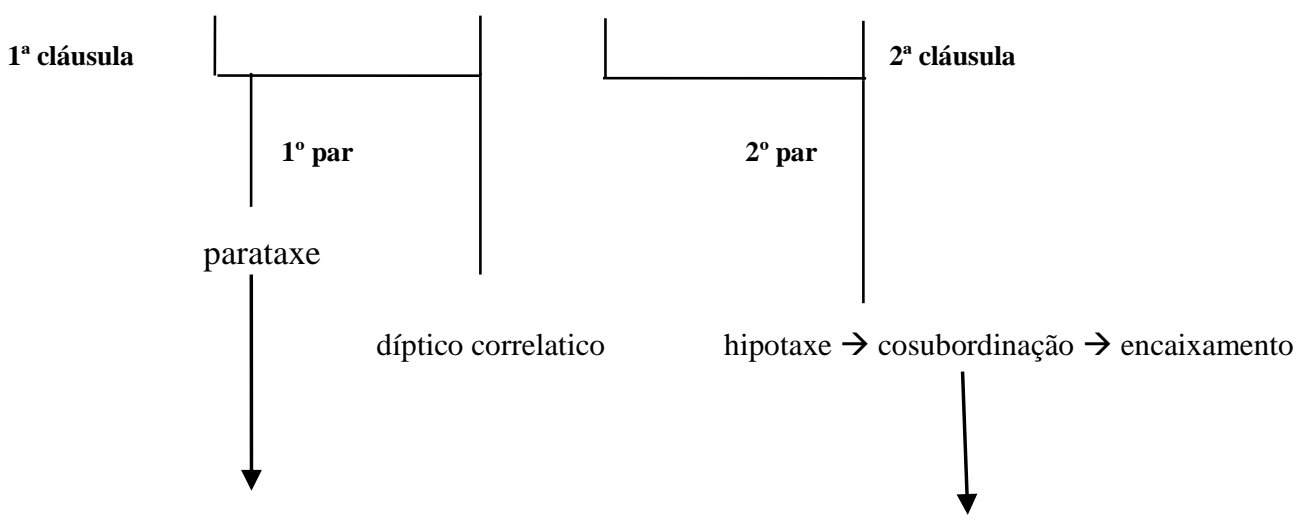


self central

self autobiográfico

Esquema 11. Correlação: do self central ao self autobiográfico.

Um dos objetivos desta tese é o de explicar e detalhar nas análises de dados, por que defendo a presença de cada self (parataxe $\rightarrow$ self central) e no encaixamento (self autobiográfico) relativos à correlação. 


\section{CAPÍTULO 3 - ASPECTOS METODOLÓGICOS}

\subsection{Corpus}

Todo trabalho que se insira numa abordagem funcionalista precisa lidar com dados em situação de uso real. Relacionar o contexto que deu origem a cada redação, ou seja, a proposta, a forma de abordagem, o recorte temático, a própria concepção na elaboração, a concepção do que é redação vestibular hoje e até mesmo a proporção candidato/vaga, pode determinar a pressão exercida sobre esse candidato no momento da elaboração de sua prova.

A Fundação Universitária para o Vestibular (FUVEST) é uma instituição autônoma, responsável pela realização dos exames vestibulares de escolas de nível superior do Estado de São Paulo. O vestibular Fuvest seleciona discentes para a USP (Universidade de São Paulo) e FCMSC-SP (Faculdade de Ciências Médicas da Santa Casa de São Paulo). Muito concorrido, sua última edição teve quase 140.000 inscritos, segundo o site da Folha-UOL, para os seus 229 cursos disponíveis.

Com o surgimento do ENEM (Exame Nacional do Ensino Médio), a Fuvest tornou a prova mais interdisciplinar, privilegiando aquele que tiver alta capacidade de raciocínio e saiba relacionar diversas áreas do conhecimento. Segundo dados da FolhaUOL, as carreiras mais concorridas são Medicina e Engenharia Aeronáutica, cuja nota de corte chegou, no ano de 2008, a 77 pontos, de 90 possíveis, a maior nota de corte da história da Fuvest. As carreiras menos concorridas são as de Letras e Informática Biomédica.

A redação faz parte da segunda fase de provas analítico-expositivas, é obrigatória para todos os candidatos dessa fase e vale 50 pontos, do total de 100 que a prova possui ; sendo a outra parte constituída de questões de interpretação de textos, gramática e literatura.

Segundo orientações advindas da própria comissão do vestibular, espera-se do candidato capacidade de mobilizar conhecimentos e opiniões, argumentar de modo 
coerente, além de expressar-se com clareza, de forma correta e adequada. Três aspectos, segundo o site de um curso preparatório para vestibulares e concursos, são avaliados: tipo de texto, abordagem do tema, estrutura e expressão. A cada um deles é atribuída uma nota. A orientação, ainda segundo esse site, é atentar-se mais especificamente ao tema e ao tipo de texto, no caso, dissertativo.

Para orientarem a como se fazer uma redação bem avaliada, duas ações são focadas: revisão gramatical e também visualização de modelos de redação nota dez, a fim de analisar o raciocínio e a construção dos períodos, compostos de linguagem diversificada que valoriza o conteúdo e o repertório cultural, conferindo originalidade ao tema. Um dado que nos chama atenção a respeito desses apontamentos desse site é a questão da linguagem diversificada, um indício de que a valorização de uma língua que se apropria das experiências conteudísticas de um candidato, já se percebe como um diferencial das melhores apontadas e analisadas.

O site ainda apresenta dez dicas para "se dar bem":

1. Manter-se informado por meio da leitura de textos que problematizam e refletem questões ligadas a aspectos sociais e econômicos, por exemplo;

2. Exercitar textos, produzir textos-modelo do vestibular para a qual prestará a prova;

3. Ler a proposta e não ignorar os textos da proposta;

4. Escrever de forma articulada;

5. Incluir uma proposta para o problema apresentado;

6. Desenvolver o texto por meio de uma dissertação argumentativa;

7. Usar obrigatoriamente a norma culta;

8. Posicionar-se, argumentar sobre a situação-problema apresentada;

9. Fazer um rascunho e revisar, antes de passar a limpo;

10. Escrever entre 25 a 30 linhas, em letra legível.

Ao comprovarmos essas orientações com as do Guia do Estudante - Redação 2013, percebemos a preocupação técnica ao escrever o texto; segundo a responsável 
pela formulação da prova de redação da Fuvest, na época de nossa consulta, Maria Thereza Fraga Rocco: "Na correção, três aspectos são avaliados: tipo de texto e abordagem do tema, estrutura e expressão".

Em relação ao tipo de texto e abordagem, a preocupação está voltada à capacidade de intelecção e compreensão do candidato; isto é, se sabe compreender a proposta, a coletânea de tipos de textos apresentados, se sabe produzir uma dissertaçãoargumentativa, se tem capacidade de fazer um texto em que haja progressão temática. No tocante à estrutura, avaliam-se aspectos relacionados à coesão e coerência de ideias; também se verifica, nesse aspecto, se o candidato extrai conclusões e também tem um planejamento e uma construção significativa para o texto. Quanto à expressão, observase se o candidato tem o domínio da norma padrão escrito da língua e a clareza na expressão das ideias. Nesse sentido, examinam-se elementos como aspectos gramaticais, como ortografia, morfologia, sintaxe e pontuação. Clareza na escolha do vocabulário, precisão de argumentos relacionados ao ponto de vista também são avaliados na expressividade.

Outros sites de cursinhos foram pesquisados e as dicas se mantêm, isto é, a técnica sobrepõe de forma que haja garantia de uma boa produção e, consequentemente, a aprovação. Veem-se também muitos comentários sobre o papel e o cuidado com relação à normatividade da língua, um indício de que continua sendo um divisor classificatório do texto bom ou não.

Vê-se que o objetivo da produção é estritamente disciplinar, uma vez que o aluno escreve para cumprir uma exigência, um treinamento, um instrumento de medição calcado numa ritualização advinda das dicas e também do material didático disponível no mercado.

Das apostilas consultadas ${ }^{26}$ a respeito das orientações da produção dos textos para os vestibulares, as dicas são, praticamente, iguais:

- Compreender a proposta e aplicar conceitos das áreas do conhecimento para desenvolver o tema;

\footnotetext{
${ }^{26}$ O material didático consultado é advindo dos cursos preparatórios para os vestibulares e concursos públicos, da Grande São Paulo. Não nos foi autorizada a menção dos nomes de cada um desses cursos, nem a citação do nem dos autores envolvidos.
} 
- Obedecer à estrutura do texto dissertativo-argumentativo;

- Selecionar, relacionar, organizar e interpretar informações, fatos, opiniões e argumentos em defesa de um ponto de vista;

- Demonstrar conhecimento dos mecanismos linguísticos, adequando-os ao tipo de texto desenvolvido;

- Elaborar proposta de solução e intervenção para a solução do problema apresentado;

- Elaborar uma introdução apresentando um fato, uma ideia, um problema, um conceito etc.;

- Apresentar algumas justificativas sob a forma de argumentos, no desenvolvimento, momento em que a opinião é formulada;

- Apresentar uma linha de ação ou de solução, na conclusão.

Encontramos, também nos materiais, balões para atinar a atenção do aluno, no tocante às questões, principalmente, do uso normativo da língua: "Nada de gírias, brincadeiras, sinais gráficos, abreviações e expressões politicamente incorretas no texto.", ou ainda, "primar pelo uso normativo, segundo os preceitos defendidos pela NGB.”

Percebe-se a incitação no tocante à questão da produção por meio da fórmula lógica, cujo texto se constrói a partir de cada relação estrutural e semântica mecanicista como uma teia. Parece que as orientações impostas por esses materiais estão focadas em como se deve fazer, sem uma preocupação sociointerativa, cuja dialogicidade é o palco desse processo. Assim, fatos como: "ter o que dizer; ter razões para dizer o que tem a dizer; ter para quem dizer o que tem a dizer; assumir-se como sujeito que diz o que diz para quem diz e escolher estratégias para dizer." (cf. Geraldi, 1991, p. 160), parecem ser desconsiderados, pois o objetivo é o de escrever para cumprir determinada meta: explorar o tema de forma sucinta e com uma preocupação excessiva em agradar ao leitor, no caso o avaliador, por isso a semelhança entre o conteúdo dos materiais voltados ao vestibular. 
Para esta tese, recorremos ao banco de dados de redações elaboradas pelos candidatos da Fuvest (Fundação para o Vestibular de São Paulo). São 700 redações de sete vestibulares distintos, no período de 2004 a 2010 (as 100 melhores de cada exame), escolhidas pela banca examinadora.

Também é importante salientar que foram disponibilizados 700 textos, também de 2004 a 2010, considerados piores, de acordo com os critérios da banca, porque são textos que apresentam problemas como: coerência, de coesão, de clareza entre as ideias, apontamentos argumentativos calcados no senso comum, que não acrescentam informações que possam levar o leitor a outros posicionamentos, e também a problemas recorrentes de norma culta.

Esses 700 textos considerados piores pela banca foram analisados preliminarmente e, durante os procedimentos, percebemos que os pares correlativos, objeto de análise desta tese, utilizados, apresentavam-se, ora comprometidos, no que diz respeito aos sentidos, ora auxiliavam para uma construção mais complexa entre as ideias. Desse modo, não se forma um texto com mais qualidade de reflexão, nem permite reconhecer o background informativo do candidato, mas somente permite reconhecer que sabe ligar uma palavra à outra, recurso que, apesar de conferir coesão, torna a porção informativa e truncada:

\section{$\underline{\text { Redação considerada pior }}$}

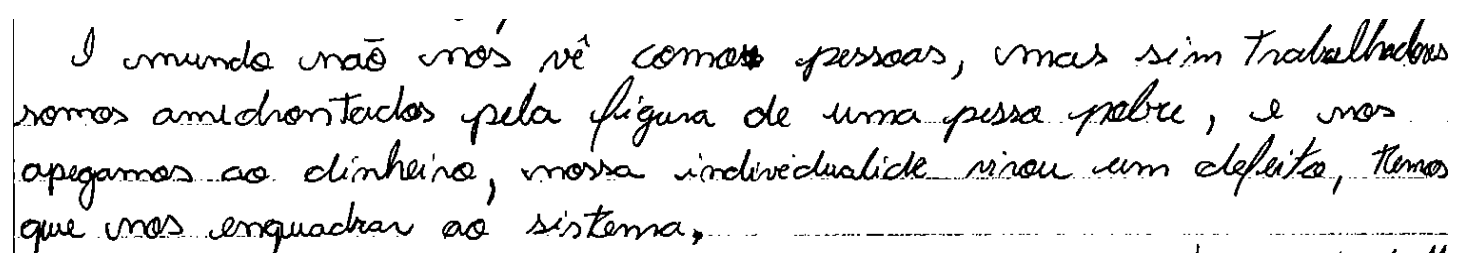

(Exemplo 9, Fuvest, 2010, p.50)

\section{$\underline{\text { Redação considerada pior }}$}




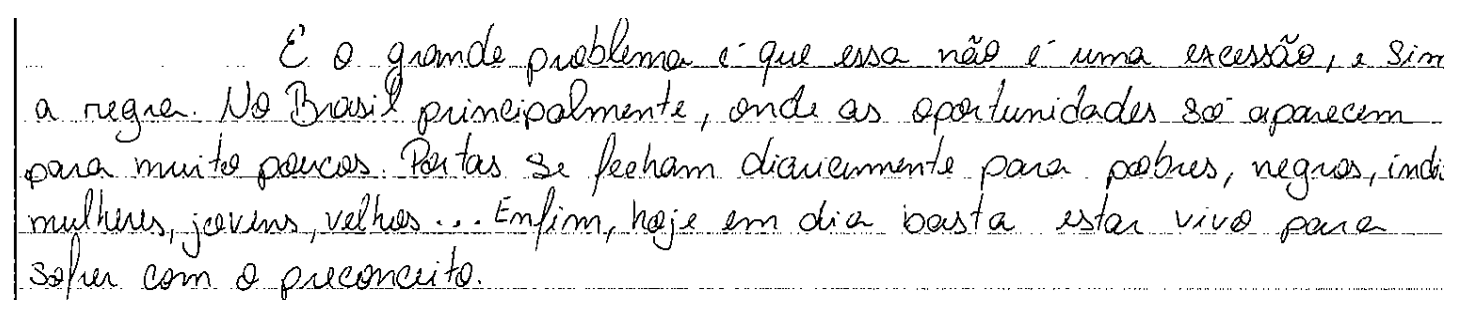

(Exemplo 10, Fuvest, 2005, p.51)

Como se pode observar, esses trechos das redações revelam que o candidato articula algumas informações, as quais, contudo, não apresentam uma complexidade. As correlações prestam-se, assim, para ligar o que, apesar de estarem sintaticamente concatenadas, não há nenhum tipo de reflexão mais elaborada. Dessa forma, sua função é adversa, pois demonstra uma concretude de raciocínio, mas sem profundidade e sem um posicionamento mais crítico.

Nas melhores redações, percebe-se a presença do par correlato como um elemento encadeador coesivo que opera funcionalmente, a fim de estabelecer sentido entre as porções informativas e, também, relacionar as ideias de forma a fundamentar a argumentação:

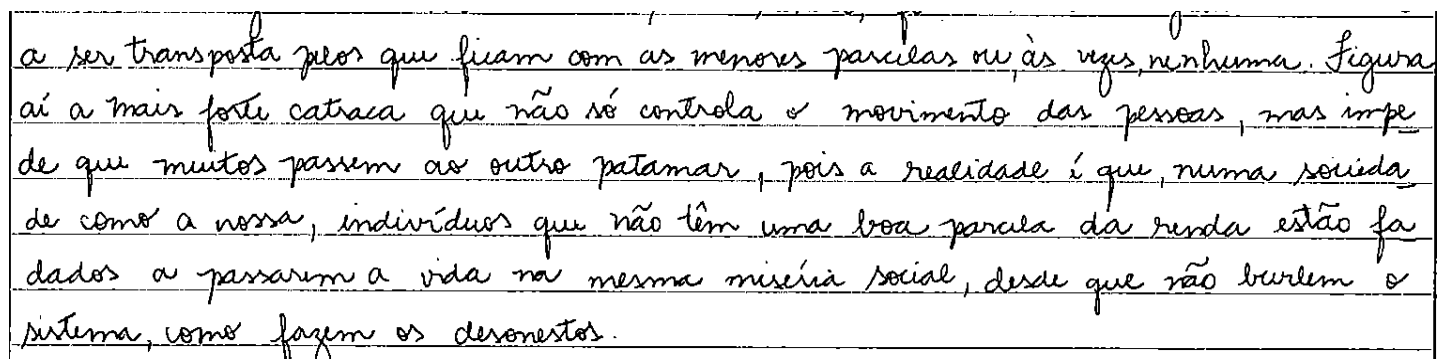

(Exemplo 11, Fuvest, 2005, p.30)

Enquanto nas redações consideradas "piores", pares correlatos servem para unir léxicos, como se fosse uma estratégia para o autor encerrar mais rapidamente a ideia, porque não consegue fundamentar, discutir, apresentar fatos; nas "melhores", a estratégia da utilização do par correlato serve para expor argumentos de forma a relacioná-los com a temática, mais consistentemente; parece haver uma contribuição do autor. Isso acontece, porque, a cada ano, os temas exigem do candidato um posicionamento mais contundente por meio de apresentação de exemplos, dados, que consigam trazer à tona uma discussão, reflexão crítica. 


\subsection{A forma de avaliação}

A escrita de um texto, sobretudo de um texto formal, não é um evento isolado, envolve questões processuais, tanto linguísticas como discursivas.

É uma atividade que mobiliza nosso repertório de conhecimentos de mundo que nos mobilizam para atinar conteúdos informacionais que se incorporarão ao texto: devem cumprir um papel social, porque envolve outro sujeito.

Todo texto é escrito em função de um "para que", "para quem", "de que forma", "por que escrever". No caso específico dos nossos, que comporão o corpus desta tese, a avaliação, por ser eliminatório, parece ser calcada nos erros cometidos pelos candidatos, principalmente no que se refere à norma culta, estruturação, temática solicitada, nos aspectos que envolvem a coesão e coerência.

Não será foco desta tese analisar o comportamento linguístico-discursivo das consideradas piores pelo fato de apresentarem algumas características, na sua grande maioria:

A) Utilizam-se de pares correlatos inapropriadamente, anulando o sentido das porções;

B) Os pares utilizados têm objetivo de integrar itens lexicais com pouco material linguístico, de pouca complexidade;

C) A maior parte das correlativas presentes nos textos serviram somente para unir itens lexicais com o objetivo de informar, apenas; não de alavancar discussões que levassem à reflexão do leitor;

D) A maior parte das correlativas empregadas foram as aditivas, e que conforme a análise, mostraram-se presente somente com a função de adicionar fatos.

\subsection{Temas}

A seguir, apresentaremos uma análise de cada um dos temas, entre os anos de 2004 a 2010, cujos textos farão parte do corpus desta tese. O objetivo é o de mostrar como o candidato deveria entender cada um desses temas e de que modo poderia argumentar. 


\title{
TEMA: DIFERENTES CONCEPÇÕES DE TEMPO/ 2004
}

\begin{abstract}
REDAÇÃO
Nos três textos abaixo, manifestam-se diferentes concepções do tempo; o autor de cada um deles expõe uma determinada relação com a passagem do tempo. Leia-os com atenção:
\end{abstract}

Texto I

Mais do que nunca a história é atualmente revista ou inventada por gente que não deseja o passado real, mas somente um passado que sirva a seus objetivos. (...) Os negócios da humanidade são hoje conduzidos especialmente por tecnocratas, resolvedores de problemas, para quem a história é quase irrelevante; por isso, ela passou a ser mais importante para nosso entendimento do mundo do que anterior.

(Eric Hobsbawm, Tempos interessantes: uma vida no século $\mathbf{X X}$ )

Texto II

O que existe é o dia-a-dia. Ninguém vai me dizer que o que aconteceu no passado tem alguma coisa a ver com o presente, muito menos com o futuro. Tudo é hoje, tudo é já. Quem não se liga na velocidade moderna, quem não acompanha as mudanças, as descobertas, as conquistas de cada dia, fica parado no tempo, não entende nada do que está acontecendo. (Herberto Linhares, depoimento)

Texto III

Não se afobe, não,

Que nada é pra já,

Sábios em vão

Tentarão decifrar

O amor não tem pressa,

Ele pode esperar em silêncio

O eco de antigas palavras,

Num fundo de armário,

Fragmentos de cartas, poemas,

Na posta-restante,

Mentiras, retratos,

Vestígios de estranha civilização.

Milênios, milênios

Não se afobe, não,

No ar...

Que nada é pra já

E quem sabe, então,

O Rio será

Amores serão sempre amáveis.

Futuros amantes quiçá

Alguma cidade submersa.

Se amarão, sem saber,

Os escafandristas virão

Com o amor que eu um dia

Explorar sua casa,

Deixei pra você

Seu quarto, suas coisas,

Sua alma, desvãos ..

(Chico Buarque, "Futuros amantes")

Redija uma DISSERTAÇÃO EM PROSA, na qual você apontará, sucintamente, as diferentes concepções do tempo, presentes nos três textos, e argumentará em favor da concepção do tempo com a qual você mais se identifica.

Figura 6. Proposta temática da Fuvest 2004.

O candidato, a partir da proposta e dos textos de apoio apresentados sobre as diferentes concepções do tempo, necessitaria apontar sucintamente cada uma delas e argumentar em favor daquela com a qual mais se identificaria.

Como cada texto ilustra uma visão sobre o tempo, diferentemente, exigiria do candidato uma competência de leitura e interpretação calcada nas habilidades 
metalinguísticas ${ }^{27}$ e epilinguísticas ${ }^{28}$ em que contribuiria com que ele fizesse uma reflexão,levando-o, posteriormente, a argumentar e concluir.

Caso escolhesse a primeira concepção (passado), seria apropriado lembrar o valor da experiência atrelado à forma de aprendizado, evolução e transformação, a fim de que possamos entender o tempo presente. Ao escolher a segunda, que privilegia o presente, caberia mencionar, dentre outros aspectos, o papel da globalização, cuja tônica é a velocidade. Para a terceira, deveria sair em defesa do tempo como aliado à calmaria, em que as relações amorosas, por exemplo, fossem baseadas nessa circunstância.

\section{TEMA: A EXISTÊNCIA DE VÁRIOS TIPOS DE CATRACA - ESPAÇO URBANO CONTEMPORÂNEO/2005}

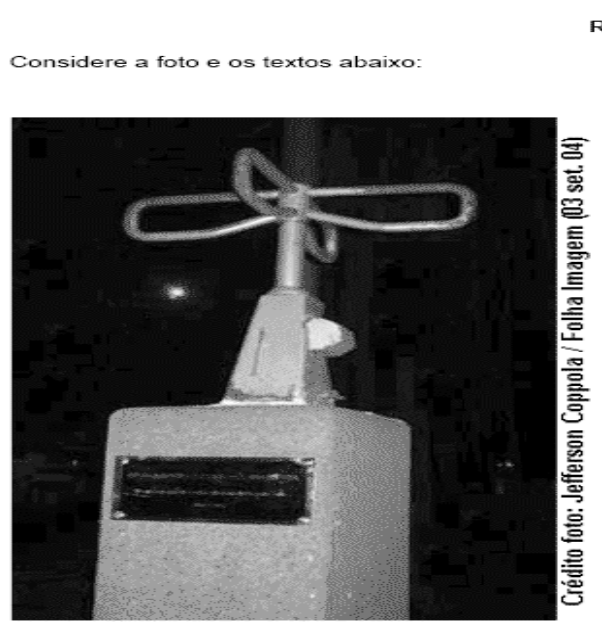

REDAÇÃo

Em site sobre o assunto, assim foi explicado o projeto do grupo "Contra File"":

"O 'Contra Filé desenvolveu o PROGRAMA PARA A DESCATRACALIZAÇÃO DA PRÓPRIA VIDA. A catraca representa um signo revelador do controle biopolítico, através de forças visiveis e/ou invisiveis. Por quantas (http://lists indymedia.org/pipemail/cmi-brasil-video/2004-july/0726-ct.html)
(n)

INSTRUCCÃO. Como você pôde verificar, observando o noticiário da imprensa e o texto da Internet aqui reproduzidos, a catraca que "apareceu" em uma praça de São Paulo era, na verdade, un "Monumento à catraca invisivel", ali instalado pelo grupo artístico "Contra File", como parte de seu "Programa para a descatracalização da vida". Tudo indica, portanto, que o grupo responsável por este programa acredita que há um excesso de controles, dos mais variados tipos, que se exercem sobre os corpos $e$ as mentes das pessoas, submetendo-as a constantes limitaçoes e constrangimentos. Tendo em vista as motivaçôes do grupo, voce julga que o programa por ele desenvolvido se justifica? DISSERTAÇA O EM PROSA, argumentando de modo a apresentar seu ponto de vista sobre o assunto.

\footnotetext{
27 Segundo Correa (2004), as atividades metalingüísticas estão calcadas na manipulação que o sujeito faz sobre a s estruturas da linguagem, há uma reflexão e compreensão coligadas à consciência.

28 Segundo Gombert (1992), as atividades epilinguísticas estão coligadas ao funcionamento da língua. Relaciona-se às várias operações linguísticas usadas durante a produção textual.
} 
Figura 7. Proposta temática da Fuvest 2005.

O candidato, a partir de uma foto, seguida de três textos, deveria posicionar-se em relação a um projeto denominado Programa para Descatralização da vida, simbolizado por uma catraca enferrujada que foi colocada, em setembro do ano de 2004, em cima de um pedestal, na região central da capital paulista, e que podia ler: "Monumento à catraca invisível".

Esperava-se do candidato que ele refletisse sobre a existência de vários tipos de catraca no espaço urbano contemporâneo, representando diversas formas de controle sobre "os corpos e as mentes das pessoas".

Para ilustrar nas considerações, o candidato poderia mencionar as restrições econômicas, políticas ou sociais - a que os cidadãos vêm sendo submetidos, em que há cerceada a liberdade. Também a respeito dos sistemas de vigilância, visíveis ou não, que nos constrangem a todo momento.

\section{TEMA:DIFERENTES VISÕES A RESPEITO DO TRABALHO/2006}

REDAÇÃO
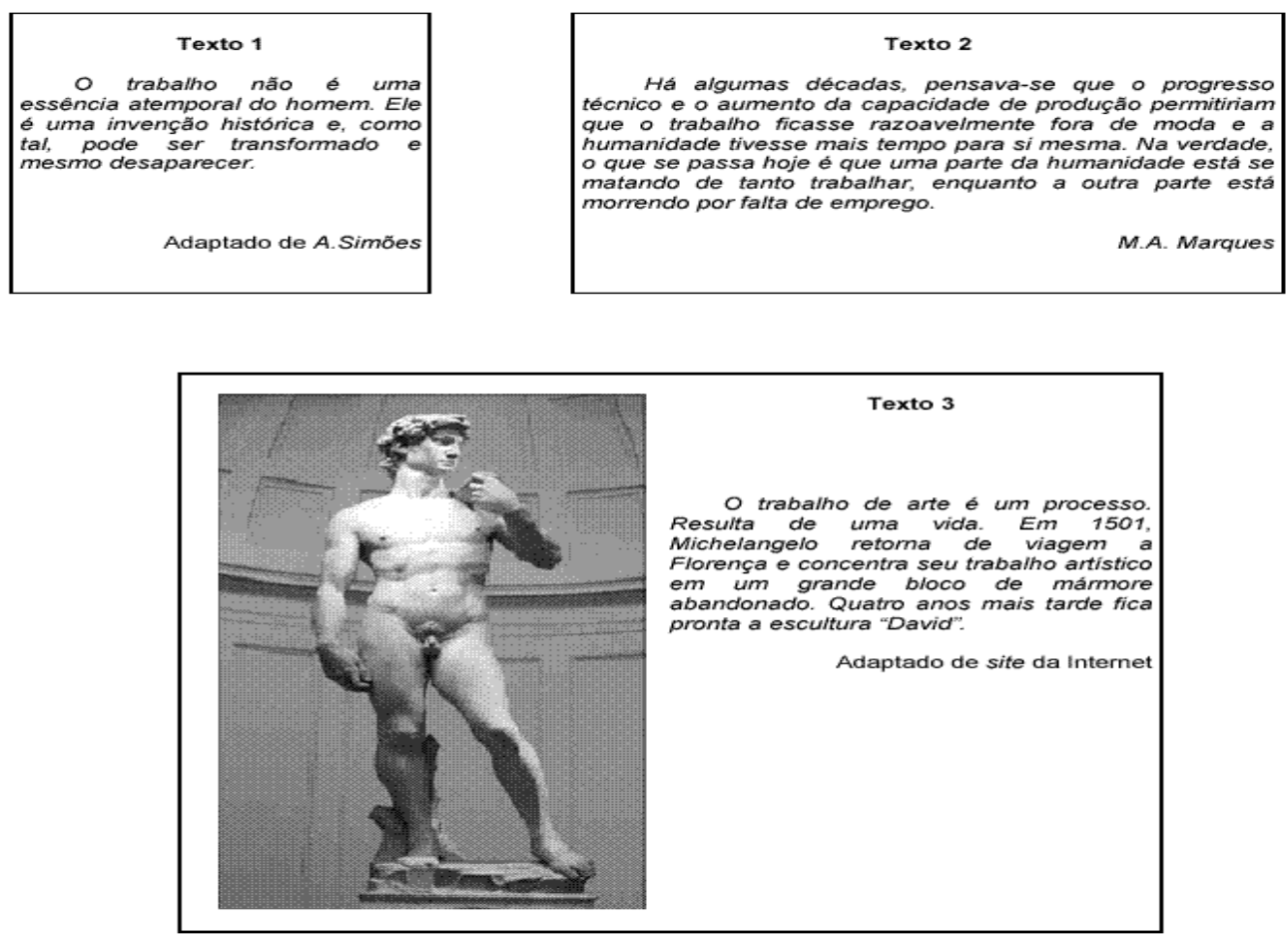

INSTRUÇÃO: Os três textos acima apresentam diferentes visões de trabalho. O primeiro procura conceituar ilustrado pela famosa escultura de Michelangelo, refere-se ao trabalho de artista. Relacione esses três textos e com base nas idéias neles contidas, além de outras que julgue relevantes, redija uma DISSERTAÇÃO EM PROSA, argumentando sobre o que leu acima e também sobre os outros pontos que você tenha considerado pertinentes. 
O candidato, a partir de três textos sob diferentes óticas a respeito do trabalho, deveria dissertar, argumentando sobre o que leu e também sobre outros pontos de vista que tenha considerado pertinentes.

Se escolhesse o primeiro, o candidato poderia definir o trabalho como uma "invenção histórica" - passível, portanto, de sofrer transformações e até mesmo desaparecer. Caberia a ele, nesse caso, reconhecer o surgimento do trabalho como forma de sobrevivência, que vem se diversificando à medida que a humanidade tem evoluído.

O segundo texto de apoio poderia ser usado para demonstrar a frustração da humanidade, que hoje vive uma dualidade: uns, que se matam pelo trabalho, e outros, que morrem pela falta de emprego; um fenômeno perverso advindo da globalização, que tem produzido uma reestruturação no mundo do trabalho, baseada no barateamento da mão de obra dos países do Terceiro Mundo.

Ao optar pelo terceiro texto, acompanhado pela foto da escultura David, de Michelangelo, que define o trabalho de arte como "um processo", caberia ao candidato discutir a relação entre o trabalho criador e o trabalho de natureza puramente repetitiva.

\section{TEMA AMIZADE/ 2007}

\section{PROPOSTA DE REDAÇÃO} Em primeiro lugar (...), pode-se realmente "viver a vida" sem conhecer a felicidade de encontrar num amigo os mesmos
sentimentos? Que haverá de mais doce que poder falar a alguém como falarias a ti mesmo? De que nos valeria a
felicidade se não tivéssemos quem com ela se alegrasse tanto quanto nós próprios? Bem difícil te seria suportar
adversidades sem um companheiro que as sofresse mais ainda.
(...)
Os que suprimem a amizade da vida parecem-me privar o mundo do sol: os deuses imortais nada nos deram de melhor,
nem de mais agradável.
(Cícero, Da amizade.)

Aprecio no mais alto grau a resposta daquele jovem soldado, a quem Ciro perguntava quanto queria pelo cavalo com o qual acabara de ganhar uma corrida, e se o trocaria por um reino: "Seguramente não, senhor, e no entanto eu o daria de bom grado se com isso obtivesse a amizade de um homem que eu considerasse digno de ser meu amigo". E estava certo ao dizer se, pois se encontramos facilmente homens aptos a travar conosco relações superficiais, o mesmo não acontece quando procuramos uma intimidade sem reservas. Nesse caso, é preciso que tudo seja límpido e ofereça completa segurança.

(Montaigne, "Da amizade” (adaptado).

Amigo é coisa pra se guardar,

Debaixo de sete chaves,

Dentro do coração...

Assim falava a canção

Que na América ouvi...

Mas quem cantava chorou,

Ao ver seu amigo partir...

Mas quem ficou,

No pensamento voou,

Com seu canto que o outro lembrou

(...)

Fernando Brant / Milton Nascimento, "Canção da

América"

(...)

E sei que a poesia está para a prosa

Assim como o amor está para a amizade.

E quem há de negar que esta lhe é superior?

(...)

Caetano Veloso, "Língua”. 
Valendo-se da própria experiência e dos exemplos que considerasse relevantes, o candidato deveria desenvolver uma dissertação em prosa a partir de textos que tratavam sobre o valor da amizade. Poderia discorrer sobre a dificuldade de se encontrar um amigo, tendo como base o ensaio do filósofo Montaigne, que apontava a amizade uma "intimidade sem reservas". Caso reconhecesse a atualidade das ideias dos pensadores Cícero, Fernando Brant, Milton Nascimento, Caetano Veloso e até mesmo Montaigne, poderia optar por discutir a amizade como um fator determinante na profundidade ou supercialidade dos relacionamentos que cultivamos.

Caberia ao candidato direcionar a linha temática que embasaria suas discussões: uma visão cética em relação à amizade, lembrar das amizades inesquecíveis que resistiram ao tempo, a distância e até mesmo os desentendimentos.

TEMA: MUNDO DIGITAL/2008 


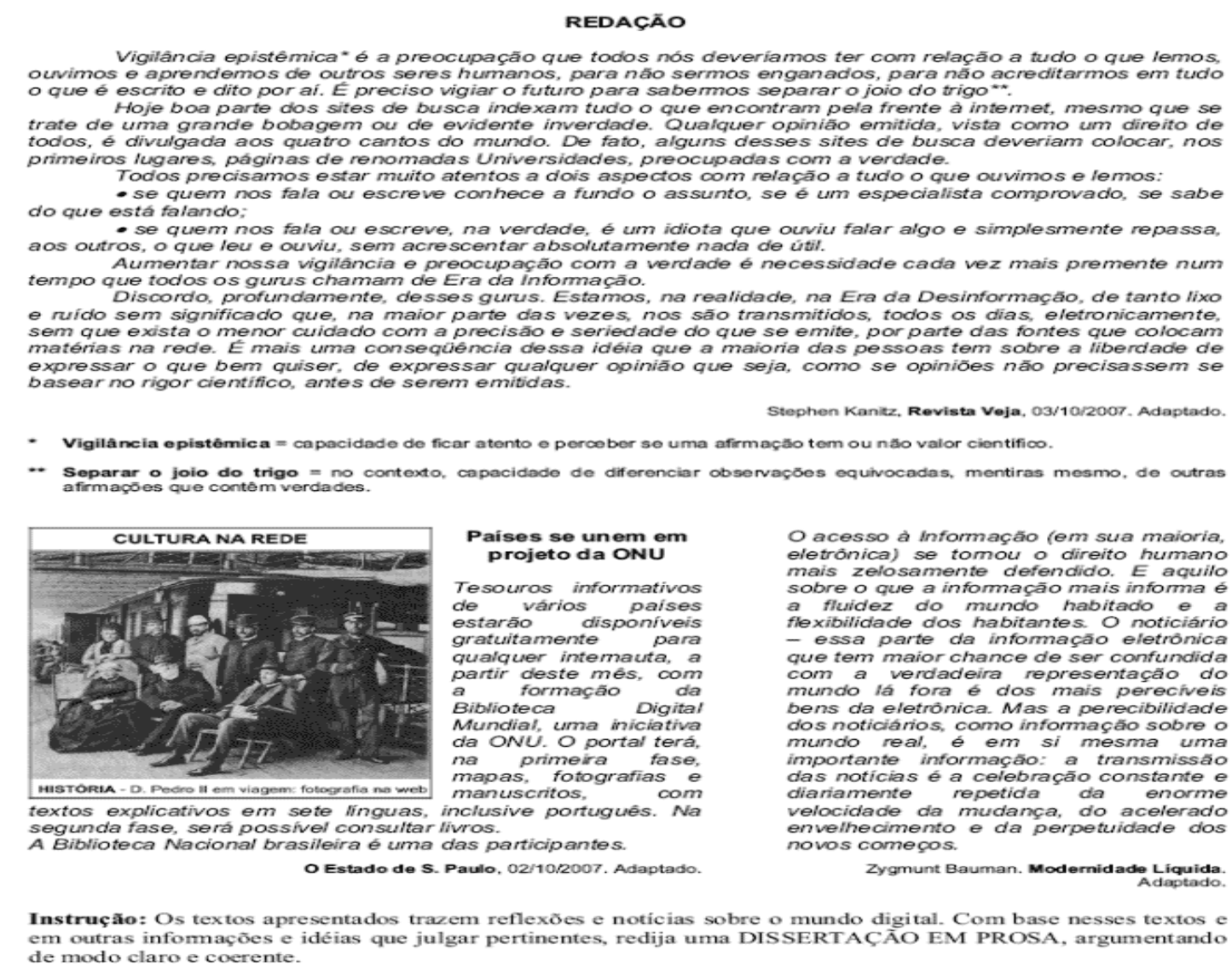

Figura 10. Proposta temática da Fuvest 2008.

Nunca se produziu, como hoje, tanta informação, fenômeno impulsionado pelo advento da internet. Com base nessa constatação, a Fuvest, no ano de 2008, propôs ao candidato, valendo-se dos três textos oferecidos como subsídios à produção, que redigisse um texto focando, por exemplo, os aspectos positivos da expansão da informação e sua consequente democratização, sem contudo deixar de observar os riscos decorrentes dessas vantagens.

Se optasse por considerar as questões a respeito do primeiro texto, discutiria sobre o alerta contra a tendência crescente de aceitar como verdadeira toda e qualquer informação disponível, sobretudo na internet. Para isso, recomenda-se uma "vigilância epistêmica" (capacidade de ficar atento e perceber se uma afirmação tem valor científico ou não). Se fosse discutir suas ideias pelo segundo texto, teria como base a notícia da Unesco: anunciou, em outubro de 2007, a criação de uma Biblioteca Digital, que conta com várias obras, inclusive na Língua Portuguesa. Ao optar pelo terceiro 
texto, fragmento adaptado da obra Modernidade Líquida, do sociólogo Bauman, trata da "perecibilidade" do rio informativo que nos cerca.

TEMA: DIFERENTES TIPOS DE FRONTEIRA MUNDIAL: SENTIDO LITERAL (GEOGRÁFICO, FÍSICO) E NO SENTIDO FIGURADO (CULTURAL, LINGUÍSTICO, CIENTÍFICO,ETC)/ 2009

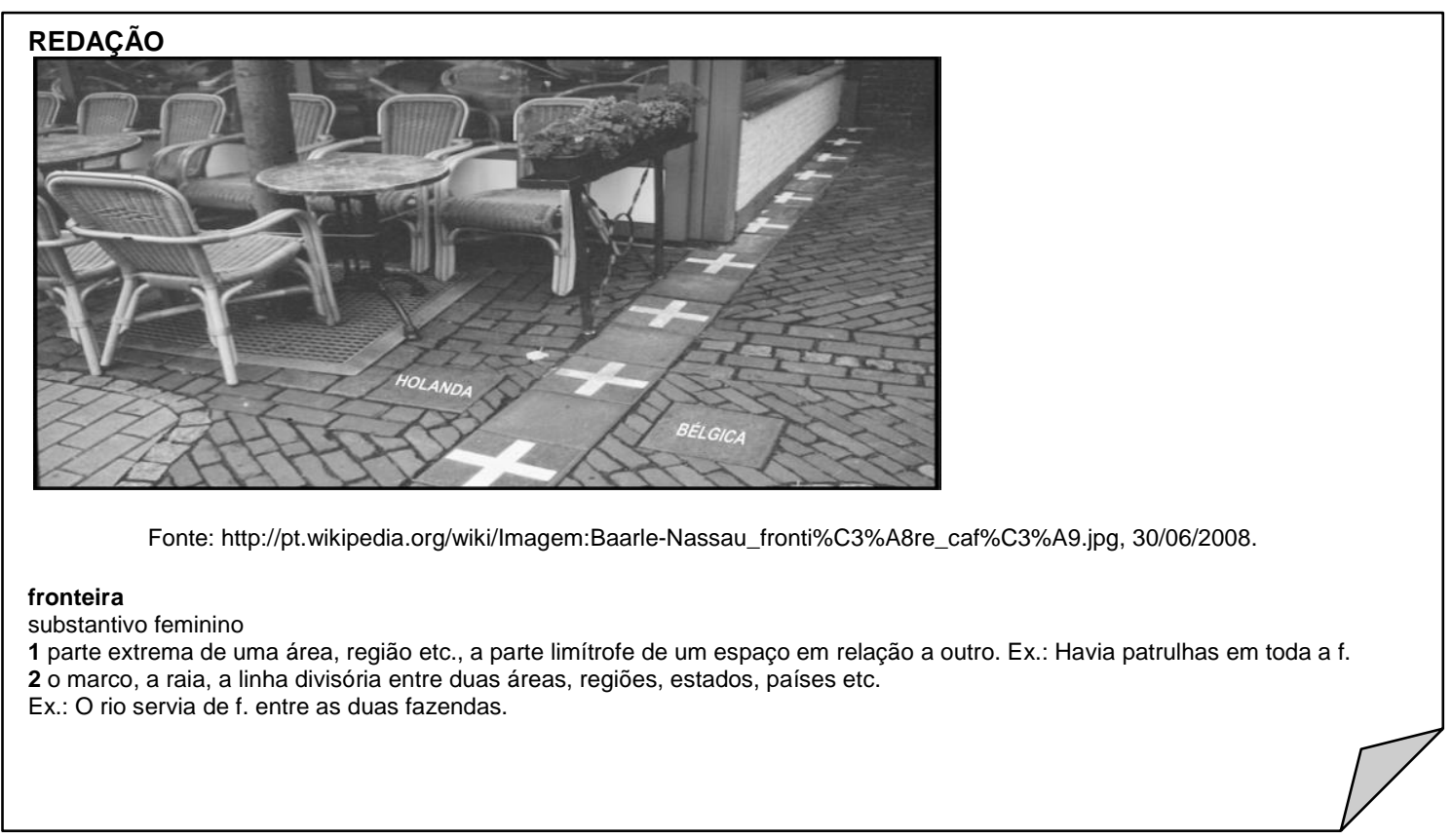

Figura 11. Proposta temática da Fuvest 2009

O candidato, a partir desse tema, pode optar, por meio dos textos de apoio, por redigir uma dissertação sobre um ou até dois tipos de fronteira, exemplificados pelo enunciado tanto no sentido literal (geográfico, físico) como no figurado (cultural, linguístico, científico, etc).

O que optou por abordar o tema ligado aos aspectos geográficos fronteiriços, por exemplo, pode utilizar-se dos critérios muitas vezes arbitrários, utilizados para demarcação de territórios, cuja consequência está calcada em guerras e conflitos mundiais.

Caso tenha optado por tratar das questões abstratas, poderia ter-se valido do preconceito linguístico existente entre os povos do próprio país e até de seus países vizinhos ou não. Barreiras sociais advindas, por exemplo, da globalização, que afasta 
culturas, instaura a democratização do conhecimento, intransponíveis. No tocante às questões relativas à ética moral, poderiam ser exploradas como "zonas fronteiriças", delimitadoras do que seria "certo ou errado", de acordo com valores de diferentes culturas.

\section{Tema:Imagem/2010}

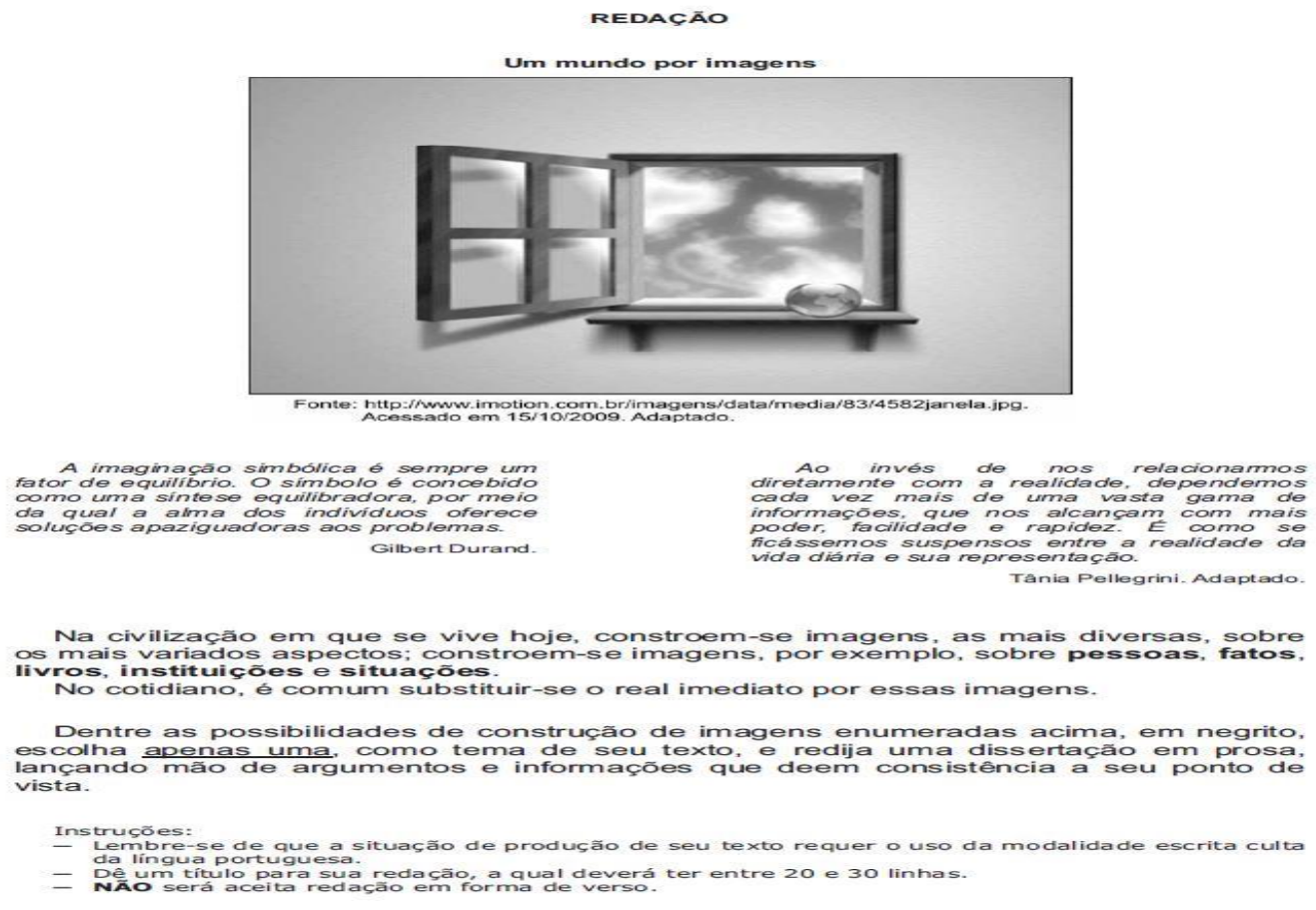

Figura 12. Proposta temática da Fuvest 2010

O candidato, para essa proposta, deveria entender que a palavra "imagem" foi empregada em sentido figurado, pois a "imagem" retratada no texto não se trata de representações visuais icônicas, mas de quaisquer representações ou caracterizações que se fazem ou se tem sobre pessoas, livros, situações, fatos, em geral.

Os textos apresentados se referem à imagem como símbolo ou substituto da realidade. No primeiro caso, ela pode ter uma função esclarecedora às almas dos indivíduos, que procuram, no outro, a solução de conflitos entre os homens. No segundo caso, a imagem não esclarece, mas oculta ou dissimula a realidade que representa.

Qualquer que fossem "as possibilidades de construção de imagens", poderia apropriar-se do cenário artístico ou político, por exemplo, como também citar versões 
de fatos, eventos, notícias, que são apresentadas de acordo com a conveniência de quem os relata, filtrando ou deturpando a imagem que chega para o público-alvo.

Os temas foram apresentados aqui com o objetivo de apontar a complexidade envolvida em cada um deles, através dos quais se requer do candidato um perfil que privilegie a língua como objeto de reflexão, apoiado nas experiências e em seus conhecimentos de mundo que sabe buscar, o que e para que, nos aspectos que enriquecerão seus apontamentos, a costura que se faz entre o passado e o presente, naquilo que ressignificou e que está se ressignificando, numa inserção de aspectos e detalhes resultantes das leituras que lhe foram expostas.

No tocante às comandas apresentadas nessas propostas, a forma que se pede para que o candidato escreva o texto vem sempre da mesma maneira: "redija uma dissertação em prosa" a partir de "argumentos" consistentes em favor à defesa de um ponto de vista.

Para isso, necessitaria, primeiramente, saber o conceito de dissertar e o de argumentar. Segundo Garcia (1988), "nossos compêndios e manuais de língua portuguesa não costumam distinguir a dissertação da argumentação" e, muitas vezes, o aluno realiza ou uma ou outra, e não necessariamente uma na outra; isto é, expor, explanar ou interpretar ideias a partir da apresentação de razões, em face da evidência das provas e à luz de um raciocínio coerente e consistente.

Para Garcia (1988), “a argumentação deve basear-se nos princípios da lógica” (p. 370), por meio da consistência do raciocínio e da evidência das provas, por isso deve pautar suas declarações, apreciações, julgamentos, pronunciamentos, a partir de validação, isto é: "só os fatos provam; sem eles, que constituem a essência dos argumentos convincentes, toda declaração é gratuita, porque infundada, é facilmente contestável" (Garcia, 1988, p. 292).

Para escrever uma dissertação em prosa, o candidato deve entender de qual tema deverá tratar, deve ter senso crítico e, quase sempre, uma solução, que se dá por meio dos exemplos apresentados, que devem ser validados. Geralmente, o tema sobre o qual o aluno/candidato deverá discorrer é pautado em um problema relativo a toda uma sociedade. 
O problema é que, por não apresentarem um repertório linguístico suficiente para atender à exigência para esse tipo de texto, alguns textos, apesar de tratarem do tema, explanam informações, muitas vezes, consideradas de "senso comum", que não acrescentam, entre as partes que as constitui, informações válidas; dissertam, mas não argumentam.

$\mathrm{Na}$ tese, o candidato deve mostrar que entendeu o tema, apresentar seu posicionamento em relação a ele, e, para isso, assumir uma das três posições: a favor, contra ou dialético (mostrar prós e contras).

No desenvolvimento, deve apresentar fundamentos que permitam ao leitor aceitar sua tese como válida, defensável. Nessa fase, o candidato deve mostrar conhecimento de mundo cultural: "a legítima argumentação, tal como deve ser entendida, não se confunde com o bate-boca estéril ou carregado de animosidade. Ela deve ser, ao contrário, construtiva, cooperativa e útil" (Garcia, 1988, p. 371). É nesse estágio que a coerência do raciocínio mais se impõe: "o autor deve escolher a que melhor se ajuste à natureza de sua tese" (Garcia, 1988, p. 380).

Quase sempre, entretanto, ao contrário do que se faz na refutação, "adota-se a ordem gradativa crescente ou climática" (Garcia, 1988, p. 380) em relação aos argumentos; é uma estratégia partir das partes mais frágeis para as mais irrefutáveis.

Outro recurso ligado à argumentação é manter o leitor quase que em suspense, fazer declarações que se converjam ao ponto de vista, de uma forma que vários argumentos dialoguem para que se encaminhem à conclusão. Podem ser por meio de confrontos, flagrantes do cotidiano humano, comparações adequadas e elucidativas, testemunho autorizado, alusões históricas, citações embasadas em fontes que dão credibilidade àquilo que se defende ou refuta.

Por fim, cabe ainda lembrar que, no desenvolvimento, é o momento oportuno para o autor frisar os pontos principais apresentados na tese que, sem dúvida, englobará na conclusão final, de maneira quanto possível enfática, se bem que suficientemente, ou ainda de se antever para possíveis objeções do leitor, e refutá-las a seu tempo.

É no e pelo desenvolvimento que o ser humano busca na mente a informação já armazenada, aquela que foi adquirida de acordo com suas experiências, parece representar o que tem de representar, e, para isso, consegue articular informações de 
maneira complexa por meio da organização e esquematização de suas próprias habilidades cognitivas, isto é, ao buscar suas experienciações para torná-las concretas linguística e imageticamente, sistematiza conteúdos de acordo com suas intenções comunicativas.

A conclusão, como aponta Garcia (1988, p. 381) "brota" das provas arroladas; em síntese, "consiste em por em termos claros, insofismáveis, a essência da proposição" (p. 381). Deve perceber a coerência entre a conclusão do texto e o objetivo traçado pelo autor (que posição tomou em relação ao tema).

Pode vir apresentada por meio de uma posição neutra do autor, por exemplo, ao encerrar por meio de uma exposição ou síntese; explicitar um posicionamento ou deixálo implícito, mas correlacionando com os argumentos apresentados; apresentar consequências lógicas dos argumentos mostrados; levantar hipóteses e sugestões relativas ao tema e até soluções para a problemática / conflito central do tema.

Entendemos a correlação, objeto de análise, como um processo usual na linguagem, a fim de conectar porções informativas; é um exercício cognitivo, em que o falante/autor busca nas suas experienciações, na sua bagagem linguística, social, cultural, instaurar entre as partes, que constituem o texto, conteúdos que servem para dar realce às unidades conectadas.

Quando o indivíduo correlaciona, é porque busca, nesse processo, ativar informações e distribuí-las de modo que possa satisfazer sua necessidade: a de comunicar, por meio de conteúdos que pragmaticamente se inserem entre as porções.

Nossa escolha por verificar o comportamento, os papéis que assumem e como se processam os correlativos linguísticos, deu-se por meio de um questionamento base: como é que pares correlativos, que integram o conjunto de porções informativas em redações vestibulares, momento em que a pressão pela normatividade é bem grande, fogem àquilo que se espera e surpreendem o leitor com escolhas criativas, que não rompem com o processo cognitivo esperado?

Nas redações da Fuvest, encontramos pares correlativos tanto considerados normatizados como aqueles considerados diferentes porque estão presentes na bagagem cognitiva herdadas historicamente na sociedade. 
Só isso não esgotaria o que é, de fato, a correlação, pois, além dos itens que se ligam numa espécie de paralelismo sintático, há um processo sociocognitivo instalado nas conceitualizações que tornam símbolos linguísticos orquestrados por processos ou modos de pensar a informação. Uma dessas formas de repensar e organizar a informação é aquela que todo ser humano tem como mais básica, a analogia. Por processos analógicos, vamos correlacionando informações, porque elas, na verdade, já estão correlacionadas na experiência humana e, por isso, parecem apresentar-se em maior quantidade no desenvolvimento do texto.

\subsection{Checando hipóteses}

\begin{tabular}{|l|c|c|c|c|c|c|c|c|}
\cline { 2 - 9 } \multicolumn{1}{c|}{} & \multicolumn{1}{l}{ ANO } & \multicolumn{1}{l|}{} \\
\hline ESTRUTURA & $\mathbf{2 0 0 4}$ & $\mathbf{2 0 0 5}$ & $\mathbf{2 0 0 6}$ & $\mathbf{2 0 0 7}$ & $\mathbf{2 0 0 8}$ & $\mathbf{2 0 0 9}$ & $\mathbf{2 0 1 0}$ & TOTAL \\
\hline TESE & $\mathbf{8}$ & $\mathbf{2 0}$ & $\mathbf{1 4}$ & $\mathbf{1 5}$ & $\mathbf{1 5}$ & $\mathbf{2 6}$ & $\mathbf{1 1}$ & $\mathbf{1 0 9}$ \\
\hline DESENVOLV & $\mathbf{4 5}$ & $\mathbf{4 3}$ & $\mathbf{4 4}$ & $\mathbf{6 4}$ & $\mathbf{3 5}$ & $\mathbf{4 2}$ & $\mathbf{3 1}$ & $\mathbf{3 0 4}$ \\
\hline CONCLUSÃO & $\mathbf{2 7}$ & $\mathbf{1 7}$ & $\mathbf{1 8}$ & $\mathbf{1 7}$ & $\mathbf{1 7}$ & $\mathbf{2 9}$ & $\mathbf{1 9}$ & $\mathbf{1 4 4}$ \\
\hline
\end{tabular}

Quadro 1. Quantificações de correlativos por Estrutura Textual (melhores)

Algumas considerações hipotéticas são pertinentes a partir dos resultados encontrados nas melhores redações:

A) É no desenvolvimento que os pares correlatos mais apareceriam; provavelmente, porque seria o momento em que haveria maior esforço mental e processual para que se buscassem exemplos, dados, experiências de fatos e de mundo para acoplar entre as porções, a informação com a qual pretende dialogar, refutar, rebater, enfim, convenceria o leitor daquilo que se quer provar, por se tratar de um espaço em que haveria maior preocupação em debruçar todo conhecimento adquirido e vivenciado, seja por leitura, experiências ao longo da vida, seja pelos anos a que assistiu, debates, reflexões. É nele, então, em que pulsos de selves centrados seriam gerados, por conta do self autobiográfico, que automaticamente daria conta de gerar pulsos de imagens, que se concretizam nessa fase do texto? 
B) Um dado que nos chama atenção é a baixa quantidade de pares nas redações do ano de 2010, tanto na tese, no desenvolvimento, quanto na conclusão. Verificase que, em 2009, por exemplo, enquanto houve 42 ocorrências no desenvolvimento, em 2010, somente 31. Isso também na tese: 2009, 26 ocorrências contra 11, em 2010. Isso não seria um indício de que a forma de se processar informações teria mudado, ou porque, ao escrever, o autor acredita que a forma de relacionar dados seria feita, implicitamente; isto é, pareceria ser desnecessária a presença de pares correlativos. Isso não sinalizaria que o modo de estabelecer ideias concatenadas mudou; está mais fragmentado, diretivo, porém solto?

C) Encontrar cinco pontos finais, num mesmo parágrafo, sendo ele, constituído de oito linhas, não seria perceber que as relações entre as partes do texto estão se constituindo por meio de porções informativas que se focalizariam, uma a uma, porém de forma fragmentada? Veja:

\section{A instituigäo da Igreja Latólica, per exemplo, apresenta dogmas bonetos co- mo a excisterucia de um Dus unico, onipotente e misericordioso. Coriou-se} essa imagem primordial de benerolência e telerância. Porém, em meados do século XVI, im insta'a Reforma Protestante, uma vertente da Igreja, chamada inquisicäs, for posta em prática. Foguira aos hereges e cerceamento aos opesitores da instituicä foram os precirtos reais vividos pela populaçao. A imagem de compreenxao e acolhimento fa substituída pela rebressäs pela visléncia nada idealizadar.

(Exemplo 12, Fuvest, 2010, pg. 17 - Melhor)

D) Existem papéis semântico-discursivo-pragmáticos diferentes para os diferentes tipos de corretivos?

E) A presença dos correlativos entre as porções informativas daria à argumentação mais força para discutir o que se quer, num jogo, cuja complexidade presente no $2^{\circ}$ par correlativo, refletiria conhecimento experienciado tanto de mundo quanto de língua?

F) As melhores teorias, então, em número maior de construções complexas, as quais não ligam apenas itens lexicais, mas também ideias que contribuem para a reflexão e profundidade, nas discussões? 
Até poderíamos apontar que essa ocorrência seria fruto de dicas de cursos apostilados de redação, de cursinhos ou até mesmo da escola, que solicita ao aluno que escreva de forma sucinta. Independentemente da causa, parece estar ocorrendo uma mudança paradigmática nas relações calcadas no fluxo processual, das informações que funcionariam por meio de cenas, em que caberia ao leitor estabelecer uma coesão entre elas.

\begin{tabular}{|l|c|c|c|c|c|c|c|}
\cline { 2 - 8 } \multicolumn{1}{c|}{} & ANO & \multicolumn{10}{c}{} \\
\hline ESTRUTURA & $\mathbf{2 0 0 4}$ & $\mathbf{2 0 0 5}$ & $\mathbf{2 0 0 6}$ & $\mathbf{2 0 0 7}$ & $\mathbf{2 0 0 8}$ & $\mathbf{2 0 0 9}$ & $\mathbf{2 0 1 0}$ \\
\hline TESE & $\mathbf{4}$ & $\mathbf{1 1}$ & $\mathbf{7}$ & $\mathbf{1 0}$ & $\mathbf{8}$ & $\mathbf{8}$ & $\mathbf{1}$ \\
\hline DESENVOLV & $\mathbf{1 7}$ & $\mathbf{2 5}$ & $\mathbf{1 4}$ & $\mathbf{2 6}$ & $\mathbf{1 8}$ & $\mathbf{1 7}$ & $\mathbf{1 4}$ \\
\hline CONCLUSÃO & $\mathbf{8}$ & $\mathbf{8}$ & $\mathbf{X}$ & $\mathbf{1 2}$ & $\mathbf{5}$ & $\mathbf{7}$ & $\mathbf{6}$ \\
\hline
\end{tabular}

Quadro 2. Quantificações por Estrutura Textual (piores)

Algumas considerações hipotéticas são pertinentes a partir dos resultados encontrados nas piores redações:

A) As piores redações da Fuvest não apresentaram pares correlativos em frequência de mesmos pares e também teriam uma produtividade baixa porque esses candidatos teriam dificuldade em lidar com elementos de coesão, para dar sustentação ao encadeamento e à argumentação, atividade altamente complexa. Isso não ocorreria pelo fato de os candidatos não saberem relacionar ideias, enxergá-las de forma estanque?

B) Apesar da maior quantidade de pares correlatos no desenvolvimento, não estariam eles apenas presentes para ligar itens lexicais, com pouco material linguístico, enfim apenas ligar, mas não argumentar mais complexamente?

C) Não seria um indício de que ligar itens lexicais com poucas ideias, simples e diretivas, é um comportamento de quem ainda apresenta pouco repertório linguístico-argumentativo?

D) Redações consideradas melhores teriam construções correlativas mais complexas; isto é, com maior quantidade de material linguístico na $2^{\mathrm{a}}$ porção informativa, a fim de servir como argumento favorável à ideia discutida? 
Outro dado importante para compor a metodologia desta tese diz respeito a um número significativo de paralelismos encontrados em trechos dos textos analisados. Entendemos que o paralelismo é um processo de encadeamento de valores sintáticos idênticos entre as porções informativas, isto é, uma simetria que tem como objetivo manter o equilíbrio entre as partes que compõem o parágrafo. Vemos como um recurso estilístico, ligado à manutenção entre os itens lexicais, que se aproximam para atender especificidades linguístico-assimilativas, preocupadas com a estrutura:

tembro de 2604 . Esse mortimento intitula de catracalizaciâ"o controle exercido pelo poder econômico e pelo institurdo sobrs os cida dãos e luta contra a iquorancia acerca dessa falta de liber dade ate tudes como a do "contra- filé "sẽo indispensaveis.

(Exemplo 13, Fuvest, 2005, p.48 - Melhor)

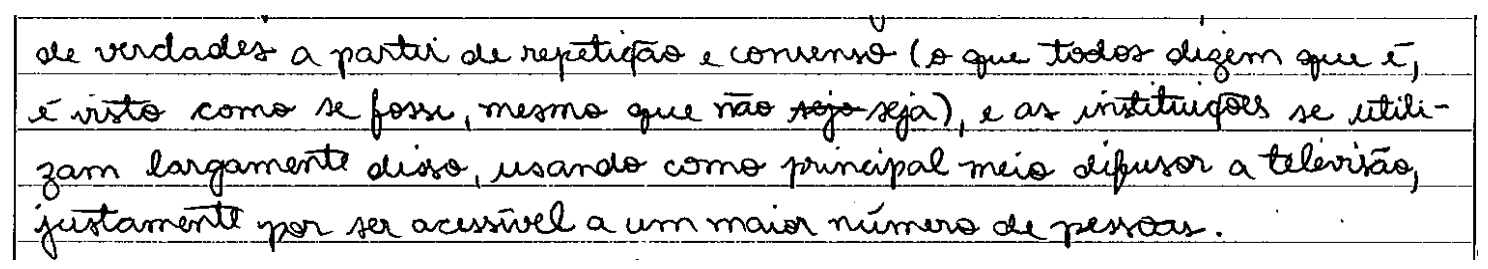

(Exemplo 14, Fuvest, 2008, p.92 - Melhor)

A nosso ver, o que diferencia o paralelismo das correlações é que eles estão a serviço do cognitivo, das intenções do ato de comunicar, envolvem operações mais complexas, experienciadas pelo individuo, que busca, nelas, uma expressividade fundamentada nos seus conhecimentos de mundo.

Chamamos atenção aos dados, como apontado a seguir, que, apesar de constituir um exemplo de correlação, não foi considerado como elemento de análise, por ser um trecho de um poema de Vinícius de Moraes:

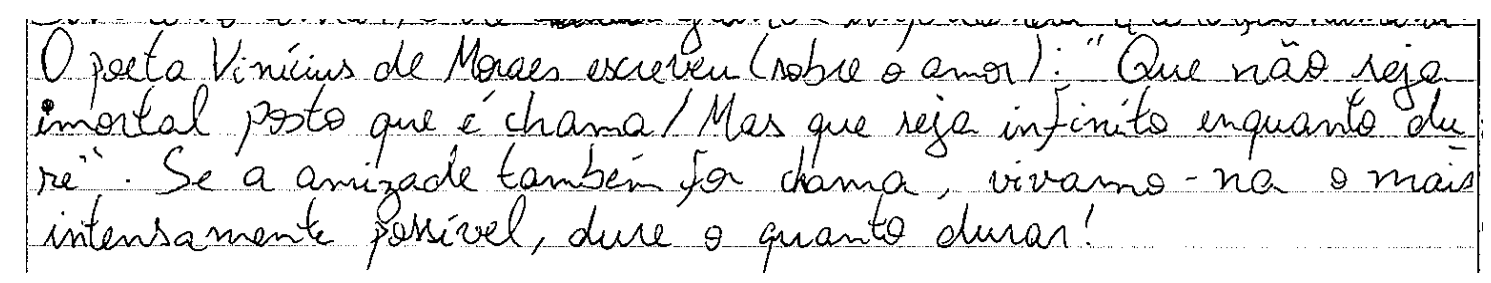

(Exemplo 15, Fuvest, 2007, p.65 - Melhor) 


\begin{tabular}{|c|c|c|c|}
\hline \multicolumn{4}{|c|}{2004} \\
\hline \multicolumn{2}{|l|}{$\begin{array}{r}\text { PIORES } \\
\end{array}$} & \multicolumn{2}{|l|}{$\begin{array}{r}\text { MELHORES } \\
\end{array}$} \\
\hline TEM CORRELAÇÃO & 35 & TEM CORRELAÇÃO & 60 \\
\hline NÃO TEM CORRELAÇÃO & 65 & NÃO TEM CORRELAÇÃO & 40 \\
\hline \multicolumn{4}{|c|}{2005} \\
\hline \multicolumn{2}{|l|}{$\begin{array}{r}\text { PIORES } \\
\end{array}$} & \multicolumn{2}{|l|}{$\begin{array}{l}\text { MELHORES } \\
\end{array}$} \\
\hline TEM CORRELAÇÃO & 35 & TEM CORRELAÇÃO & 52 \\
\hline NÃO TEM CORRELAÇÃO & 65 & NÃO TEM CORRELAÇÃO & 48 \\
\hline \multicolumn{4}{|c|}{2006} \\
\hline \multicolumn{2}{|l|}{ PIORES } & \multicolumn{2}{|l|}{ MELHORES } \\
\hline TEM CORRELAÇÃO & 20 & TEM CORRELAÇÃO & 52 \\
\hline NÃO TEM CORRELAÇÃO & 80 & NÃO TEM CORRELAÇÃO & 48 \\
\hline \multicolumn{4}{|c|}{2007} \\
\hline \multicolumn{2}{|l|}{ PIORES } & \multicolumn{2}{|l|}{ MELHORES } \\
\hline TEM CORRELAÇÃO & 41 & TEM CORRELAÇÃO & 52 \\
\hline NÃO TEM CORRELAÇÃO & 59 & NÃO TEM CORRELAÇÃO & 42 \\
\hline \multicolumn{4}{|c|}{2008} \\
\hline \multicolumn{2}{|l|}{ PIORES } & \multicolumn{2}{|l|}{ MELHORES } \\
\hline TEM CORRELAÇÃO & 31 & TEM CORRELAÇÃO & 45 \\
\hline NÃO TEM CORRELAÇÃO & 69 & NÃO TEM CORRELAÇÃO & 55 \\
\hline \multicolumn{4}{|c|}{2009} \\
\hline \multicolumn{2}{|l|}{$\begin{array}{l}\text { PIORES } \\
\end{array}$} & \multicolumn{2}{|l|}{ MELHORES } \\
\hline TEM CORRELAÇÃO & 35 & TEM CORRELAÇÃO & 58 \\
\hline NÃO TEM CORRELAÇÃO & 65 & NÃO TEM CORRELAÇÃO & 42 \\
\hline \multicolumn{4}{|c|}{2010} \\
\hline \multicolumn{2}{|l|}{ PIORES } & \multicolumn{2}{|l|}{ MELHORES } \\
\hline TEM CORRELAÇÃO & 30 & TEM CORRELAÇÃO & 46 \\
\hline NÃO TEM CORRELAÇÃO & 70 & NÃO TEM CORRELAÇÃO & 54 \\
\hline
\end{tabular}

Quadro 3. Quantificações das Melhores e Piores

O quadro anterior tem como objetivo apresentar as hipóteses, entre os textos considerados piores e melhores, entre os anos de 2004 a 2010, de pares correlativos.

Diante do levantamento feito, algumas considerações hipotéticas se fazem relevantes:

A) Ao compararmos o número de ausências de pares correlatos entre os melhores e piores textos, percebe-se um número significativo nas melhores. Não seria um indício de que a concatenação entre as porções informativas tem sido feita mais fragmentada?

B) O número das que não possuem correlação aumentou significativamente, entre os anos. Isso não representa uma mudança entre as estruturas na forma de construir e relacionar porções informativas? 
C) Se existem poucas variações, entre os anos, daquelas que não possuem correlação, é porque não existiriam incentivos quanto a aspectos culturais para aumentar o repertório do candidato?

A partir dessa coleta, separamos todas as ocorrências, por estrutura textual e por papéis semânticos que assumiram entre as porções informativas.

Todos os pares encontrados foram separados por padrões que apresentaram características linguístico-discursivas, próximas, os quais denominamos de "natureza do padrão". Após, para cada fenômeno encontrado no par, houve uma descrição e análise à luz da teoria funcionalista, a partir dos trechos das redações.

Ao nos remetermos às adversativas, houve a separação dos pares pelo comportamento em relação à natureza apresentada. A existência de ideias, imagens, que concretamente, na língua, se contrapõem, se realiza por meio de pares que funcionalmente, atendem às expectativas do autor. Com base "proto", que se realiza por meio do "mas", verificaremos a presença de pares mais complexos que envolvem experienciações de mundo que, acumuladas, adquirem outras experienciações, calcadas em combinações de itens lexicais, para atender especificidades, com relações mais abstratas: "não... mas sim"; "não que... porém”; é claro que... mas"; "não... mas"; "não... e sim"; "não... só que”; "nunca... mas sim".

Em relação às aditivas, os itens lexicais combinados nos pares assumiram também funções de aditivas comparativas e proporcionais. Inicialmente, para todos os casos, a base, que está no ato de adicionar, acaba fazendo com que haja um deslocamento funcional de acordo com as intenções do autor, que de adicionar passa também a comparar conteúdos de informações e também a equilibrar itens lexicais que, proporcionalmente, distribuem-se para colocar em foco duas porções informativas, a fim de dar mais consistência ao objeto tratado.

Interessante apontar que alguns pares correlatos aditivos remetem-se, dentro dos estágios que compõem os selves, àquilo que inicialmente está na base da mente humana, reúne imagens lincadas à realidade, ao que é mais concreto, denominado protoself. É por ele que as relações entre língua, a imagem, intenções e a própria realização concreta daquilo que pensamos se concretiza. Pares correlatos aditivos que envolvam relações menos complexas parecem ser advindos dessa fase do estágio da mente. 
Exemplos como pares: "mais... mais", "não... nem”, "não... não", "mas... também", entre outros, estão na base "proto" da língua, provavelmente, por isso, é que estão, na maioria, nos piores textos.

Entretanto, outros pares aditivos parecem sinalizar relações mais fincadas em conteúdos de materiais linguísticos que, além de auxiliarem à argumentação do autor, mostram que é pelo estágio da evolução do homem, é que ele consegue alavancar-se para outros estágios por meio de suas experienciações:

- Aditivos: "somente... mas também", "não só... mas principalmente", "além de... também", "não apenas... porém também”, "não só... mas sim";

• Aditivos comparativos: "não só... como também", "não só... como... e até", "não só... bem como", "não apenas... como também”;

- Aditivos proporcionais: "tanto... quanto".

Os pares consecutivos apresentam-se pela natureza fincada numa causa que, ligada à consequência, sinalizam algumas possibilidades de realização e combinação, a fim de estabelecer relações, cujos itens lexicais se comportam, de acordo com as necessidades do escrevente: "tão... que", "tanto... que", "de tal modo... que". Um dado que nos chamou atenção, durante nossa coleta, foram os itens "tão, tanto", que não só se comportam com a função de intensificador e quantificador, respectivamente, como denotam uma expressividade avaliação calcada na intenção do autor, por isso, serão analisados.

No tocante aos pares alternativos, a base prototípica instalada no item "ou", apresenta-se funcionalmente pela recombinação: "ou... ou”; "seja... seja”, "seja... seja... seja”, "quer... quer", “ora... ora”, "seja... quer seja”, "seja... ou”, "sejam... ou”, "seja... seja... ou", "quer... ou"; entre outros, que servem para que o leitor distribua alternativamente conteúdos informacionais a fim de avaliar, incluir, sustentar um posicionamento, que se converge a um objetivo específico: o de comunicar e, por isso, também farão parte das análises presentes nesta tese.

A coleta de dados cujos pares são comparativos deu-se a partir do comportamento funcional de cada um deles. Tendo como o protótipo baseado no par "mais... do que", que tem a função de comparar duas porções informativas, a respeito da ideia que se tem em comum e, a partir disso, estabelecer um elo; coletamos também 
outros pares que, além da função "proto" apresentada, desempenham outros papéis, para atender às expectativas do autor: "tão... quanto", "mais... que", "tão... como", "quanto mais... mais" (que, além de comparativo, também desempenhou função proporcional relação mais complexa), assim como: "só... só", "não só... como também” (de base aditiva, mas com função também comparativa), entre outros; como demonstram nossas análises.

No tocante às condicionais, os dados coletados revelarão mais do que uma simples condição apoiada numa hipótese, atrelada a um fato. Pares correlatos: "só ... se", "só ... quando", "se... é porque”, "se ... que”, "se não ... não", "se não ... também não", "de nada... senão", "não... senão", mostrarão indícios de que uma condicional poderá assumir ideia de causa, tempo, conclusão, consequência, de acordo com jogo estratégico assumido pelo autor. Para cada uma dessas ocorrências, haverá a análise de um trecho das redações, para provar essas funcionalidades.

Para as concessivas, os dados coletados revelarão de que forma o autor lança porções informativas em que há uma hipótese que parece servir de contraste à segunda porção informativa. Os concessivos "apesar de... ainda", "mesmo que... ainda", "não... ainda que", "ainda que... não", "ainda que... mister", "apesar de... já", farão parte de nossas análises, a fim de mostrar o comportamento de cada um deles, relacionado às intenções pragmático-discursivas, do autor.

As proporcionais, também como corpus para nossa análise, que tem como base a distribuição de informações entre as porções informacionais, mostraram-se funcionalmente eficientes. Haverá a coleta dos pares: "quanto mais... mais", "quanto maior... mais", "quanto maior ... maior", "quanto maior... maiores", "tantos... quantos", que foram encontrados nos trechos das redações, para mostrar que o autor, estrategicamente, enxerta as porções com material linguístico com diferentes propósitos.

Os dados: " de um lado... do outro", "o primeiro ... o segundo", encontrados nos trechos analisados, apesar de apresentar indícios de que existe uma correlação calcada numa contrastividade, parecem funcionar como um elemento que coloca em perspectiva 
as duas porções linguísticas, como se focassem "cenas de atenção conjunta"29 (Tomasello, 2003), por meio de ideias relacionadas e, por isso, não entraram no corpus de análise desta tese:

Conticas de traballu digladiavam- se de uny lado o contratante la Odesfuito de notbin mecenas) imfascimbana- se com a demova

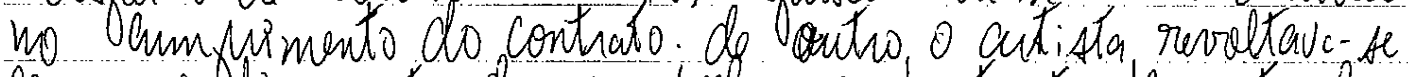
com o colli wamento da pua abra a estrito conceito de esecucas de uma taula...

(Exemplo16, Fuvest, 2006, p.82)

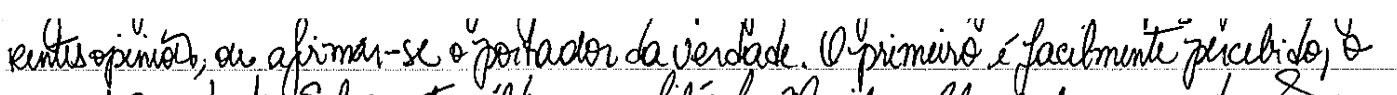
seundo 7em tanto. Sobre este viltimo, a filósopa Marilena Chau chama a atencao para

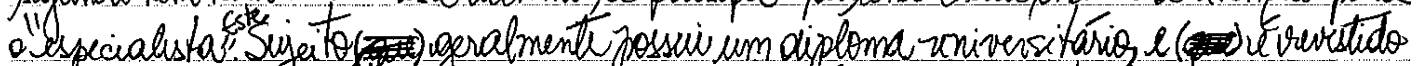

(Exemplo 17, Fuvest, 2008, p.19)

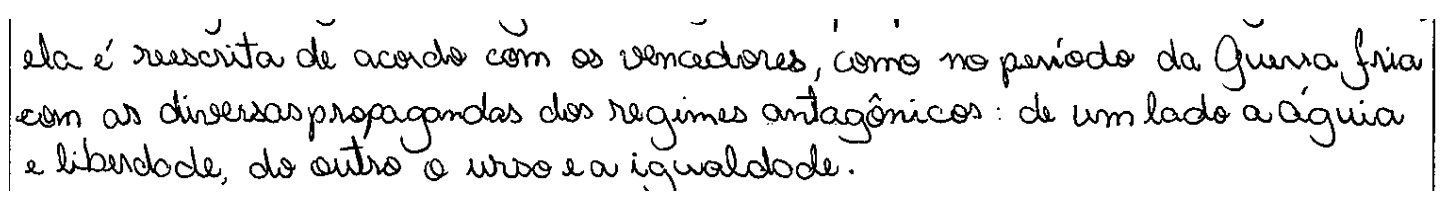

(Exemplo 18, Fuvest, 2010, p.5)

É importante salientar que a preocupação no que diz respeito ao tratamento que daremos aos dados, de um modo bastante particular e, às vezes, até reiterativo, se dá pelo fato de que entender os mecanismos subjacentes à língua e às intenções do falante, atrelados a ela, estão diretamente relacionados à funcionalidade movida pelo ato de comunicar.

\subsection{Complexidade e Formas de Apreensão}

Uma forma de lidar com a complexidade linguística é recorrer ao que organiza melhor o olhar do linguista e analista. São organizadores natos do trabalho linguístico

\footnotetext{
29 Segundo Tomasello (2003), as cenas de atenção conjunta se caracterizam pelas interações sociais entre os seres humanos, que prestam conjuntamente atenção a uma terceira coisa, e à atenção um do outro à terceira coisa, por um período razoável de tempo.
} 
os princípios. Dentre os princípios funcionalistas, alguns têm se revelado substantivo na análise de construções sintáticas, o princípio da iconicidade.

Esse princípio básico de codificação da língua remete a uma consolidação de forma-função idênticos ou, até onde podemos reconhecer, com mecanismos de identidade reconhecidos como motivados por funcionalistas. Só esse princípio, contudo, não nos dá a segurança necessária para lidar com um feixe de funções, dentre as quais a pragmática e a sintática, já complexas ao extremo.

Um segundo princípio é fundamental se aliado àquele. Trata-se do princípio de marcação, que permite reconhecer o efeito do uso em sua quantidade e percepção. Um último recurso que pode ser conjugado - e tem apresentado resultados importantes nas descrições - é o plano discursivo. Saber em que medida o falante desloca para fundo ou figura uma informação nos auxilia a identificar seus objetivos discursivo-pragmáticos.

Essas são razões suficientes para que aliemos iconicidade, marcação e planos discursivos. Desse modo, teremos condições de estabelecer alguns parâmetros, que juntamente com a análise do comportamento funcional de cada par correlativo por padrões, indicarão de que modo o falante/ escritor revela-se a si mesmo no texto, de forma proto ou mesmo de forma autobiográfica, altamente consciente. Portanto, mobilizando esses recursos, reuniremos resultados substanciais para lidar com o escrever consciente, ou seja, oferecemos ferramentas para lidar com a gramática e com a autonomia e autoria de um indivíduo que se apropria da gramática e do tema, via sociocultura. 


\section{CAPÍTULO 4 - EM BUSCA DE UMA ANÁLISE DISCURSIVO- PRAGMÁTICA ENTRE PARES CORRELATIVOS: UM PROCESSAMENTO COGNITIVO}

Este capítulo tem por objetivo apresentar os resultados qualitativos dos estudos dos pares correlativos encontrados nos textos considerados melhores pela banca avaliadora da FUVEST, entre os anos de 2004 a 2010. Cada conjunto de dados, organizado em torno de padrões, propiciará a elaboração de tabelas, o que facilitará a visualização da distribuição dos pares correlativos típicos. Não será foco de análise as piores redações de 2004 a 2010 cujos motivos estão explicitados e exemplificados ao final desse capítulo.

Um fato que chamou a atenção é que grande parte dos pares correlativos está concentrada na segunda parte do texto dissertativo, ou seja, no desenvolvimento, que apresenta a argumentação. É um indício de que o escrevente, na tentativa de ser convincente e de dar suporte ao posicionamento assumido, considera que os pares correlativos sejam instrumentos auxiliares eficientes.

Para demonstrar essa percepção, a cada padrão identificado, apresento os trechos correspondentes e a forma de sua distribuição em cada ano. Na sequência, reproduzo a forma adotada para a análise, empreendida a partir do comportamento linguístico de cada par correlativo, associado aos diferentes papéis semânticos que pode assumir. De outro modo, a descrição partirá da função discursivo-pragmática ${ }^{30}$ para delineação dos diferentes significados e da complexidade sintática ${ }^{31}$ envolvida na função.

\footnotetext{
30 Essa ideia reflete processamentos típicos da gramática se desenvolvendo. Então, o fato de identificarmos iconicidade entre a relevância da informação em contextos de correlação remete a processos de gramaticalização.

31 Essa ideia reflete processamentos típicos da gramática se desenvolvendo. Então, o fato de identificarmos efeitos de frequência em contextos de correlação remete a processos de gramaticalização.
} 


\subsection{Pares correlativos adversativos e suas funções pragmáticas}

O primeiro quadro apresentado é aquele constituído por pares correlativos que envolvem o valor semântico adversativo. Esse valor encerra a intenção de estabelecer uma "relação de desigualdade utilizada para a organização da informação e para a estruturação da argumentação" (Neves, 1999, p.757), ou seja, aponta "uma oposição existente num encadeamento seguinte de palavras, expressões relacionadas entre si" (Houaiss e Villar, 2001, p.94).

Percebe-se que a presença da correlação de base adversativa constrói um enfoque discursivo-pragmático que desloca a informação para um segundo plano de atenção, deixando para a interação em si o papel preponderante. $\mathrm{O}$ escrevente, dessa forma, sinaliza para o leitor (no caso, a banca avaliadora) que seu background o torna candidato preparado para argumentar. As informações que são correlacionadas correspondem, assim, às suas experiências, aos discursos com os quais teve contato, às ideias e imagens que conseguiu unir aos enunciados para atingir o leitor, de forma a estabelecer um elo comunicativo relevante. Observemos a distribuição desses dados nas redações analisadas:

\begin{tabular}{|c|c|c|c|c|c|c|c|c|}
\hline SEMANTICA & ESTRUT. & 2004 & & 2005 & & 2006 & & 2007 \\
\hline & $\mathrm{T}$ & nลิ ... mas & I & ¿claro quo... mas 1 & 1 & aibo...mas sim. & 2 & \\
\hline & & najo... mas apenas : & 1 & nว̀े mas & 1 & nio... mas & 3 & \\
\hline & & Eio... mas rim & & & & & & \\
\hline \multirow{10}{*}{ ADVERSATIVA } & D & nào max & 7 & nล̄o & 7 & man nim & 1 & a30. mas apenas \\
\hline & & nbe.. $\bullet$ itm & 1 & alo $(\mathrm{V}) \ldots$ somsets . mas i & 1 & alo... mas & 7 & กป้อ $\mathrm{mas}$ \\
\hline & & nio . mas apenas . & 1 & nì $\ldots$ e tim 2 & 2 & nào... mas vim & 2 & nào... mas im \\
\hline & & nio $\mathrm{man}, \mathrm{sim}$ : & 5 & & & nào . mas (apenai) & 1 & n⿳亠口冋... tim \\
\hline & & alo aptnai... mai ] & 1 & & & nào $\bullet$ tim & 5 & nล้อ.... $\operatorname{sim}$ \\
\hline & & & & & & claso que... mal & 1 & nîo $\max (\mathrm{TR})$ \\
\hline & c & nio . mas & 5 & nio... mas 4 & 4 & alo...mas sim & I & nabo... e, vim \\
\hline & & alo... mas tim : & & nàे qea portm [1. & 1 & nio... max & 1 & \\
\hline & & nào (V) a apenai . & & กมัก. ma nam 1 & 1 & & & \\
\hline & & nlo., $\lim$ & & & & & & \\
\hline ADVERS.ATTVA & T & & & & & & & \\
\hline \multirow[t]{2}{*}{ CONDICIONAL } & D & & & & & & & \\
\hline & c) & \& modo - wejentivo o... uncio - infinitivo o & & & & & & \\
\hline
\end{tabular}

Quadro 4: Pares correlativos adversativos 2004-2007 


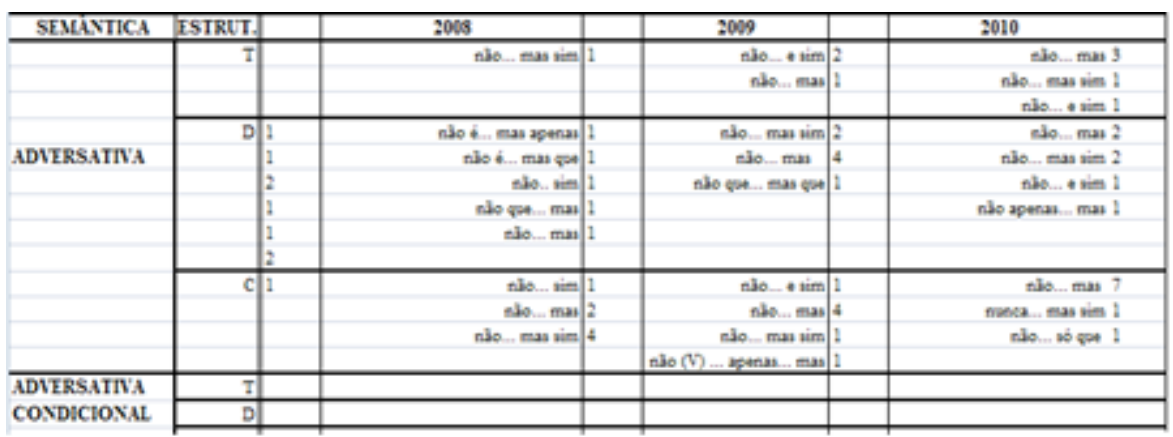

Quadro 5: Pares correlativos adversativos 2008-2010

Todos esses pares foram considerados adversativos por incluírem um elemento classicamente utilizado para construir contraste e oposições argumentativas em português: a conjunção coordenativa adversativa. Auxiliam a construção da correlação outros elementos que, comumente, aparecem em construções focalizadoras, tais como o verbo ser (em alguns casos, elidido, mas facilmente recuperável) e advérbios de inclusão. Os seguintes pares foram efetivamente empregados nas redações: não... mas, não... mas apenas, não é... mas apenas, não... mas sim, não que... porém, não que... mas, não é que... mas que, é claro que... mas.

A estratégia adotada nesses casos é aceitar ou concordar com a ideia supostamente compartilhada pelo interlocutor para, em seguida, oferecer uma justificativa. Sintaticamente, a elaboração é complexa ao extremo, pois é combinada uma ideia que se traduz no sentido de "não é apenas isso que você sabe" adicionada à exibição de uma informação considerada necessária à compreensão do argumento. Sendo assim, a natureza do padrão tem motivação pragmática e baseia-se na fórmula: Preservação da face (doravante PF) + Justificativa. Vejamos esses pares caso a caso.

\subsubsection{Não... mas}

O par encabeçado pelo item "não" seguido da palavra "mas" sinaliza uma justificativa em relação à desigualdade codificada no plano sintático (o peso morfofonológico da segunda informação é inquestionável) e no plano pragmático (não coincidem, sob o ponto de vista do escrevente, as informações conhecidas), estabelecida 
entre as porções informativas. Assim, verificamos haver uma "contraposição em direção oposta" tal como descreveu Neves (1999, p.757) para esses casos:

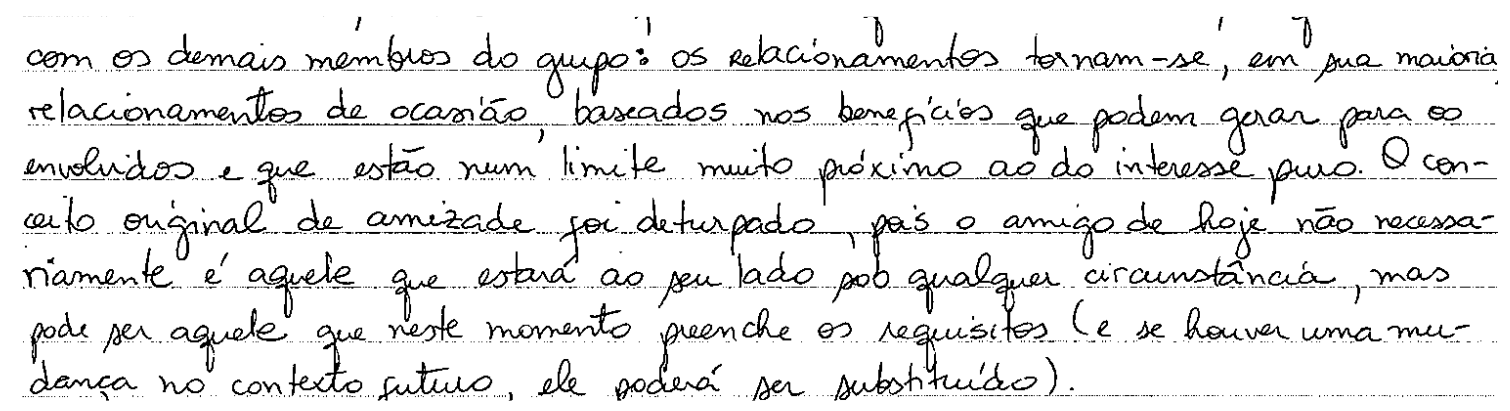

(Exemplo 19, Fuvest, 2007, p.53)

Nesse exemplo, é possível depreender que o escrevente tem, diante da banca examinadora intuída como leitor imediato, a necessidade de preservar sua face frente ao conceito que se faz sobre a amizade, pois ele deve assumir uma posição argumentativa, mas não pode 'ferir' outras concepções. Para isso, utiliza-se do circunstanciador "não necessariamente", a fim de demonstrar que percebe a existência de outras perspectivas. É como se saísse de cena para fazer um aparte, um comentário; e, a partir do $2^{\circ}$ elemento do par (mas), justificasse, explicasse, com a finalidade de não anular totalmente a informação do par anterior. Obedece, assim, a um ritual como uma "fachada social" (Goffman, 1967), isto é, a fim de obter aprovação do leitor faz uma negação não categórica, relativiza.

Chamo atenção para a utilização do verbo modal "poder" atrelado ao item “mas", com valor epistêmico (Neves, 2006). Na combinação desses usos em uma mesma construção, o escrevente produz o efeito de sentido ${ }^{32}$ de que crê naquilo que considera "o amigo de hoje". Outro fato que chama atenção é a negação numa posição hierarquicamente superior. Atuando no nível pragmático seu escopo é um item polar da $1^{\mathrm{a}}$ porção.

\footnotetext{
32 Essa ideia reflete processamentos típicos da gramática se desenvolvendo. Então, o fato de identificarmos expressões novas em contextos de correlação remete a processos de gramaticalização.
} 


\subsubsection{Não... mas apenas \\ Não é (focalizador) ... mas apenas}

Os itens que encabeçam os pares agrupados nesse conjunto incluem a correlação de duas informações: a primeira, encabeçada por "não... mas apenas" ou "não é... mas apenas" para sinalizar que uma focalização está em processamento. No caso específíco do segundo par correlativo, verifica-se um contraste adversativo com focalizador duplo (apenas):

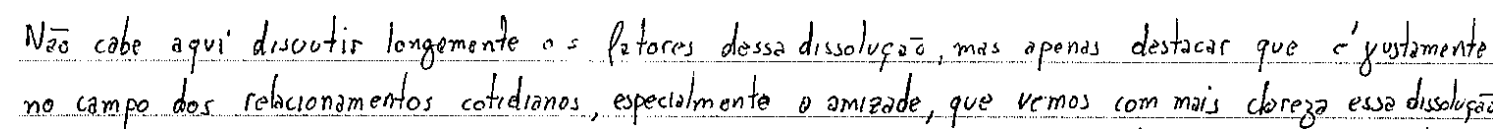

(Exemplo 20, Fuvest, 2007, p.7)

Trata-se de uma construção que chama a atenção pela mobilização do marcador de polaridade negativa "não", seguido do verbo "caber", que, segundo Bechara (2009), significa ser oportuno, conveniente. Pela ordenação dos itens lexicais, percebe-se novamente a PF intencionada pelo autor ao se recusar a discutir os fatores que levam à dissolução de uma amizade, no $1^{\circ}$ par, pois acredita não ser propício fazê-lo e, dessa forma, emprega o verbo “caber”. Estrategicamente, lança no $2^{\circ}$ elemento do par um focalizador (apenas) para guiar a atenção do leitor para, no universo daquilo que considera o sentido "relacionamento", a amizade seria um exemplo apropriado para explicá-lo. O item "apenas" tem uma função focalizadora no interior de um enunciado explicativo.

O que se tem no par encabeçado por "não é... mas apenas", além dos traços de polaridade negativa, o que torna a construção mais complexa, é a combinação com um marcador adversativo, com duplo focalizador:

te a internet más i privilegiada que tange a palta de compromino com a levodede, mas apenas

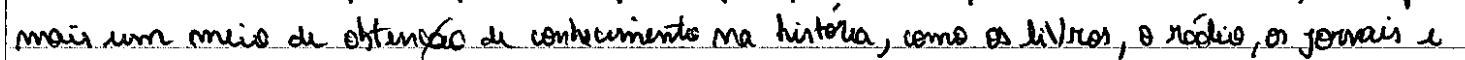
a thleluñar, todor acomitidos pelas unsuras e ide ais policialesos.

(Exemplo 21, Fuvest, 2008, p.12) 
Sendo assim, o jogo argumentativo consiste em, primeiramente, se lançar uma polaridade negativa seguida de um verbo qualificador que tem como objetivo focalizar, ou seja, guiar a atenção do leitor para aquilo que, apesar de parecer ser um fato conhecido pela sociedade, não é o considerado como verdadeiro para o escrevente. Por isso, lança, no $2^{\circ}$ elemento do par, um item focalizador (apenas), seguido de um item adversativo, a fim de evidenciar qual é, de fato, o verdadeiro papel da internet.

Como recurso estratégico, os dois focalizadores têm intenções diferentes: no $1^{\circ}$ item do par, visa-se à preservação da face, evitando, assim, criticar o papel da internet e elaborá-la como se fosse apenas um comentário a respeito do que outros indivíduos (ou o senso comum) poderiam avaliar; o $2^{\circ}$ elemento do par, permite direcionar o leitor para o fato de que, apesar de veicular notícias falsas, a internet, dentre outros meios, é um canal de informação cujo objetivo é o de publicar notícias; é mais um recurso disponível para os leitores. O focalizador "apenas" parece minimizar a responsabilidade da internet em ter de veicular somente notícias verdadeiras; ela é, assim como outros, um instrumento que disponibiliza conteúdos para consulta, mas que, segundo o autor, são policiadas, cerceadas.

\subsubsection{Não... mas sim}

Os pares correlativos "não... mas sim", apesar também de configurarem-se igualmente como um recurso de PF, comportam-se de maneira diferente:

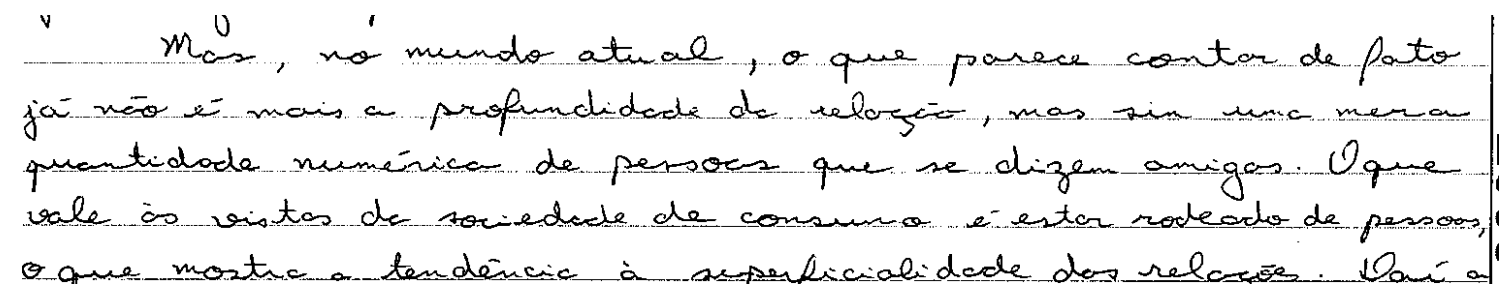

(Exemplo 22,Fuvest, 2007, p.59) 
No $1^{\circ}$ elemento par de cada um do trecho mostrado, uma avaliação é apresentada como forma estratégica de não quebrar a expectativa do leitor, por isso a escolha do conteúdo é feita de modo a satisfazer os anseios da banca examinadora; isto é, o autor se utiliza de recursos tanto linguísticos como pragmático-discursivos, intencionalmente, a fim de parecer modalizar os argumentos por ele apresentados, para não impactar ou contrariar o que espera o leitor.

O segundo elemento do par correlativo, encabeçado por um polarizador de negação, seguido de uma adversativa com focalizador "sim", funciona como um operador de argumento que reitera, de forma incisiva, a ideia polarizada. Seria possível suprimir, sem nenhum prejuízo semântico, o item "sim”, mas os prejuízos discursivopragmáticos seriam dramáticos. $\mathrm{O}$ fato de haver uma reafirmação categórica da ideia desloca o interlocutor para uma posição delicada e desconfortável em que duas respostas serão plausíveis: (i) o confronto, com drásticos efeitos para a avaliação do escrevente; (ii) a concordância, com efeitos positivos para a avaliação. Na maioria das vezes, o posicionamento argumentativo, ou seja, a manifestação de um ponto de vista, é valorizado por bancas avaliadoras de redação dissertativa. Invariavelmente, demonstra maior maturidade inclusive no domínio do tipo de texto, pois convida o leitor à reflexão. Logo, para o escrevente, o conteúdo introduzido pelo $2^{\circ}$ elemento do par, nos dois trechos, serve como uma justificativa para o que se asseverou com o $1^{\circ}$ elemento do par, a fim de se fazer mais convincente.

Corroboram essa análise o trecho apresentado. Verifica-se uma restrição que pode significar uma exclusão parcial, tal como demonstrado por Neves. Esses itens são os chamados "circunstantes limitadores" (Neves, 1999, p.761), porque, ao nos atermos às informações inseridas em cada um dos pares, verifico que, para o autor, apesar de existir a amizade, os elos que a constituem, a relação instada entre as pessoas mudou. Parece fazer um movimento cuja dinâmica está em comparar o passado com o presente para mostrar o comportamento do mundo contemporâneo: até existe a profundidade da relação, mas não é como antes. Com isso, ele não generaliza, restringe, limita o conceito sobre o relacionamento humano, na sociedade. Ao que parece, o escrevente não generaliza, justamente para garantir o espaço do interlocutor à reflexão diversa. Dessa forma, preservando a face (PF) argumentativa, alcança o objetivo de ser convincente. 


\subsubsection{Não que... porém}

\section{Não que... mas}

\section{Não é que... mas que}

A primeira parte do par encabeçado pelo item "não" seguido de "que" ou "é que" representa uma possibilidade da existência de alternativas que não se anulam ${ }^{33}$. Vejamos como esses usos se consubstanciam nas produções escritas que demandam alto grau de atenção do interlocutor, sem minimizar a relevância informativa. Três são os padrões identificados:

- Não que... porém

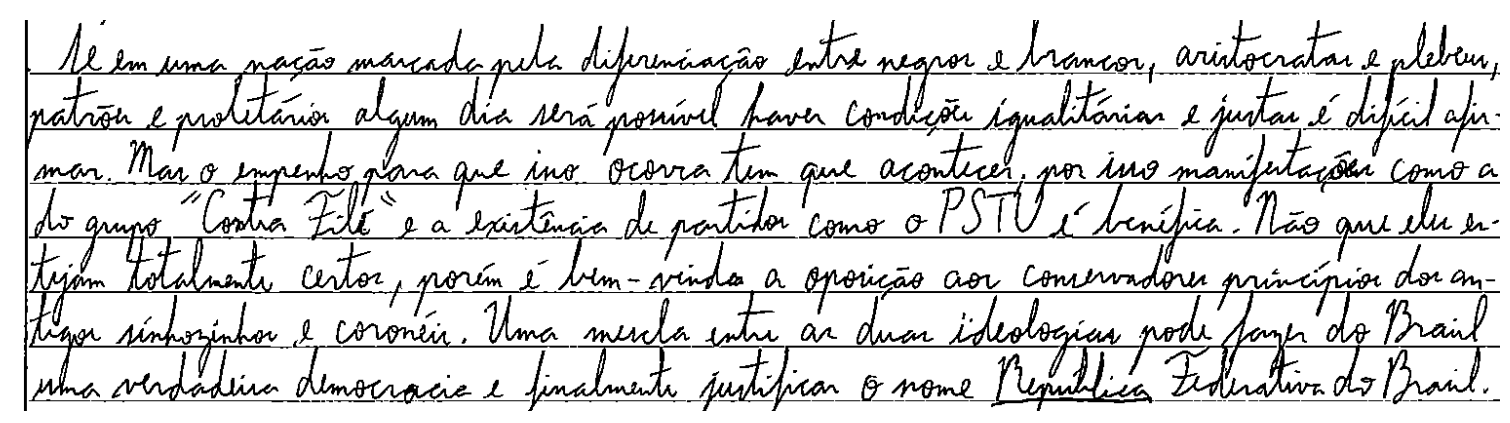

(Exemplo 23,Fuvest, 2005, p.6)

- não que... mas

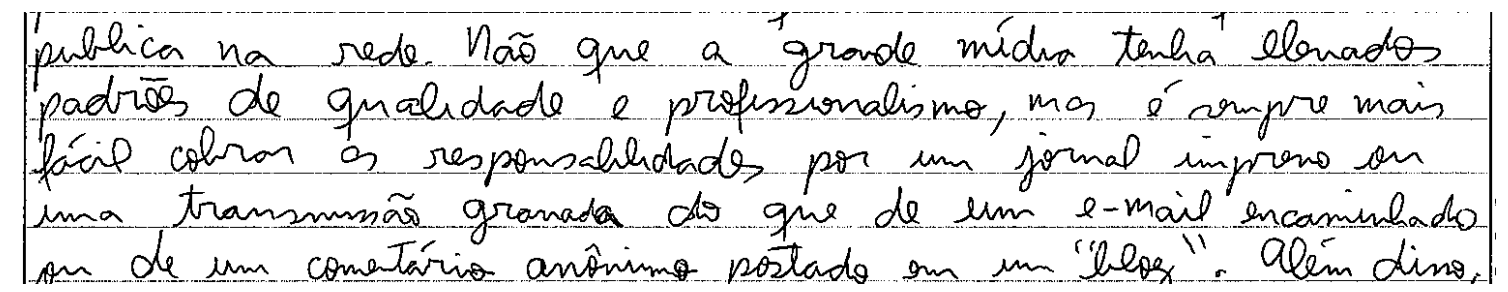

(Exemplo 24,Fuvest, 2008, p.51)

\footnotetext{
33 Para Neves (1999), o item "não" seguido de "que" (não que/ não é que) representa uma negação exclusivorestritiva (p.762) a qual aponta que o mais importante não é aquilo assegurado no enunciado, mas na existência de alternativas.
} 
- não (V) que... mas que

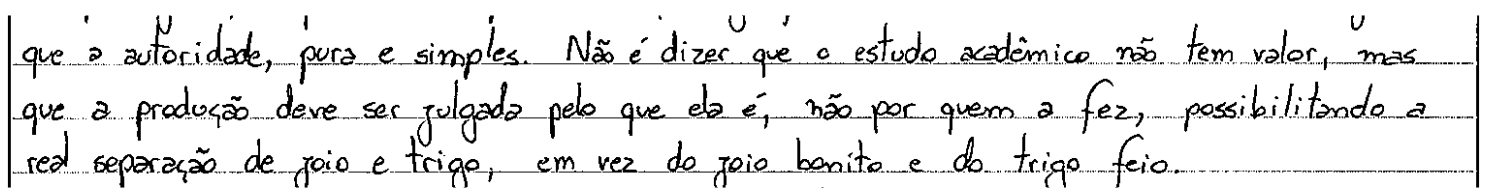

No caso dos pares apresentados, a estratégia utilizada pelo escrevente é a de que os conteúdos distribuídos entre os enunciados não são nulitivos. Um implica o outro, um contém o outro, tal como num recurso metonímico: um recurso estratégico discursivo com a preocupação quanto ao posicionamento argumentativo, demonstrado pelo efeito de PF junto ao $1^{\circ}$ elemento do par. Dessa forma, o "foco da negação"34 contribui não somente para enfatizar o marcador correlativo, mas ainda para chamar a atenção para uma avaliação (Neves, 1999). O segundo elemento do par correlativo soa como um recurso introdutório de opinião do escrevente, que se preocupa com sua imagem perante o examinador que lerá sua prova.

Outro aspecto relevante observado na combinação desses pares é, ainda em conformidade com a descrição de Neves $(1999)^{35}$, que, por ser um tipo de negação mais marcado, o verbo assume o modo subjuntivo, para produzir o efeito hipotético. Esse efeito permite ao escrevente preservar sua face (PF), pois não garante a verdade factual do que argumenta.

\footnotetext{
34 Neves (1999, p.331) aponta que "o foco da negação" representa uma porção de enunciados determinados pela interação, sendo que sua interpretação é guiada também pela entoação, que tem o papel de guiar, estabelecer uma base para a avaliação da informação registrada.

35 Para a autora, pares correlativos encabeçados por "não (V)... que" sinalizam que, de algum modo, colocam "alguma outra coisa no lugar daquilo que foi negado" (Neves, 1999, p.298).
} 


\subsection{5 É claro que... mas}

Com o emprego de um item altamente assertivo, tal como ocorre com a construção "é claro", o escrevente introduz a informação compartilhada, de modo a construir um espaço conjunto de atenção com seu leitor. Ao mesmo tempo, garante baixa exposição, é polido, antes que contribua com uma informação nova. Sendo assim, por meio de $1^{\circ}$ elemento do par, revela um grau de certeza, do ponto de vista comunicativo-pragmático:

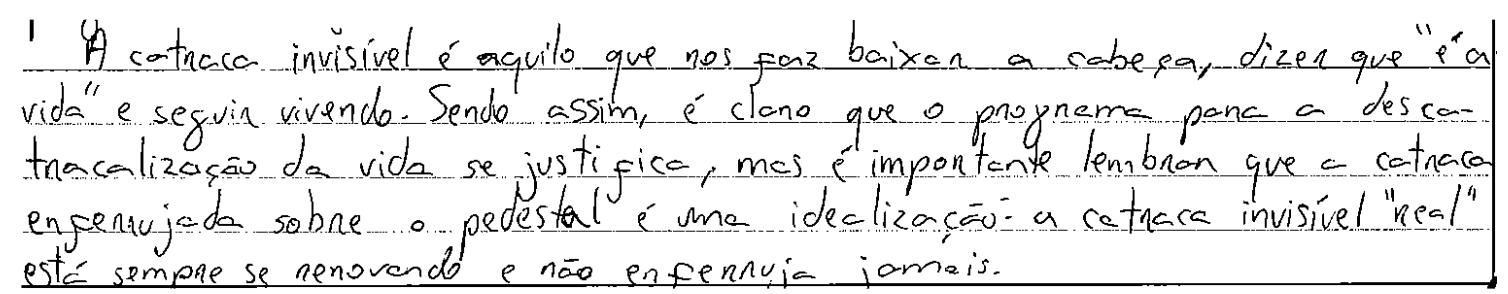

(Exemplo 26,Fuvest, 2005, p.1)

Na segunda parte do par, vem uma informação que se encontra funcionalmente ligada à modalidade deôntica. Desse modo, se na primeira parte da construção correlativa, há todo o cuidado para lidar com a informação conhecida (tema), com a polidez e o cuidado na construção de um espaço de interação apropriado, na segunda porção informativa, a construção deôntica não prototípica traz a sugestão, o conselho, a indicação da condição necessária para a que a validade da primeira porção informativa seja consubstanciada. A segunda porção, em suma, está ligada ao modo de dizer, às crenças e aos valores embutidos de partida na subjetividade.

É essa subjetividade transmitida a que Neves se refere ao descrever a modalidade deôntica como ligada a uma "moralidade interna ditada pela consciência" (Neves, 2006, p.174). A junção de pressuposto + modalidade deôntica conduz o escrevente a manifestar o que considera politicamente correto.

No trecho analisado, verifica-se que o escrevente apresenta, logo na cabeça da segunda informação correlacionada ao $2^{\circ}$ segundo elemento do par correlativo, itens lexicais que, ordenadamente, contribuem com o seu objetivo: é (verbo ser funcionando como focalizador), importante (qualificador ligado ao termo "programa para 
descatralizar"), lembrar (verbo de valor mental, cujo significado está ligado à obrigação moral). Esses elementos acompanham a informação central (catraca enferrujada sobre o pedestal), que relaciona temática e metaforicamente a situação de superioridade (Houaiss e Villar, 2001, p.2500). Nesse encadeamento sintático, o item enferrujada (qualificador de catraca) sinaliza metaforicamente a ideia daquilo que não se renova, ressignifica, carregada de preconceito; assim, deve ser considerada sobre o pedestal:

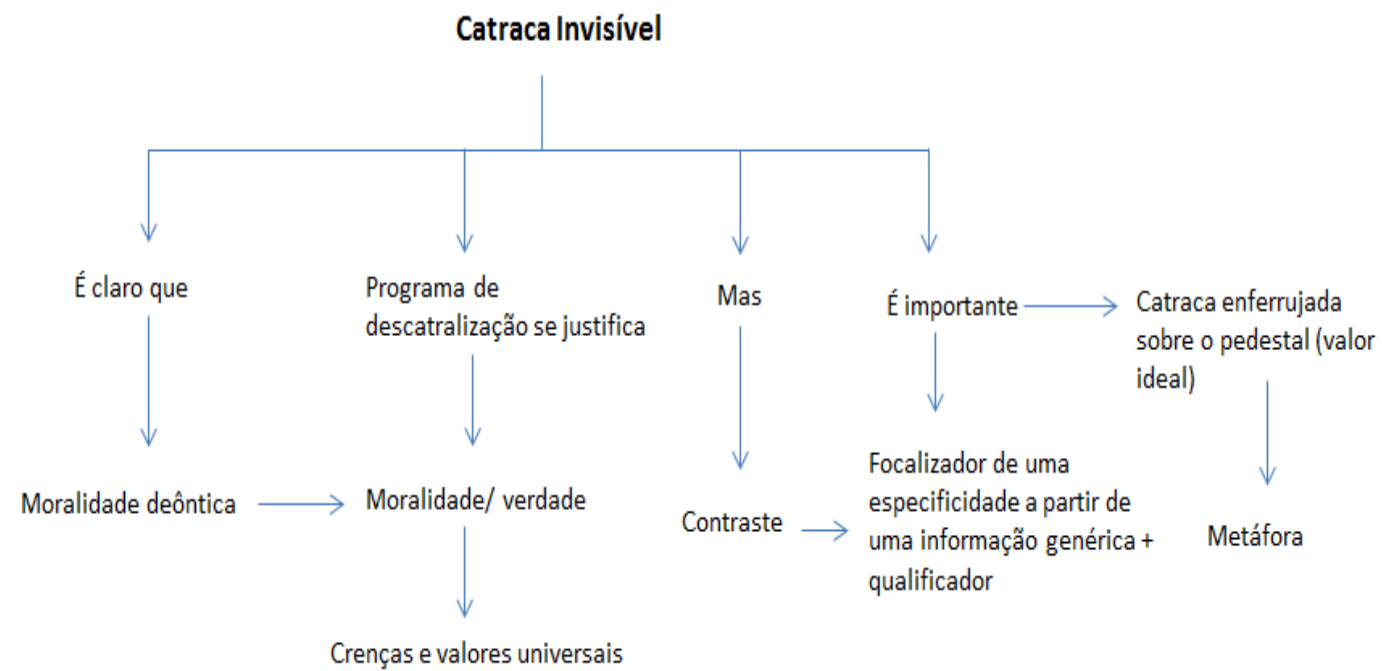

Esquema 12. Esquema interpretativo "é claro que... mas"

\subsubsection{Não... mas}

Esse par traduz o contraste entre ideias associada à polaridade nulitiva.

Os pares encabeçados pela negação e correlacionados a uma palavra de contraste, tal como ocorre com o par correlativo "não... mas", apresentam como característica comum a contraposição das ideias em que o $2^{\circ}$ elemento do par elimina o $1^{\mathrm{o}}$ elemento e toda a informação a ele vinculada. Dessa forma, emprega o recurso 
argumentativo por meio do qual o escrevente deixa sua marca opinativa de um modo mais incisivo. É assim que, eliminando uma das ideias apresentadas, projeta como maior relevância a segunda, construída a partir do repertório discursivo-pragmático do escrevente. A estratégia é altamente elaborada e faz confluir com os outros argumentos apresentados, tornando seu argumento mais estratégico e altamente persuasivo. Ao par da negação explícita, vem expresso um evento que é porção mais relevante. O emprego do item contrastivo "mas" indica que a distribuição das unidades de informação detém uma hierarquia que está a serviço da argumentação.

Outro aspecto verificado nas ocorrências desse par é que, ao optar por lançar determinada informação, o autor, com intenção de persuadir, lança mão do tema, que determina e foca o assunto tratado. Com esse ponto de partida, identifica para o leitor sua contribuição (rema) ${ }^{36}$. É assim que, conforme argumentam Gómez-González (2001, p.97-98), será possível apresentar as cinco tarefas funcionais principais para que haja o tema: a) promover um quadro de referência (framework) para interpretação do rema; b) acrescentar informação necessária para a interpretação da mensagem; c) ajudar (atuando negativamente) a construir a proeminência discursiva de itens (posicionar um item tardiamente em uma oração confere a ele o status da informação); d) contribuir para a continuidade ou descontinuidade do tópico discursivo, seja desenvolvendo, seja cancelando um pressuposto que foi estabelecido no contexto prévio; e) atuar como um orientador para a mensagem veiculada pela oração e para as expectativas do destinatário sobre compreender o que está por vir.

Nos trechos apresentados a seguir, o escrevente, ao negar e anular a informação a respeito do tema apresentado, redireciona a atenção do leitor para o $2^{\circ}$ elemento do par, focando naquilo que acredita ser necessário a respeito do tema, o rema. Nesse jogo processual, parece que, ao anular a informação postulada no $1^{\circ}$ elemento do par, um fato desaparece, pois não se incorpora à porção relevante daquilo que seria tratado a respeito do tema (o rema):

\footnotetext{
${ }^{36}$ Lembramos que a distribuição informativa entre tema e rema refere-se à terminologia postulada pelos linguistas da Escola de Praga, a qual foi desenvolvida por vários linguistas, dentre os quais Halliday (1976, 1985, 2004), parte da visão da oração como uma mensagem organizada em duas partes de distintos estatutos: uma parte ao tema, o que serve como ponto de partida da mensagem, localiza e orienta a oração em seu contexto; a outra parte, que desenvolve o tema, é o rema.
} 


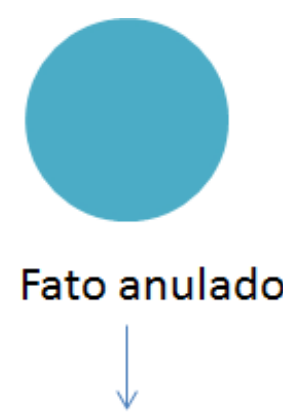

não

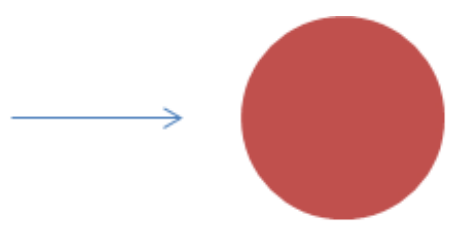

Fato novo

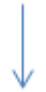

mas

Figura 13. Processamento contrastivo nulítico

Torna-se importante salientar que não necessariamente o tema precisa ser anulado para que exista o rema. É que, especificamente nesses dados apresentados, a anulação foi uma estratégia argumentativa usada pelo autor da redação, em que preserva a temática, mas muda o enfoque. De outro modo, podemos afirmar que a primeira informação é fundo (i.e., espaço de atenção conjunta) e a segunda, é figura (que faz a dinamicidade do texto e contribuição mais ativa do escrevente).

Consideremos os seguintes trechos, extraídos do conjunto de redações sob análise:

$\underline{1^{\circ} \text { trecho }}$

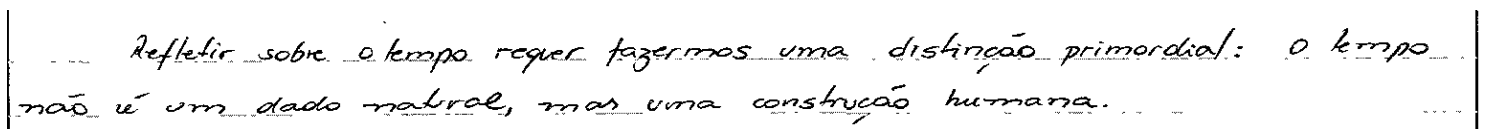

(Exemplo 27,Fuvest, 2004, p.2)

Estrategicamente, o candidato lançou mão do recurso da polaridade anulativa para focar, no rema, o conceito que faz a respeito do tema, representado pelo conceito de tempo. Curiosamente, faz isso na tese, porque sabe que essa estratégia o auxiliará na apresentação e na explanação da temática que lhe foi apresentada: 


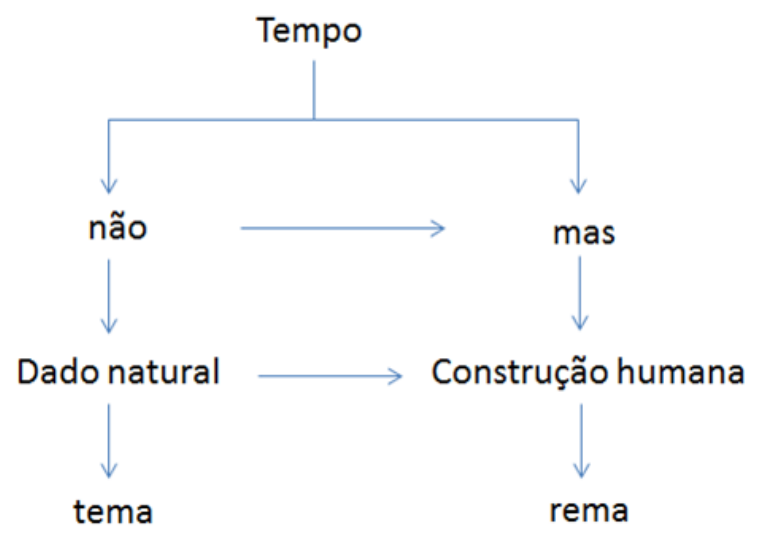

Esquema 13. Articulação tema-rema correlação nulitiva

\section{$\underline{2^{\circ} \text { trecho }}$}

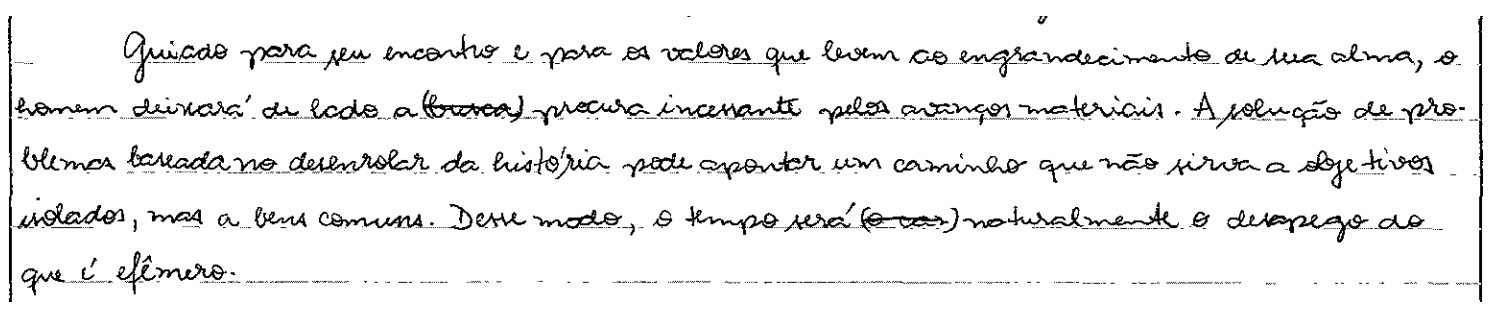

(Exemplo 28, Fuvest, 2004, p.13)

Nesse segundo caso, o candidato à Fuvest optou por anular a $1^{\mathrm{a}}$ informação do par "objetos isolados" e colocar destaque no $2^{\circ}$ segundo momento informativo "ao bem comum", porque acredita ser "o bem comum" ligado a uma prática que engrandece a alma; isto é, dá proeminência informativa à $2^{\mathrm{a}}$ informação apresentada. Demonstra, assim, que o segundo argumento, contribuição oriunda de seu repertório, detém maior valor informativo que a primeira. Vejamos a representação disso: 


\section{Tempo: engrandecimento das almas}

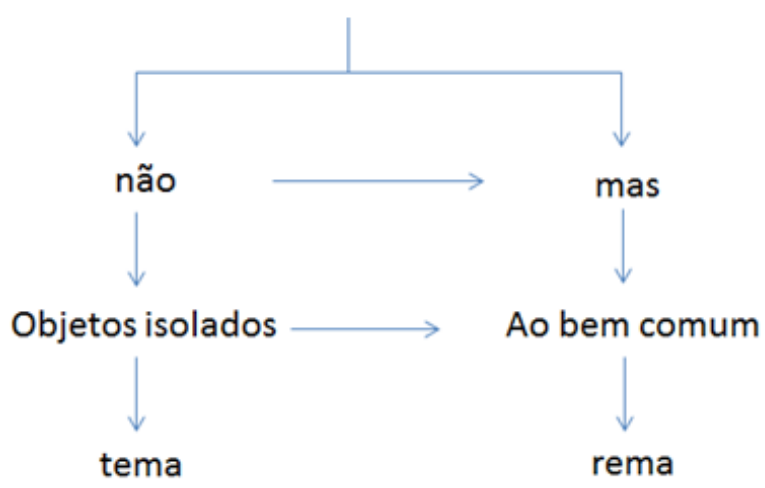

Esquema 14. Articulação tema-rema correlação nulitiva

\section{$\underline{3^{\circ} \text { trecho }}$}

- A amizade é vital pora que e ser humano nă cara na nais abjoluta solidaio. Swa impertancia é refletida nas mais diversas situacäs : o jovem que procura o amigo para falar solve sexo, o amigo desiludedo que procura no outwo um ombro para se sutentar, $\theta$ confessor que busca num padre nà umalgog, mas um "aurido anigo" e tontos outros em inumeras situacais. Qla também é resoonável sela formacão e sela

(Exemplo 29,Fuvest, 2007, p.27)

Nesse terceiro trecho, presente no desenvolvimento, a figura do padre, representada pelo primeiro conjunto de informação, se configura como aquele que condena, julga, parece ligado ao pecado. No rema, o candidato se aproxima metaforicamente da ideia de padre e de seu atributo de ouvido amigo, pois essa estratégia lhe permite exemplificar o conceito de amizade. Atente-se para a negação construída num nível hierarquicamente mais baixo. Como demonstrei no capítulo sobre processos correlativos, essa configuração produz uma avaliação. A imagem do padre algoz é anulada em detrimento da de um padre amigo, que se sobrepõe à primeira: 


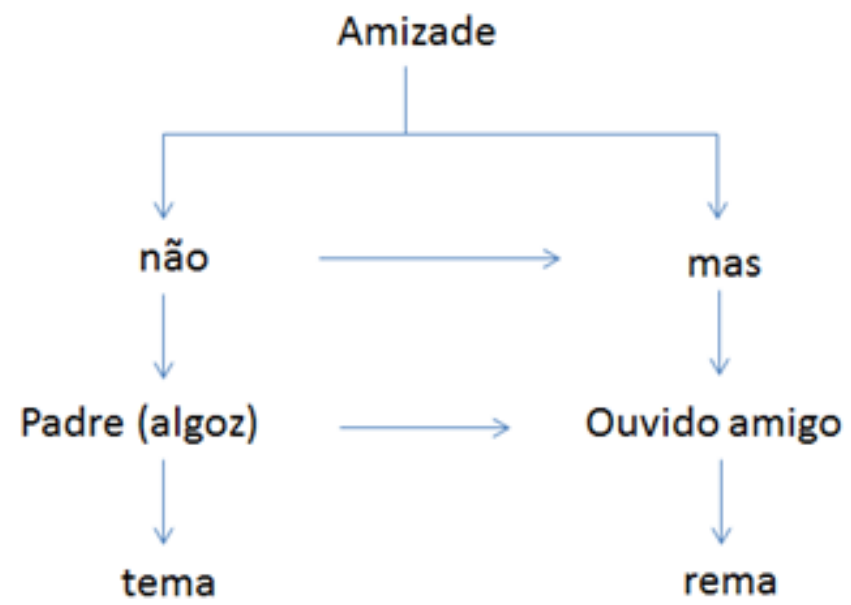

Esquema 15. Articulação tema-rema correlação nulitiva

\section{$\underline{4^{\circ} \text { trecho }}$}

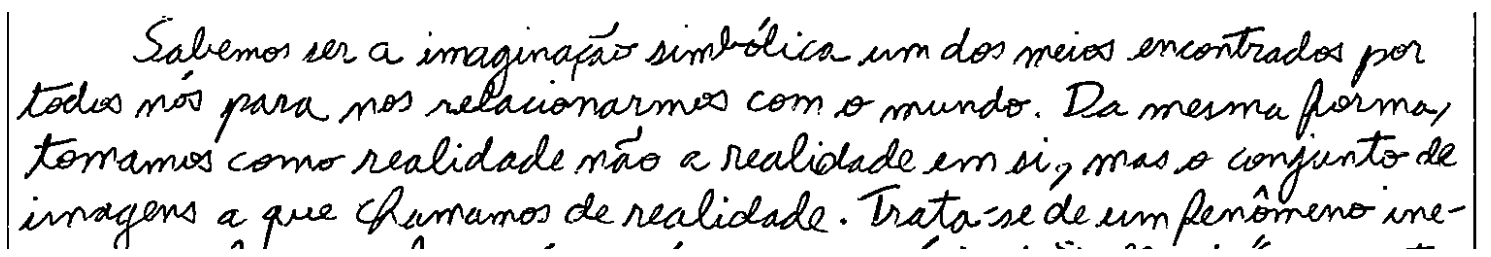

(Exemplo 30,Fuvest, 2010, p.20)

Considerando o quarto trecho, nota-se que o candidato, ao apresentar, na tese, a relação entre a realidade e suas representações simbólicas foca no rema. Isso se dá por meio de um conjunto de imagens que remetem à realidade. O que quer dizer que há uma nulidade do item "realidade" no tema, para alavancar, no rema, o que é de fato, a realidade: um conjunto de imagens que fazemos dela. Vejamos a representação da distribuição informacional: 


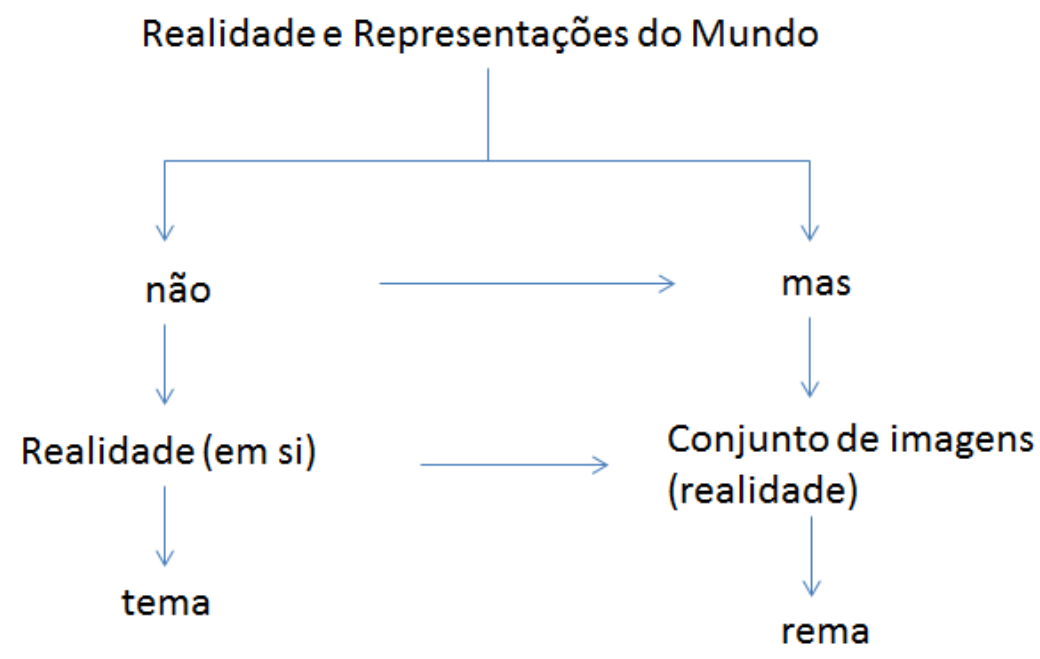

Esquema 16. Articulação tema-rema correlação nulitiva

\subsubsection{Não... e sim}

Esse par produz contraste entre ideias que se seguem, por meio da polaridade negativa. Com essa estratégia, anula-se uma informação e focaliza-se outra, de proeminência prosódica.

Esse é um tipo de correlação que apresenta o contraste das ideias também calcado na nulidade do primeiro trecho informativo ${ }^{37}$. No entanto, um elemento pragmático está presente na segunda porção correlacionada: o item "sim", que funciona como focalizador, cuja marca se dá numa relação de desigualdade entre o segmento que ocorre nos enunciados. Funciona, dessa forma, como um elemento que anula explicitamente a informação anterior e redireciona a atenção do interlocutor por meio do foco proeminente prosódico "sim” (Dik, 1997).

37 Essa ideia reflete processamentos típicos da gramática se desenvolvendo. Então, o fato de identificarmos
estruturação linguística ressignificada em contextos de correlação remete a processos de gramaticalização. 
A informação instalada pelo focalizador "sim" se dá de maneira tão convincente e verdadeira que qualquer substituição feita com o uso do $1^{\circ}$ elemento do par não mudaria o relevo da informação seguida ao $2^{\circ}$ elemento, devido à presença do focalizador. Vejamos o exemplo seguinte:

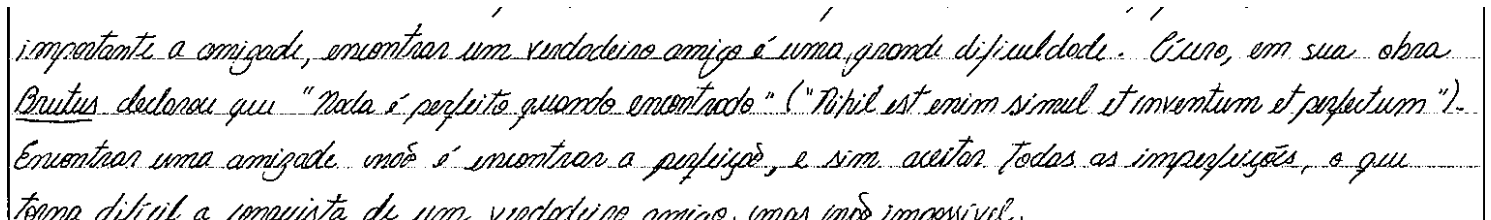

Adicionalmente, percebe-se que o focalizador “sim”, que está presente no rema, consolida-se como uma estratégia utilizada pelo autor para guardar a informação nova para o $2^{\circ}$ elemento do par:

A resposta a essas indagagoes parece estar embectida nas proprias perguntas. Nó temos uma relagáo de caura e effito epsim, uma sincronicidade complexa de interfếncias: a coisi ficagâo do homem leva a um esgancamento das relaćós, ao mesmo tempo eu que essa fra giliza çá da la cos reforca nossa reificagás.

(Exemplo 32,Fuvest, 2007, p.1)

Verifica-se que a quantidade de material linguístico, inserida no $2^{\circ}$ elemento do par, é superior ao $1^{\circ}$ par. Há, inclusive, uma discussão do autor da redação frente às relações do homem e seu tempo. A focalização, por meio do item "sim", opera como um recurso argumentativo prosódico que anula as informações presentes no $1^{\circ}$ par e se destaca no rema por meio de mais material linguístico. Parece, assim, que é na e pela entoação do item "sim" que o autor demonstra maior convicção sobre o que argumenta.

\subsubsection{Não... mas apenas}

Não... só que 
Esse par provoca o contraste de ideias com polaridade não-nulitiva com foco no restritor.

\section{- não... mas apenas}

O par constituinte "não... mas apenas" apresenta o item "não" ligado ao item contrastivo "mas". Essa correlação contrastiva, apesar de contribuir para que as ideias se contraponham, uma não anula a outra; ao contrário, uma está imbricada na outra. No $2^{\circ}$ elemento do par, o item "apenas" funciona como escopo caracterizado na informação ${ }^{38}$, pois dá relevo à $2^{\mathrm{a}}$ informação do par correlativo:

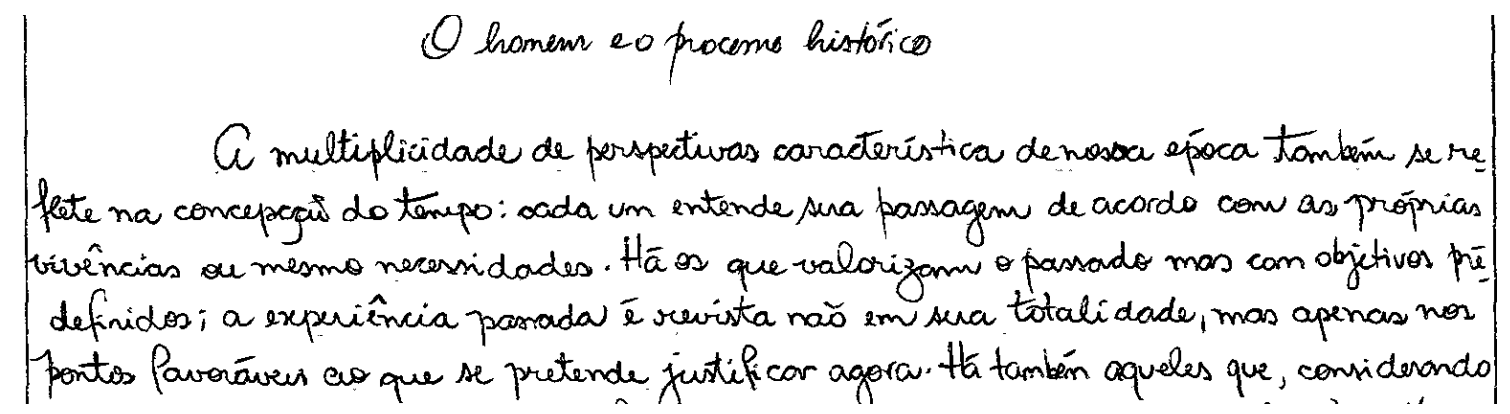

(Exemplo 33,Fuvest, 2004, p.22)

O escrevente da redação, no trecho, afirma que as pessoas valorizam o passado a partir de experiências bem definidas, focadas não na sua totalidade, mas apenas em alguns aspectos que contribuam para que se entenda o presente Com isso, produz o sentido de contraponto argumentativo. No entanto, o focalizador "apenas" oferece o relevo necessário para a expressão "pontos favoráveis", com o objetivo de evidenciar que, quando resgatamos o passado por meio de nossas experiências, somente nos atemos ao que parece ter servido de base, a fim de que entendamos o momento "presente"

38 Segundo Dik (1997), o item “apenas” funciona como escopo da informação, entendido como foco de restrição. 
O focalizador "apenas" funciona, dessa forma, como restritor, que aparece no fato específico, justamente para contribuir para a não-nulidade do fato anterior, serve como elemento que redireciona o olhar do leitor para a informação.

- não... só que ${ }^{39}$

A polaridade, assim como nos pares anteriores, auxilia na construção do contraste entre duas ideias. $\mathrm{O} 2^{\circ}$ elemento do par focaliza, também, um fato específico ligado a ele, enquanto a locução conectora "só que" desempenha valor semântico idêntico ao do conector mais geral (mas). Essa ideia já se encontra validada por Bechara (2009) e é referendada por Houaiss e Villar (2001):

saberia do que se tratta. Por isfo a imagem por si só hà cansa efeito no indisteduo e na sociedade, só que, via de regra, as imagens estäo carregadas de valores pré-
estubelecidos sorialmente.

(Exemplo 34,Fuvest, 2010, p.75)

Há um jogo discursivo pragmático por meio do qual o $1^{\circ}$ elemento do par (não) detém polaridade negativa e o focalizador (só que) chama a atenção do leitor, de modo a construir um espaço de atenção conjunta:

39 Segundo o professor Rosário, o $2^{\text {o }}$ elemento do par não constitui correlação. No entanto, decidimos por encará-lo nesse padrão porque detém os mesmos traços dos pares adversativos, apesar do curso entonacional. 


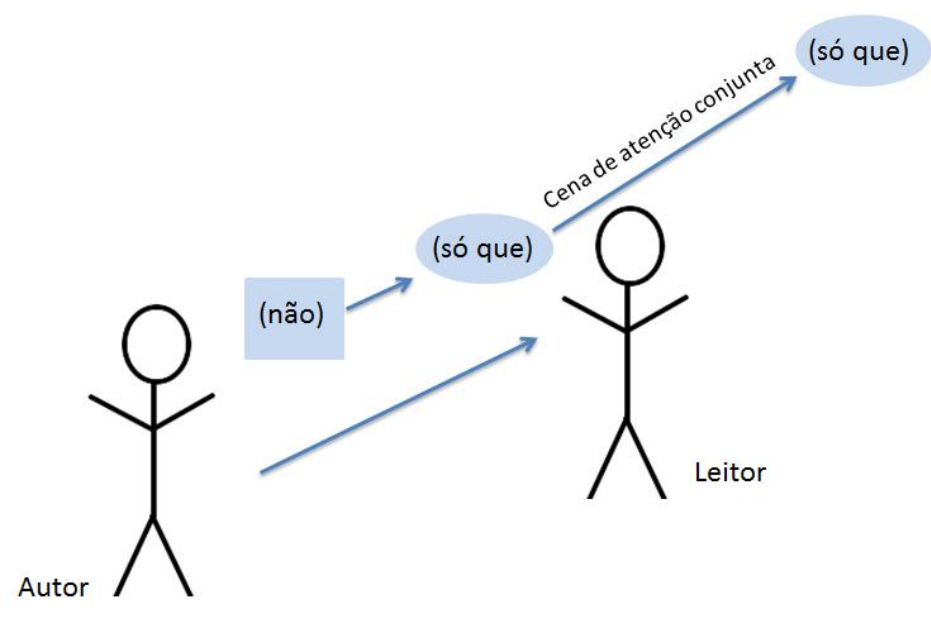

Figura 14. Cena de atenção conjunta. (Tomasello, 2003, adaptado)

A figura anterior representa aquilo que Tomasello (2003, p. 140) denomina de "cena de atenção conjunta", constituída por uma série de subconjuntos de elementos, com a finalidade de que haja um entendimento mútuo, aqui no caso entre o autor e o leitor. Para demonstrar a atenção conjunta, utilizamos algumas figuras. O quadrado e o círculo significam uma combinação de itens (subconjunto de elementos) ligada ao enunciado: (não) triângulo, (só que) círculo. A intenção de focalizar permite a utilização da estratégia de dar relevo para que a cena de atenção conjunta se projete nesse par correlativo. O que vale para o autor não é o $1^{\circ}$ elemento do par, mas o $2^{\circ}$, que funciona como um operador argumentativo de realce.

O gráfico abaixo demonstra a dinâmica instada, por meio desses pares: a $2^{\text {a }}$ porção informativa está intrinsecamente ligada à primeira, não há uma nulidade total. $\mathrm{O}$ primeiro par parece não generalizar a informação, para alavancar no $2^{\circ}$ par, aquilo que, de fato, se quer, por meio do focalizador, o de particularizar:

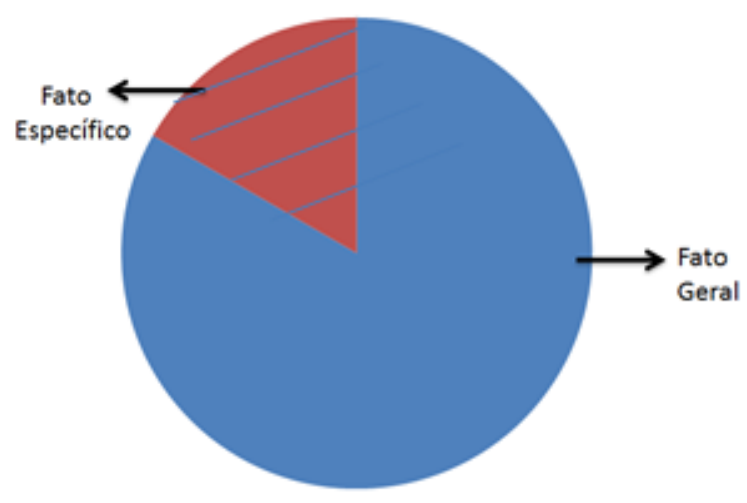




\subsubsection{Nunca... mas sim}

Esse par produz contraste entre ideias sequenciadas por meio do emprego de circunstanciador "nunca" seguido de elemento adversativo + focalizador "sim".

O par constituinte "nunca...mas sim" apresenta como característica o circunstanciador "nunca" denominado fórico ${ }^{40}$ (Neves, 1999, p.258), ligado próximo do momento da enunciação, ligado ao enunciador, seguido do par "mas sim", que tem função de focalizar a informação:

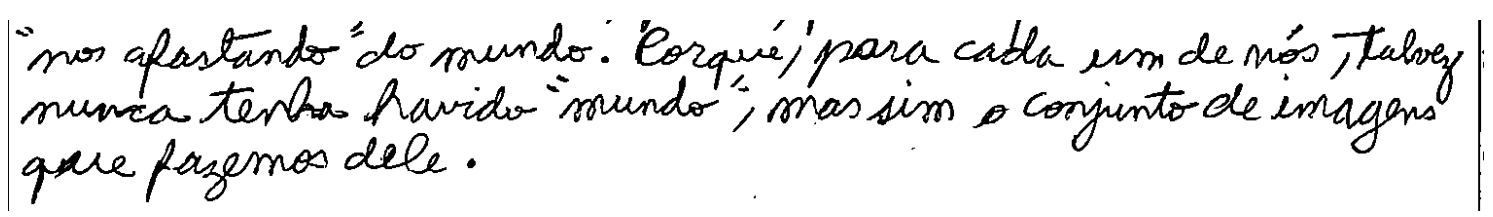

(Exemplo 35, Fuvest, 2010, p.20)

Para o autor, o jogo persuasivo $^{41}$ se dá de maneira em que modaliza o circunstanciador "nunca", que parece abranger um período maior "não só do presente, mas também do passado ou do futuro" (Neves, 1999, p.259), com a finalidade de tocar o leitor, sensibilizá-lo, seguido do elemento de contraste "mas" atrelado ao focalizador "sim", que tem o objetivo de especificar o que foi generalizado no $1^{\circ}$ elemento do par;

\footnotetext{
40 Segundo Neves (1999, pp. 258-259), o circunstanciador "nunca" tem valor de tempo fórico, porque efetua a expressão da circunstância de tempo, "que é referida ao momento da enunciação, numa escala de proximidade temporal".

41 Essa ideia reflete processamentos típicos da gramática se desenvolvendo. Então, o fato de identificarmos negociação de sentidos em contextos de correlação remete a processos de gramaticalização.
} 
isto é, o item "mundo" ( $1^{\mathrm{o}}$ elemento) se focaliza pelos itens "conjunto de imagens" $\left(2^{\circ}\right.$ elemento do par).

\subsubsection{Não (V) somente... mas}

Esse par consolida o contraste de ideias com polaridade "não (V)" seguido de focalizador "somente" atrelado a item adversativo.

Para esse par, o autor polariza a ideia inicial por meio de um focalizador, isto é, nega especificando a informação que, para ele, é considerada dada, conhecida pelo leitor. Assim, persuasivamente, lança no $2^{\circ}$ elemento do par um item adversativo que não anula a informação do conteúdo seguido ao elemento conector anterior, mas o acopla com uma informação nova:

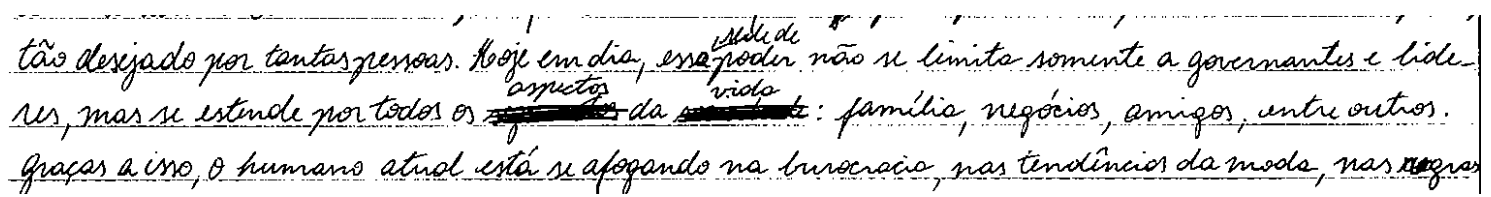

(Exemplo 36,Fuvest, 2005, p.16)

Segundo Houaiss e Villar (2001), o item "somente" pode ser interpretado como equivalente aos seguintes sentidos: “não mais que, apenas, só, unicamente; considerado um circunstanciador que tem a função de modalizador delimitador ${ }^{42 \%}$. Nesse sentido, desempenha o papel de circunscrever os limites dentro dos quais o enunciado deve ser interpretado.

No trecho apresentado, o autor aponta que "a sede de poder não se limita

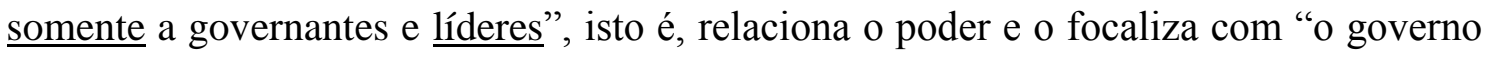

\footnotetext{
42 Segundo Neves (1999), o modalizador delimitador "fixa condição de verdade, isto é, delimitam o âmbito das afirmações e das negações”(p.250).
} 
e líderes" porque isso é conhecido, experienciado, mas, no $2^{\circ}$ elemento do par " $\underline{\text { mas }}$ se estende por todos os aspectos da vida...", quer abarcar todos os outros aspectos, que também tem a sede pelo poder. Ao delimitar, focalizar, evidenciar, sabe que o conteúdo do $1^{\mathrm{o}}$ elemento do par é mais factual, pontual, mais circunscrito e é por isso que prefere lançar o conteúdo mais geral, no $2^{\circ}$, como estratégia persuasiva.

\subsection{Pares correlativos aditivos e suas funções pragmáticas}

O quadro, a seguir, consolida os números de empregos dos pares correlativos com o valor semântico de adição.

\begin{tabular}{|c|c|c|c|c|c|c|c|}
\hline SEHAFTICA & ESTRUT & 2004 & 2005 & 2006 & & 2007 & \\
\hline & $T$ & näaramente... martambim & $\sqrt{1 \text { näar6...martamb6m }}$ & a näró... martamb6m & & ramente... martamb6m & 3 \\
\hline & & & näa...(V) spenar... $\varepsilon$ ama $(v)$ tamb6m & näaramente... mar & & näa apenar... markambirm & \\
\hline & & & & & & näar6... martamb6m & \\
\hline & & & & & & kanta.... quanta & $=$ \\
\hline & & & & & & näró...markamb6m (arpes) & \\
\hline & D & näar6... markamb6m & 1) Kanta... quanta... & njä... marapenar & & nög (V) apenar... mar tamb6m & z \\
\hline & & nän apenar... oxim & 1 näaś6... mar & näa apenar... mar tambím & & näa (V) aponar... sama tambirm & 1 \\
\hline & & näa apenar... mar tamb6m & 1 mäns6... mar tamb6m & näar6... martamb6m & & näa (V) apenar... mar & \\
\hline \multirow[t]{18}{*}{ ADITIYA } & & näaramente... martambirm & 1 häa apenar...par6m tamb6m & & & näarb... mar ainda & \\
\hline & & näasb... marprincipalmente & 1 näarb $(W) \ldots$ tamb6m $(W)$ & & & näa spenar... mas & \\
\hline & & nägrb... mar... & & & & näa apenar... mar tamb6m & \\
\hline & & näa.... (V) apenar... mar tamb6m & & & & näarb...mar mar & \\
\hline & & & & & & näarb... sama tamb6m & \\
\hline & & & & & & näaramente... mar tamb6m. & \\
\hline & & & & & & näa apenar... sama tamb bm & \\
\hline & & & & & & tanka... quanta & 5 \\
\hline & & & & & & tanta... quanta (arpes) & \\
\hline & & & & & & Eanta... quanta (exempl) & \\
\hline & & & & & & tanka.... quanka.... quanka & \\
\hline & $\mathrm{c}$ & näarb́...mar mar & 1 näarbi...mar & näa apenar... martambirm & & näar6...mar mar & a \\
\hline & & & & näarb... mar & & tanta... quanta & \\
\hline & & & & näaramente... mar & & & \\
\hline & $T$ & & tanko guanto & & & & \\
\hline & & & tanta... Eama & 4 & & & \\
\hline & & & näart... $\leq a m a \ldots$ a at6 & & & & \\
\hline & & & kanka... $\leq a m a k a m b 6 m$ & & & & \\
\hline ADITIYA & D & näa apenar... eama tamb6m & 1 tanta... quanta & Z kanta... sama & & 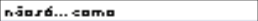 & \\
\hline \multirow[t]{5}{*}{ COMPARATIY } & & & näns6... $\leq a m a \ldots$ eat6 & & & & \\
\hline & & & nüa spenar ... eama & näaramente... sama tamb & & tanta... <ama & 3 \\
\hline & & & n.jaramente.... samatambrom & 1 n.jarb...samakambrom & & & \\
\hline & $\mathrm{c}$ & t.̈a... quanta & 1 | tanta.... sama & häa apenar... samatamb6 & & näarb́... <ama... & 1 \\
\hline & & & & Eanta.... quanta & & näará... sama tamb6m & 3 \\
\hline & $\mathbf{T}$ & & & & & & \\
\hline ADTIYA & D & tanta... quanta & 1 & & & & \\
\hline \multirow[t]{2}{*}{ PROPORC } & $L$ & & & & & & \\
\hline & c & & & Eanko.... zuanta & & & \\
\hline
\end{tabular}




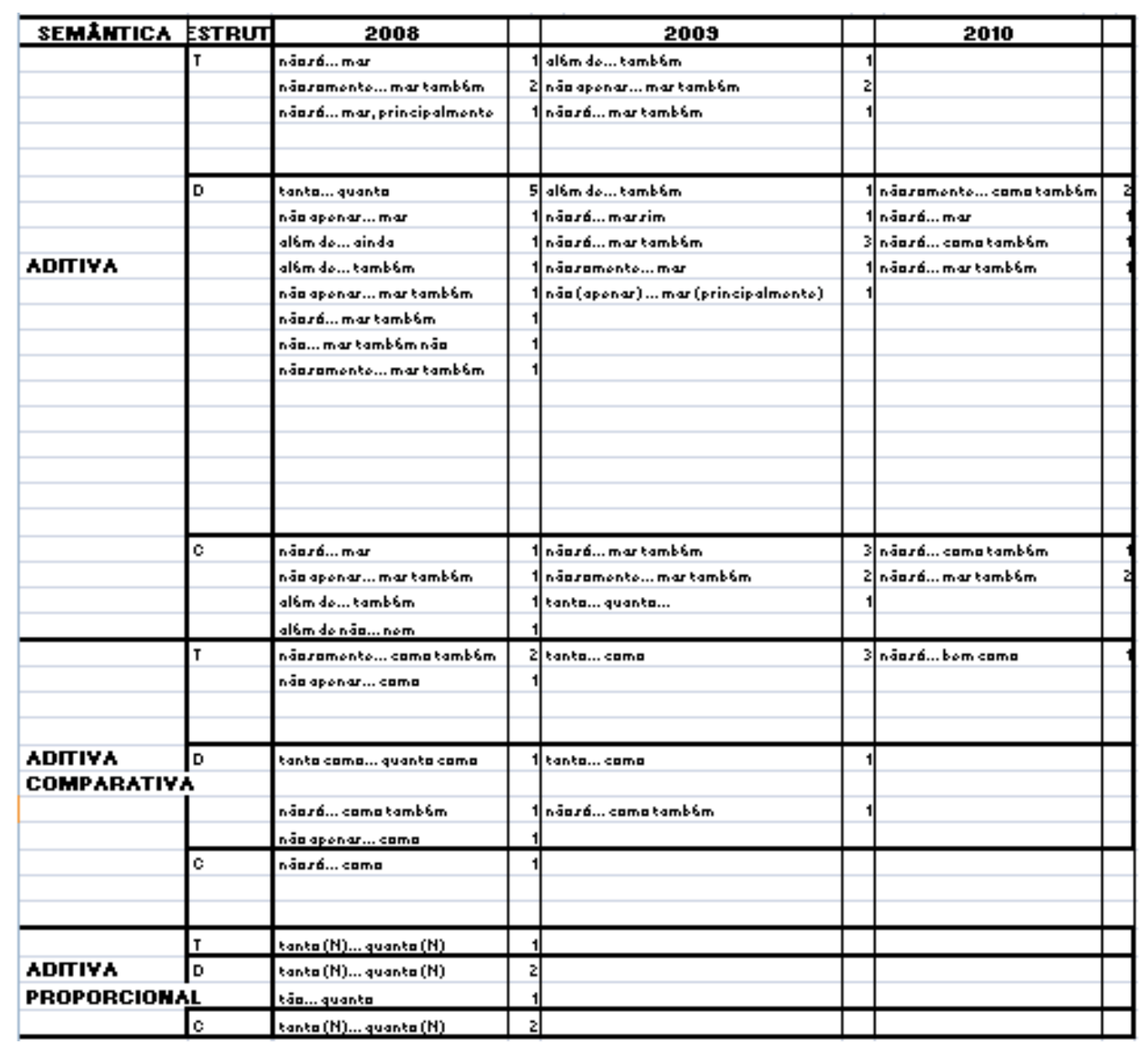

Quadro 6. Pares correlativos aditivos

\subsubsection{Correlacionadores aditivos}

Os pares do quadro aditivo apresentaram-se, nos textos analisados, as redações da Fuvest 2004 a 2010, com valores aditivos ou com a combinação da adição com comparativa e com proporcional.

Apesar de ser constituída por meio de duas porções informativas que se aproximam a fim de auxiliarem na argumentação das ideias discutidas, a maioria das ocorrências, em menor quantidade, assumiu papéis cuja função foi a de comparar e outras de oferecer uma proporção com vistas a gerar credibilidade à parte argumentativa. 
Percebe-se uma flutuação entre os marcadores, advinda das necessidades comunicativas do autor que, ao pensar no leitor, converge a combinação entre os pares de acordo com suas intenções. Isso conduz a ideia que a funcionalidade está intrinsecamente ligada ao campo pragmático, fazendo com que os itens adquiram um caráter menos neutro e mais multifacetado.

\subsubsection{Não só... como também}

Não só... mas também

Não somente... mas também

Não somente... como também

Não apenas... mas também

Não apenas... como também

Esses pares explicam-se pela aproximação de um polarizador que atua de forma inclusiva permitindo focalizar uma informação por meio da agregação de adjuntos conjuntivos de valor aditivo.

A ocorrência desses pares se dá pela necessidade de que fatos simultaneamente organizados contribuam para a intersecção entre as ideias apresentadas na argumentação. Percebe-se que o $1^{\circ}$ elemento do par focaliza a informação, restringe-a, (“denotativo negativo de restrição", cf. Oiticica, 1952, p.21) seguido do $2^{\circ}$ elemento do par, que inclui o conteúdo informativo (“denotativo de inclusão”, cf. Oiticica, 1952, p.21). Sendo assim, o escrevente utiliza-se, estrategicamente, de duas porções informativas, em que, na primeira, apesar de realçar, direcionar a atenção do leitor para as ideias contidas nesse par, parece transmitir fatos já conhecidos por ambos e, no segundo par, guarda, então, a informação nova, aquela considerada como um elementosurpresa para o leitor. 


\section{- Não só... como também ${ }^{43}$}

Nesses dois elementos que constituem o par correlativo, há uma particularidade: encabeçam um item de polaridade negativa com focalizador, seguido de "adjuntos conjuntivos com valor aditivo" (Azeredo, 2009, p.288), em que duas porções informativas distribuem e adicionam, estrategicamente, material linguístico:

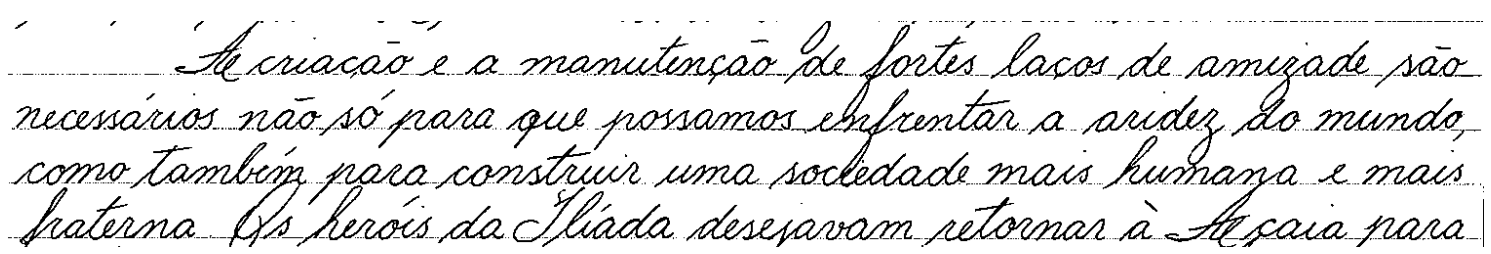

(Exemplo 37,Fuvest, 2007, p.99)

Verifica-se que o primeiro par parece guardar informações já conhecidas pelo leitor. Isso ocorre para consolidar a seguinte estratégia discursiva: primeiro, lança-se, a partir do tema (ponto de partida da mensagem), uma informação compartilhada e, logo após, no rema (ponto em que se desenvolve a mensagem), apresenta-se a informação supostamente nova para o leitor. Dois itens linguísticos chamam a atenção. São dois verbos que marcam atitudes: enfrentar (no $1^{\circ}$ elemento do par) e construir (no $2^{\circ}$ elemento do par).

\section{- Não só... mas também}

O par correlativo não só... mas também possui como estratégia discursiva a divisão entre as porções informativas, com informação velha (tema compartilhado) e a informação supostamente nova (rema):

\footnotetext{
43 Esse par correlativo a depender do contexto pode assumir outros valores semânticos, tal como comparativo. O valor aditivo é base para consolidação de outros pares correlativos.
} 
noo só que se distribuam me thores condicjes de vida a sociedade ù também que se prómova a inclusao digital. As informactes, noticias eate o entretenimento necessitam estar ao alcance de

(Exemplo 38, Fuvest, 2008, p.81)

Analisando o conteúdo da redação, verificamos que seu autor expressa que, antes de haver a inclusão digital, há necessidade da distribuição de melhores condições de vida à sociedade, uma problemática conhecida pelo leitor. Parece querer, como recurso estratégico, mostrar que, antes de promover a inclusão digital, os problemas sociais devem ser resolvidos, pois é uma necessidade primordial à sociedade.

\section{- Não somente... mas também}

\section{Não somente... como também}

Esses dois pares correlatos foram relacionados fim de se motivar a relação tema e rema, como estratégia persuasiva. Estes pares apresentam como estratégia argumentativa um focalizador atrelado ao tema que desemboca num rema mais generalizado. Parece que, cognitivamente, existe, para o $2^{\circ}$ elemento do par, uma complexidade instada pela informação, o argumento mais forte e convincente é guardado para esse elemento do par. Analisemos os exemplos a seguir:

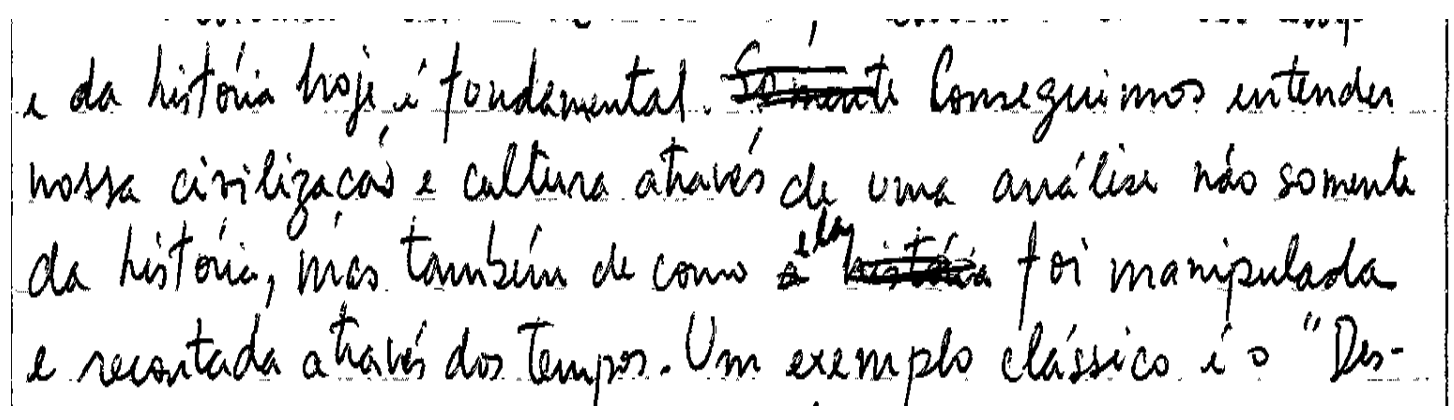

(Exemplo 39, Fuvest, 2004, p.86) 


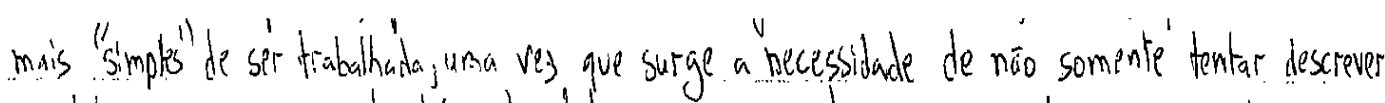
um fato, estan como também de determinar comodescrever e de se conscientizar sobre os limites da re presentaçäo.

(Exemplo 40,Fuvest, 2010, p.7)

Verificamos que o par "não somente... como também” permite correlacionar os dois elementos do par e, ao mesmo tempo, as intenções das escolhas, no rema, feitas pelo interlocutor. Há, na $2^{a}$ porção, a mais complexa informação. Assim, o candidato, ao tratar sobre a questão da relação entre a realidade e a imagem, sai em defesa do cuidado que se deve ter ao descrever um fato e de como representá-lo simbolicamente. A mesma língua deve ser observada para o par "não somente... mas também". Vejamos a representação dessa distribuição sintático-semântico-pragmática:

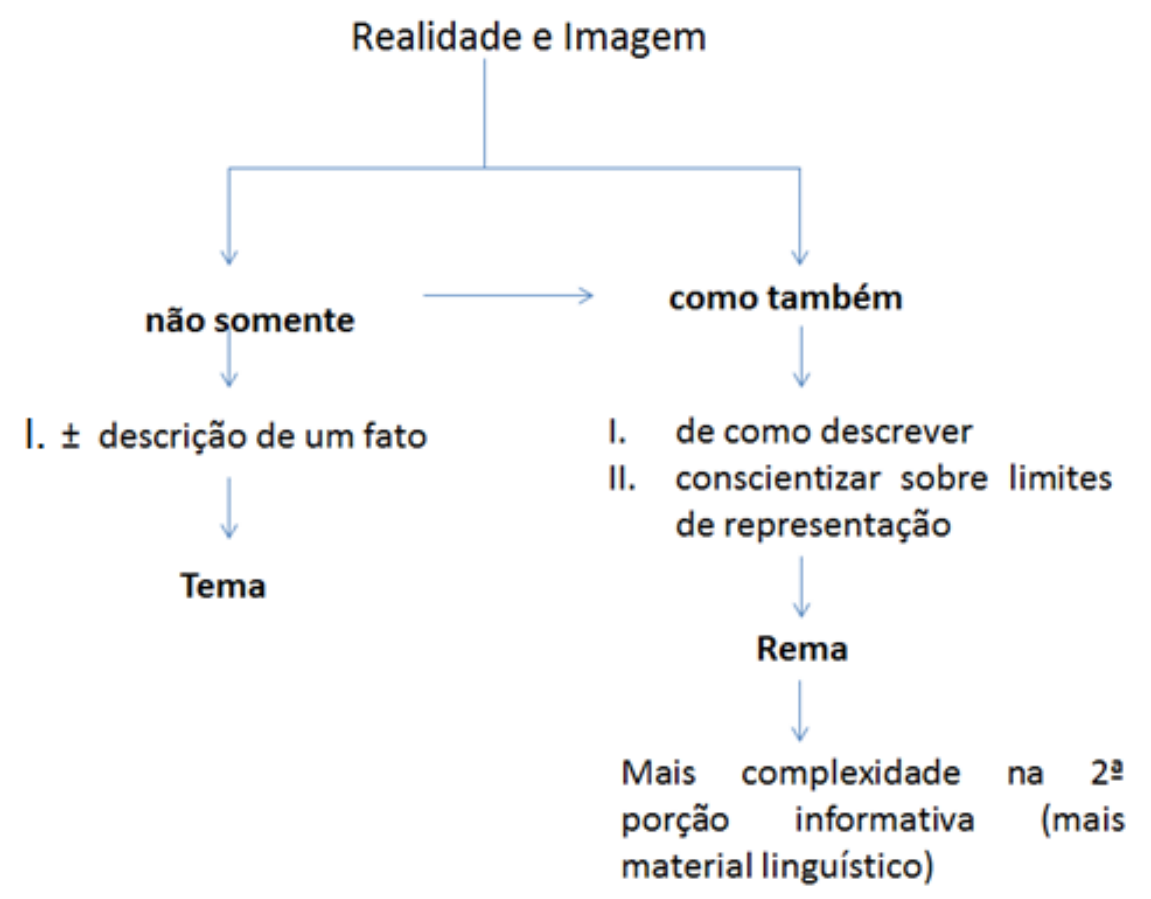

Esquema 17. Representação da distribuição sintático-semântico-pragmática - correlação aditiva

Importante apontar que o candidato, na $2^{\text {a }}$ porção, riscou o par "e sim" e o substituiu pelo par "como também” para estabelecer uma relação aditiva. Muito provavelmente não considerou o $2^{\circ}$ par "e sim" por achar que seria penalizado, haja 
vista que não é um elemento presente na norma do português padrão; logo assim, não caberia utilizá-la no trecho. Isso nos revela um cerceamento por parte de quem escreve, que tenta aproximar-se do que a gramática institui como apropriado ou não.

\section{- Não apenas... mas também}

\section{Não apenas... como também}

Esses dois pares correlativos aditivos apresentam o item "apenas", que funciona como um focalizador para a $1^{a}$ porção informativa; isto é, o relevo que lhe é conferido baseia-se na nulidade de parte da negação, projetando para a segunda porção o conteúdo, que, para o autor, parece ser o mais relevante:

Ohomem é un ser que precita de seus seuellautes para sobreniver
nos apenos en ternos materiais, nas taubém afetios Apesar

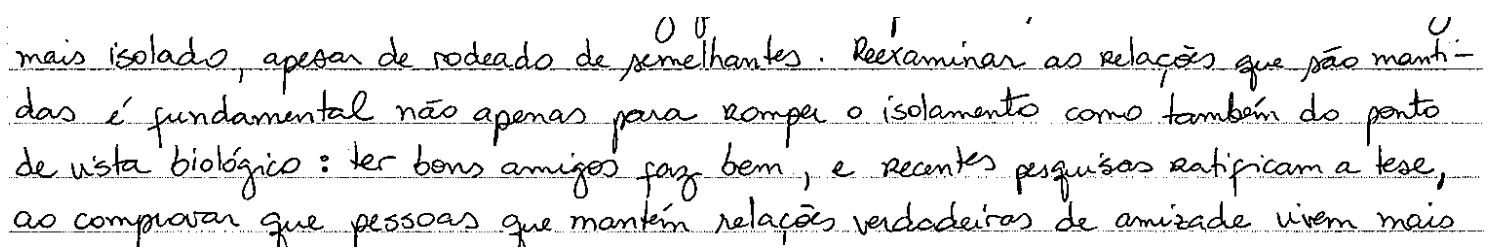

(Exemplo 42,Fuvest, 2007, p.53)

Segundo Bechara (2009), o item "apenas" significa somente; para Houaiss e Villar (2001), é mais forte o valor de exclusividade. No trecho 1, "apenas" refere-se aos itens "termos e materiais", que como parecem ter uma conotação mais ligada ao aspecto físico, lança no $2^{\circ}$ elemento do par o item "afetivo", ligado ao aspecto mais abstrato. Parece que o focalizador "apenas" inclui uma crítica, pois se sabe que o homem dá mais valor a aspectos materiais na sociedade de hoje.

No trecho 2, a adição entre os pares correlativos se caracteriza pelo tema e rema: no $1^{\circ}$ elemento do par, ajusta-se a informação já conhecida, no tema; e, no rema, 
apresenta-se o ponto de vista defendido pelo autor. Uma prova disso é a quantidade de material linguístico presente no rema para argumentar de um ponto de vista assumido. O focalizador serve para trazer à tona uma ideia que ambos conhecem: tanto o autor quanto o leitor.

Nos dois trechos, a estratégia do autor é de se utilizar do focalizador para apontar que a informação atrelada a ele não dá conta para satisfazer a necessidade do leitor. O uso do "apenas" no $1^{\circ}$ par parece servir somente para alavancar para o $2^{\circ}$ par; isto é, focaliza, mas com um objetivo de direcionar o leitor para a $2^{\mathrm{a}}$ porção.

\subsubsection{Não (V) só... (V) também}

Esse par representa o polarizador (verbo) mais focalizador seguido de (verbo) mais adjunto conjuntivo aditivo. Chamou-se atenção desse par, pois foi a única ocorrência que encontramos.

A posição intermediária do verbo "ser" (copulativo) entre o $1^{\circ}$ elemento do par "não...só" assume função de focalizar outro focalizador: "é só". Com o $2^{\circ}$ elemento do par, esse verbo parece focalizar o adjunto conjuntivo "também":

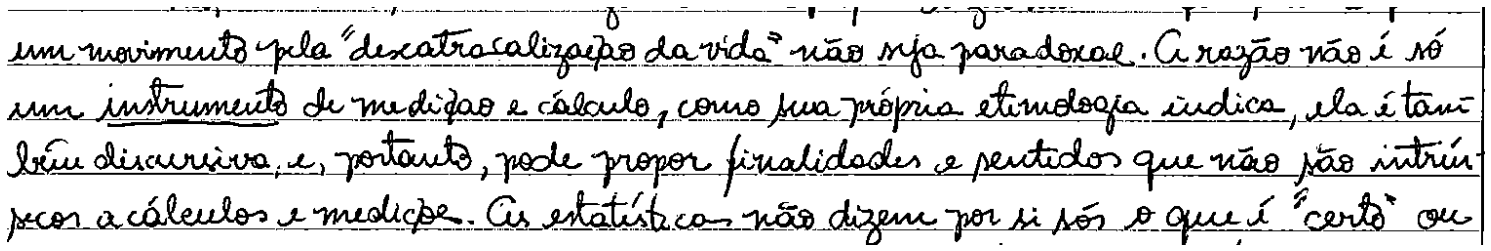

(Exemplo 43,Fuvest, 2005, p.70)

Existe uma identidade do verbo entre os pares, cuja função seria de realçar a informação proposta de cada par. No $1^{\circ}$ elemento do par: "instrumento de medição e cálculo"; no $2^{\circ}$ elemento do par: "discursiva", em que o candidato propõe ao leitor que a ideia de "catraca" seja entendida metaforicamente, demonstrando assumir um sentido que deriva de uma extensão metafórica, logo abstratizada: de medição (sentido original atribuída) para discursiva (sentido mais metafórico). O papel do verbo "ser" parece ser 
essencial para que se realcem as duas porções informativas, pois, juntas, funcionam como clivagem que produz realce para a informação que se segue ao focalizador "só" e “também”.

\subsubsection{Não só... mas}

\section{Não somente... mas}

Este padrão ilustra o polarizador focalizador seguido de elemento adversativo.

A ocorrência do par "não só...mas" demonstra que é possível elidir parte dos pares, mas não significa que sejam totalmente sinônimas as construções. Com a ausência do item "também", produz-se maior velocidade de leitura e, consequentemente, maior integração sintática. O princípio funcionalista da marcação permite explanar essa ocorrência, pois com a frequência de uso é comum que se conceptualize o uso de modo mais automatizado. Mas não é só isso. Pelo princípio de iconicidade, verifica-se que o que está mais integrado mentalmente, também será codificado mais integrado. Aqui, ao menos mais próximos estão, permitindo um processamento mais rápido também.

O trecho a seguir, de 2006, com o par “não só...mas" sinaliza, focaliza, por meio de preposição "para" duas informações que se calcam em relevo. A ideia que o escrevente quer transmitir é a de que, se focarmos nossa vida somente no trabalho, como sinônimo de labuta, seremos escravizados. São ideias altamente integradas por meio de dois verbos e nos remetem à questão dos prejuízos atrelados unicamente ao tema trabalhado.

Colocar em relevo duas informações que aditivamente se sobrepõem por meio da estrutura para + nome [+animado], parece alavancar, entre os pares, duas porções informativas relevantes para o autor, e por isso a utilização da reduplicação da preposição. Há um equilíbrio de quantidade de material lexical entre as porções: 


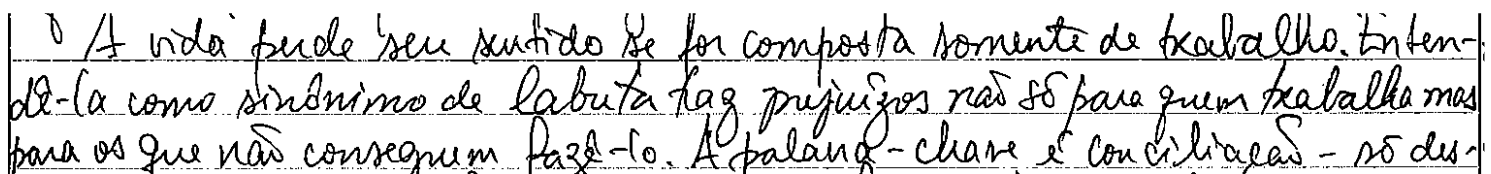

(Exemplo 44, Fuvest, 2006, p.37)

Para o par aditivo, de 2008, constituído por "não só para" atrelado a "mas para", há uma relação circunstancial aditiva, introduzida por expressões de tempo. A preposição "para", por meio dos pares correlativos, focaliza dois itens lexicais "época" e "séculos", que, metonimicamente, sinalizam para o leitor que a linguagem escrita foi relevante para a transmissão do conhecimento durante vários períodos. Imageticamente, há um extensionamento entre época $\rightarrow$ século, utilizado pelo autor, a fim de mostrar a importância da escrita na história da humanidade:

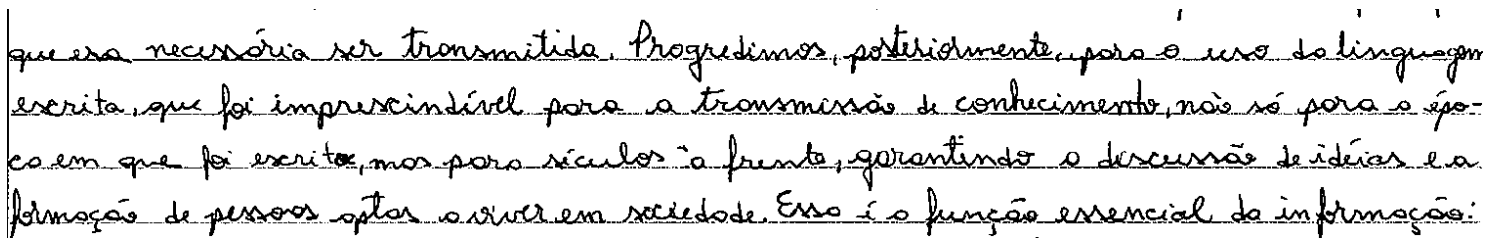

(Exemplo 45,Fuvest, 2008, p.34)

Chamamos a atenção para a constituição do par "não somente... mas" no próximo exemplo. Ele parece guardar entre as informações uma escala de contiguidade, em que o conceito atribuído à informação que sucede o elemento do primeiro par se estende ao do segundo de uma forma em que o item do $1^{\circ}$ par (pessoa), mais concreto, se abstratiza, no do $2^{\circ}$ elemento do par (nação). No caso, há uma "anunciação intrínseca" (Croft, 2004, p.283). instala-se uma relação metonímica, que iconicamente, faz com que haja uma similaridade parcial entre os itens correlacionados:

da assinatura de tratados ov cicordos. A mudanca na delimitacaio da fronteira vigente exige adentrar em orimàs, idéias, concrites e princípros nố somente de uma pessoa, mas de uma nação. Esse feito nầ serä realizado, nem cenceguiria, de modo impositio. O cunho abstrato dos limites do pensamento apresenta se com 


\subsubsection{Não só... mas principalmente}

\section{Não só... mas sim}

Esse padrão é consubstanciado pela presença de polaridade focalizadora seguida de elemento contrastivo atrelado a um focalizador.

O par aditivo não só... mas principalmente guarda uma relação que se constitui por meio de dois focalizadores "só" e "principalmente", em que parece que o $2^{\circ}$ direciona para aquilo que se quer realmente argumentar:

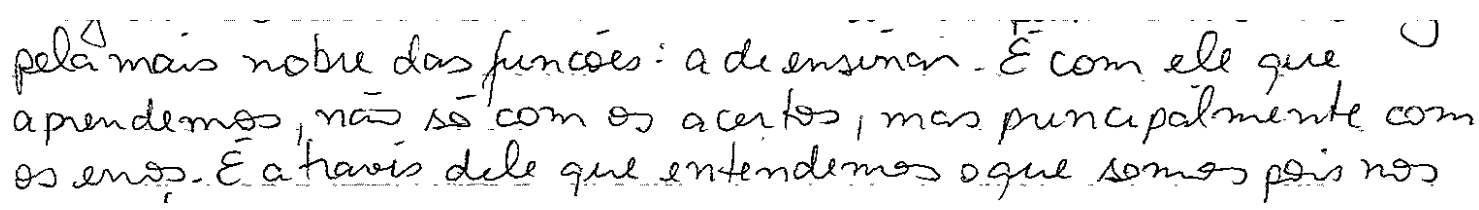

(Exemplo 47,Fuvest, 2004, p.91)

O circunstanciador "principalmente" é considerado um "modalizador" (Neves, 1999, p.244) que tem característica básica de expressividade em relação àquilo que apresenta no enunciado. Ele permite modalizar o quanto tem de verdade na porção informativa que sucede o $2^{\circ}$ elemento do par. Trata-se de uma estratégia do falante para marcar veracidade em relação ao que ele próprio diz. Analisemos, agora, o outro par.

Cóm a queda do 'Muro de Bertim, o mundo parecia 'livron-se da última fonteria que seponava as pessoas: a ideologia. A demubada do Mpro foi muite simbólica, pois sintentizava as. aspiracóés doquele momento: a uniäo parecia ser nōo só da Alemanha, mas Sin da humanidade. Alguns entusiastas chegaram a deceetan s fim da História. Francis Fubuyanna, cien-

(Exemplo 48, Fuvest, 2009, p.14)

Notemos que o par correlativo não só... mas sim é aditivo e sinaliza uma dupla focalização por meio dos circunstanciais "só" e "sim". Segundo Houaiss \& Villar 
(2001), representa uma reiteração de algo afirmado, em que parece levar o leitor, metaforicamente, ao significado "da derrubada do muro de Berlim" cuja união simboliza não só a Alemanha, mas sim a humanidade; isto é, cognitivamente esse deslocamento da parte pelo todo, é um exercício cujo processamento mental se dá de forma mais complexa, mais abstratizado. Iconicamente, dentro do continuum, das categorias cognitivas há um deslocamento do espaço que denota qualidade, pois humanidade, segundo Bechara (2009), tem seu "significado calcado na generosidade em relação aos demais" (p. 476): a união do muro de Berlim representa solidariedade, respeito ao próximo. O que é "mais conhecido e supostamente compartilhado em situação interativa é elidido da sequência sintática" (Lima-Hernandes, 2008, p.26), pois a porção "a união parecia ser", encabeçada pelo $2^{\circ}$ elemento do par, foi omitida. Aqui também verificamos a intenção de alta integração e velocidade de processamento.

\subsubsection{Não só... mas ainda}

Esse padrão produz polaridade com focalizador seguido de elemento contrastivo + adjunto conjuntivo.

$\mathrm{O}$ uso do $2^{\circ}$ elemento do par recebe o nome de "adjunto conjuntivo" (cf. Azeredo, 2009), e essa constatação nos faz compreender um pouco mais sobre a intenção de fazer ressalva em relação à porção informativa do $1^{\circ}$ elemento do par. Vejamos o exemplo:

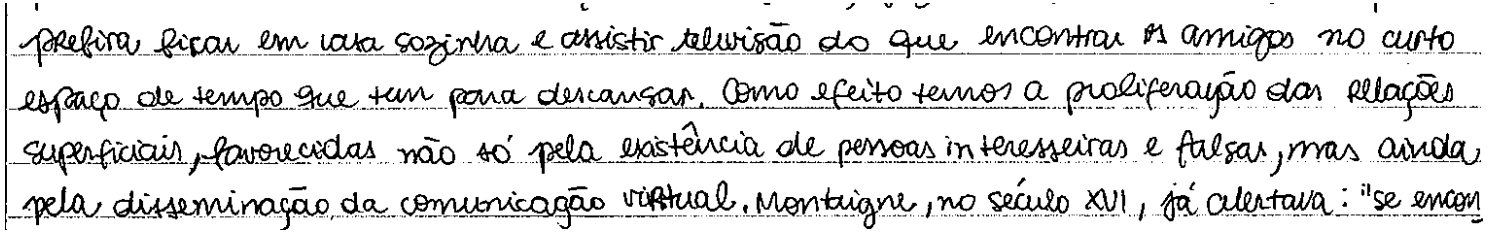

(Exemplo 49,Fuvest, 2007, p.44)

Ao nos atentarmos para a expressão circunstancial expressa no enunciado, vemos que existe uma relação (tempo e lugar) de contiguidade: no trecho, alega-se que, 
por conta de uma redução de tempo de lazer, as pessoas preferem ficar em casa a encontrar amigos (relação circunstancial). Com isso, o autor expressa que há uma proliferação de amizades superficiais não só pela existência de pessoas interesseiras e falsas, mas ainda pela disseminação da comunicação virtual (correlação aditiva).

Percebe-se um jogo discursivo, uma estratégia adotada pelo autor via mobilização de expressões circunstanciais, que antecedem os elementos do par correlativo, como se quisesse apontar a causa da superficialidade das amizades. Ao apontar "mas ainda", no $2^{\circ}$ elemento do par, há uma inversão: o tema está na segunda posição, e o rema encabeça a $1^{a}$ porção, daí a ressalva.

\subsubsection{Não (V) apenas... mas (V) também \\ Não (V) apenas... como (V) também}

Esse padrão produz a construção: polaridade $+(\mathrm{V})$ focalizador seguido de elemento contrastivo $(\mathrm{V})$ seguido de aditivo.

Alguns aspectos são relevantes apontar para a compreensão das estratégias adotadas por alguns pares correlativos, tais como a presença dos verbos, que parecem funcionar como focalizadores.

O par correlativo "não (V) apenas... mas (V) também" apresenta uma característica peculiar: o verbo ser é focalizador da porção informativa presente após o $1^{\circ}$ elemento do par e, por isso, o autor, estrategicamente, guarda a informação já conhecida $^{44}$. Não há relevo. No $2^{\circ}$ elemento do par, o escrevente apresenta a informação nova, a surpresa:

\footnotetext{
44 Essa ideia reflete processamentos típicos da gramática se desenvolvendo. Então, o fato de identificarmos motivação de economia em contextos de correlação remete a processos de gramaticalização.
} 


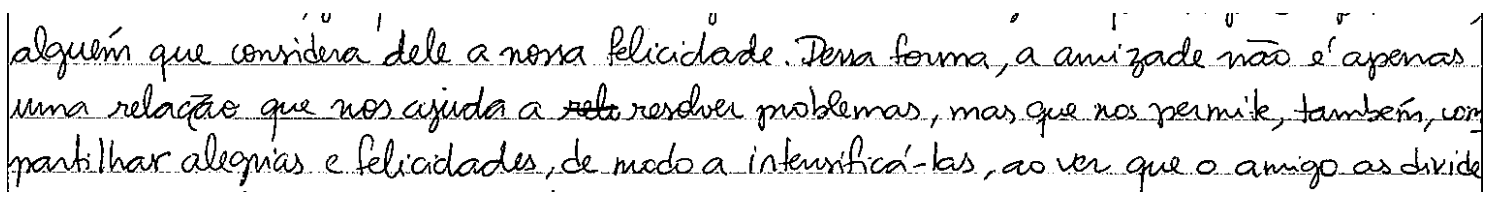

(Exemplo 50,Fuvest, 2007, p.31)

Se compararmos os dois verbos presentes entre os pares ("é" e "permite"), o verbo "ser" parece enfatizar o focalizador e o verbo "permitir" somente acompanha. Presta-se, desse modo, a funcionar como complementador da informação.

Quanto ao par correlativo "não (V) apenas... como (V) também”, verifica-se a presença de um intensificador + qualificador para cada par: "não são apenas mais tristes" "como são também mais propensas". Desse modo, configura-se uma contiguidade semântica com base nas informações de mundo. No exemplo a seguir, por influência do par, verifica-se que quem está triste tem propensão a ter problemas:

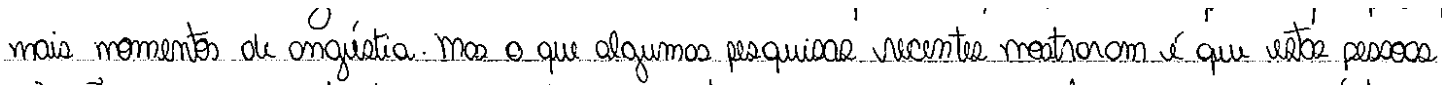

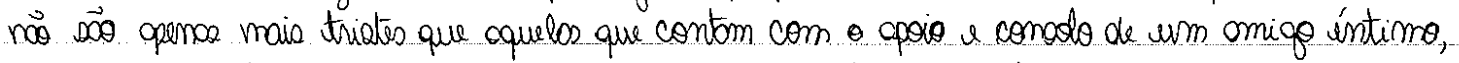
como wö tombém mais propenoas a ter problemes de saúde, disde dermos comuno do dia-a-dio a demcoo ganovo de difícil cuna.

(Exemplo 51,Fuvest, 2007, p.12)

Chamamos a atenção para o papel dos qualificadores. Entre os enunciados, apresentam uma relação de causa e de consequência, isto é, produzem a junção entre os pares aditivos, composta de "polarizador + verbo ser + focalizador seguido de correlativo como + verbo ser + correlativo também”. Além de servirem como aditivos (base), indicam uma relação composta da apresentação de um estado (pessoas tristes) que têm propensão a problemas de saúde (resultado, consequência desse estado).

\subsubsection{Não (V) apenas... mas também}

Esse padrão sedimenta-se com polarizador seguido de verbo focalizador sucedido por elementos aditivos. 


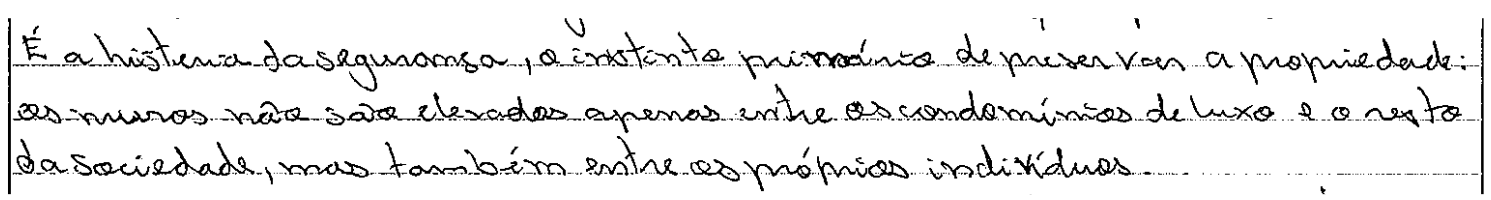

(Exemplo 52,Fuvest, 2007, p.71)

Processualmente, ocorre uma elipse de um elemento do par correlativo, especificamente na segunda porção. Tentando reconstruir essa construção, teríamos o verbo ser (são) + qualificador (elevados), produzindo o sentido de "os muros não são tão elevados apenas entre os condomínios de luxo e o resto da sociedade, mas (são elevados) também entre os próprios indivíduos". É inegável a adição como base ligada a uma relação metafórica entre item muro e indivíduo, isto é, os muros não são elevados apenas entre os condomínios de luxo, mas são elevados entre os próprios indivíduos. É empregado assim, no entanto, como uma estratégia persuasiva que abstratiza o item "muro" para mostrar a relação entre as amizades, atualmente.

\subsubsection{Não apenas... mas principalmente}

Esse padrão representa o polarizador que nega a possibilidade de o foco ser uma informação compartilhada, seguido focalização feita com base na escolha do escrevente, o que consolida o contraste pretendido:

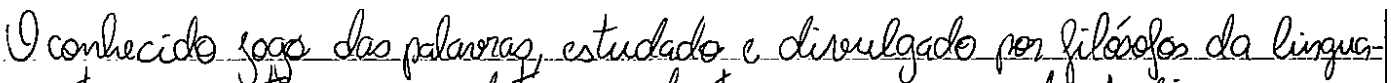
gem, permite que um determinado termo seja empregado de diveros maneinas, tragendo assim a representação de deferentes ideias. Ce enpressão fonteina constitui un peculian enemplo desse fenômeno, näa apenas por seus diversos significados, enunciados pelo dicionário, mas principalmente porque e encontro dos definiforos podem culminar na própria modificacáo das jonteiras.

(Exemplo 53,Fuvest, 2009, p.72)

Emprega-se esse par aditivo quando se pretende uma dupla focalização (apenas e principalmente), que, por seu caráter enfático, produz relevância a ambas as 
informações. Isso só é possível porque o item "principalmente", além de fazer o papel do focalizador, também produz um juízo de valor sobre a situação apontada ou discutida. Em outras palavras, "atua na dimensão ilocutória do discurso, com a finalidade de transformar certa parcela do enunciado em foco da informação" (Azeredo, 2009, p.287), ou seja, o focalizador "principalmente" é "assertivo" (cf. Neves, 1999, p.245) do tipo afirmativo, de modo que coloca fora de dúvida qualquer questionamento sobre o fato. Sendo assim, "principalmente" traduz-se na intenção de asseverar e deixar evidente que há ali uma modalização epistêmica que é marca do escrevente.

\subsubsection{Além de... também \\ Além de... ainda \\ Além de não... nem}

Esse padrão produz adjunto conjuntivo seguido de elemento aditivo.

A expressão "além de" encabeça a informação compartilhada e denuncia que mais uma informação é necessária: a do repertório do autor da redação. Em relação aos pares que compõem essas correlativas aditivas, o primeiro elemento (além de) sintaticamente marca a introdução de um adjunto conjuntivo (Azeredo, 2009), e tem um valor semântico de inclusão (Neves, 1999), pois permite incorporar porções informativas que reforçam a argumentação, propiciando o reconhecimento de índice de autoria.

- Além de... também

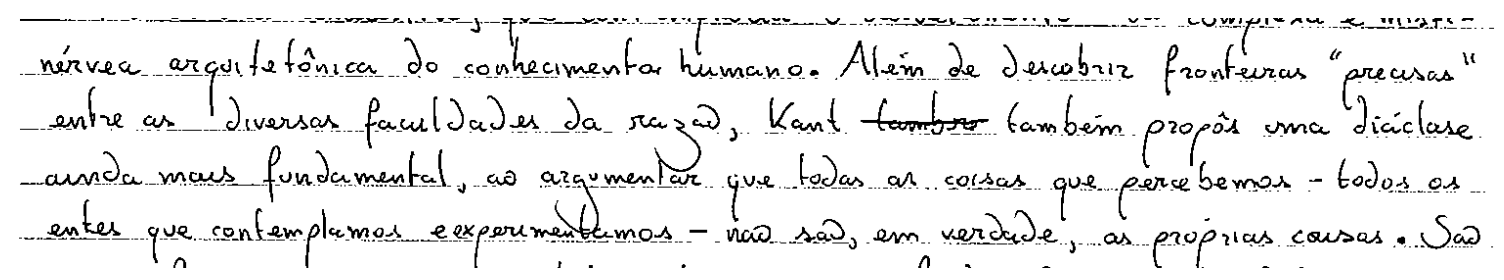

(Exemplo 54,Fuvest, 2009, p.13) 
Nesse trecho, o candidato se utiliza dos pares aditivos para auxiliá-lo na discussão a respeito dos limites da razão e da verdade. Para isso, como jogo discursivo, estratégico, ao "beber" na fonte de Kant, filósofo pensador, lança as duas porções informativas atreladas a dois verbos; um para cada par, sendo o primeiro deles, “descobrir”, um verbo factivo (Neves, 1999), que confere à informação um caráter de fato verdadeiro, que permanece firmado e apoiado, no plano cognitivo, em seu valor epistêmico (ligado ao conhecimento). No segundo elemento do par, o verbo "propor", cujo sentido pressupõe algo determinado (Houaiss \& Villar, 2001, p. 2313), permite atribuir à informação um valor factivo de caráter epistêmico. Assim, o escrevente, ao proferir as ideias baseado na concepção de Kant, entende que duas informações se correlacionam, por isso seleciona o par aditivo para sinalizar que o que está junto mentalmente também deve permanecer junto sintaticamente. No plano semântico, dois verbos sequenciam o momento da constatação e da proposição: descobrir e propor.

\section{- Além de... ainda}

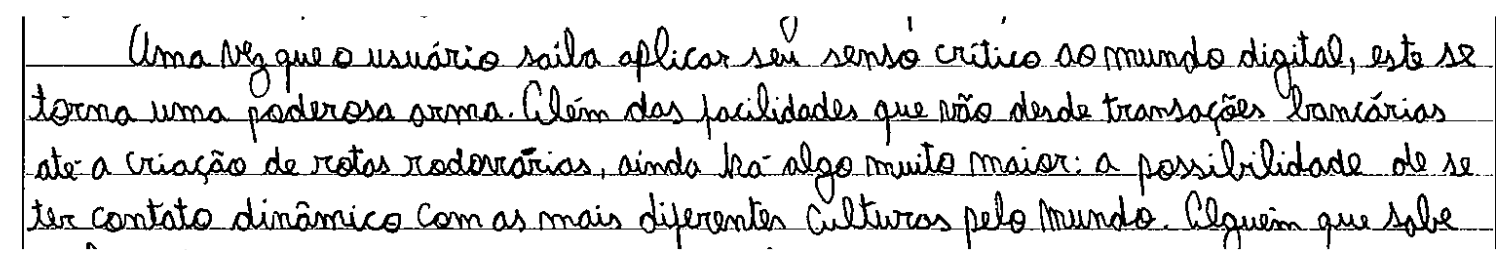

(Exemplo 55,Fuvest, 2008, p.29)

Esse par correlativo guarda as relações entre as porções informativas incluindo, de modo sutil, seu ponto de vista. É o que demanda a escolha do advérbio "ainda", que tem como objetivo adicionar algo que, a despeito de codificado sintaticamente de forma menos proeminente, tem um peso considerável em sua argumentação. Considerando o exemplo anterior, verifica-se que além de marca, auxilia na construção da transcendência argumentativa do que virá a ser explicitado na segunda porção. Assim, embora esse primeiro elemento locucional esteja no início de uma informação pesada 
morfossintaticamente, já sinaliza que algo mais relevante ainda será apresentado, a despeito de seu peso aparentemente menor.

- Além de não... nem

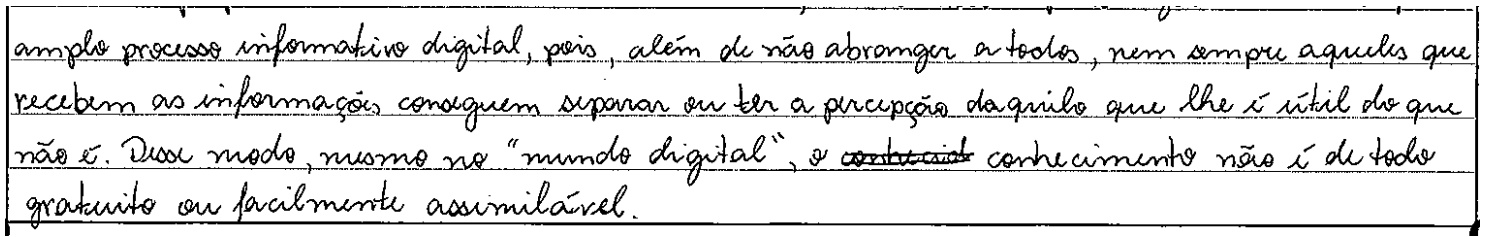

(Exemplo 56,Fuvest, 2008, p.71)

Esse par correlativo guarda uma relação aditiva negativa por meio das porções informativas, mas com uma estratégia discursiva em que o item "nem" ( $2^{\circ}$ elemento do par) funciona como reforço de privação. Percebe-se que, após a inserção do $2^{\circ}$ elemento do par (nem), um jogo argumentativo interessante que nega uma regra geral para depois questionar atributos dos casos de exceção. Então, a impressão que são duas informações independentes que se agregam negativamente é uma ilusão causada pelo primeiro elemento "além de".

\subsection{Correlacionadores Aditivos Comparativos em sua proporção}

Esse padrão representa duas informações que se seguem e acrescentam peso argumentativo a uma informação maior que vem sendo explicitada. Esses dois elementos são colocados em pé de igualdade sintática para propiciar uma comparação proporcional.

\subsubsection{Tão ... quanto}


A comparação coloca lado a lado dois elementos categorialmente próximos. No exemplo que segue, notamos dois adjetivos correlacionados. Analisemos o exemplo seguinte:

estabelecida. 'Ser significado se estende diferentemente entre as péssoas

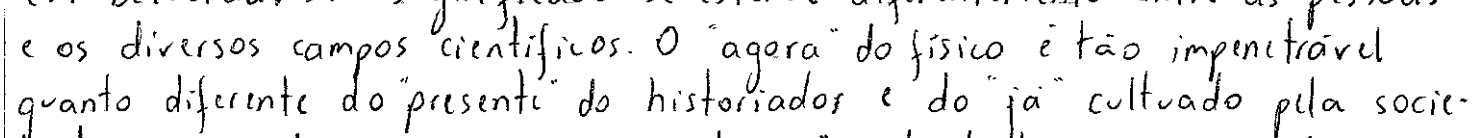
dade pós moderna que vire no "depois" e desdentha o que náo foi.

(Exemplo 57,Fuvest, 2004, p.19)

Nele, verificamos que o escrevente inicia seu enunciado assumindo que "o ‘agora' do físico é tão impenetrável quanto diferente do presente do historiador...”. Dois adjetivos são somados e, em sua proporcionalidade de ação, são comparados (impenetrável e diferente).

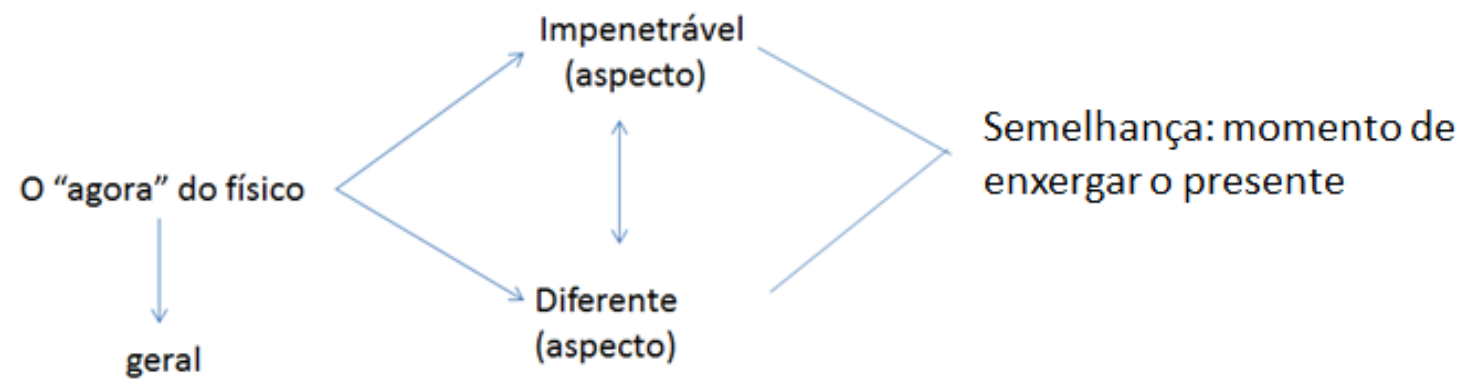

Esquema 18. Aproximação entre adição, comparação e proporcionalidade

Semanticamente, é possível perceber o paralelo. Quando o físico percebe o tempo presente, não se consegue alcançar essa forma de perceber. Essa impenetrabilidade deve-se à existência de peculiaridades e de conhecimentos que um indivíduo comum não alcança. Sendo assim, o resultado da comparação é desproporcional em resultado.

\subsubsection{Tanto... quanto}


Esse par correlativo permite a junção de elementos que especificam um mesmo objeto argumentativo. Há uma reunião de características que auxiliam na argumentação discursiva estratégica do autor. Nessa divisão de foco de atenção em duas informações também está envolvido o estatuto informação, pois há uma informação que é velha (dada, conhecida, compartilhada = tema) sobre o tema e uma informação que é pretensamente nova (não compartilhada, embora possa ser conhecida = rema). Esse jogo presta-se como tática usada pelo escrevente para dar proeminência à sua condição de autor. Entretanto, na base elaborativa desse tipo de correlação está o processo de adicionar, função que adquirimos numa fase mais tenra da aprendizagem humana. Somente depois de adicionar objetos e indivíduos, colocando-os lado a lado para observação, é que aprendemos a tornar esse processo mais consciente e passamos a fazer isso mentalmente e com ideias. Essa é a razão por que vinculamos esse par aos correlativos aditivos. Esse mesmo raciocínio pode ser feito com a constatação de proporcionalidade: primeiro, exercitamos esse conhecimento humano na infância de modo mais concreto para depois, ao longo do desenvolvimento ontogênico, distribuir proporcionalmente informações que nos cerquem daquilo que queremos também argumentar como também comparar e confrontar informações, fatos e dados, mesmo em ausência, ou seja, no plano da ideia.

Com isso, algumas características peculiares nos permitem entender, quando adicionamos medidas proporcionais e as comparamos:

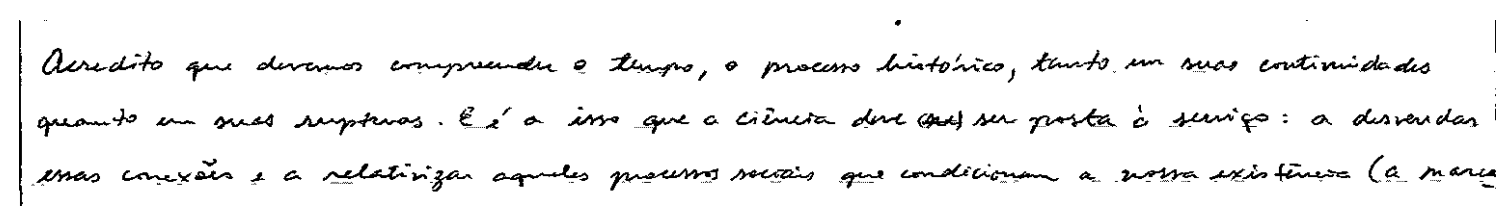

(Exemplo 58,Fuvest, 2004, p.27)

Em termos de princípios linguísticos, verifica-se que a iconicidade guia a razão. Numa ordem linear, no sintagma, o termo genérico está coligado a dois termos inerentes a ele. Isso ocorre porque o autor tinha a intenção de propiciar uma leitura de 
justaposição de elementos que podem ser comparados em sua proporção. Vejamos uma representação desse processamento:

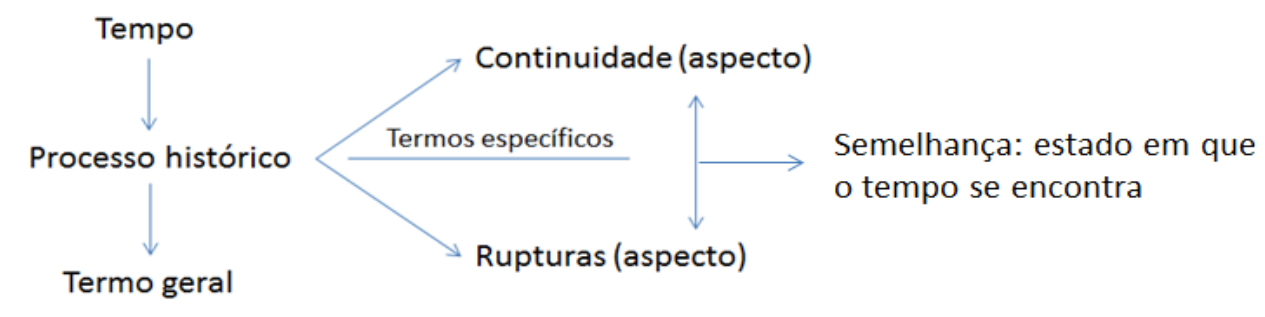

Esquema 19. Processamento comparativo de proporções

Para que se possa compreender o tempo no processo histórico, deve-se considerar tanto a continuidade como também suas rupturas. É, por isso mesmo, interessante notar que a escolha da ordem das informações não é aleatória, pois só se pode entender a ideia de ruptura, se primeiro estiver presente a ideia de continuidade, porque é dentro dela que se dão os rompimentos: adiciono e comparo.

Sendo assim, no processamento cognitivo, para a relação de tempo dentro do processo histórico, é necessário colocar lado a lado dois itens que dialoguem nessa temporalidade. A flecha simbolizada na figura permite a compreensão de um exercício cognitivo demandado pelas escolhas que se devem fazer para destacar o processo histórico, sua continuidade e sua ruptura. Analisemos outro exemplo:

A "catracalizacáo" do mundo traz conseqüências desastrosas. Há um aumento da segregacăo, tanto no nevel uletural, quanto no konómico. Assim, o trabalhador que näo atrauessa a catraca do Enibus por räo

(Exemplo 59, Fuvest, 2005, p.7)

A catracalização está ligada à segregação (termo geral) tanto no nível cultural (recorte em campo específico) quanto no econômico (recorte em campo específico). Ao mesmo tempo em que se compara, estabelece-se uma relação de proporcionalidade: 


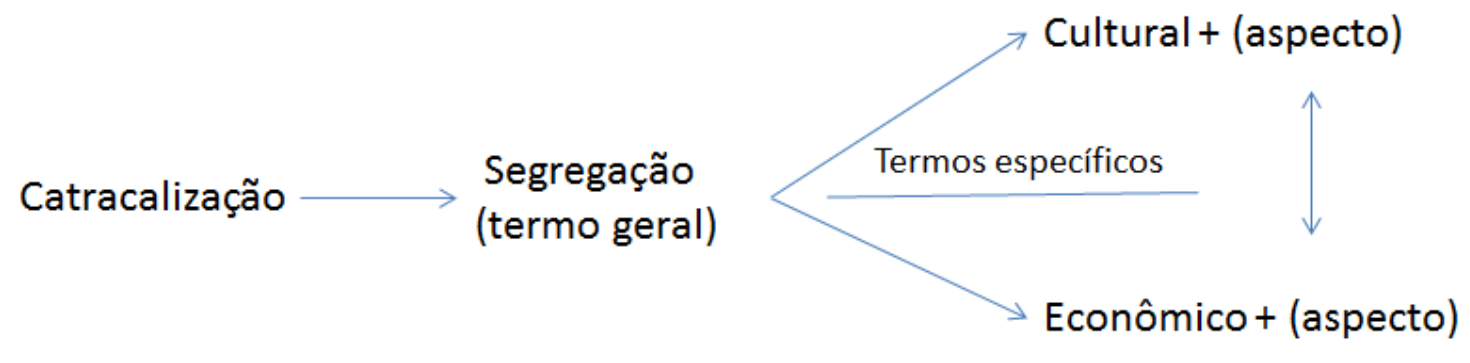

Esquema 20. Correlação e o estabelecimento de recortes específicos

Para a adição de porções informativas, é inquestionável que o conhecimento de quantidade seja mobilizado. Desse modo, ao se buscar a expressão da proporcionalidade como estratégia para informar o quanto os aspectos específicos apresentam-se ligados de forma harmoniosa a uma ideia mais geral, precisa-se de elementos que estabeleçam uma relação imagética, igualmente carregada de valor, e a quantidade é a base para essa busca. É o que notamos no seguinte caso:

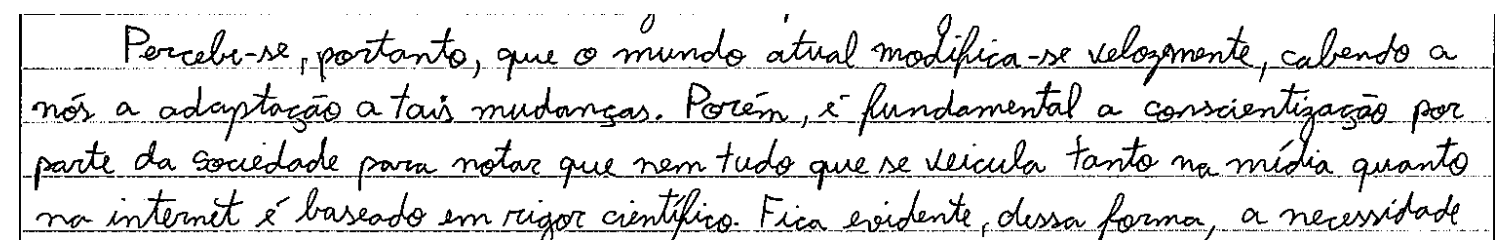

(Exemplo 60,Fuvest, 2008, p.61)

Tem-se um elemento mais geral (tudo o que se veicula) que precisa ser especificado (na mídia e na internet). No entanto, os itens que encabeçam esses elementos específicos proporcionalizam não somente sua especificidade, mas também revelam uma proporção de peso morfofonológico e de distribuição sintática (ambos atuam como circunstanciadores locativos). Com todos esses recursos, fica patente a adição proporcional ${ }^{45}$ numa construção de alta complexidade para resolver um problema igualmente complexo, que é a convincência argumentativa:

45 Não é demais lembrar que, segundo Houaiss \& Villar (2001), a proporção se dá por meio de uma propriedade que
apresenta duas grandezas. Contudo, é condição necessária a presença de equilíbrio e harmonia entre quantidades. 


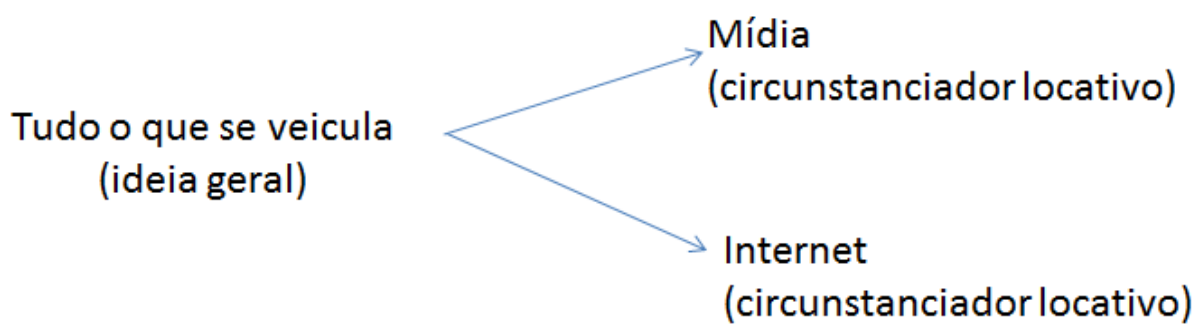

Esquema 21. Proporcionalidade e circunstanciação

\subsubsection{Tanto... como também}

\section{Tanto... como}

\section{Tanto como... quanto como}

\section{Não só... como também}

Para tratar do item como, figura central para a ideia comparativa, pode-se recorrer a um respeitável gramático, tal como Said Ali (1969), a lexicógrafos de peso, tais como Houaiss \& Villar (2001), ou simplesmente consultar a intuição sobre o componente mais básico do ser humano, a analogia.

O gramático esclarecerá que pensamentos ou conceitos que revelam semelhança em sua igualdade ou desigualdade permitem explanar o processo de comparação. Já os lexicógrafos, mais preocupados com a exatidão da resposta para dirimir dúvidas diversas dos consulentes, recorrerá também a explanações sobre construções típicas. Por isso indicarão que alguns pares descontínuos poderão também carrear uma certa semelhança ou proximidade, funcionando, portanto, como comparativo. A intuição de linguista, contudo, recorrerá aos efeitos argumentativos da comparação. Esse recurso permite demonstrar a apropriação de um conceito, porque só se apropriando dele é que podemos dizê-lo recorrendo a outras informações, originalmente atômicas. Vejamos como isso se dá num trecho de redação dissertativa:

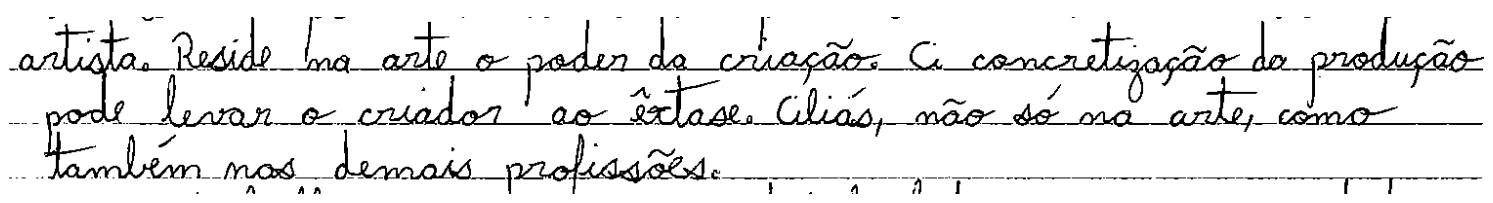




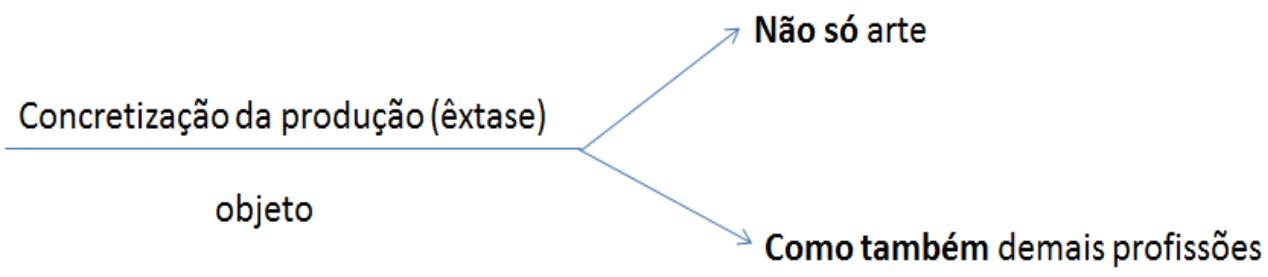

Esquema 22. Processamento comparativo na correlação

Verificamos que duas informações são ligadas à concretização da produção do trabalho que pode levar o homem ao êxtase: profissão da arte e demais profissões. Estão no mesmo campo semântico (o das profissões), na mesma função sintática (circunstanciadores), configurando-se como resposta à exigência de paralelismo gramatical. Todas as respostas, portanto, demandaram ações complexas à altura da complexidade cognitiva. Esse mesmo procedimento se aplica aos pares que integram esse padrão.

\subsubsection{Não apenas... como}

Não apenas... como também

\section{Não só... como}

Não somente... como também

\section{Não só... bem como}

No processamento correlacional, somam-se e comparam-se ${ }^{46}$, ao mesmo tempo, porções informativas numa interação que pode ser apontada de forma explícita ou implícita ${ }^{47}$. Isso ocorre com alguns exemplos que apresento a seguir. Embora a alta implicitude de informações seja típica da língua falada, nas redações sob análise isso é

\footnotetext{
${ }^{46} \mathrm{O}$ valor semântico aditivo é base para a contradição do par correlativo comparativo.

47 Segundo Azeredo (2009, p. 338), essa relação é comumente realizada por processos inferenciais, o que demanda uma reação sintonizada por parte do interlocutor ou leitor.
} 
bastante comum. O resultado é o surgimento de um par inédito, muitas vezes considerado equivocado pelos professores. Vejamos alguns casos:

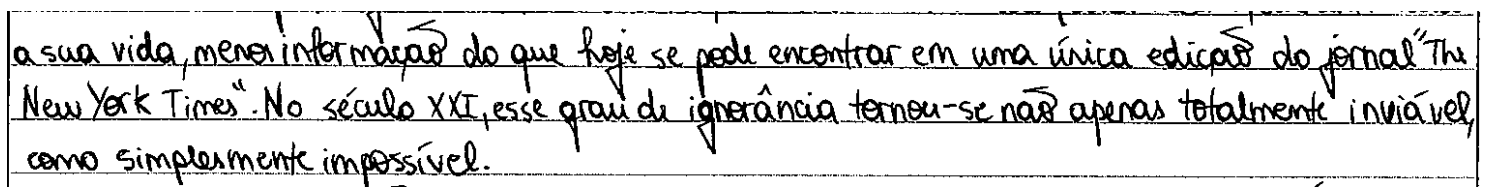

(Exemplo 62,Fuvest, 2008, p.75)

Nesse trecho, as características apresentadas no $2^{\circ}$ elemento do par (inviável e impossível), ligadas ao objeto (grau de ignorância), se adicionam e se aproximam de sentidos que se acoplam a um determinado elemento. Essa proximidade se dá pela comparação. Outra característica presente é a avaliação feita pelo autor que conta com um focalizador + circunstanciador (não apenas totalmente) no $1^{\circ}$ elemento do par, e um comparativo + circunstanciador (como simplesmente) no $2^{\circ}$ elemento do par.

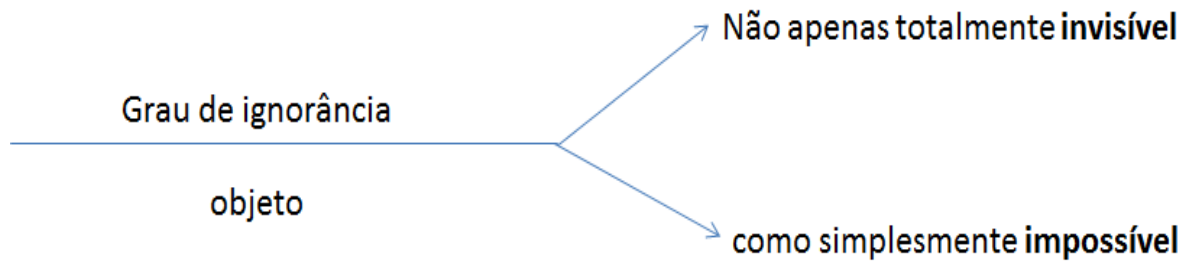

Esquema 23. Elisão de elementos dos pares correlativos

É importante salientar que alguns pares aditivos que têm, na sua constituição, o item comparativo "como" possuem sua base na junção de informações que parecem aproximar-se nas ideias culturalmente compartilhadas. Assim, como explanou Givón (2005), revela-se uma tentativa de aproximar itens que parecem ser mais acessíveis ao interlocutor. Dessa forma, pode-se também adicionar e comparar. Isso dependerá efetivamente das intenções e das informações acopladas a eles. 


\subsubsection{Não só... como... e até ${ }^{48}$}

Um caso interessante é a correlação que implica três elementos. Não se pode, assim, falar em par correlativo, mas em trio correlativo. Tem-se uma adição de porções informativas que, ao mesmo tempo, sinalizam uma proximidade de itens que livremente auxiliam na argumentação. Cabe lembrar que a correlação propriamente dita, aquela que demanda a outra porção informativa, consubstancia-se entre os dois primeiros termos e o terceiro, sem a entonação típica, apenas adiciona uma informação implicada.

A presença da partícula "até", um item que indica inclusão, contribui com a focalização e, dada sua versatilidade, acompanha qualquer espécie do enunciado. Nessa função argumentativa, contribui com a dimensão ilocutória do discurso, propiciando a transformação de parcela do enunciado em foco da informação (cf. Azeredo, 2009, p.287). Analisemos o exemplo que segue:

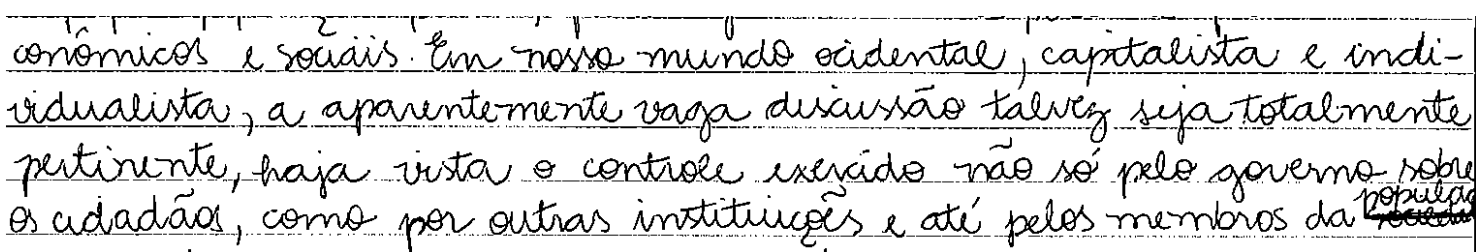

No trecho, o autor aponta que o controle é exercido: pelo governo + por outras instituições + e por membros da população. Há uma relação de base aditiva que estabelece comparações de igualdade, pois o autor distribui, em uma mesma relevância, as ações apontadas. No entanto, essa aparente igualdade se desfaz pela posição ocupada na cadeia sintática e pela marca "até", um inclusivo que permite suspeitar de uma excepcionalidade.

48 A última porção do par representa um adendo coordenativo que passa a integrar a construção correlativa. Agradeço ao professor Rosário pela crítica. 
Assim, como a avaliação do autor se faz mais presente, a porção informativa se configurará como altamente subjetiva. Por isso mesmo, é necessário reconhecer que o item "até", que tem tradicionalmente o papel de adicionar, incluir e focalizar, é um recurso persuasivo que, além de unir porções informativas, realça um posicionamento crítico, logo um ponto de vista.

\subsection{Pares correlativos consecutivos e suas funções pragmáticas}

\begin{tabular}{|c|c|c|c|c|c|c|}
\hline SEMÅNTICA & ESTRUT & 2004 & 2005 & 2006 & 2007 & \\
\hline \multirow{4}{*}{ CONSECUTIVA } & $\mathrm{T}$ & tâ๊o... que & 1 & tăo... que & 1 | ta๊o... que & \\
\hline & D & tăo... que & 4 tẫo... que & 5 tăo... que & 2 |tăo... que & 5 \\
\hline & & tal.... que & 1 de tal monta... que & 1 & & \\
\hline & C & & & tã๊o... que & 1 & \\
\hline
\end{tabular}

\begin{tabular}{|c|c|c|c|c|c|}
\hline SEMÅNTICA & ESTRUT & 2008 & 2009 & 2010 & \\
\hline \multirow{4}{*}{ CONSECUTIVA } & $\mathrm{T}$ & & & & \\
\hline & $\mathrm{D}$ & tantas $(\mathrm{N}) \ldots$ que...e & 1 & tão... que & 2 \\
\hline & & tanto $[\mathrm{N}]$... que & 1 & tanto... que & 1 \\
\hline & C & & & & \\
\hline
\end{tabular}

Quadro 7. Combinações consecutivas

O que caracteriza a marca da consecutividade é o efeito ou consequência do fato expresso na segunda porção informativa. Para Neves (1999), a intensificação baseada na relação consecutiva se caracteriza pelo estatuto do estado das coisas que remete ao resultado exercido pela intensidade do primeiro par informacional. Nesse sentido, é incontrolável que a segunda informação venha à tona como resultado da primeira.

Expresso pelos pares "tantas...que", "tão...que", "de tal modo... que", “de tal monta... que", a relação entre eles está fincada num ato intencional do autor que finaliza um esforço em querer intensificar, quantificar pelos itens do primeiro par, a fim de avaliar, deixar uma marca discursiva, presente no trato em relação ao conteúdo inserido. Deve-se lembrar, contudo, que, quando se utiliza de uma consecutiva, é porque o autor pretende, por meio da causa, mostrar o resultado de um esforço atribuído a um fato, como um jogo estratégico para argumentar. 
Ao optar pela escolha de um elemento cujo sentido, imageticamente, nos desloca de um fato, que finaliza o motivo, para outro, que desemboca na consequência, o escrevente pretende situar o leitor, intencionalmente, sobre um conhecimento que quer compartilhar para que haja a interação e, em consequência, o convencimento se faça.

\subsubsection{Tantas... que... $\mathrm{e}^{49}$}

Esse padrão produz a construção: elemento quantificador (quanto) + nome de efeito causal atrelado ao elemento (que) indicador do efeito dessa causa + elemento (e) indicador da consequência.

Parece haver um trio correlativo caracterizado na $1^{\text {a }}$ porção "tantas possibilidades", que sinaliza uma intensidade diante de "um estado de coisas" (Neves, 1999, p.913), atrelado à $2^{\mathrm{a}}$ porção que caracteriza o efeito dessa causa: "que muitas vezes, a prática vai pelo rumo contrário" e a consequência disso pelo item "e" na $3^{\mathrm{a}}$ porção: "e desemboca na estagnação". Há um processamento de informações que se deslocam como um efeito cascata:

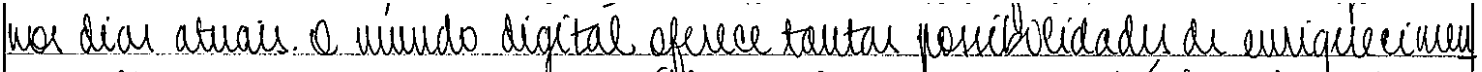
to cultural que, unitas vell, a pática, vai jelo neuro coutrario e desem boca

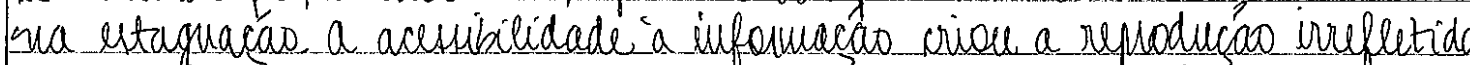
de couteudos un sumpe eqútinos. \& sitú de busca quais frequentados bo

(Exemplo 64,Fuvest, 2008, p.14)

Um recurso estratégico utilizado pelo autor é que a $2^{\mathrm{a}}$ porção informativa, como se vê no trecho apresentado, faz um movimento contrário ao que é esperado: o autor, como aponta que o mundo digital oferece tantas possibilidades de enriquecimento

\footnotetext{
49 A última porção do par representa um adendo coordenativo que passa a integrar a construção correlativa. Agradeço ao professor Rosário pela crítica.
} 
cultural...”, logo as $2^{a}$ e $3^{\text {a }}$ porções informativas deveriam vir acompanhadas também de um conteúdo que privilegiasse o mundo digital. Porém, o autor aponta que uma variedade digital poderá levar à estagnação e acessibilidade da informação, por meio dos conteúdos ilegítimos que circulam na internet.

Observe-se o esquema:

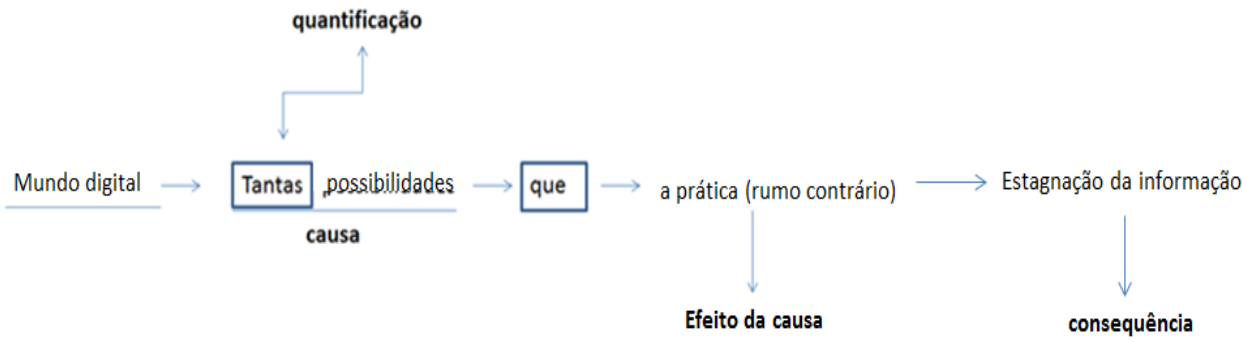

Esquema 24. Efeito cascata das correlações consecutivas

Verifica-se, assim, que a consequência apresentada se deu, inesperadamente, por meio de uma informação contrária àquela da $1^{\mathrm{a}}$ porção, o que quer dizer: um intensificador ligado a uma consequência cuja porção informativa apresenta uma ideia oposta à presente na $1^{\mathrm{a}}$ porção.

Nesse jogo, há uma relação expressa de causa, efeito dessa causa e consequência, mas com uma quebra de expectativa, pois se espera encontrar, nas $2^{\mathrm{a}}$ e $3^{\mathrm{a}}$ porções, informações que remetam à defesa das possibilidades presentes no mundo digital, e não o contrário.

Outro trecho apresentado pelo par correlativo "tanto... que" se caracteriza da seguinte forma:

I com o que entramos en contato pela internet. Trata-se do prinápió maquiavélico ' ' num modele au to - aplicado: queremos tanto a informacāo $(\mathrm{fm}$ ), gue nos despreocupamos com sev onbcisamente a como ela ternev-se disponível (meies). A falta de vigilancia epistêmica,

(Exemplo 65,Fuvest, 2008, p.18) 
Observe a sequência:

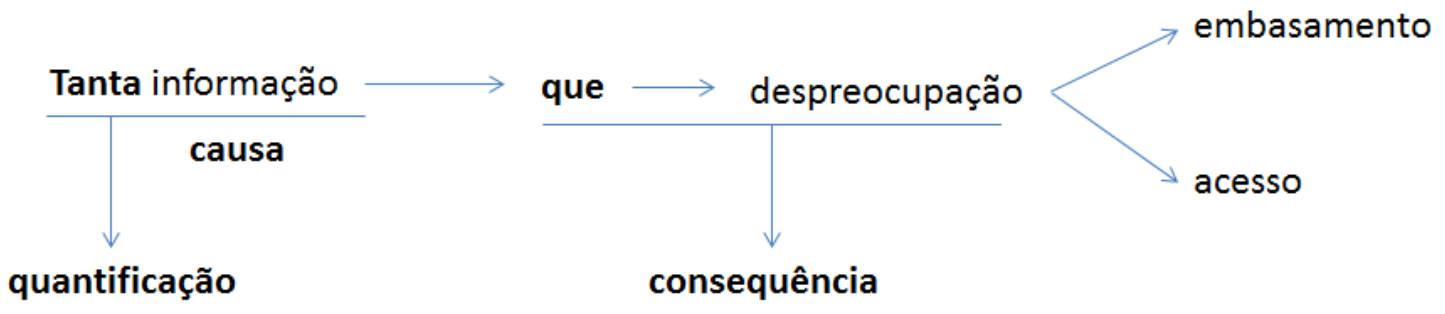

Esquema 25. Padrão da correlação consecutiva

Para Houaiss \& Villar (2001), o item "tanto/a" representa um "quantificador de intensidade" (p.2668) que parece funcionar como um marcador de argumento; isto é, o autor, ao lançar o $1^{\mathrm{o}}$ elemento do par correlativo consecutivo, encabeçando um elemento denotador intensidade e que marca uma crítica, apresenta uma opinião expressa ligada à consequência.

O par correlativo que encabeça a causa é um recurso utilizado, simplesmente, para levantar uma polêmica, pois o conteúdo principal, aquele em que consta a informação, fundada no comentário, se faz com mais material linguístico no $2^{\circ}$ elemento do par correlativo, isto é, há uma inserção de mais itens lexicais, nesse par, porque é nele que o autor apresenta maior expressividade no tocante àquilo que discute.

É importante apontar que é possível construir uma complexidade maior por meio de um trio correlativo. Entretanto, somente o $1^{\circ}$ e $2^{\circ}$ pares mantêm a entonação típica e mais correlativa. O $3^{\circ}$ par depende de compreensão maior, pois é uma ligação mais tênue, embora de maior poder de convincência.

\subsubsection{Tão... que}

Esse padrão denota um (elemento intensificador + avaliação) atrelado a um (item consecutivo (que) + informação hipotética). 
O par correlativo consecutivo "tão... que" se caracteriza por um intensificador que representa uma avaliação, um "estado de coisas" (Neves, 1999, p.913) explicitado pelo autor e em cuja sequência venha uma informação nova, mas hipotética:

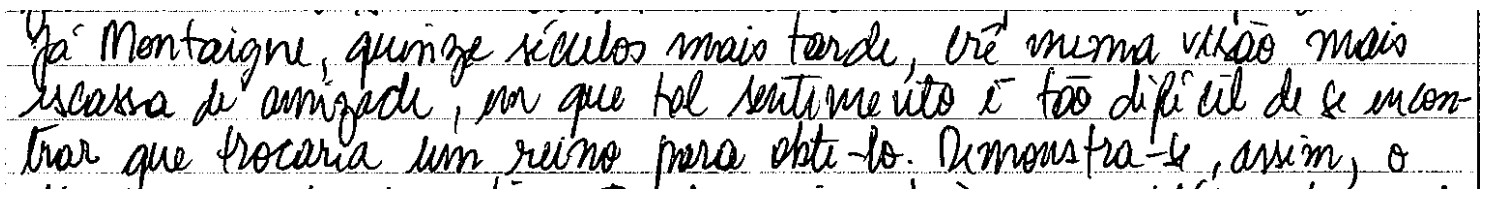

(Exemplo 66,Fuvest, 2007, p.6)

As porções informativas são encabeçadas por elementos de um par correlativo: tão (intensidade da avaliação) seguido de um item consecutivo (que). Juntos mentalmente, demonstram a contribuição do repertório do escrevente, construído sobre uma plataforma hipotética, via emprego do subjuntivo. Dessa forma, vislumbra-se a distância entre a realidade e a quimera. Com essa complexa ligação entre o real e o irreal, mas desejável, o escrevente elabora sua avaliação subjetiva, conferindo-lhe credibilidade e convincência.

Há uma ordem icônica instalada nessa relação de causa e consequência: estrategicamente, o autor lança um item carregado de subjetividade (difícil) e, logo após, lança uma informação consecutiva carregada de um "ato de fala manipulativo" (Givón, 2005). Nesse quesito da alteridade manipulada, um tema precisa vir à tona: o do envolvimento.

Para Neves (2006, p. 157): “o simples envolvimento de um falante e um ouvinte, em uma mesma situação de comunicação implica a existência de um contrato epistêmico que redefine as modalidades sentenciais em termos de conhecimento". Para Givón (1984), esse conhecimento se dá por meio de três modalidades: asseverado como real (verdade factual); conhecimento não-contestado (verdade necessária); conhecimento asseverado como irreal (verdade possível).

Quando, na $2^{\mathrm{a}}$ porção informativa, o autor lança itens lexicais que remetem a uma possibilidade, é porque o conhecimento se dá como irreal; isto é, uma proposição carregada de uma verdade condicionada a um fato possível. Sendo só uma possibilidade, não há factualidade. 
Agora é possível constatar, com clareza, que a ordem dos itens lexicais está ligada pelas atitudes, crenças e expectativas dos participantes da comunicação. Retomemos essa questão, analisando o exemplo a seguir:

média é altä. A violencia chega a miveis tấ alarmantes oue
nos impede ate mermo de sairmos de nonas caras.

(Exemplo 67,Fuvest, 2005, p.26)

Nesse trecho, o $1^{\circ}$ elemento informativo traz uma avaliação subjetiva, intensificada pelo item "tão". Esse, por sua vez, toma como escopo o adjetivo, mas acaba por impactar todo o conhecimento asseverado como real: "a violência chega a níveis tão alarmantes", e que inclui uma verdade factual: "que nos impede até mesmo de sairmos de nossas casas".

Essas proposições parecem ser escolhidas a partir de um conhecimento partilhado que se baseia nas experiências vividas pelos interlocutores; isto é, sabemos do crescimento da violência instalada no mundo atual (conhecimento real e partilhado), por isso, há uma incapacidade de contraposição quanto a essa porção presente na causa. Uma vez concordando com a causa, a consequência se torna inegável também. No caso do trecho, o impedimento de sairmos de nossas casas (verdade factual e partilhada) equivale à porção presente na consequência.

Apesar de conter uma avaliação subjetiva, o autor se encarrega de lançá-la na causa para que possa, estrategicamente, na consequência, apresentar a informação surpresa, nova, a fim de deixar uma marca de verdade na opinião expressa.

\subsubsection{De tal monta... que}

Esse padrão é sinalizado pelo elemento intensificador (avaliação sobre a causa) + elemento consecutivo irrefutável. 
O par correlativo "de tal monta...que" indica um quantificador funcionando como causa. Ao mesmo tempo, essa quantificação é subjetiva, pois não é precisa. Daí dizermos que a avaliação por parte do autor está atrelada à consequência do que foi apontado:

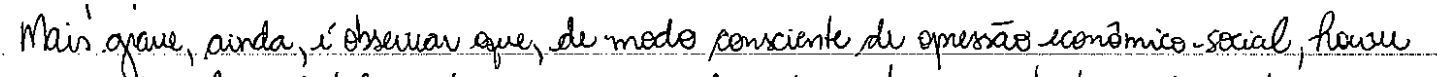
inversāo de valaes de tal monta, que passan pela patraca to nou se objelino de muitas pessoas.

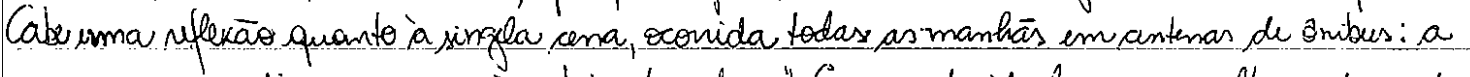
persoa pecisa pediu para passar "pou baixo da catraca". Em sew devido lugav, na altura dos per de -

(Exemplo 68, Fuvest, 2005, p.35)

$\mathrm{O}$ autor, inicialmente, explicitou a causa (inversão de valores) que remete à quantidade de pessoas que passaram a agir de modo errôneo. Sendo assim, o escrevente utilizou-se desse par correlativo para avaliar o que, negativamente, tem acontecido nas atitudes das pessoas. Logo após, na $2^{\mathrm{a}}$ porção, como consequência, argumentou que as pessoas passaram a tornar a prática de "passar por baixo da catraca" como realidade social, isto é, o resultado dessa inversão.

\subsubsection{Tal... que}

Esse padrão representa elemento intensificador (tal) atrelado a consecutivo (que).

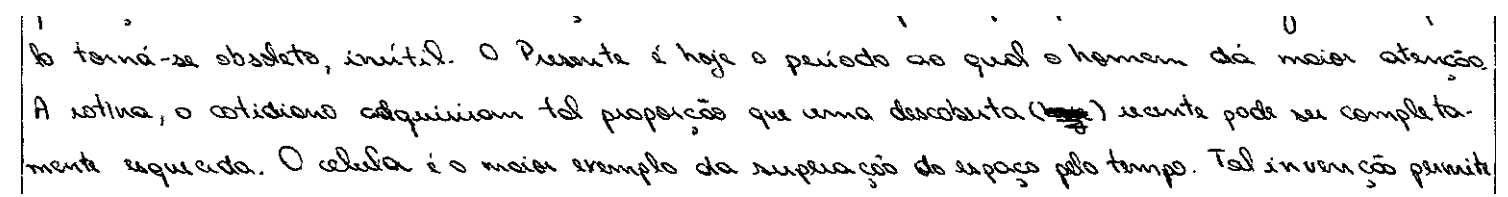

(Exemplo 69, Fuvest, 2004, p.95)

Como é sabido, mas demonstramos por meio de dados nesta seção, a consequência resulta de um fato enunciado enfaticamente, isto é, "com vigor acima do comum" (Oiticica, 1952, p.41). No trecho, o autor da redação argumenta que a rotina, 
ou seja, o cotidiano compartilhado pelas pessoas as submete ao excesso de notícias. Esse fato é tão intenso que uma descoberta ou um fato novo pode ser esquecido ou se tornar invisível. A proporção parece ser a estratégia ideal para lidar com essa combinação porque ela permite apresentar o "efeito causado, importância" (Houaiss \& Villar, 2001, p.2313).

Existe também, na $1^{\mathrm{a}}$ porção informativa, uma avaliação feita pelo autor, de forma que parece chamar a atenção do seu interlocutor por meio do verbo "adquirir", que, segundo Houaiss \& Villar (2001), significa "passar a ter ou apresentar novas características". Em consonância a isso, a ideia de que antigamente o tempo presente não era tão fugaz, como o é hoje, é uma avaliação plausível com a ocorrência do verbo adquirir.

\subsection{Pares correlativos alternativos e suas funções pragmáticas}

\begin{tabular}{|c|c|c|c|c|c|c|c|c|c|}
\hline SEMÁNTICA & ESTRUT. & 2004 & & 2005 & & 2006 & & 2007 & \\
\hline & $\mathrm{T}$ & seja... seja & 1 & seja... seja & 2 & seja... ov 5 & 5 & seja... ov & 2 \\
\hline & & & & ora... ora & 1 & quer $(\mathrm{V}) \ldots$ ov $(\mathrm{V})$ & 1 & seja... seja & 1 \\
\hline & & & & ov... ov & 1 & & & ora $\ldots$ ora $\ldots$ & 1 \\
\hline & & & & seja... ov & 1 & & & & \\
\hline & $\mathrm{D}$ & seja... ov & 5 & ora... ora & 2 & $\operatorname{seja} \ldots$ ov 2 & 2 & quer... ov & 1 \\
\hline \multirow[t]{7}{*}{ ALTERNATIVA } & & ora... ora & 1 & seja... seja & 2 & & & seja... ov & 6 \\
\hline & & ov... ov & 1 & seja... seja... seja & 1 & & & ov... ov & 1 \\
\hline & & & & $\operatorname{sej} \mathrm{a}(\mathrm{m}) \ldots$ ov & 2 & & & seja... seja... seja & 2 \\
\hline & $\mathrm{c}$ & quer seja... quer seja & 1 & seja... ov & 4 & seja... of 4 & 4 & ora... ora & 1 \\
\hline & & ov... ov & 1 & ov... ov & 2 & & & seja... ov... & 1 \\
\hline & & seja $(m) \ldots$ ov & 5 & & & & & & \\
\hline & & quer... ov & 1 & & & & & & \\
\hline
\end{tabular}

\begin{tabular}{|c|c|c|c|c|c|c|c|}
\hline SEMÁNTICA & ESTRUT. & 2008 & & 2009 & & 2010 & \\
\hline & $\mathrm{T}$ & seja.. ou & 3 & seja... seja & 2 & sejam... ov & 2 \\
\hline & & & & seja... ov & 3 & seja... ov & 3 \\
\hline & & & & quer... quer & 1 & & \\
\hline & & & & sejam... ov & 2 & & \\
\hline & $\mathrm{D}$ & seja... seja & 2 & seja... ov & 6 & seja... ov & 3 \\
\hline \multirow[t]{7}{*}{ ALTERNATIVA } & & & & seja... seja & 6 & sejam... ov & 1 \\
\hline & & & & ov... ov & 1 & ov... ov & 1 \\
\hline & & & & quer... quer & 1 & & \\
\hline & $\mathrm{C}$ & seja... seja & 1 & seja... ov & 5 & seja... ov & 4 \\
\hline & & & & sejamos... ov & 1 & seja... seja & 1 \\
\hline & & & & sejam... ov & 2 & & \\
\hline & & & & seja... seja... ov & 1 & & \\
\hline
\end{tabular}

Quadro 8: Pares correlativos alternativos 
Os pares correlativos alternativos enlaçam unidades, entre porções informativas, matizando-as de um valor alternativo, para exprimir quer "a incompatibilidade dos conceitos envolvidos" (Bechara, 2001, p.321), quer uma relação equitativa entre eles.

Apesar de considerado, por excelência, o item "ou" como a prototípica alternativa característica que marca "disjunção" (Neves, 1999, p.771), outros itens lexicais foram encontrados como elementos funcionais, que também fazem por meio da combinação o papel da alternância: "seja... ou", "seja... seja", "quer... ou”, "quer seja... quer seja", "ora... ora", "quer... quer". Essa parceria de itens gêmeos, contudo, não é condição sine qua non para a correlação alternativa.

Essa construção permite a compreensão de que essa combinação (às vezes gêmea) sinaliza intenções comunicativas para atender às expectativas do autor, em primeiro lugar. Para isso, a própria escolha da distribuição de porções informacionais alternadas, da escolha de um item alternativo, que funciona como um focalizador, avaliação do autor, contida entre os pares, por meio dos conteúdos que se alternam, são inerentes a um fenômeno calcado no uso.

\subsubsection{Ou... ou}

Esse padrão representa um item disjuntivo atrelado a item disjuntivo exclusivo.

Segundo Neves (1999, p.771), Bechara (2009, p.656), a correlativa “ou” indica uma disjunção exclusiva, em que os elementos, apesar de se excluírem, mantêm uma "simetria entre os membros da disjunção que podem facilmente permutar de posição, com resultado de sentido que difere apenas do ponto de vista da distribuição da informação" (cf. Neves, 1999, p. 782):

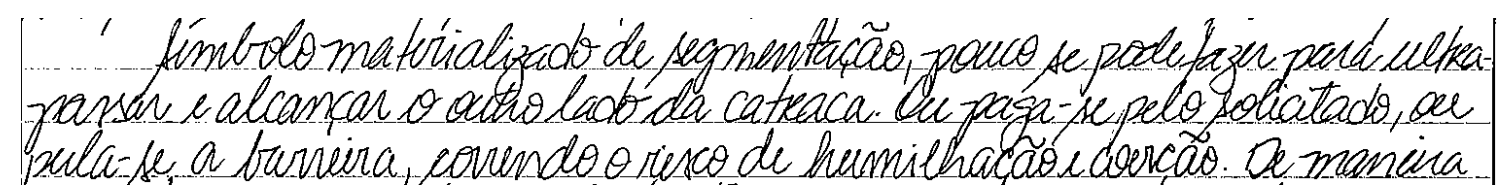

(Exemplo 70,Fuvest, 2005, p.85) 
A ordem da escolha das porções informativas é composta por intenções demarcadas, pois, apesar de se relacionarem, a primeira aparece como um fato que é autorizado institucionalmente pela sociedade; é aquilo que todo leitor espera como comportamento ideal dentro de um grupo social; no $2^{\circ}$, o contrário, apresenta um fato, comportamento, atitude inversa, socialmente. Estrategicamente, o escrevente lança o primeiro par alternativo para sinalizar o que é ideologicamente correto: no trecho analisado, a catraca, considerada um símbolo de materialidade segmentada, ou seja, acesso restrito a todos, ou se obedece e se joga para poder ter acesso a ela, ou se desrespeita, mas sabe-se do risco eminente de coerção pela desobediência.

Apesar de haver a possibilidade de permutar as porções informativas, o autor lança, primeiramente, aquela que é socialmente aceita. Dessa forma, coloca em campo um jogo persuasivo e sinalizado.

\subsubsection{Seja... seja}

Seja... seja... seja

Esse padrão apresenta focalizador alternativo atrelado a focalizador alternativo.

Segundo Houaiss \& Villar (2001), o item "seja" serve para ligar elementos ou enunciados, indicando ênfase (focalização) antes de cada termo da alternativa; ou seja, há também marcas de intenções que levam o autor à opção da distribuição entre as porções informativas. Analisemos os dados seguintes:

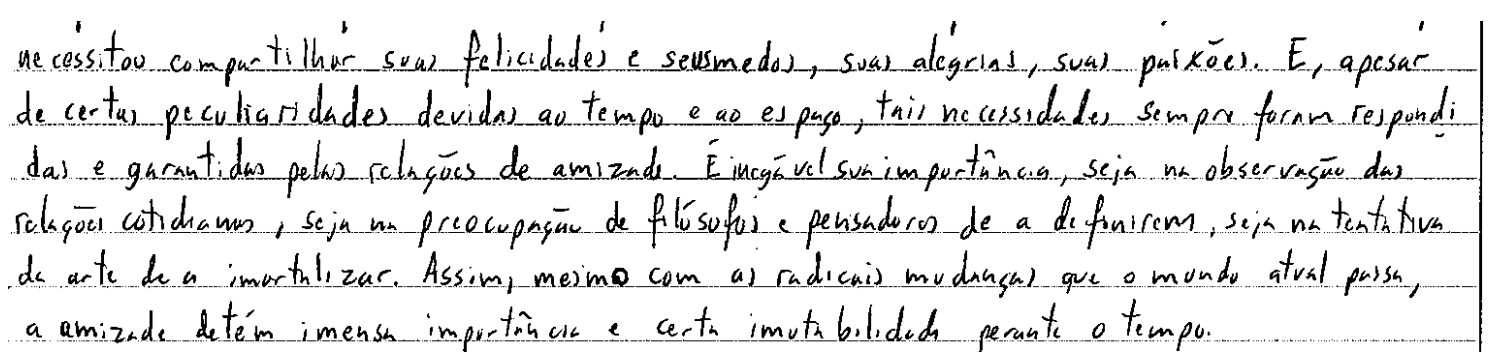


A iusaú existente 'quanto à garantia da liberdade de se expressar foi rompida no estabelecimento da democracia. O homem teve a percepcão, com tal ruptura, dachance de abor dár assuntos de qualquer maneira, seja verdade, seja uma afirmativa falsa. Há, na linternet e

(Exemplo 72,Fuvest, 2008, p.88)

Quanto ao par "seja...seja”, além da preocupação do autor em validar a primeira porção informativa, no $1^{\circ}$ par, como aquela democraticamente correta, verifica-se também que existe uma avaliação embutida nessa opção, tem-se um posicionamento, um índice de autoria fortalecido.

No trecho de 2007, a opção por inserir três elementos correlacionados "seja" se deu a partir da focalização a respeito da importância da amizade. Estrategicamente, o autor quer explicar por quais caminhos e alternativas vê a amizade, frente ao tempo e ao espaço, como instrumento relevante. Ao lançar opções, o autor quis minimizar qualquer possibilidade da não aceitabilidade, pelo leitor, de encarar a amizade como uma ação inerente à condição humana; e, por isso, lança a alternativa "seja", como um recurso persuasivo.

No trecho de 2008, o autor aponta o rompimento da ilusão quanto à liberdade de expressão na busca pela democracia, pois o homem, dentro desse cenário, pôde optar pela verdade ou pela afirmativa falsa, uma escolha que fez. É interessante que, dentre as opções, o autor lançou no $1^{\text {o }}$ item "seja" junto do item "verdade", que, segundo Bechara, "revela um princípio moral fundamentado na crença, atitude" (2009, p.902) de alguém frente às ações. O escrevente adapta a argumentação e demonstra, com isso, querer preservar sua imagem, optando por inserir um item que carreie a imagem positiva. 


\subsubsection{Quer...quer}

Segundo Houaiss \& Villar (2001), o item “quer" alternativo tem sua base calcada no sentido de "buscar, procurar, esforçar-se, procurar obter, procurar saber, pedir, requerer" (p.2354). Isso quer dizer que, ao lançar esse par como opção para sustentar seu posicionamento frente ao que se discute, o autor lança porções informativas que remetem a essa questão:

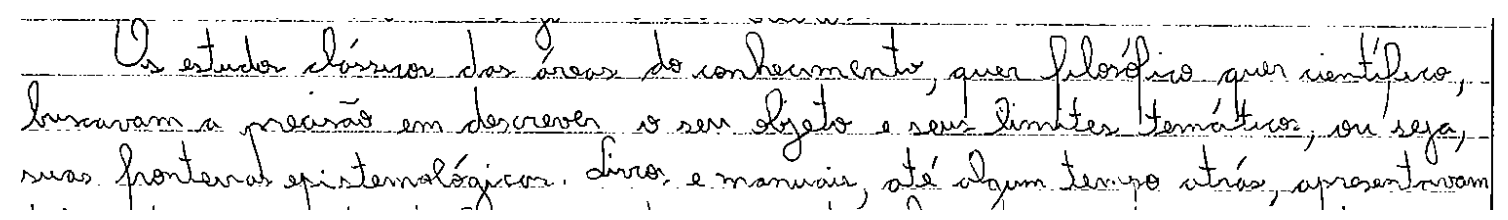

(Exemplo 73, Fuvest, 2009, p.88)

Verifica-se que a intenção de lançar duas porções informativas entre os pares alternativos "quer... quer", no trecho do texto de 2009, analisado, é porque o escrevente, ao apontar a precisão do ato de descrever o objeto de estudo, ligado aos estudos clássicos da área do conhecimento, busca entre os pares alternativos inserir, como material linguístico, os itens "filosófico" e "científico", com o objetivo de mostrar que, em qualquer área em que se procure obter conhecimento, a descrição fará parte desse processo.

\subsubsection{Quer seja... quer seja}

Outra estratégia utilizada pelo autor foi a de lançar um par informativo constituído por dois itens que se combinam:

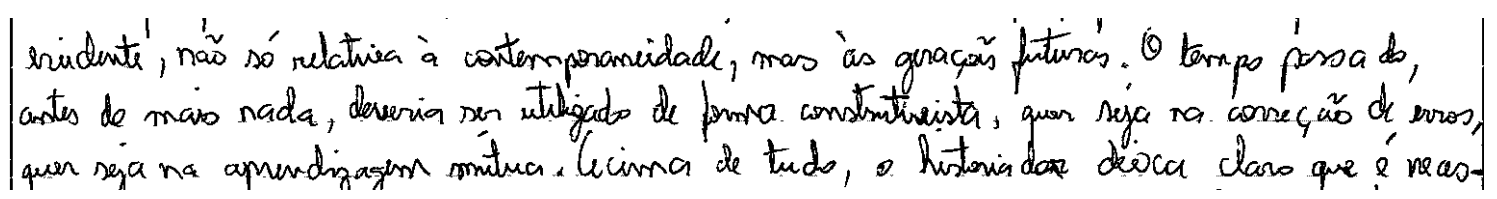

(Exemplo 74,Fuvest, 2004, p.6) 
O item "quer", faz com que o leitor busque possibilidades na aprendizagem de encontrar no tempo uma forma construtivista de se viver, e também pelo item "seja", focaliza, dá um caráter enfático para cada um dos itens distribuídos entre os pares.

\subsubsection{Ora... ora}

O par correlativo alternativo “ora... ora", segundo Houaiss e Villar (2001), serve para ligar palavras ou enunciados seguidos, com valor de alternância. Especifica as porções informativas presentes entre os itens correlativos como recurso argumentativo para mostrar, que, independentemente do conteúdo inserido, a informação seguida a cada um deles se encaixa, serve como referência para o leitor:

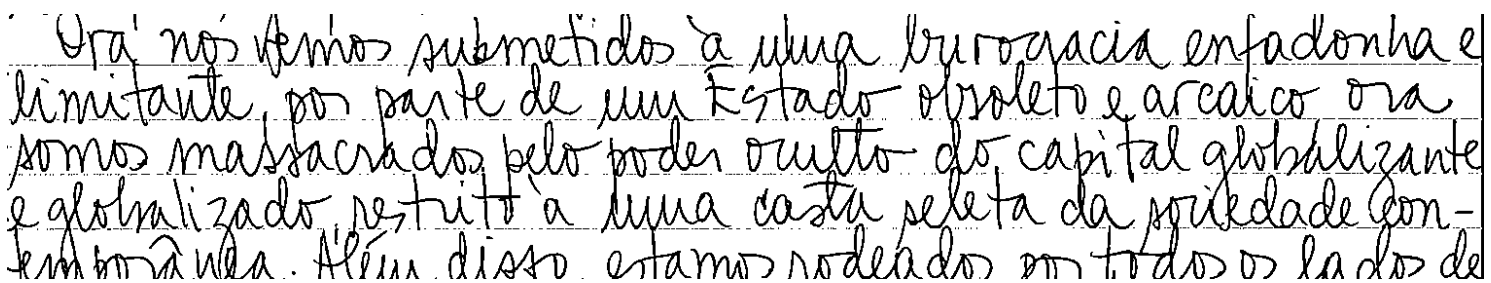

(Exemplo 75, Fuvest, 2005, p.17)

O escrevente, ao discutir as influências pelas quais nos leva a viver sob a forma de controle, pode, pela simbologia da catraca, apontar dois aspectos específicos que, alternativamente, não nos deixa escapar do controle da seleta casta da sociedade contemporânea. Os argumentativos apresentados, sob a forma de alternativas, que enriquecem mais a discussão oferecida pelo autor. É uma estratégia discursiva que tem como foco apresentar possibilidades, e mesmo descartada uma delas, a outra servirá para que o leitor possa aceitar e entender como parte da discussão.

\subsubsection{Seja... ou}

Sejam... ou 
Os correlativos alternativos "seja...ou", "sejam...ou" e "seja...seja...ou" ligam porções informacionais que servem de especificadores por meio de fatos, pontos de vista, como estratégia argumentativa.

O trecho seguido de "seja... ou", que tem como objetivo encerrar a discussão a respeito das condições de acesso à informação que teremos no futuro, estabelece uma relação contrária: de um lado, aponta que poderemos ter acesso à informação com base científica; do outro, uma informação simples, opinião pessoal. Observe-se o esquema do trecho a seguir:

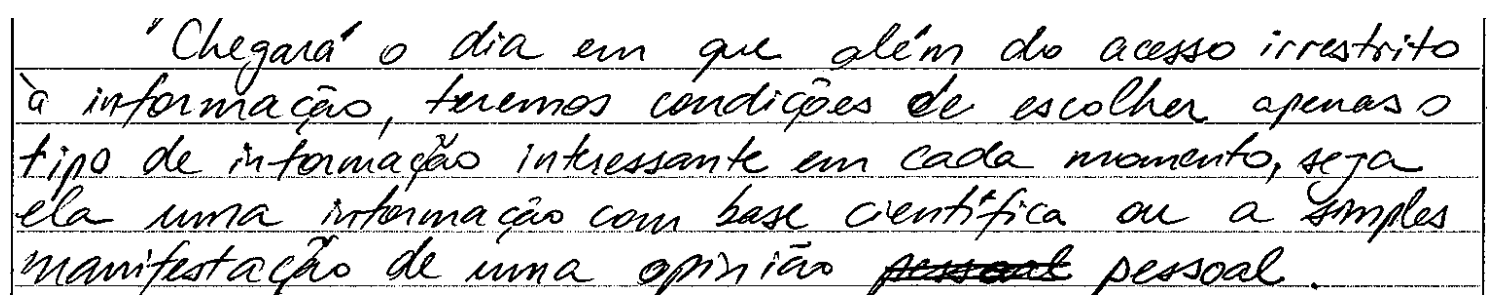

(Exemplo 76,Fuvest, 2008, p.89)

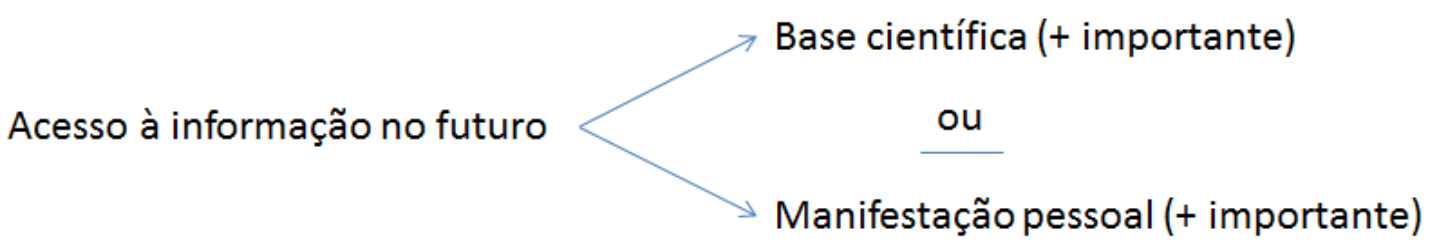

Esquema 26. Construção da correlação alternativa

Há um jogo estratégico-discursivo feito pelo autor, que lança duas informações que se alternam, mas que possuem escalas de avaliação diferentes e podem também assumir a mesma importância pela proximidade de sentidos, como no caso do par "sejam... ou":

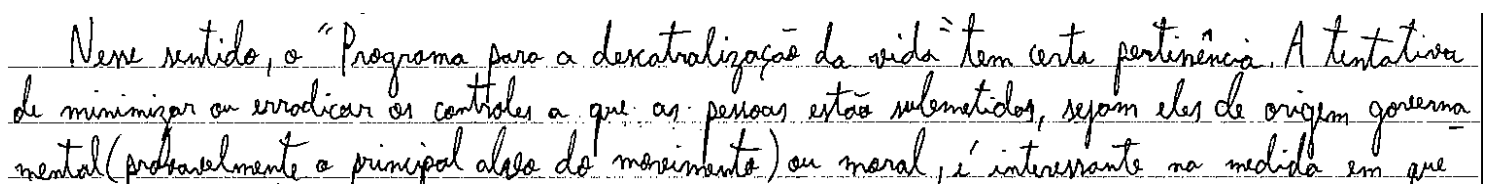


O par correlativo "sejam... ou", nesse trecho, estabelece uma relação que tanto o conteúdo informativo referente ao $1^{\circ}$ elemento do par como no $2^{\circ}$ elemento mantêm uma proximidade entre os itens lexicais. Apesar da opção de inserção de cada conteúdo feito pelo autor, tem uma intenção estabelecida; isto é, aponta que pessoas estão submetidas ao controle governamental ou passam também a ser monitoradas pelo controle moral.

A escolha pela inserção dos itens "origem governamental", provavelmente se deu, porque, ao nos atermos à discussão sobre obstáculos que a sociedade nos impõe, sobre as "catracas", que nos impedem de realizarmos nossas ações individuais, a imagem das instituições públicas, materializadas pela imagem do governo, logo nos vem à mente. Mas a questão da "moralidade" apontada, posteriormente, também se insere dentro desse cenário imagético; ambos os itens caberiam dentro desse par correlativo alternativo, que viabiliza pela proximidade das escolhas lexicais.

O terceiro par representa três alternativas e consubstanciam-se identicamente a esses pares.

\subsubsection{Quer sejam... ou}

O par correlativo alternativo "quer sejam... ou" simboliza opções de escolhas, mas com algumas características peculiares: existe uma avaliação por parte do autor, que auxilia na manutenção argumentativa; o item "quer" permite reconhecer uma constatação direcionada no sentido de esforçar-se para desejar, querer:

Todos as concepcos de amizaces, desele a antigividade até os dias de hoje, convergem para u iduia de

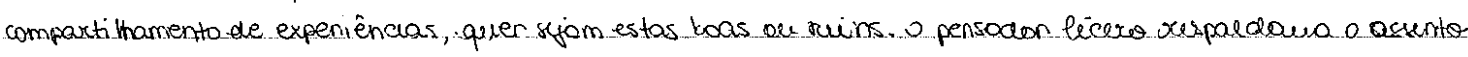


Nesse trecho, os itens "boas" ou "ruins" indicam uma avaliação realizada pelo autor frente ao conceito de amizade e do compartilhamento de experiências, atrelado a ela. O escrevente utiliza-se da alternância para enxertar entre os itens, qualificadores, com o objetivo de transmitir para seu leitor que, independentemente das relações experenciadas, elas convergem para um compartilhamento de amizades. $\mathrm{O}$ autor optou por inserir o qualificador "boas" como $1^{\circ}$ elemento do par correlativo sinalizado sua crença em que o leitor também tenha uma concepção de amizade ligada, primeiramente, à fraternidade e, por isso, lança, intencionalmente, esse qualificador.

\subsubsection{Quer (V)... ou não (V)}

Esse padrão produz item alternativo seguido de verbo atrelado a um item alternativo com polaridade negativa elíptica do verbo.

O par correlativo "quer (V)... ou (não + elipse do verbo) tem na alternatividade uma polaridade instalada com o objetivo de enfatizar a ação atrelada a uma escolha por meio de identidade verbal atrelada a um circunstanciador:

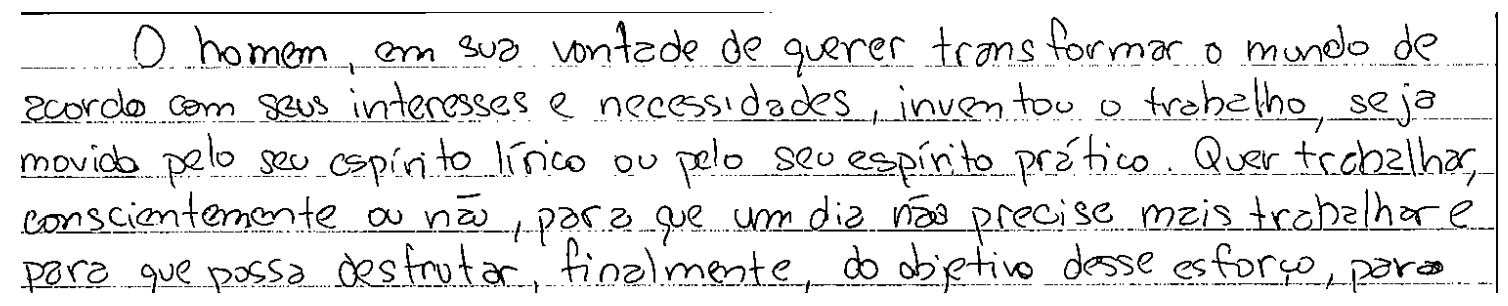

(Exemplo 79,Fuvest, 2006, p.35)

Enfatiza-se a identidade do verbo "trabalhar" por meio de uma polaridade calcada na alternatividade com o objetivo de mostrar que, independentemente, da escolha feita, consciente ou não, ao final há uma recompensa por conta da atividade exercida, ao longo da vida.

Os dois pares correlativos alternativos permitem a inserção de um conteúdo linguístico, mas que intencionalmente direcionam a opção do escrevente, que parece 
priorizar trabalho, como uma atividade inerente ao homem; isto é, defende a ideia de que se deva exercê-lo, por isso, lança no item volitivo "quer" o conteúdo com sentido de esforço, querer, desejar, que parece focalizar o verbo "trabalhar".

\subsection{Pares correlativos comparativos e suas funções pragmáticas}

\begin{tabular}{|c|c|c|c|c|c|c|c|c|c|}
\hline SEMÁNTICA & ESTRUT. & 2004 & & 2005 & & 2006 & & 2007 & \\
\hline & $\mathrm{T}$ & mais... do que & 1 & tão... quanto & 1 & & & tão... quanto & 1 \\
\hline & & tanto... quanto & 1 & & & & & mais... que & 1 \\
\hline & D & mais... que & 1 & mais... do que & 4 & $\begin{array}{ll}\text { mais... do que } & 6\end{array}$ & 6 & tão... quanto & 4 \\
\hline \multirow[t]{10}{*}{ COMPARATIVA } & & tão... quanto & 2 & mais... que & 1 & mais... que 2 & 2 & mais... do que & 5 \\
\hline & & mais... do que & 5 & & & & & mais... que & 3 \\
\hline & & tanto... quanto & 1 & & & & & tão... como & 2 \\
\hline & c & mais... do que & 3 & & & mais... do que 1 & 1 & tão... quanto & 3 \\
\hline & & mais... que & 1 & & & & & mais... que & 1 \\
\hline & & assim como só... só & 1 & & & & & & \\
\hline & & tanto... como & 1 & & & & & & \\
\hline & & tanto... quanto & 1 & & & & & & \\
\hline & $\mathrm{T}$ & & & tão... quanto & 1 & & & & \\
\hline & & & & nem mesmo... quanto mais & 1 & & & & \\
\hline \multirow{3}{*}{$\begin{array}{l}\text { COMPARATIVA } \\
\text { PROPORCIONAL }\end{array}$} & $\mathrm{D}$ & & & tão... quanto & 1 & tanto... quanto 1 & 1 & tão... quanto & 1 \\
\hline & & & & & & & & & \\
\hline & c & & & tão... quanto & & tanto... quanto 1 & & & \\
\hline
\end{tabular}

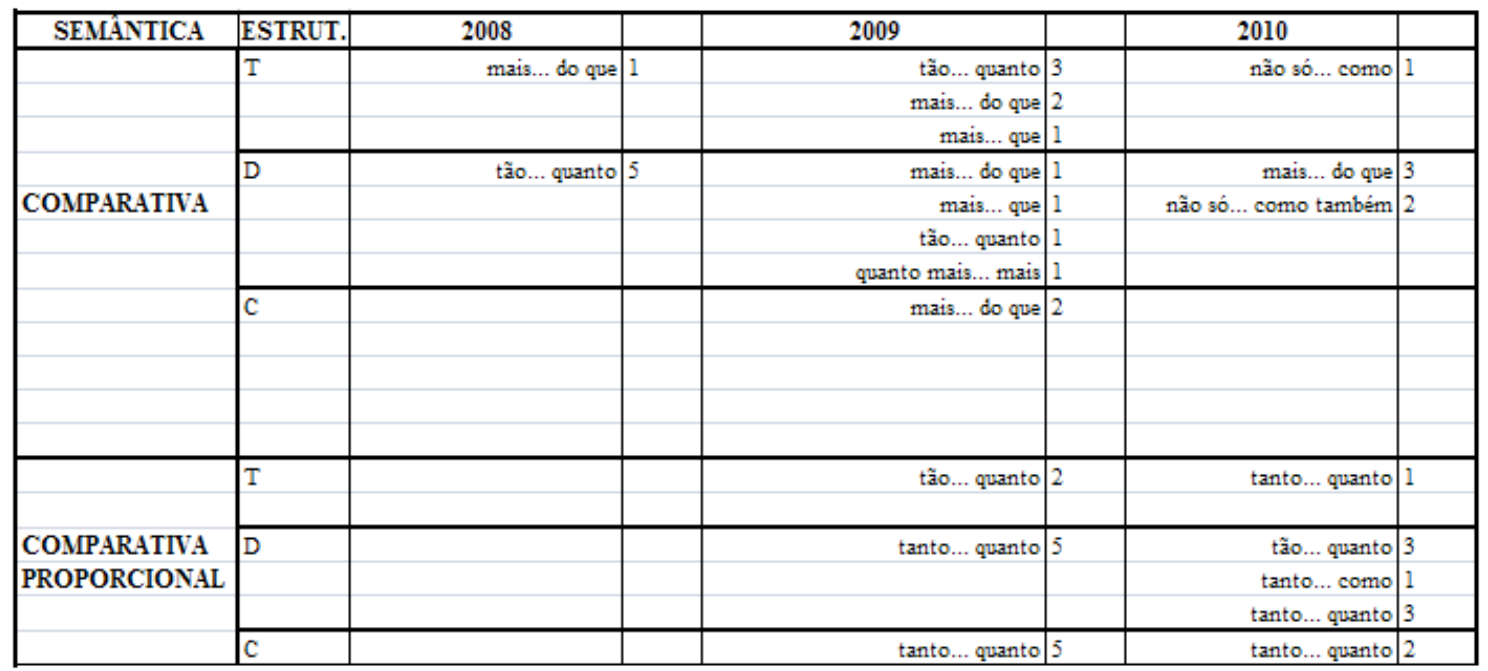

Quadro 9. Pares correlativos comparativos

O quadro anterior representa os padrões dos pares correlativos comparativos que, apesar de apresentarem-se sob a forma-base (dois membros que, paralelamente, 
possuem uma característica em comum por meio de evento atrelado a outro, assumem outros papéis/ funções, por conta das necessidades comunicacionais do falante.

Ao comparar porções informativas, por exemplo, anteriormente, adicionam-se, correlacionam-se eventos. Estes, ao carregarem uma particularidade comum, produzem uma comparação que poderá desembocar numa proporcionalidade, a fim de enfatizar, equilibrar itens lexicais de conteúdo informacional, que tanto priorizarão a $1^{\mathrm{a}}$ como a $2^{\mathrm{a}}$ porção.

Ao se utilizar da comparação para argumentar, por exemplo, o falante/ escrevente usa pares correlativos encabeçados por focalizadores. Esse recurso serve para direcionar uma atenção conjunta entre ele e seu interlocutor, a fim de, por exemplo, lançar, na outra porção do par correlativo, uma informação nova, surpreendente. Isso é um indício de que usos mais prototípicos estão se recombinando com outros itens menos prototípicos, a fim de que atendam às necessidades discursivo-pragmáticas do autor, que, num jogo interacional, contribui para que haja uma comunicação.

\subsubsection{Mais... do que \\ Mais... que}

Esse padrão é representado pelo item comparativo focalizador atrelado a item comparativo.

A base de comparação está em "dois membros que têm algo em comum" (Neves, 1999, p.894). Segundo a autora ainda, o mecanismo de comparação pode ser explicitado da seguinte forma: existe um elemento de contraste que pode ser apresentado tanto na forma de desigualdade (superioridade ou inferioridade) como pode indica forma de igualdade. Existem "eventos paralelos" (Neves, 1999, p.895) ligados aos membros comparados que se diferem por meio de dois constituintes entre dois sintagmas nominais que possuem uma qualidade, característica em comum. Há uma extensão construcional em que a natureza do $1^{\circ}$ elemento do par correlativo está calcada 
na do $2^{\circ}$ elemento, em que o intensificador atrelado ao comparativo indica marcador de foco:

ASSIM, ATIRMAR QVE SE TRATA dE UMA INVENGẼ HISTÓfICA, QVE "PODE SER THANSFORMADO E MESMO DESAPARECEF" TALVEZ SEJA UMA REFLEXÁ MVITO MAIS ATR ELADA AOS MODOS DE PROBUGĀO (COMO FEUDALISMO EOCAPMTALISMO DA ATUALIDADE) DO QNE TO SENTIDO MATS

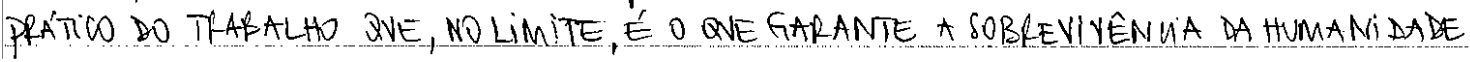

(Exemplo 80,Fuvest, 2006, p.64)

Percebe-se, nesse trecho, que existe um intensificador "mais" atrelado à informação comparada por meio do "elemento de contraste" do que. Há uma intenção do autor em comparar as duas porções informativas a respeito da ideia comum que se tem a respeito de que a função do trabalho pode desaparecer; em que, de um lado, parece criticar que essa questão, muitas vezes considerada filosófica, é um mito calcado na invenção histórica; do outro lado, parece defender a praticidade do trabalho como forma de subsistência.

Com isso, ao comparar as duas porções informativas, coloca em foco a $1^{\text {a }}$, que, atrelada à $2^{\mathrm{a}}$, produz um desnivelamento entre elas. Um jogo estratégico do autor para criticar aqueles que veem o fim da atividade do ato de trabalhar simplesmente como mera reflexão, distante da realidade contemporânea.

Outro trecho exemplificador correlativo comparativo é formado por "mais... que", baseado na "relação de interdependência entre os termos postos em confronto" (Neves, 1999, p.894). A porção informativa do $2^{\circ}$ elemento do par apresenta "uma redução de volume" (p.894), também considerada uma estratégia persuasiva:

Gres exemplos demenstram que, para a população, as fronteiras sócio- culturais säo mais concretas e significativas que as geo políti cas. Apesar

(Exemplo 81,Fuvest, 2009, p.20)

Verifica-se que, com o intensificador "mais", o autor estabelece a comparação atrelada ao item "que", por meio de uma estratégia: insere mais conteúdo no $1^{\circ}$ elemento do par porque é nele que apresenta fatos positivos em relação àquilo que pensa 
sobre as fronteiras, isto é, no intensificador lança mais informações intencionalmente, pois acredita ser o momento e o local apropriados para sair em defesa do seu ponto de vista. A redução de volume no $2^{\circ}$ elemento do par "geopolíticas" auxilia para que essa estratégia tenha credibilidade e força argumentativa.

\subsubsection{Tão... quanto \\ Tão... como}

Esse padrão é composto por elemento comparativo focalizador avaliativo atrelado a elemento comparativo.

Para esses pares correlativos comparativos, o intensificador "tão", acompanhado do seu comparativo, assume o papel de marcador de foco, em que existe uma avaliação do autor de um ponto de vista que, ao comparar com o $2^{\circ}$ elemento do par (quanto/como), o faz simplesmente como jogo argumentativo. Dessa forma, estabelece semelhanças entre os fatos, mas enfatiza, pelo $1^{\circ}$ par, aquilo que pretende convencer o leitor a respeito do que se discute, isto é, "enfatiza o $1^{\circ}$ membro do cotejo" (Neves, 1999, p.901):

\section{Trecho 1}

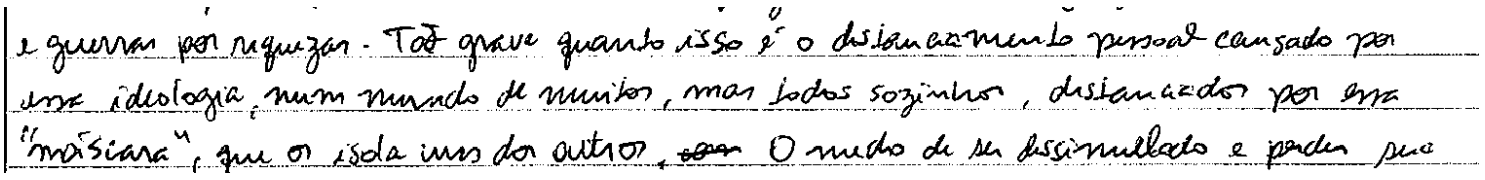

\section{Trecho 2}

eles. Nom ambiente tó multifacetado como 0 atud thar as próximo e ver nele um retrato de si mesmo serve como a bencäa que diz ná estarmos absolutamente sós. 
Observe-se o esquema:

$\underline{\text { Trecho } 1}$

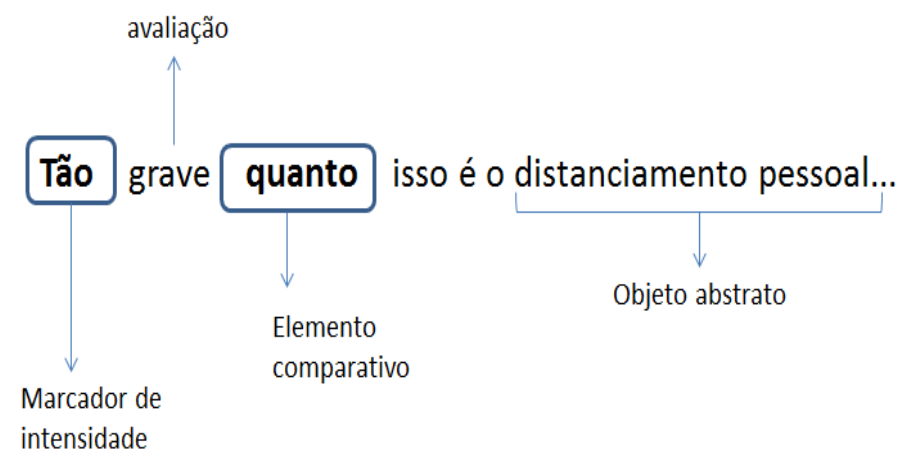

Esquema 27. Avaliação na correlação comparativa

\section{Trecho 2}

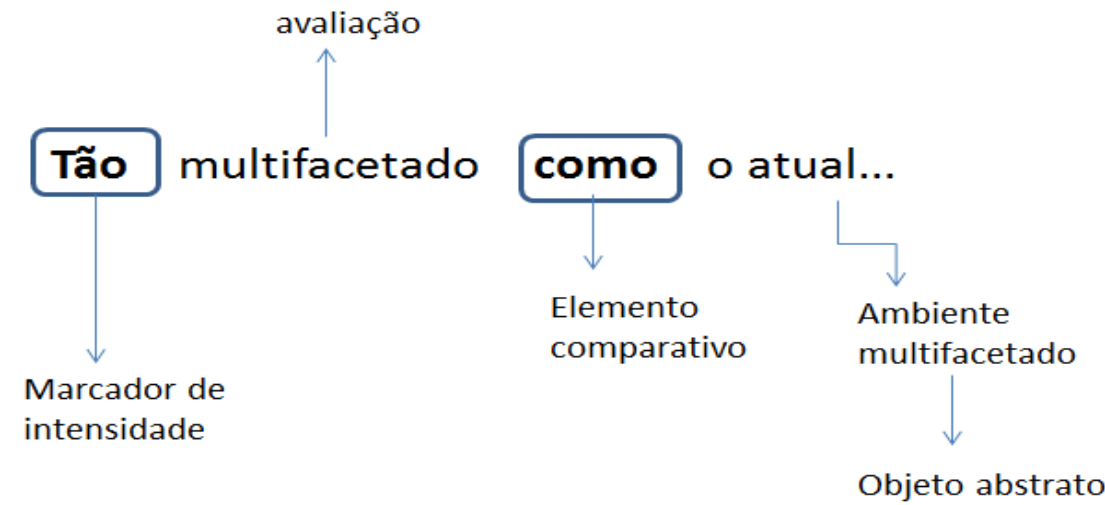

Esquema 28. Avaliação na correlação comparativa

Há alguns pontos em comum que caracterizam o par correlativo comparativo: o $1^{\mathrm{o}}$ par intensificador (tão) serve de instrumento avaliativo, há um posicionamento do autor frente ao que se discute e, provavelmente, por isso, é que optou em encabeçar, linearmente, um marcador + avaliação, seguido de um objeto abstrato com um comentário argumentativo. 
Já no $2^{\circ}$ elemento do par comparativo, opta por inserir mais material linguístico, encabeçado por objeto abstrato com a finalidade de tornar mais complexo, profundo, persuasivo, o que se discute: um recurso altamente discursivo e pragmático.

\subsubsection{Quanto mais... mais}

Esse padrão é representado por quantificador atrelado a um intensificador seguido de outro intensificador comparativo.

Esse par correlativo comparativo é constituído de dois intensificadores que sinalizam ações paralelas que co-ocorrem simultaneamente num equilíbrio de porções informativas, em que "características, atitudes e valores embutidos nas ações humanas estão inerentes a um grupo de indivíduos ou vice-versa" (Neves, 1999, p.902):

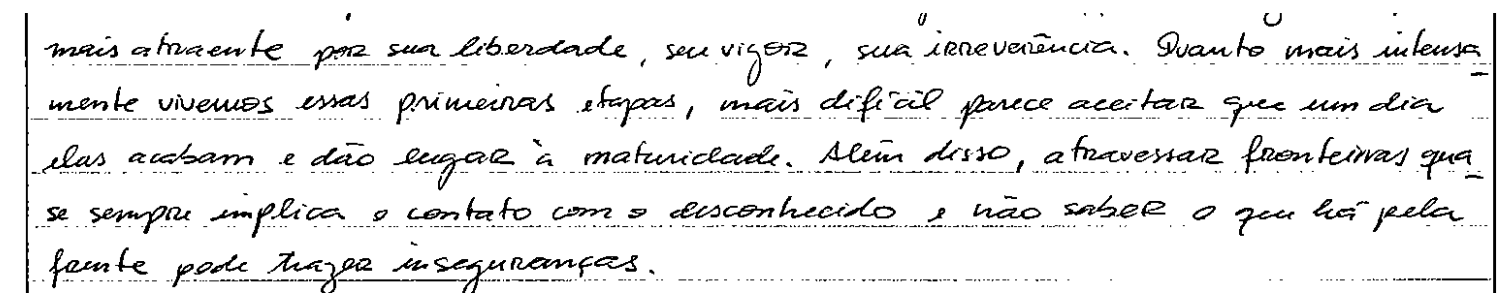

(Exemplo 84, Fuvest, 2009, p.89)

Verifica-se, no trecho, que os itens no $1^{\circ}$ item do par (intensamente vivemos...) atrelado ao $2^{\circ}$ elemento do par (mais difícil...) são propriedades típicas da juventude (grupo de indivíduos). O intensificador parece contribuir para que se instale uma relação de causa (mais intensamente vivemos...) e consequência (mais difícil acertar..) 


\subsection{Par Correlativo Comparativo-Proporcional}

\subsubsection{Quanto mais... mais}

Esse padrão inclui quantificador seguido de intensificador atrelado a intensificador proporcional.

O que caracteriza o par correlativo comparativo proporcional é que, além da relação próxima que os pares correlatos, nos remete quanto a características comuns, ligados a um objeto/ indivíduo, iconicamente, há uma combinação entre itens lexicais que se aproximam e sugerem em equilíbrio de ordem numérica, entre as partes que se relacionam, imageticamente:

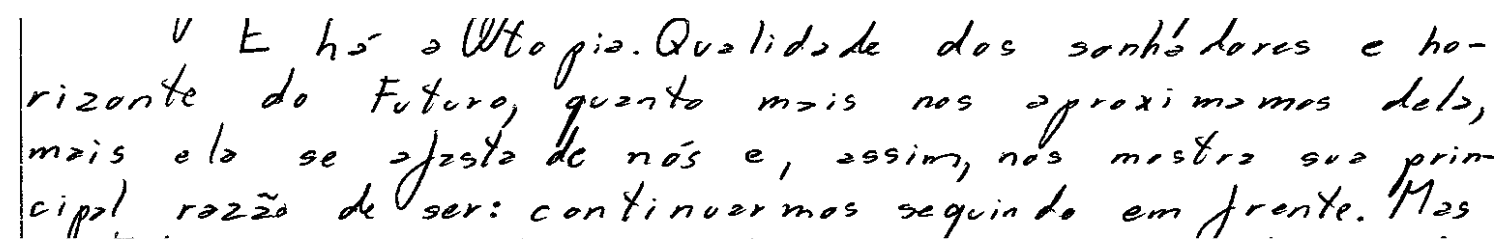

(Exemplo 85, Fuvest, 2004, p.79)

Percebe-se que os itens dos pares tratam da questão da utopia: quanto mais nos aproximamos dela, mais ela se afasta. Isso nos dá razão para continuarmos seguindo em frente. Os itens "aproximamos", "afastar", "seguir em frente" nos remetem a um deslocamento de espaço que imageticamente nos leva a pensar em quantidade, apesar de abstrato.

\subsubsection{Assim como só... só}


Esse padrão é constituído por elemento comparativo focalizador atrelado a elemento focalizador.

Nesses pares correlativos, o focalizador "só" assume um papel de sinalizador que remete à informação contida na $1^{\circ}$ porção, de forma a direcionar a atenção para o leitor. No $2^{\circ}$ elemento do par, o focalizador "só" refere-se ao que foi destacado na $1^{\text {a }}$ porção; isto é, mantem, paralelamente, uma proximidade entre as porções, apesar do elemento enfático, intencionalmente:

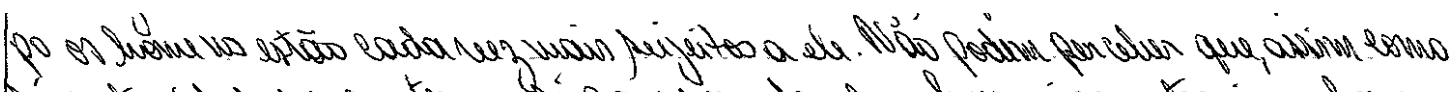

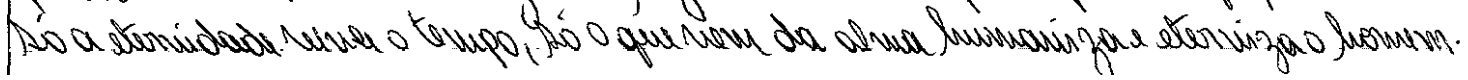

(Exemplo 86, Fuvest, 2004, p.71)

Esse par apresenta dois focalizadores que, linearmente, relacionam duas palavras que aproximam pelas porções informativas: eternidade $\left(1^{\circ}\right.$ item $)$ e alma humanizada $\left(2^{\circ}\right.$ elemento do par).

\subsubsection{Não só... como também}

Não só... como

Esse padrão revela-se pelo sequenciamento de um polarizador (não) + focalizador (só) atrelado a elemento comparativo e tem o papel de direcionar a atenção do leitor por meio de itens lexicais específicos que convergem a um mesmo conceito geral, isto é, dois itens que proporcionalmente se referem a um item geral: 


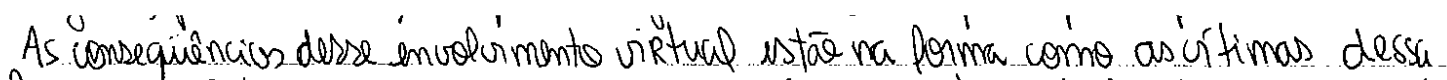

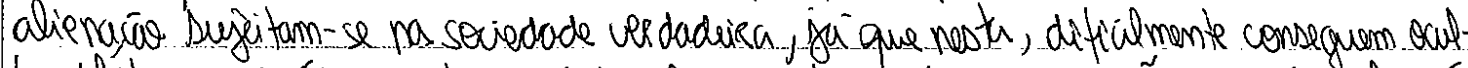
tan deleitos econacterístius antes escondidos pelo computador. As criumcos sáo as más vulneráveis a elses casos. Aquelos que miontram problemos de pelacionamento na esolu e se mantén ex.

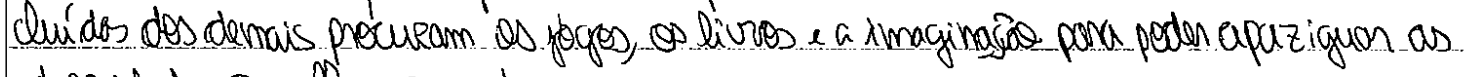
adversidodes que lles acometem.

Mas náo só as criomcas, como tombin os adultos sāo vítimos desse fato. Muritos individuos buscom no munds ilubório u ma maneira para a temurn una frustrasió amo rosa ou socont

(Exemplo 87,Fuvest, 2010, p.26)

\section{CONFLITO DE VIDAS}

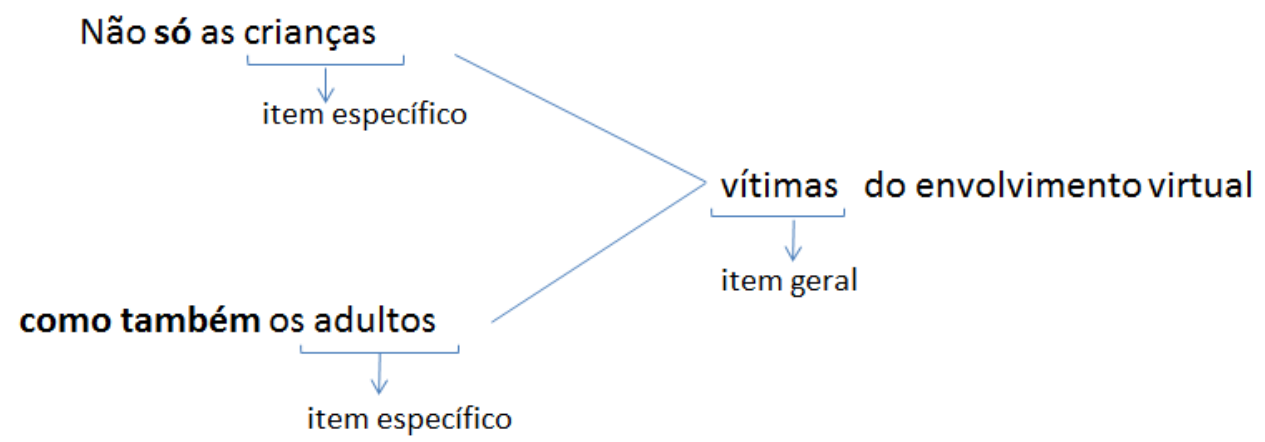

Esquema 29. Convergências de itens específicos na comparação-proporcional

\section{As realidodes do fato}

$O$ homem se distinguie dos animois. Tel diferenca imclui em suos justilicativos fatores como inteligéncia (pensamento e racionalidode) e criacoo de uma linguagem (comunicacío e copacido de de abstracioo). Entretanto, nö só a organizacioo do pensomento, cómo sua externalizaciò para outra pessoa ou para o meio físico,... necessitam de uma mesma bose prumórdial a linquoqem.

(Exemplo 88, Fuvest, 2010, p.52) 


\section{A REALIDADE DO FATO}

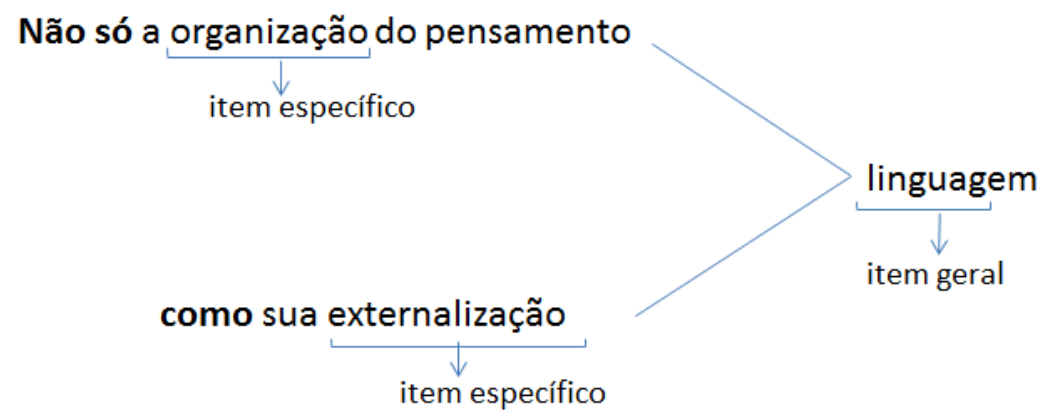

Esquema 30. Convergência de itens específicos na comparação-proporcional

Percebe-se que, nos dois trechos apontados, existem dois itens lexicais que apresentam uma particularidade em comum, ou ainda, que se remetem a um grupo específico ligados a outro item geral.

No $1^{\circ}$ trecho, há um ponto comum convergente aos itens específicos: crianças e adultos $\rightarrow$ pessoas, que são vítimas. No $2^{\circ}$ trecho, o ponto comum convergente entre os itens organização e externalização $\rightarrow$ linguagem. Enquanto a adição aproxima porções informativas, a comparativa aproxima itens lexicais que possuem características comuns ligadas a um objeto ou pessoas e assumem proporção idêntica.

\subsubsection{Tanto mais... quanto menor \\ Tão mais... quanto mais}

Tendo como base a comparação, a correlativa proporcional apresenta também características comuns em relação a um objeto, sujeito, mas, cognitivamente, por conta da intenção do autor, percebe-se uma relação de equilíbrio numérico entre os conteúdos apresentados nos pares; há itens linguísticos que, mentalmente, nos remetem a uma ideia numérica quantitativa. Em ambas, verifica-se a manifestação da proporção inversa via polaridade negativa: 
qui H dichorer descrevé em neie clepoimento

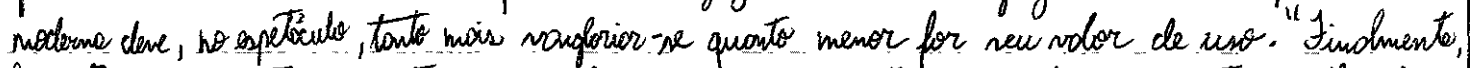

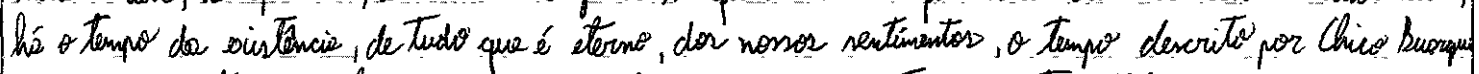
do anor ene tempo que boje ne encoutro velmerso em preconcietos a sentimentolismos, ne esquecendo

(Exemplo 89, Fuvest, 2004, p.15)

como tempo histórico. E, segundo ele, a historria é tas mais
importante para nosso entendimento do mundo quanto
mais irrelevante para os tecrocratas de plantais.

(Exemplo 90, Fuvest, 2004, p.33)

\subsubsection{Tanto... quanto \\ Tanto... como}

Integram este padrão item comparativo avaliativo atrelado a item comparativo proporcional.

De base comparativa, os pares "tanto... quanto" e "tanto... como" podem representar também uma relação calcada na proporcionalidade, em que, no $1^{\circ}$ item, existe uma avaliação subjetiva por parte do autor que tenta aproximar, encontrar um viés, uma relação com o $2^{\circ}$ elemento do par, por meio das características apresentadas em relação ao objeto, e assim o faz pela comparação. Entretanto, verifica-se que existe dessa aproximação comparativa um equilíbrio, que está a serviço da intencionalidade como elemento de persuasão, a fim de dar destaque para ambos os conteúdos dos pares, de forma proporcional:

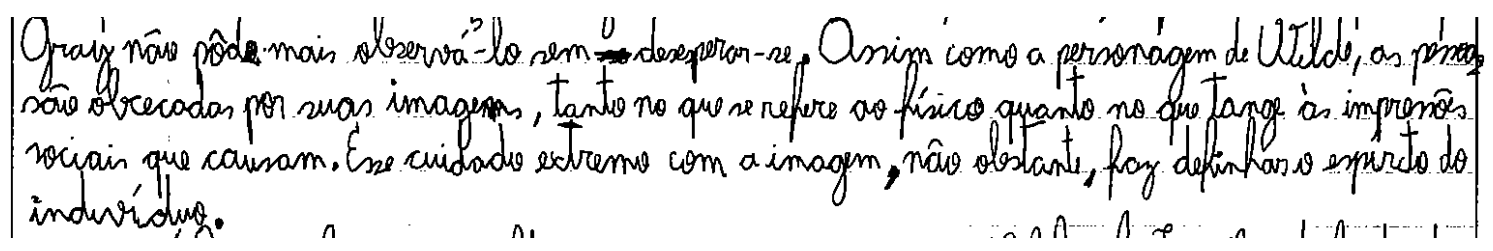

(Exemplo 91, Fuvest, 2010, p.63) 
Ao tratar sobre a questão da obsessão que as pessoas têm sobre suas próprias imagens, o autor aponta que isso acontece tanto no aspecto físico quanto nas impressões sociais que deixam transparecer. Poderíamos apontar o elemento comum comparativo que daria conta do conteúdo dos pares. Seria, por exemplo, o da preocupação das pessoas ligadas à imagem própria. Quantitativamente, existe uma relação de proporção, pois, da mesma forma que o físico é preocupante, as impressões ligadas a ele também são. O que nos remete à ideia numérica é "tanto", atrelado ao "quanto" (Houaiss \& Villar, 2001) intensificador.

O par "tanto...como" apresenta também uma base comparativa apoiada na proporcionalidade:

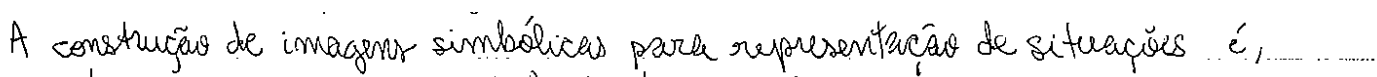
atualmente, recurso imprescindível tanto a vé́culos de conunicacéa como em nossas rulacies interpessoair do cotidiano. Tornou-se comum encontrarmos no.

(Exemplo 92,Fuvest, 2010, p.58)

O que caracteriza o elemento comparativo entre os pares é o item "como", que, segundo Houaiss \& Villar (2001), representa "da mesma maneira", e Bechara (2009) aponta que pode ser substituído por "tanto... quanto". No trecho, há uma relação de proximidade de sentidos convergentes a um único elemento: a construção das imagens simbólicas.

O autor demonstrou que a imagem representada nas situações cotidianas é um recurso imprescindível para os veículos de comunicação e para as relações interpessoais do cotidiano; isto é, ambas estão comparativamente equilibradas em relação à necessidade que têm da representação das imagens nas ações cotidianas. O item "tanto" exerce o papel de intensificador avaliativo, pois funciona como um enfatizador.

\subsubsection{Tão... quanto}


Esse padrão representa-se sob a forma de item comparativo avaliativo atrelado a item comparativo proporcional.

O termo "tão" funciona como um intensificador que contém uma avaliação por parte do autor. Segundo Bechara (2009), indica comparação "de tal maneira que", sinalizando uma comparação que, atrelada ao quanto, sugere uma ideia simbólica ligada a número, quantidade:

conceitos superficiais sobre pessoas e iqualando as por veres as produtos que ofere:

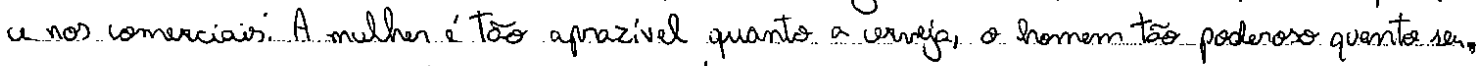
carro. se seu parceiro täo amonoso quanto a lasa qug comparar.

(Exemplo 93,Fuvest, 2010, p.22)

Além da relação comparativa, calcada numa avaliação subjetiva do autor que estabelece características próximas de sentido: mulher $\rightarrow$ cerveja (prazer); homem $\rightarrow$ carro (poder); parceiro e casa (afetividade e segurança), há também, no $2^{\circ}$ elemento do par, a constituição de itens que se abstratizam: "cerveja", "carro" e "casa", pois todos estão ligados, proporcionalmente, à superficialidade presente nos comerciais.

\subsection{Pares correlativos concessivos e suas funções pragmáticas}

\begin{tabular}{|l|l|l|l|l|l|l|l|l|l|}
\hline SEMÂNTICA & ESTRUT. & $\mathbf{2 0 0 4}$ & & $\mathbf{2 0 0 5}$ & & $\mathbf{2 0 0 6}$ & & $\mathbf{2 0 0 7}$ & \\
\hline \multirow{3}{*}{ CONCESSIVA } & $\mathrm{T}$ & & & & & apesar de... nã̃o & 1 & & \\
\cline { 2 - 9 } & $\mathrm{D}$ & & & apesar de... já & 1 & apesar de... ainda & 1 & & \\
\cline { 2 - 9 } & $\mathrm{C}$ & & & & & $\begin{array}{l}\text { mesmo que... ainda } \\
\text { não... ainda que }\end{array}$ & 1 & & \\
\hline
\end{tabular}

\begin{tabular}{|c|c|c|c|c|c|c|}
\hline SEMÂNTICA & ESTRUT. & 2008 & & 2009 & & 2010 \\
\hline & $\mathrm{T}$ & ainda que.. Não & 1 & & & \\
\hline \multirow[t]{2}{*}{ CONCESSIVA } & $\mathrm{D}$ & & & & & \\
\hline & C & ainda que... Mister & 1 & năo (V)... ainda que (V) & 1 & \\
\hline
\end{tabular}

Quadro 10. Pares correlativos concessivos 
O quadro anterior sintetiza os pares correlativos concessivos que têm como foco estratégico, a partir de um fato real, sinalizar uma hipótese, obstáculo que parece servir como recurso argumentativo para contrastar, o que foi generalizado na $1^{a}$ porção informativa.

Ao apresentar a concessividade, diante de um fato exposto, o autor traz à tona um recurso assertivo, como um elemento persuasivo que confere maior credibilidade e confiança àquilo que informa.

Para isso, os pares correlativos concessivos refutam na $1^{\circ}$ porção para contrastar; outros encabeçam uma polaridade "não", seguida de uma "concessão", com o objetivo de aproximar-se da verdade, daquilo que é real; outros, ainda, apresentam uma concessão, sinalizada por uma concessiva temporal, que funciona como focalizador.

A relação concessiva é caracterizada por aquilo que expressa uma informação vista como um fato real, mas que é apoiada numa hipótese ou irrealidade, um recurso estratégico do falante, que tenta apresentar um obstáculo incapaz de impedir que se realize o que vem expresso na $1^{\mathrm{a}}$ porção informativa.

Segundo Neves (1999), as conexões fincadas na concessividade têm proximidade nas contrastivas, cujo significado básico "é contrário à expectativa" (p.864). Sendo assim, esse "significado se origina do conteúdo, do processo comunicativo e da relação falante-ouvinte" (Neves, 1999).

Para a autora, ainda, do ponto de vista pragmático, as concessivas indicam que “o falante pressupõe uma objeção à sua asserção, mas que a objeção é por ele refutada, prevalecendo a sua asserção" (p.874); isto quer dizer que existe na concessividade uma hipótese de objeção por parte do interlocutor, em que se pode pensar em "tópicos de contraste" (Neves, 1999) estabelecidos nessa relação falante e ouvinte, tais como apresentadas a seguir:

\subsubsection{Apesar de... ainda}

Mesmo que... ainda 
Esse padrão inclui a construção de um item correlato concessivo refutativo seguido de item concessivo de contraste asseverativo.

O par correlativo encabeçado por "apesar de" apresenta conteúdos/ argumentos que têm a finalidade de refutar, inicialmente, a informação instada na $1^{a}$ porção, que, ao se lançar para o $2^{\circ}$ elemento do par, encabeçado pelo item "ainda", apresenta um conteúdo asseverativo:

Contudo, hoje aindá dizemos sim e começamo outro dia de tralollho. invisivel sem que sejamos atropelados Cysesar da pressao da falta de empugo, o dexaparecimento do tralalho e os michelangelos atuais, ainda somos prototipos de Inacabra batendo a tecla e esperando pelo final do més e a felicidade, pair í a úmico que alimenta nossa forne de consumo, há algux séculos au nos mantinha ocupados antes disso la precura por estabilidade nos liva a pensar o náo e verborragizar a afirmaçào.

(Exemplo 94,Fuvest, 2006, p.5)

O autor, na $1^{a}$ porção, faz uma precisão daquilo que considera pertinente para o interlocutor, como se tivesse esperado, mentalmente, uma objeção e, para isso, estrategicamente, se antecipa. Por isso, suas escolhas lexicais são projetadas por meio de itens culturalmente compartilhados. Há um julgamento, por parte do autor, que realiza uma contraposição: desaparecimento do trabalho frente à persistência da atividade.

É interessante que, entre as porções informativas, existem duas verdades estabelecidas: $1^{a}$ porção $\rightarrow$ possibilidade do desaparecimento do trabalho $\rightarrow 2^{\text {a }}$ porção $\rightarrow$ necessidade pelo trabalho; cujos conteúdos envolvem uma avaliação epistêmica do falante (autor) em relação ao leitor.

O par encabeçado pelo item "mesmo que" apresenta uma concessividade que se lançar para o autor de uma forma distante daquilo que considera como real, uma eventual realização, que, hipoteticamente, poderá ocorrer: 


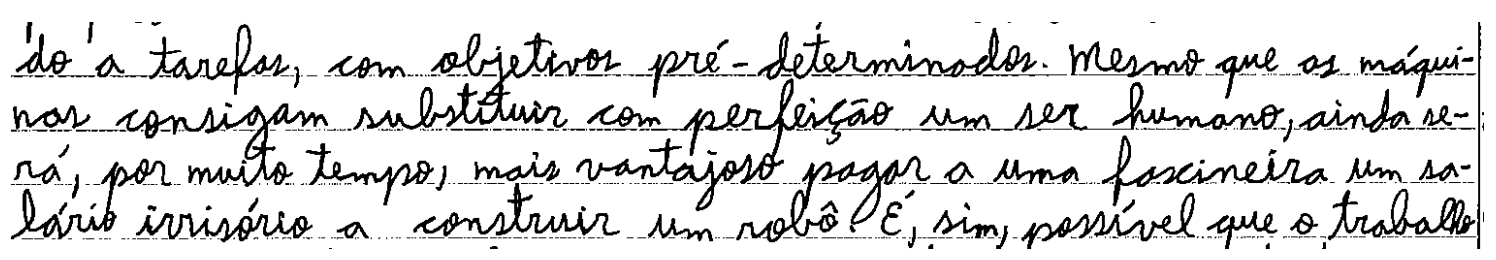

(Exemplo 95,Fuvest, 2006, p.73)

No trecho, o par encabeçado pelo "mesmo que" apresenta um conteúdo asseverado pelo autor, apesar de o verbo estar no subjuntivo, expresso por uma hipótese: dada a potencialidade do item concessivo e do seu conteúdo informacional, "não necessariamente se segue a realização/ verdade a não realização/ a falsidade" (Neves, 1999, p.856) em relação à $1^{a}$ porção informativa. Uma estratégia discursiva do autor aponta os conteúdos que, pelo $2^{\circ}$ elemento do par, fazem a relação contrastiva à expectativa do leitor.

\subsubsection{Não... ainda que}

Esse padrão constitui-se pelo item polarizador "não" deôntico seguido de item concessivo factual.

O par correlativo "não...ainda que" apresenta, na $1^{\mathrm{a}}$ porção informativa, encabeçada pelo polarizador “não", uma expressão calcada numa "obrigação moral, interna, ditada pela consciência" (Neves, 2006, p.174) do autor, ligada a uma crença, valores, que, no $2^{\circ}$ elemento do par informativo, sugerem uma aproximação com a verdade, com o factual, o real:

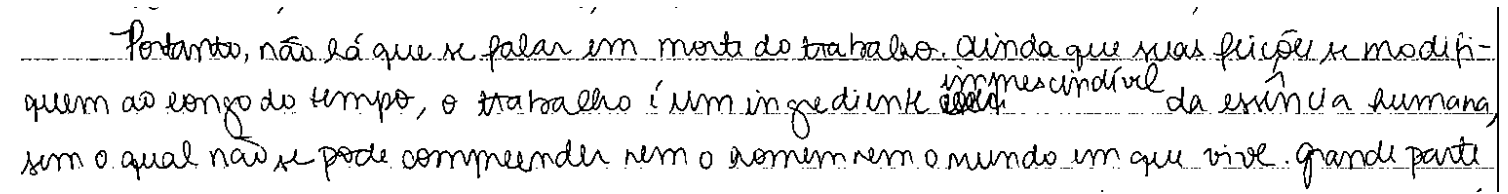


No trecho, o autor é incisivo ao tratar sobre a possibilidade do desaparecimento do trabalho, tanto que, no $2^{\circ}$ elemento do par correlativo, apesar de apresentar a ideia de que o trabalho poderá modificar-se, ao longo do tempo, usa esse par "ainda que" como se essa possibilidade se aproximasse.

A $1^{\text {a }}$ porção informativa expressa uma futuridade calcada numa "categoria deôntica (obrigações)" (Neves, 2006), que diz respeito à conduta "não há que se falar" que remete à $2^{\mathrm{a}}$ porção informativa uma existência de uma "possibilidade factual, em algum tempo ainda por vir" (Givón, 1984, p.272) e, por isso, a presença de um verbo no subjuntivo "se modifiquem".

\subsubsection{Ainda que... não}

Esse padrão apresenta item concessivo factual seguido de item polarizador "não" deôntico.

Esse par correlativo apresenta, na $1^{a}$ porção informativa, item concessivo cujo conteúdo está calcado "numa existência potencial em algum tempo ainda por vir" (Givón, 1984, p.272), isto é, o autor utiliza-se dessa estratégia para fazer uma crítica em relação ao progresso tecnológico, distante da realidade:

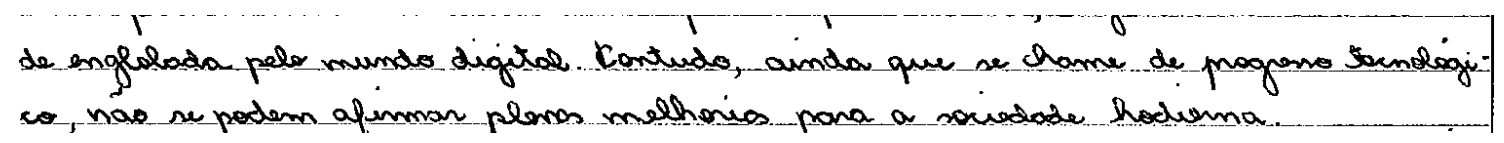

(Exemplo 97,Fuvest, 2008, p.1)

O autor do texto se utiliza de modalidade deôntica calcada numa obrigatoriedade constituída pelo item (não + verbo poder) que leva o leitor à possibilidade de acreditar, de fato, que a sociedade está distante das melhorias do progresso tecnológico.

Os dois pares correlativos concessivos estão atrelados a verbos no subjuntivo (chamar) que contribuem para que haja uma relação eventual: "dada a potencialidade do 
conteúdo apresentado no par concessivo, não necessariamente se segue a realização da verdade" (Neves, 2006, p.856).

Há um comprometimento epistêmico ligado ao falante/autor que deonticamente está centrado no leitor, em que o autor parece não acreditar no acesso do progresso tecnológico à sociedade.

\subsubsection{Ainda que... mister}

Esse padrão constrói-se pelo item concessivo factual seguido de item "mister" deôntico.

Outro par constituído por uma ideia de concessão e que apresenta verdade condicionada a um fato, é o "ainda que... mister":

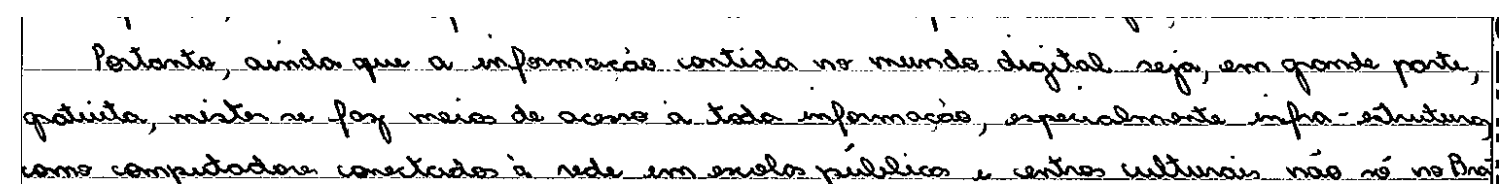

(Exemplo 98,Fuvest, 2008, p.1)

O que nos chama atenção dessa ocorrência é a presença do item "mister", no $2^{\circ}$ elemento do par correlativo, que segundo Houaiss e Villar (2001) significa "haver necessidade, ser preciso, precisar, carecer de" (p.1934), que sinaliza uma modalidade deôntica. Verifica-se a intenção de dar credibilidade para aquilo que defende: meios de acesso a todas informações e mais infraestrutura. É interessante apontar que o conteúdo de material linguístico se faz presente em maior quantidade no $2^{\circ}$ elemento do par correlativo; isto é, por conta da necessidade do autor de querer potencializar essa porção, lança mão desse recurso.

O item "mister" funciona como focalizador, dá ênfase ao conteúdo explicitado. É um recurso persuasivo utilizado pelo autor que se utiliza da modalidade deôntica para atingir o objetivo, em que apesar de admitir, concessivamente, que a informação contida 
no mundo digital seja gratuita, defende mais investimentos. Há um jogo de contraposição mascarado pela quebra de expectativas do interlocutor.

\subsubsection{Apesar de... já}

Esse padrão é encabeçado pelo item correlato concessivo seguido de um focalizador temporal e apresenta uma peculiaridade na $2^{\mathrm{a}}$ porção informativa: a presença de um item correlativo "já", que além, de remeter a uma ideia temporal funciona como um focalizador:

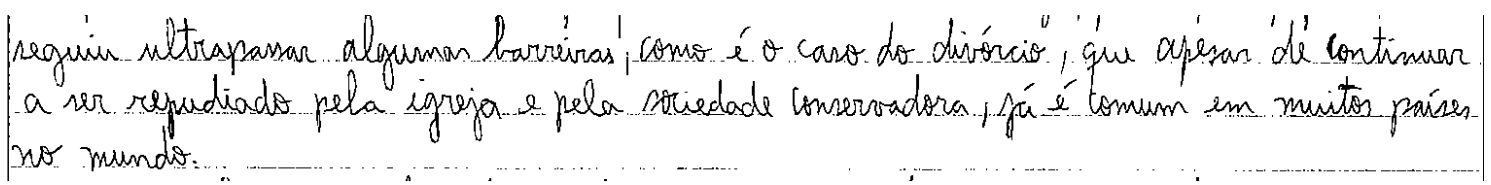

$\mathrm{Na} 1^{\mathrm{a}}$ porção, o autor apresenta uma refutação, a respeito do divórcio, em que a igreja e a sociedade conservadora veem nele uma barreira social. Logo na $2^{\mathrm{a}}$ porção, utiliza-se do item temporal "já" para, cognitivamente, mostrar que, apesar dessa não aceitabilidade, o divórcio é uma prática comum entre os países. Há um focalizador temporal para remeter o leitor ao tempo presente, para mostrar que atualmente, a imagem que se tem do divórcio, modificou-se.

Segundo Neves (1999), “o conectivo 'apesar de’ aponta conteúdos ou argumentos novos após aparentemente concluída uma primeira porção do enunciado" (p.879), o que acontece de forma diferente nesse trecho, pois o autor lança a informação velha, considerada conhecida pelo leitor na porção, em que se encontra o par correlativo "apesar de" e no $2^{\circ}$ elemento do par, o correlativo "já", para mostrar a nova informação. Há uma estratégia persuasiva.

Sintaticamente, ordena duas porções de modo que haja na $2^{\mathrm{a}}$ uma certeza instada naquilo que, concessivamente, ainda está distante da verdade. Processualmente, o autor ao lançar uma concessiva acredita numa possibilidade de que o fato poderá acontecer, 
mas remete na outra porção, o que de fato, sugere estar mais próximo daquilo que acredita, da realidade. Há uma dinâmica mental nesse processo, pois ordena e lança material linguístico na $2^{\mathrm{a}}$ porção, daquela mais próxima do senso comum.

\subsection{Pares correlativos condicionais e suas funções pragmáticas}

\begin{tabular}{|c|c|c|c|c|c|c|}
\hline SEMÁNTICA & ESTRUT. & 2004 & 2005 & 2006 & 2007 & \\
\hline & T & & & & & \\
\hline & $D$ & & & & & \\
\hline \multicolumn{7}{|l|}{ CONDICIONAL } \\
\hline & $\mathrm{C}$ & de nada... senäo & 1 & só... quando & 1 só $(\mathrm{V}) \ldots$ se & 1 \\
\hline CONDICIONAL & $\mathrm{T}$ & & & & & \\
\hline \multirow[t]{2}{*}{ TEMPORAL } & D & & só... quando & 1 & & \\
\hline & C & & só... quando & 2 & & \\
\hline CONDICIONAL & $\mathrm{T}$ & & & & & \\
\hline \multirow[t]{2}{*}{ FOCALLZADORA } & D & & só... se & 1 & & \\
\hline & C & & & & & \\
\hline
\end{tabular}

\begin{tabular}{|c|c|c|c|c|c|c|}
\hline SEMÁNTICA & ESTRUT. & 2008 & & 2009 & & 2010 \\
\hline & $\mathrm{T}$ & & & & & \\
\hline & D & se... é porque & & รe กลีం... กี๊o & 1 & \\
\hline \multirow[t]{2}{*}{ CONDICIONAL } & & se não... também não & & กม̃o ... รอกล๊o & 1 & \\
\hline & $\mathrm{C}$ & se... que & 2 & & & \\
\hline CONDICIONAL & $\mathrm{T}$ & & & & & \\
\hline \multirow[t]{2}{*}{ TEMPORAL } & $\mathrm{D}$ & & & & & \\
\hline & $\mathrm{C}$ & & & & & \\
\hline CONDICIONAL & $\mathrm{T}$ & & & & & \\
\hline \multirow[t]{2}{*}{ FOCALIZADORA } & $\mathrm{D}$ & & & & & \\
\hline & $\mathrm{C}$ & & & & & \\
\hline
\end{tabular}

Quadro 11. Pares correlativos condicionais

O quadro dos pares correlativos condicionais representa as ocorrências funcionais que sinalizam uma hipótese, subjetividade de matrizes, que parecem atender às necessidade do falante/autor em relação à realidade da informação e à condição atrelada a ela.

Por meio dos padrões apresentados, o par correlativo condicional apresentou-se de forma flutuante, pois, ao se recombinar com outros itens, assumiu papéis diversos, para atender o que se quer argumentar. 
Atrelado ao item "só", um focalizador assumiu não só papel de condicional causal, mas também de condicional temporal e de condicional conclusivo. Adicionalmente, também consecutivo, concessivo e até aditivo.

Isso é uma prova de que cada item linguístico ligado a experienciações sociais do falante/ autor, ocorre dentro das porções informativas, para alavancar não somente aquilo que se quer apontar, mas como e para que apontar, com um único objetivo: o de uma interação.

A relação condicional é caracterizada por pares correlativos cuja relação está calcada numa condição que se apoia numa hipótese. Para Neves (1999, p.833), as condicionais formam uma espécie de moldura de referência, em que de um lado, na $1^{\text {a }}$ porção informativa, tem-se o fato; e de outro, na $2^{\mathrm{a}}$ porção, à condição atrelada a ele, que segundo a autora, ainda, o conteúdo informativo, apresentado nas condicionais, não é visto como novo, como uma novidade.

Para Azeredo (2009), a condição baseia-se numa "distinção de atitudes do enunciador em relação à realidade da informação" (p.325). Para o autor, ainda, a "atitude de incerteza, de suspeita, de suposição" se expressa na porção em que haja a condição que pode ser composta pelos itens, "se, caso, desde que, contanto que, a menos que" (p.325). Os verbos se caracterizam, em geral, pelo subjuntivo.

Com isso, "ao contrário da certeza, que é objetiva, o campo da hipótese é subjetivo, amplo e difuso" (p.325).

\subsubsection{Só (V)... se (V)}

Esse padrão se configura pelo focalizador de exclusão seguido de item condicional causal.

Esse par correlativo condicional é constituído pelo focalizador "só" seguido de verbo, atrelado a um condicional "se" seguido de verbo no futuro hipotético, subjuntivo, caracterizando um fato provável atrelado a uma possibilidade. O que chama atenção é o 
fato de que na porção em que ocorre o "se", há uma causa e um resultado, uma consequência, hipotética, instalados:

eltodo: Do se achor alguimuspucial, vabriza-se usta rensoa do máxime, com quem momentos umpoztomter da vida duseró compartilhodos. A troca só ecorre \& for conveniente ans corticisantes dessa atividade.

(Exemplo 100, Fuvest, 2007, p.43)

No trecho, o autor aponta que a conveniência está ligada à troca, isto é, por acaso se houver interesse dos participantes da atividade é porque houve uma sinergia entre as pessoas. O verbo "ocorrer" é focalizado pelo item "só", que indica exclusão. Segundo Bechara (2009), "significa acontecer, suceder (episódio, fato), surgir no pensamento de alguém" (p.643). O significado desse verbo atrelado ao focalizador "só" revela que o autor intuiu que esse ato aconteceria, de fato, a partir do momento que satisfizesse o outro momento.

Segundo Neves (1999), existe uma "implicação" (p.843) entre as partes das porções informativas, isto é, uma está implicada na outra, imbricada. Essa implicação ocorre quando se trata, conforme o trecho acima, de uma condição necessária e suficiente ("somente se"), "caso em que a condicional é geralmente posposta" (p.843).

No outro trecho apresentado pelo par correlativo "só (V)... se (V)", o "só" também focaliza um qualificador atrelado a uma informação que traz à tona um fato eventual, serve de argumento em caráter epistêmico, porque o autor lança de forma próxima da certeza:

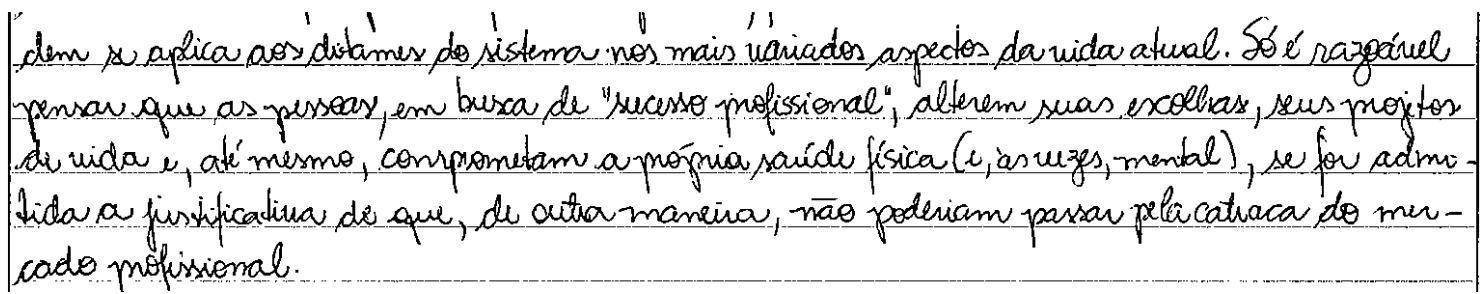


No trecho, o autor mostra, focaliza o evento que é atrelado a outro, num jogo em que há uma potencialidade seguida de uma eventualidade. $\mathrm{O}$ que se tem é a factualidade do que é dito, mas não que esteja sendo afirmada necessariamente uma realidade.

Existe também uma relação, na condicional, da causa que atrelada a uma consequência, isto é, a condicional tem sua "matriz causal" (Neves, 1999) que iconicamente reúne itens lexicais de avaliação subjetiva "só é razoável..." e por isso, a grande quantidade de material linguístico, na $1^{\mathrm{a}}$ porção atrelada a outra porção que indica o resultado das ações e fatos inerentes à primeira.

\subsubsection{Só... quando}

Esse padrão representa um focalizador de exclusão seguido de item condicional temporal. Essa configuração indica um focalizador atrelado a um item temporal, que assume o papel de condição, havendo uma potencialidade condicionante seguida de uma eventualidade na porção informativa em que existe a condição:

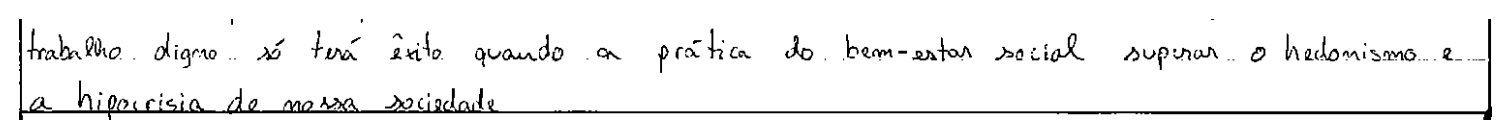

(Exemplo 102,Fuvest, 2006, p.23)

O focalizador "só", atrelado ao verbo ter dá ênfase com qualificador "êxito" ligado ao trabalho digno. É importante salientar a dinâmica dos tempos verbais entre as porções informativas: o verbo está no futuro e parece funcionar perto de uma verdade necessária e suficiente. Ela é condicionada a um fato, e por isso a presença do focalizador.

A $2^{\text {a }}$ porção informativa, encabeçada pelo item "quando", funciona como elemento que, pragmaticamente, remete a uma possibilidade eventual, distante da verdade. É um recurso persuasivo do autor que parece utilizar-se de uma ordem inversa à icônica. Contudo, como a mentira é uma reversão da verdade esperada, também a construção semântica é revertida, com a consequência antecipando-se à causa. A 
iconicidade garante-se pela reversão construída intencionalmente. Primeiro lança o resultado da ação e logo após a ação propriamente; isso parece acontecer por conta da condição excludente e focalizadora "só" que atrelada ao qualificador "êxito" remete o leitor à ação única, exclusiva.

\subsubsection{Se... é porque}

Esse padrão é construído pelo item condicional factual atrelado a item (porque) que assume o papel conclusivo.

Nesse par correlativo "se... é porque", há uma relação calcada numa condição factual em que o elemento "se" encabeça um fato apresentado como "verificado": diz-se que esse fato é ou não é, embora apresentando como um item condicional. O outro segmento que contrabalança a ideia apresentada, na $1^{\text {a }}$ porção, constitui outro fato, do qual, em vista do primeiro fato, também se diz que é, ou que não é. Segue o trecho:

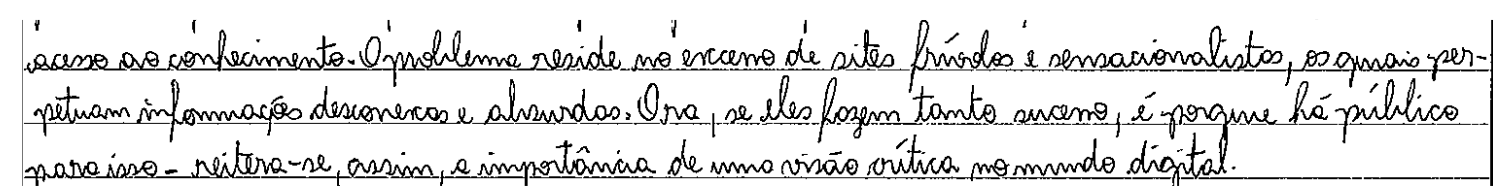

(Exemplo 103,Fuvest, 2008, p.28)

Pode-se dizer que existe aí uma relação "factual implicativa” (Neves, 1999, p.838) entre o fato expresso na $1^{\mathrm{a}}$ porção informativa e o fato expresso na $2^{\mathrm{a}}$ porção. Isso significa que um fato, enunciado como condição já preenchida "se eles fazem tanto sucesso" implica outro, simplesmente enunciado: "é porque há público para isso". O item "porque" faz o papel de um conclusivo. O item condicional "se" vem lembrar que houve uma verificação da factualidade apontada, atrelada a um fato implicado, conclusivo. 


\subsubsection{Se (V)... que (V)}

Esse padrão revela-se pela construção do item condicional (se) (não factual) atrelado a item (que) consecutivo.

Nesse par correlativo, há uma potencialidade do condicional "se" seguido da eventualidade do contexto atrelado pelo item correlato "que". O $1^{\circ}$ elemento do par condicional guarda uma informação de senso comum atrelado a uma modalidade deôntica, cuja obrigatoriedade parece estar ligada à "consciência material" (Neves, 2006, p.174):

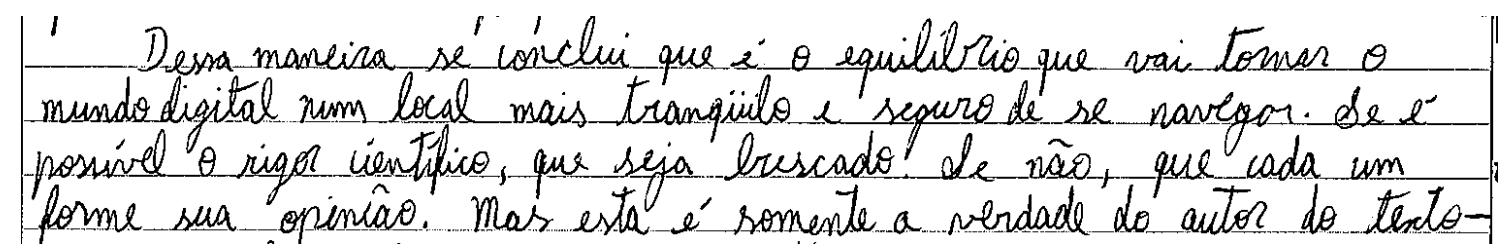

(Exemplo 104,Fuvest, 2008, p.62)

Parece haver entre as informações uma coocorrência de modalidades: no $1^{\circ}$ elemento do par informativo "se é possível..." existe uma modalidade epistêmica manifestada no campo da não-certeza, imprecisão, calcada pela dúvida do autor quanto à questão do rigor científico; e no $2^{\circ}$ elemento do par "que seja..." uma obrigatoriedade ligada a circunstâncias externas "que seja buscado o rigor científico", carregado de uma força que se caracteriza por um elemento de desejo (Jespersen, 1924). Percebe-se um jogo manipulativo para persuadir o leitor, em que o evento não é factual, se é possível (hipótese), embora haja certo grau de probabilidade de que ocorre. Assim, o item "que" assume papel consecutivo, resultado daquilo que é provável.

\subsubsection{Se não... não}


Esse padrão é formado pelo item condicional polarizador (focalizador) atrelado a item polarizador (focalizador) que assume papel consecutivo.

O par correlativo constituído por "se não... não" expressa uma relação entre o fato e a conclusão. Tem-se um duplo focalizador com a marca de polaridade realçada. $\mathrm{O}$ autor guarda no par condicional uma informação calcada no senso comum atrelada a uma consecutividade, também. Observe o trecho:

pasaivel aos sentidoe e à geraças de concitos. Porém, is quanto a dewees, alma e outras entidades? Cra, se náo săo emforicamente teeta dos, năo podem seer conhecidar

(Exemplo 105,Fuvest, 2009, p.40)

Primeiramente, o autor, ao apontar que se, entidades, em geral, não podem ser empiricamente testadas (senso comum), não podem ser conhecidas (ideia consecutiva) refere-se à condição da $1^{a}$ porção. O verbo "ser" é atrelado ao elemento polarizado para uma força persuasiva, factual, ligada a uma modalidade epistêmica, calcada na obrigatoriedade no campo da certeza, precisão (Neves, 1999). Apoia a certeza, a previsão que parece coligar-se ao conhecimento de mundo do autor. Pelo $2^{\circ}$ elemento do par, temos o verbo "poder" em modalidade deôntica, determinada pela força dos enunciado que explicitamente parece ser próxima da verdade.

\subsubsection{Se não... também não}

Esse padrão constitui-se pelo elemento condicional (polarizador) atrelado a elemento aditivo (polarizador).

Esse par correlativo "se não... também não" é constituído por uma condição polarizada atrelada a uma aditiva, no $2^{\circ}$ elemento do par. Há um processamento em que 
o autor guarda no $1^{\circ}$ elemento do par uma informação já conhecida e para o $2^{\circ}$ elemento do par, uma considerada nova. Há uma imbricação de uma atrelada à outra:

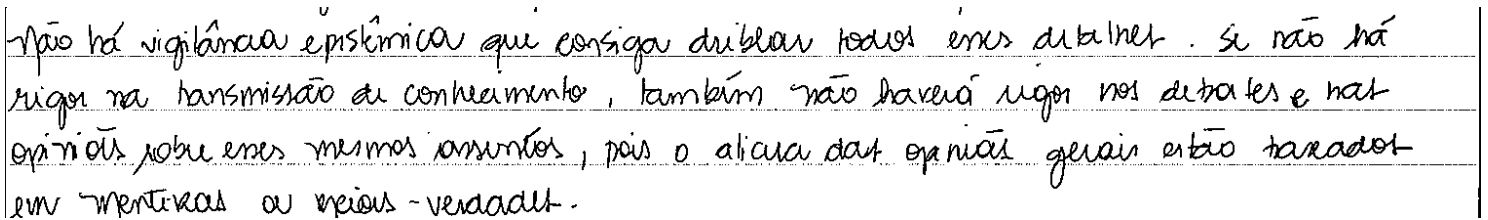

No trecho, a condição que encabeça o $1^{\circ}$ elemento do par sinaliza uma focalização da não-realização/ a não-factualidade, a que segue necessariamente, o $2^{\circ}$ elemento do par com a informação da não-realização/ a não-factualidade, focalizada.

Mas o que difere, estrategicamente, é que o autor lança uma informação conhecida, no $1^{\mathrm{o}}$ elemento do par, pois é de conhecimento comum que existe manipulação de dados via imprensa, e com isso, "não há rigor na transmissão de conhecimento". No $2^{\circ}$ elemento do par, lança o conteúdo que considera novo, surpresa: “também não há rigor nos debates e nas opiniões...”. Parece haver uma condição, que atrelada, no $2^{\circ}$ elemento do par, a outras informações, adiciona elementos, que discursivamente contribuem para a argumentação. Então, temos uma condição de caráter aditivo.

Neves (1999) afirma que o elemento se encabeça um fato apresentado como "verificado": “diz-se que esse "fato é ou não é" " (Neves, 1999, p.837), embora haja o condicionador "se". O outro segmento também acompanhará o mesmo mecanismo: "é ou não é" (p.837). Percebe-se a dinâmica do tempo verbal: "se não há" (presente), também "não haverá", (futuro do presente), certo, sem dúvida, que indica precisão.

$\mathrm{O}$ autor lança o presente atrelado ao futuro do presente porque tem certeza que isso dará a ele uma combinação de ideias, que parece "certeza" tanto na $1^{\mathrm{a}}$ quanto na $2^{\mathrm{a}}$ porção.

\subsubsection{De nada... senão}


Esse padrão é caracterizado pelo polarizador (de nada) atrelado a condicional concessiva (senão).

Segundo Houaiss \& Villar (2001) um dos sentidos atrelados ao item "nada" está ligado àquilo que se opõe, contradiz, se afasta, em sentido absoluto. Para Bechara (2009), o item "de nada" tem seu significado calcado naquilo que não tem relevância, coisa alguma. Em relação ao item "senão", para Bechara (2009), tem valor de "salvo, a não ser"; para Houaiss \& Villar (2001), significa "com exceção de, a não ser, salvo, exceto":

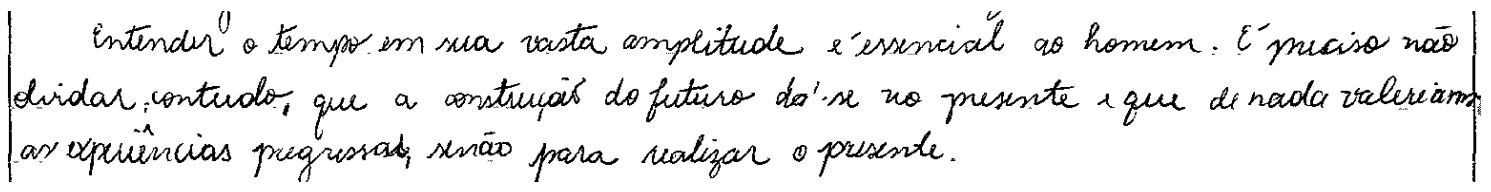

(Exemplo 107,Fuvest, 2004, p.67)

Primeiramente, esses pares realizam, por meio dos tempos verbais, um processamento em que um item "de nada" afasta qualquer possibilidade, frente a uma concessão "senão", que sinaliza uma exceção, uma brecha, para que haja validação condicional; isto é, o autor utiliza-se dessa estratégia argumentativa para sensibilizar o leitor.

Isso é percebido por conta dos tempos verbais entre as porções: ao se utilizar do imperfeito do subjuntivo "de nada valeriam" $\rightarrow$ "senão para realizar" (infinitivo), parece haver uma mobilidade de um tempo ao outro, uma intenção: sensibilizar o leitor a fim de mostrar que as experiências pregressas contribuem para ações do presente e para a construção do futuro.

O item "senão" é uma condição com matiz concessivo que inverte a polaridade da $1^{a}$ porção informativa, que tem o valor de negação.

Outra questão importante é que etimologicamente tem-se "se + não", no século XIII senõ, se non, no século XIV senã, ssenom, século XVI senão. Assim, o item polar "não" serve como um focalizador em que teríamos a seguinte mecânica: "senão para realizar o presente..." em que o "se" serviria como uma condição: realizar ou não; e o 
"não" focalizar: não realização do presente; isto é, condição + focalizador: se não houver a realização do presente, não haverá futuro.

\subsubsection{Não... senão}

Esse padrão forma-se pela polaridade (não) atrelada a condicional concessiva assumindo papel de polarizador focalizador.

O par "não... senão" é constituído por um focalizador "não" seguido de uma condicional "se" que parece atrelar-se ao "não", (focalizador), para fazer o papel de uma condição ligada a uma concessão:

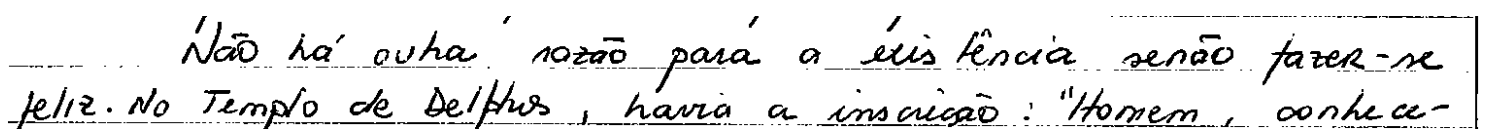

(Exemplo 108,Fuvest, 2009, p.62)

Existem duas polaridades: "não..." e "senão" que focalizam duas informações: uma que nega "não há outra razão..." e a outra que abre um precedente, "uma condição necessária e suficiente" (Neves, 1999, p.845) para que possa realizar-se "fazer-se feliz".

O item "senão" serve como uma concessão ligada a uma condição; isto é, se houver a felicidade, haverá razão para a existência, abre-se uma brecha para a condicional "se" atrelada ao item "não" assumindo o papel de concessão; isto é, no trecho, somente com a felicidade, haverá razão para a existência; abre-se uma brecha para que se concretize a ação.

A presença de dois verbos entre os pares: há ( $1^{\circ}$ elemento do par) e fazer-se $\left(2^{\circ}\right.$ elemento do par), em que se tem o verbo haver (presente) e fazer-se (infinito + se) parece remeter a duas porções informativas que estão implicadas uma à outra: se houver felicidade, há razão para a existência. 
Assim, as condicionais exprimem um fato que não se realizou ou, com toda a certeza, não se realizará. Isso se dá, por meio da ordem das porções informativas, que sintaticamente se relacionam de acordo como o sujeito falante orienta suas escolhas. Estas são calcadas no "mundo do dizer" (Neves, 2006, p.163) ligadas à crença e à ordem da sua visão de mundo.

Epistemicamente, é por conta do dinamismo instalado a partir do que o leitor espera encontrar, é que o autor, pragmaticamente, distribui também a quantidade de material lexical entre as porções: pouca inserção no $1^{\circ}$ elemento e mais no $2^{\circ}$. Revela-se um jogo entre a possibilidade da existência de um fato atrelado à condição de verdade aceita pelo ouvinte/ leitor. É na $2^{a}$ porção que a complexidade das ideias atribuídas se dá de maneira efetiva, ligada à certeza daquilo que se quer argumentar.

Processualmente, o autor sabe que, para convencer, deve, na condição, focar a informação que possibilita a existência de uma situação ou fato, para logo após lançar o que considera, verdadeiramente, convincente.

\subsection{Pares correlativos proporcionais e suas funções pragmáticas}

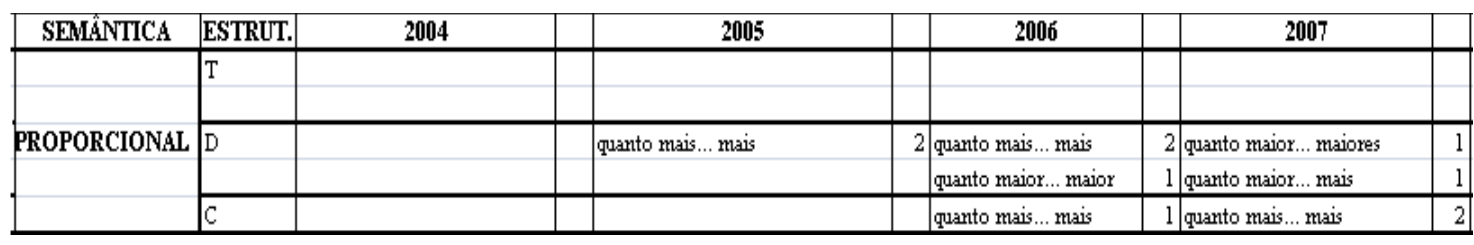

\begin{tabular}{|c|l|l|r|l|l|l|l|}
\hline SEMÁNTICA & ESTRUT. & \multicolumn{1}{|c|}{$\mathbf{2 0 0 8}$} & & $\mathbf{2 0 0 9}$ & & $\mathbf{2 0 1 0}$ & \\
\hline & T & quanto mais... mais & 1 & & & & \\
\hline \multirow{2}{*}{ PROPORCIONAL } & & quanto maior... maior & 1 & & & & \\
\cline { 2 - 8 } & & tantos... quantos & 1 & quanto maior... mais & 1 & & \\
\hline
\end{tabular}

Quadro 12. Pares correlativos proporcionais

A relação proporcional expressa por meio dos pares correlativos está calcada na proporção entre o que é expresso na $1^{\mathrm{a}}$ porção e na $2^{\mathrm{a}}$ porção informativa. 
Remete a uma ideia de equilíbrio numérico, grandeza proporcional, cujo objetivo do falante/ autor é o de querer contrabalancear informações, ou sobressair uma a outra a fim de levar o leitor a imaginar a proporção instalada entre as ideias que se perfazem por meio de seus argumentos.

Os pares correlativos proporcionais apresentados nos levaram a concluir que, ao proporcionar informações, o autor/ falante estabelece uma relação de causa e de consequência, de tal modo imbricadas, que denuncia um jogo de intenções marcado pela quantidade de itens lexicais, pela avaliação por parte de quem diz e pela distribuição desses elementos que funcionalmente se recombinam para atender às necessidades do ato de comunicar.

A proporção é, a rigor, uma relação paralela e harmônica entre "as partes de um todo, o qual respeita padrões estéticos" (Bechara, 2009, p.732). Percebe-se que na proporção existe uma igualdade entre as partes, uma ação que está concomitante à outra. Para Azeredo (2009), é comum em textos de caráter argumentativo a noção de causar efeito sobressalente à ideia de paralelismo, nos casos proporcionais. Para o autor, ainda, consiste no desenrolar paralelo de dois fatos, entre os quais pode haver até uma relação cuja especificidade é temporal.

\subsubsection{Quanto mais... mais}

Esse padrão se revela por meio de um item proporcional (causal) avaliativo atrelado a item proporcional (consequência) avaliativo.

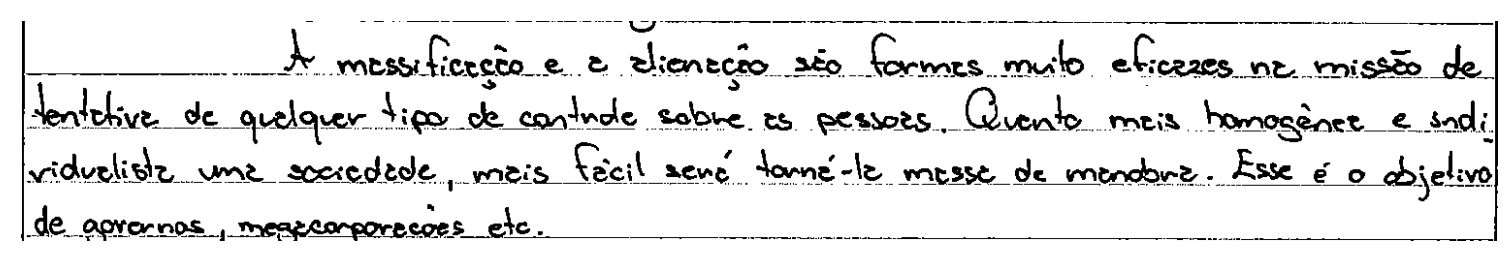

(Exemplo 109, Fuvest, 2005, p.40) 
O que se percebe, nesse trecho, é uma relação de causa/ efeito estabelecida paralelamente entre as porções informativas: quanto mais homogênea e individualista uma sociedade (causa $-1^{\mathrm{a}}$ porção)... mais fácil será torná-la massa de manobra (consequência $-2^{\mathrm{a}}$ porção). O quantificador "quanto do latim quantus, significa quão grande, quanto/ em correlação com tantus" (Houaiss \& Villar, 2001, p.2345). Por isso está atrelado a um item que indica uma intensificação: "mais", que juntos remetem a uma ideia de grandeza, quantidade, que, atrelada ao outro par "mais", parece denotar "ir além de", juntar àquilo que já se tem. Há uma avaliação do autor, ao lançar o "mais" que contribui para isso, funcionando como um focalizador:

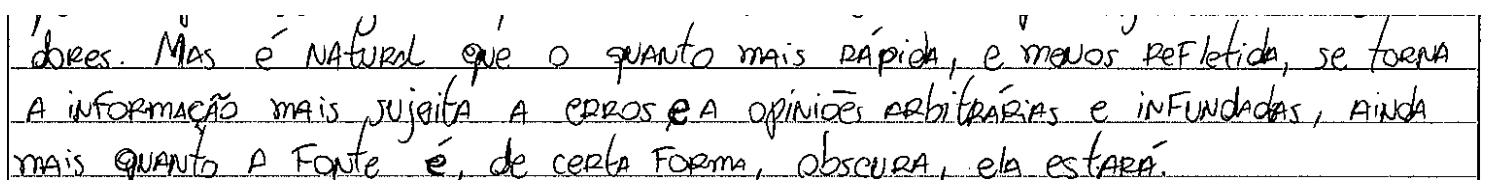

(Exemplo 110, Fuvest, 2008, p.16)

Esse trecho, composto pelos itens "quanto mais... mais", é proporcional, pois obedece às características apontadas por Azeredo (2009): indica uma relação de causa e consequência: $1^{\mathrm{a}}$ porção (quanto mais rápida...), $2^{\mathrm{a}}$ porção (mais sujeita a erros...). Outro fato que chama a atenção é a quantidade de material entre os pares correlativos: parece também ser equilibrada. $\mathrm{O}$ que é proporcionalmente pensado parece ser proporcionalmente falado/ escrito. Isso é um processamento mental que satisfaz as necessidades intencionais do autor/falante. Há também uma avaliação subjetiva focalizadora entre os pares, que se apresenta por meio dos qualificadores "rápida" e "sujeita". Iconicamente, a ordem dos itens é pensada para atender ao resultado comunicacional.

\subsubsection{Quanto maior... mais}

Esse padrão se constitui pelo item proporcional (causal) avaliativo atrelado a item proporcional (consecutivo) avaliativo. 
Também existe uma relação calcada na causa e consequência, característica inerente à proporcionalidade. O item "maior", segundo Azeredo (2009) tem uma conotação ligada à grandeza, intensidade, duração, excelência, pois se atrela ao item "quanto" cujo significado está calcado na intensificação, quantidade. Para Bechara (2009), o item “maior” está ligado à grandeza, duração, mínimo. Há também uma avaliação subjetiva por parte do autor, entre os pares correlativos, e por isso parecem denotar uma ideia de qualidade:

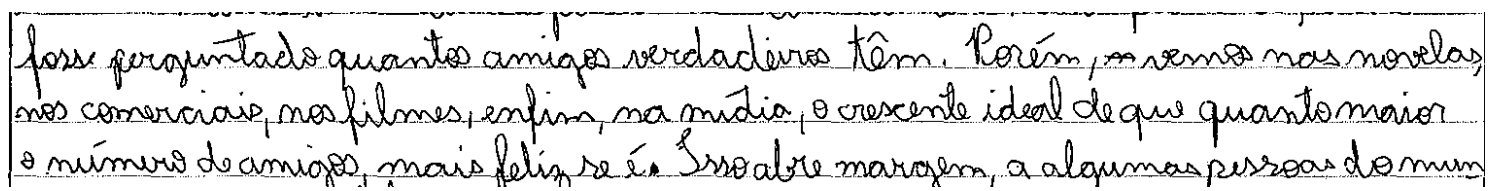

(Exemplo 111, Fuvest, 2007, p.81)

Algumas características merecem ser apontadas: primeiramente a relação entre a causa ("quanto o maior número de amigos") ligada à consequência ("mais feliz se é"), pertinentes à relação de proporção entre os pares. Outra questão importante: o item "maior", que funciona lincado a uma ideia de quantidade numérica, assume também, uma função qualificadora, que ao manter uma ligação com o item "mais", o influencia a também adquirir alguns traços de qualidade, e por isso funciona também como argumentos avaliativos.

\subsubsection{Quanto maior... maior \\ Quanto maior... maiores}

Esse padrão é composto pelo item proporcional (consequência) atrelado a item proporcional causa. 
Esses pares correlativos estão constituídos pelos itens "maior/ maiores", ligados à grandeza numérica, quantitativa. Possuem uma característica peculiar que é aproxima itens que se referem a consequência e causa:

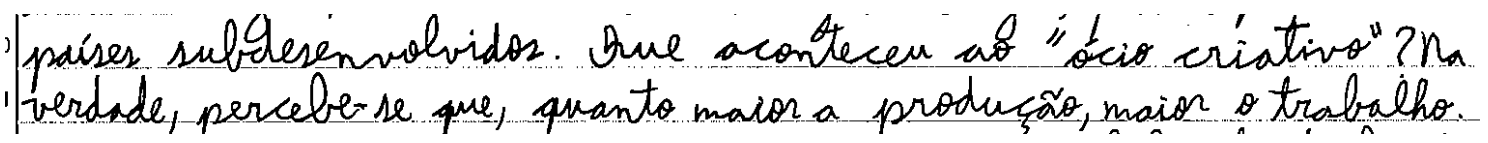

(Exemplo 112, Fuvest, 2006, p.73)

O item "maior" do $1^{\circ}$ elemento do par atrai o nome "produção" que ao remeterse ao $2^{\circ}$ elemento do par, também constituído pelo item "maior", atrai o nome “trabalho". Proporcionalmente, o que nos leva a pensar numa relação quantitativa, parece ser o item "maior", que além de representar uma grandeza numérica, quantidade, dá-nos a ideia de que contém mais volume, do que originalmente, maior $\rightarrow$ maior. Há também instituída uma relação de consequência e causa, apesar de sutil: quanto mais se produz, mais se trabalha.

Pela recombinação dos itens lexicais, denota-se uma proporção de grandeza muito superior à original, de forma intencional:

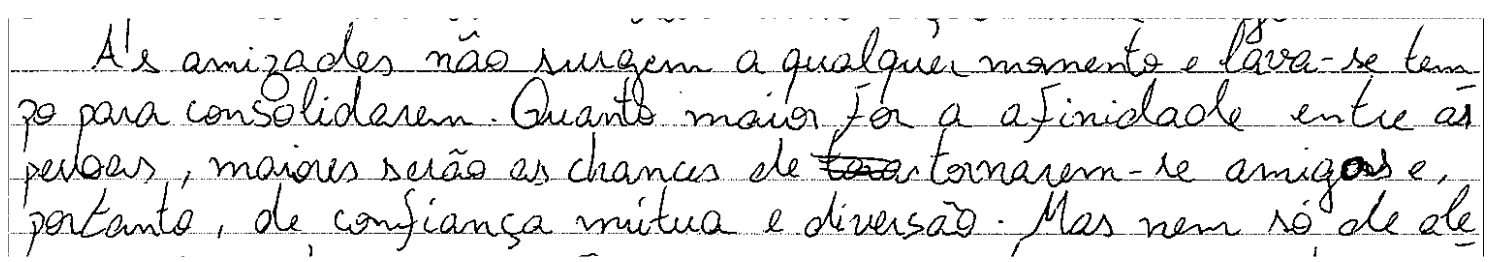

(Exemplo 113, Fuvest, 2007, p.65)

Esse trecho também possui uma relação por meio dos pares, causa e consequência: afinidade $\rightarrow$ chances; isto é, maior afinidade $\rightarrow$ maiores $\rightarrow$ são as chances de tornarem-se amigas. Os tempos verbais entre os pares sinalizam uma probabilidade maior de acontecer o fato: um subjuntivo futuro (for) associa-se a outro subjuntivo futuro (serão), mas que conta do item "maiores", parece estar mais próximo da realidade. A ordem dos itens lexicais muda a dinâmica dos sentidos, pois o conteúdo presente, no $1^{\circ}$ elemento do par, mostra que existe um grau intenso de afinidade entre as pessoas, porém não necessariamente se tornar amigas, de fato. Somente com a inserção, 
no $2^{\circ}$ elemento do par, do item "maiores" é que a possibilidade de isso acontecer aumentou.

\subsubsection{Tantos... quantos}

Esse padrão é sinalizado pela construção do item proporcional (quantificador) atrelado a item proporcional (quantificador).

Esse par correlativo constituído de "tantos" atrelado a "quantos" identifica dois itens que sinalizam à ideia de grandeza numérica proporcional. Apresenta conteúdo informacional, de uma forma diferente: pouca quantidade de material linguístico, no $1^{\circ}$ elemento do par, seguido de bastante quantidade, no $2^{\circ}$ elemento do par. Parece ser um recurso altamente argumentativo utilizado pelo autor:

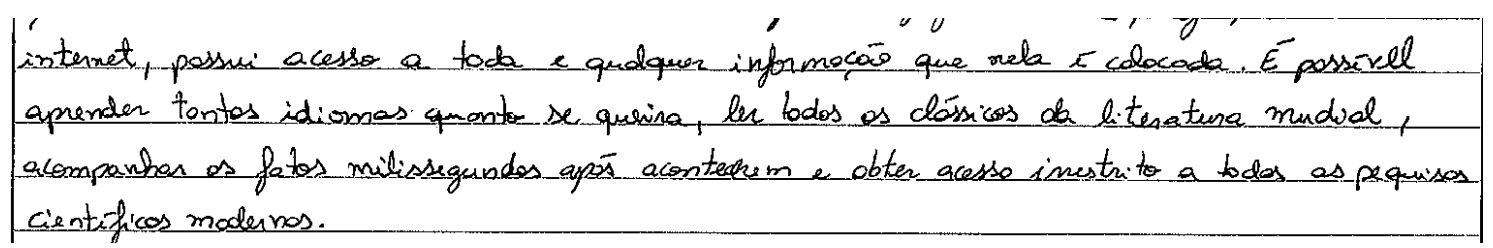

Além da relação instalada de causa e consequência (aprender idioma) e querer aprender proporcionalmente tem o papel de estabelecer uma imbricação entre as ações das porções informativas. A presença do verbo no infinitivo "aprender", antecipa o resultado do verbo. A ordenação parece subverter a ordem dos fatos (querer $\rightarrow$ aprender), mas não se pode ignorar que é um período encabeçado por uma oração de caráter epistêmico.

Sintaticamente, percebe-se que o par correlativo proporcional está intrinsicamente ligado a uma escolha, cuja ordem se dá por meio da inserção de material linguístico, que paralelamente, parece conferir, entre as porções informativas, um 
equilíbrio associado às intenções no ato do dizer. A partir daquilo que se declara na $1^{\mathrm{a}}$ porção, existe um aumento ou diminuição na mesma proporção.

Se há pouco material linguístico na $1^{\mathrm{a}}$ porção haverá também pouco material linguístico na $2^{\mathrm{a}}$. Entretanto, em alguns casos, na $2^{\mathrm{a}}$ porção, houve uma quantidade superior de material linguístico em relação à $1^{\mathrm{a}}$ porção. Isto ocorre porque, como a proporção exige que seus itens sejam iconicamente atrelados muito próximos uns dos outros, o autor burla essa pressuposição invertendo a ordem natural do fator (aprender $\rightarrow$ querer).

Parece haver um processamento mental calcado numa logicidade, cuja ordem dos vocábulos entre as porções se faz de maneira estratégica: o autor utiliza-se da proporcional para que haja maior aceitabilidade e velocidade da informação, mas, ao mesmo tempo, cria mecanismos de inserção de conteúdo no $2^{\circ}$ par, a fím de poder tornar mais verdadeiro, validade e notado aquilo que aponta.

De caráter epistêmico, a organização é proporcionalmente distribuída entre as porções, orientada para o "sujeito da enunciação" (Neves, 2006, p.163). A modalidade epistêmica está relacionada com a necessidade do falante de representar os estados das coisas, a partir do que vê e sente no mundo; e por isso ele lança mão de material lexical entre pares, que sinalizam pela proporção, uma compatibilidade entre as porções informativas: uma está imbricada na outra.

Para Neves, ainda, "o conhecimento do falante sobre o mundo é representável como um conjunto de proposições" (Neves, 2006, p.160) que estabelecem relações a partir daquilo que sabe sobre as coisas que o cercam. Parece que o uso da proporcional entre as porções é epistemicamente necessário para balancear e aproximar conhecimentos de mundo concretizados por meio de material lexical; isto é, deve haver uma proximidade entre o que o autor pensa e o que ele pensa sobre o que direciona o mundo.

A partir da exposição das tabelas abaixo, de 2004 a 2010, divididas ano a ano, por meio da quantidade de cada padrão apresentado, a relação semântica expressa, a estrutura e se estabelece uma relação simples ou complexa, elencaremos a seguir as razões que nos levaram a não priorizar as análises das piores, como um dos objetivos desta tese. 
Ao nos atermos aos dados dos textos de 2004, além de pouca quantidade de correlações apresentadas, a relação semântica expressa também é feita, na sua maioria, por aditivas e adversativas, sendo que apenas 2 delas apresentaram porções informativas, de estruturas mais complexas, bem elaboradas, em que o $2^{\circ}$ par correlativo contém mais material linguístico e ideias que levam o leitor a uma reflexão, uma das razões que nos levaram a não optar pela análise das piores redações.

A seguir, apresentaremos alguns trechos de aditivas e adversativas, a fim de provas que o autor, apesar de se utilizar de uma correlativa inovadora, o faz, simplesmente, para focalizar dois itens. Parece que faz com objetivo único de aproximálos, mas seu propósito argumentativo.

\section{$\underline{\text { Pares correlativos aditivos }}$}

"não... nem"

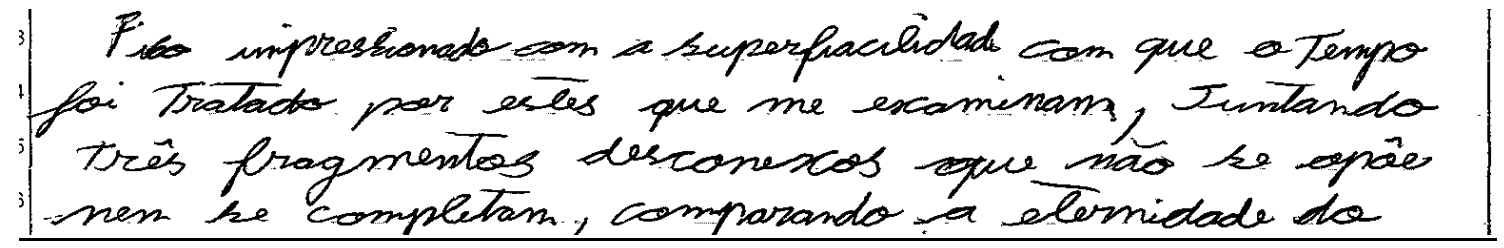

(Exemplo 115, Fuvest, 2004, p.1)

"não...e nem"

A preucupaça excusina com o futuro nos laz esquecer - presente," planejar e nå niver" nä pode ser 9 novo lema da noca geraças e nem torna-la smecanizada a lasx-la.

"tanto... quanto"

Sendo assion o tem po é necessório tunto para a hustoria do passodo quonto as presente le os futuro pois um dia des seros historia.

(Exemplo 117, Fuvest, 2004, p.87) 
"não só... mas"

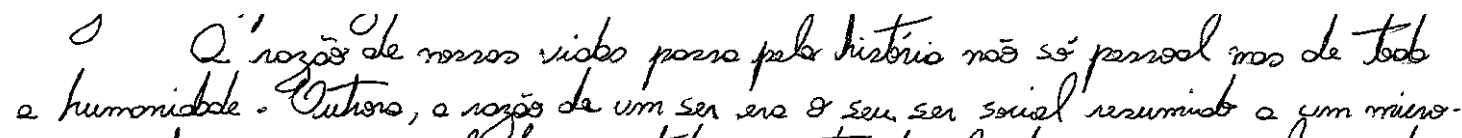

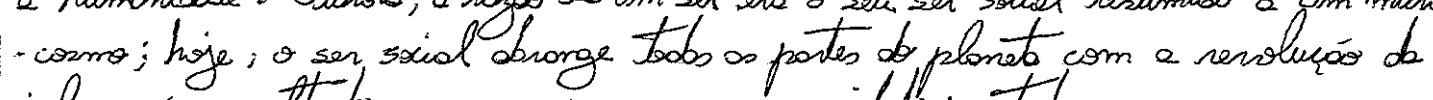

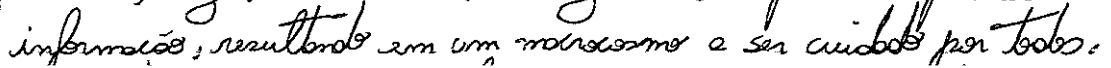

(Exemplo 118, Fuvest, 2004, p.90)

"não só... mas também"

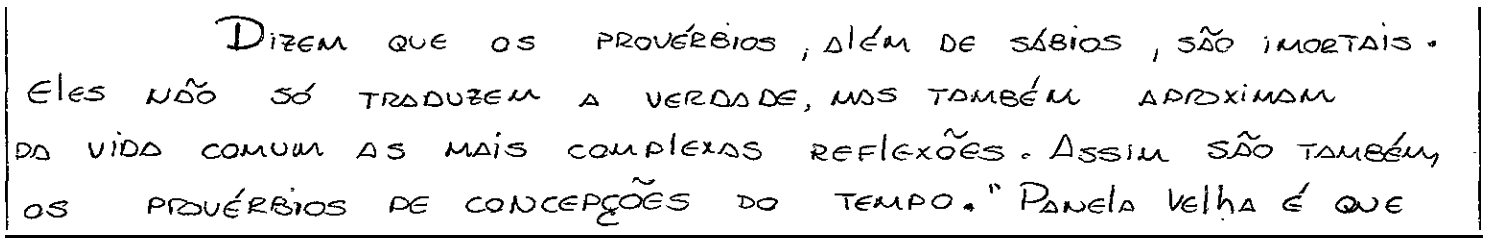

(Exemplo 119, Fuvest, 2004, p.8)

"desde... até"

athanis destos" e no dia-a-dia baseram seus atos a compontamentos semelhantes ao de alguma Distória.

(Exemplo 120, Fuvest, 2004, p.77)

$\underline{\text { Pares correlativos adversativos }}$

"não... mas sim"

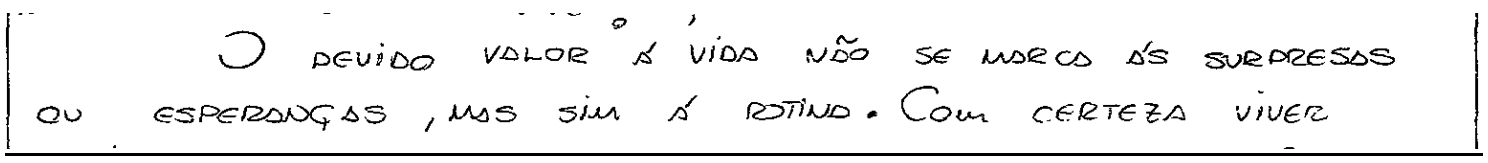

(Exemplo 121, Fuvest, 2004, p.8)

"não... e sim"

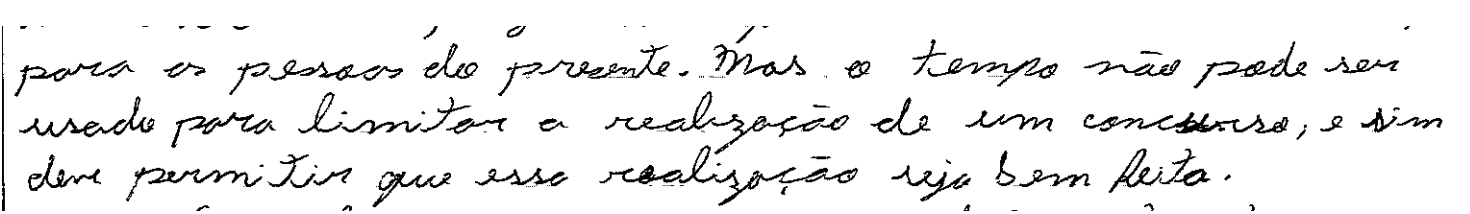

(Exemplo 122, Fuvest, 2004, p.38) 
Toda essa correria do dia-a dia das pessoas éválida mas não é $\theta$ essencial, e sim paz parte do que é essencial. Existem momeiras e momeiras de se associar com $\theta$ tempo, basta colocar couda coisa em seu engar.

Tanto nos pares correlativos aditivos e adversativos, nota-se que os autores reúnem itens com o objetivo apenas de focalizar a soma ou contrariedade entre os itens lexicais. Não há uma quantidade de material linguístico que sirva como suporte

à argumentação; e isso acaba comprometendo a reflexão solicitada pela banca examinadora. Das 16 aditivas, todas são advindas de relações correlativas simples; das 9 adversativas, 7 foram consideradas simples, também.

Ainda houve a presença de apenas 1 comparativa e 5 alternativas, todas compostas de estruturas simples.

Para o ano de 2005, constatou-se a presença de pares correlativos aditivos (14), adversativos (12), proporcional (2), alternativas (6) e comparativas (3); tendo como as estruturas simples presente na maior parte delas. Vejamos alguns dos tipos:

\section{$\underline{\text { Pares correlativos aditivos }}$}

"não só... mas também"

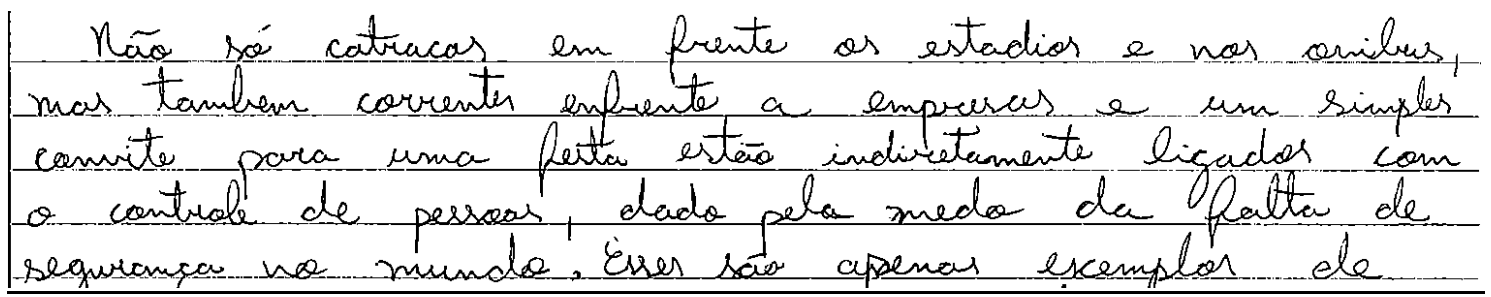


Há locais também como os bancos gue uticizam as catracas come meio de segunanga, visto a violéncia afual, objetos esses gue vīo atón do exdenon, contar, pois com uso de tecnologia atual estäo também identificando metais, gue podem ser encontrados tanto em armas de 1000 como brancas. Há catracan

(Exemplo 125, Fuvest, 2005, p.18)

"não só... mais"

E' necestara que duminuo al hurovoua em nosse pais, noo sópara reduzir os transtornos bo a

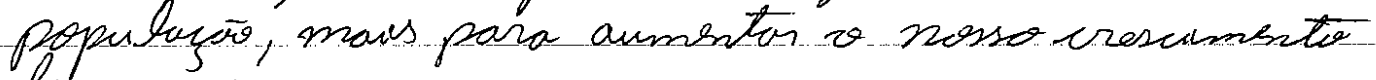
Limancever.

(Exemplo 126, Fuvest, 2005, p.59)

$\underline{\text { Pares correlativos adversativos }}$

"não só... mas sim"

volver suas futuras jerações. O homem 'porem ' se torna um caso a parte, pois sua evolugão nào é mais física mas sim social, e o seletur muitas vezes não permite que o ser humamo se desenvolva colocando barreiras, obstáculos e por mezrores desmecesarios para 2. maioria. Outro ponto que distinqui é o fato que o ser animal mán

(Exemplo 127, Fuvest, 2005, p.73)

"não... sim"

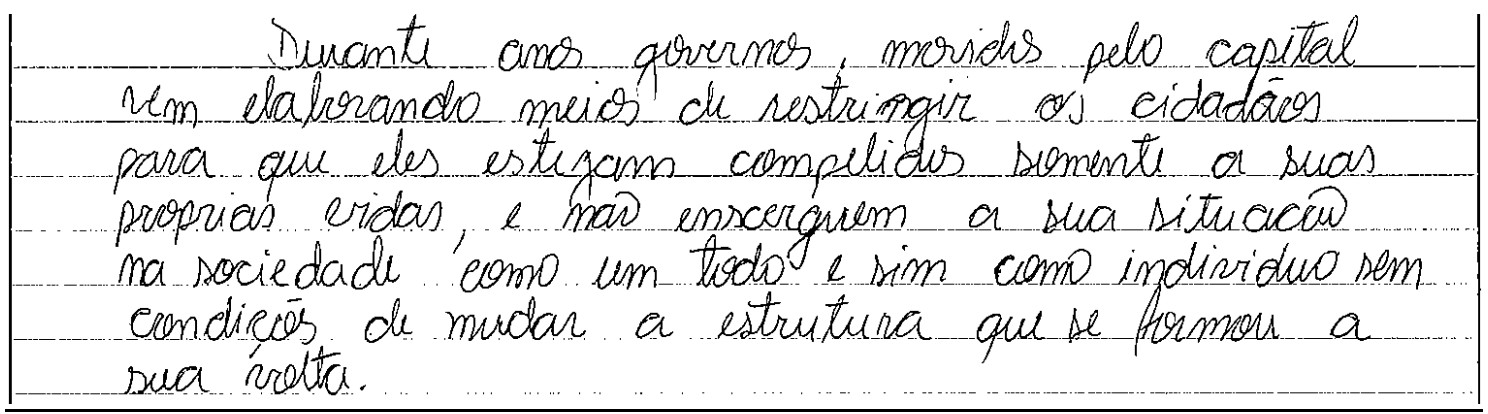

(Exemplo 128, Fuvest, 2005, p.81)

"não... mais" 


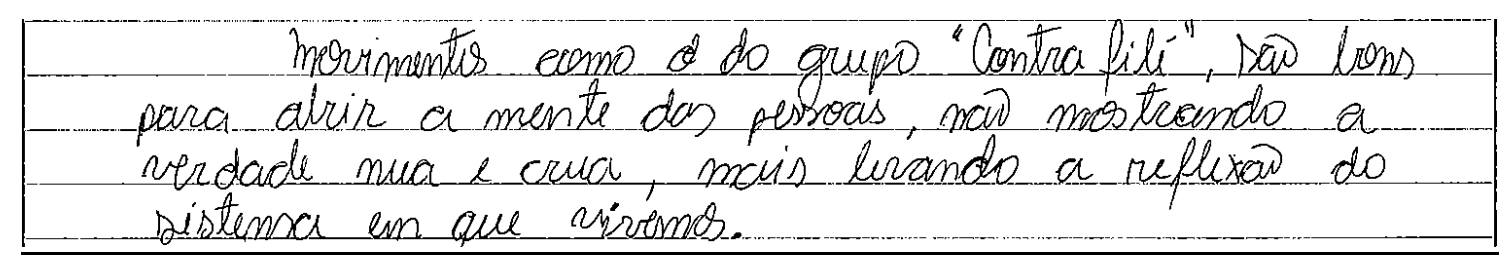

(Exemplo 129, Fuvest, 2005, p.81)

$\underline{\text { Par correlativo proporcional }}$

"quanto mais... mais"

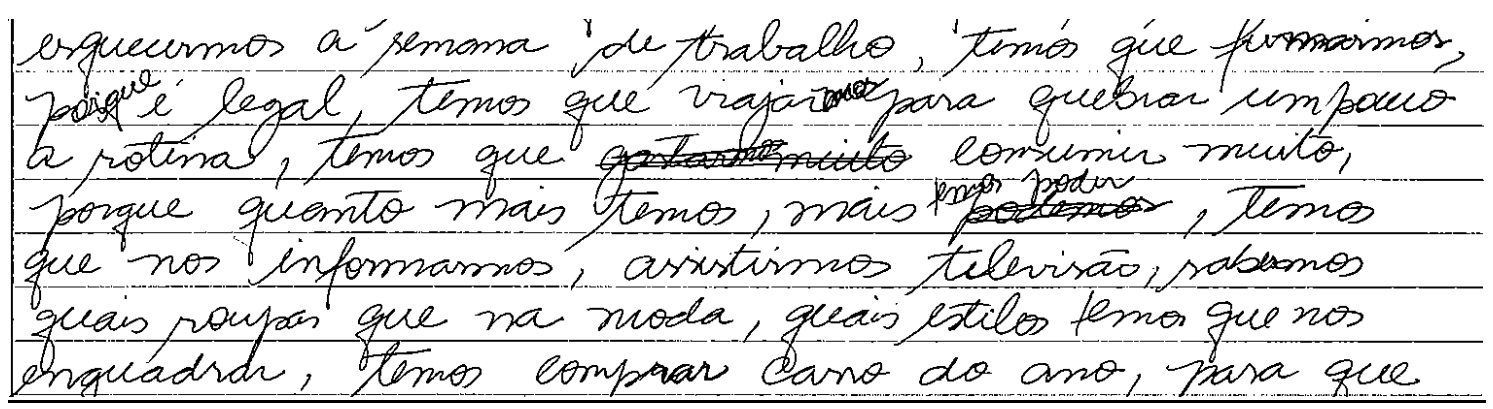

(Exemplo 130, Fuvest, 2005, p.10)

$\underline{\text { Pares correlativos alternativos }}$

"seja... ou"

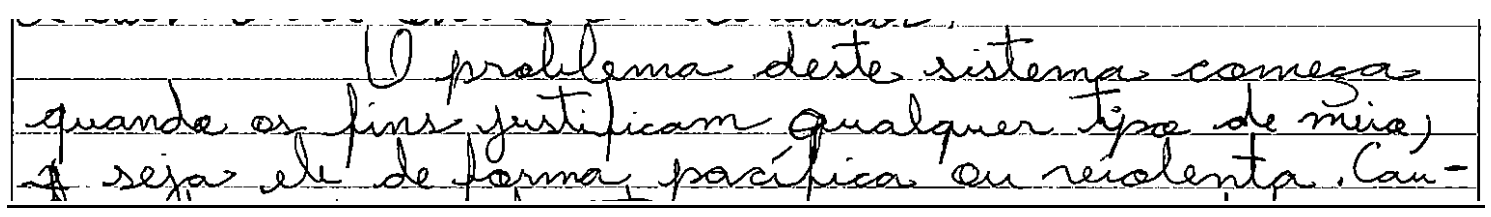

(Exemplo 131, Fuvest, 2005, p.15)

"seja... seja"

pgir, comviver. Ha' jugar, há estipûlocotes, onde o corpo e a mer.

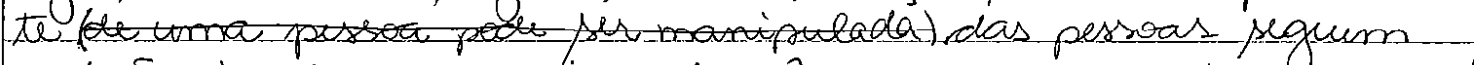
hadrais. Modas, ididogias, terdincias, , a companham, a mais A maré, claro, guiada e estipulada conforme interesses seja de govemantes sixa de rutursous de capital 
$\underline{\text { Par correlativo comparativo }}$

"mais... do que"

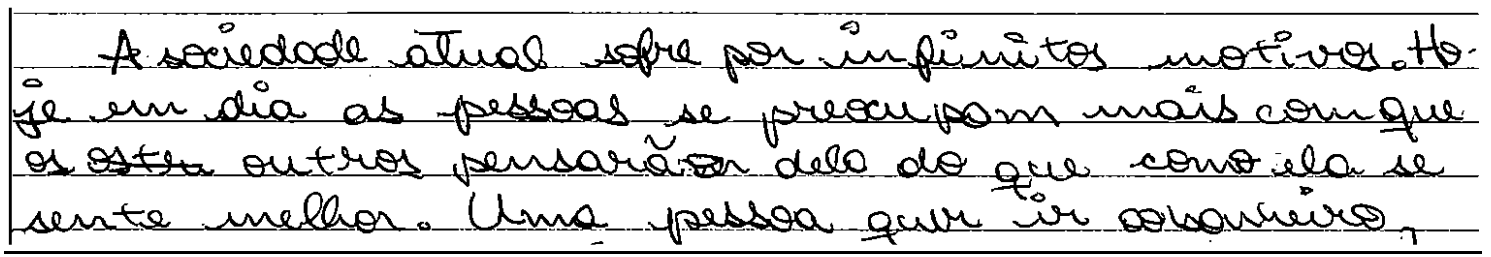

(Exemplo 133, Fuvest, 2005, p.40)

Chamamos atenção para mais um fato: apesar da coerência presente nas discussões, nos trechos, percebe-se que há sérios problemas de coesão, que prejudicam o sentido, afeta diretamente as intenções daquilo que o leitor quer comunicar. Há também um truncamento em que os parágrafos que contribuem para quebra de expectativa do leitor: problema da redação. Parece, em alguns trechos, que o leitor une palavras, mas que num conjunto, perdem o sentido que se pretendia estabelecer: "o homem porém se torna um caso a parte, pois sua evolução não é mais física, mas sim social, e o seletor muitas vezes não permite que o ser humano se desenvolva colocando barreiras..." (Fuvest, 2005).

Quanto aos textos piores de 2006, temos 11 aditivos, 10 adversativos, 1 proporcional, 1 comparativo e 1 alternativo, sendo no total 15 com estrutura simples.

$\underline{\text { Pares correlativos aditivos }}$

"desde... até"

E ftuto do labor desde prédios cinzos monoctom a tico até obros attistican milenares, e embora tentam finalidades diferentes ambos são fruto do trabalho do bomem. 
Isto tudo gera un ciclo vicioso, pols a populacão, con salänos defasados näo poupa nem. investe seu dinherro, o gre gera quedas nas vendas e va producho, que, por suaver. aera corte de funcionários nas empresas.

(Exemplo 135, Fuvest, 2006, p.73)

$\underline{\text { Par correlativo adversativo }}$

"não... sim"

Por fim, "Michelangelo realizon um trabalho belimimo "a obra era perfuta", amalisando esta prase traballo fisico e sim de traballo antistico, dera de arte.

(Exemplo 136, Fuvest, 2006, p.10)

$\underline{\text { Par correlativo comparativo }}$

"mais... do que"

I Abéncoados fram Picasso michelangelo i tantos outwos gue desenvolveram em suas vinas haballos que loje sīo vistos como arte uma gande obra,. Pois hoje em pia gemais facil ver um artista haballá do gue o taballo

(Exemplo 137, Fuvest, 2006, p.31)

$\underline{\text { Par correlativo alternativo }}$

"sejam... ou"

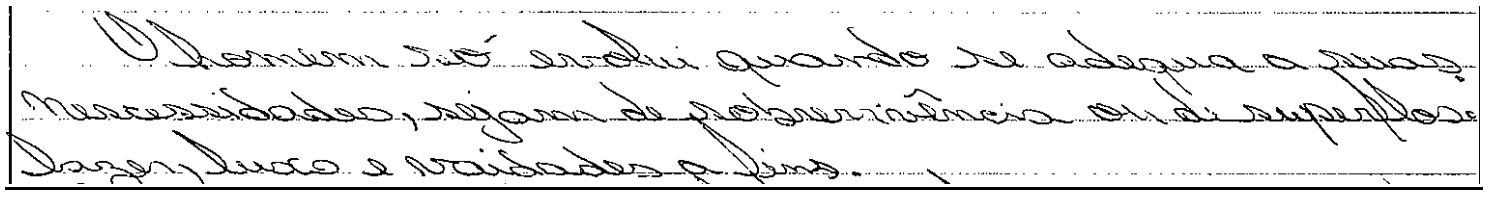

(Exemplo 138, Fuvest, 2006, p.76) 
Se comparássemos um trecho considerado melhor, de 2006, também apresentando um par correlativo alternativo, por exemplo, algumas considerações poderiam referendar do porquê da escolha em optar por analisar somente as consideradas melhores pela banca. Tem-se o trecho:

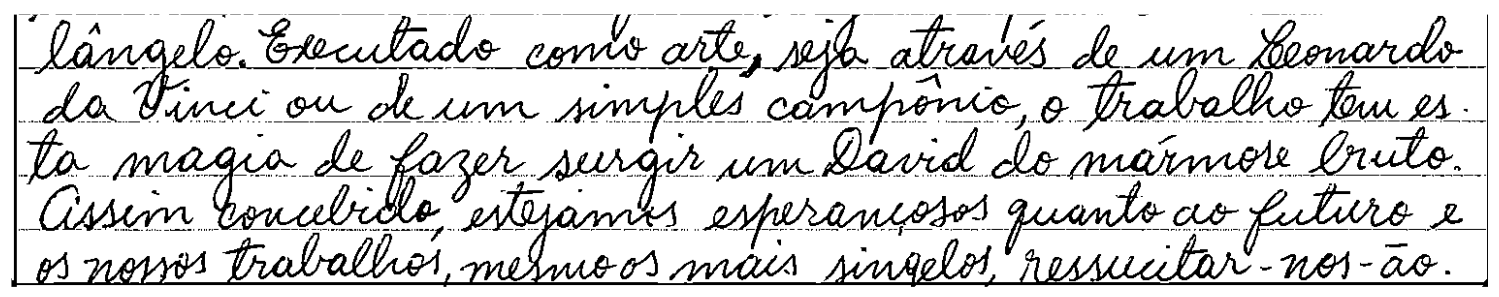

(Exemplo 139, Fuvest, 2006, p.9)

Percebe-se que enquanto o trecho considerado pior utiliza-se do par correlativo para alternar elementos que se contradizem em relação ao sentido (necessidade de supérfluos?) o autor aproxima elementos que contribuem para atingir coesão e coerência.

Claramente, a utilização do par correlativo é feita de maneira normatizadora, mas sem levar em consideração a ideia e fatos discursivamente pragmáticos que interferem no sentido atribuído.

Em relação aos textos apresentados no ano de 2007, tem-se: 15 aditivos, 10 adversativos, 10 comparativos, 5 consecutivos, 7 alternativos, num total de 38 constituídos por estruturas simples, dentre eles:

$\underline{\text { Pares correlativos aditivos }}$

"não só... como também"

Os benefícios sõó tremendós. Nầ só vocề se alegrará com uma, vitória, como tombém fará su amigo. O contrá-

"tanto... quanto"

Tante a pessoa crica gurantel a poble tem um
animal aus de cher fill a ele 
$\underline{\text { Pares correlativos adversativos }}$

"não... mas"

Muitas pessoas passam por nossas vidas. As que ficum, pode ser consideradas amigas, eas que to cam tumbóm, Porque amigo nuo é a quele qu estará sempre con vocè , mas que quando vocè precisar, estara la para te ajudar, nem que seju somente para te tezer compania.

(Exemplo 142, Fuvest, 2007, p.65)

"não... e sim"

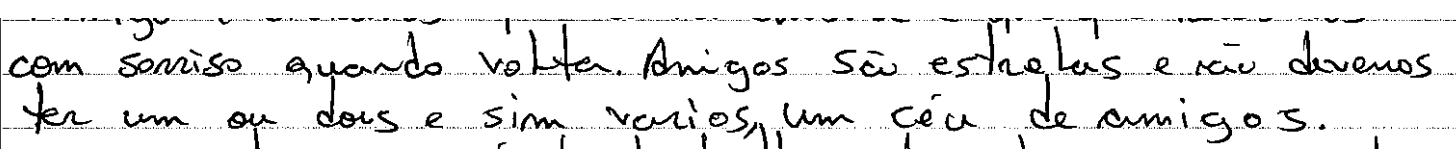

(Exemplo 143, Fuvest, 2007, p.80)

$\underline{\text { Pares correlativos comparativos }}$

"melhor... do que"

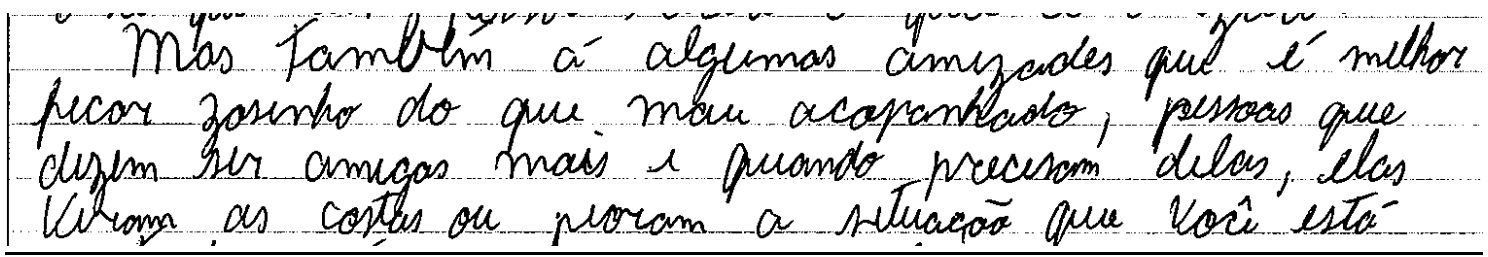

(Exemplo 144, Fuvest, 2007, p.86)

"menos... que"

A amizade é, hajier no brosil, menos valorizado qu o amon, afinal mōo. rende tanto quanto iste. No entonto parece que nem sempre foi assion. Da antiavidade ate' talum ó século XIX a aminade boi mai valorizada.

(Exemplo 145, Fuvest, 2007, p.90)

$\underline{\text { Pares correlativos alternativos }}$

"seja... seja" 
- Quanto se faz necessário que a tenHamos mesmo as

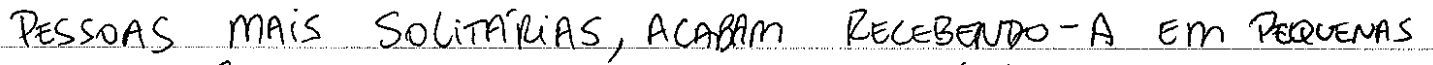
Doses, seja no aproximar de um pássaro, sesa no sorriso Do VENDEDOR DE SORNAIS.

"ou... ou"

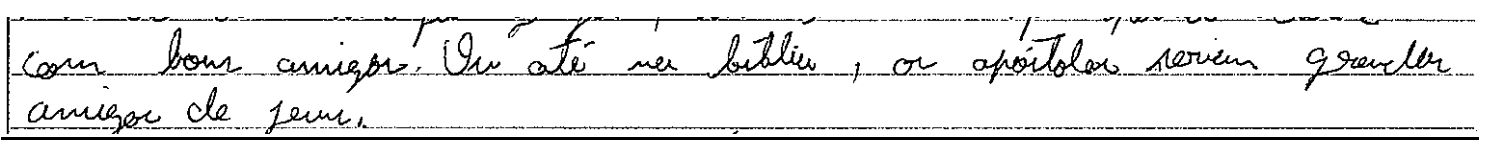

(Exemplo 147, Fuvest, 2007, p.98)

$\underline{\text { Par correlativo consecutivo }}$

"tão... que"

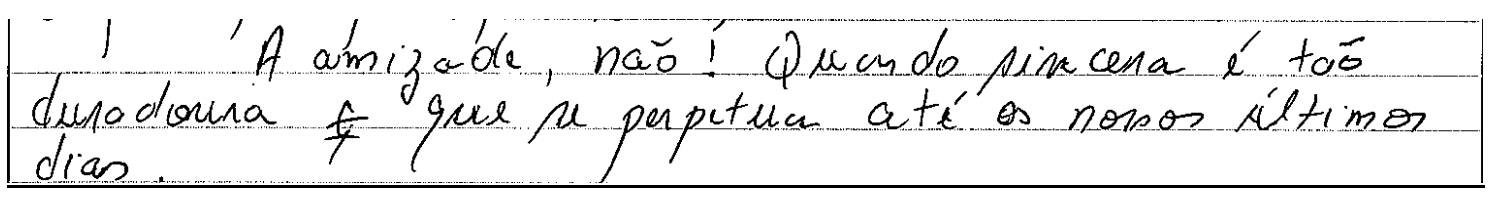

(Exemplo 148, Fuvest, 2007, p.31)

Apesar da consecutiva aparecer como correlata no ano de 2007, se faz de maneira simples, nos dá complexidade entre as porções dos elementos entre os pares correlativos. $\mathrm{O}$ autor as utiliza num processamento causa e consequência, mas sem debater e discutir a ideia proposta.

Até poderia ser alvo de nossa discussão, se o trecho fizesse parte de um parágrafo maior, que abarcasse ideias e que relacione itens lexicais. Mas não é isso o que se apresenta, por isso não ser alvo de nossa análise, assim como as outras correlativas elencadas.

Os textos do ano de 2008 dividiram-se por meio de aditivos (20), adversativos (5), alternativos (9), comparativo (1). Dentre eles, temos:

$\underline{\text { Pares correlativos aditivos }}$

"só... mas também" 
Com o ascesso as informocoes via intemet, duemos
tomar cuidodo com as mesmas, e tor o disernimento
que nat importa so quantidode mas tamet
Comberm qualidode. (Exemplo 149, Fuvest, 2008, p.58)

"tanto... quanto"

Esse mundo digutal no qual ivemos pode nos atrapalhap tanto quanto pode nos asudar a enriguecer nossa cultura. Para hos ajudar, existem

(Exemplo 150, Fuvest, 2008, p.75)

$\underline{\text { Pares correlativos adversativos }}$

“mas não... mais sim"

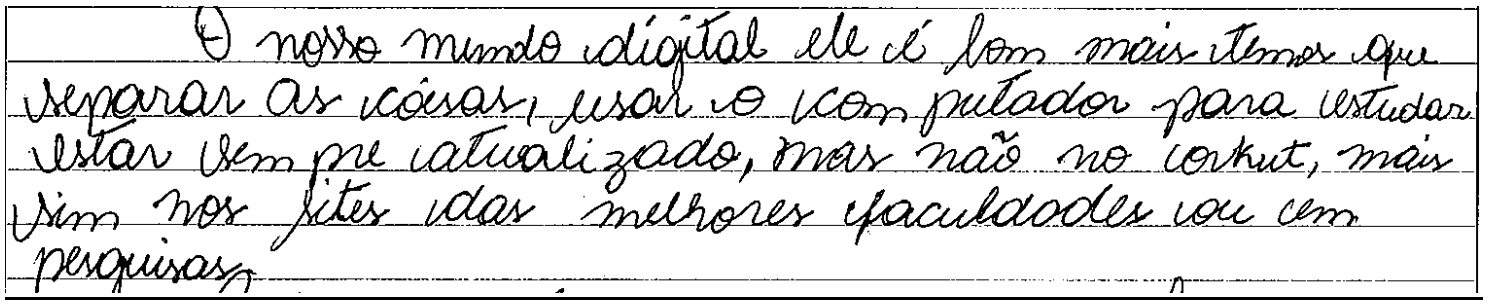

(Exemplo 151, Fuvest, 2008, p.11)

"não... e sim"

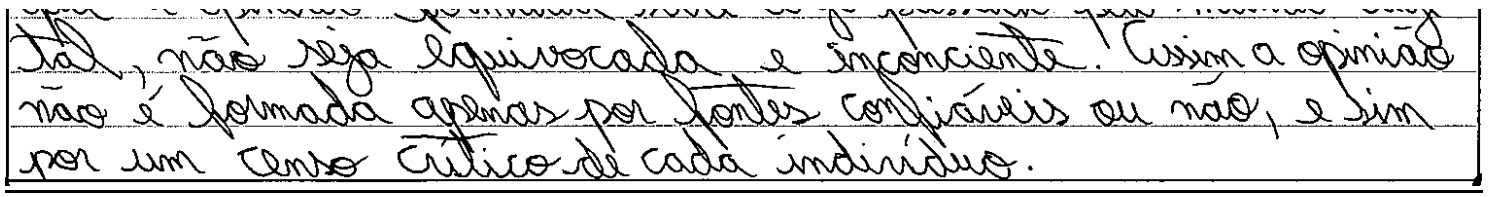

(Exemplo 152, Fuvest, 2008, p.41)

$\underline{\text { Par correlativo alternativo }}$

"sejam...ou"

A mídia de hoge tern por objetivo levav o que é halado ow o que

acontece aos quatio cantos do mundos sefarm os latos verdade ow não. hão

(Exemplo 153, Fuvest, 2008, p.76) 
$\underline{\text { Par correlativo comparativo }}$

"menos... do que"

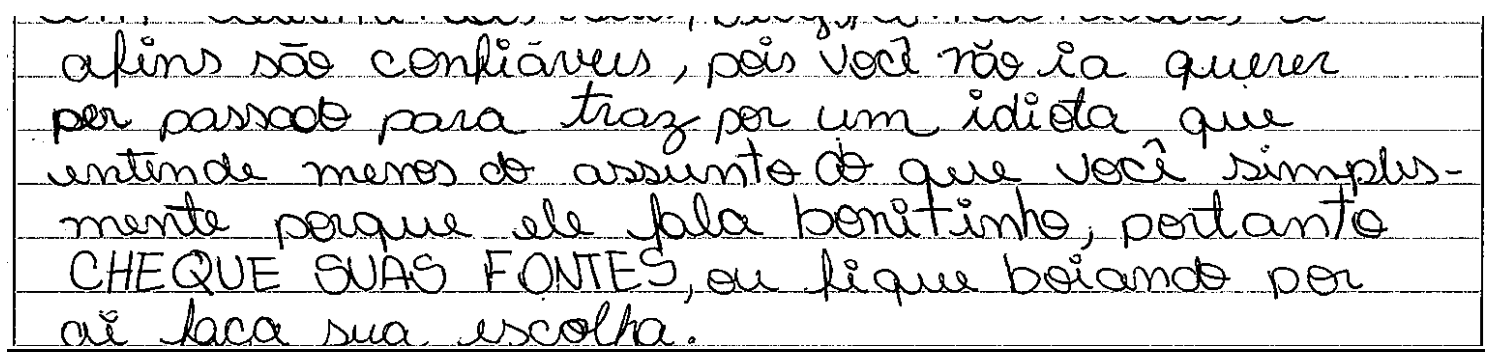

(Exemplo 154, Fuvest, 2008, p.86)

O que nos chama atenção é a baixa presença da quantidade de correlativos nesse ano; e também a respeito dos pares utilizados principalmente, dos aditivos, presentes na gramática do português padrão. Isso nos remete a apontar que os autores buscam a normatividade para garantir minimamente a certeza da utilização ideal de elementos lexicais, mas que ao mesmo tempo são acoplados de informações com material linguístico.

Parece que o autor do texto quer garantir a legibilidade daquilo que aponta por meio desses pares, mas que por falta de conteúdo lexical, empobrece as porções e compromete o debate.

Parece como a consecutiva, alternativa, condicionais, concessivas não são utilizados nos textos pelos candidatos; isto porque exigiram, provavelmente, um maior nível de complexidade pautado em informações, fatos.

Nas analisadas referentes ao ano de 2009, têm-se 11 aditivas, 10 adversativas, 2 comparativas, 9 alternativas, 2 consecutivas e 2 proporcionais.

$\underline{\text { Pares correlativos aditivos }}$

"não...nem" 
mas o grande responsáred por isse tudo ser possinel, nấc số os traficantes de produtos a nem os fiscar, mas a govemne e sue fatte de

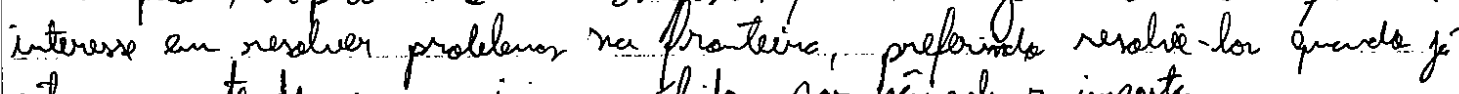

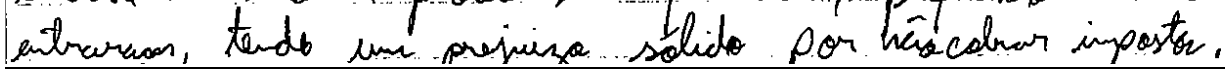

(Exemplo 155, Fuvest, 2009, p.48)

"não só... mas também"

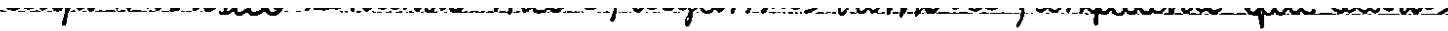
estoo felizes. A difuimeo untre as persoas logo pode ser notoda, mäo sopela nacionalidode mas tamberr pelo modo de oqie. Há quem dega qui näo existe pessoas com sensomentes lquais, no entanto, há um sentimento que todos possuem a qeralmente $x$ copoz de fozer todas as deferencas desapaucerem. \& a amor.

(Exemplo 156, Fuvest, 2009, p.88)

$\underline{\text { Pares correlativos adversativos }}$

"não... mas sim"

principalmente entre religiors. 0 importante não è a religiãos: mas sim a fé dentro de cada um.

"não... e sim"

taj diferentes sempse the couberar a soluçá de' seus problemas atribuir a guerra, que por sua vez nunca trouxe benefício algur a rentum desses povas pois a disputa pelo mesmo solo nas ten carater de cunto apenas territorial, e sim de muitas faces, mas o principal e mais explícito o religioso.

$\cap i \quad n$

(Exemplo 158, Fuvest, 2009, p.35)

$\underline{\text { Par correlativo alternativo }}$

"seja... ou" 


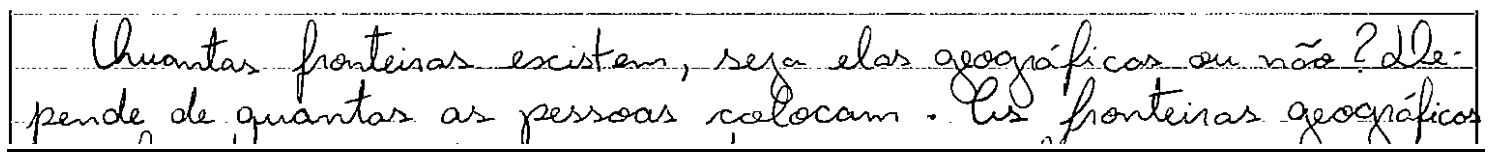

(Exemplo 159, Fuvest, 2009, p.89)

\section{$\underline{\text { Par correlativo comparativo }}$}

"tão... quanto"

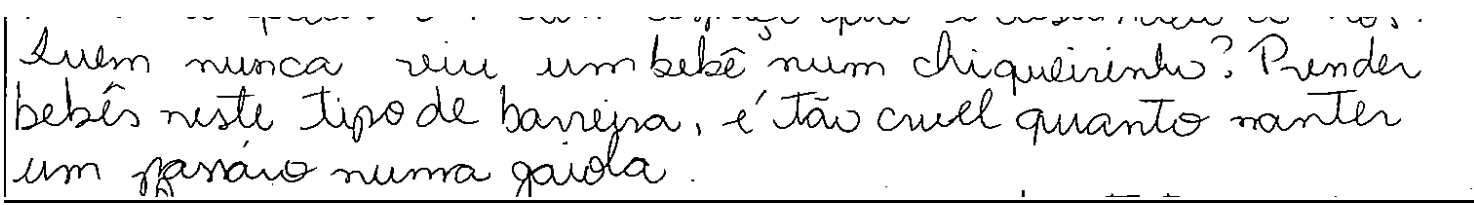

(Exemplo 160, Fuvest, 2009, p.25)

\section{$\underline{\text { Par correlativo proporcional }}$}

"quanto mais... mais"

Jáfoe provado que quanto mais maneinas diferentes al guém ntilizar pora aprender uma mesma caisa, mais dificil será para este esquecer. as navas simapses (ligaccées entre neurânicas) criadas auciliam na memória e l'assim que se constrái verdadeina comhecimento.

(Exemplo 161, Fuvest, 2009, p.91)

Também a aditiva e a adversativa foram as que mais apareceram nos textos dos candidatos desse ano. A característica presente na maior parte dos textos: unir ou opor itens lexicais que somente aproximam ou opõem itens lexicais que tornam as relações entre as porções informacionais menos complexas. Interessante apontar que o número de estruturas simples contribui para ausência de uma argumentação que leve a um debate, reflexão. Parece que o trecho feito pelo candidato apesar de dissertativo, pois envolve minimamente uma escolha de itens que se ligam ao tema, não é argumentativo. A opinião é calcada somente entre elementos que se confluem ao tema, mas que não são aprofundados. 
Se o papel da argumentação é o de convencer o outro sobre determinada ideia, influenciando-o e transformando seus valores a fim de que posicionar-se sobre o tema, a consistência por meio de uma complexidade de dados e fatos, é uma operação que se exige para tal. Isso não percebemos nos dados coletados.

Quanto aos textos de 2010, as aditivas foram as mais presentes nos trechos das redações (14 ocorrências), seguida de 5 adversativas, 8 alternativas e 1 consecutiva, prova também da pouca ocorrência de correlativas presentes nas produções desse ano.

\section{$\underline{\text { Pares correlativos aditivos }}$}

"não... nem"

() Não importa qual sefa a sua crença, nem qual tecrologia esta por vir. En todas elas há a imaqem

“além... também"

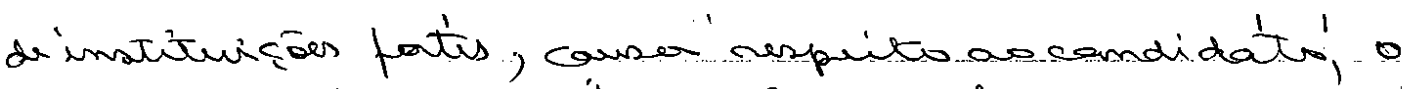
candidate Jeve muite combicimento pongure nestab

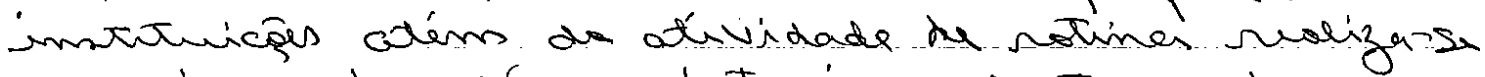
proquisa tambirm, fato impotants ma 'aner formasêntic a y mos men serupre stas caacteúiticas condiz com a meunidade dos requintos da industir mas a imogen forte

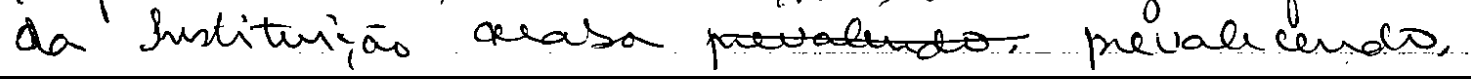

“somente... mas também"

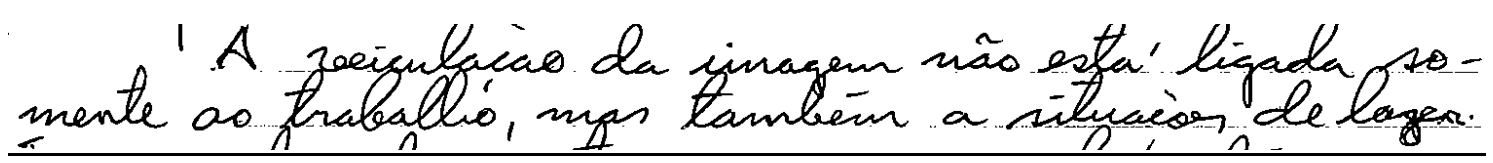

(Exemplo 164, Fuvest, 2010, p.77)

"tanto... quanto" 
Portanto, é dificie defender ou acubar adaptaciöers de obras literárias para o cinema, já que ersa pode ser tanto boa quarto ruim aos espectadores. ingo, uma indicaçäo é que todos deviam ler o livro antes de ir a a a'nema, para assim terem pelo menos um pouco al imagina çăo, $\theta$ que é essencial na vida de todo mundo.

(Exemplo 165, Fuvest, 2010, p.86)

"não... nem"

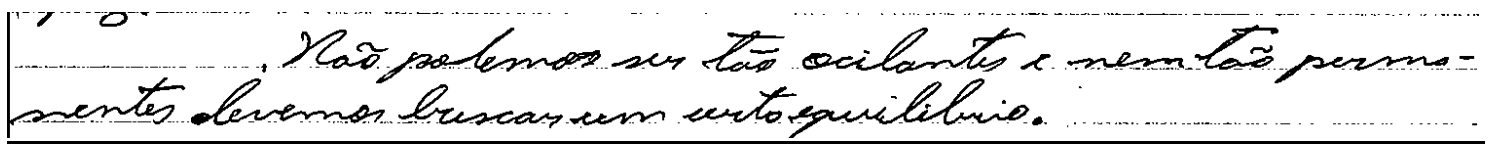

(Exemplo 166, Fuvest, 2010, p.95)

"não só...mas também"

depoimentas, tempos depois cam a desenvalvimento das telecomunicaçäes para uso comum, surgiu a televisar e como conseqüência 0 tele-jornal, qual poderia exibir não só fotos mas também videos de acontecimentos, o que era ótimo, pois é uma imacem em movimento, demanstrando oque está aconteciada no local com mais realidade e detalhes eque. uma fato inerte.

$\underline{\text { Pares correlativos adversativos }}$

"seja... ou"

"G moneirc com que a inprense trato a informcis reje para. gonher de concorenic on ncio de fato i refletido ko rosso dic dia, pozendo com que picuens defendente da viscio críticr de oütros...

(Exemplo 168, Fuvest, 2010, p.46)

"não... mas sim"

I mundo nav ino's về coma pessoas, mas sim trabalhadbes somos amichonteuclos pela figura de uma pessa pabu, e nos apegamos a dimheino, mossa individualide vinou um defeite, themos que mos enquadrar ao sistema. 
"não como... mas como"

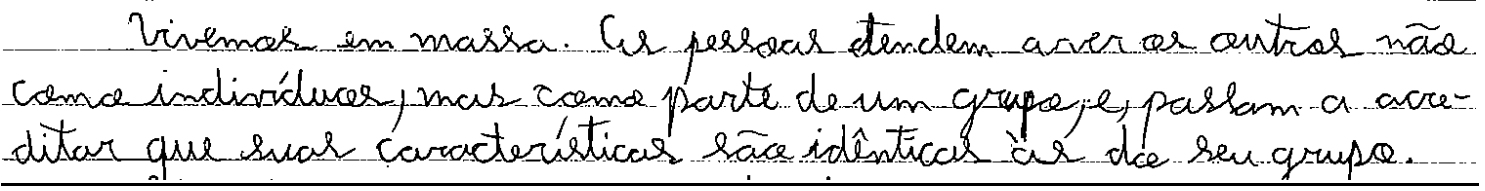

$\underline{\text { Par correlativo alternativo }}$

"seja...ou"

QUANDO ALGUEM AESETA CONFERIR VERACIOADE A ALUMA INFORMACAO LOCO DIZ OLE EL'ESTA' CONTIOS EM UB LURO. SA ELE'MANUA L, DIBLIA, ALMANAPUE OV ENCKLO BE'DIA. MESMD OLE EJSE PCOUEM ESTEJA MEUTINDO DIFCI LBENTE SERA CONESSADO DON O CONFANCA OUE O DALAVRA ESCRITA INSPIRA E'MMEATIVEL.

O ano de 2010 também apresentou a aditiva como a mais presente nos pares correlatos entre as porções informativas. Novamente se caracterizam apenas para combinar itens lexicais que tem como objetivo unir fatos, mas sem necessariamente discuti-los.

Ao final de nossos apontamentos, fica claro que apesar da utilização de pares inovadores, foco de nossa análise, os autores dos trechos apresentados, utilizaram-se das correlativas com um único propósito: relacionar itens que se aproximam e se recombinam, somente. 
PIORES 2004

\begin{tabular}{|c|c|c|c|}
\hline \multirow[t]{2}{*}{ PADRÃO } & \multirow[t]{2}{*}{ QNTIDADE } & \multirow{2}{*}{ REL. SEMÂNTICA } & ESTRUTURA \\
\hline & & & SIMPLES / COMPLEXA \\
\hline não... nem & 3 & Aditiva & S S S \\
\hline não só... mas também & 2 & Aditiva & S S \\
\hline tanto... como & 1 & Aditiva & $\mathrm{s}$ \\
\hline não... mas somente & 1 & Aditiva & $\mathrm{S}$ \\
\hline desde... até & 1 & Aditiva & $\mathrm{s}$ \\
\hline não só... como também & 1 & Aditiva & $\mathrm{s}$ \\
\hline nem... nem & 1 & Aditiva & $\mathrm{S}$ \\
\hline não... e nem & 2 & Aditiva & S S \\
\hline desde... até & 1 & Aditiva & $\mathrm{s}$ \\
\hline tanto... quanto & 2 & Aditiva & S s \\
\hline não só... mas & 1 & Aditiva & $\mathrm{s}$ \\
\hline
\end{tabular}

Quadro 13. Pares correlativos e suas funções pragmáticas - Piores 2004 Aditivas.

PIORES 2004

\begin{tabular}{|l|l|l|c|}
\hline PADRÃo & QNTIDADE & REL. SEMÂNTICA & $\begin{array}{c}\text { ESTRUTURA } \\
\text { SIMPLES / COMPLEXA }\end{array}$ \\
\hline mas não... apenas & 1 & Adversativa & S C \\
\hline não... e sim & 2 & Adversativa & S \\
\hline não... mas sim & 3 & Adversativa & S S \\
\hline mas... e sim & 1 & Adversativa & C C S \\
\hline não... sim & 1 & Adversativa & S \\
\hline não... mas sim & 1 & Adversativa & S \\
\hline
\end{tabular}

Quadro 14. Pares correlativos e suas funções pragmáticas - Piores 2004 Adversativas.

PIORES 2004

\begin{tabular}{|l|l|l|c|}
\hline PADRÃO & QNTIDADE & REL. SEMÂNTICA & ESTRUTURA \\
& & & SIMPLES / COMPLEXA \\
\hline mais... do que & 2 & Comparativa & S S \\
\hline
\end{tabular}

Quadro 15. Pares correlativos e suas funções pragmáticas - Piores 2004 Comparativas.

PIORES 2004

\begin{tabular}{|l|l|l|c|}
\hline PADRÃO & QNTIDADE & REL. SEMÂNTICA & ESTRUTURA \\
SIMPLES / COMPLEXA \\
\hline seja... ou & 3 & Alternativa & S S S \\
\hline ou... ou & 2 & Alternativa & S S \\
\hline
\end{tabular}


Quadro 16. Pares correlativos e suas funções pragmáticas - Piores 2004 Alternativas.

PIORES 2005

\begin{tabular}{|l|l|l|c|}
\hline PADRÃo & QNTIDADE & REL. SEMÂNTICA & $\begin{array}{c}\text { ESTRUTURA } \\
\text { SIMPLES / COMPLEXA }\end{array}$ \\
\hline não só... mas também & 1 & Aditiva & $\mathrm{C}$ \\
\hline desde... até & 2 & Aditiva & $\mathrm{SS}$ \\
\hline tanto... quanto & 2 & Aditiva & $\mathrm{S} \mathrm{S}$ \\
\hline tanto... como & 1 & Aditiva & $\mathrm{S}$ \\
\hline tanto... como & 1 & Aditiva & $\mathrm{S}$ \\
\hline tão somente... mas também & 1 & Aditiva & $\mathrm{S}$ \\
\hline não só... "mais" & 1 & Aditiva & $\mathrm{S}$ \\
\hline não só... mas também & 1 & Aditiva & $\mathrm{S}$ \\
\hline não só... como & 3 & Aditiva & $\mathrm{S}$ \\
\hline não só... mas & 1 & Aditiva & $\mathrm{S}$ \\
\hline
\end{tabular}

Quadro 17. Pares correlativos e suas funções pragmáticas - Piores 2005 Aditivas.

PIORES 2005

\begin{tabular}{|l|l|l|c|}
\hline PADRÃo & QNTIDADE & REL. SEMÂNTICA & $\begin{array}{c}\text { ESTRUTURA } \\
\text { SIMPLES / COMPLEXA }\end{array}$ \\
\hline não... e sim & 4 & Adversativa & S C S S \\
\hline não... mas & 1 & Adversativa & C \\
\hline não... mas sim & 3 & Adversativa & S S S \\
\hline não... e sim & 1 & Adversativa & S \\
\hline não... e sim & 1 & Adversativa & C \\
\hline não... sim & 1 & Adversativa & S \\
\hline não como... sim como & 1 & Adversativa & C \\
\hline
\end{tabular}

Quadro 18. Pares correlativos e suas funções pragmáticas - Piores 2005 Adversativas.

PIORES 2005

\begin{tabular}{|l|l|l|c|}
\hline PADRÃo & QNTIDADE & REL. SEMÂNTICA & $\begin{array}{c}\text { ESTRUTURA } \\
\text { SIMPLES / COMPLEXA }\end{array}$ \\
\hline quanto mais... Mais & 2 & Proporcional & S S \\
\hline
\end{tabular}

Quadro 19. Pares correlativos e suas funções pragmáticas - Piores 2005 Proporcional. 
PIORES 2005

\begin{tabular}{|l|l|l|c|}
\hline PADRÃO & QNTIDADE & REL. SEMÂNTICA & $\begin{array}{c}\text { ESTRUTURA } \\
\text { SIMPLES / COMPLEXA }\end{array}$ \\
\hline seja... ou & 1 & Alternativa & S \\
\hline seja... seja & 1 & Alternativa & S \\
\hline como... ou & 1 & Alternativa & S \\
\hline sejam... ou & 1 & Alternativa & S \\
\hline tanto... ou & 1 & Alternativa & S \\
\hline ou... ou & 1 & Alternativa & S \\
\hline
\end{tabular}

Quadro 20. Pares correlativos e suas funções pragmáticas - Piores 2005 Alternativas.

PIORES 2005

\begin{tabular}{|l|l|l|c|}
\hline PADRÃo & QNTIDADE & REL. SEMÂNTICA & $\begin{array}{c}\text { ESTRUTURA } \\
\text { SIMPLES / COMPLEXA }\end{array}$ \\
\hline como tão... quanto & 1 & Comparativa & $\mathrm{S}$ \\
\hline mais... de que & 1 & Comparativa & $\mathrm{S}$ \\
\hline tão... quanto & 1 & Comparativa & $\mathrm{S}$ \\
\hline
\end{tabular}

Quadro 21. Pares correlativos e suas funções pragmáticas - Piores 2005 Comparativas.

PIORES 2006

\begin{tabular}{|l|l|l|c|}
\hline PADRÃo & QNTIDADE & REL. SEMÂNTICA & $\begin{array}{c}\text { ESTRUTURA } \\
\text { SIMPLES / COMPLEXA }\end{array}$ \\
\hline não só... também & 1 & Aditiva & S \\
\hline desde... até & 5 & Aditiva & S C C \\
\hline não apenas... mas sim & 1 & Aditiva & S \\
\hline não... nem & 2 & Aditiva & S S S \\
\hline assim como... também & 1 & Aditiva & C \\
\hline tanto... como & 1 & Aditiva & \\
\hline
\end{tabular}

Quadro 22. Pares correlativos e suas funções pragmáticas - Piores 2006 Aditivas.

PIORES 2006

\begin{tabular}{|l|l|l|c|}
\hline PADRÃo & QNTIDADE & REL. SEMÂNTICA & $\begin{array}{c}\text { ESTRUTURA } \\
\text { SIMPLES / COMPLEXA }\end{array}$ \\
\hline não... e sim & 3 & Adversativa & S C \\
\hline não... mas sim & 1 & Adversativa & S \\
\hline não que... mas & 2 & Adversativa & $\mathrm{C}$ \\
\hline não... e sim & 1 & Adversativa & $\mathrm{S}$ \\
\hline não que... porém & 1 & Adversativa & $\mathrm{C} \mathrm{C}$ \\
\hline não... mas sim & 2 & Adversativa & \\
\hline
\end{tabular}

Quadro 23. Pares correlativos e suas funções pragmáticas - Piores 2006 Adversativas. 
PIORES 2006

\begin{tabular}{|l|l|l|c|}
\hline PADRÃo & QNTIDADE & REL. SEMÂNTICA & $\begin{array}{c}\text { ESTRUTURA } \\
\text { SIMPLES / COMPLEXA }\end{array}$ \\
\hline quanto mais... mais & 1 & Proporcional & $\mathrm{S}$ \\
\hline
\end{tabular}

Quadro 24. Pares correlativos e suas funções pragmáticas - Piores 2006 Proporcional.

PIORES 2006

\begin{tabular}{|l|l|l|c|}
\hline PADRÃo & QNTIDADE & REL. SEMÂNTICA & $\begin{array}{c}\text { ESTRUTURA } \\
\text { SIMPLES / COMPLEXA }\end{array}$ \\
\hline mais... do que & 3 & Comparativa & S C S \\
\hline
\end{tabular}

Quadro 25. Pares correlativos e suas funções pragmáticas - Piores 2006 Comparativa.

\section{PIORES 2006}

\begin{tabular}{|l|l|l|c|}
\hline PADRÃo & QNTIDADE & REL. SEMÂNTICA & $\begin{array}{c}\text { ESTRUTURA } \\
\text { SIMPLES / COMPLEXA }\end{array}$ \\
\hline seja... ou & 1 & Alternativa & S \\
\hline sejam... ou & 1 & Alternativa & S \\
\hline
\end{tabular}

Quadro 26. Pares correlativos e suas funções pragmáticas - Piores 2006 Alternativa.

PIORES 2007

\begin{tabular}{|l|l|l|c|}
\hline PADRÃo & QNTIDADE & REL. SEMÂNTICA & $\begin{array}{c}\text { ESTRUTURA } \\
\text { SIMPLES / COMPLEXA }\end{array}$ \\
\hline não... mas & 4 & Adversativa & S S S C \\
\hline não... mas sim & 2 & Adversativa & S C \\
\hline não... e sim & 3 & Adversativa & S S \\
\hline não que... e sim & 1 & Adversativa & \\
\hline
\end{tabular}

Quadro 27. Pares correlativos e suas funções pragmáticas - Piores 2007 Adversativas.

PIORES 2007

\begin{tabular}{|l|l|l|c|}
\hline PADRÃo & QNTIDADE & REL. SEMÂNTICA & $\begin{array}{c}\text { ESTRUTURA } \\
\text { SIMPLES / COMPLEXA }\end{array}$ \\
\hline tão... como & 2 & Comparativa & S S \\
\hline mais... do que & 3 & Comparativa & S C S \\
\hline tanto... como & 1 & Comparativa & S \\
\hline mais... que & 2 & Comparativa & S S \\
\hline melhor... do que & 1 & Comparativa & S \\
\hline menos... que & 1 & Comparativa & S \\
\hline
\end{tabular}


Quadro 28. Pares correlativos e suas funções pragmáticas - Piores 2007 Comparativas.

PIORES 2007

\begin{tabular}{|l|l|l|c|}
\hline PADRÃo & QNTIDADE & REL. SEMÂNTICA & $\begin{array}{c}\text { ESTRUTURA } \\
\text { SIMPLES / COMPLEXA }\end{array}$ \\
\hline tanto... que & 1 & Consecutiva & S \\
\hline tão... que & 4 & Consecutiva & S S S S \\
\hline
\end{tabular}

Quadro 29 Pares correlativos e suas funções pragmáticas - Piores 2007 Consecutivas.

PIORES 2007

\begin{tabular}{|l|l|l|c|}
\hline PADRÃo & QNTIDADE & REL. SEMÂNTICA & $\begin{array}{c}\text { ESTRUTURA } \\
\text { SIMPLES / COMPLEXA }\end{array}$ \\
\hline tanto... como & 3 & Aditiva & S S S \\
\hline não apenas... mas sim & 1 & Aditiva & C S S \\
\hline não só... mas também & 2 & Aditiva & C S S S \\
\hline desde... até & 4 & Aditiva & S \\
\hline não só... como também & 1 & Aditiva & S \\
\hline tanto... quanto & 1 & Aditiva & S \\
\hline não... mas também & 1 & Aditiva & S \\
\hline tão... quanto & 1 & Aditiva & Aditiva \\
\hline além.... ainda & 1 & &
\end{tabular}

Quadro 30 Pares correlativos e suas funções pragmáticas - Piores 2007 Aditivas.

PIORES 2007

\begin{tabular}{|l|l|l|c|}
\hline PADRÃO & QNTIDADE & REL. SEMÂNTICA & \multicolumn{1}{|c|}{ ESTRUTURA } \\
& & & SIMPLES / COMPLEXA \\
\hline sejam... ou & 3 & Alternativa & S C \\
\hline como... ou & 1 & Alternativa & S C S \\
\hline seja... ou & 3 & Alternativa & \\
\hline
\end{tabular}

Quadro 31 Pares correlativos e suas funções pragmáticas - Piores 2007 Alternativas.

\section{PIORES 2008}

\begin{tabular}{|l|l|l|c|}
\hline PADRÃo & QNTIDADE & REL. SEMÂNTICA & $\begin{array}{c}\text { ESTRUTURA } \\
\text { SIMPLES / COMPLEXA }\end{array}$ \\
\hline tanto... quanto & 3 & Aditiva & C S S \\
\hline desde... até & 5 & Aditiva & S C S S S \\
\hline não só... mas & 3 & Aditiva & S \\
\hline não somente... mas também & 1 & Aditiva & C C S S \\
\hline tanto... como & 5 & Aditiva & S S \\
\hline não só... mas também & 2 & Aditiva & Aditiva \\
\hline só... mas também & 2 & &
\end{tabular}


Quadro 32 Pares correlativos e suas funções pragmáticas - Piores 2008 Aditivas.

PIORES 2008

\begin{tabular}{|l|l|l|c|}
\hline PADRÃo & QNTIDADE & REL. SEMÂNTICA & $\begin{array}{c}\text { ESTRUTURA } \\
\text { SIMPLES / COMPLEXA }\end{array}$ \\
\hline não... e sim & 1 & Adversativa & $\mathrm{C}$ \\
\hline mas não... mais sim & 1 & Adversativa & $\mathrm{S}$ \\
\hline não... mas & 1 & Adversativa & $\mathrm{C}$ \\
\hline não apenas... e sim & 1 & Adversativa & $\mathrm{S}$ \\
\hline não... mas sim & 1 & Adversativa & $\mathrm{S}$ \\
\hline
\end{tabular}

Quadro 33 Pares correlativos e suas funções pragmáticas - Piores 2008 Adversativas.

PIORES 2008

\begin{tabular}{|l|l|l|l|}
\hline PADRÃo & QNTIDADE & REL. SEMÂNTICA & $\begin{array}{c}\text { ESTRUTURA } \\
\text { SIMPLES / COMPLEXA }\end{array}$ \\
\hline seja... ou & & ou S S S S S S \\
\hline sejam... ou & 8 & Alternativa & S \\
\hline
\end{tabular}

Quadro 34 Pares correlativos e suas funções pragmáticas - Piores 2008 Alternativas.

PIORES 2008

\begin{tabular}{|l|l|l|c|}
\hline PADRÃo & QNTIDADE & REL. SEMÂNTICA & $\begin{array}{c}\text { ESTRUTURA } \\
\text { SIMPLES / COMPLEXA }\end{array}$ \\
\hline menos... do que & 1 & Comparativa & S \\
\hline
\end{tabular}

Quadro 35 Pares correlativos e suas funções pragmáticas - Piores 2008 Comparativas.

PIORES 2009

\begin{tabular}{|l|l|l|c|}
\hline PADRÃo & QNTIDADE & REL. SEMÂNTICA & $\begin{array}{c}\text { ESTRUTURA } \\
\text { SIMPLES / COMPLEXA }\end{array}$ \\
\hline não só... mas também & 1 & Aditiva & S \\
\hline tão... quanto & 4 & Aditiva & S S C S \\
\hline além... também & 1 & Aditiva & S \\
\hline não... nem & 1 & Aditiva & S S \\
\hline tanto... como & 2 & Aditiva & S \\
\hline não só... mas também & 1 & Aditiva & C \\
\hline não só... mas sim & 1 & Aditiva & \\
\hline
\end{tabular}

Quadro 36 Pares correlativos e suas funções pragmáticas - Piores 2009 Aditivas. 
PIORES 2009

\begin{tabular}{|l|l|l|c|}
\hline PADRÃO & QNTIDADE & REL. SEMÂNTICA & $\begin{array}{c}\text { ESTRUTURA } \\
\text { SIMPLES / COMPLEXA }\end{array}$ \\
\hline ora... ora & 1 & Alternativa & S \\
\hline seja... ou & 6 & Alternativa & S S S S S S \\
\hline seje... ou & 1 & Alternativa & S \\
\hline sejam... ou & 1 & Alternativa & S \\
\hline
\end{tabular}

Quadro 37 Pares correlativos e suas funções pragmáticas - Piores 2009 Alternativas.

PIORES 2009

\begin{tabular}{|l|l|l|c|}
\hline PADRÃo & QNTIDADE & REL. SEMÂNTICA & ESTRUTURA \\
& & SIMPLES / COMPLEXA \\
\hline tão... como & 2 & Comparativa & S S S \\
\hline tanto... quanto & 3 & Comparativa & . \\
\hline
\end{tabular}

Quadro 38 Pares correlativos e suas funções pragmáticas - Piores 2009 Comparativas.

PIORES 2009

\begin{tabular}{|l|l|l|c|}
\hline PADRÃo & QNTIDADE & REL. SEMÂNTICA & $\begin{array}{c}\text { ESTRUTURA } \\
\text { SIMPLES / COMPLEXA }\end{array}$ \\
\hline não... mas & 1 & Adversativa & S \\
\hline não... mas sim & 4 & Adversativa & S S S S \\
\hline não... e sim & 3 & Adversativa & S S \\
\hline não... e sim & 1 & Adversativa & S \\
\hline apenas... não mas & 1 & Adversativa & \\
\hline
\end{tabular}

Quadro 39 Pares correlativos e suas funções pragmáticas - Piores 2009 Adversativas.

PIORES 2009

\begin{tabular}{|l|l|l|c|}
\hline PADRÃo & QNTIDADE & REL. SEMÂNTICA & $\begin{array}{c}\text { ESTRUTURA } \\
\text { SIMPLES / COMPLEXA }\end{array}$ \\
\hline tão... que & 2 & Consecutiva & S C \\
\hline
\end{tabular}

Quadro 40 Pares correlativos e suas funções pragmáticas - Piores 2009 Consecutivas.

PIORES 2009

\begin{tabular}{|l|l|l|c|}
\hline PADRÃo & QNTIDADE & REL. SEMÂNTICA & ESTRUTURA \\
& & & SIMPLES / COMPLEXA \\
\hline quanto mais... mais & 2 & Proporcional & S C \\
\hline
\end{tabular}

Quadro 41 Pares correlativos e suas funções pragmáticas - Piores 2009 Proporcional. 
PIORES 2010

\begin{tabular}{|l|l|l|c|}
\hline PADRÃo & QNTIDADE & REL. SEMÂNTICA & $\begin{array}{c}\text { ESTRUTURA } \\
\text { SIMPLES / COMPLEXA }\end{array}$ \\
\hline assim como... também & 2 & Aditiva & $\mathrm{S}$ S \\
\hline não... nem & 1 & Aditiva & $\mathrm{S}$ S S \\
\hline além de... também & 3 & Aditiva & $\mathrm{S}$ \\
\hline não só... mas & 1 & Aditiva & $\mathrm{S}$ \\
\hline seja... E & 1 & Aditiva & $\mathrm{S}$ \\
\hline tanto... quanto & 2 & Aditiva & $\mathrm{S}$ \\
\hline não somente... mas também & 1 & Aditiva & $\mathrm{S}$ \\
\hline não só... como & 1 & Aditiva & $\mathrm{S}$ \\
\hline não só... mas como & 1 & Aditiva & $\mathrm{S}$ \\
\hline não só... mas também & 1 & Aditiva & Aditiva \\
\hline tanto... como & 1 & & \\
\hline
\end{tabular}

Quadro 42 Pares correlativos e suas funções pragmáticas - Piores 2010 Aditiva.

PIORES 2010

\begin{tabular}{|l|l|l|ll|}
\hline PADRÃO & QNTIDADE & REL. SEMÂNTICA & \multicolumn{2}{|c|}{ ESTRUTURA } \\
& & & S S \\
\hline seja... ou & 2 & Alternativa & S & \\
\hline ou... ou ainda & 1 & Alternativa & S & \\
\hline ora... ora & 1 & Alternativa & S S S S \\
\hline sejam... ou & 4 & Alternativa &
\end{tabular}

Quadro 43 Pares correlativos e suas funções pragmáticas - Piores 2010 Alternativa.

PIORES 2010

\begin{tabular}{|l|l|l|c|}
\hline PADRÃo & QNTIDADE & REL. SEMÂNTICA & $\begin{array}{c}\text { ESTRUTURA } \\
\text { SIMPLES / COMPLEXA }\end{array}$ \\
\hline não que...mas & 1 & Adversativa & $\mathrm{S}$ \\
\hline não... mas sim & 1 & Adversativa & $\mathrm{S}$ \\
\hline não... e sim & 1 & Adversativa & $\mathrm{S}$ \\
\hline não como... mas sim & 1 & Adversativa & $\mathrm{S}$ \\
\hline não como... não como & 1 & Adversativa & $\mathrm{S}$ \\
\hline
\end{tabular}

Quadro 44 Pares correlativos e suas funções pragmáticas - Piores 2010 Adversativas.

PIORES 2010

\begin{tabular}{|l|l|l|c|}
\hline PADRÃo & QNTIDADE & REL. SEMÂNTICA & $\begin{array}{c}\text { ESTRUTURA } \\
\text { SIMPLES / COMPLEXA }\end{array}$ \\
\hline tão... que & 1 & Consecutiva & C \\
\hline
\end{tabular}

Quadro 45 Pares correlativos e suas funções pragmáticas - Piores 2010 Consecutiva. 


\section{RESULTADOS}

Em relação às análises, alguns elementos se fizeram presentes em mais de um padrão estabelecido. Isso ocorreu porque o falante tem um objetivo específico quando se utiliza da configuração e reconfiguração de itens lexicais: criar um espaço conjunto de atenção em que seja convincente e se mostre apto a alcançar seu intento.

\section{COMPLEXIDADE E AS FORMAS DE APREENSÃO}

Gradação e Princípio da Iconicidade

Os trechos a seguir são retomados com o objetivo de apresentar algumas características e considerações inerentes ao princípio da iconicidade, que aponta a língua como parte constitutiva de experiências ligadas à sua estrutura, que simbolicamente vão se perfazendo no percurso cognitivo do estágio evolutivo da mente humana, acoplando-se a outras experiências anteriores e se reconfigurando. Observemse os exemplos seguintes:

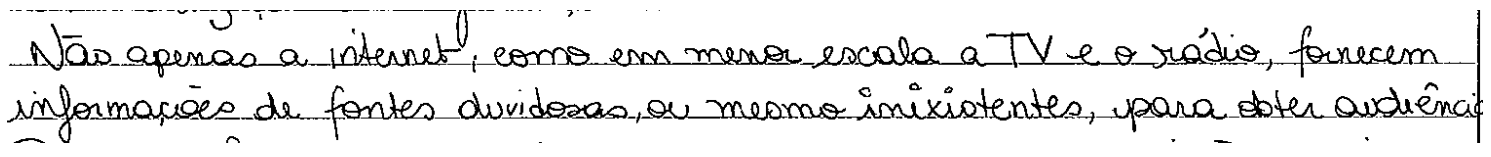
(Exemplo 115,Fuvest, 2008, p.64) 

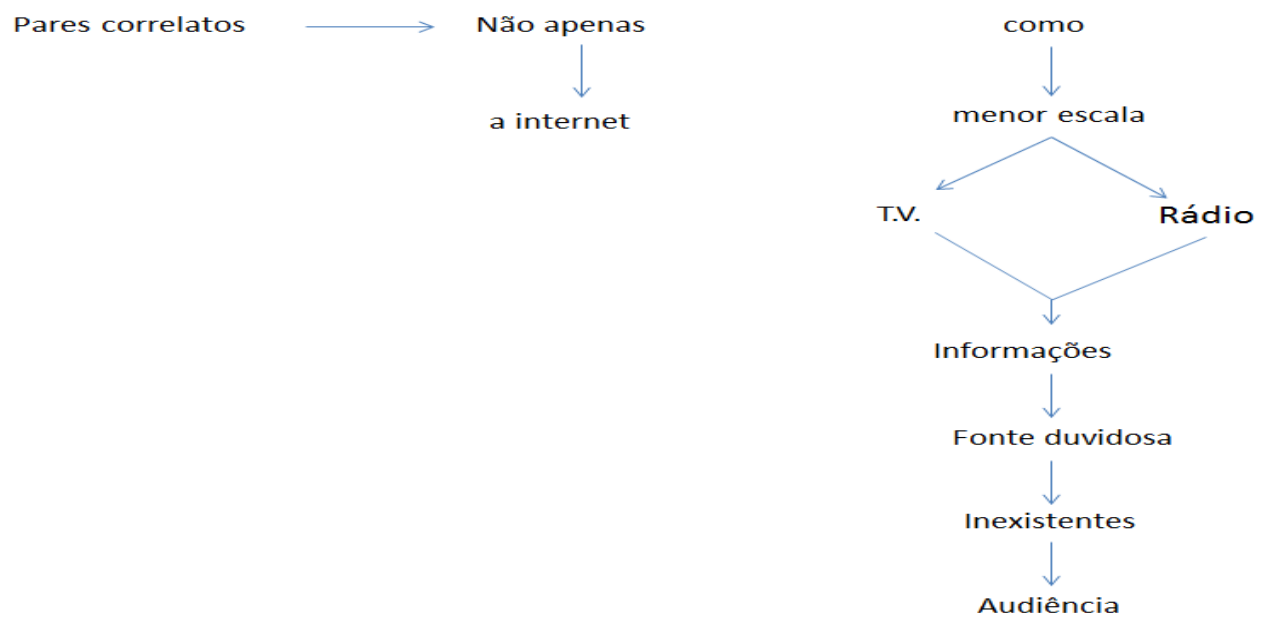

Esquema 31. Representação icônica 1

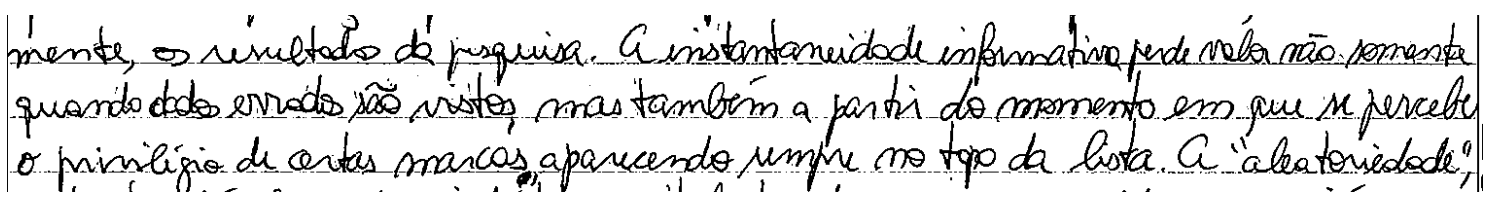

(Exemplo 116,Fuvest, 2008, p.98)

\section{Título do texto: "Olhos de desconfiança"}

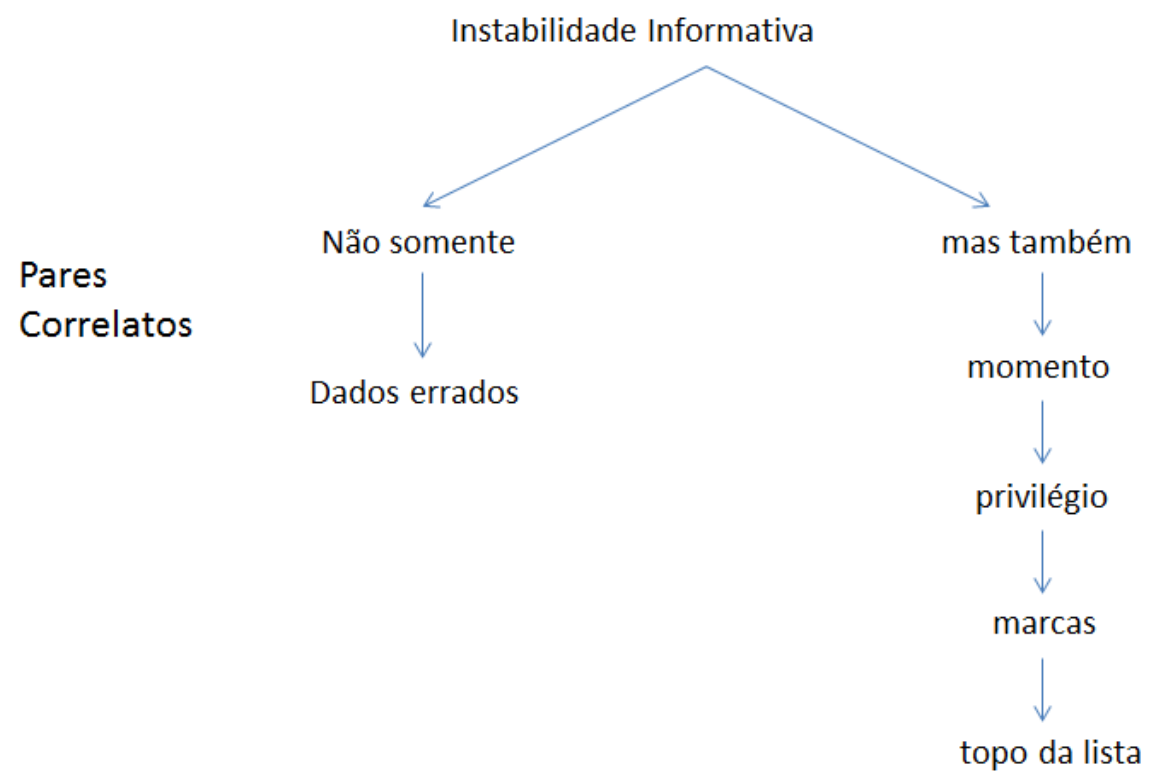

Esquema 32. Representação icônica 2 
A partir desses dois trechos algumas considerações finais se fazem pertinentes:

A) As formas linguísticas, iconicamente, são usadas por motivações funcionais, estrategicamente voltadas às expectativas do autor;

B) Nos trechos, entre os pares correlativos, as porções informativas estão distribuídas de acordo com essas motivações: como recurso argumentativo, o autor lança pouco material linguístico no $1^{\circ}$ elemento do par e, em maior quantidade, lança material linguístico no $2^{\circ}$ elemento do par;

C) Essa estratégia é vista por Givón (1991) como o subprincípio da quantidade, em que a informação considerada menos importante, previsível, contém menos formas de construção linguística; o que é menos esperado, surpresa, há mais formas;

D) Pode-se apontar que esse processamento se dá pelo esforço mental voltado, nos parece, ao interlocutor: o falante/ leitor ativa conhecimento que envolve menor complexidade naquilo que é conhecido entre ambos, e o que é, para ele, a informação nova, surpresa, envolve maior complexidade;

E) Dentro desse processamento, o autor busca, pela consciência, material linguístico que parece alavancar, por meio dos estágios selfianos, imagens que, estrategicamente, são acopladas entre as porções informativas; há um deslocamento de um estágio a outro: na $1^{a}$ porção informativa, o autor busca experiências já vividas por ele; e, por isso, vincula-se ao self-central, estágio da consciência resultante da interação entre ele, organismo e o objeto da discussão. É pelo self-central que lincamos com aquilo que, imageticamente, contém uma relação muito próxima do que ouvimos, tocamos, escutamos, enfim, do que compartilhamos pelo conhecimento de mundo. A partir do momento em que se resgatam novas imagens e sentimentos/ objetos que relacionados às experienciações anteriores, impulsionam novas informações e itens lexicais, cujas estruturas são mais complexas, é porque aí houve uma migração do selfcentral para o autobiográfico, estágio em que há pulsos lincados em novas experienciações, articulações e usos lexicais;

F) Isso nos leva a apontar que, pelo princípio de quantidade, o indivíduo distribui, estrategicamente, as informações, que são buscadas na consciência da mente. 
Provavelmente, por isso, as redações consideradas melhores, além de distribuírem informações, cujo conteúdo lincado no self autobiográfico, parece ser mais rico e interativo, possuem também maior índice de correlações. Há maior complexidade entre os itens lexicais, nas consideradas melhores;

G) O indivíduo, ao se utilizar de pares correlativos considerados inovadores, pelo fato de que são atípicos em relação à sua presença em gramáticas, livros didáticos, textos, em geral, também lança mais porções informativas, em que há mais argumentação, tal como exemplificado a seguir:

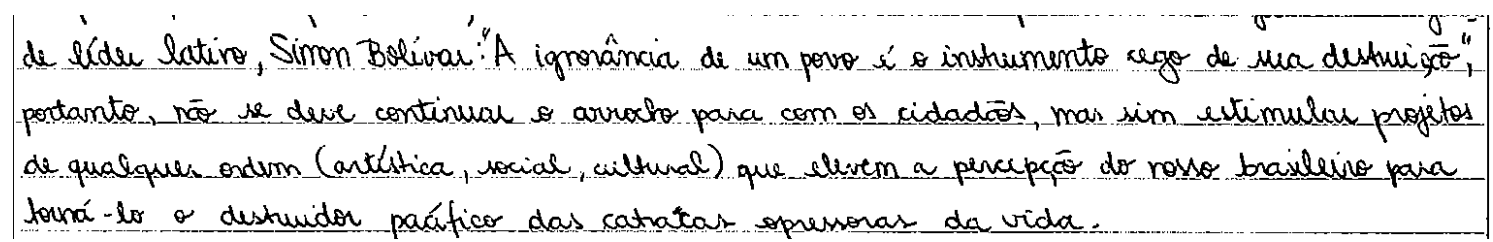

(Exemplo 117,Fuvest, 2005, p.52)

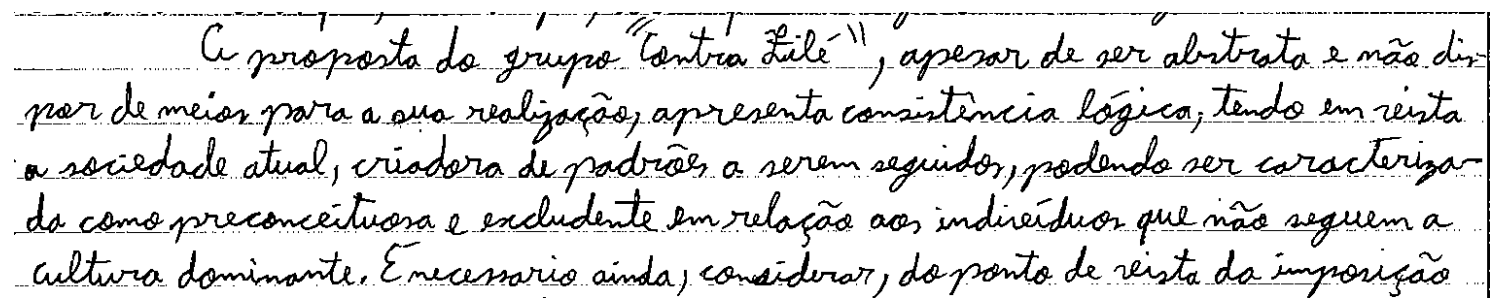

(Exemplo 118,Fuvest, 2005, p.55)

Outro subprincípio estabelecido por Givón (1991) que visa a complementar a análise é o da adjacência, em que a escolha de formas linguísticas se atraem para que possam contribuir com a integração dos dados. Isso se manifesta por meio de uma sequência cujas estruturas se acoplam, de acordo com o que o falante/ autor traz de conhecimento de mundo, e se refletem, concretizando-se na estruturação entre as porções informativas.

$\mathrm{Na}$ análise das consideradas melhores redações, há também essa configuração presente entre as porções informativas, cujos pares correlativos atraem itens lexicais que se integram para configurar maior expressividade. É o que ilustra o exemplo seguinte: 


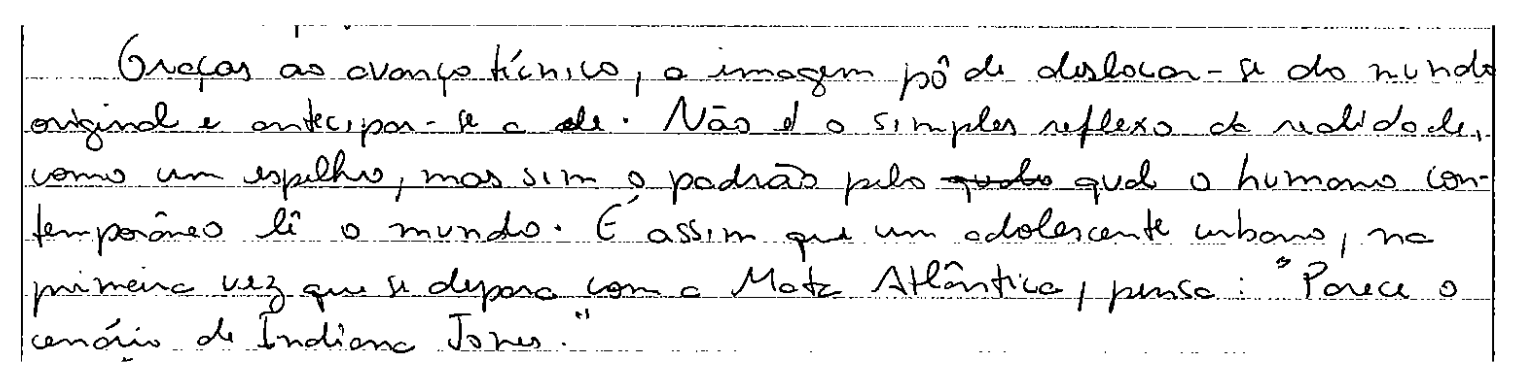

(Exemplo 119, Fuvest, 2010, p.44)

A partir desse subprincípio, algumas considerações finais também subsidiarão os encaminhamentos e apontamentos desta tese:

A) É interessante apontar a combinação entre os pares correlativos que incorporam a porção informativa: um polarizador "não" (considerado circunstanciador) atrelado a um item contrastivo conjuntivo "mas", junto de um circunstanciador de afirmação "sim", funciona como focalizador e forma um par correlativo, cuja função é a de opor ideias, havendo integração entre "não" e "mas";

B) Nesse subprincípio, percebe-se também o jogo instituído por meio do processamento mental do estágio evolutivo: o conteúdo inserido na $1^{\text {a }}$ porção informativa está subjacente ao self-central, que traz à tona experiências já conhecidas. No trecho, temos como a $1^{a}$ porção uma informação calcada num compartilhamento de mundo: quando olhamos no espelho, vemos à frente nossa realidade e o reflexo dela, porém na $2^{\mathrm{a}}$ porção: o que nos difere é o modo como enxergamos o mundo, que traz à tona experiências autobiográficas; há também um jogo integrado entre as porções;

C) Há um processamento integrado entre os itens lexicais, de modo a buscar, na e pela consciência em vigília, elementos que confluem à argumentação: na última linha do parágrafo, há os itens "Mata Atlântica" (que parece ser o reflexo da nossa realidade), mas que, ao lermos de modo diferente, assume o cenário do "Indiana Jones" (que é a interpretação metafórica de como lemos o mundo): o que é próximo mentalmente é próximo sintaticamente;

D) Por esse princípio gradativo, o que está cognitivamente mais integrado no nível da codificação (mais próximo mentalmente) está mais próximo sintaticamente: o item “imagem” refere-se ao conteúdo dos itens do par correlativo, há uma correlação da distância linear das expressões ligadas às suas ideias. 
O último subprincípio que cabe discutir na iconicidade está ligado a códigos e conteúdos, é o da ordenação linear, cujos elementos são dispostos de acordo com o grau de importância que assumem dentro da estrutura informacional.

Isso nos leva a explorar que o falante/ escrevente une aspectos situacionalsocioculturais, de acordo com os eventos que lhe vêm à mente determinando suas escolhas e tão logo pela distribuição os itens lexicais entre as porções informativas. Vejamos:

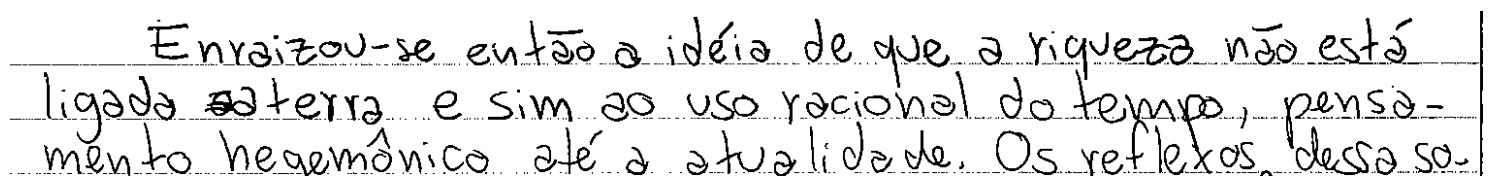

(Exemplo 120,Fuvest, 2006, p.89)

A partir desse subprincípio, outras considerações finais se fazem necessárias para que possamos entender como o processo de funcionamento da língua está intrinsecamente ligado às intenções comunicacionais:

A) As escolhas lexicais e a ordem disponibilizada entre as duas porções levam-nos a entender por que o autor inicia o trecho com o verbo "enraizar", que imageticamente nos remete à ideia de fincar raízes, estabelecer-se;

B) Como a temática da proposta de redação envolvia a questão do trabalho e de suas relações com o homem contemporâneo, o candidato optou por distribuir, entre as porções, itens que, ordenadamente, parecem fazer um movimento cronológico. Analisemos:

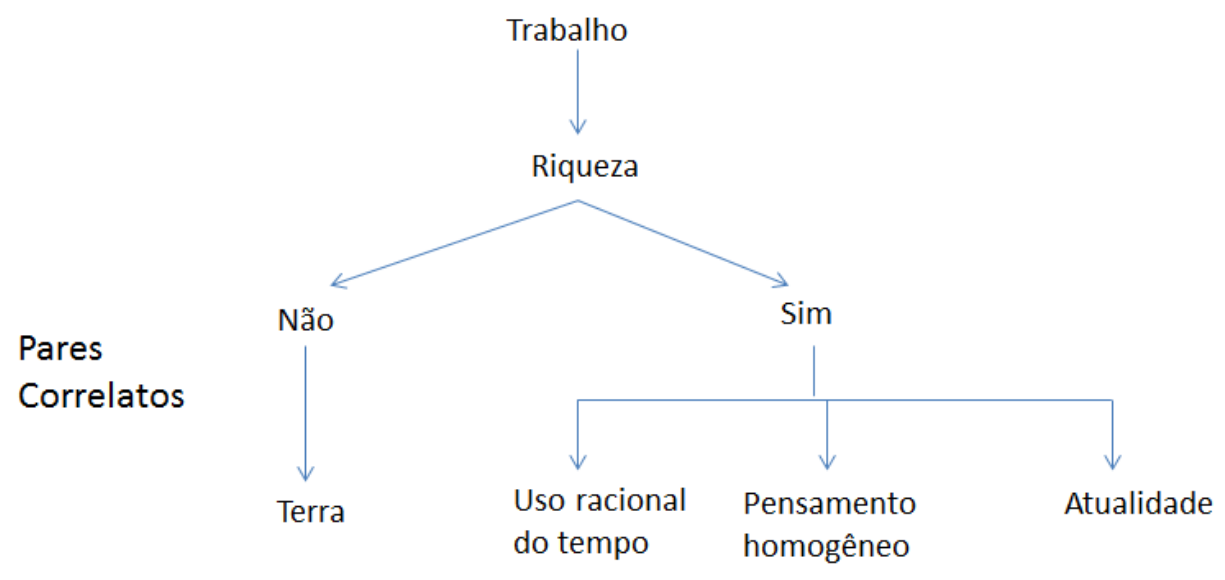


Esquema 33. Representação do subprincípio da ordenação linear.

C) A escolha pela ordenação dos itens, em que inicialmente se dá pela ideia do trabalho ligado à terra e logo depois ligada a aspectos contemporâneos, que conferem credibilidade àquilo que o autor defende, parece satisfazer o que Givón (1991) assente a respeito de língua como um processo maleável, cuja gramática é emergente, porque tende a correlacionar-se aos propósitos comunicativos e intencionais;

D) Ao concluirmos o ciclo que encerra os subprincípios subjacentes à língua, fica, então, a ideia de que linguagem e mente são aspectos que fazem parte de um complexo de sistema integrado, que, ligados ao estágio da mente humana, contribuem para que haja a combinação de itens, a ordenação e sua integração, as próprias intenções lincadas à quantidade de itens lexicais, para defender que existe uma mente consciente (Damasio, 2009) fincada na realização do uso ideal para o contexto ideal.

As análises dos pares correlativos puderam demonstrar que o comportamento dos itens lexicais está altamente relacionado.

A) às intenções pragmático-discursivas do falante/ escritor;

B) à aproximação, ordenação e quantificação que auxiliam a concretizar, na língua, conteúdos que, imageticamente, se configuram por meio das experiências;

C) à iconicidade, que, dentro do fluxo informativo, parece estar presente na consciência da mente humana, por meio dos estágios selfianos que trazem à tona experienciações, que se reconfiguram à medida que o ser humano é exposto a outros ambientes sociais;

D) à quantidade de elementos culturais a que o ser humano é exposto.

\section{Gradação e Princípio da Marcação}

Para remetermos à importância do conceito da marcação, no que diz respeito ao uso da língua, temos que focalizar formas linguísticas mais corriqueiras, com alto grau 
de frequência, pois elas tendem a ser mais conceptualizadas de modo mais automatizado pelo usuário da língua: têm pouca expressividade. Quando querem ser expressivos, os seres humanos tendem a usar formas mais marcadas.

Uma informação intrigante nos revela: os pares "não... mas", por exemplo, presentes nos dados, se deram de forma significativa: 149 ocorrências, no total. A negação que encabeça esses pares correlatos, considerada mais complexa em termos cognitivos, menos esperada, menos frequente, segundo Givón (1995), constitui um caso mais marcado. Cabe ressaltar que, em certas situações de uso, um item é mais ou menos marcado, dependendo do contexto em que está inserido.

Por não constar na gramática normativa, esse elemento parece estar próximo à coloquialidade da língua, porém presente nos textos das melhores redações analisadas. Apesar de ser um item presente na oralidade, ele tende a ser não-marcado, pois, pelos dados de trechos apresentados e analisados, percebe-se que um item faz ligações, conecta palavras, com uma estrutura menor, o que o torna inesperado para redações prototípicas da Fuvest. São consideradas, assim, marcadas.

Em relação à complexidade cognitiva, percebo que o par, nas melhores, é mais marcado, pois há um esforço mental e um processamento para que haja atenção do leitor. Nas piores, entretanto, percebe-se menor complexidade e menos esforço para compreensão, a despeito disso é considerada não-marcada. A seguir, ilustro com duas redações, uma de cada grupo mencionado:

\section{Melhor}

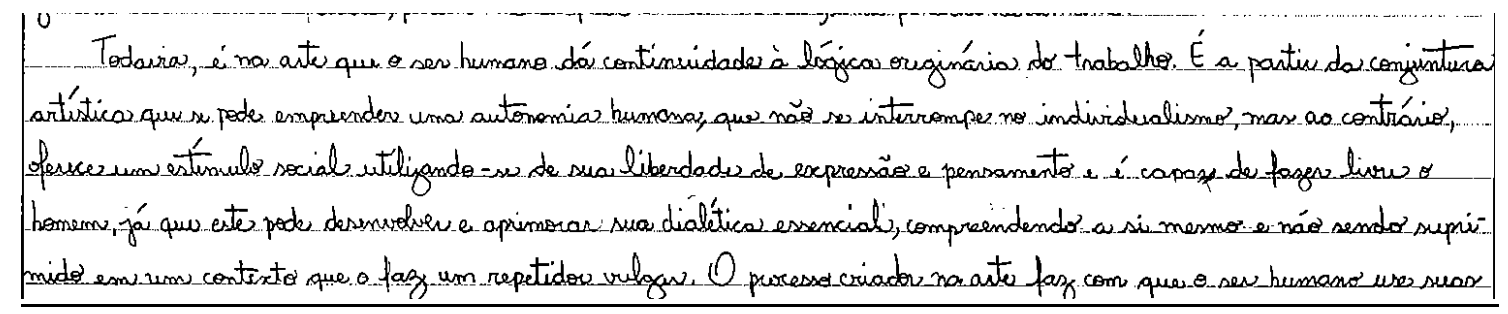




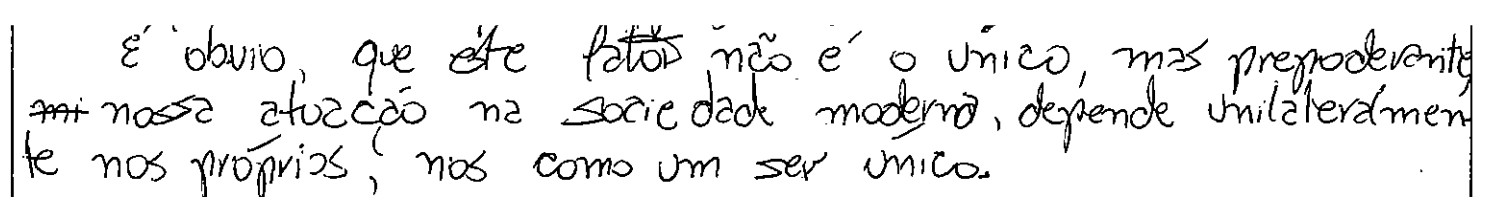

(Exemplo 122,Fuvest, 2009, p.23)

Algumas considerações de nossa análise se fazem pertinentes:

A) Quanto maior esforço mental, mais itens lexicais se fazem necessários por meio da busca de conteúdos inerentes ao estágio autobiográfico;

B) Nas piores, como o nível de exigência do esforço mental é memorizado, parece ainda que se busca, no self-central, conteúdos que, muitas vezes, ainda faltam ao candidato;

C) Parece que formas marcadas, para contextos em que se exige maior complexidade, são buscadas no estágio autobiográfico da evolução, que exige do indivíduo mais autonomia e habilidade em relação à busca dos conteúdos inseridos entre os pares correlativos;

D) O que chamou atenção foi a presença de um par, ausente na gramática normativa, considerando coloquial, presente num tipo de texto cuja exigência se busca e se prima pela normatividade da língua e também pelos estágios mais avançados da consciência humana: não... mas. Isso nos conduz à ideia de que o uso está sobreposto àquilo que se define: oral ou escrito.

\section{$\underline{\text { Plano Discursivo }}$}

Quando se fala em plano discursivo, sempre se deve ter em mente que não há como se destacar uma informação se toda ela assumir o mesmo estatuto dentro de um período. Como num texto dissertativo (e em todas as situações comunicativas), esperase que o outro compreenda, compartilhe e, principalmente, compre a ideia do escrevente, então um jogo de baixo/alto relevo informacional é colocado em campo.

No plano discursivo, lida-se com figuras e fundos. As figuras são porções centrais do texto, e fundo são porções periféricas do texto; ambas devem ser vistas em 
sua dinâmica, como num continuum em que configuram a superfigura (dado mais importante) e superfundo (vago, difuso).

Ao analisarmos alguns trechos de dados, percebe-se que, ao iniciar com uma negativa, o autor dá relevo àquela porção cuja complexidade de ideias está introduzida pelo segundo elemento do par correlativo. Observemos:

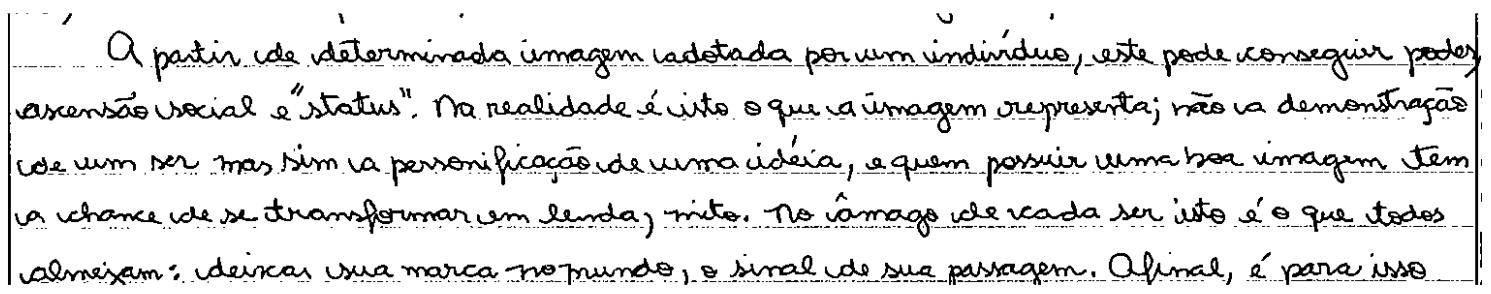

(Exemplo 123,Fuvest, 2010, p.87)

Percebe-se a utilização de uma estratégia discursivo-pragmática, pois se pretende mostrar conhecimento aprofundado sobre o tema. E o lugar disso é a segunda posição da porção informativa. Há o estabelecimento de um jogo por meio dos pares: negar a primeira porção e afirmar na segunda. Dentro do continuum apresenta o fundo e logo após a figura, a fim de valorizar as informações; isto é, inicia com uma informação, que para ele não é o conceito correto ou modo certo de enxergar o fato. Faz isso porque representa o fundo em relação à segunda porção, cuja informação é a decisiva para a argumentação.

Com isso algumas considerações finais se fazem presentes:

A) Pares correlatos são um continuum compostos de polos subjacentes à estrutura das porções informativas;

B) Há um deslocamento de ideias alavancadas entre as porções: para a $1^{\text {a }}$ porção, o autor busca conteúdo linguístico já experenciado; para a $2^{\mathrm{a}}$, o novo, o que realmente importa para ele;

C) Elementos de self-central são presentes na $1^{a}$ porção mais próximos da realidade experienciada entre autor e leitor;

D) Elementos de self autobiográfico são presentes na $2^{a}$ porção, mais próximos da originalidade, da concatenação e observação de detalhes entre as ideias apresentadas. 
Como parte dos encaminhamentos finais desta tese, percebe-se que o falante se atém aos mecanismos linguístico-discursivos a fim de explicitar aquilo que, imageticamente, pretende comunicar, concretizar, aqui especificamente, enunciados que se distribuem entre as porções informativas, a fim de argumentar, sair em defesa de um ponto de vista operacional. Por isso, combina, recombina itens lexicais que assumem papéis semânticos, por conta do conteúdo inserido, a partir do que apreende: informações que satisfaçam suas necessidades reais, ligadas às intenções. Para isso, o papel da consciência, nesse processamento, é fundamental, pois o autor busca, na mente, material linguístico condizente com seus desejos, com leitores de mundo, com aquilo que enxergam e entendem do/no outro, enfim, resgatam informações que atendam às suas realizações discursivo-pragmáticas.

Para isso, mobiliza estratégias, esta tese, identificadas de forma linguística, conforme sintetizado a seguir.

Nos pares correlativos adversativos, que, estrategicamente, foram utilizados num processamento intencional pelo falante a fim de opor ideias, percebeu-se alguns comportamentos distintos dos itens lexicais:

A) Os pares: "não... mas", "não... mas apenas", "não é... mas apenas", "não... mas sim", "não que... porém", "não que... mas", "não é que... mas que”, "é claro que... mas" foram utilizados pelo autor a fim de buscar a polaridade como estratégia para preservar a imagem, por meio da inserção de material linguístico que o remetesse para fora do foco da cena e, logo a seguir, inserisse um focalizador, no $2^{\circ}$ item de modo a apontar qual era, de fato, a informação-foco, a relevante para ele atingir e convencer seu leitor. Percebe-se que há um equilíbrio de material linguístico entre as duas porções;

B) Outros pares foram utilizados como estratégia de anular o que foi apontado no $1^{\circ}$ item, para alavancar no $2^{\circ}$ item, colocar em relevo, a informação que o autor acreditava ser a principal. Dentre eles, temos: "não... mas" e "não... e sim". Houve a inserção de maior quantidade de material lexical no $2^{\circ}$ item. Isto ocorreu porque, ao anular a primeira informação, houve a necessidade da expressividade, do que comunicar, no $2^{\circ}$ item, ao leitor; 
C) Outros pares levantados foram: "não... mas apenas", "não... só que", "nunca... mas sim" e "não (V) somente... mas", com o objetivo de opor ideias, mas com uma estratégia diferente: não há nulidade entre o conteúdo das porções informativas, uma estando imbricada na outra. Nesse jogo pragmático, parece que as relações são mais complexas, há maior quantidade de material linguístico na $2^{\mathrm{a}}$ porção por ser a focalizadora.

Nos pares correlativos aditivos, percebi que o processamento se deu por meio da junção de conteúdos lexicais entre as porções:

A) $\mathrm{O}$ autor une porções em que primeiramente apresenta uma informação conhecida atrelada à outra nova, como forma estratégica de persuadir seu leitor: insere no rema uma maior quantidade de informações mais complexas e, por isso, provavelmente, utiliza-se do item do $2^{\circ}$ item um focalizador. Uma não anula a outra, estão acopladas. Alguns deles: "não somente... mas também", "não apenas... mas também", "não somente... mas", "não só... mas sim";

B) Outro comportamento funcional instado pela presença de pares correlativos aditivos foi a de adicionar comparativamente informações em sua proporção. Percebi que os pares correlativos foram colocados em pé de igualdade sintática proporcionalmente, a fim de alavancar entre as duas porções compartilhadas e complexamente lincadas a um objeto. A quantidade de material lexical é equilibrada como forma estratégica de colocar em cena dois focos de informações. Alguns deles: "tão... quanto", "tanto... quanto", "tanto... como também", "tanto como... quanto como";

C) Houve a presença de um trio correlativo "não só... como... e até" que parece incluir porções informativas com o item "até" funcionando como um focalizador de caráter crítico, que possibilita realçar o posicionamento do autor. Há equilíbrio de informações entre as porções;

D) No processamento correlacional, somam-se e se comparam, ao mesmo tempo, porções informativas numa interação que pode ser apontada de forma explícita ou implícita. Isso ocorreu com alguns exemplos que apresentei. Embora a alta implicitude de informações seja típica da língua falada, nas redações sob análise 
isso foi bastante comum. O resultado foi o surgimento de um par inédito, muitas vezes considerado equivocado pelos professores.

Em relação aos correlativos consecutivos, houve um processamento numa relação de uma causa (no $1^{\circ}$ item do par) ligada ao resultado, ao efeito dessa motivação (no $2^{\circ}$ par):

A) Os correlativos apresentaram na $1^{a}$ porção um item calcado numa avaliação, por parte do autor, que parece intensificar, a fim de realçar o conteúdo, por meio de uma crítica;

B) Os correlativos da $2^{a}$ porção sinalizaram maior quantidade de material lexical. Isso ocorreu porque, ao justificar o resultado apontado pela causa, houve necessidade dessa inserção. As relações pareceram mais complexas.

Para as alternativas, a distribuição de porções entre os correlativos foi feita estrategicamente pelo autor, que parecia equilibrar informações que servem como pontos de vista organizados sintaticamente:

A) Apesar de estabelecerem uma exclusão, o conteúdo apresentado entre os pares mantém uma relação simétrica, que se prestou de argumento para o autor;

B) Focaliza-se por meio dos itens correlativos cenas que sinalizam focos de informação; um recurso altamente complexo e argumentativo.

O comportamento funcional dos pares correlativos comparativos apresentou-se a partir do conceito de que existem elementos que possuem características em comum e combinatórias, a fim de alavancar os apontamentos e discussões do autor:

A) Percebi a presença, no $1^{\circ}$ par, de um focalizador que coloca em cena a informação comprovada atrelada a uma avaliação subjetiva por meio do item no 
$1^{\text {o }}$ item do par. Há um esforço processual instado de modo a aproximar características semelhantes entre os pares, mas enfatizando a $1^{\text {a }}$ delas;

B) Há, entre os pares, um equilíbrio de informações comparadas que pareciam sinalizar uma preocupação do autor em querer inserir material linguístico que apresentasse proximidade de sentidos para enfatizar as duas porções;

C) O indivíduo compara porções informativas ora para aproximar características de um objeto, pessoa, que parece convergir o olhar, direcionar a atenção do leitor para algo que lhe chame atenção; ora também para equilibrar porções informativas para que processualmente ele possa avaliar também características, aspectos que, convergentemente, simbolizam-se numa mesma proporção. Há um exercício cognitivo experienciado e discursivamente planejado.

Em relação às concessivas, o comportamento funcional entre as porções sinalizou que o autor utiliza-se da concessividade para lançar uma porção que denota hipótese, servindo como um recurso estratégico:

A) O lançamento de uma porção que sinaliza uma hipótese relacionada a outra assertiva, que parece funcionar como um focalizador da informação, ou seja, uma estratégia funcional e complexa do autor; de um lado, lança uma informação que representa um obstáculo à concretização do que se quer afirmar; e, de outro, a informação, considerada por ele, verdadeira e mais realizável. Um recurso altamente complexo;

B) As relações instadas nesse processo se fazem contrastivamente, como se servissem como uma quebra de expectativa do leitor para referenciar, na $2^{\mathrm{a}}$ porção, o que realmente queria apontar;

C) Um recurso estratégico apresentado foi o da inserção de maior quantidade de item lexical na $1^{\mathrm{a}}$ porção, e não na $2^{\mathrm{a}}$. Isso porque o autor para, após referendar o que, de fato, acredita ser coerente e verdadeiro, na $2^{\mathrm{a}}$ porção. Uma estratégia altamente cognitiva. 
Para as condicionais, houve a necessidade de o autor estabelecer a realidade da informação atrelada à condição imposta por ela:

A) Os pares da $2^{\mathrm{a}}$ porção em: "se... é porque", "se (V)... que (V)", "de modo... senão", "não... senão", apresentaram a focalização como um recurso estratégico para colocar a informação em relevo porque é nela que está a argumentação persuasiva. Um jogo complexo e diretivo para o autor: apresentar uma condição e a possibilidade da realização do fato atrelada a ela;

B) Outro recurso instituído pelo autor foi o de combinar a ordem entre os itens lexicais, estrategicamente: as condicionais apresentaram uma ideia distante da realização; e, por isso, atrelaram a informação a uma outra porção, de caráter mais próximo da verdade, da realização efetiva do fato.

No tocante às proporcionais, pares são efetivamente utilizados para contrabalancear informações como recurso persuasivo:

A) Pares encabeçados pelo quantificador "quanto" atrelado a "mais" funcionaram como mecanismos avaliativos, que, proporcionalmente, distribuem-se como focalizadores a fim de colocar em cena informações imbricadas umas às outras;

B) Houve um equilíbrio da quantidade de material inserido dentro das porções informativas. Ao que parece, houve uma necessidade do autor de enxertar entre as porções a mesma quantidade de itens lexicais que, imageticamente, auxiliaram para enfatizar as duas informações.

A partir desses resultados, é fato: o autor busca, no âmbito pragmático da língua consciente, elementos subjacentes às suas experiências socioculturais que se concretizam a fim de atender seus anseios, desejos, uma maior vontade da realização diante do outro, a de poder buscar, no mundo que o perpassa, cenas que o remetem à concretização linguística, aqui, no caso, distribuída entre as porções informativas. 
Diante de todas as análises que pude realizar no estudo da combinação de pares correlativos, fica clara a ideia de que o uso é o que move, adapta, modifica, faz ressurgir elementos de língua que, cognitivamente, se comportam, a fim de dar conta do sujeito que evolui juntamente com um mundo selfiano de incertezas e contradições. 


\section{CONCLUSÃO}

Ao final desta tese, o primeiro aspecto que nos move a elaborar um comentário daquilo que os teóricos privilegiam no tocante à gramaticalização, numa perspectiva calcada no léxico ou discursivo, parece merecer uma revisão: a partir da mudança de comportamento linguístico-pragmático verificado entre os pares correlativos, objeto desta tese, presentes nos trechos das redações da Fuvest, percebi uma dinâmica dentro desse processo, em que os itens se abstratizam a partir de como os seres humanos entendem e conceitualizam o mundo, por meio de suas experienciações.

Com isso, é importante resgatar a ideia de que a estrutura da língua reflete a estrutura da experiência, como lembra Croft (1990); isto é, quando nos atemos à verificação de um item linguístico que, num processo unidirecional, assume outras funções discursivo-pragmáticos "que são reconfiguradas e que sofrem mudanças em relação à estocagem local e ao processamento em tempo real" (Bybee, 2003), é porque é ligado "ao experienciamento humano de ações e eventos, à rotinização e habitualização de fatos que, de tão produtivos e frequentes, passam a integrar novas camadas significativas de uso" (cf. Casseb-Galvão e Lima-Hernandes, 2012, p.166).

Quando o indivíduo fala/ escreve, busca, na mente, informações armazenadas como se fossem uma unidade convencional, representada cognitivamente, e as acopla de acordo com suas necessidades operacionais: intenção, contexto, a imagem que faz do falante, a fim de obter a interação, atender às expectativas do ouvinte/ leitor.

O falante, ao combinar e recombinar itens lexicais, movido por uma intenção discursiva no fluxo informacional, passa a redesenhá-los, por meio de marcas linguístico-discursivas intencionais. Isso decorre de sua capacidade de adaptar, ajustar, acomodar, enfim, flexibilizar material linguístico antigo por outro novo (Hopper, 1988, p.18), e assim o acomoda de acordo com as pressões a que é submetido (Neves, 2004).

Como aponta Lyons (1979, apud Martelotta, 2003, p.71):

"há muitos fatores diferentes que, tanto interna quanto externamente, podem determinar a transformação de língua de estado sincrônico por outro" (p.49), que se convergem a recriação de formas e de sentidos de acordo com as necessidades comunicativas do indivíduo, que quando as "percebe, aprecia e adotada" (Bolinger, 1975, p.389) 
elas permanecem, "podendo vir a gerar situações efetivas de mudança" (cf. Martelotta, 2003, p.71).

Com isso, tendo como foco atender às especificidades do leitor, o autor utilizouse dos pares correlativos para enobrecer e aumentar a elasticidade de suas discussões.

Demonstrei, nesta tese, que o termo "discurso" está relacionado a um ciclo em que as diversas formas criativas de uso, organizadas pelo falante/ escrevente, quando regularizadas, entram para a gramática da língua, mas que também, no momento em que começam a ter comportamentos e papéis diferentes, voltam para o discurso. É uma rota, cuja trajetória, está instada na instabilidade e na regularização do uso da língua, como defendem funcionalistas:

O que foi sistematizado entra no processo de desgaste, com liberdade progressiva da expressão em termos de restrição da ocorrência, e com liberdade progressiva do conteúdo em termos de desbotamento e esvaziamento semântico. (cf. Furtado da Cunha; Costa e Cezário, 2003, p.41).

Dessa forma, expus que a língua é calcada numa fluidez que, numa unidirecionalidade, vai assumindo formas ilimitadas e que, reestruturadas, "são ressemantizadas durante o efetivo uso" (Hopper, 1998, p.158).

O uso de um par correlativo que foge da exigência normativa e é usado numa limitação cujo tipo de texto exige uma prescritividade, direciona e nos instiga para um questionamento que, ao longo das análises, demonstrou-se contundente: como um candidato, pressionado pelo contexto de um processo seletivo cuja exigência está fincada, no rigor do padrão da língua, lança mão de pares correlativos, por exemplo, diferentes dos determinados, institucionalizados pela gramática do português, como em Bechara: “... não só... mas também", "não só... mas ainda", "não só... senão também” (cf. Bechara, 2001, p.320)?

Torna-se relevante recorrer ao que aponta Marcuschi (2005) para entender, de fato, a escolha desses pares correlativos: "a maneira como nós dizemos aos outros as coisas é decorrência de nossa atuação intersubjetiva sobre o mundo e da inserção sócio- 
cognitiva no mundo em que vivemos" (p.52). Isso nos leva a entender que a escolha de um elemento linguístico está ligada ao agir mediante as atitudes, ao entendimento do olhar do outro a partir de pontos de vista. Construímos novos conceitos a partir da linguagem do mundo que nos cerca, mas que é retratada de acordo com as experiências de cada falante, atrelada ao seu interlocutor, e esse prisma muda de acordo com o comportamento, atitudes e valores mediante às suas diversas realidades.

Para Langacker (1997), o desenvolvimento de uma língua depende da capacidade inata e de certos sistemas simbólicos que a constituem como um instrumento vinculado não só a condições mentais, mas também a condições comunicativas que exercem papel preponderante para sua evolução.

Para o autor, existe uma "convergência substancial nos mundos mentais construídos" (Langacker, 1987, p.233). Isso quer dizer que a representação da linguagem muda de acordo com o tempo, espaço, de nós com outros homens; não é uma fotografia mental fixa, imutável, mas opera de acordo também com a interação de outras mentes que nos cercam: “As representações mentais não são fixas, pois elas emergem na interação, são negociadas e móveis" (cf. Marcuschi, 2005, p.64)

Por isso, se as representações mentais modificam-se, é porque o cérebro funciona como uma caixa de entradas que permite que itens lexicais, por exemplo, os que se compuseram como elementos desta análise, se recodifiquem a partir de várias associações ativadas, e, assim, recebam outros contornos e assumam outras formas e funções atreladas ao uso.

Como parte da conclusão desta tese, não se pode pensar na língua como um sistema advindo de inserções inertes monolíticas, mas como instrumento advindo de uma "comunidade de mentes sociais construindo as significações" (Davidson, 1974, p.197). Por isso, é importante entender que "instabilidade e mudança são uma dimensão intrínseca, vinculadas às estruturas da gramática da língua, que se reconfiguram no discurso cujas categorias linguísticas e cognitivas são instáveis e culturalmente sensíveis" (Marcuschi, 2005, p.68).

Essas considerações nos apoiam em apontar, então, que o aspecto cultural tem um papel significativo nessa empreitada: o ser humano, ao entender o outro como parte de seu grupo social, seu "co-específico" (Tomasello, 2003, p.13), filogeneticamente, 
compreende-o como um "ser mental e intencional igual a ele mesmo", e assim, há uma absorção, nesse processo, das atitudes e representações simbólicas pertencentes ao grupo, historicamente constituídos, ontogeneticamente.

A língua, nesse aspecto, parece ser a protagonista que move toda a condição humana, num jogo estratégico: o indivíduo, ao perceber que uma atitude linguística é inerente a seu grupo, logo a outorgará como parte de suas estratégias discursivopragmáticas por meio da "aprendizagem cultural" (Tomasello, 2003, p.287) e, assim, desenvolverá capacidades cognitivas a fim de associar-se, por meio de uma "emulação ritualizada" (p.293), a práticas sócio-linguístico-discursivas, que o autorizam a fazer parte do grupo social à que pertence.

Com isso, chegamos a algumas conclusões, ao nos atermos ao corpus analisado nesta tese:

A) O autor escolhe itens lexicais e conteúdos que o projetarão para um determinado grupo social, no caso específico para esta tese, a banca examinadora, a qual the aceitará ou não como tal;

B) Para isso, (candidato) faz suas relações baseando-se nas suas experienciações, conhecimentos de mundo e enciclopédicos, naquilo que conhece; acredita ser adequado para atender às expectativas do leitor;

C) Prediz seu comportamento linguístico, a partir das estratégias comunicacionais e sociais que o levarão a pertencer a seu grupo social;

D) Busca trazer à tona uma reflexão calcada nas resoluções dos problemas, na formação de alianças sociais que o fizeram aprender a tomar atitudes ligadas ao comportamento do grupo;

E) Lança porções informativas a partir do resultado das várias formas de aprendizagem social que aprendeu com seus co-específicos: ambiente cultural, social, escolar, o da família, entre outros;

F) Faz analogias entre as informações acumuladas advindas da interpretação intersubjetiva que faz do mundo, e as concretiza em material linguístico.

Com isso, percebe-se que as escolhas são impulsionadas tanto pelo “conhecimento implícito" (Tomasello, 2003), aquele construído sobre bases inatas, mas 
que se modificam por influência de fatores externos, quanto pelo "conhecimento explícito" (p.272), que advém de práticas requeridas por meio de habilidades e competências, satisfatórias, e, assim, provavelmente fazem parte de seu repertório. Dessa forma, quando o indivíduo escreve, busca representações linguístico-discursivopragmáticas por meio dessas duas aprendizagens.

Dessa forma, considerar uma atitude linguística, em que o indivíduo se apropria de um estágio "proto da língua" e não evolui, é desprezar a própria história da condição humana. Parece que isso tem movido, infelizmente, algumas ações educativas, no que diz respeito à aquisição e aprendizado de língua materna: não oferecer instrumentos eficientes, capazes de fazer com que o falante/ escritor crie habilidades para lidar com situações de adequação tanto na oralidade quanto na escrita. Isso foi percebido nas redações consideradas "piores".

O que defendemos, nesta tese, é que somente uma práxis inserida numa instrução coordenada por um conjunto de profissionais, que se mobilizem para isso, é que se criarão possibilidades de aprendizagem mais significativas:

A) Interação entre alunos e professores inserida numa prática "de atenção conjunta intersubjetiva" (Tomasello, 2003), de tal modo que possa entender os símbolos, manipulá-los, a partir do que seu co-específico faz e, num jogo de cooperação, ambos assumirem papéis que possam levar a uma aprendizagem social;

B) Ações em que se convirjam as dificuldades e avanços instaladas num processo, em que estados mentais se coligam, a fim de que possa entender o outro como sujeito;

C) Necessidade de se entender o processo de imitação inerente à aprendizagem humana, pois é, a partir dele, que o indivíduo entende seu "co-específico" (Tomasello, 2003), adquire habilidades em lidar com o objeto e começa a refletir sobre as razões desse sucesso. Com isso, isola aspectos que considere relevantes dessa aprendizagem ressignificativa;

D) Para tanto, deve ocorrer, por parte do professor, uma facilitação adaptativa que atenda ao grupo específico, com seus avanços e dificuldades nesse processo;

E) Entender que o papel do professor para aprendizado da língua é fundamental: "um indivíduo só domina plenamente o uso de símbolos e suas concomitantes maneiras de pensar, depois de um período de vários anos de interação, 
praticamente contínua, com usuários maduros de símbolos” (Tomasello, 2003, p.300); nesse caso, específico, o docente.

Esses apontamentos se deram por conta da comparação que fizemos, ao verificarmos as hipóteses presentes, a partir dos quadros indicativos de quantificação das correlativas, por estrutura lexical.

Dados, na checagem das hipóteses, em relação às melhores, confirmaram-se: o candidato, ao optar pela distribuição de material linguístico, entre os pares correlatos, busca maior quantidade de itens lexicais para dar sustentação àquilo que pretende argumentar; assim, lança mão por meio de sua consciência de imagens atreladas ao seu conhecimento de mundo, daquilo que leu, discutiu, refletiu.

O princípio da iconicidade auxiliou para que chegássemos a essa conclusão: a estrutura da língua relaciona-se à estrutura da experiência. Ingredientes como a quantidade, ordem entre os itens lexicais, subprincípios ligados a esse princípio também reforçaram nossa hipótese: o candidato ordena, quantifica dados informacionais, intencionalmente. Busca, também no estágio autobiográfico, material mais complexo e experienciado que contribui para que esse mecanismo icônico aconteça harmoniosamente.

Outros dados confirmaram algumas hipóteses: o modo de relacionar as ideias entre os parágrafos se dá de forma diretiva, há focos de atenção, em que o autor os fragmenta como recurso estratégico para pontuar fato por fato, porém não perde a coesão e tem coerência.

Pelo princípio da marcação resta claro que marcas de pares correlativos, considerados não-normatizados, são marcados como elementos subjacentes à argumentação. Adicionalmente, o conceito, a imagem que se faz do que é normativo ou não-normativo mudou, confirmando-se a inovação.

Há uma imbricação, um hibridismo mesclado entre o uso, as experiências do autor, o conteúdo informativo que vem à tona, a intenção e suas marcas, o interlocutor. 
O autor do texto está mais voltado ao que dizer, do que propriamente ao uso calcado na regra. Para ele, importa mais o conteúdo "em foco", que coloca em cena para chamar a atenção sobre os aspectos que trata.

O que é mais marcado cognitivamente se efetiva concretamente nas amarras entre as porções informativas.

Quanto ao plano discursivo, as porções informativas, entre os pares, revelaramse produtivas: o modo como o falante processa seu discurso está fundamentado entre as porções centrais e periféricas.

$\mathrm{O}$ autor lança mão do conteúdo informativo, no $1^{\circ}$ momento, constituído por material lexical já conhecido pelos interlocutores e compondo um fundo.

A figura, no $2^{\circ}$ momento, representa a informação nova, surpresa, que estrategicamente é constituída por mais quantidade de material lexical a fím de mostrar ao leitor que domina, discute, reflete, argumenta.

Estrategicamente, o autor lança, primeiramente, o fundo e, logo após, a figura, como uma estratégia discursivo-pragmática. Na figura, procura explicitar experiências, conhecimentos de mundo presentes no uso efetivo da língua; há uma relação próxima entre o uso e língua.

O modo de unir porções informativas está mais relacionado a um processo discursivo dinâmico, em que as ideias estão no nível da cognição experiencial entre os interlocutores, do que na exigência, amarrada no estilo da produção, em que há obrigatoriedade da utilização dos aspectos de coesão e coerência textuais.

Os conteúdos estão distribuídos como focalizadores que colocam em cena, lado a lado, informações que se costuram. Há uma sequência e, por isso, são considerados textos bons.

Em relação aos textos das piores, parece que alunos que apresentaram dificuldade em estabelecer correlação entre as porções informativas é porque provavelmente não tiveram um ensino adequado para tal, e por isso, não têm todas as estratégias de correlação.

Diante dessa constatação, defendo que o papel de ensino da língua portuguesa precisa ser revisto, como lembra Geraldi (1997): 
[...] o ensino da língua portuguesa, hoje, busca desenvolver no aluno seu potencial crítico, sua percepção das múltiplas possibilidades de expressão linguística, sua capacitação como leitor efetivo dos mais diversos textos representativos da nossa cultura. Para além da memorização mecânica de regras gramaticais (...) o aluno deve ter meios de ampliar e articular conhecimentos e competências que possam ser mobilizadas nas inúmeras situações de uso da língua" (PCN, 2002).

É essencial entender que o uso da língua está imbricado num dinamismo, em que não cabe distanciar as intenções comunicativas e a realização concreta numa discursividade vinculada a um pragmatismo que mobiliza as atitudes linguísticodiscursivas. A partir do momento em que usos de pares correlativos, considerados inovadores, estão presentes em textos da Fuvest, é porque existe uma mudança paradigmática de quem diz e para quem se diz.

Como demonstramos nas análises, o fato de identificarmos

A) interactantes compartilhando informações novas e velhas servindo-se de construções produtoras da língua;

B) informações iconicamente distribuídas guindo a atenção dos interactantes;

C) negociação de sentido comuns sendo feitas por meio de construções inovadoras sem prejuízo de compreensão; e

D) recorrência de usos dando origem a novas configurações sintáticas.

representam instâncias de processos de gramaticalização porque

A) surgem sem construções e

B) codificam-se novos sentidos propiciando que deslizamentos categoriais semântico-pragmáticos sejam sintaticizados. 


\section{REFERÊNCIAS BIBLIOGRÁFICAS}

ABAGNANO, N. Dicionário de Filosofia. São Paulo: Martins Fontes, 1999.

ABAURRE M. L. e PORTARA, M. Gramática/Texto. Análise e Construção de Sentidos, Ed. Moderna, 2010.

ABBAGNANO, N. Dicionário de Filosofia. São Paulo: Martins Fontes, 1998.

ABREU, A. S. Coordenação e Subordinação - uma proposta de descrição gramatical. In: ALFA - Revista de Linguística, São Paulo, v. 41, Fundação Editora da UNESP, 1997.

ADAM, J. M. Les textes: types et prototypes. Paris: Nathan, 1999.

AMARAL, E.; FERREIRA, M. et alli. Novas Palavras. São Paulo: Editora FTD, 2010.

ANSCOMBRE, J.-C., \& ZACCARIA, G. Fonctionnalisme et pragmatique - A propos de la notion de thème, Milan, Unicopli, 1990,

ARISTÓTELES. The works of Aristotle. V.I. Chicago: Great Books of the Western World, 1952.

AULETE, C. Dicionário Contemporâneo da Língua Portuguesa. $3^{\mathrm{a}}$ Ed. Rio de Janeiro: Delta (direitos da Pinto Bastos Ed. Ltda. - Lisboa), 1970.

AZEREDO, J. C. Fundamentos da Gramática do Português. $2^{\mathrm{a}}$ Ed. Rio de Janeiro: Jorge Zahar Editor, 2002.

AZEREDO, José Carlos de. Gramática Houaiss da língua portuguesa. São Paulo: Publifolha, 2008.

Gramática Houaiss da Língua Portuguesa. São Paulo: Publifolha, 2011.

Sobre os processos de estruturação sintática. Niterói: Faculdade de Letras/UFRJ, 1979. (mimeo.)

BARRETO, Ricardo Gonçalves. Português Ser Protagonista. São Paulo: Editora S.M, 2010.

BARROS, João de. Grammatica da Língua Portugueza. Apud Ludouicum Rotorigiu Typographum, Olyssipone (BPMP:R1-116; BNL:L.14.793V), 1496 BECHARA, E. Moderna gramática portuguesa. São Paulo: Companhia Editora Nacional, 2003.

BASALLA, G. The Evolution of Technology. Cambridge: Cambridge University Press, 1988.

BATES, E. MACWHINNEY, B. Functionalist approaches to grammar. In: Wanner, E. GLITMAN, L.R. (eds) Language acquisition:The state of the art. New York: CUP, 1976

BEAUGRANDE, R. A. Introduction to the study of text and discourse. Wien: Universitäts Verlag (pré-impressão), 1993.

BECHARA, E. Moderna Gramática Portuguesa. São Paulo: Cia. Ed. Nacional, 1968.

2009.

Minidicionário da Língua Portuguesa. Rio de Janeiro: Ed. Nova Fronteira,

BLOOM, L. One word at a time: The use of single-word utterances before syntax. The Hague: Mouton. 1973

BLOOMFIELD, L. (1993). Language. California. University of Chicago Press.

BOLINGER, D. Aspects of Language. Nova York: Harcourt Brace Janovich, 1975.

Meaning and Form. New York: Longmans, 1977. 
BORBA, Francisco. Dicionário Gramatical de Verbos do Português Contemporâneo da Brasil. São Paulo: Unesp, 1997.

Dicionário de usos do Português do Brasil. $1^{\text {a }}$ Ed. São Paulo: Ática, 2002.

BRAGA, M. L. A Concordância de número no Sintagma Nominal no Triângulo Mineiro. Rio de Janeiro: PUC, Departamento de Letras, 1977. 88 fl. Mimeo. Dissertação de Mestrado em Linguística.

BROWN, H. D. Children's comprehension of relative English sentences. Child Developmente, v. 42, 1971, p. 1923-1926.

BRUNER, S. J. The course of cognitive growth. American Psychologist, v. 19, 1974, p. 1-15.

BRUNER; Zeltner. Dicionário de Psicopedagogia e Psicologia Educacional. Petrópolis: Vozes, 2004.

BYBEE, J. Cognitive processes in grammaticalization. In: TOMASELLO, M. M. (ed.). The new psychology of language. V. 2. New Jersey: Lawrence Erlbaum, 2003.

BYBEE, J.; HOPPER, P. (Eds.). Frequency and the emergence of linguistic structure. Amsterdam/Phiçadelphia: John Benjamins, 2001.

BYBEE, J. Language, usage and cognition. Cambridge: CUP, 2010.

BYBEE, J.L. THOMPSON, S.A. Three frequency effects in syntox, in Matthew L Juge y Jeri O Moxley (eds) Proceeding of the $\mathbf{2 3}$ rd Annual Meeting of the Berkely Linguistics Society; Berkeley, Berkeley Linguistics Society, pp 378-388

CAMARA JR., J. C. Dicionário de lingüística e gramática. Petrópolis: Vozes, 1981.

CAMPBELL, L.; JANDA, R. Introduction: conceptions of grammaticalization and their problems. Language Sciences, 23:93-112, 2001.

CARONE, Flávia de Barros. Subordinação e coordenação - confrontos e contrastes. São Paulo: Ática, 2003.

CASSEB-GALVÃO, Vânia. C. A incidência da negação: critério de distinção de um paradigma evidencial gramaticalizado no PB. Estudos linguísticos XXXVI, São Paulo, v.1, p.12-17, 2007.

CASTILHO, A. T. de. A língua falada no ensino de português. São Paulo: Contexto, 2002.

Língua falada e gramaticalização. Filologia e Lingüística Portuguesa, São Paulo, v. 1, p. 107-120, 1997.

95. v. 38 .

Um ponto de vista funcional sobre a predicação. São Paulo: Alfa, 1994, p. 75-

A Linguagem falada culta na cidade de São Paulo: materiais para seu estudo. V. II - diálogo entre dois informantes. São Paulo: T.A. Queiroz/FAPESP, 1987.

CERejA, W. R.; MAgalhães, T. C. Português: linguagens, $7^{0}$ Ano. São Paulo: Atual, 2012.

CHAFE, W. Giveness, Contrastiveness definiteness, subjects topics and point of view. In: LI; CHARLES. (ed) Subject and Topic. New York: Academic Press, 1976.

1977.

.Meaning and the sctructure of language. Chicago: University of Chicago Press,

How people use adverbial clauses. In: Annual Meeting of the Berkeley Linguistics Society, 10, 1984, Berkeley. Proceedings. Berkeley: Berkeley Linguistics Society, 1984, p.437-449 
Cognitive constraints on information flow. In: TOMLIN, J. A.; LAMPERT, M.

D. Coherence and grounding in discourse. Philadelphia: John Benjamins Publishing Company, 1987.

Discourse, Consciousness and Time. Chicago. University of Chicago Press, 1994.

CHEDIAK, A. J. (org). Nomenclatura gramatical brasileira e sua elaboração. CADES, 1960.

CHOI, S., \& BOWERMAN, M. Learning to express motion events in English and Korean: The influence of language-specific lexicalization patterns. 1991.

CHOMSKY, N. Syntatic structures. The Hague. Haia: Mouton, 1967. Novos Horizontes nos estudos de linguagem. In: PINGUELLI ROSA, L.; LEMLE, M. (coord.). Noam Chomsky na Universidade Federal do Rio de Janeiro. Rio de Janeiro: UFRJ, 1998.

CIPRO NETO, P.; INFANTE, U. Gramática da Língua. São Paulo: Scipione, 2012.

CLARK, H. H. Arenas of language use. Chicago: University of Chicago Press, 1992

Using language. Cambridge: CUP, 1996.

The lexicon in acquisition. Cambridge, UK: CUP, 1993.

First language acquisition. Cambridge, UK: CUP, 2003.

COATES, J. The Semantics of the modal auxiliaries. Beckenham: Croom Helm, 1983.

COMPANY COMPANY. Concepción? Qué es un cambio linguístico? In.: SOLER, M. A.; AIROLDI, F. C. (Coord.) Cambio lingüístico y normatividad. México: Univ. Nac. Autónoma de México, 2003

CONNOLLY, J. H. Context in Functional Discourse Grammar. Alfa: Revista de Linguística. São Paulo. 2007. p. 11-33

CORNISH, F. Text and discourse: Discourse anaphora and the FDG Contextual Component. In: KEIZER, E.; WANDERS, G.(Eds.). Web Papers in functional Discurse Grammar. Amsterdam, v.82, 2009.

CORREA, J. Avaliação da Consciência Sintática na criança: uma análise metodológica. Psicologia: teoria e pesquisa. 2004-pg. 69-75.

COSERIU, E. Sincronia, diacronia e história. Rio de Janeiro: Presença, EDUSP, 1979.

CROFT, William. B. Latent concept expansion using markov random fields. Amsterdam. The Netherlands, 2007.

Syntactic categories and grammatical relations: the cognitive organization of information. Chicago: University of Chicago Press, 1991.

Toward a social cognitive linguistics. New directions in cognitive linguistics, ed. Vyvyan Evans and Stéphanie Pourcel, 395-420. Amsterdam: John Benjamins. 1991

Typology and Universals. Cambridge: Cambridge University Press, 1990.

Radical Construction grammar; syntactic theory in typological perspective. Oxford: Osford University Press, 2001.

Explaining language change: an evolutionary approach. Harlow, Essex. Longman.ridge: CUP, 2003.

Typology and universals, $2^{\text {nd }}$ edition. Camb

CROFT, William; CRUSE, D. Alan. Linguística Cognitiva. (Traducción de Antonio Benitez Burraco). Madrid: Ediciones Akal, 2008. 
CRYSTAL, D. Dicionário de Linguística e Fonética. Rio de Janeiro: Jorge Zahar, 1997.

CUNHA, A. G. da. Dicionário Etimológico Nova Fronteira da Língua Portuguesa. Rio de Janeiro: Nova Fronteira, 1996.

CUNHA, C. Gramática da Língua Portuguesa. Rio de Janeiro: Fename, 1975.

CUNHA, C.; CINTRA, L. Nova gramática do português contemporâneo. $3^{a}$ ed. Rio de Janeiro: Nova Fronteira, 2001.

CUNHA, M. A. F. Gramática da língua portuguesa. 12ª ed. Rio de Janeiro: FAE, 1990.

CUNHA, M. A. F. da. A negação no português: uma perspectiva pancrônica. In: FURTADO DA CUNHA. (Org.) Procedimentos discursivos na fala de Natal: uma abordagem funcionalista. Natal: EDUFRN, 2000.

CUNHA, M. A. F. Gramaticalização dos Mecanismos de Negação em Natal. In: MARTELOTTA, M. E.; VOTRE, S. J.; CEZARIO, M. M. (orgs). Gramaticalização no Português do Brasil. Rio de Janeiro: Tempo Brasileiro, 1996.

CUNHA, M. A. F.; MARTELOTTA, M. E. (org). Linguística funcional: teoria e prática. Rio de Janeiro: FAPER/RJ, 2003.

D’AVILA, S. Gramática em prática: textos e exercícios. São Paulo: Editora do Brasil, 2011.

DAMÁSIO, António R. (2011) E o cérebro criou o homem. Tradução de Laura Teixeira Motta. Campinas/São Paulo: Companhia das Letras.

DE LANCEY, S. An interpretation of split ergativity and related patterns. Language, v. 57 , n.3, p. 626-657, 1981.

DEACON, T. The symbolic species: the co-evolution of language and the brain. New York: W. W. Norton, 1998.

DECAT, M. B. N. Por uma Abordagem da (in)dependência de cláusulas à luz da Noção de "unidade informacional". In: Scripta (Linguística e filologia). Belo Horizonte: PUC-Minas, v. $2, \mathrm{n}^{\mathrm{o}} 4,2^{\circ}$ sem, p. 23-38.

Aspectos da Gramática do Português: uma Abordagem Funcionalista. Campinas/SP: Mercado das Letras, 2001.

DIAS, N. B; LIMA-HERNANDES, M. C. Flexão como processo de expressão de Relações e Valores. São Paulo: Parábola, 2010

DIK, Simon C. The Theory of Functional Grammar. Berlin/New York: Mouton de Gryter, 1977. (Parte 1: The structure of the clause).

Publications, 1978a.

Functional Grammar. Dorderecht-Holland/Cinnaminson-EUA: Foris

Gramática Funcional. Trad.: Leocadio Martin Mingorance e Fernando Serrano Valverde. Madrid: Soc. Gen. Española de Libreria, 1978 b.

Seventeen sentences: basic principles and application of function Grammar. In: MORAVCSIK, E.; WIRTH, J. R. (ed.). Syntax and Semantics. V. 13: Current Approaches to syntax, Londres/New York: Academic Press, 1980.

The theory of functional grammar: the structure of the clause. Dordrecht: Foris Publications, 1989.

Discourse and the ecology of grammar: strategy, grammaticization, and the locus. Rice Symposium, MS, University of California: Santa Barbara, 1993. 
The theory of functional grammar. $2^{\mathrm{a}}$ ed. By K. HENGEVEED. Berlin/New York: Mouton de Gruyter, 1997.

DILLINGER, M. Forma e função na Linguística. D.E.L.T.A., v. 7, nº 1, 1991.

DUBOIS, J. W. Beyond Defineteness: the Trace of Identityn in Discourse. In: DAMÁSIO, A. R. E o cérebro criou o homem. Tradução: Laura Teixeira Motta. São Paulo: Companhia das Letras, 2009.

DUQUE, P. H.; COSTA, M. A.. Linguística Cognitiva: em busca de uma arquitetura de linguagem compatível com modelos de armazenamento e categorização de experiências. Natal/RN: EDUFRN, 2012.

ENGLEBRESTON, Robert (ed.) Stancetaking in Discourse . Amsterdam: John Benjamins. 2007.

FARACO, C. E.; MOURA, F. M.; MARUXO, J. JR. Gramática. São Paulo: Ática, 2012.

FAUCONNIER, G. \& TURNER, M. The way we think. New York: Basic Books, 2003.

FERNANDES, F. Dicionário de Sinônimos e Antônimos. Porto Alegre: Livraria da Globo, 1970.

FERREIRA, A. B. H. Novo Dicionário da Língua Portuguesa. $2^{\mathrm{a}}$ Ed. Rio de Janeiro: Nova Fronteira, 1986.

Novo Aurélio Século XXI: O Dicionário da Língua Portuguesa. $3^{\mathrm{a}}$ ed. Rio de Janeiro: Nova Fronteira,1999.

FILLMORE, C. J. Topical in Lexical Semantics. In: R. COLE(ed.). Current Issues in Linguistic Theory. Bloomington: Indiana University Press, 1977, pp.77-138.

Frame Semantics and the Nature of Language. In: S. R. HARNARD ET alii (esds.). Origins and Evolution of Language and Speeche. Nova York: New Yord Academy of Sciences, 1976.

FRAGOMENI A. M. Dicionário enciclopédico de informática. São Paulo: Editora Campus, 1986.

FURTADO DA CUNHA, M. A.; OLIVEIRA, M. R.; MARTELOTTA, M. (orgs.) Linguística Funcional: teoria e prática. Rio de Janeiro: DP \& A, 2003.

FURTADO DA CUNHA, M. A.; (ORG) Corpus discurso e gramática - a língua falada e escrita na cidade de Natal,Natal:EDUFRN, 1998

FURTADO DA CUNHA, M.A.; TAVARES, M.A. Funcionalismo e evento de gramática. Natal:EDUFRN, 2007.

FUVEST, Fundação Universitária para o Vestibular. Fuvest, 2010, Redações. Algumas das 100 piores e 100 melhores notas. São Paulo: 2010.

GARCIA, O. M. Comunicação em prosa moderna. 14ª ed. Rio de Janeiro: Fundação Getúlio Vargas, 1988.

GERALDI, J. W. Portos de Passagem. São Paulo: Martins Fontes, 1991.

Da redação à produção de textos. In: GERALDI, J. W.; CITELLI, B. (Coord.). Aprender e ensinar com textos de alunos. São Paulo: Cortez, 1997.

GIVÓN, T. On understanding Grammar. New York: Academic Press, 1979.

Syntax and semantics. V. 12, Discourse an Syntax. New York: Academic Press, 1979. 
From discourse to syntax: grammar a processing strategy. In: GIVÓN, T. (ed.) Syntax and semantics: discourse and syntax. New York: Academic Press, 1979.

1984.

.Syntax a functional-typological introduction. Vol. 1. Amsterdam: Benjamins,

.Syntax a functional-typological introduction. Vol. 2. Amsterdam: Benjamins, 1990.

Syntax: an introduction. Amsterdam; Philadelpjia: Benjamins,2001.

Serial Verbs and the Mental Reality of "Event": Grammatical vs. Cognitive Packaging. In: E. TRAUGOTT \& B. HEINE (eds.). Approaches to Grammaticalization. V. 1. Amsterdam/Filadelfia: John Benjamins Publishing Company, 1991.

1993.

Grammar of English. A function-based introduction. Ansterdam: Benjamins,

Functionalism and Grammar. Amsterdam/Philadelphia: John Benjamins, 1995.

Compreendendo a Gramática. Tradução de: Maria Angélica Furtado da Cunha.

Natal: Edufrn, 2011.

GOFFMAN, E. A representação do eu na vida cotidiana. Tradução: Maria Célia Santos Raposo. Petrópolis: Vozes, 1985.

GOIS, C. Método de Análise (léxica e lógica) ou sintaxe das Relações. Rio de Janeiro: Francisco Alvez, 1955.

GOLDBERG, A. E.; JACKENDOFF, R. The English resultative as a family of constructions. Language 80, 2004: 532-567.

GOLDBERG, A. E. A construction grammar approach $h$ to argument structure. Chicago/London: The University of Chicago Press, 1995.

Constructions at work: the nature of generalization in language. Oxford: Oxford University Press, 2006.

GOMBERT, J. Metalinguistic development. Hertfordshire: Harverster Whesheaf, 1992.

GÓMEZ-GONZÁLEZ, M.A.The Theme-Topic Interface:Evidence for English.Amsterdam\&Philadelphia:John Benjamins, 2001

GONÇALVES, S. C. L.; LIMA-HERNANDES, M. C.; CASSEB-GALVÃO, V. C. (orgs.). Introdução à Gramaticalização. São Paulo: Parábola, 2007.

GORSKI, E. O tópico semântico-discursivo na narrativa oral e escrita. Rio de Janeiro, 1994. Tese (Doutorado em Linguística - Universidade do Federal do Rio de Janeiro).

GREIMAS, A. J.; COURTÉS, J. Dicionário de Semiótica. São Paulo: Cultrix, 1979.

GRICE, H. P. Logic and Conversation. In: COLE, P.; MORGAN, J. (eds). Speech Acts. New York: Academic Press, 1975 (Volume 3: Syntax and semantics).

GUIMARÃES, E. Texto e argumentação: um estudo de conjunções do português. Campinas: Pontes, 1987.

HAIMANN, J. Conditionals are Topics. Language, V. 54, 1978.

Iconic and economic motivation. Language, V. 59, 1983.

HALliDAY, M. A. K. Class in relation to the Axes of Chain and Choice in Language. Linguistics, V.2, 1963.

Notes on Transitivity and Theme in English. Journal of Linguistics, V. 3. 1967. 
Explorations in the functions of Language. Londres: Edward Arnold, 1973.

. The Functional Basis of Language. In: B. BERNSTEIN. (ed.) Class, Codes and Control. Londres: Routledge and Kegan Paul, 1973.

An Introduction to functional Grammar. Baltimore: Edward Arnold, 1985.

HALLIDAY, M. A. K.; HASSAN, R. Cohesion in English. London: Longman, 1973.

HARRIS, A. C. \& CAMPBELL, L Historical syntax in cross - linguistic perspective. Cambridge: CUP, 1995.

HARRIS, M. B. The historical development of si-clauses in Romance. In: TRAUGOTT, E. C. et al. (eds) On conditionals. Cambridge: Cambridge University Press, 1986, p. 265-284.

HEINE, B.; CLAUDI, U.; HŮNNEMEYER, F. Grammaticalization. A conceptual framework. Chicago: The University of Chicago Press, 1991.;

HEINE, Bernd. Grammaticalization. In JOSEPH, B JANDA, R (eds) A handbooks of historical linguistics. Oxford: Blackweel, 2003. p.575-601.

HENGEVELD, K. Clausestructure and modality in functional grammar. In: AUWERA, J. V. D.; GROOSSENS, I. (eds.). Ins and outs of the predication. Dordrecht: Foris Publications, 1987. Gruyter, 1997.

(ed.). DIK: the theory of functional grammar 2. Berlim/New York: Monton de

The architecture of a functional discourse grammar. In: GOMES GONZÁLES, M. A.; MACKENZIE, J. L. (eds.). A new architecteture for functional grammar. Berlin: Mouton de Gruyter, 2003.

HJELMSLEV, L. Prolegômenos a uma teoria da linguagem. São Paulo: Perspectiva, 2006.

HOPPER, P. J. An introduction to Natural Generative Phonology. New York: Academic Press, 1976.

Emergent Grammar. Berkeley Linguistic Society, n. 13, 1987, p. 139-57.

Aspect and Foregrounding in Discourse. In: GIVÓN, T. (ed). Syntax and Semantics. New York: Academic Press, 1979 (Vol. 12: discourse and sintax).

.On some principles on grammaticalization. In: TRAUGOTT, E. HEINE,B. Approaches to grammaticalization. Philadelphia: John Benjamins Company, 1991. v.1 0.1735

HOPPER, P. An introduction to natural generative phonology. New York: Academic Press, 1976.

Aspect and foregrounding in discourse. In: GIVÓN,T. (ed) Syntax and Semantics. New York: Academic Press, 1979. (volume 12: discourse and syntax)

Emergent Grammar. In: TOMASELLO, M. The new psychology of language. Lawrwnce Erlbaum: New Jersey, 1998, p. 155-175.

HOPPER, P.; TRAUGOTT, E. Grammaticalization. Cambridge: Cambridge University Press, 1993.

Grammaticalization across clauses. Cambridge: Cambridge University Press, 2003.

HOUAISS, A.; VILlaR, M. S. Dicionário Houaiss da Língua Portuguesa. Rio de Janeiro: Ed. Objetiva, 2001. 
HULL, D. L. Science as a process: an evolutionary account of the social and conceptual development of science. Chicago: University of Chicago Press, 1988.

HYMES, D. On communicative competence. In J.B. Pride \& J. Holmes (Eds.), Sociolinguistics. Harmondsworth: Penguin , 1972.

Foundations in Sociolinguistics: an ethnographic approach. London: Tavistock Publications Limited, 1974.

INSTITUTO ANTONIO HOUAISS. Dicionário de Física. Rio de Janeiro: Objetiva, 2005.

IUDÍCIBUS, S.; MARION, J. C.; PEREIRA, E.; Dicionário de Termos de Contabilidade. São Paulo: Atlas, 2003.

ILARI, Rodolfo; GERALDI, João Wanderley. Semântica. São Paulo: Ática, 1985.

JESPERSEN, O. Analytic Syntax. London: George Allen \& Unwin Ltd, 1937.

JOHNSON, A. G. Dicionário de Sociologia - Guia Prático da Linguagem Sociológica. Rio de Janeiro: Jorge Zahar, 1997.

JOHNSON, M. The Body in the Mind: The bodily basis of meaning, imagination and reason. Chicago: the University of Chicago Press, 1987.

KARMILOFF-SNITH, A. Beyond Modularity: A Developmental Perspective on Cognitive Sciense. Cambridge, MA: MIT Press, 1992.

KAY, P.; FILLMORE, C.J. The goals of Construction Grammar. Berkeley Cognitive Science Program Technical Report no. 50. University of California at Berkeley, 1987

KEENAN, E. Some universals of passive in relational grammar. Papers from the Eleventh Meeting. Chicago Linguistic Society.

KLIMA E.S.; \& BELLUGI, U. Teaching apes to communicate. In G.Miller (Ed.), Communication, language and meaning (pp.95-106).New York: Basic Books

KUNO, S. Functional sentence perspective. Linguistc Inquiry, v. 3, 1972.

KURY, A. G. Novas Lições da Análise Sintática. São Paulo: Ática, 2002.

KURYLOWICZ, J. The evolution of grammatical categories. Esquisses Linguístiques, Munich, v. II, p.38-54, [1965] 1975.

LABOV, W. The social stratification of English in New York. Washington, D. C.: center for applied Linguistc, 1966.

The boundaries of words and their meanings, en Joshua Fishman (ed), New ways of analyzing variation in English, Washington D. C. Georgetown University Press, pp. 340-373.

LAKOFF, G. Women, Fire and Dangerous Things: what categories reveal about the mind. Chicago/London: The University of Chicago Press, 1987.

LAMENDELLA, J. The early growth of language and cognition: A neuropsychological approach. [19--]

LANCASTER, J. (ed.) . The origins and evolution of language and speech. New York: New York Academy of Science, 1976.

LANGACKER, R. Foundations of cognitive Grammar. V.1: theoretical prerequisites. Stanford: Stanford University Press, 1987;

Semantic representations and the linguistic relativity hypothesis, Foundation of Language 14, 1976.

LEÃO, Ângela Vaz. O Período Hipotético Iniciado Por Se. Belo Horizonte, Universidade de 
Minas Gerais, 1961

LEHMANN, C. Towards a typology of clause linkage. In: HAIMAN, J.; THOMPSON, S. A. Clause combining in grammar and discourse. Amsterdam: John Benjamins Publishing, 1988.

LEHMANN, W. P. A. A structural principle of language and its implications. Language, v. 49, 1973.

LEWIS, D. Convention. Cambridge: Mass., MIT Press, 1969.

LIMA, R. Gramática Normativa da Língua Portuguesa. Rio de Janeiro: José Olympio, 1985.

LIMA-HERNANDES, M. C. (org). Gramaticalização em Perspectiva: Cognição, Textualidade e Ensino. São Paulo: Paulistana, 2010.

Gramaticalização de estruturas x-que no português do Brasil. In: XV ALFAL, 2008, Montevidéu. Anais do XV ALFAL. Montevidéu : ALFAL, 2008. v. 1.

Estudos sobre gramaticalização: Objetos, Métodos e Problemas. In: OLIVEIRA, M. R.; ROSARIO, I. C. (org). Pesquisa em Linguística Funcional: convergências e divergências. Niterói: Leo Christiano Editorial, 2009, p. 21-33.

O princípio da iconicidade e sua atuação no português do Brasil. In: Filologia e lingüística portuguesa, $\mathrm{n}^{\circ} 8,2006$.

Tratado geral sobre gramaticalização. In: LIMA-HERNANDEZ, M. C.; GONÇALVES, S. C. L.; CASSEB-GALVÃO, V. C. (orgs.). Introdução à Gramaticalização. São Paulo: Parábola, 2007, p. 15-90.

LIMA-HERNANDES, M. C.; SILVA, R. T. E. Anjos de Macau. Fragmentum (UFSM), v. 35, p. 1, 2012.

LUFT, C. P. Dicionário Prático de Regência Verbal. São Paulo: Ática, 2003.

Gramática Resumida. Porto Alegre: Globo, 1978.

Ática, 2002.

. Língua e Liberdade: Por uma nova concepção da língua materna. São Paulo:

Novo Guia Ortográfico. Porto Alegre: Editora Globo, 2004

LYONS, J. Semantics. London: Longmans, 1977.

(Ed.). New directions in linguistics. London: Penguin, 1970.

MACAMBIRA, J. R. A. A estrutura morfo-sintática do Português. São Paulo: Pioneira, 2001.

MACHADO, I. L.; MELLO, R. (Org.). Gêneros: reflexões em análise do discurso. Belo Horizonte: NAD/FALE/UFMG, 2004.

MACIEL, M. Grammatica descriptiva baseada nas doutrinas modernas. Rio de Janeiro: Francisco Alves, 1931.

MARCUSCHI, L. A. Análise de conversação. São Paulo: Ática, 2007.

2005.

Da fala para a escrita - Atividades de Retextualização. São Paulo: Cortez,

Produção textual, análise de gêneros e compreensão. São Paulo: Parábola, 2008.

2000 (mimeogr.).

Quando a referência é uma inferência. Conferência Apresentada no GEL-SP, 
MARTELlOTA, M. E. Mudança Linguística: uma abordagem baseada no uso. São Paulo: ED. Cortez, 2001.

(mimeogr.).

Figura e fundo. Uma proposta prática de análise. Rio de Janeiro: UFRJ, 1998

Gramaticalização em operadores argumentativos. In: MARTELOTTA, M. E. et al. (orgs). Gramaticalização no Português do Brasil: uma abordagem funcional. Rio de Janeiro: Tempo Brasileiro/UFRJ, 1996, p. 191-200.

ET alii. Manual de Linguística. São Paulo: Contexto, 2011.

Processos de Gramaticalização envolvendo cláusulas finais. Relatório parcial enviado ao CNPq. Rio de Janeiro: UFRJ, 1998.

(mimeogr.)

Figura e fundo. Uma proposta prática de análise. Rio de Janeiro: UFRJ, 1998.

et al. (orgs). Gramaticalização no português do Brasil: uma abordagem funcional. Rio de Janeiro: Tempo Brasileiro/UFRJ, 1996, p.191-200.

Contexto, 2011.

MARTELOTTA, Mário Eduardo (org.). Manual de Linguística. São Paulo:

Operadores argumentativos e marcadores discursivos. In VOTRE S. J.; CEZARIO, M. M. (orgs). ,MARTELOTTA, MÁRIO E. Gramaticalização. Rio de Janeiro: Faculdade de Letras, UFRJ, 2004.

MARTELOTTA, M. E. Gramaticalização em operadores argumentativos. In: MATERLLOTA, M. E.; VOTRE, S. J.; CEZARIO, M. M. (orgs). Gramaticalização no Português do Brasil: uma abordagem funcional. Rio de Janeiro: Tempo Brasileiro/UFRJ, 1996.

MATERLLOTA, M. E.; VOTRE, S. J.; CEZARIO, M. M. (orgs).Funcionalismo e cognição: a interface linguagem e ensino. Natal:EDUFRN, 2006.

MARTINET, A. Grammaire fonctionnelle du français, Paris: Didier / Crédif, 1979.

Qu'este-ce que La linguistique fonctionelle? ALFA, 1994.

MATTOSO CÂMARA JR. Dicionário de Linguística e Gramática. 25aㅡ. Petrópolis: Vozes, 1986.

MATEUS, M. H. et al. Gramática da Língua Portuguesa. Lisboa: Caminho, 2003.

MATISOFF, James A. A resl and universal dimension of Grammaticalization in Lahu. In: TRAUGOTT, Elizabeth Closs, HEINE, Bernd (eds) Approaches to Grammaticalization. Amsterdã: John Benjamins, 1991. vol. 2.

MATTHIESSEN, Christian; THOMPSON, Sandra A. The structure of discourse and 'subordination'. In: HAIMAN; THOMPSON (Ed.). Clause combining in grammar and discourse. Amsterdam: John Benjamins Publishing, 1988.

MEILLET, A. Linguistique historique et linguistique genérale. Paris: Klinncksied, 1906.

L'évolution des formes grammaticales. Scientia (Rivista di Scienza) 12, No 26, 6. Linguistique historique et linguistique générale, 130-48. Paris: Librairie Ancienne Honoré Champion, 1912.

MELO, G. C. M. Gramática fundamental da língua portuguesa. Rio de Janeiro: Ao Livro Técnico, 1978.

MESQUITA R. M. M.; RIVAS C. M. Gramática Pedagógica São Paulo: Ed. Saraiva, 2009.

MIRANDA, N. S.; NAME, M. C. Linguística e Cognição. Juiz de Fora: Ed. UFJF, 2005. 
MITHEN, S. A pré-história da mente. São Paulo: Ed. Unesp, 2002.

MITHUN, M. The grammaticalization of coordination. In: HAIMAN, J. ; THOMPSON,1988.

MÓDOLO, M. As construções correlatas. In: ILARI, R.; NEVES, M. H. M. Gramática do Português Culto Falado no Brasil. vol. 2. São Paulo: Unicamp, 2008

Gramaticalização das conjunções correlativas no Português. 2004. (Tese de Doutorado em Filologia e Língua Portuguesa, Universidade de São Paulo, São Paulo, 2004).

MOISÉS, M. Dicionários de Termos Literários. São Paulo: Cultrix, 1999.

MOLLICA, M. C.; BRAGA, M. L. (orgs). Introdução à sociolinguística: o tratamento da variação. São Paulo: contexto, 2012.

MONDADA, L. Verbalisation de I'espace et fabrication Du savoir. Aproche linguístique de La construction des objets de discours. Lausanne: University de Lausanne, 1994.

MONDADA. L.; DUBOIS, D. Construction des objets de discours ET catégorization: une approche des processos de référenciation. TRANEL (Travaux neuchátelóis de línguistique), 1995.

MONTEIRO, José Lemos. A Estilística. Rio de Janeiro: Ática, 1991.

MOURÃO, R. F. Dicionário Enciclopédico de Astronomia e Astronáutica. Rio de Janeiro: Nova Fronteira, 1995.

MOURÃO, C.; MAGALHÃES, C. "Português. Linguagens" São Paulo: Editora Atual, 2012.

NARO, A. J.; BRAGA, M; L. A interface sociolingüística/gramaticalização. Gragoatá, n. 9, 2000, p. 125-135.

NASCIMENTO, M. J. R. Repensando as vogais temáticas nominais a partir da gramática das construções. 2006. Tese (Doutorado em Letras Vernáculas), Universidade Federal do Rio de Janeiro), Rio de Janeiro: 2006.

NEVES, M.aria Helena de Moura. Gramática de Usos do Português. São Paulo: Ed. UNESP, 2000.

A gramática na escola. São Paulo: Contexto, 1991.

Estudos Funcionalistas no Brasil. Alfa, 1999a.

da Unicamp, 1999b.

(org.) Gramática do Português falado. São Paulo/Campinas: Humanitas/Editora

O tratamento da articulação da oração. In: (org.). Descrição do português: definindo rumos de pesquisa. Araraquara/são Paulo: FCL/Laboratório Editorial/Unesp; Cultura Acadêmica Editora, 2001.

A gramática: história, teoria e análise, ensino. São Paulo: Ed. UNESP, 2002.

Que gramática estudas na escola?Norma e uso na língua portuguesa. São Paulo: Contexto, 2003.

A Gramática Funcional. São Paulo: Ed. Martins Fontes, 2004.

.Texto e gramática. São Paulo: Contexto, 2006.

Um painel do Acordo - As idas e vindas da qustões políticas que envolveram a unificação da nova grafia. Revista Língua Portuguesa Guia da Nova Ortografia. São Paulo: Segmento. Número especial, abril, p, 26-28, 2009. Contexto, 2010.

Estudos de língua e vivência de linguagem. Temas em confronto. São Paulo. 
Gramática e ensino: de quando facilitar complica. In: DAHLET, V. (coord.). Ciências da linguagem e didática das línguas. São Paulo: Humanitas/ FAPESP, 2011, p. 259284.

NEVES, M. H. M.; BRAGA, M. L. Hipotaxe e gramaticalização: uma análise das construções de tempo e de condição. D.E.L.T.A., v. 14 (n. especial), 1998, p. 191-208.

NEY, J. L. N. Guia de análise sintática. Rio de Janeiro: Organização Simões, 1955.

OITICICA, J. Manual de análise léxica e sintática. $6^{\text {a }}$ Ed. Rio de Janeiro: Francisco Alves, 1942.

Teoria da Correlação. Rio de Janeiro: Organizações Simões, 1952.

OLIVEIRA, M. R.; VOTRE, S. J. A trajetória das concepções de discurso e de gramática na perspectiva funcionalista. Rio de Janeiro: Matraga, v. 16, n. 24, jan/jun. 2009.

PAIVA, M. C. A. Ordenação das cláusulas causais: forma e função. Rio de Janeiro: UFRJ, Faculdade de Letras. 232 fl. mimeo. Tese de doutorado em Linguística, 1991.

PAULIKONIS, M. A. A estrutura correlativa como operador discursivo. In: DECAT, M. B. N. ET AL. (org). Escrita: Linguística e Filologia. Revista do programa de Pós-Graduação em Letras e do CES-PUC. Belo Horizonte: PUC/Minas, 2001, v. 5, n. 9, p. 119-125.

PERINI, M. Gramática descritiva do Português. São Paulo: Ática, 2000.

PINKER, S; PRINCE, A, Regular and irregular morphology and the psychological status of rules of grammar en Susan D Lima, R. T. Corrigan y Gregory K Iverson (eds) The reality of linguistics rules. Amsterdam, John Benjamin, 1994, pp353-388.

PLANTIM, C. A argumentação: histórias, teorias, perspectivas. São Paulo: Parábola, 2008.

PRETI, D. Fala e escrita em questão. São Paulo: Humanitas/FFLCH/USP, 2000.

PRINCE, E. Toward a taxonomy of given new information. IN Cole, P. (ed) Radical pragmatics. New York: Academic Press, 1981, p.223-256

ROCHA LIMA, C. H. Gramática Normativa da Língua Portuguesa. Rio de Janeiro; José Olympio Ed., 2010.

RODRIGUES, V. V. (orgs). Articulação de orações: pesquisa e ensino. Rio de Janeiro: UFRJ, 2010.

O caráter polissêmico das conjunções. Rio de Janeiro: 1999. Mimeo.

O uso das conjunções subordinadas na língua padrão. In: BERNARDO, S. P.; CARDOSO, V. (orgs). Estudos da Linguagem: Renovação e síntese. Anais do VIII Congresso da ASSEL-RIO. Rio de Janeiro: Assoc. de Estudos de Linguagem do Rio de Janeiro, 1999, p. 761-769.

Correlação. In: VIEIRA, S. R.; BRANDÃO, S. F. (Org.). Ensino de gramática: descrição e uso. São Paulo: Contexto, 2007.

ROSÁRIO, I. C. Gramaticalização de até: usos na linguagem padrão dos séculos XIX e XX. 2007. Dissertação (Mestrado em Língua Portuguesa) - Instituto de Letras, Universidade Federal Fluminense, Niterói, 2007.

Construções correlatas aditivas em perspectiva funcional. Tese 2012- 250.

SAID ALI, M. Gramática Secundária da Língua Portuguesa. São Paulo: Melhoramentos, 1966.

SARMENTO, L. L. Gramática em Textos. São Paulo: Editora Moderna, 2012.

SANDRONI, P. Dicionário de Economia. São Paulo: Beste Seller, 1989. 
SARTIN, E. Gramaticalização de orações para + infinito no Português brasileiro. 2008. Dissertação. (Mestrado em Filologia e Língua Portuguesa) - Universidade de São Paulo. São Paulo: 2008 .

SAUSSURE, Ferdinand. Curso de Linguística geral. São Paulo: Cultrix, $1975 .$.

SCHERRE, M. M. A regra de concordância de número no sintagma nominal em português. Rio de Janeiro: PUC, Departamento de Letras, 1978. Mimeo. Dissertação de Mestrado em Linguística.

SILVA, V. L. P. P. Cartas cariocas: a variação do sujeito na escrita informal. Rio de Janeiro: UFRJ, Faculdade de Letras, 1988. 330 fl. Mimeo. (Tese de Doutorado em Linguística.).

SLOBIN, Dan.I. Psicolinguística. Trad. Rossine Sales Fernandes. São Paulo: Ed. Nacinal/Edusp, 1980.

Crosslinguistic evidence for the language-making capacity. In SLOBIN, Dan Isaac (ed) The crosslinguistic study of language acquisition, v.2. Theoretical Issues, Mahwah, NJ: Lawrence Erlbaum Associates, 1985.

SMITH, C. B.; ADAMSON, L. B.; BAKEMAN, R. Interactional predictors of early language. First Language 8, 1988, p. 143-156.

SUGUIO, K.. Dicionário de Geologia Sedimentar e áreas afins. Rio de Janeiro; Bertrand Brasil Editora, 1998, 1217p.

SWEETSER, E. E. From etymology to pragmatics: metaphorical and cultural aspects of semantic structure. Cambridge: Cambridge University Press, 1990.

TARALLO, Fernando. The cultural origins of human cognition. Cambridge/London: Harvard University Press, 1999.

A pesquisa sociolingüística. São Paulo: Ática, 1986.

TAVARES, Maria. Alice. A gramaticalização de e, aí, daí e então: estratificação / variação e mudança no domínio funcional da sequenciação retroativo-propulsora de informações. Florianópolis: Universidade Federal de Santa Catarina, 2003.

TAVARES, Maria. Alice. Daí (veio) o uso do daí na codificação lingüística da articulação discursiva. In: Working papers em linguística. Universidade Federal de Santa Catarina. Florianópolis/SC: CPGLg, 2012-115.

TERRA, E. ; NICOLA, J. A Gramática de Hoje. São Paulo: Ed. Scipione, 1995.

THOMPSON, S; MULAC, A.A. Quantitive Perspective on the Grammaticalization of Epistemic Parenthericals in English. In: E TRAUGOTT; B. HEINE (eds) approaches to Gram maticalization, v1. Amsterdam Filadélfia: John Benjamins Publishing Company, 1991, pp 313330.

TOMASEllo, M. Origens Culturais da Aquisição do Conhecimento Humano. São Paulo: Martins Fontes, 2003.

(ed.) The new psychology of language: cognitive and functional approaches to language structure. New Jersey/London: Lawrence Eribaum Associates Publishers, 1998.

. "The cultural ecology of young children's interactions with objects and artifacts". In: Approaches to cognition: Essays in House of Ulric Neisser. Mahwah, NJ: Erlbaum, 1999..

TOMASELLO, M.; CALL, J. "Social cognition of monkeys and apes Yearbook of Physical Anthropology, 37, 273-305, 1997.

TOMASELLO, M.; KRUGER; A.C. RATNER, H. H. “Cultural Learning”, behavioral and brain Sciences. 16, 495-552, 1993. 
TRAUGOTT, Elizabeth Closs. Construction: In Grammaticalization. In: JOSEPH, B. D. E. e JANDA, R. D. (eds). The handbook of historical linguistics. Oxford: Blackwell, 2003.

TRAUGOTT, E. \& HEINE, B. (Eds.). Approaches to grammaticalization. Vol. I e II. Amsterdam: Benjamins, 1991.

TRAUGOTT, E.C.; DASHER, R. Regulatority in semantic change. Cambridge: Cambridge University Press, 2005

TRAUGOTT, E.C. Constructions in Grammaticalization In: JOSEPH, Brian D. JANDA, Richard D. (eds) The handbook of historical linguistics. Oxford: Blackwell Publishing Ltd, 2003.

TRAVAGLIA, L. C. Gramática e Interação: uma proposta para o ensino de gramática no $\mathbf{1}^{\mathbf{0}}$ e $\mathbf{2}^{\mathbf{0}}$ graus. São Paulo: Cortez, 1997.

VIGOTSKI, L. Mind in society: The Development of Higher Psychological Process. Ed. M. Cole. Cambridge, MA: Harvard University Press, 1978.

VIHMAN, M. M. \& KUNNARI, S. The sources of phonological knowledge: A crosslinguistic perspective. Recherches Linguistiques de Vincennes, 35, 133-164, 2006.

VITRAL, L.; COELHO, S. (orgs.). Estudos de Processos de Gramaticalização em Português - Metodologias e Aplicações. Campinas/SP: Ed. Mercado de Letras, 2010.

VOTRE, S. J. Linguística e educação, ou por uma teoria da atividade linguageira em sala de aula. In: PASSEGI, L.; OLIVEIRA, M. S. (org). Linguística e educação: gramática, discurso ensino. São Paulo: Terceira Margem, 2001, PP. 9-54.

VOTRE, S. J.; NARO, A. J. Mecanismos funcionais do uso da língua. D.E.L.T.A., v. 7, n. 2 , 1989, pp. 169-184.

VOTRE, S. J.; CEZARIO, M. M.; MARTELOTTA, M. Gramaticalização. Rio de Janeiro: Faculdade de Letras/UFRJ, 2004.

VOTRE, S. J.; RIOS, M. (orgs). A língua falada e escrita na cidade do Rio de Janeiro: materiais para o seu estudo. Rio de Janeiro: Faculdade de Letras, UFRJ, 1995.

WALLACE, L. On the bases of conservation. In: ELKIND, D.; FLAVELL, J. (eds) Studies in cognitive Development. Oxford: Oxford University Press, 1969.

WEINER, J.; LABOV, W. Constraints on the agentless passive. Journal of linguistics, 1983, 19:p.29-58.

WEINREICH, U.; LABOV, W.; HERZOG, M. Empirical foundations for a theory of language change. In: LEHMAN, W.; MALKIEL, Y. (eds). Directions for historical linguistics. Austin: University of Texas Press, 1968.

WEINREICH, U.; LABOV, W.; HERZOG, M. Fundamentos empíricos para uma teoria da mudança linguística. (Tradução: Marcos Bagno). Rio de Janeiro: Parábola, 2006.

WHITAKER, H.; WHITAKER, H. A. (ed). Studies in Neurolinguistics, v. 3 New York: Academic Press, 1978.

Webgrafia:

- $\quad$ Parâmetros Curriculares Nacionais- PCN- Ensino Médio. Disponível em http://portal.mec.gov.br/index.php?option=com_content\&id=12598\%3Apublicacoes\&It emid=859 (Acesso em 04/05/2014). 
